\title{
AN INTRODUCTION TO THE MECHANICS OF PERFORMANCE ASSESSMENT USING EXAMPLES OF CALCULATIONS DONE FOR THE WASTE ISOLATION PILOT PLANT BETWEEN 1990 AND 1992
}

\author{
Rob P. Rechard \\ WIPP Performance Assessment Department (6749) \\ Sandia National Laboratories \\ Albuquerque, New Mexico 87185
}

\begin{abstract}
This document provides an overview of the process used to assess the performance of the Waste Isolation Pilot Plant (WIPP), a proposed repository for transuranic wastes that is located in southeastern New Mexico. The quantitative metrics used in the performance-assessment (PA) process are those put forward in the Environmental Protection Agency's Environmental Standards for the Management and Disposal of Spent Nuclear Fuel, High-Level and Transuranic Radioactive Wastes (40 CFR 191). Much has been written about the individual building blocks that comprise the foundation of PA theory and practice, and that WIPP literature is well cited herein. However, the present approach is to provide an accurate, well documented overview of the process, from the perspective of the mechanical steps used to perform the actual PA calculations. Specifically, the preliminary stochastic simulations that comprise the WIPP PAs of 1990,1991 , and 1992 are summarized.
\end{abstract}




\section{DISCLAMMIER}

Portions of this document may be illegible in electronic image produets. Images are produced from the best available original document. 


\section{PREFACE}

In broad terms, performance assessments (PAs) for the Waste Isolation Pilot Plant (WIPP) are stochastic simulations that estimate probabilistically the behavior of human-made and/or natural structures for the express purpose of comparing their performance to regulatory standards. The available literature on the WIPP's various performance assessments for the WIPP is extensive. However, relatively little has been written about the overall mechanics of the WIPP PA process itself. To help remedy that situation, the principal purpose and perspective adopted in this report have been to provide overview of the structure, form, and function of the WIPP PA process.

\section{Purpose}

The purpose of this document is to describe in overview the process used by Sandia National Laboratories since 1986 to assess the performance of the WIPP using examples of calculations from 1990 through 1992. The document also serves as a reader's guide to the tomes of more detailed information that Sandia (as scientific investigator and advisor for the Department of Energy on characterizing the WIPP) has published since 1975 on specific and related topics. Each topic treated herein is accompanied by a list of basic references on that subject. The document is also intended to serve as a primer on the performance assessment calculation process. It was the latter purpose that provided the first impetus to collect the information presented in the report. However, the former two purposes provided the motivation to set the information in writing and determined the organization and content of the report as a whole. Knowledge of the evolution of the PA calculation process and its application to the WIPP is important to fully understand the general calculational approach that will be used in the draft and final applications certifying compliance of the WIPP with regulations of the Environmental Protection Agency.

\section{Organization}

The report is divided into eight chapters. Those chapters are subdivided into sections and subsections. Most subsections consist of a single page of text that includes a reference list, and a single figure that illustrates its corresponding text. The text/figure pairs are designed to be fairly self-contained. Therefore, readers with specific interests may treat the document as a handbook or manual. Traditional readers will discover that subsections within a section provide progressively more detail about the mechanics of the process being discussed. The final subsection within each section usually describes the detailed linkage of the modularly designed computer codes used in that part of the PA process. Such information will be of interest to anyone endeavoring to understand the working details of the system, but it is probably not of interest to more casual readers.

The introductory chapter sets the stage by overviewing compliance strategy. It subdivides the various tasks of the WIPP PA process into six progressive steps and addresses the critical role of multiple itcrations. The introduction also includes a brief history of the WIPP project and PA methodology. The chapters following the introduction treat the various PA tasks in the order in which they are described in the introduction, which is: Chapter 2, disposal-system characterization; Chapter 3, scenario development; Chapter 4, probability modeling; Chapter 5, consequence modeling; Chapter 6 , regulatory assessment; Chapter 7 , sensitivity analysis. Chapter 8 , the final chapter, provides summary figures of the PA process and of the linkages among the modeling subsystems of the WIPP PA for calculations through 1992.

\section{Using This Report}

Because cach subsection of the report is self-contained, the reader can casily choose the type of information to be read and the desired level of detail. A general reader seeking an overview may choose to read only the first subsection under each of the PA steps, that is, only the main headings of the report. However, a PA analyst endeavoring to learn how to contribute to or evaluate the inner workings of the PA modeling system may wish to concentrate solely on the subsections under his/her PA step of interest, with cursory forays into neighboring steps so as to understand the interfaces between his/her work and the other subsystems within the overall PA process.

\section{Caveats}

This report focuses on the calculational process used for the 1990, 1991, and 1992 WIPP PAs. The readers should not take the descriptions as an exact prescription of what will take place in future PAs. For cxample, changes can occur based on availability of new experimental data and improvements in the modeling process. 
This report is designed for a spectrum of readers having a broad band of technical backgrounds. It is not. however, written for general nontechnical readers. General readers may find the report useful in that it provides a measure of insight into the PA process, but it also assumes some technical competency and familiarity with basic technical nomenclature. On the other hand, knowledgeable readers should not expect a definitive, step-by-step users' guide with in-depth technical bases for each of the WIPP PA codes. although the documents in which those topics are treated are referenced.

The reader should bear in mind that no single individual carried out the 1990, 1991, or 1992 annual PAs. As practiced in the United States, stochastic PAs for nuclear waste disposal system are complicated, interdisciplinary, demanding tasks that require diverse skills and a thorough understanding of myriad aspects of the physical and mathematical sciences. They start as conceptual models that must bc transformed into sound theoretical, then computational, and finally applied models. To date, WIPP PAs have resulted from the well coordinated efforts by a sizable team of experienced specialists who have become experts in their specific subareas of the PA calculation.

The committed reader will want to start with the overall calculational procedure. Once that is understood, he/she should then turn to the science of the models and then endeavor to understand how all of the models interact as a system, thus endeavoring to appreciate both the microscopic and macrossopic viewpoints of the various WIPP PAs. A concise document such as this cannot promise to support that entire goal unaided. It can, however, serve as a useful introduction and guide to the inherently complex stochastic PA of nuclear waste disposal systems in the United States and to the literature that supports it.

\section{Related Overview Documents}

Readers who require additional information on the mechanics of the PA process are referred to the following overview documents:

Rechard, R.P., ed. 1992. User's Reference Manual for CAMCON: Compliance Assessment Methodology Controller, Version 3.0. SAND90-1983. Albuquerque, NM: Sandia National Laboratories.

Rechard, R.P., A.P. Gilkey, H.J. Iuzzolino, D.K. Rudeen, and K.A. Byle. 1993a. Programmer's Manual for CAMCON: Compliance Assessment Methodology Controller. SAND90-1984. Albuquerque, NM: Sandia National Laboratories.

The User's Guide to the WIPP PA Codes that is being written by W.F. Simmons and G.K. Froehlich.

The individual users' guides and corresponding technical-basis manuals for each of the modular WIPP PA codes that are under preparation.

Those seeking additional information on the results and applications of the PA process are referred to the following two sets of reports:

WIPP PA (Performance Assessment) Department. 1992/1993. Preliminary Performance Assessment for the Waste Isolation Pilot Plant, December 1992. SAND92-0700/1/2/3/4/5. Albuquerque, NM: Sandia National Laboratories. Vols. 1-5.

Rechard, R.P., ed. 1995. Performance Assessment of the Direct Disposal in Unsaturated Tuff of Spent Nuclear Fuel and High-Level Waste Owned by U.S. Department of Energy. Volume 1: Executive Summary. Volume 2: Methodology and Results. Volume 3: Appendices. SAND94-2563/1/2/3. Albuquerque, NM: Sandia National Laboratories.

Note: The second of the two reports does not pertain to the WIPP Project, but it uses the same general methodology. It has the advantage of describing an entire PA calculation in one main volume (Volume 2), rather than the five or more volumes necessary to treat the WIPP.

\section{Acknowledgments}

A probabilistic PA of a disposal system like the WIPP requires many individuals having expertise covering a wide range of fields of science and technology. Without the exemplary work of this well coordinated team of dedicated researchers, the PA process could not have been brought to scientifically acceptable fruition. The summary contributions of the WIPP Project's "PA team," led by D.R. Anderson and M.G. Marietta, form the scientific basis of this document. Their work is gratefully acknowledged. 
Section 1.5.1, Timeline of Events for the WIPP Project, took a great deal of cffort to compile, diagram, and verify. Hugh Ho, a Sandia summer employee, Carol Crawford (13415), and Darcy Pulliam of Tech Reps, Inc., helped greatly with this task. Section 1.5.2, Timeline of Events Influencing Probabilistic Analysis of Systems, benefited greatly from interviews with M.S. Tierney, M.G. Marietta, D.R. Anderson, J.C. Helton, and J.E. Campbell; all gave graciously of their time and provided important background information on the many topics presented. Ching Wo, a Sandia summer employee, and Kathy Best of Tech Reps. Inc., also helped with this particular section.

The author appreciates the considered comments by the final technical reviews, M.S. Tierney (6741), P.N. Swift (6707), D.A. Galson (Galson Sciences, Ltd.), and W.F. Simmons (Tech Reps, Inc.). D. Duncan (MacTech) drafted many of the illustrations. The cover was designed by Hawaii Olmstead and illustrated by Steve Scatliffe of Tech Reps, Inc. Editorial assistance provided by Marilyn Gruebel (Tech Reps, Inc.) on early drafts and extensive editorial assistance with the final text and figures provided by Molly Minahan and Hawaii Olmstead of Tech Reps, Inc., greatly improved the presentation. 
Preface

。

vi 


\section{CONTENTS}

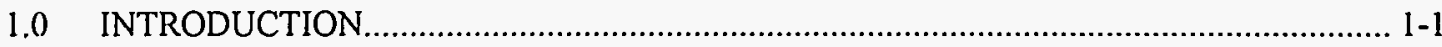

$1.1 \quad 40$ CFR 191 - Based Compliance Strategy …........................................................ 1-5

1.1.1 The Modeling Style of the PA for the WIPP ............................................... 1-6

1.1.2 Multiple Iterations: a Performance Assessment Strategy.................................. 1-8

1.2 The Six Principal Steps of Performance Assessment ........................................... 1-11

1.2.1 Components of the Six Performance Assessment Steps................................ 1-12

1.2.2 Performance Assessment as an Ordered Triplet........................................... 1-14

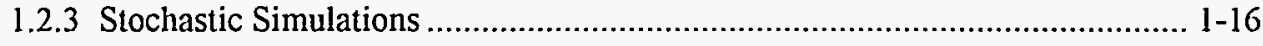

1.2.4 Model Development ........................................................................ 1-18

1.3 Types of Uncertainty in Performance Assessments .............................................. 1-21

1.3.1 Propagating Uncertain Parameters (Epistemic Uncertainty)

through Consequence Models................................................................ 1-22

1.3.2 Propagating Aleatoric Uncertainty through Performance Assessment ............. 1-24

1.3.3 Quality Assurance Procedures for the 1990-1992 Calculations ...................... 1-26

1.4 Terminology of a Mined Geologic Disposal System ................................................ 1-29

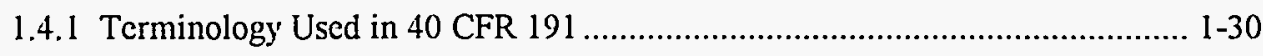

1.4.2 Description of the Waste Containment System ....................................... 1-32

1.5 Regulatory Influences on the Waste Isolation Pilot Plant Project ........................... 1-35

1.5.1 Timeline of Events for the WIPP Project ................................................ 1-36

1.5.2 Timeline of Events Influencing Performance Assessment Process ..................1-50

2.0 DISPOSAL SYSTEM AND REGIONAL CHARACTERIZATION................................... 2-1

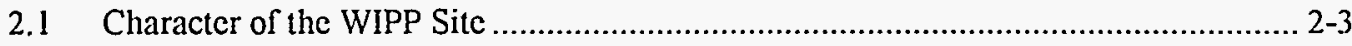

2.1.1 Physical Setting, including Natural Resources .............................................. 2-6

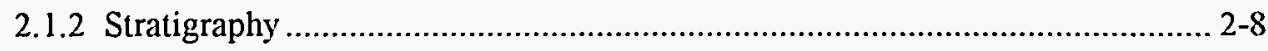

2.1.3 Regional Geology ..................................................................................... 2-10

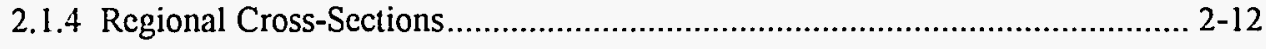

2.1.5 Hydrological Characterization of the Culcbra ................................................ 2-14

2.1.6 Climatic Variability ................................................................................. 2-16

2.2 Propertics of the Waste ........................................................................................ 2-19

2.2.1 Contact-Handled and Remotely Handled TRU ............................................ 2-20

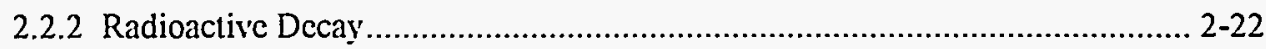

2.2.3 Changes in Radionuclide Activity ........................................................... 2-24

2.3 Design of the Repository (Engincered Barrier) ....................................................... 2-27

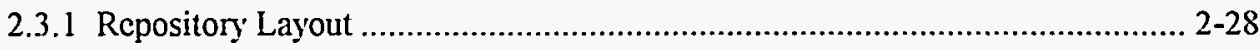

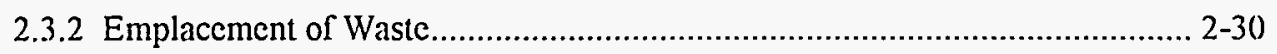


3.1 Identifying Features, Events, and Processes........................................................ 3-3

3.1.1 Identification and Selection Procedures .......................................................... 3-4

3.1.2 The Universe of Features, Events, and Processes ..................................... 3-6

3.2 Grouping Features, Events, and Processes into Scenarios ......................................... 3-9

3.2.1 General Development Procedure ............................................................ 3-10

3.2.2 Applying the Grouping Procedure to the WIPP ........................................ 3-12

3.2.3 Undisturbed Summary Scenario ........................................................... 3-14

3.2.4 Human Intrusion Summary Scenarios ...................................................... 3-16

3.3 Modeling System Selection ............................................................................ 3-19

3.3.1 External Scales for Consequence Models.............................................. 3-20

3.3.2 The Component Computational Models ................................................. 3-22

3.3.3 Support Codes Used in the Modeling System............................................... 3-24

3.3.4 The CAMCON Modeling System............................................................. 3-26

3.3.5 CAMCON Support of Performance Assessment Calculations ........................ 3-28

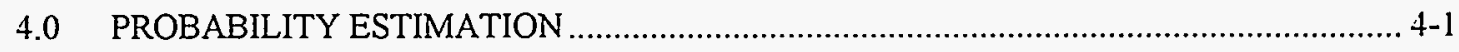

4.1 Assigning Parameter Uncertainties ....................................................................... 4-3

4.1.1 Characterizing Parameter Uncertainty ..................................................... 4-4

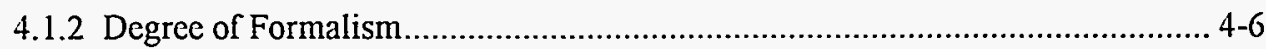

4.1.3 Example of Data Interpretation to Evaluate Model Parameters ........................ 4-8

4.1.4 Example of Formalized Data Interpretation................................................. 4-10

4.2 Compiling Model Parameters........................................................................ 4-13

4.2.1 Gathering and Storing Model Parameters.................................................... 4-14

4.2.2 Latin Hypercube Sampling .................................................................... 4-16

4.2.3 Executing Latin Hypercube Sampling …............................................... 4-18

4.3 Estimating Probability of Human Intrusion Scenario ........................................... 4-21

4.3.1 Using Poisson Functions to Estimate the Probability of Human Intrusion ....... 4-22

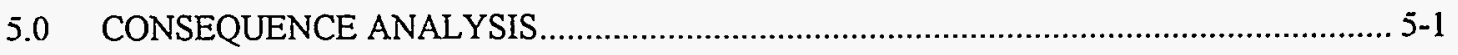

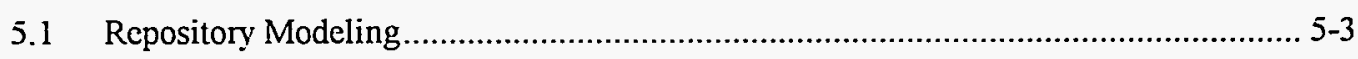

5.1.1 Repository Episodes Leading to Undisturbed Conditions ................................ 5-4

5.1.2 Repository Episodes after Intrusion ......................................................... 5-6

5.1 .3 Modeling of Cuttings/Cavings.............................................................. 5-8

5.1.4 Linkage of the CUTTINGS Model ...................................................... 5-10

5.1.5 Modeling of Two-Phase Flow .................................................................... 5-12

5.1.6 Linkage of the BRAGFLO Code......................................................... 5-14 
5.1.7 Modeling of Source-Term $5-16$

5.1.8 Linkage of PANEL Code. $5-18$

5.2 Groundwater Flow Modeling 5-21

5.2.1 Regional and Local Groundwater Flow Modeling. $5-22$

5.2.2 Cumulative Travel-Time Distributions 5-24

5.2.3 Neutrally Buoyant Particle Paths ......................................................... 5-26

5.2.4 Linkage for 1990 Groundwater-Flow Simulations ................................... 5-28

5.2.5 Linkage of the SECOFL2D Flow Code .................................................. 5-30

5.2.6 Generating Transmissivity Fields ............................................................ 5-32

5.2.7 Transmissivity Fields by Pilot Points ........................................................ 5-34

5.3 Radionuclide Transport Modeling.............................................................. 5-37

5.3.1 Example of Radionuclide Transport .................................................... 5-38

5.3.2 Modeling of Radionuclide Transport .......................................................... 5-40

5.3.3 Code Linkage for 1990-1991 Transport.................................................. 5-42

5.3.4 Linkage of the SECOTP2D Transport Code ............................................ 5-44

5.4 Biosphere Transport Modeling .................................................................... 5-47

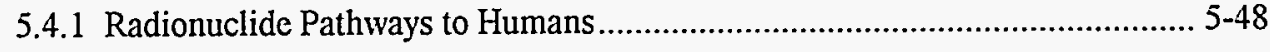

5.4.2 Executing Biosphere Transport Codes .................................................. 5-50

6.0 LONG-TERM REGULATORY ASSESSMENT ........................................................ 6-1

6.1 Environmental Protection Agency 40 CFR 191 Simulations...................................... 6-3

6.1.1 Overview of 40 CFR 191 ..................................................................... 6-4

6.1.2 Environmental Protection Agency Release Limits ...................................... 6-6

6.1.3 Containment Requirements ....................................................................... 6-8

6.1.4 CCDFs When Parameter Space is Not Decomposed into Scenarios................ 6-10

6.1.5 CCDFs When Parameter Space is Decomposed into Scenarios ...................... 6-12

6.1.6 Software for Calculating Complementary Cumulative Distribution Functions. 6-14

6.2 National Environmental Policy Act Simulations ................................................. 6-17

6.2.1 Dose Assessments ............................................................................. 6-18

6.2.2 Evaluations of Human Health Effects Per Year......................................... 6-20

6.3 Resource Conservation and Recovery Act Simulations ........................................... 6-23

7.0 SENSITIVITY/UNCERTAINTY ANALYSIS …......................................................... $7-1$

7.1 Evaluations of Statistical Correlations.................................................................. 7-3

7.1.1 Ranking Important Model Parameters ....................................................... 7-4

7.1.2 Computing Statistical Correlations.......................................................... 7-6 
8.0 PERFORMANCE ASSESSMENT ALGORITHM SUMMARY ....................................... 8-1

8.1 Concise Review of the Six-Step Performance Assessment Process ............................. 8-3

8.2 Summary of Performance Assessment Software Linkages ...................................... 8-7

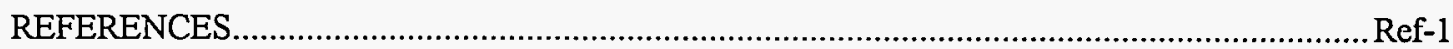

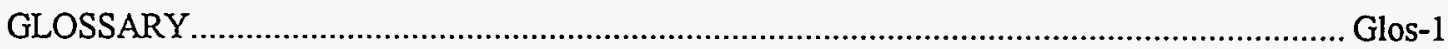




\subsection{INTRODUCTION}

In 1979, Congress authorized the U.S. Department of Energy (DOE) ${ }^{*}$ to build a research and development facility to test the safe management, storage, and disposal of wastes containing transuranic (TRU) radionuclides. The Waste Isolation Pilot Plant (WIPP) was designed and built as a full-scale pilot repository. It is mined horizontally at a depth of $655 \mathrm{~m}(2150 \mathrm{ft})$ in a thick and extensive bedded salt formation (mostly halite) $42 \mathrm{~km}$ ( $26 \mathrm{mi}$ ) east of Carlsbad, New Mexico. If the design proves tenable on the basis of all regulatory criteria, the facility would become a permanent repository for TRU radioactive wastes produced by federal programs for the development and manufacture of nuclear weapons (transuranic refers to elements with atomic numbers greater than uranium-92). Because these wastes contain radionuclides and other hazardous constituents, such as heavy metals and volatile organic compounds (VOCs), a full suite of regulatory criteria has to be satisfied before the WIPP can be certified as an acceptable repository for federal wastes. In 1992, Congress charged the U.S. Environmental Protection Agency (EPA) to review the DOE's published findings on the WIPP and to certify whether or not overall compliance has been satisfactorily demonstrated..$^{* *}$

In general, the overall process of assessing whether a waste disposal system meets a set of performance criteria is known as a performance assessment (PA).$^{2^{* * *}}$ A PA provides important input to decisions on the safety (i.e., social acceptability of the risks) of a plan of action using a detailed procedure and scientific knowledge. For radioactive wastes, a computationally demanding set of risk-based performance criteria is specified in the EPA's Environmental Radiation Protection Standards for Management and Disposal of Spent Nuclear Fuel, High-Level and Transuranic Radioactive Wastes (40 CFR 191), 3,4 They are specific, quantitative criteria that specify probabilistic limits that must be met for the first 10,000 years of operation of a waste repository. Clearly, it is not sufficient to develop an accurate scientific understanding of the current status of a disposal system. Rather, calculations illustrating possible behavior well into the future are required. Consequently, a PA is carried out on a suite of models that represents and illustrates the disposal system's present and future behavior, and the assessment is through computer simulation. The physical, chemical, and geological processes that determine the behavior and evolution of the site are complex and often highly nonlinear. Accordingly, the models that describe the processes are themselves complex and often technically sophisticated.

This document describes in overview the procedural steps that comprise a WIPP performance assessment. Specifically, it treats the 1990, 1991, and 1992 PAs, $, 5,6,7$ which were evolutionary in nature, each building on and extending the scope and results of the ones before. The 1990 PA highlighted the backbone of the assessment modeling system, the so-called Compliance Assessment Methodology CONtroller (CAMCON ${ }^{8,9,10}$ ). The CAMCON system is the central information-transmission and qualityassurance system to which PA computational and utility codes connect, and through which they communicate. It served as the central utility code for the subsequent PAs in 1991 and 1992. ${ }^{10,7}$ With CAMCON in place, the 1991 PA featured a complete suite of computational components and highlighted the documentation. ${ }^{6}$ With a complete array of working models in place, the 1992 PA used improved field

* The U.S. Department of Energy was formed in 1977 by the Department of Energy Organization Act (Public Law 95-91, 912 Stat. 565). It replaced the Energy Research and Development Agency (ERDA). ERDA was formed by the 1974 Energy Reorganization Act (Public Law 93-438) and replaced the Atomic Energy Commission (AEC), which was formed in 1946 (Public Law 585, August I, 1946, 60 Stat. 755).

** The WIPP is not regulated by the Nuclear Regulatory Commission (NRC). ${ }^{2}$ (See also Section 1.5.1, Timeline of Events for the Waste Isolation Pilot Plant.)

*** This general definition of a PA is used herein. However, the $40 \mathrm{CFR} 191$ regulation defines a performance assessment as an

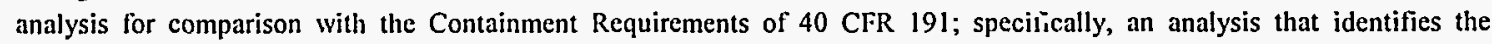
processes and events that might affect the disposal system, examines the effects of these processes and events on the performance of the disposal system, and estimates the cumulative releases of radionuclides, considering the associated uncertainties, caused by all significant processes and events. Concerning these events, Appendix C of 40 CFR 191 states that the most severe anthropogenic event to consider is human intrusion into the repository from exploratory drilling.

T As noted in the preface, because of changes instituted by the DOE in response to the Waste Isolation Pilot Plant Land Withdrawal Act (Public Law 102-579 ) and changes introduced by the Secretary of the Department of Energy to accelerate the regulatory compliance program, the information in this document may not apply to future PAs. 
data and highlighted both the conceptual and refined computational models that had been developed to comprise the WIPP PA modeling system. ${ }^{5+\dagger}$

The EPA's official guidance concerning the nature of performance assessments (50 FR 38066) ${ }^{3}$ suggests a PA in the United States requires a stochastic simulation of the possible long-term behaviors of a real system based on computer-implemented mathematical models of that system. In that respect, WIPP PAs are similar to other, perhaps more familiar, large-scale stochastic simulations such as the Reactor Safety Study. ${ }^{11,12}$ These large-scale simulations have been used by federal agencies to explore policy options and to develop regulatory criteria. ${ }^{13}$ However, unlike those simulations, PA results are not intended merely to gain insight into the behavior of a system for purposes of rational bases for governmental policy or regulatory standards. Rather, they are used to test the compliance of a real system (i.e., the WIPP) with environmental standards. But bear in mind, PAs are not truly predictive, but rather illustrative calculations for comparison to regulatory measures. Thus, not only are the PA results themselves of critical importance, but also equally important are the uncertainty analyses that accompany them. The quantitative analysis of uncertainty in PA calculations is not just good scientific practice, it is strongly suggested as necessary by EPA regulations. Moreover, a disposal system cannot be analyzed and assessed piecemeal. By federal regulation, all results must be combined to form an "overall probability distribution" whenever practicable.

Use of a stochastic simulation to quantitatively evaluate uncertainty is only one of several constraints that complicate PAs. Modeling problems are often compounded by the inherent characteristics of the disposal system itself. The principal elements of geological waste-disposal systems are natural materials, that is, stratified layers of soils, sands, clays, rocks, salts, and other minerals that have been deformed and worked for millennia by tectonic, hydrological, and climatic forces. The distribution and physical and chemical characteristics of these natural components are not well known, usually inhomogeneous, anisotropic, and temporally variable on scales that are difficult to characterize thoroughly.

Correspondingly, the EPA has acknowledged explicitly that a performance assessment, being an indirect demonstration or illustration of possible future conditions, need not providecomplete assurance that performance requirements will be met. Quoting from 40 CFR 191, "Because of the long time period involved and the nature of the events and processes of interest, there will inevitably be substantial uncertainties in projecting disposal-system performance. Proof of the future performance of a disposal system is not to be had in the ordinary sense of the word in situations that deal with much shorter time frames. Instead, what is required is a reasonable expectation, on the basis of the record before the implementing agency, that compliance with 191.13(a) (Containment Requirements, see Sections 6.1.2 and 6.1.3) will be achieved."

This document presents a condensed overview of the overall calculation procedure for assessing the performance of the WIPP for 10,000 yr. It endeavors to present the system at several levels of technical sophistication so as to be useful to readers with a broad spectrum of technical backgrounds. To make that possible, the physics, chemistry, and mathematics of the WIPP PA models have been described only functionally. The nuances of the various natural phenomena treated in the WIPP's scientific models have been intentionally omitted so as to save the overview reader from inevitable and considerable technical encumbrances. These nuances are treated extensively in the referenced documents. Technical manuals describing each of the WIPP codes are presently in preparation. They are scheduled to appear some time during 1995 and 1996. Readers should regard them as additions to this document's list of references.

In addition to providing a general overview of the PA process, this document may be used as a guide to the extensive and more detailed WIPP scientific literature. Each subsection of the body of the report includes an abbreviated reference list that gives the principal scientific references related to the topic treated in that subsection. In addition, readers having access to the WIPP codes, the required computational hardware, and the desire to run them are referred to the Users' Guide to the WIPP PA Codes that is currently being written and may be regarded as a companion volume to this document for serious technical readers.

The remaining sections of this introduction describe (a) Sandia's overall strategy for evaluating the WIPP in terms of the various environmental regulations and the multiple-iteration technique used to improve the quality of the PA (Section 1.1), (b) the general steps that comprise Sandia's PA process (Section 1.2), (c) the types of uncertainty that arise in a PA (Section 1.3), (d) the terminology pertinent to a

tt An early 1989 PA highlighted the methodology to be used in the following years. ${ }^{14}$ However. the modeling system used was only a prototype of the one used for the later PAs. Consequently, the PA mechanics described in this document do not apply to the $1989 \mathrm{PA}$. 
geologic disposal system (Section 1.4), and (e) a history of waste-disposal issues that affected the initiation and evolution of the WIPP Project (Section 1.5).

The organization of the remainder of the report follows the steps of a performance assessment as they are described in Section 1.2. Each section of a chapter explains one aspect of that chapter, and each subsection of that section offers increasing detail on the PA process being discussed. Thus, the final subsection of each section usually describes the detailed linkage of codes used for that portion of the PA process code linkages that are clearly of interest to readers endeavoring to master the operational details of the PA process. However, they are probably not of interest to the casual reader. Thus, a reasonable strategy for approaching this document is to obtain a general overview of the PA process by skimming the text of the main chapter headings (denoted $1.0,2.0,3.0, \ldots$ ). Technically inclined readers can then delve more into the details of the process by progressively reading the text in the main sections of the report (denoted 1.1, 1.2, $\ldots, 2.1,2.2, \ldots, 3.1, \ldots)$ and then studying the text and figures of the subsections (denoted 1.1.1, 1.1.2, 1.2.1, $1.2 .2,1.3 .1, \ldots)$.

\section{References}

1 Public Law 102-579. 1992. Waste Isolation Pilot Plant Land Withdrawal Act (106 Stat. 4777).

2 Public Law 96-164. 1979. Department of Energy National Security and Military Applications of Nuclear Energy Authorization Act of 1980.

3 EPA (Environmental Protection Agency). 1985a. "40 CFR Part 191: Environmental Standards for the Management and Disposal of Spent Nuclear Fuel, HighLevel and Transuranic Radioactive Wastes; Final Rule," Federal Register. Vol. 50, no. 182, 38066-38089.

4 EPA (Environmental Protection Agency). 1992a. "Environmental Radiation Protection Standards for Management and Disposal of Spent Nuclear Fuel, High-Level and Transuranic Radioactive Wastes," Code of Federal Regulations 40, Part 191. Washington, DC: Superintendent of Documents, U.S. Government Printing Office.

5 WIPP PA (Performance Assessment) Department. 1992/1993. Preliminary Performance Assessment for the Waste Isolation Pilot Plant, December 1992. SAND92-0700/1,2,3,4,5. Albuquerque, NM: Sandia National Laboratories. Vols. $1-5$.

6 WIPP PA (Performance Assessment) Division. 1991. Preliminary Comparison with 40 CFR Part 191, Subpart B for the Waste Isolation Pilot Plant, December 1991. SAND91-0893/1,2,3,4. Albuquerque, NM: Sandia National Laboratories. Vols. 1-4.

7 Bertram-Howery, S.G., M.G. Marietta, R.P. Rechard, P.N. Swift, D.R. Anderson, B.L. Baker, J.E. Bean, Jr., W. Beyeler, K.F. Brinster, R.V. Guzowski, J.C Helton, R.D. McCurley, D.K. Rudeen, J.D. Schreiber, and P. Vaughn. 1990a. Preliminary Comparison with 40 CFR Part 191. Subpart B for the Waste Isolation Pilot Plant, December 1990. SAND90-2347. Albuquerque, NM: Sandia National Laboratories.

8 Rechard, R.P., ed. 1992. User's Reference Manual for CAMCON: Compliance Assessment Methodology Controller, Version 3.0. SAND90-1983. Albuquerque, NM: Sandia National Laboratories.

9 Rechard, R.P., A.P. Gilkey, H.J. Iuzzolino, D.K. Rudeen, and K.A. Byle. 1993a. Programmer's Manual for CAMCON: Compliance Assessment Methodology Controller. SAND90-1984. Albuquerque, NM: Sandia National Laboratories.

10 Rechard, R.P., H. Iuzzolino, and J.S. Sandha. 1990a. Data Used in Preliminary Performance Assessment of the Waste Isolation Pilot Plant (1990). SAND89-2408. Albuquerque, NM: Sandia National Laboratories.

11 Rasmussen, N.C. 1975. Reactor Safety Study: An Assessment of Accident Risks in U.S. Commercial Nuclear Power Plants. NUREG-75/014, WASH-1400. Washington, DC: U.S. Nuclear Regulatory Commission.

12 Helton, J.C. 1994. "Treatment of Uncertainty in Performance Assessments for Computer Systems," Risk Analysis. SAND93-1713J. Vol. 14, no. 4, 483-511.

13 Morgan, M.G., M. Henrion, and M. Small. 1990. Uncertainty: A Guide to Dealing with Uncertainty in Quantitative Risk and Policy Analysis. New York, NY: Cambridge University Press. 
14 Marietta, M.G., S.G. Bertram-Howery, D.R. Anderson, K.F. Brinster, R.V. Guzowski, H. Iuzzolino, and R.P. Rechard. 1989. Performance Assessment Methodology Demonstration: Methodology Development for Evaluating Compliance with EPA 40 CFR 191, Subpart B, for the Waste Isolation Pilot Plant. SAND89-2027. Albuquerque, NM: Sandia National Laboratories. 


\subsection{CFR 191 - Based Compliance Strategy}

The Environmental Protection Agency (EPA) standard, Environmental Radiation Protection Standards for Management and Disposal of Spent Nuclear Fuel, High-Level and Transuranic Radioactive Wastes (40 CFR 191) requires extensive computations of a probabilistic nature to illustrate the performance of the disposal system of the Waste Isolation Pilot Plant (WIPP). Thus, it provides the incentive for the development of the modeling methodology and associated analysis tools devised and compiled by Sandia National Laboratories to evaluate the long-term behavior of the WIPP disposal system. 'That methodology, with modifications, also serves to assess compliance with other environmental regulations and laws concerned with long-term release of nonradioactive contaminants, such as the regulations of the Resource Conservation and Recovery Act of 1976 (see Chapter 6.0, Long-Term Regulatory Assessment).*

Essentially, the EPA standard 40 CFR 191 specifies the required safety of a geologic disposal system, that is, the risk from the WIPP that is acceptable in the United States. In turn, risk ${ }^{* *}$ is the potential that some unwanted loss may occur. Although $40 \mathrm{CFR} 191$ does not directly use that risk to human health as a criterion, its requirements are related to health risk. Specifically, the individual protection requirements set limits on radionuclide doses to humans, and the containment requirements set limits on (a) radionuclide releases and (b) on the probability that such releases will occur. Because 40 CFR 191 explicitly recognizes the uncertainty of scientific explanations, uncertainties associated with the WIPP modeling process must also be quantified to the extent possible (see Chapter 6.0, Long-Term Regulatory Assessment).

Sandia's overall assessment approach was developed simultaneously with early drafts of 40 CFR 191, so as to evaluate early options for regulating deep, geologic repositories. ${ }^{2-4}$ Sandia's approach to assessment modeling benefited further from its scientific participation in earlier studies of the feasibility of subseabed disposal of radioactive wastes in deep-ocean sediments. Those studies were conducted under the auspices of the Nuclear Energy Agency of the International Organisation for Economic Co-Operation and Development. ${ }^{5}$ Sandia used information from those exploratory analyses to guide the development of performance-assessment techniques for the WIPP.

Attention is called to two important aspects of the compliance strategy of the WIPP, namely: (1) the use of a detailed modeling style, and (2) multiple iterations performed to improve assessment quality. These aspects are described further in the two subsections that follow.

\section{References}

1 Helton, J.C. 1994. "Treatment of Uncertainty in Performance Assessments for Complex Systems," Risk Analysis. SAND93-1713J. Vol. 14, no. 4, 483-511.

2 Chu, M.S., N.R. Ortiz, K.K. Wahi, R.E. Pepping, and J.E. Campbell. 1983.An Assessment of the Proposed Rule (IOCFR60) for Disposal of High-Level Radioactive Wastes in Geologic Repositories. SAND82-2969, NUREG/CR-3111. Albuquerque, NM: Sandia National Laboratories. Vol. 1.

3 Pepping, R.E., M.S. Chu, and M.D. Siegel. 1983. "A Simplified Analysis of a Hypothetical High-Level Waste Repository in a Bedded Salt Formation," Technical Assistance for Regulatory Development: Review and Evaluation of the Draft EPA Standard 40CFRI91 for Disposal of High-Level Waste. SAND82-1557. NUREG/CR-3235. Albuquerque, NM: Sandia National Laboratories. Vol. 4.

4 Campbell, J.E., and R.M. Cranwell. 1988. "Performance Assessment of Radioactive Waste Repositories,"Science. Vol. 239, no. 4846, 1389-1392.

5 Marietta, M.G., and W.F. Simmons. 1988. Feasibility of Disposal of High-Level Radioactive Wastes Into the Seabed. Volume 5-Dispersal of Radionuclides in the Oceans: Models. Data Sets, and Regional Descriptions. SAND87-0753. Albuquerque, NM: Sandia National Laboratories.

\footnotetext{
* An alternative compliance strategy might have been to start by implementing the RCRA regulations because they include well defined legal steps (e.g., applications, hearings, etc.). However, the RCRA regulations are less demanding of the models. Furthermore, these regulations were the last to be applied to the WIPP and so their influence is not as strong (see Section 1.5.1, Timeline of Events for the WIPP Project).

** To arrive at a quantifiable risk (or a risk related measure) requires describing what may happen, quantifying the probability of some unwanted loss happening, and quantifying the loss (see Section 1.2.2, Performance Assessment as an Ordered Triplet) Although not done here, authors frequently define risk as the product of the loss (consequence) and the probability of the loss. Herein the loss and the probability loss for various happenings (scenarios) are paired to form the complementary cumulative distribution function (CCDF) (see Section 1.3 and Chapter 6).
} 


\subsubsection{The Modeling Style of the PA for the WIPP}

The general definition of performance assessment (PA) - a process of assessing whether a system meets a set of performance criteria-is easy to understand. Even the six general steps of a performance assessment for a waste disposal system described in Section 1.2 are easy to comprehend because, in general, the steps are tied to the process of building scientific models. It is the approaches within these six steps that were used for analyzing the Waste Isolation Pilot Plant (WIPP) from 1990 through 1992 that this report seeks to illuminate. ${ }^{*}$ In this report, the guiding philosophy used to construct models is termed "modeling style." Examples of modeling style include the following: the type of natural and anthropogenic phenomena considered, assumptions of symmetry and dimensionality of the conceptual model, and density of spatially varying data. The modeling style, in turn, is dependent upon the type of system, the performance criteria, and the available assessment technology. Different modelers approach and frame modeling problems differently. For the geologic disposal systems in general, and the WIPP in particular, modeling style was determined by Sandia scientists and engineers. Important influences on this style were congressional policies set forth in laws (e.g., NEPA ${ }^{1}$ and the WIPP Land Withdrawal $\mathrm{Act}^{2}$ ) and regulations of the Environmental Protection Agency (EPA) implementing these laws (e.g., 40 CFR 19 $\mathrm{P}$ ). Future influences will be determined by the EPA as they review the WIPP compliance application (e.g., $40 \mathrm{CFR}$ $194^{4}$ ). For example, $40 \mathrm{CFR} 191$ specifies performance criteria for $10,000 \mathrm{yr}$; therefore, the system is necessarily a mathematical model. Furthermore, 40 CFR 191 uses a probabilistic performance criterion for assessing compliance and requests an applicant display the results of the analysis as a "complementary cumulative distribution function" (CCDF).

The modeling style adopted must be adequate to provide the EPA with ". . . a reasonable expectation ... that compliance will be achieved." In the calculations through 1992 for assessing the safety of the WIPP, Sandia adopted a detailed ${ }^{* *}$ modeling style (i.e, a style that included phenomenological details and often multiple dimensions in the model, and avoided simplified or conservative models and/or parameters unless required data or knowledge was not available ${ }^{* * *}$ ). Certainly, an important reason for using a detailed modeling style was the general acceptance in the United States of using detailed probabilistic risk assessments (PRAs) for nuclear regulatory matters; PRAs were used because of the pioneering work in 1975 in the Reactor Safety Study 5 that was the backdrop for the development of 40 CFR 191 in the late 1970s and early 1980s. Similarly, Sandia also used detailed models in the major update of theReactor Safety Study ${ }^{6}$ and in the process of examining deep seabed disposal of nuclear waste. ${ }^{7}$ Also, a detailed modeling style has been proposed as policy by the Nuclear Regulatory Commission. ${ }^{8}$ Furthermore, early comment received from the EPA ${ }^{9}$ and the WIPP Panel of the National Academy of Science encouraged Sandia to continue using a detailed modeling style (at least for preliminary assessments when determining general understanding of the disposal system).

The principal advantage of the detailed modeling style is that is provides a sufficient level of realism (1) to provide general scientific understanding ${ }^{\dagger}$ of the WIPP disposal system over $10,000 \mathrm{yr}$, (2) to explore many potential sources of uncertainty, and (3) be able to tie any lack of understanding or sources of uncertainty directly to measurable quantities, should they be important to study further in other modeling iterations. The major self-imposed constraint on the amount of detail and what type of phenomena to include was Sandia's desire to perform an entire performance assessment each year to obtain the benefits of performance assessment iterations (see Section 1.1.2, Multiple Iterations: a Performance Assessment Strategy).

* Should the myriad details presented throughout the remainder of the report become confusing, recall that the structure of the report is such that much can be gleaned about the modeling style by reading the major sections rather than the many subsections.

** A frequently used term is "realistic," but even realistic models are models nonetheless, and only mimic nature; thus, the term is avoided in this report.

*** Although not adopted for preliminary assessments of the WIPP, the use of simple and often conservative models and/or parameters to give conservative results can be a convincing approach to use in a compliance applications; thus. this is one aspect that can change from the preliminary assessments discussed in this report and future compliance applications.

$\dagger$ Science is a consensual human endeavor, but consensus on scientific issues can take many years to form; thus, scientific consensus that all potentially important knowledge that could be obtained about the site had indeed occurred was certainly desired but was not a goal. 


\section{References}

1 Public Law 91-190. 1970. National Environmental Policy Act of 1969 (83 Stat. 852; 42 U.S.C. 1801 et seq.).

2 Public Law 102-579. 1992. Waste Isolation Pilot Plant Land Withdrawal Act (106 Stat. 4777).

3 EPA (Environmental Protection Agency). 1993a. "40 CFR Part 191: Environmental Radiation Protection Standards for the Management and Disposal of Spent Nuclear Fuel, High-Level and Transuranic Radioactive Wastes, Final Rule," Federal Register. Vol. 58, no. 242, 66398-66416.

4 EPA (Environmental Protection Agency). 1993b. "Criteria for the Certification of Compliance with Environmental Radiation Protection Standards for the Management and Disposal of Spent Nuclear Fuel, HighLevel and Transuranic Radioactive Wastes; Advanced Notice and Proposing Rulemaking," Federal Register. Vol. 58 , no. $27,8029-8030$.

5 Rasmussen, N.C. 1975. Reactor Safety Study: An Assessment of Accident Risks in U.S. Commercial Nuclear Power Plants. NUREG-75/014, WASH-1400. Washington, DC: U.S. Nuclear Regulatory Commission.

6 NRC (Nuclear Regulatory Commission). 1990. Severe Accident Risks: An Assessment for Five U.S. Nuclear Power Plants. NUREG/1150. Washington, DC: Nuclear Regulatory Commission.

7 Marietta, M.G., and W.F. Simmons. 1988. Feasibility of Disposal of High-Level Radioactive Wastes Into the Seabed. Volume 5-Dispersal of Radionuclides in the Oceans: Models, Data Sets, and Regional Descriptions. SAND87-0753. Albuquerque, NM: Sandia National Laboratories.

8 NRC (Nuclear Regulatory Commission). 1994b. "Use of Probabilistic Rick Assessment Methods in Nuclear Regulatory Activities; Proposed Policy Statement," Federal Register. Vol. 59, no. 235, 63389.

9 Bertram-Howery, S.G., M.G. Marietta, R.P. Rechard, P.N. Swift, D.R. Anderson, B.L. Baker, J.E. Bean, Jr., W. Beyeler, K.F. Brinster, R.V. Guzowski, J.C. Helton, R.D. McCurley, D.K. Rudeen, J.D. Schreiber, and P. Vaughn. 1990b. "Appendix D: Response to Review Comments," Preliminary Comparison with 40 CFR Part 191, Subpart B for the Waste Isolation Pilot Plant, December 1990. SAND90-2347. Albuquerque, NM: Sandia National Laboratories. D-1 through D-13. 


\subsubsection{Multiple Iterations: a Performance Assessment Strategy}

The strategy of conducting sequential performance assessment (PA) iterations (see Figure 1.1-2) is beneficial because each iteration provides enhanced information about the disposal system in precisely those areas where it is required. Initially, available data and supplementary information are used to develop preliminary scenarios. These are analyzed with simple models and produce preliminary results, which may be but simple bounding values. If these initial results are either indefensible or indecisive, better data, more complete conceptual models, and more realistic computational models are sought and used in subsequent calculations. By repeating this process iteratively, engineers and scientists can replace weak links in the simulation chain and, eventually, devise defensible, definitive calculations on which intelligent decisions about radioactive waste disposal at the Waste Isolation Pilot Plant (WIPP) can be made.

In addition to assuring the overall goal of producing defensible calculations, multiple PA iterations achieve six other goals, as follows:

- The analysis team focuses on the expectations to both the customer (purchasers of PA, i.e., the Department of Energy [DOE]), regulators (e.g., Environmental Protection Agency), and the stakeholders (agencies and individuals with internal and possible desire to impact PA). Moreover, the customers, regulators, and stakeholders can become involved in the PA process. These iterative interactions facilitate decisions that must be made by more than one person or agency over long periods of time, e.g., nuclear waste disposal decisions.

- Because different performance hypotheses can be tested, analysts develop insight as to the behavior of the disposal system.

- Through periodic peer reviews, analysts receive invaluable scientific feedback that can provide new approaches, and insights, as well as new interactions for multidisciplinary teams.

- In instances where critical questions can be posed, early analyses can sometimes be partially validated in later iterations based on more advanced models or newly collected data.

- Through sensitivity analyses on the results of simplified preliminary systems, project managers and the participants can decide intelligently how best to allocate resources for supplementary data collection and whether models should be elaborated or simplified.

- The WIPP PA, which is a large, long-term project, can be divided into several smaller parts, each with more easily agreed upon constraints and schedules. The PA becomes a series of smaller projects repeated and refined several times-a useful technique, providing a quality product.

\section{References}

1 Marietta, M.G., S.G. Bertram-Howery, D.R. Anderson, K.F. Brinster, R.V. Guzowski, H. Iuzzolino, and R.P. Rechard. 1989. Performance Assessment Methodology Demonstration: Methodology Development for Evaluating Compliance with EPA 40 CFR 191, Subpart B, for the Waste Isolation Pilot Plant. SAND89-2027. Albuquerque, NM: Sandia National Laboratories.

2 Marietta, M.G., S.G. Bertram-Howery. R.P. Rechard, and D.R. Anderson. 1991. "Status of WIPP Compliance with EPA 40 CFR 191, December 1990." High Level Radioactive Waste Management. Proceedings of the Second Annual International Conference, Las Vegas, NV, April 28-May 3, 1991 SAND90-2424C. La Grange Park, IL: American Nuclear Society, Inc.; New York, NY: American Society of Civil Engineers. Vol. 2, 1181-1188.

3 WIPP PA (Performance Assessment) Department. 1992/1993. Preliminary Performance Assessment for the Waste Isolation Pilot Plant, December 1992. SAND92-0700/1,2,3,4,5. Albuquerque, NM: Sandia National Laboratories. Vols. 1-5.

4 WIPP PA (Performance Assessment) Division. 1991. Preliminary Comparison with 40 CFR Part 191, Subpart B for the Waste Isolation Pilot Plant, December 1991. SAND91-0893/1,2,3,4. Albuquerque, NM: Sandia National Laboratories. Vols. 1-4.

5 Rechard, R.P., D.K. Rudeen, and P.J. Roache. 1992a. Quality Assurance Procedures for Analyses and Report Reviews Supporting Performance Assessments of the Waste Isolation Pilot Plant. SAND91-0428. Albuquerque, NM: Sandia National Laboratories.

* Sandia's PA Department performed annual iterative PAs of the WIPP from 1989 through $1992 .^{1-4}$ Along with the iterative PAs, the DOE intended to perform in situ experiments on actual waste at the WIPP. However, circumstances associated with the in situ experiments caused the DOE to decide in October 1993 to (1) eliminate in situ experiments at the WIPP, (2) perform any necessary experiments with waste above ground away from the WIPP, and (3) implement an accelerated regulatory compliance program that included preparing a draft application for certifying compliance of the WIPP as a means to begin discussions with the Environmental Protection Agency (EPA) (see Section 1.5.1, Timeline of Events for the WIPP Project). The latter decision required the curtailment of the annual PAs performed by Sandia. 


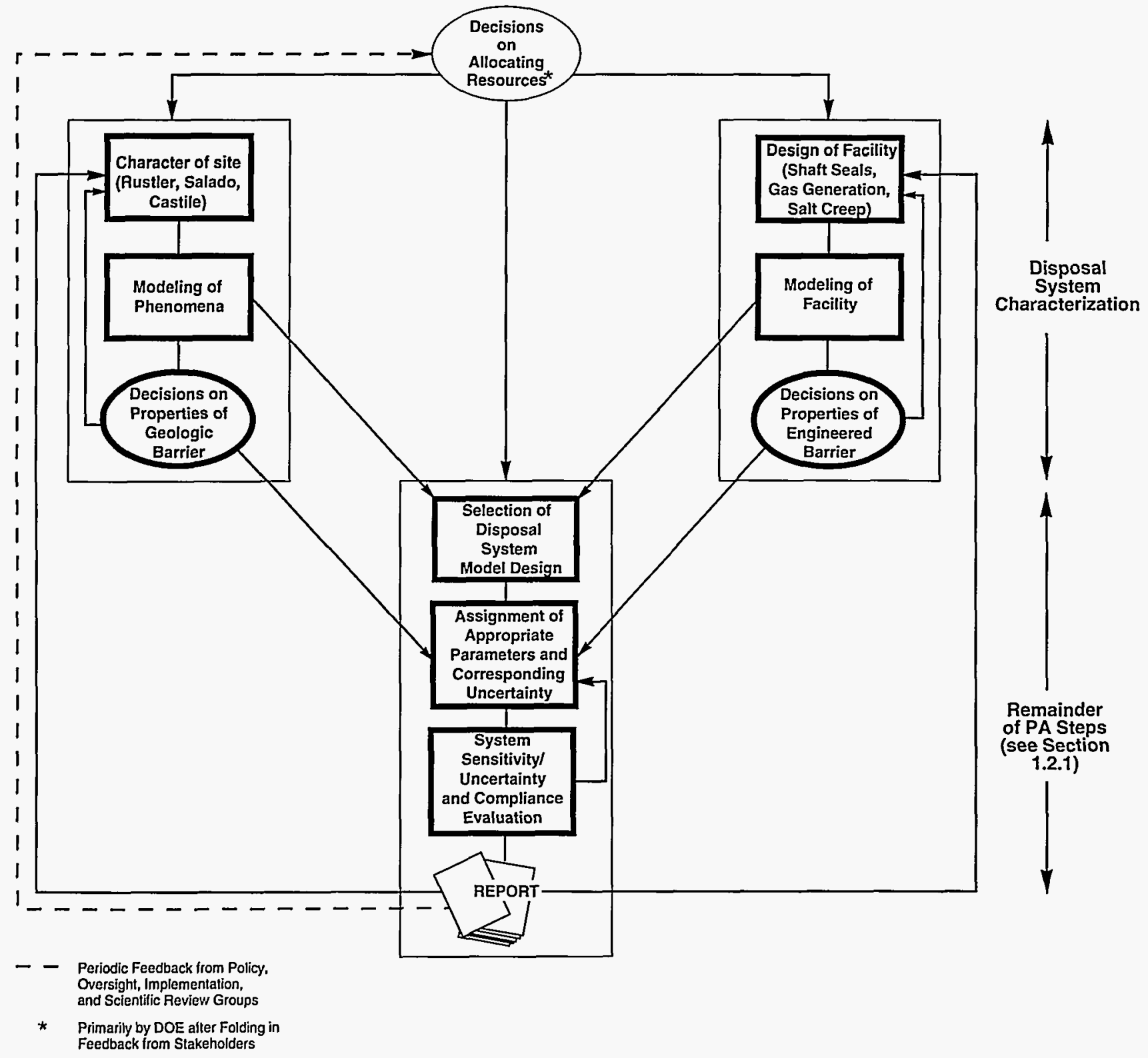

TRI-6334-23-2-a

Figure 1.1-2. Multiple performance assessment iterations. In addition to clarifying general issues to groups outside Sandia, multiple iterations of performance assessments can help develop scientific consensus on issues important to the performance assessment. Feedback to investigators performing disposal-system characterization is shown as an example. (Rechard et al., 1992a, Figure 1-2). 5 
1.0 Introduction 


\subsection{The Six Principal Steps of Performance Assessment}

In this report, performance assessments (PAs) are subdivided into six principal steps, ${ }^{1,2}$ as follows:

1. Disposal-system and regional characterization entails data collection on waste properties, facility design, regional geology, and regional hydrology.

2. Scenario development identifies and selects features, events, and processes that collectively comprise the scenarios, $S_{j}(x)$, through which contaminants might be released to the "accessible environment" as defined by the Environmental Protection Agency. It provides guidance for subsequent model development.

3. Probability estimation models likelihoods that the various scenarios will occur, $P\left(\mathbf{x}, S_{j}(\mathbf{x})\right)$.

4. Consequence analysis including uncertainty propagation calculates the potential amounts of contaminants that might be released for a given scenario, $C\left(\mathbf{x}, S_{j}(\mathbf{x})\right)$, and includes the quantitative evaluation of uncertainties associated with those predictions.

5. Long-term regulatory compliance assessment involves the construction of CCDFs and other performance and uncertainty metrics and their comparisons with the relevant long-term environmental regulations.

6. Sensitivity analysis determines the individual parameters and model forms that most influence performance metrics and thereby provides guidance to WIPP project managers on where to direct resources to further evaluate uncertainty of the parameters.

The first two performance assessment steps (see Chapters 2.0 and 3.0) are referred to collectively as "model conceptualization" in this report. The third step, probability estimation, evaluates the probability of occurrence of the various scenarios and includes the uncertainty in some of the system parameters (e.g., exploratory drilling for resources [human intrusion]) (see Chapter 4.0, Probability Estimation).

The fourth step, consequence analysis, consists of simulating the relevant physical, chemical, biological, geological, and climatological processes that could influence repository performance (see Chapter 5.0, Consequence Analysis). It is important to understand that it would take too long and cost too much to build and run a single, three-dimensional, system model that would represent the Waste Isolation Pilot Plant (WIPP) in sufficient detail to simulate all the events and processes that affect its performance. Consequently, a suite of interconnecting submodels is used as the system model. Each submodel simulates one of the WIPP's principal physical components. A "consequence model" is, thus, not a single model, but a suite of many submodels that interface through CAMCON. This so-called "modular" approach to consequence modeling is well suited to model development and refinement. To treat parameter uncertainty, system parameters are sampled probabilistically, and the model is exercised many times over to yield a suite of realizations illustrating the possible performance of the system.

The fifth step involves calculation of performance metrics such as cumulative release over $10,000 \mathrm{yr}$, or individual dose. Metrics are evaluated and compared to established regulatory performance criteria (see Chapter 6.0, Long-Term Regulatory Assessment).

In the final step, sensitivity analysis, the quantitative systemic effect of externally imposed variations in selected individual parameters $\left(x_{n}\right)$ is assessed in terms of predicted consequences or the probabilities of their occurrence (see Chapter 7.0, Sensitivity/Uncertainty Analysis).

The following subsections describe the general component of the six steps and then introduce several underlying concepts of PAs.

\section{References}

1 Rechard, R.P. 1993. "Introduction," Initial Performance Assessment of the Disposal of Spent Nuclear Fuel and High-Level Waste Stored at Idaho National Engineering Laboratory. Volume 1: Methodology and Results. Ed. R.P. Rechard. SAND93-2330/1. Albuquerque, NM: Sandia National Laboratories. 1-1 through 1-20.

2 Rechard, R.P. 1989. Review and Discussion of Code Linkage and Data Flow in Nuclear Waste Compliance Assessments. SAND87-2833. Albuquerque, NM: Sandia National Laboratories. 


\subsubsection{Components of the Six Performance Assessment Steps}

Figure 1.2-1 displays the various components (shown as boxes) of the six performance assessment (PA) steps and the flow of information through these components. The information flow is normally sequential and usually follows the general order shown. However, in part because of the modular nature of the PA system and in part because of its exercise through multiple iterations, system characterization and the development of scenarios, probability models, and consequence models can occur concurrently with consequence modeling. The system is modular and dynamic, and development is an ongoing process. One component of the probability modeling step, estimates of probability, is normally postponed and calculated concurrently with the construction of performance metrics (complementary cumulative distribution function) during the regulatory assessment step.

Although the location and flow of information is generally as depicted in Figure 1.2-1, it is important to realize that discrete boxes were selected more for illustrative purposes than for their absolute accuracy in representing PA organizational subdivisions and the flow of information. In fact, the boundaries between many of the subdivisions are fuzzy, and subareas can overlap to a great extent. For example, gathering new input data might be categorized equally well as site characterization or model parameter compilation. Moreover, the distribution of tasks among the depicted components is not unique, in part because the process of performing the specific tasks is more continuous than discrete. Despite its inherent deficiencies, the figure remains a useful tool in describing the complex operational nature of the PA process.

Note that the bottom-most box of Figure 1.2-1 is connected via an upward-pointing arrow to the topmost boxes, suggesting the iterative nature of the PA process. Iterative refinement is not confined to the entire PA (once per year between 1989 and 1992), but it may occur more frequently over many of the subprocesses. ${ }^{1}$ For example, inner iterations frequently occur during disposal system characterizations. A particularly important "inner" iteration is the appropriate assignment of parameters and uncertainties to fit the scale and detail of the models chosen for the PA analysis, given the facility design and knowledge of the character of the site (see Chapter 3.0, Scenario Development).

The individual components shown in Figure 1.2-1 are discussed in greater detail in subsections of this report. The figure is repeated at the beginning of each chapter and the components treated in that chapter are highlighted in boldface.

\section{Reference}

1 Morgan, M.G., M. Henrion, and M. Small. 1990. Uncertainty: A Guide to Dealing with Uncertainty in Quantitative Risk and Policy Analysis. New York, NY: Cambridge University Press. 


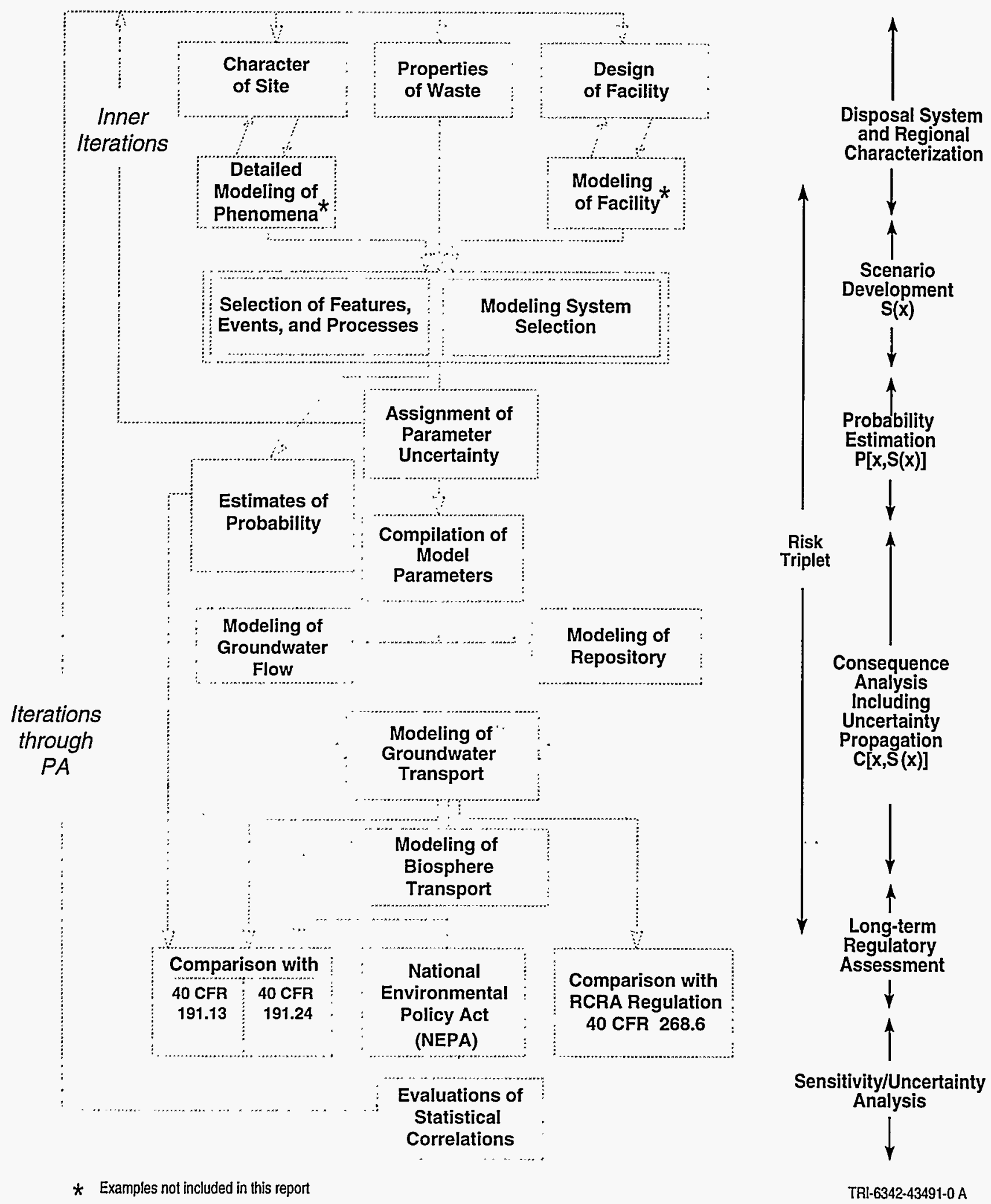

Figure 1.2-1. Components of the six general steps of a performance assessment. 


\subsubsection{Performance Assessment as an Ordered Triplet}

A revealing description of the performance assessment (PA) task (see Figure 1.1-2) arises if the riskbased performance criteria of the Containment Requirements in 40 CFR 191 (see Section 6.1.3, Containment Requirements) are viewed as a set of ordered triplets, each triplet consisting of answers to the following three questions ${ }^{1-3}$ :

- What can happen? [hereafter called scenarios, $S_{j}(\mathrm{x})$, where $\left.j=1,2, \ldots, n S\right]$.

- How likely are these things to happen? (probabilities of scenarios, $\left(P\left[\mathrm{x}, S_{j}(\mathrm{x})\right]\right)$.'

- What are the outcomes of these happenings? (consequences of scennarios, $C\left[\mathrm{x}, S_{j}(\mathrm{x})\right]$ ), where $\mathrm{x}$ represents all the numerical parameters required to quantify the applied model, and $n S$ is the number of scenarios to be included.

The first question is answered via the scenario development process (see Chapter 3.0). Part of scenario development consists of selecting features, events, and processes from a general list to create a set of plausible occurrences that specify what might happen to the disposal system in the future. These are denoted $S_{j}(\mathrm{x})$, where $j=1,2, \ldots, n S$. The second question requires a modeling system capable of estimating the probability $P\left[\mathrm{x}, S_{j}(\mathrm{x})\right]$ that the $j$ th scenario will occur. The third question requires several modeling systems capable of estimating the consequences of each of the $n S$ scenarios, $C\left[\mathrm{x}, S_{j}(\mathrm{x})\right]^{*}$ (see Chapter 5.0, Consequence Analysis). For a given scenario, a complementary cumulative distribution function (CCDF) displays as a single curve the second and third elements, that is, the consequence and the probability of that consequence occurring [see Section 6.1, Environmental Protection Agency 40 CFR 191 Simulations, and Section 1.3.1, Propagating Uncertain Parameters (Epistemic Uncertainty) through Consequence Models]. For $n S$ scenarios, there will be $n S$ CCDF curves. Uncertainty in the calculation of the CCDF can arise from uncertainty in any of the three elements of the triplet (scenario selection, probability model form, consequence model form) or in the underlying numerical parameters characterizing the system $\left(x=x_{1}, \ldots\right.$, $x_{n V}$, where $n V$ is the total number of parameters required). ${ }^{* *}$ Evaluations of predictive uncertainty that cannot be derived quantitatively may be derived qualitatively by expert judgment (see Section 4.1, Assigning Parameter Uncertainties).

\section{References}

1 Kaplan, S., and B.J. Garrick. 1981. "On the Quantitative Definition of Risk," Risk Analysis. Vol. 1, no. 1, 11-27.

2 Helton, J.C. 1993a. "Risk, Uncertainty in Risk, and the EPA Release Limits for Radioactive Waste Disposal," Nuclear Technology. SAND91-1255J. Vol. 101, no. 1, 18-39.

3 Helton, J.C., M.G. Marietta, and R.P. Rechard. 1993a. "Conceptual Structure of Performance Assessments Conducted for the Waste Isolation Pilot Plant," Scientific Basis for Nuclear Waste Management XVI, Materials Research Society Symposium Proceedings, Boston, MA, November 30-December 4, 1992 Eds. C.G. Interrante and R.T. Pabalan. SAND92-2285C. Pittsburgh, PA: Materials Research Society. Vol. 294, 885-898.

\footnotetext{
* In evaluating compliance, a suite of $n S$ consequences, $C\left[x, S_{j}(\mathrm{x})\right]$, where $j=1,2, \ldots, n S$, is produced, one for each scenario. These may then be combined into a single performance metric, denoted $R$ (see Section 6.1, Environmental Protection Agency 40 CFR 191 Simulations and Figure 1.1-2).

** The transition from three parts of stochastic simulation to the three components of the PA triplet is discussed in Section 1.2.3. See also Section 8.1, Concise Review of the Six-Step Performance Assessment Process.
} 


\section{Risk Triplet}

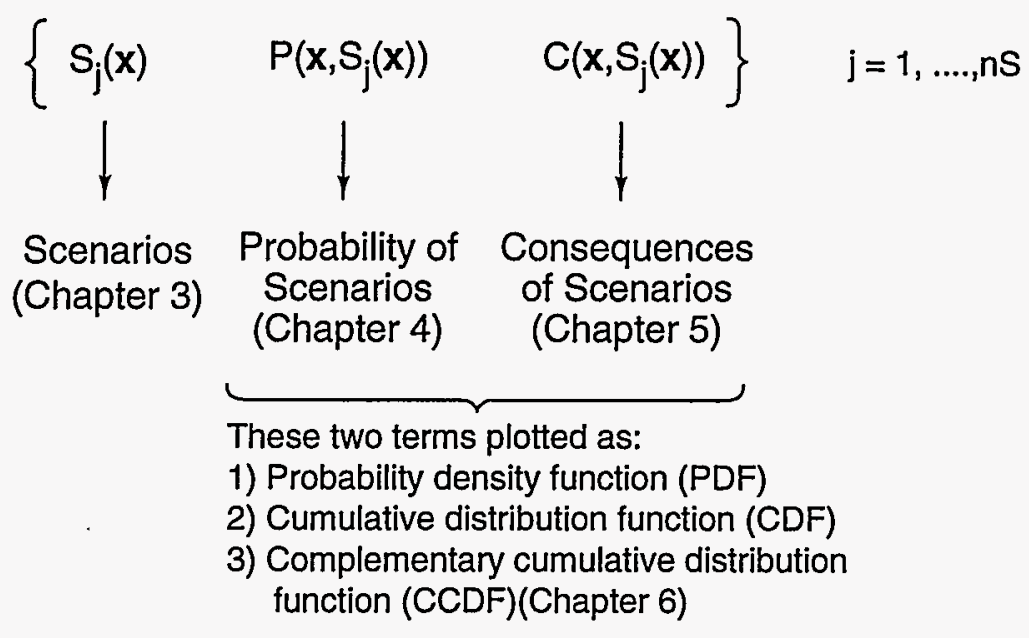

TRI-6342-4332-0

Figure 1.2-2. The ordered triplet of a performance assessment. 


\subsubsection{Stochastic Simulations}

Three elements are required to evaluate the statistical properties of the outcomes of a model (a stochastic simulation). I They are (1) a parameter space, $D_{n w}$, for a model composed of $n V$ parameters, (2) a joint probability distribution for the uncertain parameters, $F(x)$, and a complete system model, $C$ (see Section 1.2.4, Model Development). For parameters that are statistically independent, the joint probability distribution is equivalent to the product of the probability distributions of the individual parameters $F(x)=$ $F_{1}\left(x_{1}\right) \bullet F_{2}\left(x_{2}\right) \bullet \ldots \bullet F_{n V}\left(x_{n V}\right)$ (Figure 1.2-3).

Usually for the practical application of stochastic simulation for a large structured probabilistic analysis, several steps are made to arrive at a risk triplet (as described in Section 1.1.2). First, the parameter space, $D_{n} \gamma$, is divided into disjoint sets that form scenarios-i.e., a scenario space (see Chapter 3.0). The partition of the parameter space, $D_{n \nu}$, into scenarios is somewhat arbitrary and depends on the purposes of the analysis. Ideally, those parameters whose variability can be classified epistemic (related to precision of knowledge) and thus describable by a distribution remain in the parameter space." [Those parameters that are aleatoric (related to chance) describe chance features or events, such as an inadvertent human intrusion, and can be used to define individual scenarios]. For the partition of the parameter space to be practical, the probability of each disjoint occurring set must be calculable by a probability model, $P$, which is devised in the second step. The description of the distributions of the parameters remaining in the parameter space is also part of the second step. (The description of the distribution is usually through a subjective probability model, see Section 4.1). The third step is to evaluate the distribution of the results, $C\left[x, S_{j}(x)\right]$, from the complete system model, $C$. The most common way is through random sampling (see Section 1.3). This information is then displayed as a complementary cumulative distribution function (CCDF) (see Section 1.3.1).

Although identical in theory, any structured probabilistic analysis can differ in the emphasis and assumptions made in the three simplifying steps described above. A probabilistic risk assessment (PRA) for a nuclear power plant and a performance assessment (PA) for a nuclear waste repository demonstrate the different emphasis possible. ${ }^{* *}$ To elaborate, in a PRA many events can be postulated from numerous phenomena that are threaded together in event tree that forms scenarios. The probability of the phenomena is often evaluated through a large fault tree that because the failure phenomena are short-term events (i.e., the duration of the phenomena in relation to the regulatory period of $40 \mathrm{yr}$ is very short), and measured failure rates of components are often available. Consequences of the most probable events are then modeled, often using extensive empirical data that can substitute for mechanistic models. In a PA, the event tree is simpler. The event tree defining the few scenarios is often related to unknown human or geologic behavior far in the future, thus, their probability of occurrence is evaluated with simple analytic functions. Fault trees are usually not used because the phenomena of most interest, possible change of the initially stable environment of the repository, occur over geologic time scales of the same relative duration as the regulatory period (10,000 yr or longer). The consequences of the various phenomena are evaluated directly in often complex, mechanistic models that involve wide uncertainty because direct observation of the phenomena of interest cannot be obtained over the time scales of interest.

\section{References}

1 Tierney, M.S. 1993. "PA Methodology Overview," Initial Performance Assessment of the Disposal of Spent Nuclear Fuel and High-Level Waste Stored at Idaho National Engineering Laboratory. Volume 1: Methodology and Results. Ed. R.P. Rechard. SAND93-2330/1. Albuquerque, NM: Sandia National Laboratories. 3-1 through 3-28.

2 Chernoff, H., and L.E. Moses. 1959. Elementary Decision Theory. New York, NY: John Wiley \& Sons, Inc.

\footnotetext{
* The reader should realize that although the differences between these two categories can be subtle and that the classification of some model parameters may be somewhat nebulous, the distinction has been recognized and used in the scientific community for many years (e.g., see Chernoff and Moses, 1959, p.1) ${ }^{2}$

** Herein, a PRA refers to a system composed solely of human-engineered components and performance criteria that include risk to health over a short time (e.g., human lifetime) relative to geologic time. Whereas, a PA refers to a system composed of both natural and engineered components that include performance measures such as dose to individuals or cumulative releases over geologic time.
} 
Stochastic simulation consists of three components.
For PA or PRA, three steps are made to arrive at risk triplet $\left\{S_{j}[x], P\left[x, S_{j}(x)\right], C\left[x, S_{j}(x)\right]\right\}$ (see \$1,2,2).
Differences in system and corresponding time scale account for the differences in emphasis of the above three steps in a

PA or PRA.

1. Parameter space of model, $D_{n v}$ (see Chapter 3).

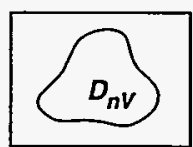

2. Joint probability density function, $F(x)$ where

$F(x)=F_{1}\left(x_{1}\right) \cdot F_{2}\left(x_{2}\right) \ldots \ldots F_{n v}\left(x_{n v}\right)$ (see Chapter 4).

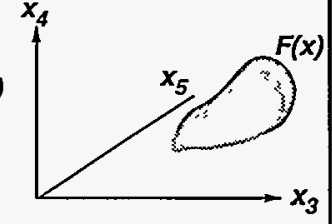

3. Model of complete system, $C$ (see Chapter 5).

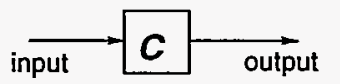

1. Divide parameter space into subsets (scenarios) (see § 3.2).
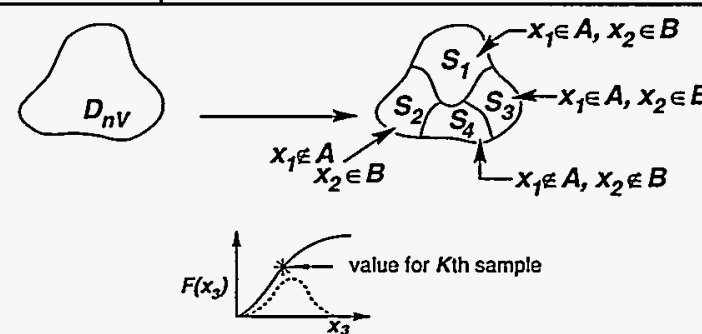

2a Assuming the components of $F(x)$ are independent, take random samples of each individual distribution e.g., $\left[F_{n V}\left(X_{n v}\right)\right]$ (see $\left.\S 4.1\right)$.
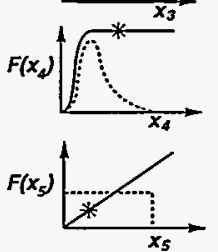

$2 \mathrm{~b}$ Develop and evaluate probability models of scenarios (see §4.3).

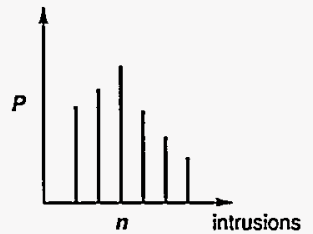

3. Run complete system mode using parameters for scenarios $S_{1}, S_{2} \ldots$.. (subsets of $D_{n v}$ ) (see § 1.3.1 and Chapter 5).

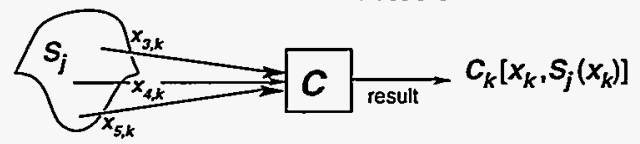

For PA, usually

1. Not many scenarios, $s_{j}$

2. Probability model, $P$, composed of simple analytic functions

3. Model, $C$, incorporates many physical phenomena of gradual change of system.
For PRA, for nuclear reactor study, often

1. Many scenarios, $S_{j}$

2. Probability model, $P$, can be evaluated by fault trees

3. Model, $C$, incorporates much empirical evidence from operation of facility (e.g., pump failure rates)

TRI-6342-4354-0

Figure 1.2-3. Three components of a stochastic simulation and their translation into the ordered triplet of a WIPP performance assessment, with comparison to a probabilistic risk assessment of a nuclear reactor. 


\subsubsection{Model Development}

As previously stated, performance assessments (PAs) are designed to determine whether a system meets a set of performance criteria. Because the Waste Isolation Pilot Plant's (WIPP's) performance criteria must be applied over a 10,000-yr period, it is necessary to apply them to a model of the system, not the system itself. Hence, the process of performing a PA is intimately tied to the process of building models. Obviously, that model must be capable of representing the "real-world" disposal system in those aspects that pertain vitally to waste-disposal performance. Model development normally occurs in several steps (see Figure 1.2-2), and uncertainties are generated at each step. ${ }^{1,2}$ For example, there is scientific uncertainty associated with model selection and degree of simplification. ${ }^{*}$ Four principal model types are recognized, as follows.

A conceptual model is the set of hypotheses and assumptions about the physical characteristics of a system (e.g., aquifer structure, boundaries, or boundary types) and the phenomena that ensue there (e.g., single-porosity darcy flow) that describe, in terms of scientific postulates, the behavior of pertinent aspects of that system. A diagram that represents the geology of a region as simplified stratigraphy or a paragraph of text that describes a phenomenon are examples of conceptual models. For WIPP PAs, conceptual models provide the foundation for subsequent model-development steps.

A mathematical model is the mathematical description of the conceptual model. It might include algebraic, ordinary differential, partial differential, or integral equations characterizing accepted conservation laws (e.g., conservation of mass, energy, or momentum) as well as appropriate constitutive equations that describe material behavior in the domain of the conceptual model. These equations are augmented by boundary and initial conditions of the dependent variables.

A computational model is the solution and implementation of the mathematical model. The solution be analytical, numerical, or empirical. Analytical solutions are, in principle, possible, but in the WIPP, they are rare. Empirical models use data directly by means of lookup tables or statistical relationships and are normally used to propagate information into data-sparse regions between discrete points where observational data are available. In the WIPP, solutions are almost universally implemented via numerical techniques on computers and consequently the computational models are often called computer or numerical models.

An applied model is the analyst's application of a computational model to a particular system using appropriate values. Computational models are generic by nature. They cannot be used until all parameter values, boundary values, initial values, and discretizations of time and space have been specified. The solutions they provide apply only to particular values used. For the WIPP, the system in question is the WIPP waste disposal site, and the applied models are sometimes referred to as site-specific models.

\section{References}

1 Bear, J., and A. Verruijt. 1987. Modeling Groundwater Flow and Pollution: With Computer Programs for Sample Cases. Dordrecht, Holland: D. Reidel Publishing Company.

2 Rechard, R.P., D.K. Rudeen, and P.J. Roache. 1992a. Quality Assurance Procedures for Analyses and Report Reviews Supporting Performance Assessments of the Waste Isolation Pilot Plant. SAND91-0428. Albuquerque, NM: Sandia National Laboratories.

* Alternatives in model form may exist at each stage of model development. Alternatives at the first stage of model development (alternative conceptual models) are often of greatest concern. Specifically, alternative conceptual models are multiple working sets of hypotheses and assumptions of a system that are all scientifically acceptable (i.e., consistent with the purpose of the model, with one another, and in agreement with existing facts and observations).

Verification of a (computational) model is the process of assuring that model appropriately solves and implements the mathematical model. In other words, model verification is the process of illustrating that the mathematical model is being solved appropriately.

The assumptions underlying the model system should also be validated using system-specific data (see "applied model" above). The validation of an applied model is the ongoing process of assuring that corresponding conceptual, mathematical, computational, and applied models describe the given "real-world" system with sufficient validity and soundness, consistent with the purposes of the model. 


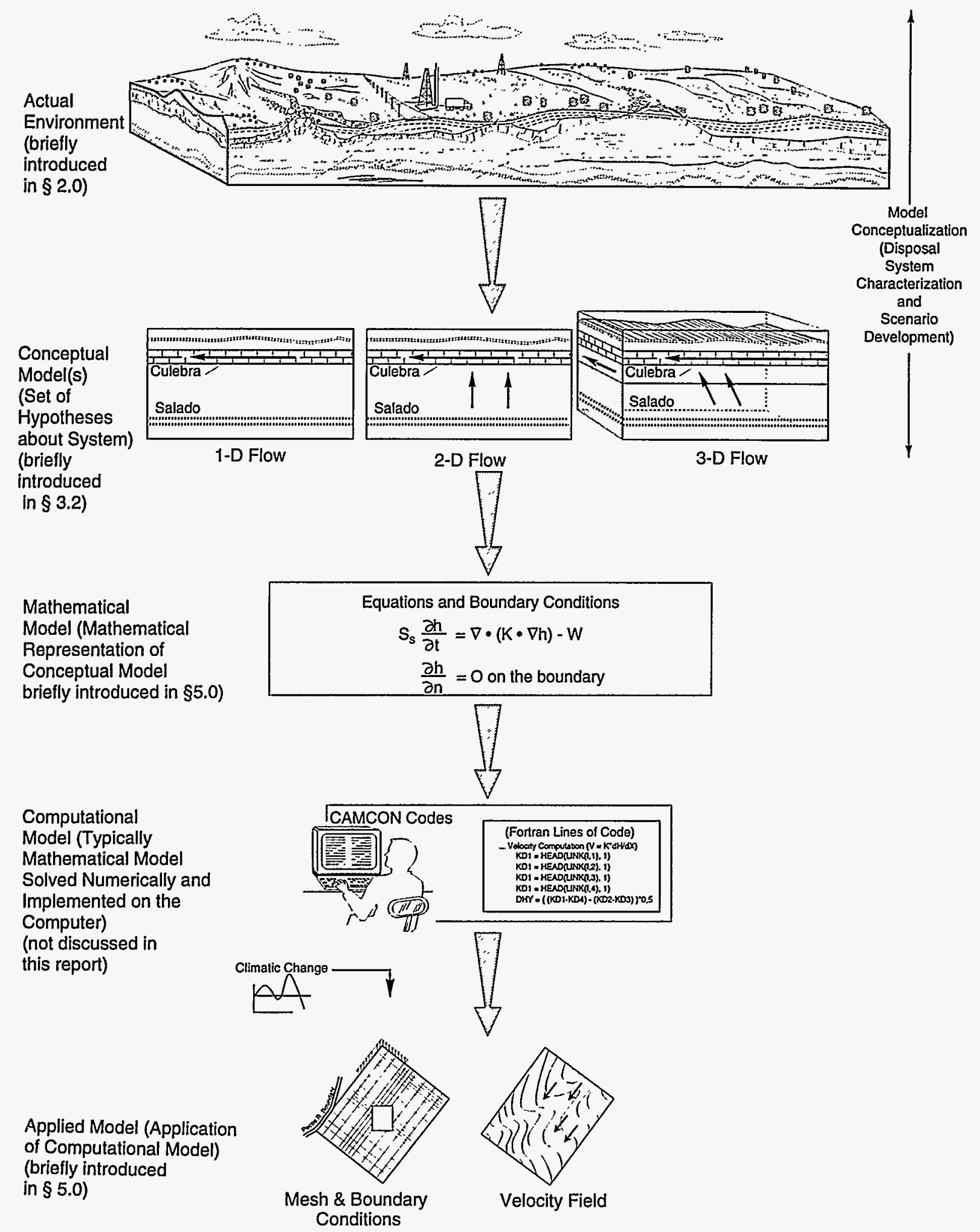

TRI-6342-3908-0

Figure 1.2-4. Hierarchy of model development selection of features, events, and processes to include and corresponding methods of modeling (i.e., selection of form of model[s]) (after Rechard et al., 1992a, Figure 1-6). ${ }^{2}$ 
1.0 Introduction 


\subsection{Types of Uncertainty in Performance Assessments}

Three major sources of uncertainty arise in performance assessments (PAs) of geologic disposal systems. They are (1) parameter uncertainty, that is, uncertainty in the parameters of an applied model (where a "parameter" is an underlying fundamental entity (e.g., number) required by an applied model, whereas "data" are the information collected in the field or elsewhere, organized, and used in preparing parameter values); (2) scenario uncertainty, that is, uncertainty as to the most appropriate features, events, and processes to include in scenarios and the most appropriate way to group the features, events, and processes for modeling; and (3) model form uncertainty, that is, uncertainty about the hypotheses and the appropriate model forms and, of course, uncertainty regarding the adequacy of model verification and validation (where developing alternative conceptual models is an effective way to acknowledge and quantify model form uncertainty).

These three sources of uncertainty are related. Occasionally, data are used directly as model parameters. However, in most situations, data must be transformed so as to convey necessary meaning (e.g., "data reduction"), which, in turn, requires a model. Conversely, model uncertainty can result from sparse data or dearth of information to corroborate or refute alternative models. Hence, model uncertainty can affect parameter uncertainty and vice versa.

Parameter uncertainty and scenario uncertainty are also closely related because, as noted in Section 1.1.2, Multiple Iterations: a Performance Assessment Strategy, scenarios may be thought of as partitions of the set of all model parameters. Finally, scenario uncertainty and model uncertainty are related through uncertainty that all impartial contributions to behavior of a system have been included. This "completeness uncertainty" cannot be quantified but only acknowledged and evaluated through expert judgment and peer review.

The following are techniques for controlling* and/or evaluating the influence of uncertainty:

Type of Uncertainty

Parameter values and variability

Scenarios (completeness, logic, and probabilities)

Model form
Technique for Controlling or Evaluating

Data collection programs; parameter selection guidelines; sensitivity/uncertainty analysis ${ }^{2}$

Expert judgment and peer review 1

Expert judgment and peer review, ${ }_{1}^{1}$ sensitivity/uncertainty analysis, ${ }^{2}$ verification and validation ${ }^{3}$

Model-form uncertainty was introduced in Section 1.2.4, Model Development. Sections 1.3.1 and 1.3.2 introduce methods for evaluating the influence of uncertainty from parameter and scenario variability on a modeling system. Section 1.3.3 discusses the quality assurance procedures developed for the preliminary PA calculations. Because uncertainty is pervasive throughout the PA process, only a few facets of uncertainty can be discussed in these three subsections. Other facets of uncertainty will be discussed elsewhere (see Chapters 3.0 and 4.0 ).

\section{References ${ }^{\star *}$}

1 Rechard, R.P., K.M. Trauth, and R.V. Guzowski. 1992b.Quality Assurance Procedures for Parameter Selection and Use of Expert Panels Supporting Performance Assessments of the Waste Isolation Pilot Plant. SAND910429. Albuquerque, NM: Sandia National Laboratories.

2 Rechard, R.P., D.K. Rudeen, and P.J. Roache. 1992a. Quality Assurance Procedures for Analyses and Report Reviews Supporting Performance Assessments of the Waste Isolation Pilot Plant. SAND91-0428. Albuquerque, NM: Sandia National Laboratories.

3 Rechard, R.P., P.J, Roache, R.L. Blaine, A.P. Gilkey, and D.K. Rudeen. 1991h. Quality Assurance Procedures for Computer Software Supporting Performance Assessments of the Waste Isolation Pilot Plant. SAND90-1240. Albuquerque, NM: Sandia National Laboratories.

* Ideally, initial uncertainty is largest and subsequent examination "reduces" it, but knowledge does not always progress in that fashion.

** Quality Assurance procedures undergo continual modifications. These reports represent the set of procedures developed in conjunction with the 1990, 1991, and 1992 PA calculations. 


\subsubsection{Propagating Uncertain Parameters (Epistemic Uncertainty) through Consequence Models}

Once highly or moderately uncertain parameters, $x_{n}$, have been selected and their uncertainties characterized as probability distributions (see Section 4.1.1, Characterizing Parameter Uncertainty), they must be propagated through the consequence models to determine the uncertainty they produce in the results. This process is termed uncertainty propagation. The Waste Isolation Pilot Plant (WIPP) Performance Assessment Department propagates uncertainty from underlying parameters (or uncertainties from scenarios, probability models, or consequence models that can be expressed as parameter uncertainties) through its deterministic computational models using a Monte Carlo technique ${ }^{1,2}$ (see Figure 1.3-1). A Monte Carlo technique was selected for the following six reasons ${ }^{3}$. (1) it easily propagates uncertainty through a sequence of linked models; (2) it produces a mapping of input to output that can be studied by a variety of standard statistical techniques (e.g., scatterplots, regression analysis); (3) it does not require an intermediate model that might smooth and obscure discontinuities or other transitions between regimes of behavior; (4) it does not require that deterministic computer models be modified; (5) it can include parameters with empirical or subjective distributions having wide ranges and discontinuities; and (6) it allows the uncertain parameters to be correlated.

Monte Carlo techniques are used as follows. First, a sample is generated from the specified distributions and correlations between uncertain parameters that vary $\mathrm{x}_{k}=\left(x_{1, k}, x_{2, k}, \ldots, x_{n V, k}\right) k=1, \ldots, n K$, where $n K$ is the size of the sample and $n V$ is the number of uncertain parameters. Then, the model calculation is performed $n K$ times using each sample element $x_{k}$, which yields a sequence of $n K$ results of the form $C\left(\mathrm{x}_{1}\right), C\left(\mathrm{x}_{2}\right), \ldots, C\left(\mathrm{x}_{n K}\right)$. These results can be plotted as one of several types of distribution function, namely a $\mathrm{PDF}^{*}$ a $\mathrm{CDF},{ }^{* *}$ or a $\mathrm{CCDF}{ }^{* * *}$ The latter two functions are more commonly used. In practice, Latin hypercube sampling ${ }^{4,5}$ (see Sections 4.2 .3 and 4.2.4) is used to minimize the number of sample elements needed to capture parameter variability adequately.

\section{References}

1 Hammersley, J.M., and D.C. Handscomb. 1954. Monte Carlo Methods. New York, NY: John Wiley \& Sons, Inc.

2 Ripley, B.D. 1987. Stochastic Simulation. New York, NY: John Wiley \& Sons, Inc.

3 Helton, J.C., J.W. Garner, R.D. McCurley, and D.K. Rudeen. 1991. Sensitivity Analysis Techniques and Results for Performance Assessment at the Waste Isolation Pilot Plant. SAND90-7103. Albuquerque, NM: Sandia National Laboratories.

4 McKay, M.D., R.J. Beckman, and W.J. Conover. 1979. "A Comparison of Three Methods for Selecting Values of Input Variables in the Analysis of Output from a Computer Code," Technometrics. Vol. 21, no. 2, 239-245.

5 Iman, R.L., and W.J. Conover. 1980a. "Small Sample Sensitivity Analysis Techniques for Computer Models, With an Application to Risk Assessment," Communications in Statistics. Vol. A9, no. 17, 1749-1842.

* A probability density function (PDF) is analogous to a mass density function in physics. Whereas a mass density function is integrated over volume to obtain the mass between the limits of integration, a probability density function is integrated over outcome to obtain the probability of an outcome between the limits of integration.

** A cumulative distribution function (CDF) is the sum (or integral, as appropriate) of the probability density over those values of a random variable that are less than or equal to a specified value, $C$, and represents the probability that an outcome of $C$ or less will occur.

*** A complementary cumulative distribution function (CCDF) is one minus the cumulative distribution function. It represents the probability of exceeding a consequence value of $C$. For the containment requirements in 40 CFR 191, the consequence value is the sum of all releases (normalized by the Environmental Protection Agency release limits) accumulated over 10,000 yr. 

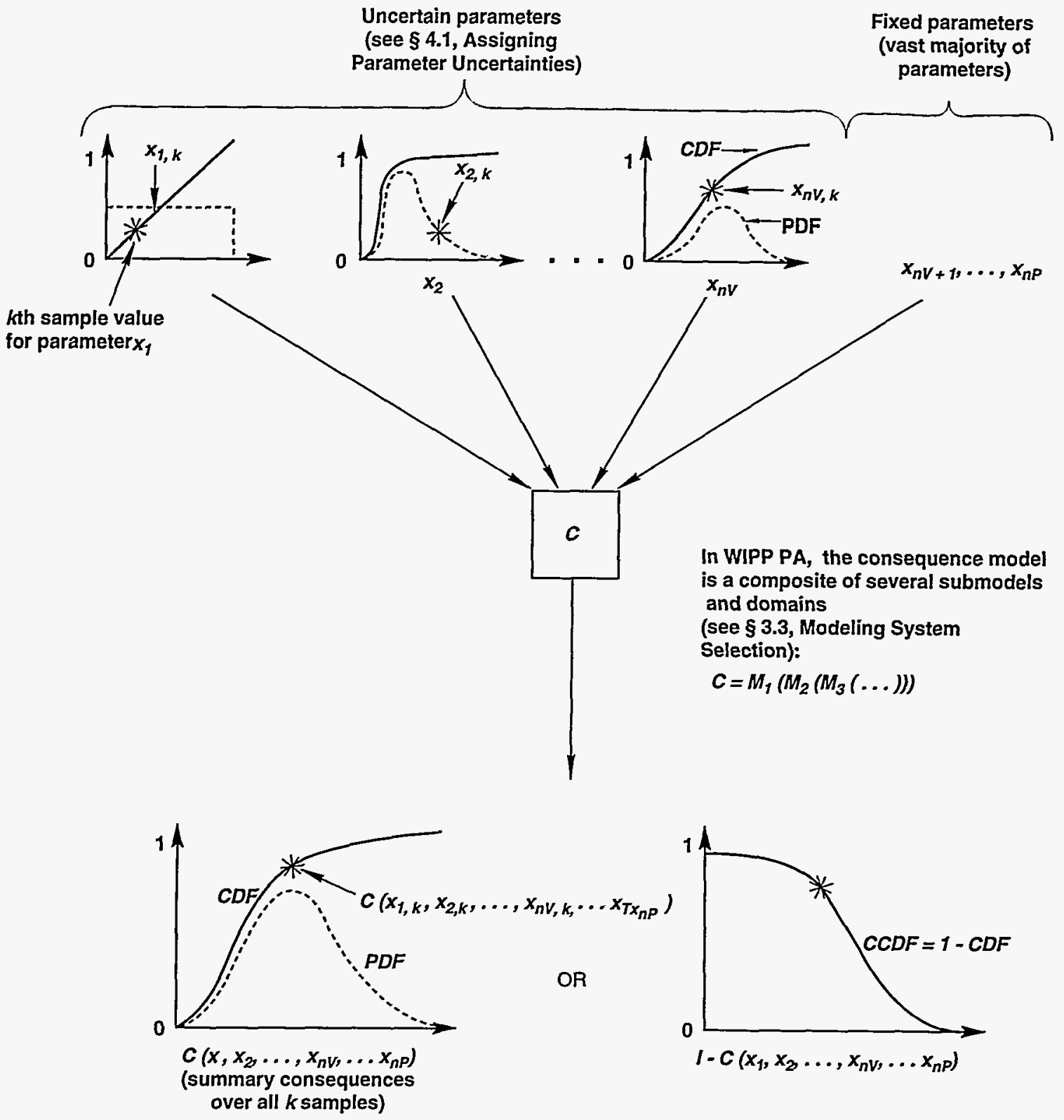
CDF (or CCDF) represents uncertainty in consequence value resulting from uncertainty in input parameters.

Figure 1.3-1. Monte Carlo analysis is used to propagate parameter uncertainty, that is, numerous sample sets of all the uncertain parameters are run through the deterministic consequence model, $C$, to define the distribution of the result. The $k$ th sample set, $x_{k}$, of the parameters and the deterministic result are shown as an example. 


\subsubsection{Propagating Aleatoric Uncertainty through Performance Assessment *}

How uncertainty is propagated through an entire performance assessment (PA) depends on the source of the uncertaintyl: (1) scenarios and form of consequence and probability models underlying the model and (2) parameters (refer to Section 1.3, Types of Uncertainty in Performance Assessments). Uncertainty in consequences arising from different scenarios is represented by differences in the complementary cumulative distribution functions resulting from each scenario (see Section 1.1.2, Multiple Iterations: a Performance Assessment Strategy, and Section 6.1, Environmental Protection Agency 40 CFR 191 Simulations). Uncertainty in parameters used by computational models is discussed in Section 1.3.1. If these two types of uncertainty $2^{* *}$ are described mathematically (and a Monte Carlo approach is assumed to propagate uncertainty), the following mathematical statement results and is depicted in Figure 1.3-2:

$$
\begin{aligned}
\operatorname{Risk}\left(x_{k}\right)= & \left(\left\{S_{j}\left[x_{k}\right], C\left[x_{k}, S_{j}\left(x_{k}\right)\right],\right.\right. \\
& \text { scenarios, consequences, probabilities }
\end{aligned}
$$

Uncertainty concerning completeness of physical processes included in the consequence model (e.g., inclusion of all significant process parameters) or the completeness of events and features (e.g., inclusion of all significant model parameters representing features) can be controlled only through a specially defined procedure or peer review; it cannot be "propagated." Uncertainty associated with the formation of the scenarios and the development of the form of models in the PA can be quantitatively evaluated through the use of alternatives (e.g., alternative conceptual or mathematical models of fluid flow and transport through fractures) (see Section 1.2.4, Model Development). Realistically, however, the number of alternatives examined in preliminary performance assessments is strongly dependent upon the number of model parameters declared as uncertain and hence requiring propagation through the models. Furthermore, examining alternatives associated with model form will be useful primarily during preliminary PAs. The final PA used for determining compliance will likely use only one model form thought to best capture the behavior of the disposal system.

\section{References}

I Helton, J.C., J.W. Garner, R.D. McCurley, and D.K. Rudeen. 1991. Sensitivity Analysis Techniques and Results for Performance Assessment at the Waste Isolation Pilot Plant. SAND90-7103. Albuquerque, NM: Sandia National Laboratories.

2 Chernoff, H., and L.E. Moses. 1959. Elementary Decision Theory. New York, NY: John Wiley \& Sons, Inc.

\footnotetext{
* Although important to discuss in the introductory chapter, this topic is easier to discuss after the overall PA process is somewhat understood. Section 8.1, Concise Review of the Six-Step Performance Assessment Process, provides a good starting point from which to observe (1) the propagation of uncertainty in a PA from parameters used to describe scenarios and thus represented by individual CCDFs and (2) the propagation of uncertainty in a PA from parameters in the computational models.
}

** Although this general division of uncertainty is somewhat nebulous, it has been recognized and accepted by the scientific community for many years (e.g., see Chernoff and Moses, 1959, p. 1). ${ }^{2}$ See also Section 4.1, Assigning Parameter Uncertainties. 
CCDF from 1st Monte Carlo sample
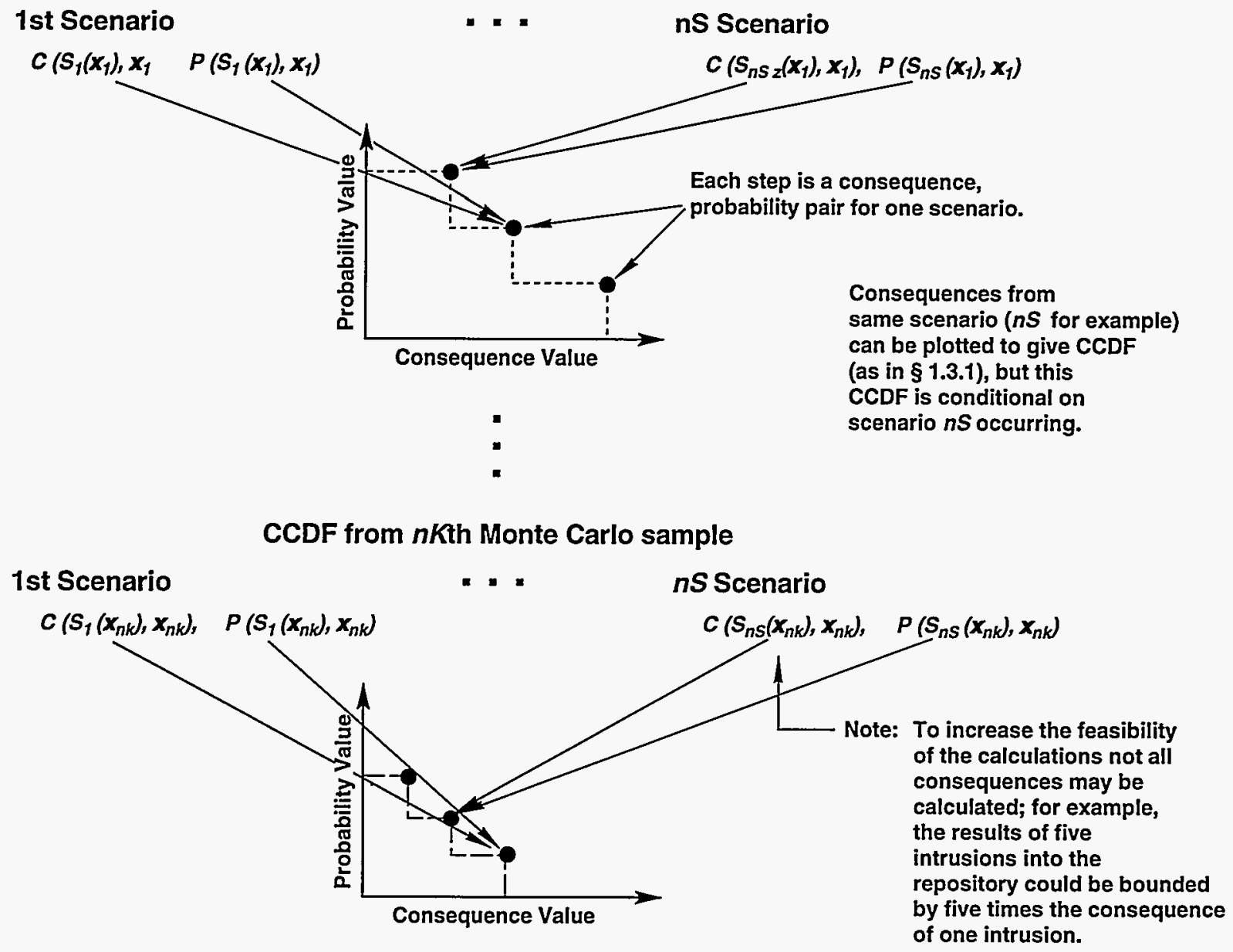

Plotting all CCDFs simultaneously shows quantifiable uncertainty from scenarios and parameters (model form uncertainty requires the same approach but simulations with an alternative model form, $C^{\prime}$ or $\left.P^{\prime}\right)$.

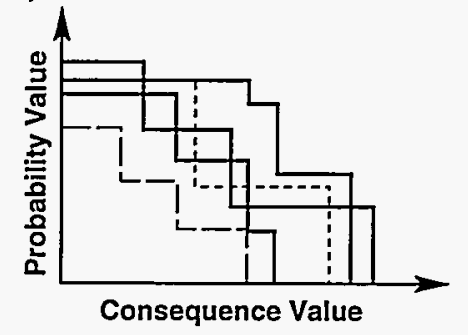

TRI-6342-4312-0

Figure 1.3-2. Propagating aleatoric uncertainty through performance assessment. 


\subsubsection{Quality Assurance Procedures for 1990-1992 Calculations}

Given the emphasis of this report on the mechanics of the performance assessment (PA) process, it is important to mention the concepts behind the procedures developed to provide a reasonable degree of assurance that the results from the PA process at that time presented a scientifically reliable view of the Waste Isolation Pilot Plant (WIPP) performance based on current knowledge and the explicitly identified sources of uncertainty. What follows is a description of the quality assurance (QA) procedures developed concurrently with the 1990-1992 PA calculations. The QA procedures provided assurance by specifying requirements in three primary areas of the analysis process: Parameter Selection, Software, and Analysis. These primary areas were distinct processes and usually involved different participants. The procedures also ensured quality in two other areas-Report Review and Expert Judgment Panels (Figure 3.3-3). These two subareas were not necessarily distinct from the primary areas because, for example, all three primary $\mathrm{QA}$ areas required reports followed by review. In addition, some personnel participating in the Parameter, Software, and Analysis QA areas were able to participate in documentation and/or Expert Judgment Panels. A brief introduction to the procedures is described below.

The Parameter QA procedures ${ }^{1}$ sought to provide the PA analyst with consistent computational model parameters. The fundamental requirement was the development of a secondary data base managed by a Secondary Data Base Task Leader who was responsible for selecting appropriate data in consultation with site Investigators and PA Analysts. Transferring data from experimental groups to the secondary data base was an important means by which the PA Analysts interacted with other groups within the WIPP Project. The Software QA procedures ${ }^{2}$ were designed to ensure that the software performed to meet the expectations of the PA Analyst. The fundamental requirement was the development of a Software Management System (the CAMCON Modeling System; see Section 3.3.4) directed by Software Sponsors who enter an assigned code into the system and serve as a point of contact for PA Analysts. The Analysis QA procedures established a framework for the analysis so that the results presented a scientifically acceptable view of the WIPP performance based on current knowledge. The fundamental requirement was the division of the PA analysis into small tasks followed by peer review. The Expert Judgment Panel QA procedures ${ }^{1}$ were intended to ensure that as much observation data as possible supported the judgment and that as much rigor as possible went into the judgment-making process. The fundamental requirement was the composition of an issue statement for the expert panel. The Report Review QA procedures were intended to provide the decision makers and all participants in the WIPP Project with assurance that the final products contained the necessary information on Parameter, Software, Analysis, and Expert Judgment Panels and were adequately reviewed. The fundamental requirement was a two-level approach to quality in that all documents underwent a standard review, but selected documents were also more rigorously reviewed by a PA Peer Review Panel of peers selected from outside the Sandia WIPP Project.

The QA procedures for Parameter, Software, and Analysis were formally structured around the five steps of an analysis: define, investigate and implement, verify, review, and document. An exception is that neither Software nor Parameter QA included the first step, define, because these steps were defined within the project. As an example, the Software QA procedures addressed analysis investigation, verification, review, and documentation in the following ways: (1) investigation through traceability (by requiring version IDs based on a three-level classification of code, developer names, and dates on output) and retrievability (by requiring the CAMCON system); (2) verification through performing test cases; (3) review by means of a Software Review Committee; and (4) documentation through on-line, computerized documentation ("help files"), general abstracts, records on changes and verification, internal comments, and user and theory manual formal reports. The other procedures have comparable controls in the five steps of an analysis.

The areas covered by the QA procedures roughly corresponded to the basic steps for performing a PA analysis (see Section 1.2). To elaborate, Parameter Selection QA procedures set requirements to address parameter uncertainty and compilation/interpretation of data for disposal system characterization/conceptual model development; Software QA procedures set requirements for software development of consequence and probability computational models; Analysis QA procedures set requirements for use of software tools to address scenario and model form uncertainty and perform consequence and sensitivity/uncertainty analysis; Expert Judgment and Document Review QA set procedures for all tasks including scenario uncertainty and regulatory performance evaluation. 


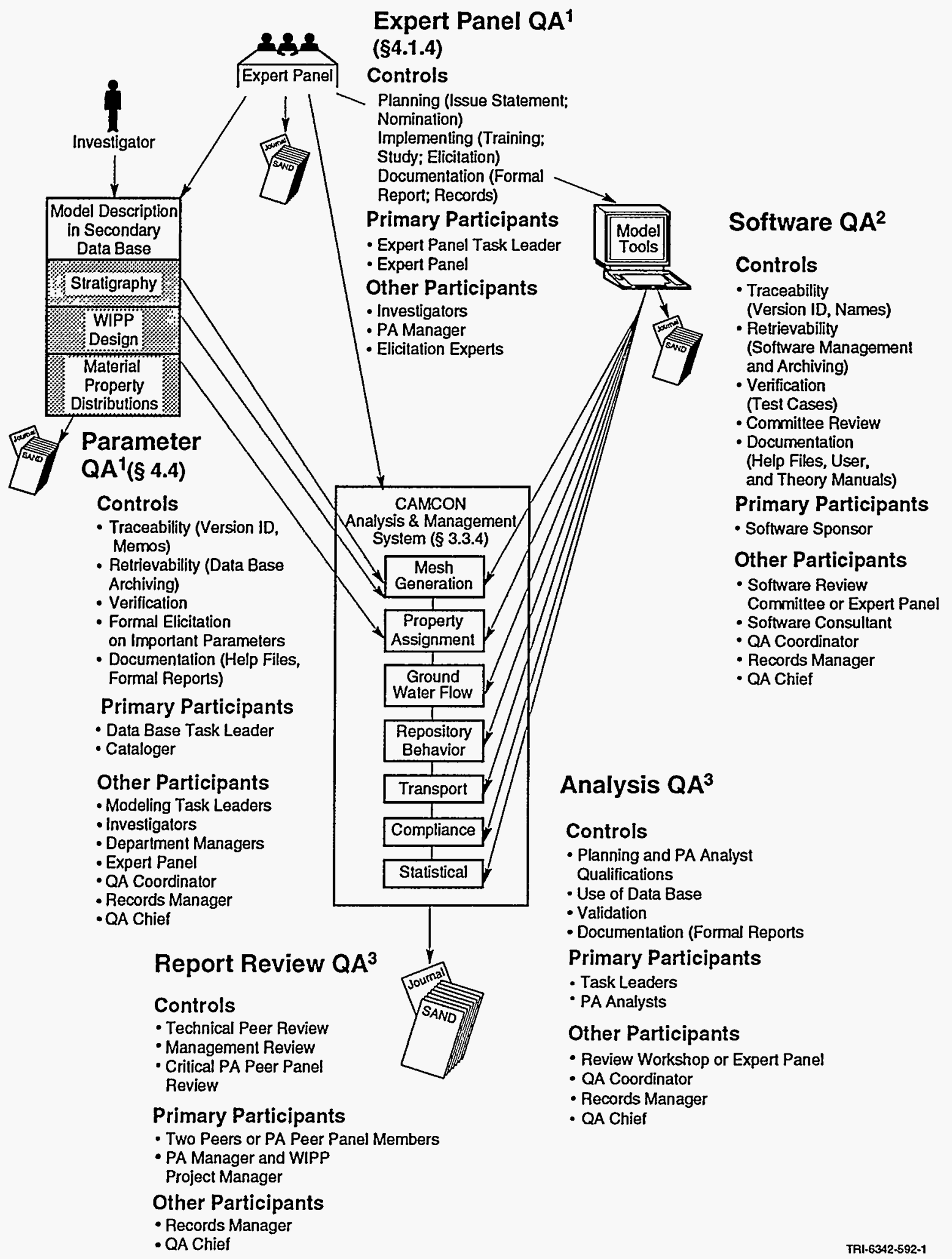

Figure 1.3-3 Three primary areas-software, parameters, and analysis-and two subareasreport review and expert panels - controlled by the quality assurance procedures for the 1990-1992 performance assessment calculations. ${ }^{3}$ Implicit in these quality assurance procedures was the understanding that the $\mathrm{PA}$ process would be repeated several times. 


\subsubsection{Quality Assurance Procedures for 1990-1992 Calculations (Cont'd)}

The QA procedures implicitly assumed the PA process would be repeated several times (See Section 1.1.2, Multiple Iterations: a Performance Assessment Strategy); thus, the PA task within the WIPP Project was treated as an ongoing process or operation and not a project. To elaborate, the QA procedures were concerned primarily with the analysis product and PA process quality rather than the WIPP Project management quality and, hence, the procedures (e.g., Software QA) did not address the project life cycle, project triple constraints (cost, schedule, performance), project planning, human resource allocation, or project change control.

\section{References}

1 Rechard, R.P., K.M. Trauth, and R.V. Guzowski. 1992b. Quality Assurance Procedures for Parameter Selection and Use of Expert Judgment Panels Supporting Performance Assessments of the Waste Isolation Pilot Plant. SAND91-0429. Albuquerque, NM: Sandia National Laboratories.

2 Rechard, R.P. D.K. Rudeen, and P.J. Roache. 1992a. Quality Assurance Procedures for Analyses and Report Reviews Supporting Performance Assessments of the Waste Isolation Pilot Plant. SAND91-0428. Albuquerque, NM: Sandia National Laboratories.

3 Rechard, R.P., P.J. Roache, R.L. Blaine, A.P. Gilkey, and D.K. Rudeen. 1991b. Quality Assurance Procedures for Computer Software Supporting Performance Assessments of the Waste Isolation Pilot Plant. SAND90-1240. Albuquerque, NM: Sandia National Laboratories. 


\subsection{Terminology of a Mined Geologic Disposal System}

As with many fields of study, once the meaning of the specialized terminology is understood, the reader can understand related concepts more readily. Nuclear waste disposal is no exception. The following two sections define (1) terminology used in Environmental Protection Agency regulation 40CFR 191, and (2) terminology used to describe common features of a geologic repository for the disposal of nuclear waste. 


\subsubsection{Terminology Used in 40 CFR 191}

As defined in 40 CFR 191, Subpart $B,{ }^{1}$ the disposal system is the combination of the engineered barriers of the repository system and the natural barriers of the disposal site that isolate the radioactive wastes from the accessible environment, where "barrier," as given in \$191.12[a], "means any material or structure that prevents or substantially delays movement of water or radionuclides toward the accessible environment." Accessible environment is defined below and in Figure 1.4-1. Engineered barriers are designed by humans and include backfill in the emplacement facilities or plugs in boreholes. Natural barriers are the subsurface geologic and hydrologic features within the "controlled area" that inhibit release and migration of hazardous materials. "Controlled area" is defined below and in Figure 1.4-1. Barriers are not limited to the examples given in the regulator's documentation, nor are those examples mandatory. Furthermore, the Environmental Protection Agency (EPA) states in Appendix B of 40CFR 191, "...reasonable projections for the protection expected from all of the engineered and natural barriers...will be considered." 2

According to $\$ 191.12$ of 40 CFR 191, the "controlled area" mentioned above is "(1) a surface location, to be identified by passive institutional controls, that encompasses no more than 100 square kilometers and extends horizontally no more than five kilometers in any direction from the outer boundary of the original location of the radioactive wastes in a disposal system; and (2) the subsurface underlying such a surface location." Furthermore, paragraph $[\mathrm{k}]$ of that same section defines the "accessible environment" as ". . (1) the atmosphere, (2) land surfaces, (3) surface water, (4) oceans, and (5) all of the lithosphere that is beyond the controlled area." For assessment purposes, the overall performance of the disposal system is normally calculated at the boundary between these two regions.

As used herein, the "site" is the general location of the controlled area (the disposal system, including the land surface directly above it), but includes any important features surrounding the controlled area. Except for the latter addition, this report's definition of site is most similar to the regulatory definition in 10 CFR $60.2^{3}$ : "the location of the controlled area."

\section{References}

1 EPA (Environmental Protection Agency). 1993a. "40 CFR Part 191: Environmental Radiation Protection Standards for the Management and Disposal of Spent Nuclear Fuel, High-Level and Transuranic Radioactive Wastes, Final Rule," Federal Register. Vol. 58, no. 242, 66398-66416.

2 EPA (Environmental Protection Agency). 1985a. "40 CFR Part 191: Environmental Standards for the Management and Disposal of Spent Nuclear Fuel, High-Level and Transuranic Radioactive Wastes; Final Rule," Federal Register. Vol. 50, no. 182, 38088.

3 NRC (Nuclear Regulatory Commission). 1993. "Part 60-Disposal of High-Level Radioactive Wastes in Geologic Repositories," Code of Federal Regulations 10, Part 60 Washington, DC: Superintendent of Documents, U.S. Government Printing Office.

4 Public Law 102-579. 1992. Waste Isolation Pilot Plant Land Withdrawal Act (106 Stat. 4777).

5 EPA (Environmental Protection Agency). 1990. "Conditional No-Migration Determination for the Department of Energy Waste Isolation Pilot Plant (WIPP)," Federal Register. Vol. 55, no. 220, 47700-47721.

6 Bertram-Howery, S.G., and R.L. Hunter, eds. 1989. Preliminary Plan for Disposal-System Characterization and Long-Term Performance Evaluation of the Waste Isolation Pilot Plant. SAND89-0178. Albuquerque, NM: Sandia National Laboratories. 


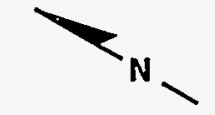

The "Controlled Area" is the Disposal System Plus the Land Surface Directly Above it.

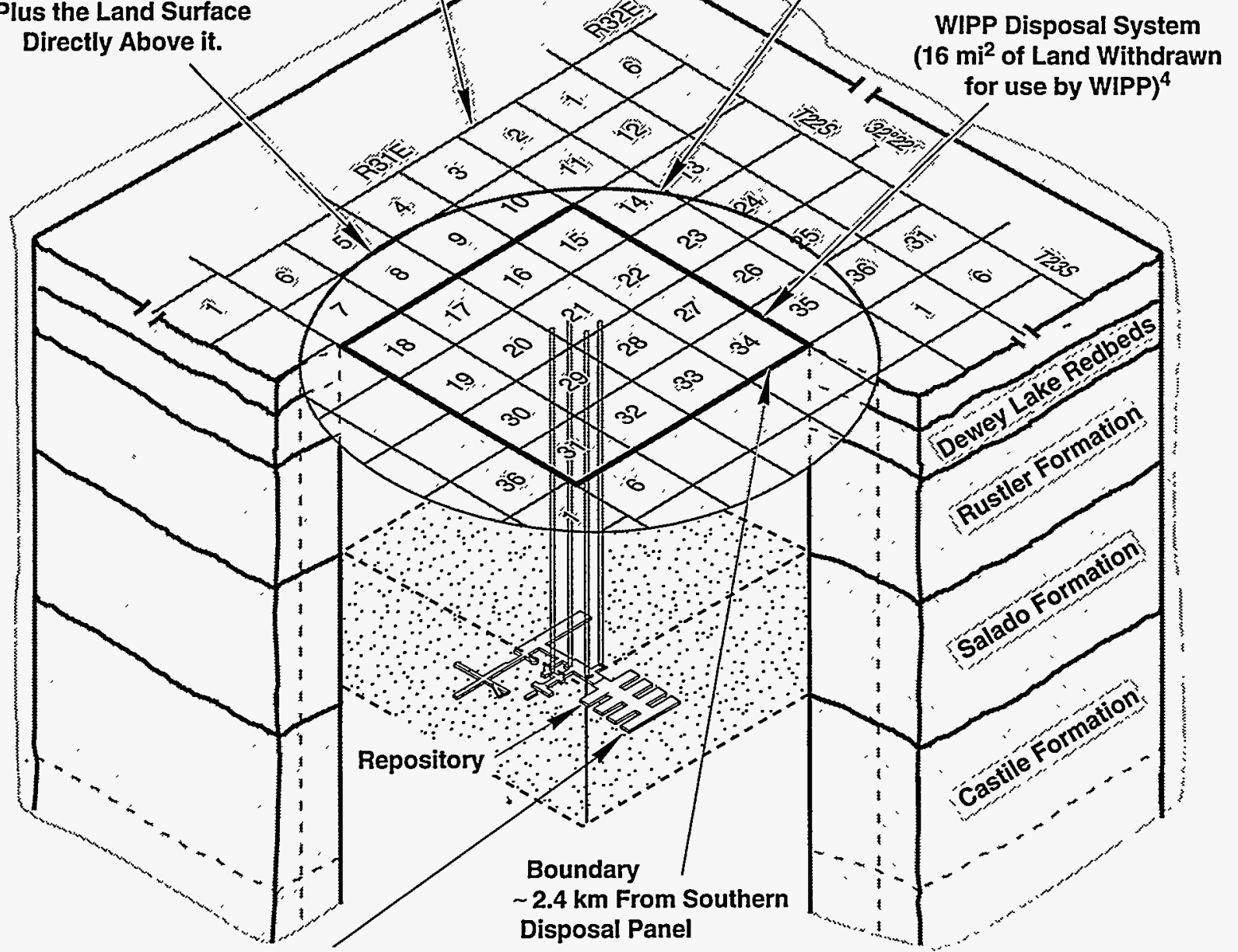

The "Repository Site" or "Site" is the General Location of the Disposal System.
"Disposal System" Includes
Engineered and Geologic
Barriers Bounded by
Accessible Environment; Maximum size is $\leq 5 \mathrm{~km}$ from Waste and $\leq 100 \mathrm{~km}^{2}$ Area.

Engineered Barriers Include:

- Waste Parcel

Accessible Environment

- Waste Form

- Internal Backfill

- Containers

- Repository

- Backfill around Waste

Parcel and in Drift

- Facility Layout

- Waste Distribution

- Backfill in Shafts

\section{Disposal Panel} for 40 CFR 191. 1,2 (Rest of World)

Probable Disposal Unit for 40 CFR 268. 5

*Disposal System Barriers are any Material or Structure that Delays Movement of Radionuclides toward the Accessible Environment; in this Report they are Categorized as either Geologic or Engineered

TRI-6330-7-13

Figure 1.4-1. Artist's concept of a mined geologic disposal system portraying terminology used in this report. ${ }^{6}$ 


\subsubsection{Description of the Waste Containment System}

In this report, a radioactive-waste containment system includes three principal subsystems: institutional controls, engineered barriers, and geologic barriers, and their major components (shown symbolically in Figure 1.4-2).

The first subsystem-institutional controls-consists of components such as U.S. Government ownership of the land and resources, fencing and signs around the property, permanent markers, public records and archives, and other methods of preserving knowledge about the disposal system. ${ }^{1,2}$

The physical features of the repository (e.g., design of the repository, waste form, waste parcel, and backfill) are components of the second subsystem, engineered barriers. For purposes of discussion, the components of the engineered barrier system are further grouped into two subdivisions - the waste parcel and the repository. In this report, the waste parcel is defined as the waste form, waste containers, and any internal backfill. The repository is the portion of the disposal facility that includes the waste panels, access drift, and access shafts. Although the Waste Isolation Pilot Plant is not regulated by the Nuclear Regulatory Commission, a few terms from their 10 CFR $60^{3}$ are included in Figure 1.4-2 to demonstrate the slight differences in terminology that can occur. For example, the 10 CFR 60 "engineered barrier" definition, which omits shafts, boreholes, and their seals, is narrower than the definition used in this report. Also, the term "waste emplacement package" signifies the waste parcel and any backfill-buffer placed between the waste parcel and the host rock.

The third subsystem-geologic barriers-includes the lithosphere that extends from the engineered barrier up to the ground surface no more than $5 \mathrm{~km}(3 \mathrm{mi})$ from the outer boundary of waste-emplacement rooms and drifts. In other words, it extends to the accessible environment.

The disposal system is defined as the combination of engineered and natural barriers that isolate spent nuclear fuel or radioactive waste after disposal (40 CFR 191.12[a]). ${ }^{4}$ As part of the performance assessment, analysts must investigate how the disposal system behaves. Specific situations are assumed (i.e., various combinations of features, events, and processes) that represent possible future conditions at the repository. Depending on the situation, different parts of the engineered and geologic barrier subsystems are assembled into a conceptual model that is then described mathematically.

\section{References}

1 Trauth, K.M., S.C. Hora, and R.V. Guzowski. 1993. Expert Judgment on Markers to Deter Inadvertent Human Intrusion into the Waste Isolation Pilot Plant. SAND92-1382. Albuquerque, NM: Sandia National Laboratories.

2 Rechard, R.P., K.M. Trauth, J.S. Rath, R.V. Guzowski, S.C. Hora, and M.S. Tierney. 1993b. "The Use of Formal and Informal Expert Judgments When Interpreting Data for Performance Assessments," Scientific Basis for Nuclear Waste Management XVI, Materials Research Society Symposium Proceedings, Boston, MA, November 30-December 4, 1992. Eds. C.G. Interrante and R.T. Pabalan. SAND92-1148C. Pittsburgh, PA: Materials Research Society. Vol. 294, 943-950.

3 NRC (Nuclear Regulatory Commission). 1993. "Part 60-Disposal of High-Level Radioactive Wastes in Geologic Repositories," Code of Federal Regulations 10, Part 60 Washington, DC: Superintendent of Documents, U.S. Government Printing Office.

4 EPA (Environmental Protection Agency). 1993a. "40 CFR Part 191: Environmental Radiation Protection Standards for the Management and Disposal of Spent Nuclear Fuel, High-Level and Transuranic Radioactive Wastes, Final Rule," Federal Register. Vol. 58, no. 242, 66398-66416.

5 Rechard, R.P., ed. 1993. Initial Performance Assessment of the Disposal of Spent Nuclear Fuel and High-Level Waste Stored at Idaho National Engineering Laboratory. Volume 1: Methodology and Results. SAND93-2330/1. Albuquerque, NM: Sandia National Laboratories. p. 1-9. 


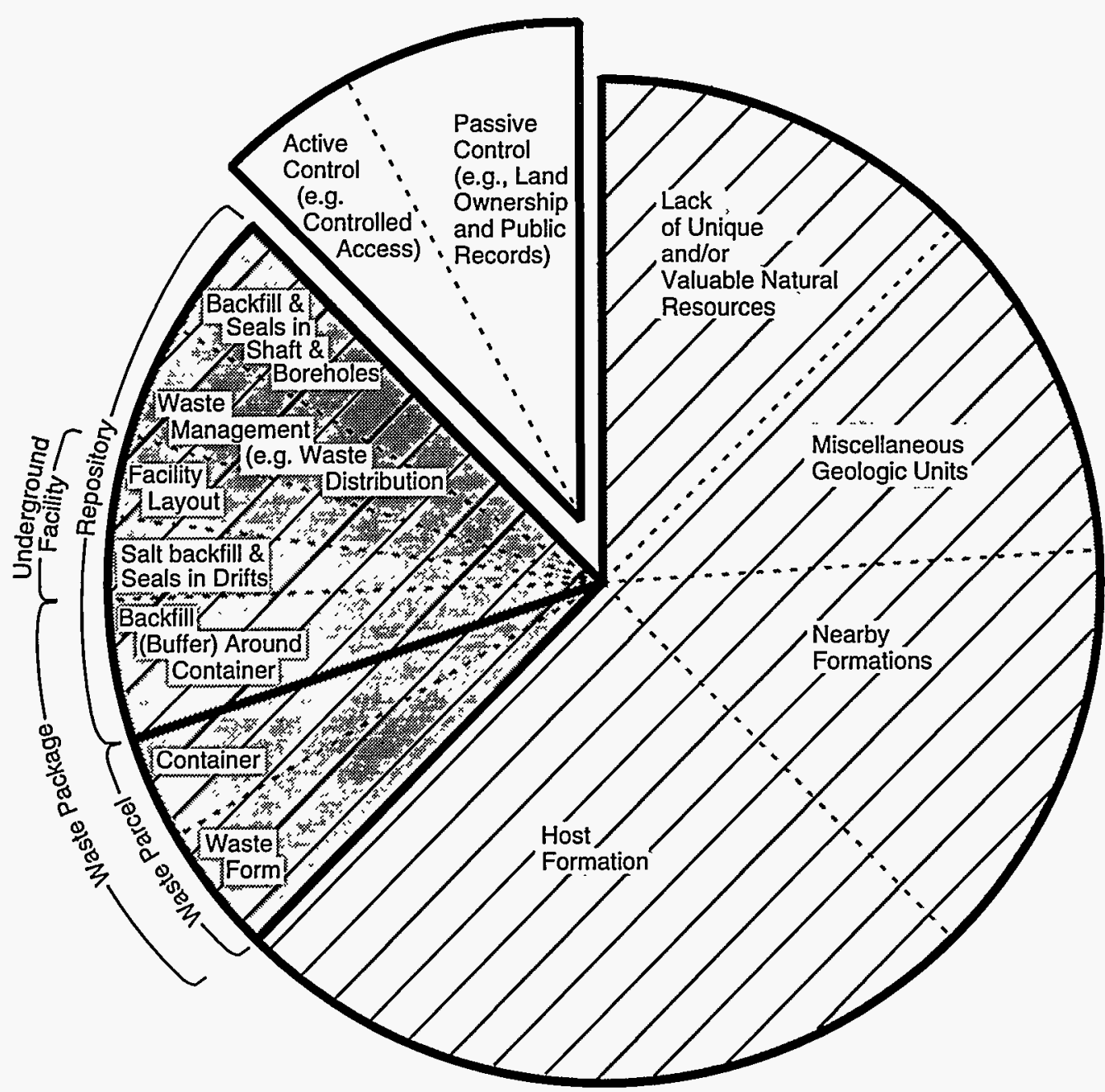

DD Disposal System

Engineered Barrier Subsystem

10 CFR 60 omits shaft and borehole backfill and waste management from engineered barrier system.

Institutional Control Subsystem

40 CFR 191 does not allow the DOE to depend upon the enforcement of active institutional controls after $100 \mathrm{yr}$, for performance assessments.

Geologic Barrier Subsystem

(Maximum $5 \mathrm{~km}$ Distance Around Waste Disposal Area)

The requirement in 40 CFR 191 to consider human intrusion implies that parts or all of the geologic barrier can be effectively by-passed.

Various groupings of the engineered barrier -- "waste parcel" and "repository" are primarily used in this report.

TRI-6334-250-4

Figure 1.4-2. Subsystems and components of a radioactive waste containment system. The disposal system, as defined in 40 CFR 191, comprises the geologic and engineered subsystems of the waste containment system (Rechard, ed., 1993b, p. 1-9). 5 
1.0 Introduction

$1-34$ 


\subsection{Regulatory Influences on the Waste Isolation Pilot Plant Project}

At present, the Waste Isolation Pilot Plant (WIPP) Project is about 20 years old, and more years lie ahead before the regulatory process for the disposal facility is completed. National policy issues, regulatory influences, negotiated agreements, and court settlements over the first half of the project have had a strong influence on the amount and type of scientific data collected. In the second half of the project, federal compliance policy and actual regulations were set more firmly. The WIPP will have to comply with these if it is to operate as a repository.

Prior to the WIPP Project, the precursor to the Department of Energy (DOE), the Atomic Energy Commission (AEC), spent the period from 1955 through the late 1960s formulating a Commission policy on nuclear waste disposal. ${ }^{1}$ As soon as it appeared, Congress established its own broad national policy requiring environmental impact statements (EISs) on large federally funded projects (83 Stat. 852, 42 U.S.C. 4332$)^{2}{ }^{2}$ The EIS process exerted its influence during the 1970 s as the AEC, then the Energy Research and Development Agency, and finally the DOE, searched for and located a bedded salt deposit satisfactory for use as a repository. That site was to become the present WIPP site, near Carlsbad, New Mexico. Just as the WIPP EIS was nearing completion in 1979, Congress established anew the purpose of the WIPP Project and granted self-regulation to the DOE. ${ }^{3}$ [Although regulations by the Nuclear Regulatory Commission (NRC) ${ }^{*}$ would have been possible, NRC had been established to regulate primarily commercial nuclear reactors and waste].

Negotiated settlements with the State of New Mexico in the early 1980s, and early drafts of the Environmental Protection Agency (EPA) nuclear waste disposal standard, 40 CFR 191, focused on hydrologic data collection near the site. National advisory groups, particularly the WIPP Panel of the Board of Radioactive Waste Management (BRWM) of the National Academy of Sciences and independent stateselected evaluation groups, such as the New Mexico Environmental Evaluation Group, were set up on the initiative of the DOE to monitor its self regulation. The promulgation of 40 CFR 191 in 1985 established the primary regulation with which the WIPP would have to comply. However, the definition of radioactive waste as hazardous in 1986 and 1987 (42 U.S.C. 6901et seq.) established another set of regulations, those for chemical waste with which WIPP must also comply. Then, in 1992, the Congress established a specific compliance process and designated the EPA (rather than the DOE) as the regulator of the WIPP. ${ }^{4}$

WIPP-Project history is not essential to acquire an understanding of the performance assessment (PA) process. However, it clarifies the evolution and emphasizes how only recently, in relation to the age of the project, stochastic simulations were introduced as a tool for the assessment of WIPP performance. Assessment activities before the late 1980s were undertaken primarily (1) to satisfy needs for environmental impact statements, (2) to satisfy negotiated agreements with the State of New Mexico, or (3) to develop general understanding of selected natural phenomena associated with nuclear waste disposal, as deemed prudent by Sandia scientists (working with peers in waste management) and/or as suggested by scientists on the WIPP Panel of the BRWM of the National Academy of Sciences. Thus, many activities performed throughout the history of the WIPP Project cannot be neatly categorized in terms of fulfilling the specific needs of the PA process. The following section and figure present a timeline of regulation and other events that influenced the formation, maintenance, and current status of the WIPP Project.

\section{References}

1 Carter, L.J. 1987. Nuclear Imperatives and Public Trust: Dealing with Radioactive Waste. Washington, DC: Resources for the Future, Inc.

2 Public Law 91-190. 1970. National Environmental Policy Act of 1969 (83 Stat. 852; 42 U.S.C. 1801 et seq.).

3 Public Law 96-164. 1979. Department of Energy National Security and Military Applications of Nuclear Energy Authorization Act of 1980.

4 Public Law 102-579. 1992. Waste Isolation Pilot Plant Land Withdrawal Act (106 Stat. 4777).

5 Public Law 93-438. 1974. Energy Reorganization Act of 1973 (42 U.S.C. 5801 et seq.).

* The Nuclear Regulatory Commission was formed by the 1974 Energy Reorganization Act. ${ }^{5}$ It was formerly part of the Atomic Energy Commission. 


\subsubsection{Timeline of Events for the WIPP Project ${ }^{*}$}

Systematic studies of disposal options for radioactive waste began in the United States in 1955 when the Atomic Energy Commission (AEC), which later became the Department of Energy (DOE), asked the National Academy of Sciences (NAS) to examine the issue in detail (see Table 1.5-1). In 1957, the NAS reported that while various options and disposal sites were feasible, disposal in salt beds was the most promising method. From that point through the early 1970s, Oak Ridge National Laboratory conducted radioactive-waste experiments, most notably Project Salt Vault in an abandoned salt mine near Lyons, Kansas. ${ }^{1}$ Although the AEC considered using the mine as a repository, the discovery of boreholes in the nearby area prompted the AEC to search for more suitable sites.

At the invitation of New Mexico's governor, the AEC investigated the Delaware Basin in the Carlsbad area of New Mexico. After an initial examination, a potential site was identified in the 1970s. The site was named the Waste Isolation Pilot Plant (WIPP) in January $1976 . .^{3}$ During the site-characterization phase, two technical oversight groups were formed: the WIPP Panel of the Board of Radioactive Waste Management of the NAS, and the New Mexico Environmental Evaluation Group. The regional sitecharacterization phase of this potential waste disposal site ${ }^{4}$ ended with the preparation of a draft Environmental Impact Statement (EIS) in 1979, as required by the National Environmental Policy Act of 1969 (NEPA). ${ }^{5}$ In response to that EIS, the DOE decided to proceed with a preliminary design phase at this site.

During the 1970s, the original mission of the WIPP, and thus the design, ${ }^{6}$ oscillated between including and not including defense high-level waste (HLW) in addition to transuranic (TRU) wastes. However, with passage of the National Security and Military Applications of Nuclear Energy Authorization Act of $1980,{ }^{7}$ Congress defined the WIPP as a research and development facility for storage and disposal of TRU wastes only, and exempted the WIPP from regulation by the Nuclear Regulatory Commission.

In 1981, the "Stipulated Agreement" and "Consultation and Cooperation Agreement" defined the WIPP's relationship with the State of New Mexico and stipulated specific geotechnical experiments required by the state. After much planning, which included a site and preliminary design phase, full construction of the WIPP facility began in 1983. Experiments to characterize the local disposal system followed. ${ }^{8,9}$ The report by Lynch et al. ${ }^{10}$ provides an overview of technical aspects relevant to that work. In preparation for the WIPP's opening, a Supplemental EIS was published. It identified gas generation the gas being generated through normal corrosion of waste containers in time ${ }^{11}$-as an important issue. This issue became the primary purpose of proposed tests using actual TRU waste within the repository during a carefully monitored test phase. ${ }^{12}$

In the Waste Isolation Pilot Plant Land Withdrawal Act of $1992^{13}$ Congress defined the process by which WIPP compliance would have to be evaluated and transferred ownership of the WIPP site to the DOE. This act officially marked the transition from the construction and disposal-system-characterization phase to the compliance and testing phases, although those phases had begun unofficially in 1985 when the U.S. Environmental Protection Agency (EPA) issued 40 CFR 191 and in 1989 when Sandia first began to assess performance using the EPA standard.

\section{References for Section 1.5.1 Text}

1 Bradshaw, R.L., and W.C. McClain. 1971.Project Salt Vault: A Demonstration of the Disposal of High-Activity Solidified Wastes in Underground Salt Mines. ORNL-4555. Oak Ridge, TN: Oak Ridge National Laboratory.

2 Carter, L.J. 1987. Nuclear Imperatives and Public Trust: Dealing with Radioactive Waste. Washington, DC: Resources for the Future, Inc.

3 NAS/NRC (National Academy of Sciences/National Research Council). 1984. Review of the Scientific and Technical Criteria for the Waste Isolation Pilot Plant (WIPP). DOE/DP/48015-1. Washington, DC: National Academy Press.

* Because the WIPP Project spans more than 20 years, more events have occurred than can easily be covered in a few pages; thus, the timeline is selective, with more emphasis placed on the role of overall national policy and its influence on the WIPP Project than the numerous milestones and scientific studies conducted at the site. 
4 Powers, D.W., S.J. Lambert, S-E. Shaffer, L.R. Hill, and W.D. Weart, eds. 1978. Geological Characterization Report, Waste Isolation Pilot Plant (WIPP) Site, Southeastern New Mexica SAND78-1596. Albuquerque, NM: Sandia National Laboratories. Vols. I-II.

5 Public Law 91-190. 1970. National Environmental Policy Act of 1969 (83 Stat. 852; 42 U.S.C. 1801 et seq.).

6 Weart, W.D. 1979. "WIPP: A Bedded Salt Repository for Defense Radioactive Waste in Southeastern New Mexico," Radioactive Waste in Geologic Storage, 176th Annual Meeting of the American Chemical Society, Miami Beach, FL, September 11-15, 1978 Ed. S. Fried. SAND78-0934C. ACS Symposium Series No. 100. Washington, DC: American Chemical Society. 13-36.

7 Public Law 96-164. 1979. Department of Energy National Security and Military Applications of Nuclear Energy Authorization Act of 1980.

8 Lappin, A.R. 1988. Summary of Site-Characterization Studies Conducted From 1983 Through 1987 at the Waste Isolation Pilot Plant (WIPP) Site, Southeastern New Mexica SAND88-0157. Albuquerque, NM: Sandia National Laboratories.

9 Tyler, L.D., R.V. Matalucci, M.A. Molecke, D.E. Munson, E.J. Nowak, and J.C. Stormont. 1988. Summary Report for the WIPP Technology Development Program for Isolation of Radioactive Waste. SAND88-0844. Albuquerque, NM: Sandia National Laboratories.

10 Lynch, R.W., R.L. Hunter, D.R. Anderson, F.W. Bingham, J.M. Covan, G.F. Hohnstrieter, T.O. Hunter, R.D. Klett, E.E. Ryder, T.L. Sanders, and W.D. Weart. 1991.Deep Geologic Disposal in the United States: The Waste Isolation Pilot Plant and Yucca Mountain Projects. SAND90-1656. Albuquerque, NM: Sandia National Laboratories.

11 Lappin, A.R., R.L. Hunter, D.P. Garber, and P.B. Davies, eds. 1989. Systems Analysis, Long-Term Radionuclide Transport, and Dose Assessments, Waste Isolation Pilot Plant (WIPP), Southeastern New Mexico; March 1989 SAND89-0462. Albuquerque, NM: Sandia National Laboratories.

12 U.S. DOE (U.S. Department of Energy). 1993a. Test Phase Plan for the Waste Isolation Pilot Plant. DOE/WIPP 89-011, Revision 1. Albuquerque, NM: U.S. Department of Energy, WIPP Project Integration Office.

13 Public Law 102-579. 1992. Waste Isolation Pilot Plant Land Withdrawal Act (106 Stat. 4777). 


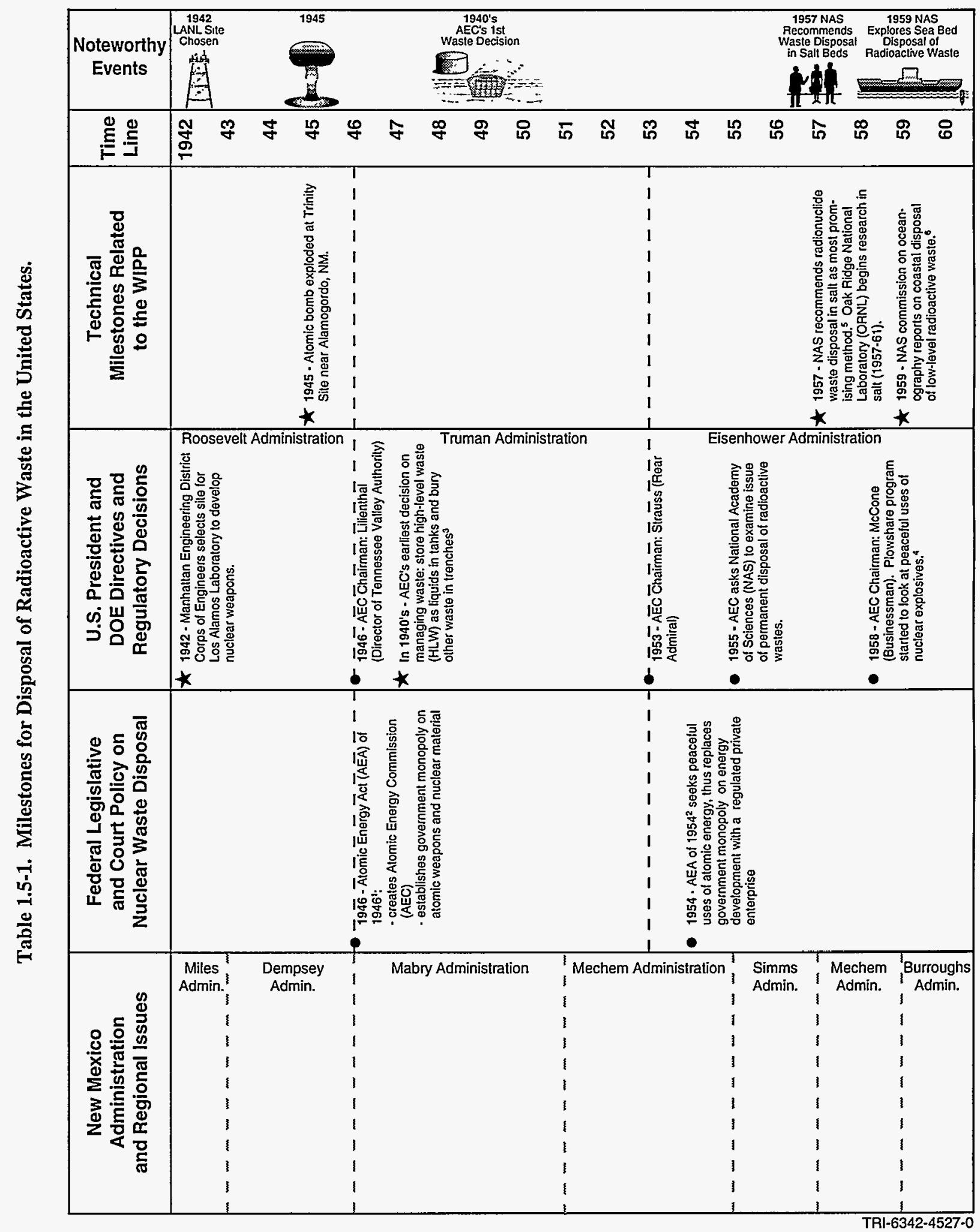




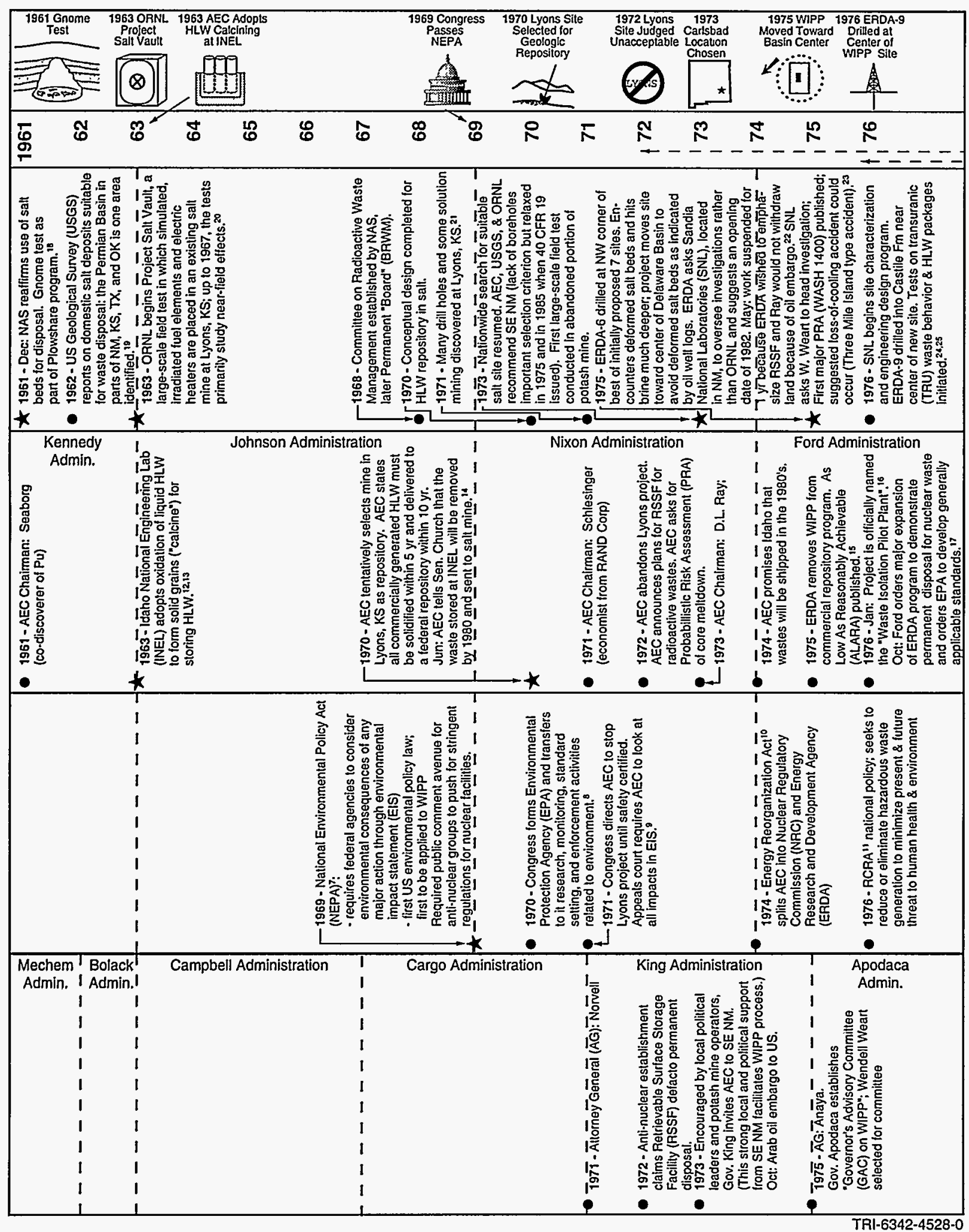


Table 1.5-1. Milestones for Disposal of Radioactive Waste in the United States.

\begin{tabular}{|c|c|c|c|c|c|}
\hline $\begin{array}{c}\text { New Mexico } \\
\text { Administration } \\
\text { and Regional Issues }\end{array}$ & $\begin{array}{l}\text { Federal Legislative } \\
\text { and Court Policy on } \\
\text { Nuclear Waste Disposal }\end{array}$ & $\begin{array}{l}\text { U.S. President and } \\
\text { DOE Directives and } \\
\text { Regulatory Decisions }\end{array}$ & $\begin{array}{l}\text { Technical } \\
\text { Milestones Related } \\
\text { to the WIPP }\end{array}$ & $\begin{array}{l}\text { Time } \\
\text { Line }\end{array}$ & 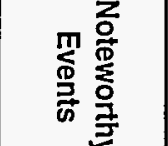 \\
\hline 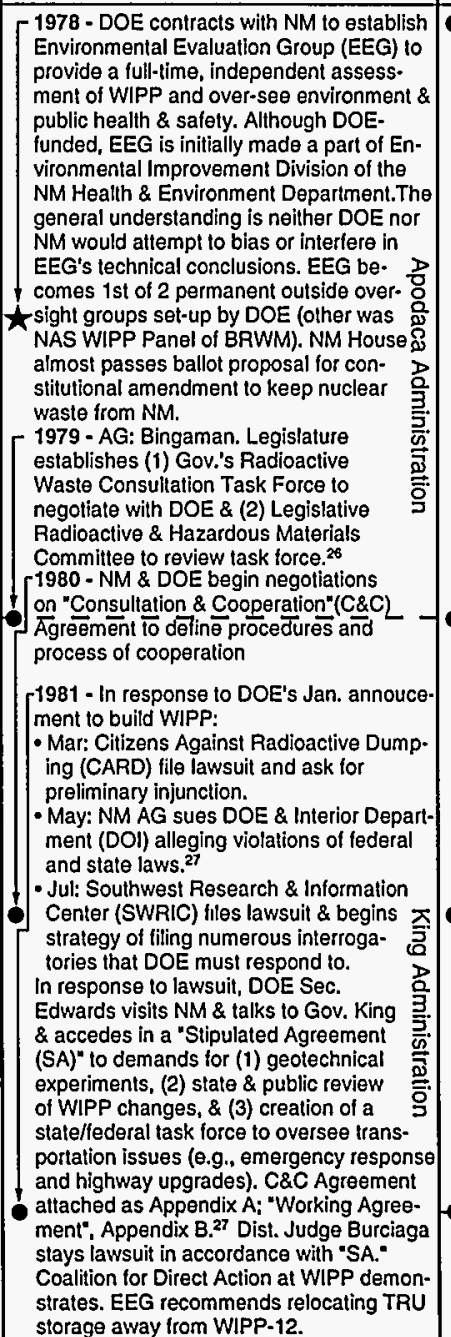 & 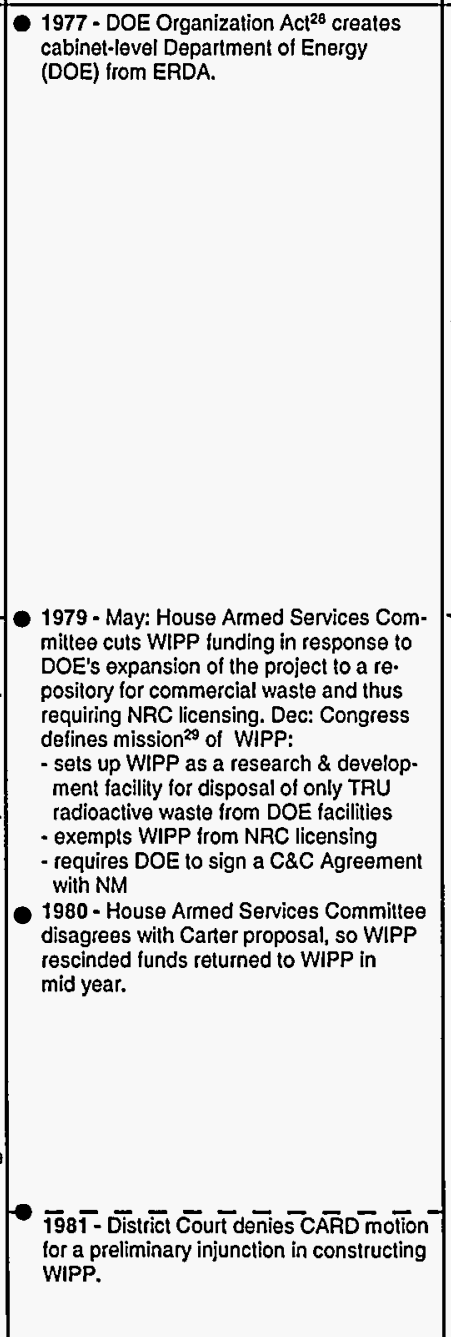 & 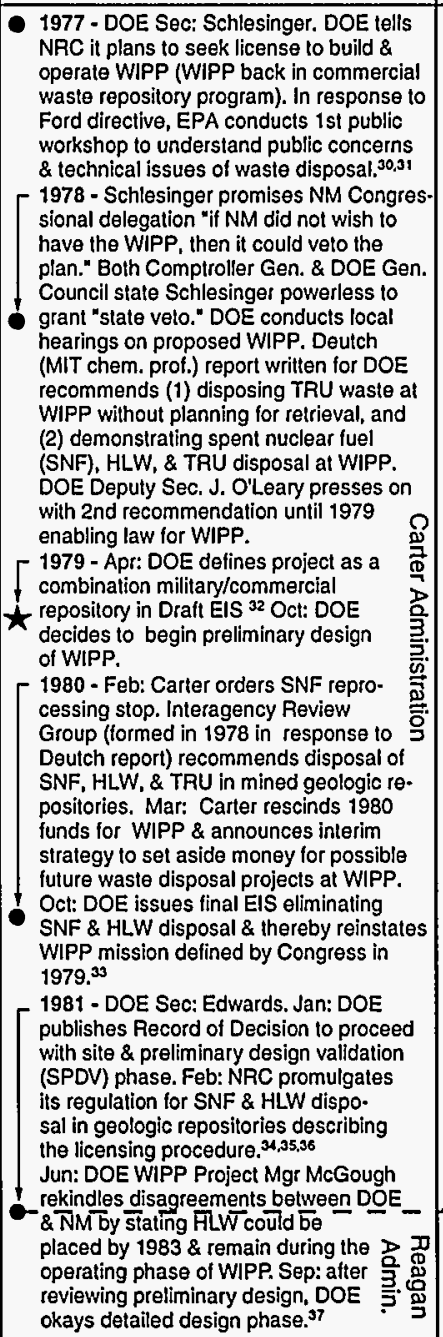 & 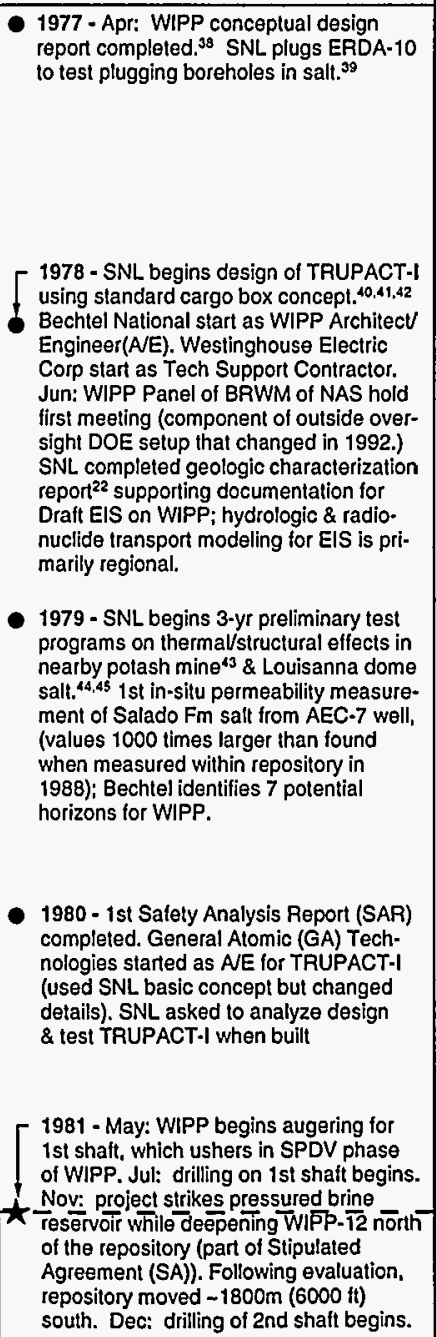 & 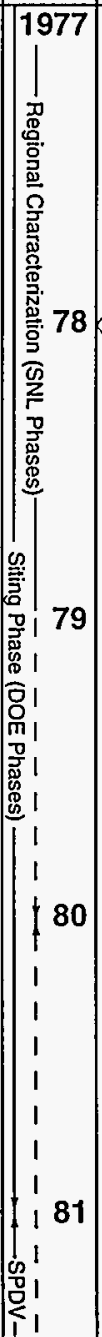 & 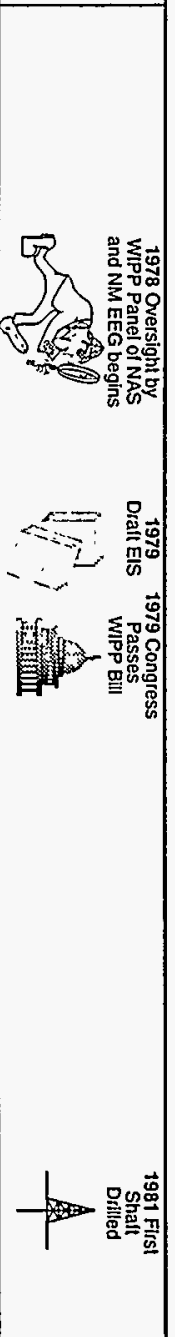 \\
\hline
\end{tabular}




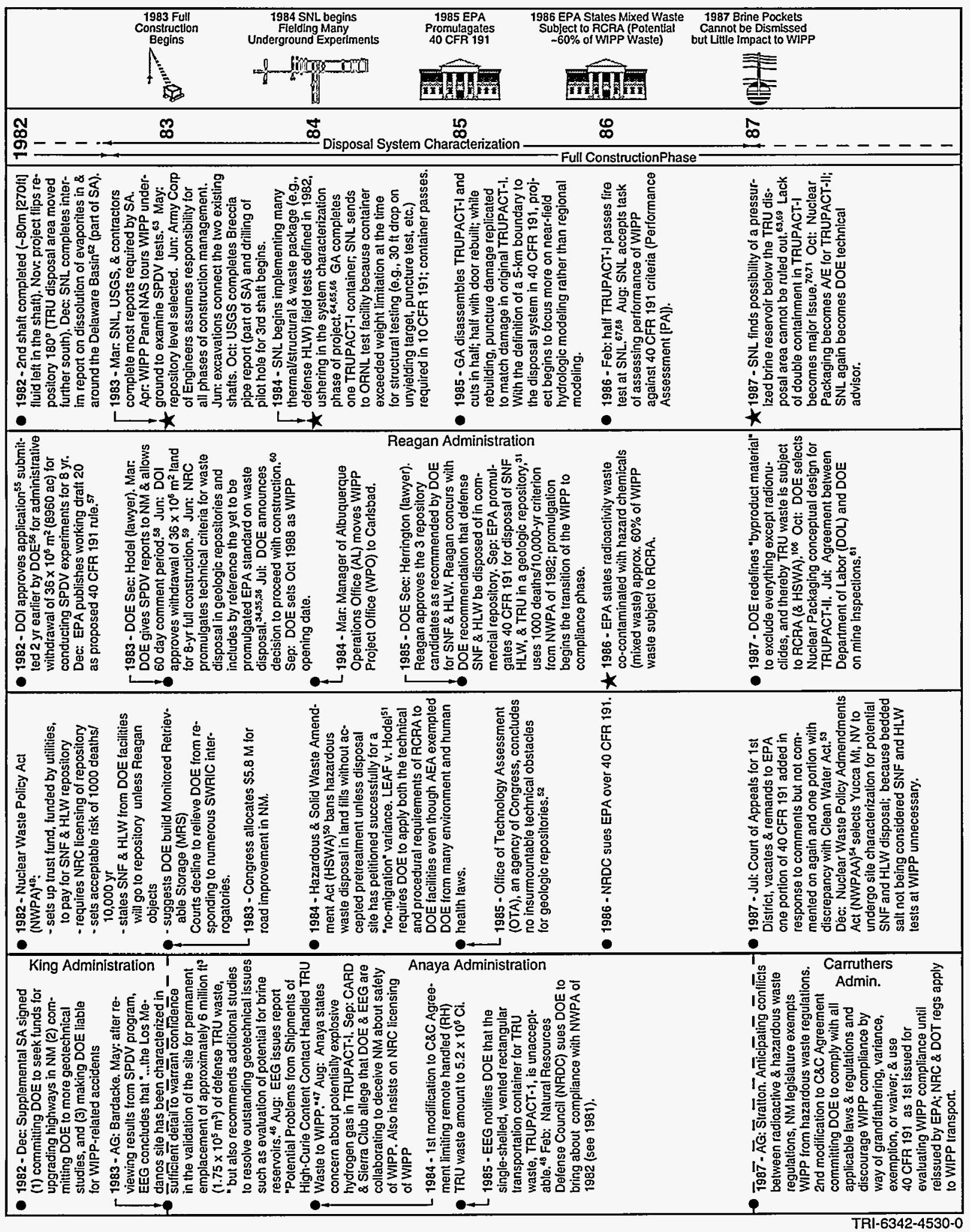


Table 1.5-1. Milestones for Disposal of Radioactive Waste in the United States.

\begin{tabular}{|c|c|c|c|c|c|}
\hline $\begin{array}{c}\text { New Mexico } \\
\text { Administration } \\
\text { and Regional Issues }\end{array}$ & $\begin{array}{c}\text { Federal Legislative } \\
\text { and Court Policy on } \\
\text { Nuclear Waste Disposal }\end{array}$ & $\begin{array}{l}\text { U.S. President and } \\
\text { DOE Directives and } \\
\text { Regulatory Decisions }\end{array}$ & $\begin{array}{l}\text { Technical } \\
\text { Milestones Related } \\
\text { to the WIPP }\end{array}$ & $\begin{array}{l}\text { Time } \\
\text { Line }\end{array}$ & 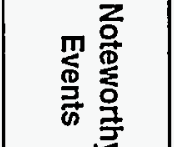 \\
\hline 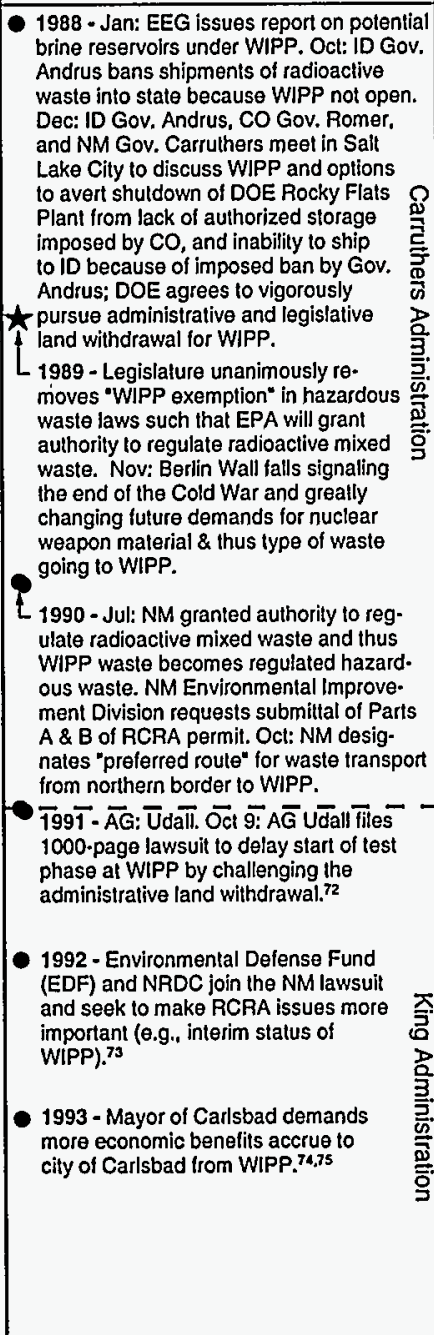 & 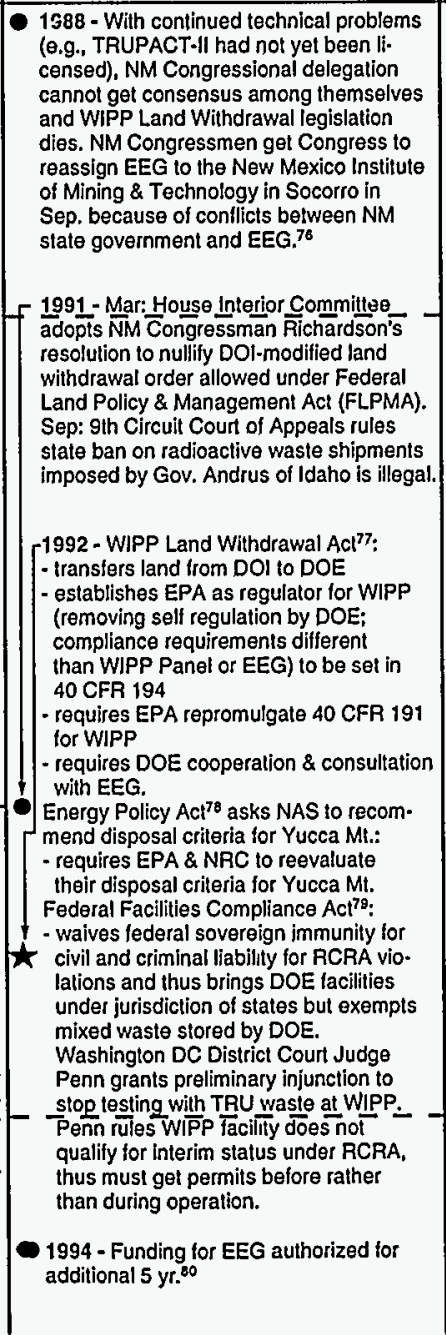 & 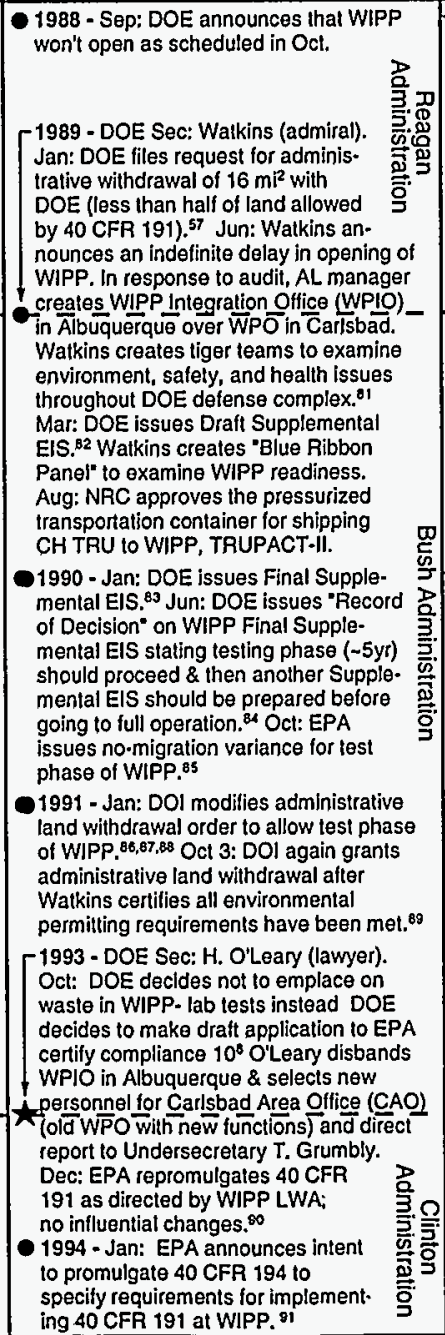 & 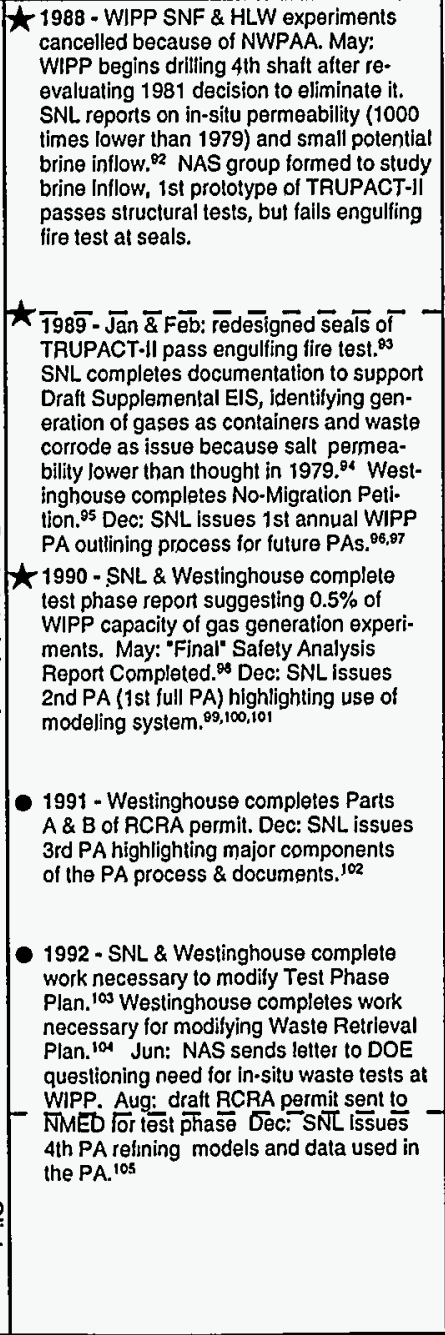 & 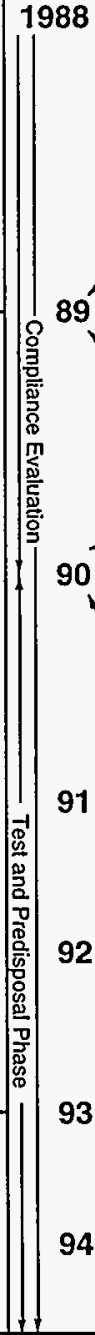 & 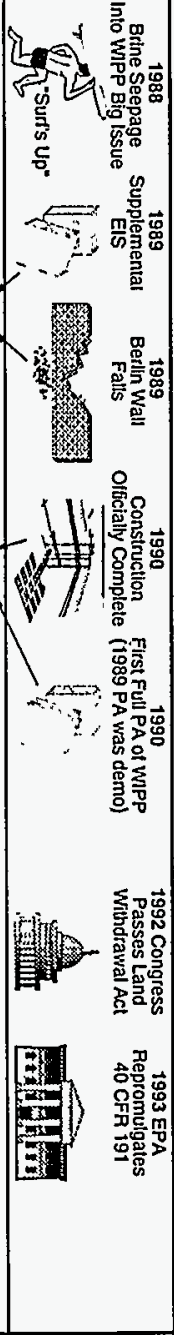 \\
\hline
\end{tabular}




\section{Table 1.5-1 References}

1 Public Law 585. 1946. Atomic Energy Act of 1946.

2 Public Law 703. 1954. Atomic Energy Act of 1954 (60 Stat. 755; 42 U.S.C. 1801 et seq.).

3 U.S. DOE (U.S. Department of Energy). 1980b. Final Environmental Impact Statement: Waste Isolation Pilot Plant. DOE/EIS-0026. Washington, DC: U.S. Department of Energy. p. 1-1.

4 Teller, E. 1959. "The Plowshare Program," Proceedings of the Second Plowshare Symposium, San Francisco, CA, May 13-15, 1959. UCRL-5675. Livermore, CA: Lawrence Radiation Laboratory. 8-13.

5 NAS/NRC (National Academy of Sciences/National Research Council). 1957.The Disposal of Radioactive Waste on Land: Report of the Committee on Waste Disposal of the Division of Earth Sciences. Publication 519. Washington, DC: National Academy of Sciences/National Research Council.

6 NAS/NRC (National Academy of Sciences/National Research Council). 1959. Radioactive Waste Disposal into Atlantic and Gulf Coastal Waters. Publication 655. Washington, DC: Working Group of the Committee on Oceanography of the National Academy of Sciences - National Research Council.

7 Public Law 91-190. 1970. National Environmental Policy Act of 1969. (83 Stat. 852; 42 U.S.C. 1801 et seq.).

8 EPA (Environmental Protection Agency). 1993c. "Part $1-$ Statement of Organization and General Information," Code of Federal Regulations 40, Part 1. Washington, DC: Superintendent of Documents, U.S. Government Printing Office.

9 Calvert Cliffs' Coordinating Committee, Inc., et al., Petitioners v. United States Atomic Energy Commission and United States of America, Respondents. Nos. 24839, 24871. 1971. 449 F. $2 d 1109$.

10 Public Law 93-438. 1974. Energy Reorganization Act of 1974 (42 U.S.C. 5801 et seq.).

11 Public Law 94-580. 1976. Resource Conservation and Recovery Act of 1976 (90 Stat. 2795 and subsequent amendments).

12 Wheeler, B.R., B.R. Dickey, G.E. Lohse, D.E. Black, D.W. Rhodes, and J.A. Buckham. 1967. "Storage of Radioactive Solids in Underground Facilities: Current ICPP Practices and Future Concepts," Disposal of Radioactive Wastes into the Ground, Proceedings of a Symposium Jointly Organized by the International Atomic Energy Agency and the European Nuclear Energy Agency of the OECD, Vienna, Austria, May 29-June 2, 1967 Vienna: International Atomic Energy Agency. 421-440.

13 Lakey, L.T., and J.R. Bower, eds. 1963. ICPP Waste Calcining Facility Safety Analysis Report. IDO-14620. Idaho Falls, ID: Phillips Petroleum Co., Atomic Energy Division.

14 Carter, L.J. 1978. "Trouble Even in New Mexico for Nuclear Waste Disposal,"Science. Vol. 199, no. 4333, 10501051 .

15 *NRC (Nuclear Regulatory Commission). 1975. "10 CFR Part 50, Appendix I-Numerical Guides for Design Objectives and Limiting Conditions for Operation to Meet the Criterion 'As Low as Practicable' for Radioactive Material in Light-Water-Cooled Nuclear Power Reactor Effluents," Federal Register. Vol 40, no. 87, 1944219443.

16 NAS/NRC (National Academy of Sciences/National Research Council). 1984. Review of the Scientific and Technical Criteria for the Waste Isolation Pilot Plant (WIPP). DOE/DP/48015-1. Washington, DC: National Academy Press.

17 EPA (Environmental Protection Agency). 1985a. "40 CFR Part 191: Environmental Standards for the Management and Disposal of Spent Nuclear Fuel, High-Level and Transuranic Radioactive Wastes; Final Rule," Federal Register. Vol. 50, no. 182, 38067.

18 Gard, L.M. 1968. Geologic Studies Project Gnome, Eddy County, New Mexico. Professional Paper 589. Washington, DC: U.S. Geological Survey. 
19 Pierce, W.G., and E.I. Rich. 1962. Summary of Rock Salt Deposits in the United States as Possible Storage Sites for Radioactive Waste Materials. Geological Survey Bulletin 1148. Washington, DC: Geological Survey.

20 Bradshaw, R.L., and W.C. McClain. 1971. Project Salt Vault: A Demonstration of the Disposal of High-Activity Solidified Wastes in Underground Salt Mines. ORNL-4555. Oak Ridge, TN: Oak Ridge National Laboratory.

21 Carter, L.J. 1987. Nuclear Imperatives and Public Trust: Dealing with Radioactive Waste. Washington, DC: Resources for the Future, Inc.

22 Powers, D.W., S.J. Lambert, S-E. Shaffer, L.R. Hill, and W.D. Weart, eds. 1978. Geological Characterization Report, Waste Isolation Pilot Plant (WIPP) Site, Southeastern New Mexica SAND78-1596. Albuquerque, NM: Sandia National Laboratories. Vols. I-II.

23 Rasmussen, N.C. 1975. Reactor Safety Study: An Assessment of Accident Risks in U.S. Commercial Nuclear Power Plants. NUREG-75/014, WASH-1400. Washington, DC: U.S. Nuclear Regulatory Commission.

24 Molecke, M.A. 1978. Waste Isolation Pilot Plant Transuranic Wastes Experimental Characterization Program: Executive Summary. SAND78-1356. Albuquerque, NM: Sandia [National] Laboratories.

25 Sandia [National] Laboratories. 1979. Summary of Research and Development Activities in Support of Waste Acceptance Criteria for WIPP. Comp. T.O. Hunter. SAND79-1305. Albuquerque, NM: Sandia [National] Laboratories.

26 "Radioactive and Hazardous Materials Act," New Mexico Statutes Annotated 1978 (1993 Repl.). Vol. 13, Chapter 74, Article 4A, Section 74-4A-2. Charlottesville, VA: The Michie Company.

27 State of New Mexico, ex rel., Jeff Bingaman, Attorney General of the State of New Mexico, Plaintiff, v. The United States Department of Energy, et al., Defendants. 1981. "Stipulated Agreement." Civil Action No. 81-0363 JB. (United States District Court for the District of New Mexico). July 1, 1981. (Copy on file at the Sandia WIPP Central Files, Sandia National Laboratories, Albuquerque, NM.)

28 Public Law 95-91. 1977. Department of Energy Organization Act (42 U.S.C. 7101 et seq.).

29 Public Law 96-164. 1979. Department of Energy National Security and Military Applications of Nuclear Energy Authorization Act of 1980.

30 EPA (Environmental Protection Agency). 1985a. "40 CFR 191: Environmental Standards for the Management and Disposal of Spent Nuclear Fuel, High-Level and Transuranic Radioactive Wastes; Final Rule," Federal Register. Vol. 50, no. 182, 38066-38089.

31 EPA (Environmental Protection Agency). 1992a. "Environmental Radiation Protection Standards for Management and Disposal of Spent Nuclear Fuel, High-Level and Transuranic Radioactive Wastes," Code of Federal Regulations 40, Part 19l. Washington, DC: Superintendent of Documents, U.S. Government Printing Office.

32 Weart, W.D. 1979. "WIPP: A Bedded Salt Repository for Defense Radioactive Waste in Southeastern New Mexico," Radioactive Waste in Geologic Storage, 176th Annual Meeting of the American Chemical Society, Miami Beach, FL, September 11-15, 1978 Ed. S. Fried. SAND78-0934C. ACS Symposium Series No. 100. Washington, DC: American Chemical Society. 13-36.

33 U.S. DOE (U.S. Department of Energy). 1980b. Final Environmental Impact Statement: Waste Isolation Pilot Plant. DOE/EIS-0026. Washington, DC: U.S. Department of Energy. Vols. 1-2.

34 NRC (U.S. Nuclear Regulatory Commission). 1981. "Disposal of High Level Radioactive Wastes in Geologic Repositories: Licensing Procedures," Federal Register. Vol. 46, no. 37, 13971-13987.

35 NRC (U.S. Nuclear Regulatory Commission). 1983. "Disposal of High-Level Radioactive Wastes in Geologic Repositories: Technical Criteria," Federal Register. Vol. 48, no. 120, 28194-28230.

36 NRC (U.S. Nuclear Regulatory Commission). 1993. "Part 60-Disposal of High-Level Radioactive Wastes in Geologic Repositories," Code of Federal Regulations 10, Part 60 Washington, DC: Superintendent of Documents, U.S. Government Printing Office. 
37 U.S. DOE (U.S. Department of Energy). 1992. "Definitive Design (Title II)," Project Management System. DOE Order 4700.1. Washington, DC: U.S. Department of Energy. V-40 through V-41.

38 Sandia [National] Laboratories. 1977. Waste Isolation Pilot Plant (WIPP) Conceptual Design Report. SAND770274. Albuquerque, NM: Sandia Laboratories.

39 Gulick, C.W., Jr. 1979. Borehole Plugging Program, Plugging of ERDA No. 10 Drill Hole. SAND79-0789. Albuquerque, NM: Sandia National Laboratories.

40 Lamoreaux, G.H., L.E. Romesberg, S.H. Sutherland, and T.A. Duffey. 1980. "Contact-Handled Transuranic Transportation System Structural Analysis (TRUPACT)," Patram 80, 6th International Symposium on Packaging and Transporting Radioactive Materials, Berlin, Germany, November 10-14, 1980 SAND80-0792C. Berlin, Germany: Bundesanst für Materialprüf (BAM). 536-539.

41 May, R.A., L.E. Romesberg, H.R. Yoshimura, W.E. Baker, and J.C. Hokanson. 1980. "Analytical and Empirical Evaluation of Low-Level Waste Drum Response to Accident Environments," Patram 80, 6th International Symposium on Packaging and Transporting Radioactive Material, Berlin, Germany, November 10-14, 1980 SAND80-0861C. Berlin, Germany: Bundesanst für Materialprüf (BAM). 584-587.

42 Romesberg, L.E., S.H. Sutherland, G.H. Lamoreaux, and R.G. Eakes. 1981. "Design of Packaging for Transporting Transuranic Contaminated Wastes," Conference on Designing for Damage Prevention in the Transportation Environment, Gaithersburg, MD, October 21, 1981 SAND81-1308C. Albuquerque, NM: Sandia National Laboratories.

43 Sattler, A.R., and C.L. Christensen. 1980. Measurements of Very Large Deformations in "Potash Salt" in Conjunction With an Ongoing Mining Operation SAND79-2254. Albuquerque, NM: Sandia National Laboratories.

44 McVey, D.F. 1981. Analysis of Data from Line Source Thermal Conductivity Measurements Taken In Situ in Dome Salt at the Avery Island Mine. SAND81-1232. Albuquerque, NM: Sandia National Laboratories.

45 Ewing, R.I. 1981. WIPP Test of a Radiant Heater in the Avery Island Salt Mine. SAND81-1305. Albuquerque, NM: Sandia National Laboratories.

46 Neill, R.H., J.K. Channell, M.S. Little, K. Rehfeldt, and P. Speigler. 1983. Evaluation of the Suitability of the WIPP Site. EEG-23. Santa Fe, NM: Environmental Evaluation Group.

47 Neill, R.H., and J.K. Channell. 1983. Potential Problems from Shipment of High-Curie Content Contact-Handled Transuranic (CH-TRU) Waste to WIPP (Waste Isolation Pilot Plant). EEG-24. Santa Fe, NM: New Mexico Health and Environment Department, Environmental Evaluation Group.

48 Channell, J.K., J.C. Rodgers, and R.H. Neill. 1986. Adequacy of TRUPACT-I Design for Transporting ContactHandled Transuranic Wastes to WIPP (Waste Isolation Pilot Plant). EEG-33. Santa Fe, NM: New Mexico Health and Environment Department, Environmental Evaluation Group.

49 Public Law 97-425. 1983. Nuclear Waste Policy Act of 1982. (42 U.S.C. 10101 et. seq.).

50 Public Law 98-616. 1984. The Hazardous and Solid Waste Amendments of 1984 (98 Stat. 3221 ).

51 Legal Environmental Assistance Foundation, Inc. and Natural Resources Defense Council, Inc. State of Tennessee on behalf of Tennessee Department of Health and Environment (Intervening Plaintiff) v. Donald Hodel, Secretary, United States Department of Energy and United States Department of Energy. No. CIV. 3-83-562. 1984.586 Federal Supplement 1163.

52 U.S. Congress. Office of Technology Assessment. 1985. Managing the Nation's Commercial High-Level Radioactive Waste. OTA-O-171. Washington, DC: Superintendent of Documents, U.S. Government Printing Office.

53 NRDC (Natural Resources Defense Council, Inc.) v. United States Environmental Protection Agency, et al. 1987. 824 Federal Reporter, $2 d$ Series 1258.

54 Public Law 100-203. 1987. Nuclear Waste Policy Act Amendments of 1987 (42 U.S.C. 10101 et seq.). 
55 U.S. Department of the Interior. Bureau of Land Management. 1982. "43 CFR Public Land Order 6232. New Mexico; Withdrawal of Lands," Federal Register. Vol. 47, no. 61, 13340.

56 U.S. DOE (U.S. Department of Energy). 1980a. "New Mexico; Proposed Withdrawal and Reservations of Lands," Federal Register. Vol. 45, no. 223, 75768-75769.

57 EPA (Environmental Protection Agency). 1982. "40 CFR Part 191: Environmental Standards for the Management and Disposal of Spent Nuclear Fuel, High-Level and Transuranic Radioactive Wastes; Proposed Rule,"Federal Register. Vol. 47, no. 250, 58196-58206.

58 U.S. DOE (U.S. Department of Energy). 1983b. Summary of the Results of the Evaluation of the WIPP Site and Preliminary Design Validation Program. WIPP-DOE-161. Albuquerque, NM: U.S. Department of Energy.

59 U.S. Department of the Interior. Bureau of Land Management. 1983. "43 CFR Public Land Order 6403. New Mexico; Withdrawal of Lands," Federal Register. Vol. 48, no. 130, 31038-31039.

60 U.S. DOE (U.S. Department of Energy). 1983a. "Announcement of Decision to Proceed with Construction of the Waste Isolation Pilot Plant (WIPP)," Federal Register. Vol. 48, no. 128, 30427-30428.

61 "Memorandum of Understanding between the U.S. Department of Energy and the U.S. Department of Labor," signed by R.L. Bernard, DOL Administrator for Metal and Nonmetal Mine Safety and Health, and R.G. Romatowski, DOE Manager of Albuquerque Operations Office, dated July 9, 1987. (Copy on file in the Sandia WIPP Central Files, Sandia National Laboratories, Albuquerque, NM.)

62 Lambert, S.J. 1983. Dissolution of Evaporites In and Around the Delaware Basin, Southeastern New Mexico and West Texas. SAND82-0461. Albuquerque, NM: Sandia National Laboratories.

63 Earth Technology Corporation. 1988. Final Report for Time Domain Electromagnetic (TDEM) Surveys at the WIPP Site. SAND87-7144. Albuquerque, NM: Sandia National Laboratories.

64 Matalucci, R.V., C.L. Christensen, T.O. Hunter, M.A. Molecke, and D.E. Munson. 1982. Waste Isolation Pilot Plant (WIPP) Research and Development Program: In Situ Testing Plan, March 1982 SAND81-2628. Albuquerque, NM: Sandia National Laboratories.

65 Lynch, R.W., R.L. Hunter, D.R. Anderson, F.W. Bingham, J.M. Covan, G.F. Hohnstrieter, T.O. Hunter, R.D. Klett, E.E. Ryder, T.L. Sanders, and W.D. Weart. 1991.Deep Geologic Disposal in the United States: The Waste Isolation Pilot Plant and Yucca Mountain Projects. SAND90-1656. Albuquerque, NM: Sandia National Laboratories.

66 Tyler, L.D., R.V. Matalucci, M.A. Molecke, D.E. Munson, E.J. Nowak, and J.C. Stormont. 1988. Summary Report for the WIPP Technology Development Program for Isolation of Radioactive Waste. SAND88-0844. Albuquerque, NM: Sandia National Laboratories.

67 Romesberg, L.E., and M.L. Hudson. 1986. "Impact, Puncture and Thermal Testing of TRUPACT-I,"Proceedings of an International Symposium on the Packaging and Transportation of Radioactive Materials (PATRAM '86), Davos, Switzerland, June 16-20, 1986 SAND84-2067C, IAEA-SM-286/107. Vienna, Austria: International Atomic Energy Agency. Vol. 2, 511-519.

68 Romesberg, L.E., R.S. Longenbaugh, and B.J. Joseph. 1989.Fire Testing and Analysis of TRUPACT-I Thermal Test Article. SAND86-2710, TTC-0704. Albuquerque, NM: Sandia National Laboratories.

69 Lappin, A.R. 1988. Summary of Site-Characterization Studies Conducted From 1983 Through 1987 at the Waste Isolation Pilot Plant (WIPP) Site, Southeastern New Mexica SAND88-0157. Albuquerque, NM: Sandia National Laboratories.

70 Sandoval, R.P., and L.C. Sanchez. 1986. "TRUPACT Containment Issues," Proceedings of an International Symposium on the Packaging and Transportation of Radioactive Materials (PATRAM '86), Davos, Switzerland, June 16-20, 1986. SAND85-2203C. Vienna, Austria: International Atomic Energy Agency. Vol. 2, 719-727.

71 Warrant, M.M., J.M. Nelsen, and S.W. Woolfolk. 1986. "Containment Analysis of TRUPACT-I,"Proceedings of an International Symposium on the Packaging and Transportation of Radioactive Materials (PATRAM '86), 
Davos, Switzerland, June 16-20, 1986 SAND85-2188C, IAEA-SM-286-111P. Vienna, Austria: International Atomic Energy Agency. Vol. 2, 529-536.

72 State of New Mexico, ex rel., Tom Udall, Attorney General, Plaintiffs, Natural Resources Defense Council, et al., and State of Texas, ex rel., Dan Morales, Attorney General, Plaintiffs-Intervenors, v. James D. Watkins, Secretary of the Department of Energy, et al., Defendants. Environmental Defense Fund, et al., Plaintiffs, v. James D. Watkins, Secretary of the Department of Energy, et al., Defendants. Civ. A. Nos. 91-2527, 91-2929. United States District Court, District of Columbia. Dec. 13, 1991. 783 Federal Supplement 628.

73 State of New Mexico, ex rel., Tom Udall, Attorney General, Plaintiffs, Natural Resources Defense Council, et al., and State of Texas, ex rel. Dan Morales, Attorney General, Plaintiffs-Intervenors, v. James D. Watkins, Secretary of Energy, et al., Defendants. v. James D. Watkins, Secretary of the Department of Energy, et al., Defendants. Civ. A. No. 91-2527, 91-2929. United States District Court, District of Columbia. February 3, 1992.783 Federal Supplement 633.

74 Albuquerque Journal. June 11, 1993, p. 3D. "WIPP staff won't move to Carlsbad."

75 Welch, B. August 24, 1993. "Local group to meet Energy secretary over WIPP standstill," Current Argus.

76 Public Law 100-456. 1988. National Defense Authorization Act, Fiscal Year 1989.

77 Public Law 102-579. 1992. Waste Isolation Pilot Plant Land Withdrawal Act (106 Stat. 4777).

78 Public Law 102-486. 1976. Energy Policy Act of 1992 (106 Stat. 2776; 42 U.S.C. 13201).

79 Public Law 102-386. 1992. Federal Facility Compliance Act of 1992.

80 Public Law 103-160. 1993. National Defense Authorization Act for Fiscal Year 1994 (107 Stat. 1547).

81 Albuquerque Journal. June 28, 1989, p. A1. "Embattled WIPP won't open in '89."

82 U.S. DOE (U.S. Department of Energy). 1989a. "Waste Isolation Pilot Plant; Availability of Draft Supplement to the Final Environmental Impact Statement," Federal Register. Vol. 54, no. 76, 16350-16352.

83 U.S. DOE (U.S. Department of Energy). 1990c. Final Supplement Environmental Impact Statement, Waste Isolation Pilot Plant. DOE/EIS-0026-FS. Washington, DC: U.S. Department of Energy, Office of Environmental Restoration and Waste Management. Vols. 1-13.

84 U.S. DOE (U.S. Department of Energy). 1990a. "Record of Decision; Waste Isolation Pilot Plant," Federal Register. Vol. 55, no. 121, 25689-25692.

85 EPA (Environmental Protection Agency). 1990. "Conditional No-Migration Determination for the Department of Energy Waste Isolation Pilot Plant (WIPP)," Federal Register. Vol. 55, no. 220, 47700-47721.

86 U.S. Department of the Interior. Bureau of Land Management. 1991a. "43 CFR Public Land Order 6826. Modification of Public Land Order No. 6503; New Mexico," Federal Register. Vol. 56, no. 18, 3038-3039.

87 U.S. Department of the Interior. Bureau of Land Management. 1991b. "Record of Decision (ROD), Waste Isolation Pilot Plant (WIPP) Project; New Mexico," Federal Register, Vol. 56, no. 18, 3114-3115.

88 U.S. Department of the Interior. Bureau of Land Management. 1991c. "43 CFR Public Land Order 6826. Modification of Public Land Order No. 6403; New Mexico," Federal Register. Vol. 56, no. 29, 5731.

89 U.S. Department of the Interior. Bureau of Land Management. 1991d. "Notice to Proceed, Waste Isolation Pilot Plant (WIPP) Project, New Mexico," Federal Register. Vol. 56, no. 196, 50923-50924.

90 EPA (Environmental Protection Agency). 1993a. "40 CFR Part 191: Environmental Radiation Protection Standards for the Management and Disposal of Spent Nuclear Fuel, High-Level and Transuranic Radioactive Wastes, Final Rule," Federal Register. Vol. 58, no. 242, 66398-66416.

91 EPA (Environmental Protection Agency). 1993b. "Criteria for the Certification of Compliance with Environmental Radiation Protection Standards for the Management and Disposal of Spent Nuclear Fuel, HighLevel and Transuranic Radioactive Wastes; Advanced Notice and Proposed Rulemaking,"Federal Register. Vol. 58 , no. $27,8029-8030$. 
92 Nowak, E.J., D.F. McTigue, and R. Beraún. 1988. Brine Inflow to WIPP Disposal Rooms: Data, Modeling, and Assessment. SAND88-0112. Albuquerque, NM: Sandia National Laboratories.

93 Nuclear Packaging, Inc. 1989. Safety Analysis Report for the TRUPACT-II Shipping Package, Rev. 4 SR00045. Washington, DC: Nuclear Packaging, Inc. Vols. 1-5. (Copy on file in the U.S. Nuclear Regulatory Commission Reading Room, Washington, DC.)

94 Lappin, A.R., R.L. Hunter, D.P. Garber, and P.B. Davies, eds. 1989. Systems Analysis, Long-Term Radionuclide Transport, and Dose Assessments, Waste Isolation Pilot Plant (WIPP), Southeastern New Mexico; March 1989 SAND89-0462. Albuquerque, NM: Sandia National Laboratories.

95 U.S. DOE (U.S. Department of Energy). 1989b. Waste Isolation Pilot Plant No-Migration Variance Petition DOE/WIPP 89-003, Rev. 0. Carlsbad, NM: Westinghouse Electric Corporation, Waste Isolation Division

96 Marietta, M.G., S.G. Bertram-Howery, D.R. Anderson, K.F. Brinster, R.V. Guzowski, H. Iuzzolino, and R.P. Rechard. 1989. Performance Assessment Methodology Demonstration: Methodology Development for Evaluating Compliance With EPA 40 CFR 191. Subpart B, for the Waste Isolation Pilot Plant. SAND89-2027. Albuquerque, NM: Sandia National Laboratories.

97 Bertram-Howery, S.G., M.G. Marietta, D.R. Anderson, K.F. Brinster, L.S. Gomez, R.V. Guzowski, and R.P. Rechard. 1989. Draft Forecast of the Final Report for the Comparison to 40 CFR Part 191, Subpart B, for the Waste Isolation Pilot Plant. SAND88-1452. Albuquerque, NM: Sandia National Laboratories.

98 U.S. DOE (U.S. Department of Energy). 1990b. Final Safety Analysis Report, Waste Isolation Pilot Plant, Carlsbad, New Mexico. WP 02-9, Rev. 0. Carlsbad, NM: Westinghouse Electric Corporation.

99 Rechard, R.P., H.J. Iuzzolino, J.S. Rath, A.P. Gilkey, R.D. McCurley, and D.K. Rudeen. 1989. User's Manual for CAMCON: Compliance Assessment Methodology Controller. SAND88-1496. Albuquerque, NM: Sandia National Laboratories.

100 Bertram-Howery, S.G., M.G. Marietta, R.P. Rechard, P.N. Swift, D.R. Anderson, B.L. Baker, J.E. Bean, Jr., W. Beyeler, K.F. Brinster, R.V. Guzowski, J.C. Helton, R.D. McCurley, D.K. Rudeen, J.D. Schreiber, and P. Vaughn. 1990a. Preliminary Comparison with 40 CFR Part 191, Subpart B for the Waste Isolation Pilot Plant, December 1990. SAND90-2347. Albuquerque, NM: Sandia National Laboratories.

101 Rechard, R.P., W. Beyeler, R.D. McCurley, D.K. Rudeen, J.E. Bean, and J.D. Schreiber. 1990b. Parameter Sensitivity Studies of Selected Components of the Waste Isolation Pilot Plant Repository/Shaft System. SAND892030. Albuquerque, NM: Sandia National Laboratories.

102 WIPP PA (Performance Assessment) Division. 1991. Preliminary Comparison with 40 CFR Part 191, Subpart B for the Waste Isolation Pilot Plant, December 1991. SAND91-0893/1/2/3. Albuquerque, NM: Sandia National Laboratories. Vols. 1-3.

103 U.S. DOE (U.S. Department of Energy). 1993a. Test Phase Plan for the Waste Isolation Pilot Plant. DOE/WIPP 89-011, Revision 1. Albuquerque, NM: U.S. Department of Energy, WIPP Project Integration Office.

104 U.S. DOE (U.S. Department of Energy). 1993b. Waste Retrieval Plan for the Waste Isolation Pilot Plant. DOE/WIPP-89-022, Rev. 1. Washington, DC: U.S. Department of Energy.

105 WIPP PA (Performance Assessment) Department. 1992/1993. Preliminary Performance Assessment for the Waste Isolation Pilot Plant, December 1992. SAND92-0700/1/2/3. Albuquerque, NM: Sandia National Laboratories. Vols. 1-3.

106 U.S. DOE (Department of Energy). 1987. "10 CFR Part 962-Byproduct Material," Federal Register. Vol. 52, no. 84,15940 .

107 "Reversal on Nuclear Waste Tests," Science News. Vol. 144, no. 19, 303.

108 U.S. DOE (U.S. Department of Energy). 1995b. Draft 40 CFR 191 Compliance Certification Application for the Waste Isolation Pilot Plant. Phase II Review. DOE/CAO - Predecisional Draft-2056. Carlsbad, NM: U.S. Department of Energy, Waste Isolation Pilot Plant, Carlsbad Area Office. 
1.5 Regulatory Influences on the Waste Isolation Pilot Plant Project 


\subsubsection{Timeline of Events Influencing Performance Assessment Process}

The progress in itegrating many disciplines and developing corresponding computational tools for a performance assessment (PA) is directly tied to the major projects that have been funded to this specific type of policy analysis. However, the events influencing the PA process are more than just a long list of major projects each making an evolutionary improvement. In this section and tabulated in Table 1.5-2, aspects of the history of the performance assessment process are grouped into four main subject categories: (1) events directly associated with nuclear reactor risk assessments in the United States, (2) events associated with performance assessments of nuclear waste repositories in the United States and abroad, (3) events associated with risk assessments with transporting nuclear waste and in disciplines other than nuclear facilities, and (4) outside influences affecting the performance assessment process in general. In the following discussion, a temporal categorization is also used. The first temporal category is the foundation phase (1947-1975) where most aspects of the underlying theory were developed for the PA process and limited applications of that theory were made. The second is the large-scale, interdisciplinary phase (19751985) where probabilistic risk assessments (PRA) and probabilistic performance assessments (PA) were done for the first time in the United States for large, complex nuclear facilities that require the integration of many scientific disciplines. The third is the diverse application phase $(\sim 1985$ onward) where many applications to different physical systems have been made.

Besides the mathematical fields of probability and statistics, ${ }^{1}$ the foundations of the performance assessment process discussed in this report have evolved largely out of the U. S. nuclear weapons programs. The most important foundation technique was the development of the Monte Carlo method (see Section 1.3.1) by the Manhattan Project to evaluate the physics of weapons, specifically nuclear diffusion of neutrons through fissile material. ${ }^{2}$ Also drawn upon was the reservoir of techniques that were developed for the analysis of the reliability of delivery systems for nuclear weapons in the 1950 s and early 1960s. One such example is the fault tree technique developed by Bell Laboratories and applied by Boeing to evaluate the Minuteman Missile. ${ }^{3}$ Another important foundational development for PAs in the United States was the development of the Latin Hypercube sampling technique in the summer of 1975 (see Section 4.2.2, Latin Hypercube Sampling).

The National Environmental Policy Act of 1969 (NEPA) (see Section 6.2) created a need to predict risks of large federally funded actions - especially technological actions. NEPA also provided an avenue through the public comment period on the Environmental Impact Statement (EIS) for special interest groups to call for more stringent analysis of the associated hazards of technological actions and resulted in a shift to detailed modeling to predict the consequences of these outcomes. ${ }^{4}$ An important technology to be significantly affected by NEPA was nuclear power. Although not directly tied to a formal EIS, the justly famous Reactor Safety Study ${ }^{5}$ requested by the Atomic Energy Commission Chairman, James Schlesinger, to evaluate hazards from severe accidents at commercial nuclear reactors was one of the earliest analysis to met the general needs of detailed analysis required in the new atmosphere created by the NEPA. The critiques of the Reactor Safety Study also published in 1975 (e.g., Lewis Report' recognized its significant contribution as the first detailed, comprehensive, quantitative look at a large, complex nuclear facility. However, the critiques also noted that uncertainty associated with estimates for parameter values needed to be included besides uncertainty in behavior of the system, which had been evaluated through event trees and fault trees (see Section 1.3, Types of Uncertainty in Performance Assessments).

Demands for permanent solutions to nuclear waste provided an impetus for President Ford to call for more vigorous pursuit of applicable standards in 1977 for proposed waste repositories that culminated in the first probabilistic standard (see Section 6.1). It was during this period that the term performance assessment was adopted for assessments of waste disposal systems. Analysts at Sandia adopted a thorough and rigorous probabilistic approach, similar to the pioneering work in the Reactor Safety Study probabilistic risk assessment. Although the underlying theory of the PRA and the PA are the same, not all the analysis tools developed for assessing nuclear reactors could be used for assessing a geological disposal system. Both the engineered and geologic components of a waste disposal system are subject to natural process over geologic time ${ }^{7}$; hence, fault trees to calculate probabilities are not used and simple event trees usually omit temporal effects. ${ }^{8}$ Furthermore, computational tools differed because more phenomenological models were needed in order to include geologic processes. Although Sandia developed codes to be loosely connected in a PA in the late 1970 s and early $1980 \mathrm{~s},{ }^{9}$ the Canadians developed the first integrated system, SYVAC, in $1981 . .^{10}$ This was followed by other systems, including the CAMCON system, developed primarily between 1988 
and 1990. The capabilities implemented in CAMCON greatly determined the approaches used and described in this report on the WIPP PA (see Section 3.3, Modeling System Selection)

During the late 1970 s and early 1980 s, exchange of ideas and concepts about national nuclear waste disposal occurred through the International Atomic Energy Agency (IAEA) located in Vienna and the Nuclear Energy Agency (NEA) located in Paris (e.g., the international subseabed disposal system program and the Probabilistic Systems Assessment Code [PSAC] user group ${ }^{1}$ ). Also during the 1980s and 1990s, many diverse applications of PRA and PA occurred beyond those done initially for nuclear facilities. Several accidents and one disaster helped prompt the more frequent use of risk assessment. The first was the accident in one unit of the Three-Mile Island nuclear power plant in 1979. Another important accident was the Challenger space shuttle explosion in 1986. Both accidents helped give more credence to risk assessment. In 1984, the disaster at the chemical plant in Bhopal, India, where safety responsibilities had been turned over to local authorities who did not appreciate the gravity of ignoring safety procedures, helped encourage more extensive risk assessments within the chemical industry. Surprisingly, the risk culture that developed for nuclear facilities and the risk culture that developed for other disciplines, specifically environmental hazards from chemicals (summarized by the National Academy of Sciences in $1983^{12}$ ), have not frequently learned from each other-as evidenced, for example, by the different terms used for describing types of uncertainty. Some cross over has occurred, ${ }^{13}$ but until very recently the occurrences have generally remained isolated instances of what could be called probabilistic system assessments.

\section{References for Section 1.5.2 Text}

1 Hacking, I. 1975. The Emergence of Probability. New York, NY: Cambridge University Press.

2 Hammersley, J.M., and D.C. Handscomb. 1964. Monte Carlo Methods. New York, NY: John Wiley \& Sons, Inc.

3 Hixenbaugh, A.F. 1968. Fault Tree for Safety. D6-53604. Seattle, WA: Boeing Company, Support Systems Engineering.

4 Kaye S.V. 1983. "Foreword," Radiological Assessment: A Textbook On Environmental Dose Analysis. Eds. J.E. Till and H.R. Meyer. NUREG/CR-3332. Washington, DC: U.S. Nuclear Regulatory Commission, Office of Nuclear Reactor Regulation. xi-xiv.

5 Rasmussen, N.C. 1975. Reactor Safety Study: An Assessment of Accident Risks in U.S. Commercial Nuclear Power Plants. NUREG-75/014, WASH-1400. Washington, DC: U.S. Nuclear Regulatory Commission.

6 Lewis, H.W., R.J. Budnitz, H.J.C. Kouts, W.B. Loewenstein, W.D. Rowe, F. von Hippel, and F. Zachariasen. 1978. Risk Assessment Review Group Report to the U.S. Nuclear Regulatory Commission. NUREG/CR-0400. Washington, DC: U.S. Nuclear Regulatory Commission.

7 Logan, S.E. 1976. Workshop on Geologic Data Requirements for Radioactive Waste Management Assessment Models, Santa Fe, NM, June 28-July 1, 1976. Y/OW1/SUB-76/8/726. Albuquerque, NM: College of Engineering, University of New Mexico for the Office of Waste Isolation.

8 U.S. DOE (U.S. Department of Energy). 1988. Site Characterization Plan, Yucca Mountain Site, Nevada Research and Development Area, Nevada. DOE/RW-0199. Washington, DC: U.S. Department of Energy. Section 8.3.5.13.

9 Iman, R.L., J.C. Helton, and J.E. Campbell. 1978. Risk Methodology for Geologic Disposal of Radioactive Waste: Sensitivity Analysis Techniques. SAND78-0912, NUREG/CR-0390. Albuquerque, NM: Sandia National Laboratories.

10 Dormuth, K.W., and G.R. Sherman. 1981. SYVAC-A Computer Program for Assessment of Nuclear-Fuel Waste-Management Systems, Incorporating Parameter Variability. AECL-6814. Pinawa, Manitoba: Atomic Energy of Canada Ltd., Whiteshell Nuclear Research Establishment.

11 Thompson, B.G.J., and B. Sager. 1993. "The Development and Application of Integrated Procedures for PostClosure Assessment, Based Upon Monte Carlo Simulation: The Probabilistic Systems Assessment (PSA) Approach," Reliability Engineering and System Safety. Vol. 42, no. 2-3, 125-160.

12 NAS/NRC (National Academy of Sciences/National Research Council). 1983. Risk Assessment in the Federal Government. Washington, DC: National Academy Press.

13 Rechard, R.P., M.S.Y. Chu, and S.L. Brown. 1988. SRS: Site Ranking System for Hazardous Chemical and Radioactive Waste. SAND86-2994, DOE/FWP-26. Albuquerque, NM: Sandia National Laboratories. 


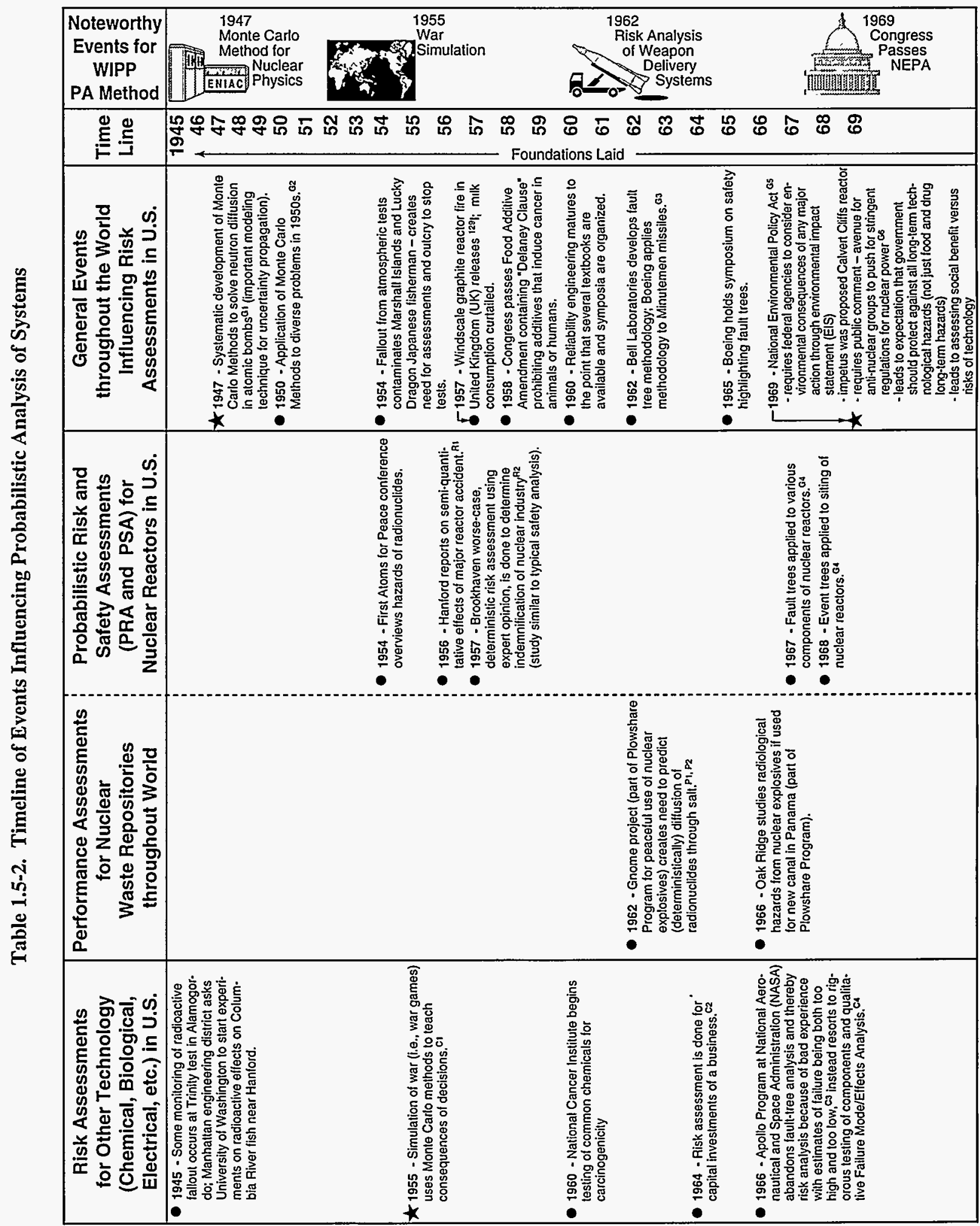

TRI-6342-4516-0 


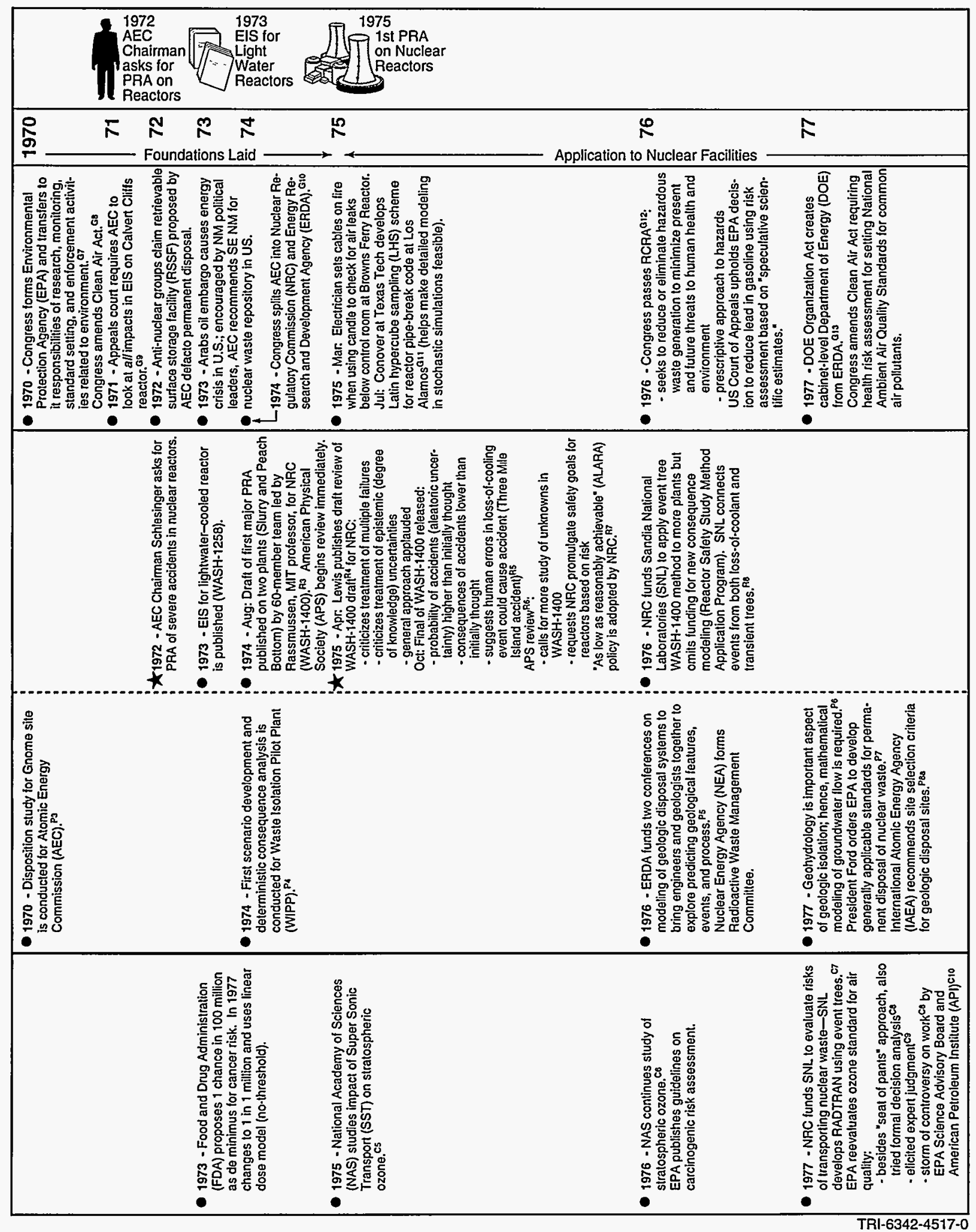




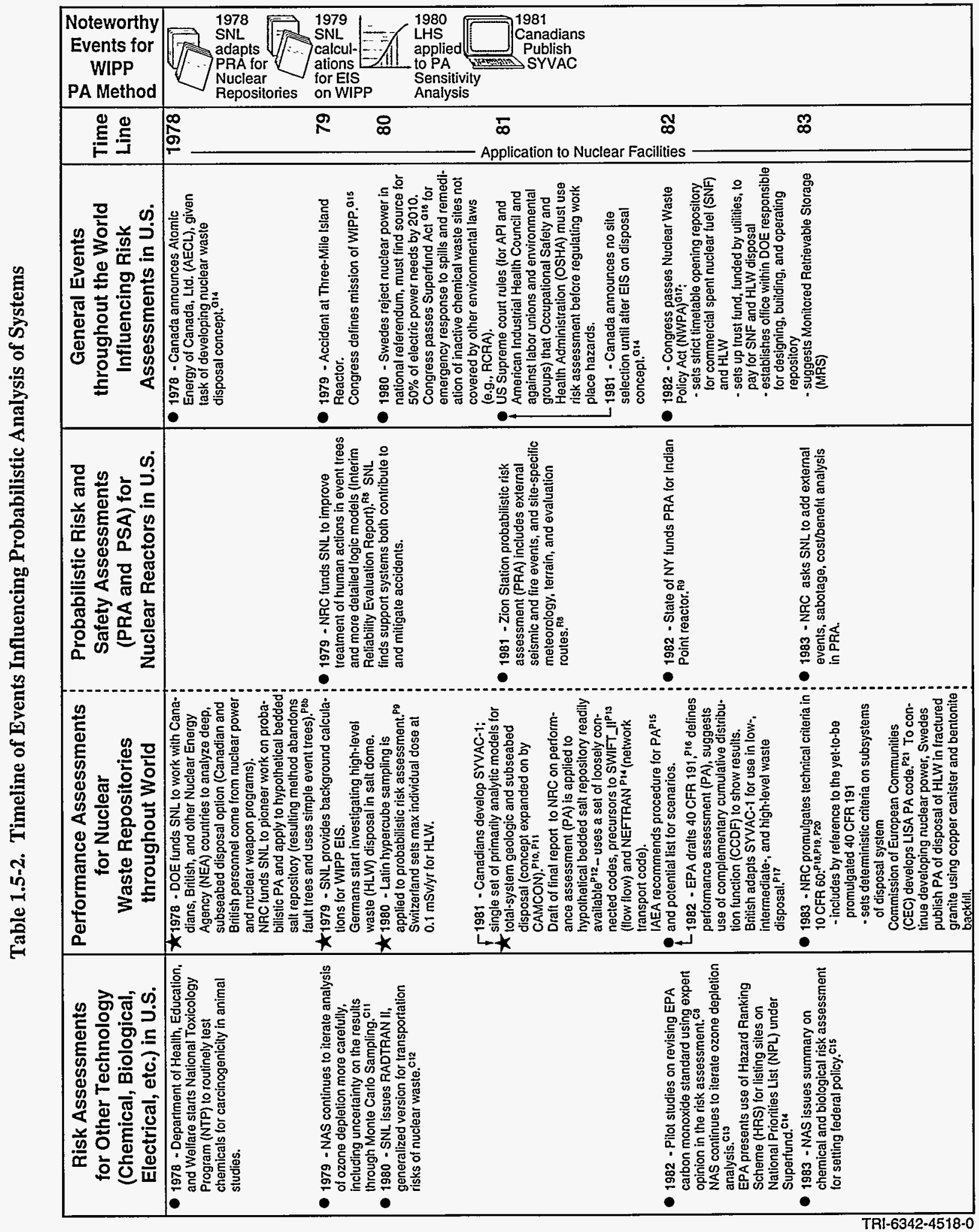




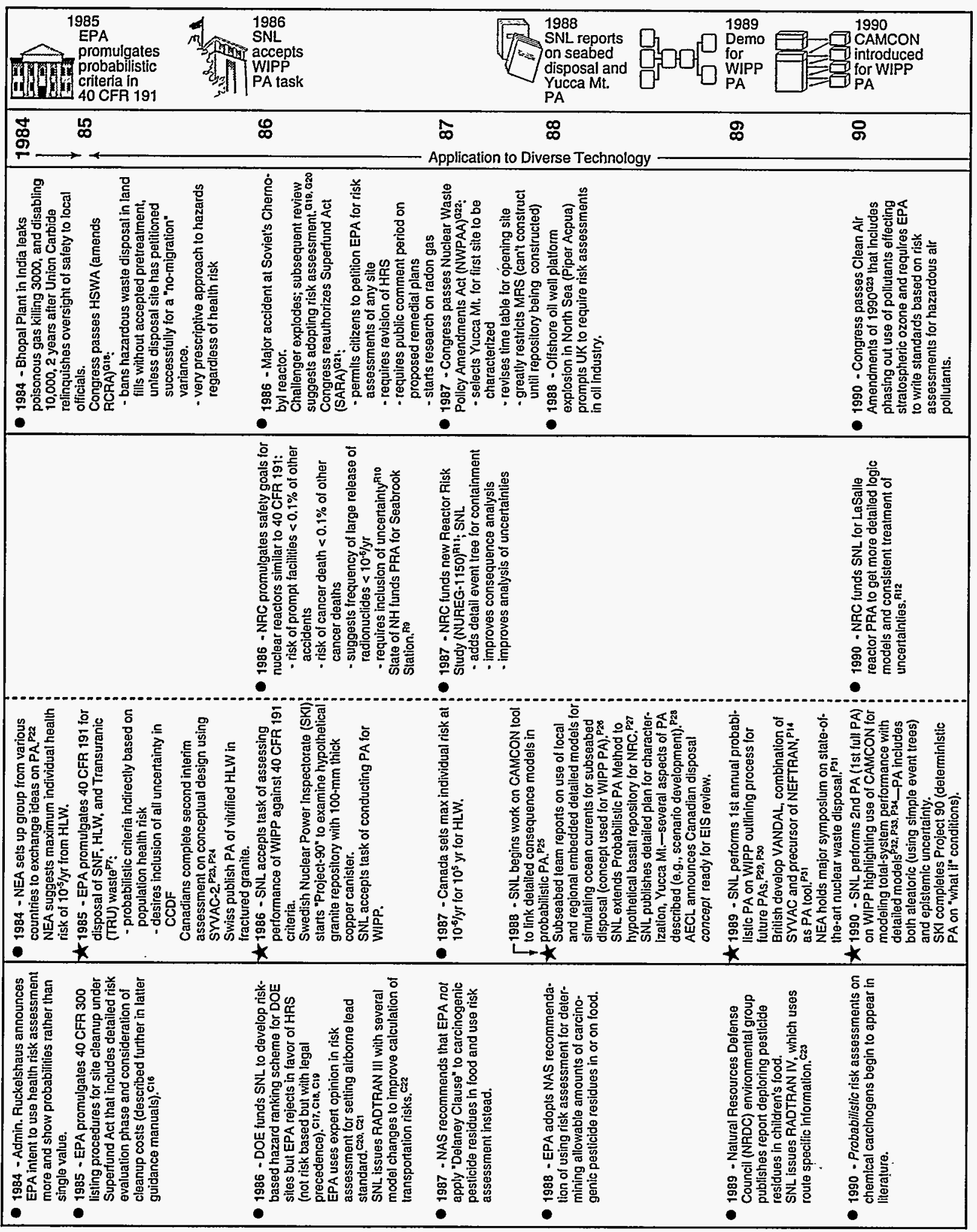




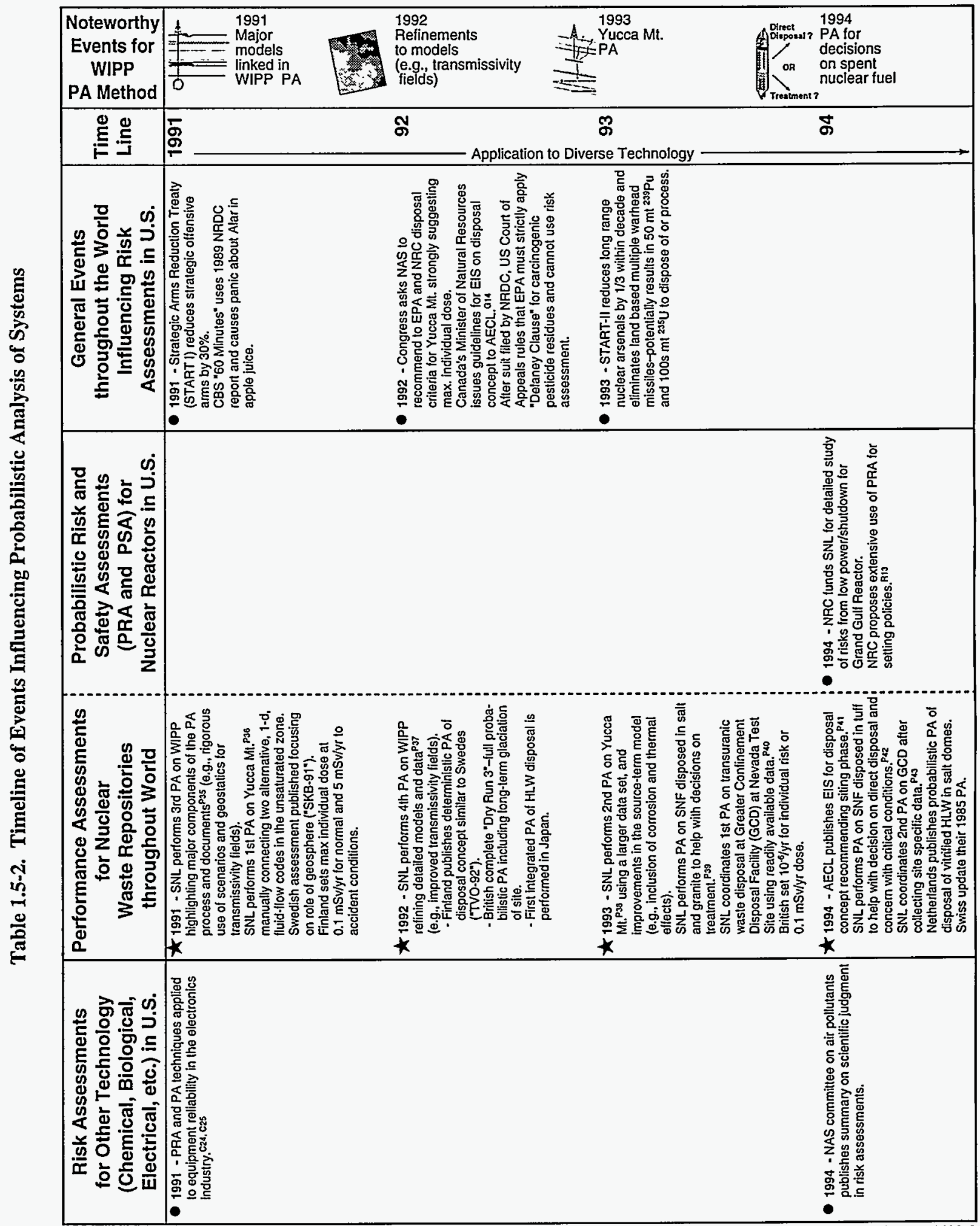

TRI-6342-4520-0 


\section{Table 1.5-2 References}

C1 Zimmerman, R.E., G. Cramer, and E. Joseph. 1956 (Declassified 1959). Monte Carlo Computer War Gaming. A Feasibility Study. RAC-T-325; AD-94 459. McLean, VA: Research Analysis Corp.; St. Paul, MN: Engineering Research Associates, Inc. (Available from National Technical Information Service, Springfield, VA.)

C2 Hertz, D.B. 1964. "Risk Analysis in Capital Investment," Harvard Business Review. Vol. 42, no. 1, 95-106.

C3 Garrick, B.J. 1991. "The Approach to Risk Analysis in Three Industries: Nuclear Power, Space Systems and Chemical Process," Risk Management: Expanding Horizons in Nuclear Power and Other Industries. Ed. R.A. Knief. New York, NY: Hemisphere Publishing Corporation. 173-181.

C4 DOD (U.S. Department of Defense). 1984. System Safety Program Requirements. MIL-STD-882B. Washington, DC: U.S. Department of Defense.

C5 NAS/NRC (National Academy of Sciences/National Research Council). 1975. Environmental Impact of Stratospheric Flight: Biological and Climatic Effects of Aircraft Emissions in the Stratosphere. Washington, DC: National Academy of Sciences.

C6 NAS/NRC (National Academy of Sciences/National Research Council). 1976. Halocarbons: Environmental Effects of Chlorofluoromethane Release. Washington, DC: National Research Council, Assembly of Mathematical and Physical Sciences.

C7 Taylor, J.M., and S.L. Daniel. 1977. RADTRAN: A Computer Code to Analyze Transportation of Radioactive Material. SAND76-0243. Albuquerque, NM: Sandia [National] Laboratories.

C8 Morgan, M.G., M. Henrion, and M. Small. 1990. Uncertainty, a Guide to Dealing With Uncertainty in Quantitative Risk and Policy Analysis. New York, NY: Cambridge University Press.

C9 Feagans, T.B., and W.F. Biller. 1981. "Risk Assessment: Describing The Protection Provided by Ambient Air Quality Standards, "The Environmental Professional. Vol. 3, no. 3/4, 235-247.

C10 Marraro, C.H. 1982. "Revising the Ozone Standard," Quantitative Risk Assessment in Regulation Ed. L.B. Lave. Washington, D.C: Brookings Institution. 55-97.

C11 NAS/NRC (National Academy of Sciences/National Research Council). 1979. Stratospheric Ozone Depletion by Halocarbons: Chemistry and Transport. Washington, DC: National Academy of Sciences.

C12 Taylor, J.M., S.L. Daniel, and B.E. Biringer. 1980. "RADTRAN II: A Computerized Model for Risk Analysis for Transportation of Radioactive Material," Proceedings of 6th International Symposium, Packaging and Transportation of Radioactive Materials, PATRAM '80, West Berlin, West Germany, November 10-14, 1980 Ed. H.W. Hübner. Hamburg: K.O. Storck \& Co. Vol. 1, 161-167.

C13 NAS/NRC (National Academy of Sciences/National Research Council). 1982. Causes and Effects of Stratospheric Ozone Reduction: An Update. Washington, DC: National Academy Press.

C14 HRS (Hazard Ranking Scheme) Workshop. 1982. Selection of Hazardous Waste Sites for Superfund Funding: Workshop. Sponsored by Subcommittee on Department of Housing and Urban Development-Independent Agencies for the Committee on Appropriations, U.S. Senate, March 19-20, 1982 Washington: U.S. G.P.O., For Sale by the Superintendent of Documents, U.S. G.P.O.

C15 NAS/NRC (National Academy of Sciences/National Research Council). 1983. Risk Assessment in the Federal Government: Managing the Process. Washington, DC: National Academy Press.*

C16 EPA (Environmental Protection Agency). 1985c. "Part 300-National Oil and Hazardous Substances Pollution Contingency Plan," Federal Register. Vol. 50, no. 224, 47950-47979.

C17 Chu, M.S.Y., J.V. Rodricks, C. St. Hilaire, and R.L. Bras. 1986. Risk Assessment and Ranking Methodologies for Hazardous Chemical Defense Waste: A State-of-the-Art Review and Evaluation, Task I Report. SAND86-0530. Albuquerque, NM: Sandia National Laboratories.

C18 Rechard, R.P., M.S.Y. Chu, and S.L. Brown. 1988. SRS: Site Ranking, System for Hazardous Chemical and Radioactive Waste. SAND86-2994, DOE/HWP-26. Albuquerque, NM: Sandia National Laboratories. 
C19 Rechard, R.P., G.F. Wilkinson, and J.D. Schreiber. 1991a. User's Manual for SRS88: Site Ranking System for Chemical and Radioactive Waste. SAND87-2815, DOE/HWP-26. Albuquerque, NM: Sandia National Laboratories.

C20 Whitfield, R.G., and T.S. Wallsten. 1989. "A Risk Assessment for Selected Lead-Induced Health Effects: An Example of a General Methodology," Risk Analysis. Vol. 9, no. 2, 197-207.

C21 Richmond, H.M. 1987. "Development of Probabilistic Health Risk Assessment for National Ambient Air Quality Standards," Regulatory Approaches for Control of Air Pollutants, Proceedings of an APCA Specialty Conference, Atlanta, GA, February 1987. Pittsburgh, PA: Air Pollution Control Association. 178-192.

C22 Madsen, M.M., J.M. Taylor, R.M. Ostmeyer, and P.C. Reardon. 1986. RADTRAN III. SAND84-0036. Albuquerque, NM: Sandia National Laboratories.

C23 Neuhauser, K.S. and P.C. Reardon. 1989. "RADTRAN 4.0: Advanced Computer Code for Transportation Risk Assessment," International Symposium on Packaging and Transporting of Radioactive Materials (PATRAM '89), Washington, DC, June 11-16, 1989. SAND89-1137C. Albuquerque, NM: Sandia National Laboratories.

C24 Painton, L., and J. Campbell. 1993. "Identification of Components to Optimize Improvement in System Reliability," Probabilistic Safety Assessment and Management, (PSAM), 2nd, San Diego, CA, March 20-25, 1993. SAND93-2420C. Albuquerque, NM: Sandia National Laboratories.

C25 Painton, L., and J.E. Campbell. 1995. "Genetic Algorithms in Optimization of System Reliability," IEEE Transactions on Reliability. Vol. 44, no. 2, 172-178.

G1 LANL (Los Alamos National Laboratory). 1987. "Stanislaw Ulam 1909-1984,"Los Alamos Science. No. 15, Special Issue. Los Alamos, NM: Los Alamos National Laboratory.

G2 Hammersley, J.M., and D.C. Handscomb. 1964. Monte Carlo Methods. New York, NY: John Wiley \& Sons, Inc.

G3 Hixenbaugh, A.F. 1968. Fault Tree for Safety. D6-53604. Seattle, WA: Boeing Company, Support Systems Engineering.

G4 Apostolakis, G. 1974. Mathematical Methods of Probabilistic Safety Analysis. UCLA-ENG-7464. Los Angeles, CA: University of California at Los Angeles, School of Engineering and Applied Science.

G5 Public Law 91-190. 1970. National Environmental Policy Act of 1969. (83 Stat. 852; 42 U.S.C. 1801 et seq) .

G6 Kaye, S.V. 1983. "Foreword," Radiological Assessment: A Textbook On Environmental Dose Analysis. Eds. J.E. Till and H.R. Meyer. NUREG/CR-3332. Washington, DC: U.S. Nuclear Regulatory Commission, Office of Nuclear Reactor Regulation. xi-xiv.

G7 EPA (Environmental Protection Agency). 1993c. "Part 1-Statement of Organization and General Information," Code of Fea'eral Regulation 40, Part 1. Washington DC: Superintendent of Documents, U.S. Government Printing Office.

G8 Public Law 91-604. 1970. Clean Air Amendments of 1970 (81 Stat. 486; 42 U.S.C. 1857 et seq.).

G9 Calvert Cliffs' Coordinating Committee. Inc., et al., Petitioners v. United States Atomic Energy Commission and United States of America Respondents. Nos. 24839, 24871. 1971. 440 F. 2 d l l O9.

G10 Public Law 93-438. 1974. Energy Reorganization Act of 1974 (42 U.S.C. 5801 et seq) -

G11 McKay, M.D., R.J. Beckman, and W.J. Conover. 1979. "A Comparison of Three Methods for Selecting Values of Input Variables in the Analysis of Output from a Computer Code," Technometrics. Vol. 21; no. 2, 239-245.

G12 Public Law 94-580. 1976. Resource Conservation and Recovery Act of 1976 (90 Stat. 2795).

G13 Public Law 95-91. 1977. Department of Energy Organization Act (42 U.S.C. 7101 et seq.).

G14 AECL (Atomic Energy of Canada, Ltd.). 1994. Summary of the Environmental Impact Statement on the Concept for Disposal of Canada's Nuclear Fuel Waste. AECL-10721. Pinawa, Manitoba: Atomic Energy of Canada, Ltd. 
G15 Public Law 96-164. 1979. Department of Energy National Security and Military Applications of Nuclear Energy Authorization Act of 1980.

G16 Public Law 96-510. Comprehensive Environmental Response, Compensation, and Liability Act of 1980 (Superfund). 94 Stat. 2767.

G17 Public Law 97-425. 1983. Nuclear Waste Policy Act of 1982. (42 U.S.C. 10101 et. seq).

G18 Public Law 98-616. 1984. The Hazardous and Solid Waste Amendments of 1984 (98 Stat. 3221).

G19 U.S. Congress. 1986. "Investigation of the Challenger Accident," House Report 99-1016 U.S. House of Representatives, Committee on Science and Technology, Ninety-Ninth Congress, Second Session. Washington, DC: U.S. Government Printing Office.

G20 Marshall, E. 1986. "Feynman Issues His Own Shuttle Report, Attacking NASA Risk Estimates,"Science. Vol. 232, no. 4758, 1596.

G21 Public Law 99-499. The Superfund Amendment and Reauthorization Act of 1986 (SARA).

G22 Public Law 100-203. 1987. Nuclear Waste Policy Act Amendments of 1987 (42 U.S.C. 10101 et seq.).

G23 Public Law 101-549. 1990. Clean Air Act Amendments of 1990.

PI Gard, L.M., J.B. Cooper, D.D. Dickey, C.G. Bowles, B.M. Madsen, R.D. Carroll, C.M. Bunker, V.J. Janzer, M.C. Goldberg, C.G. Angelo, W.A. Beetem, and W.A. Mourant. 1962. Hydrologic and Geologic Studies for Project Gnome - Progress Report. PNE-130F. Washington, D.C.: United States Department of the Interior, Geological Survey. (Copy available from the National Technical Information Service, Springfield, VA.)

P2 Cooper, J.B., and V.M. Glanzman. 1971. Geohydrology of Project Gnome Site, Eddy County, New Mexico Geological Survey Professional Paper 712-A. Washington, DC: U.S. Government Printing Office.

P3 Gardner, M.C., and J.J. Sigalove. 1970. Evaluation of the Project Gnome/Coach Site, Carlsbad, New Mexico, for Disposition, Including Identification of Restrictions, Part I. NVO-1229-106. Las Vegas, NV: U.S. Atomic Energy Commission, Nevada Operations Office.

P4 Claiborne, H.C., and F. Gera. 1974. Potential Containment Failure Mechanisms and Their Consequences at a Radioactive Waste Repository in Bedded Salt in New Mexica ORNL-TM-4639. Oak Ridge, TN: Oak Ridge National Laboratories.

P5 Logan, S.E. 1976. Workshop on Geologic Data Requirements for Radioactive Waste Management Assessment Models, Santa Fe, NM, June 28-July 1, 1976. Y/OW1/SUB-76/81726. Albuquerque, NM: University of New Mexico, College of Engineering for the Office of Waste Isolation.

P6 de Marsily, G., E. Ledoux, A. Barbreau, and J. Margat. 1977. "Nuclear Waste Disposal: Can the Geologists Guarantee Isolation?" Science. Vol. 197, no. 4303, 519-526.

P7 EPA (Environmental Protection Agency). 1985a. "40 CFR Part 191: Environmental Standards for the Management and Disposal of Spent Nuclear Fuel, High-Level and Transuranic Radioactive Wastes; Final Rule," Federal Register. Vol. 50, no. 182, 38067.

P8a IAEA (International Atomic Energy Agency). 1977. Site Selection Factors for Repositories of Solid, High-Level and Alpha-Bearing Wastes in Geological Formations. Technical Reports Series No. 177. Vienna, Austria: International Atomic Energy Agency.

P8b Campbell, J.E., R.T. Dillon, M.S. Tierney, H.T. Davis, P.E. McGrath, F.J. Pearson, Jr., H.R. Shaw, J.C. Helton, and F.A. Donath. 1978. Risk Methodology for Geologic Disposal of Radioactive Waste: Interim Report. SAND78-0029, NUREG/CR-0458. Albuquerque, NM: Sandia National Laboratories.

P9 Iman, R.L., and W.J. Conover. 1980a. "Small Sample Sensitivity Analysis Techniques for Computer Models, With an Application to Risk Assessment," Communications in Statistics. Vol. A9, no. 17, 1749-1842. 
P10 Dormuth, K.W., and G.R. Sherman. 1981. SYVAC-A Computer Program for Assessment of Nuclear-Fuel Waste-Management Systems, Incorporating Parameter Variability. AECL-6814. Pinawa, Manitoba: Atomic Energy of Canada Ltd., Whiteshell Nuclear Research Establishment.

P11 Lyon, R.B. 1982. "Nuclear Waste Disposal: The Interface Between Performance Assessment and Research," Scientific Basis for Nuclear Waste Management, Proceedings of the Materials Research Society Annual Meeting, Boston, MA, November 1981. Ed. S.V. Topp. New York, NY: North-Holland. Vol. 6, 473-480.

P12 Cranwell, R.M., J.E. Campbell, J.C. Helton, R.L. Iman, D.E. Longsine, N.R. Ortiz, G.E. Runkle, and M.J. Shortencarier. 1987. Risk Methodology for Geological Disposal of Radioactive Waste: Final Report. SAND812573, NUREG/CR-2452. Albuquerque, NM: Sandia National Laboratories.

P13 Reeves, M., D.S. Ward, N.D. Johns, and R.M. Cranwell. 1986b. Theory and Implementation for SWIFT II, The Sandia Waste-Isolation Flow and Transport Model for Fractured Media, Release 4.84 SAND83-1159, NUREG/CR-3328. Albuquerque, NM: Sandia National Laboratories.

P14 Campbell, J.E., D.E. Longsine, and R.M. Cranwell. 1981. Risk Methodology for Geologic Disposal of Radioactive Waste: The NWFT/DVM Computer Code Users' Manual. SAND81-0886, NUREG/CR-2081. Albuquerque, NM: Sandia National Laboratories.

P15 IAEA (International Atomic Energy Agency). 1981. Safety Assessment for the Underground Disposal of Radioactive Waste. Safety Series No. 56. Vienna, Austria: International Atomic Energy Agency.

P16 EPA (Environmental Protection Agency). 1982. "40 CFR Part 191: Environmental Standards for the Management and Disposal of Spent Nuclear Fuel, High-Level and Transuranic Radioactive Wastes; Proposed Rule," Federal Register. Vol. 47, no. 250, 58196-58206.

-P17 Thompson, B.G.J. 1987. "The Development of Procedures for the Risk Assessment of Underground Disposal of Radioactive Wastes: Research Funded by the Department of the Environment 1982-1987,"Radioactive Waste Management (Switzerland). Vol. 91, no. 1-3, 215-256.

P18 NRC (Nuclear Regulatory Commission). 1981. "Disposal of High Level Radioactive Wastes in Geologic Repositories: Licensing Procedures," Federal Register. Vol. 46, no. 37, 13971-13987.

P19 NRC (Nuclear Regulatory Commission). 1983. "Disposal of High-Level Radioactive Wastes in Geologic Repositories: Technical Criteria," Federal Register. Vol. 48, no. 120, 28194-28230.

P20 NRC (Nuclear Regulatory Commission). 1993. "Part 60-Disposal of High-Level Radioactive Wastes in Geologic Repositories," Code of Federal Regulations 10, Part 60. Washington, DC: Superintendent of Documents, U.S. Government Printing Office.

P21 Saltelli, A., T. Homma, P. Prado, and C. Torres. 1990. "Development of the LISA Code," Proceedings of the Symposium on Safety Assessment of Radioactive Waste Repositories, Paris, October 9-13, 1989 Paris: Organisation for Economic Co-Operation and Development. 639-648.

P22 Thompson, B.G.J., and B. Sagar. 1993. "The Development and Application of Integrated Procedures for PostClosure Assessment, Based Upon Monte Carlo Simulation: The Probabilistic Systems Assessment (PSA) Approach," Reliability Engineering Safety. Vol. 42, no. 2-3, 125-160.

P23 Wuschke, D.M., P.A. Gillespie, K.K. Mehta, W.F. Heinrich, D.M. Leneveu, G.R. Sherman, V.M. Guvanasen, D.C. Donahue, B.W. Goodwin, T.H. Andres, and R.B. Lyon. 1985. Second Interim Assessment of the Canadian Concept for Nuclear Waste Disposal, Volume 4: Post Closure Assessment. AECL-3873-4. Pinawa, Manitoba: Atomic Energy of Canada Limited, Whiteshell Nuclear Research Establishment.

P24 Sherman, G.R., D.C. Donahue, S.G. King, and A. So. 1986. The Systems Variability Analysis Code SYVAC2 and Submodels for the Second Interim Assessment of the Canadian Concept for Nuclear Fuel Waste Disposal. TR317. Pinawa, Manitoba: Atomic Energy of Canada Limited, Whiteshell Nuclear Research Establishment.

P25 Rechard, R.P. 1989. Review and Discussion of Code Linkage and Data Flow in Nuclear Waste Compliance Assessments. SAND87-2833. Albuquerque, NM: Sandia National Laboratories. 
P26 Marietta, M.G., and W.F. Simmons. 1988. Feasibility of Disposal of High-Level Radioactive Waste Into the Seabeds. Volume 5-Dispersal of Radionuclides in the Oceans: Models, Data Sets, and Regional Descriptions. SAND87-0753. Albuquerque, NM: Sandia National Laboratories.

P27 Bonano, E.J., P.A. Davis, L.R. Shipers, K.F. Brinster, W.E. Beyeler, C.D. Updegraff, E.R. Shepherd, L.M. Tilton, and K.K. Wahi. 1988. Demonstration of a Performance Assessment Methodology for High-Level Radioactive Waste Disposal in Basalt Formations. SAND86-2325, NUREG/CR-4759. Albuquerque; NM: Sandia National Laboratories.

P28 U.S. DOE (U.S. Department of Energy). 1988. Site Characterization Plan, Yucca Mountain Site, Nevada Research and Development Area, Nevada. DOE/RW-0199. Washington, DC: U.S. Department of Energy. Section 8.3.5.13.

P29 Marietta, M.G., S.G. Bertram-Howery, D.R. Anderson, K.F. Brinster, R.V. Guzowski, H. Iuzzolino, and R.P. Rechard. 1989. Performance Assessment Methodology Demonstration: Methodology Development for Evaluating Compliance With EPA 40 CFR 191, Subpart B, for the Waste Isolation Pilot Plant. SAND89-2027. Albuquerque, NM: Sandia National Laboratories.

P30 Bertram-Howery, S.G., M.G. Marietta, D.R. Anderson, K.F. Brinster, L.S. Gomez, R.V. Guzowski, and R.P. Rechard. 1989. Draft Forecast of the Final Report for the Comparison to 40 CFR Part 191, Subpart B, for the Waste Isolation Pilot Plant. SAND88-1452. Albuquerque, NM: Sandia National Laboratories.

P31 Laurens, J.M., B.G.J. Thompson, and T.J. Sumerling. 1989. "The Development and Application of an Integrated Radiological Risk Assessment Procedure Using Time-Dependent Probabilistic Risk Analysis," Proceedings of the Symposium on Safety Assessment of Radiological Waste Repositories, Paris, October 9-13, 1989 Paris: Organisation for Economic Co-Operation and Development. 627-638.

P32 Rechard, R.P., H.J. Iuzzolino, J.S. Rath, A.P. Gilkey, R.D. McCurley, and D.K. Rudeen. 1989. User's Manual for CAMCON: Compliance Assessment Methodology Controller. SAND88-1496. Albuquerque, NM: Sandia National Laboratories.

P33 Bertram-Howery, S.G., M.G. Marietta, R.P. Rechard, P.N. Swift, D.R. Anderson, B.L. Baker, J.E. Bean, Jr., W. Beyeler, K.F. Brinster, R.V. Guzowski, J.C. Helton, R.D. McCurley, D.K. Rudeen, J.D. Schreiber, and P. Vaughn. 1990a. Preliminary Comparison with 40 CFR Part 191, Subpart B for the Isolation Pilot Plant, December 1990. SAND90-2347. Albuquerque, NM: Sandia National Laboratories.

P34 Rechard, R.P., W. Beyeler, R.D. McCurley, D.K. Rudeen, J.E. Bean, and J.D. Schreiber. 1990b. Parameter Sensitivity Studies of Selected Components of the Waste Isolation Pilot Plant Repository/Shaft System. SAND892030. Albuquerque, NM: Sandia National Laboratories.

P35 WIPP PA (Performance Assessment) Division. 1991. Preliminary Comparison with 40 CFR Part 191, Subpart B for the Waste Isolation Pilot Plant, December 1991. SAND91-0893/1/2/3. Albuquerque, NM: Sandia National Laboratories. Vols. 1-3.

P36 Barnard, R.W., M.L. Wilson, H.A. Dockery, J.H. Gauthier, P.G. Kaplan, R.R. Eaton, F.W. Bingham, and T.H. Robey. 1992. TSPA 1991: An Initial Total-System Performance Assessment for Yucca Mountain SAND912795. Albuquerque, NM: Sandia National Laboratories.

P37 WIPP PA (Performance Assessment) Department. 1992/1993. Preliminary Performance Assessment for the Waste Isolation Pilot Plant, December 1992. SAND92-0700/1/2/3. Albuquerque, NM: Sandia National Laboratories. Vols. 1-3.

P38 Wilson, M.L., et al. 1994. Total-System Performance Assessment for Yucca Mountain-SNL Second Iteration (TSPA-1993). SAND93-2675. Albuquerque, NM: Sandia National Laboratories.

P39 Rechard, R.P., ed. 1993. Initial Performance Assessment of the Disposal of Spent Nuclear Fuel and High-Level Waste Stored at Idaho National Engineering Laboratory. Volume 1: Methodology and Results. Volume 2: Appendices. SAND93-2330/1/2. Albuquerque, NM: Sandia National Laboratories. Vols. 1-2.

P40 Price, L.L., S.H. Conrad, D.A. Zimmerman, N.E. Olague, K.C. Gaither, W.B. Cox, J.T. McCord, and C.P. Harlan. 1993. Preliminary Performance Assessment of the Greater Confinement Disposal Facility at the Nevada Test 
Site. Volume 1: Executive Summary. Volume 2: Technical Discussion. Volume 3: Supporting Details. SAND91-0047. Albuquerque, NM: Sandia National Laboratories.

P41 AECL (Atomic Energy of Canada, Ltd). 1994. Summary of the Environmental Impact Statement on the Concept for Disposal of Canada's Nuclear Fuel Waste. AECL-10721. Pinawa, Manitoba: Atomic Energy of Canada, Ltd.

P42 Rechard, R.P., ed. 1995. Performance Assessment of the Direct Disposal in Unsaturated Tuff of Spent Nuclear Fuel and High-Level Waste Owned by U.S. Department of Energy. Volume 1: Executive Summary. Volume 2: Methodology and Results. Volume 3: Appendices. SAND94-2563/1/2/3. Albuquerque, NM: Sandia National Laboratories. Vols. 1-3.

P43 Baer, T.A., L.L. Price, J.N. Emery, and N.E. Olague. 1994. Second Performance Assessment Iteration of the Greater Confinement Disposal Facility at the Nevada Test Site. SAND93-0089. Albuquerque, NM: Sandia National Laboratories.

R1 Stannard, J.N. 1988. Radioactivity and Health, A History. Ed. R.W. Baalman, Jr. DOE/RL/01830-T59. Richland, WA: Pacific Northwest Laboratory; Springfield, VA: Available from National Technical Information Service.

R2 AEC (Atomic Energy Commission). 1957. Theoretical Possibilities and Consequences of Major Accidents in Large Nuclear Power Plants: A Study of Possible Consequences if Certain Assumed Accidents, Theoretically Possible but Highly Improbable, Were to Occur in Large Nuclear Power Plants. WASH-740. Washington, DC: Atomic Energy Commission.

R3 Rasmussen, N.C. 1975. Reactor Safety Study: An Assessment of Accident Risks in U.S. Commercial Nuclear Power Plants. NUREG-75/014, WASH-1400. Washington, DC: U.S. Nuclear Regulatory Commission.

R4 Lewis, H.W., R.J. Budnitz, H.J.C. Kouts, W.B. Loewenstein, W.D. Rowe, F. von Hippel, and F. Zachariasen. 1978. Risk Assessment Review Group Report to the U.S. Nuclear Regulatory Commission. NUREG/CR-0400. Washington, DC: U.S. Nuclear Regulatory Commission.

R5 Lewis, H.W. 1980. "The Safety of Fission Reactors," Scientific American. Vol. 242, no. 3, 53-65.

R6 APS (American Physical Society). 1975. "Report to the American Physical Society by the Study Group on LightWater Reactor Safety," Reviews of Modern Physics. Vol. 47, Supplement No. 1.

R7 NRC (Nuclear Regulatory Commission). 1975. "10 CFR Part 50, Appendix I-Numerical Guides for Design Objectives and Limiting Conditions for Operation to Meet the Criterion 'As Low as Practicable' for Radioactive Material in Light-Water-Cooled Nuclear Power Reactor Effluents," Federal Register. Vol. 40, no. 87, 1944219443.

R8 Breeding, R.J., T.J. Leahy, and J. Young. 1985. Probabilistic Risk Assessment Course Documentation. Vol. 1 PRA Fundamentals. SAND85-1495/1, NUREG/CR-4350/1. Albuquerque, NM: Sandia National Laboratories.

R9 Garrick, B.J. 1987. "Lessons Learned from 21 Nuclear Plant PRAs," Probabilistic Safety Assessment and Risk Management, PSA '87, International Topical Meeting, Zurich, Switzerland, August 31, 1987 Koeln, Germany: Verl. TUEV Rheinland. 369-387.

R10 NRC (Nuclear Regulatory Commission). 1986. "Safety Goals for the Operations of Nuclear Power Plants; Policy Statement," Federal Register. Vol. 51, no. 149, 28044-28049.

R11 Breeding, R.J., J.C. Helton, E.D. Gorham, and F.T. Harper. 1992. "Summary Description of Methods Used in Probabilistic Risk Assessments for NUREG-1150," Nuclear Engineering and Design. Vol. 135, no. 1, 1-27.

R12 Lambright, J.A., D.A. Brosseau, A.C. Payne, Jr., and S.L. Daniel. 1993. Analysis of the LaSalle Unit 2 Nuclear Power Plant: Risk Methods Integration and Evaluation Program (RMIEP) Internal Fire Analysis. SAND920537 - Vol. 9, NUREG/CR-4832 - Vol. 9. Albuquerque, NM: Sandia National Laboratories.

R13 NRC (Nuclear Regulatory Commission). 1994b. "Use of Probabilistic Risk Assessment Methods in Nuclear Regulatory Activities; Proposed Policy Statement," Federal Register. Vol. 59, no. 235, 63389. 


\subsection{DISPOSAL SYSTEM AND REGIONAL CHARACTERIZATION}

To model the Waste Isolation Pilot Plant (WIPP) disposal system ${ }^{*}$ for a performance assessment requires gathering available information about the wastes it will contain, the proposed design of the repository, the geology and hydrology of the surrounding site, and the physical processes that operate there.* Gathering this information is termed system characterization. It is a vital step in any model development program (see Section 3.2, Grouping Features, Events, and Processes into Scenarios) and the first step of a performance assessment (PA). Model development and system characterization can drive one another as PA methodology evolves. System characterization determines the kinds of models that must be designed. The data requirements of the resultant models determine the kinds of additional measurements that must be carried out. These, in turn, can redefine the models in various ways, which, in turn, can redefine the data needs. Thus, each activity can steer the development of the other.

This chapter describes (1) the geologic character of the site and natural barrier system and (2) waste inventory and repository design of engineered barrier systems used in the 1990-1992 PA calculations (see Figure 2.0).

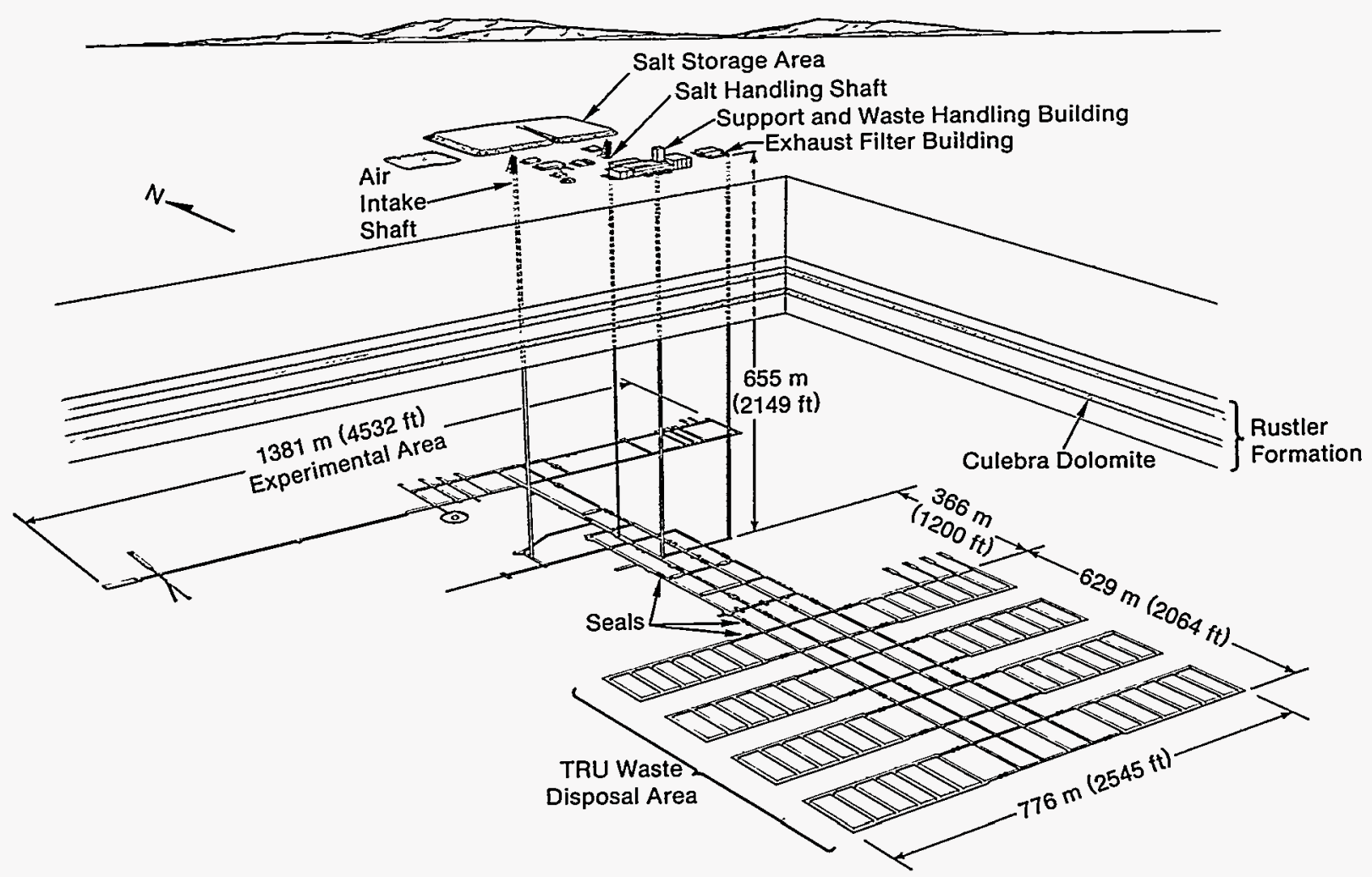

TAI-6346-59-1

Figure 2.0. WIPP repository, showing surface facilities, proposed TRU disposal areas, and experimental areas.

* A disposal system is any combination of engineered and natural barriers that isolate transuranic spent nuclear fuel, or radioactive waste after disposal [40 CFR 191.12(a)]. The natural barriers extend to the accessible environment.

** The general environment as used in 40 CFR 191, Subpart A is described as the "total terrestrial, atmospheric, and aquatic environments outside sites within which any activity, operation, or process associated with the management and storage of ... radioactive waste is conducted" (Section 191.02). 


\subsection{Character of the WIPP Site}

The Waste Isolation Pilot Plant (WIPP) is located in semiarid rangeland in southeastern New Mexico. Population density close to the WIPP is very low. Fewer than 30 permanent residents live within a 16-km $(10-\mathrm{mi})$ radius of the repository. Very little of the well water within $16 \mathrm{~km}(10 \mathrm{mi})$ of the WIPP is used for human consumption, largely because the water contains significant concentrations of dissolved salts. The surrounding area is used primarily for grazing, potash mining, and hydrocarbon production. . $^{1,2}$

The WIPP repository is located in a bedded salt deposit known as the Salado Formation, roughly

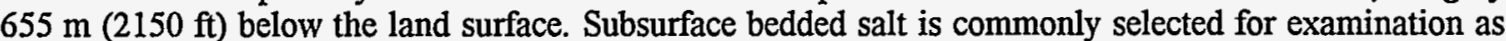
waste repositories. France (NEA, 1991, p. 20), ${ }^{3}$ Germany (NEA, 1991, p. 20), ${ }^{3}$ the Netherlands (Cornelissen, 1991), ${ }^{4}$ and Spain (NEA, 1993, p. 27) ${ }^{5}$ have all investigated the suitability of bedded salt or domal salt formations in their respective countries for deep disposal of radioactive wastes and Germany has ongoing investigations. Salt repositories have also been examined as part of the Commission of the European Communities (CEC) Performance Assessment of Geological Isolation Systems (PAGIS) project. ${ }^{6}$ Other CEC studies have considered disposal of alpha-contaminated wastes and intermediatelevel wastes in salt domes located in Germany. ${ }^{7}$

Salt beds possess both advantages and disadvantages for the disposal of radioactive waste. The principal advantages of salt are that salt (1) entombs the waste, (2) readily consolidates and regains physical properties close to those of the original host rock properties, e.g., permeability, density, porosity, (3) can be found in regions of tectonic stability, (4) can be found relatively near the surface in many parts of the continental United States, (5) is easy to mine, (6) has extremely small groundwater fluxes, (7) is relatively homogeneous, ${ }^{*}$ and (8) provides good heat conduction, thus preventing excessively high temperatures in the waste and at the waste parcel/salt interfaces.

Disadvantages include the following: (1) the wastes would be difficult to retrieve safely with current mining techniques after disposal, (2) keeping a repository open would require extensive, costly maintenance, (3) drilling for natural resources, such as hydrocarbons, has often occurred in bedded salt areas; that is, the potential for co-location with economically valuable minerals exists in salt beds (see Appendix C of 40 CFR 191). ${ }^{8}$

The advantageous natural features of the WIPP site include the following: (1) a lack of pre-existing boreholes (through the evaporites) within $1.6 \mathrm{~km}(1 \mathrm{mi})$ of site, ${ }^{* *}(2)$ salt of high purity, (3) a relatively thick layer of halite, nominally from $300-\mathrm{m}$ (984-ft) to $900-\mathrm{m}$ (2952-ft) depth, (4) lack of extensive dissolution, (5) lack of deformation (extensive horizontal bedding), (6) tectonic stability, and (7) a relative lack of valuable resources (i.e., no known oil or gas resource at the site), and the resources that do exist can be found readily elsewhere. ${ }^{9}$ Advantageous social and economic characteristics at the site include (1) strong public support in the region, (2) absence of land use and strong resource conflicts, and (3) a very low population density in the area because the land surface is primarily used for grazing. ${ }^{2}$

Characterization of the natural barriers of the WIPP disposal system is a lengthy task that has been ongoing since site characterization efforts began in 1973 (see Section 1.5.1, Timeline of Events for the WIPP Project). Information from site characterization activities and other sources ${ }^{10}$ are described in detail in many reports including those by Hiss (1975) ${ }^{11}$; Cheeseman (1978) ${ }^{12}$; Williamson (1978) 13 ; Hills (1984) 14; Ward et al. (1986) 15; Harms and Williamson (1988) 16; Holt and Powers (1988, 17 $1990^{18}$ ); Beauheim and Holt (1990) 19; Brinster (1991) ${ }^{20}$; Powers et al. (1978) 9; Bechtel (1986) ${ }^{21}$; Lappin et al. (1989) ${ }^{22}$; the WIPP Final Environmental Impact Statement (FEIS) (U.S. DOE, 1980b) 23; the WIPP Final Safety Analysis Report (FSAR) (U.S. DOE, 1990b) ${ }^{24}$; the WIPP Final Supplement Environmental Impact Statement (FSEIS) (U.S. DOE, 1990c), ${ }^{1}$ and Volumes 2 and 3 of 1992 Preliminary Performance Assessment report for the WIPP (Sandia WIPP Project, 1992b). ${ }^{25}$

The following subsections provide only a sampling of the vast amount of information available on the character of the site. They introduce the physical setting (Section 2.1.1), stratigraphy (Section 2.1.2), regional geology (Section 2.1.3), regional cross-sections (Section 2.1.4), hydrological characterization of

Although fairly homogeneous relative to other rock types, it is the possible heterogeneities that are of concern in any performance assessment.

** Although a scarcity of boreholes was considered an important criterion in the early 1970s, the EPA standard promulgated in 1985 and 1993 has since made the point less critical. The EPA regulation specifies that human intrusion by means of an exploratory borehole must be examined regardless of the absence of previous boreholes. Only the rate of drilling is now an issue. 
the Culebra (Section 2.1.5), and climate variability (Section 2.1.6). The latter is not really a characteristic of the disposal system. It is an agent that acts on the disposal system, but it is convenient to discuss it here.

\section{References}

1 U.S. DOE (U.S. Department of Energy). 1990c. Final Supplement Environmental Impact Statement, Waste Isolation Pilot Plant. DOE/EIS-0026-FS. Washington, DC: U.S. Department of Energy, Office of Environmental Restoration and Waste Management. Vols. 1-13.

2 Weart, W.D. 1979. "WIPP: A Bedded Salt Repository for Defense Radioactive Waste in Southeastern New Mexico," Radioactive Waste in Geologic Storage, 176th Annual Meeting of the American Chemical Society, Miami Beach, FL, September 11-15, 1978. Ed. S. Fried. SAND78-0934C. ACS Symposium Series No. 100. Washington, DC: American Chemical Society. 13-36.

3 NEA (Nuclear Energy Agency). 1991. Disposal of Radioactive Waste: Review of Safety Assessment Methods. Paris, France: Organisation for Economic Co-Operation and Development, Nuclear Energy Agency.

4 Comelissen, A. 1991. "Development on Criteria for Geological Waste Disposal in the Netherlands," Disposal of High-Level Radioactive Wastes, Radiation Protection and Safety Criteria, Proceedings of an NEA Workshop, Paris, France, November 5-7, 1990. Paris, France: Organisation for Economic Co-Operation and Development, Nuclear Energy Agency. 71-80.

5 NEA (Nuclear Energy Agency). 1993. "Update on Waste Management Policies and Programmes," Nuclear Waste Bulletin (Bulletin sur les Dechets Nucleaires) Vol. 8, July 1993, 2-84.

6 Storck, R., J. Aschenbach, R.P. Hirsekorn, A. Nies, and N. Stelte. 1988. Performance Assessment of Geological Isolation Systems for Radioactive Waste, Disposal in Salt Formations. EUR 11778 EN. Luxembourg: Commission of the European Communities.

7 Hirsekorn, R.P., A. Nies, H. Rausch, and R. Storck. 1991. Performance Assessment of Confinements for Medium-Level and a-contaminated Waste, Pacoma Project, Rock Salt Option. EUR 13634 EN. Luxembourg: Commission of the European Communities.

8 EPA (Environmental Protection Agency). 1993a. "40 CFR Part 191: Environmental Radiation Protection Standards for the Management and Disposal of Spent Nuclear Fuel, High-Level and Transuranic Radioactive Wastes, Final Rule," Federal Register, Vol. 58, no. 242, 66398-66416.

9 Powers, D.W., S.J. Lambert, S-E. Shaffer, L.R. Hill, and W.D. Weart, eds. 1978. Geological Characterization Report, Waste Isolation Pilot Plant (WIPP) Site, Southeastern New Mexico. SAND78-1596. Albuquerque, NM: Sandia National Laboratories. Vols. I-II.

10 Powers, D.W., and M.L. Martin. 1993. A Select Bibliography with Abstracts of Reports Related to Waste Isolation Pilot Plant Geotechnical Studies (1972-1990). SAND92-7277. Albuquerque, NM: Sandia National Laboratories.

11 Hiss, W.L. 1975. "Stratigraphy and Ground-Water Hydrology of the Capitan Aquifer, Southeastern New Mexico and Western Texas." Ph.D. dissertation. Boulder, CO: University of Colorado.

12 Cheeseman, R.J. 1978. "Geology and Oil/Potash Resources of Delaware Basin, Eddy and Lea Counties, New Mexico," Geology and Mineral Deposits of Ochoan Rocks in Delaware Basin and Adjacent Areas. Comp. G.S. Austin. New Mexico Bureau of Mines and Mineral Resources Circular No. 159. Socorro, NM: New Mexico Bureau of Mines and Mineral Resources. 7-14.

13 Williamson, C.R. 1978. "Depositional Processes, Diagenesis and Reservoir Properties of Permian Deep-Sea Sandstones, Bell Canyon Formation, Texas-New Mexico." Ph.D. dissertation. Austin, TX: University of Texas at Austin.

14 Hills, J.M. 1984. "Sedimentation, Tectonism, and Hydrocarbon Generation in Delaware Basin, West Texas and Southeastern New Mexico," American Association of Petroleum Geologists Bulletin. Vol. 68, no. 3, $250-267$. 
15 Ward, R.F., C.G. St. C. Kendall, and P.M. Harris. 1986. "Upper Permian (Guadalupian) Facies and Their Association with Hydrocarbons-Permian Basin, West Texas and New Mexico," American Association of Petroleum Geologists Bulletin. Vol. 70, no. 3, 239-262.

16 Harms, J.C., and C.R. Williamson. 1988. "Deep-Water Density Current Deposits of Delaware Mountain Group (Permian), Delaware Basin, Texas and New Mexico," American Association of Petroleum Geologists Bulletin. Vol. 72, no. 3, 299-317.

17 Holt, R.M., and D.W. Powers. 1988. Facies Variability and Post-Depositional Alteration Within the Rustler Formation in the Vicinity of the Waste Isolation Pilot Plant, Southeastern New Mexico. DOE/WIPP 88-004. Carlsbad, NM: Westinghouse Electric Corporation.

18 Holt, R.M., and D.W. Powers. 1990. Geologic Mapping of the Air Intake Shaft at the Waste Isolation Pilot Plant. DOE/WIPP 90-051. Carlsbad, NM: Westinghouse Electric Corporation.

19 Beauheim, R.L., and R.M. Holt. 1990. "Hydrogeology of the WIPP Site," Geological and Hydrological Studies of Evaporites in the Northern Delaware Basin for the Waste Isolation Pilot Plant (WIPP), New Mexico, Field Trip \#14 Guidebook, Geological Society of America 1990 Annual Meeting, Dallas, TX, October 29-November 1, 1990. SAND90-2035J. Dallas, TX: Dallas Geological Society. 131-179.

20 Brinster, K.F. 1991. Preliminary Geohydrologic Conceptual Model of the Los Medaños Region Near the Waste Isolation Pilot Plant for the Purpose of Performance Assessment. SAND89-7147. Albuquerque, NM: Sandia National Laboratories.

21 Bechtel National, Inc. 1986. Waste Isolation Pilot Plant Design Validation Final Report. DOE/WIPP-86-010. Prepared for U.S. Department of Energy. San Francisco, CA: Bechtel National, Inc.

22 Lappin, A.R., R.L. Hunter, D.P. Garber, and P.B. Davies, eds. 1989. Systems Analysis, Long-Term Radionuclide Transport, and Dose Assessments, Waste Isolation Pilot Plant (WIPP), Southeastern New Mexico; March 1989. SAND89-0462. Albuquerque, NM: Sandia National Laboratories.

23 U.S. DOE (U.S. Department of Energy). 1980b. Final Environmental Impact Statement: Waste Isolation Pilot Plant. DOE/EIS-0026. Washington, DC: U.S. Department of Energy. Vols. 1-2.

24 U.S. DOE (U.S. Department of Energy). 1990b. Final Safety Analysis Report, Waste Isolation Pilot Plant, Carlsbad, New Mexico. WP 02-9, Rev. 0. Carlsbad, NM: Westinghouse Electric Corporation.

25 Sandia WIPP Project. 1992b. Preliminary Performance Assessment for the Waste Isolation Pilot Plant, December 1992. Volume 3: Model Parameters. SAND92-0700/3. Albuquerque, NM: Sandia National Laboratories. 


\subsubsection{Physical Setting, including Natural Resources}

\section{Physical Setting of the WIPP}

The Waste Isolation Pilot Plant (WIPP) is located in southeastern New Mexico $42 \mathrm{~km}$ (26 mi) east of the city of Carlsbad, $20 \mathrm{~km}$ (12 mi) northeast of the Pecos River, and $45 \mathrm{~km}(28 \mathrm{mi})$ west of the high plains of west Texas. The region is known locally as Los Medaños ("the Dunes"). Most sand dunes in the area are stabilized by vegetation. There is relatively little local topographic relief. Major geographical features in the region include Nash Draw, Laguna Grande de la Sal, and the Pecos River (Figure 2.1-1).

The land surface within Los Medaños slopes gradually upward to the northeast from Livingston Ridge on the eastern boundary of Nash Draw to a low ridge called "The Divide." Nash Draw, $8 \mathrm{~km}(5 \mathrm{mi})$ west of the WIPP, is a broad, shallow topographic depression with no external surface drainage. Nash Draw extends northeast about $35 \mathrm{~km}$ (22 mi) from the Pecos River east of Loving, New Mexico, to the Maroon Cliffs area. This feature is bounded on the east by Livingston Ridge and on the west by Quahada Ridge.

Laguna Grande de la Sal, about $9.5 \mathrm{~km}(6 \mathrm{mi})$ west-southwest of the WIPP, is a large playa about $3.2 \mathrm{~km}(2 \mathrm{mi})$ wide and $4.8 \mathrm{~km}(3 \mathrm{mi})$ long, formed by coalesced collapse sinks that were created by dissolution of evaporite deposits. In the geologic past, a relatively permanent, saline lake occupied the playa. In recent history, however, the lake has undergone numerous cycles of filling and evaporation in response to wet and dry seasons. Effluent from the potash, oil, and gas industries has enlarged the lake.

The Pecos River, the principal surface-water feature in southeastern New Mexico, flows southeastward, draining into the Rio Grande in western Texas. Surface drainage from the WIPP does not reach the river or its ephemeral tributaries.

\section{Natural Resources}

Potash, oil, and gas are the only known, commercially important, mineral resources in the vicinity of the WIPP. Estimates of the volumes and locations of these resources are reported by U.S. Department of Energy. 1 Numerous productive oil and gas wells are near the WIPP. The wells generally tap Pennsylvanian strata, about $4,200 \mathrm{~m}(14,000 \mathrm{ft})$ deep. Interest in oil exploration near the WIPP Project has increased in the last few years and could be an important aspect to address regarding permanent markers for the site (Assurance Requirements of 40 CFR 191; see Section 6.1.1). Three potash mines and two associated chemical-processing plants are located between 8 and $16 \mathrm{~km}(5$ and $10 \mathrm{mi})$ from the WIPP. ${ }^{2}$ Potash-enriched beds are found stratigraphically above the repository horizon. Neither mining of potash nor exploratory drilling for potash reserves reaches the repository horizon.

\section{Other Salt Deposits}

Salt ${ }^{*}$ deposits can originate in a variety of settings. Under proper conditions, thick sequences of gypsum and halite can accumulate. For an evaporite deposit to be preserved, it must be protected from subsequent dissolution by undersaturated water as has occurred at the WIPP site for 255 million years $(0.004 \%$ of the regulatory period of $10,000 \mathrm{yr})$. Evaporitic sequences, protected by thicknesses of overburden sufficient to inhibit dissolution of the soluble evaporites, exist all around the world. In the United States, salt deposits are located in about half the states and cover a wide span of geologic time, ranging in age from the Silurian to the Pliocene.

\section{References}

1 U.S. DOE (U.S. Department of Energy). 1980b. Final Environmental Impact Statement: Waste Isolation Pilot Plant. DOE/EIS-0026. Washington, DC: U.S. Department of Energy. Vols. 1-2.

2 U.S. DOE (U.S. Department of Energy). 1990b. Final Safety Analysis Report, Waste Isolation Pilot Plant, Carlsbad, New Mexico. WP 02-9, Rev. 0. Carlsbad, NM: Westinghouse Electric Corporation.

3 Pierce, W.G., and E.I. Rich. 1962. Summary of Rock Salt Deposits in the United States as Possible Storage Sites for Radioactive Waste Materials. Geological Survey Bulletin 1148. Washington, DC: Geological Survey.

* In this report, salt refers to evaporite deposits that are predominantly sodium chloride $(\mathrm{NaCl})$. Mineralogic names such as halite $(\mathrm{NaCl})$, sylvite $(\mathrm{KCL})$, gypsum $\left(\mathrm{CaSO}_{4} \cdot \mathrm{H}_{2} \mathrm{O}\right)$, and anhydrite $\left(\mathrm{CaSO}_{4}\right)$ are used when referring to specific evaporite minerals. The term evaporite includes all of the above minerals. Evaporites are formed by the evaporation of a solution that contains dissolved solids; in this case, the solution was ancient sea water. 


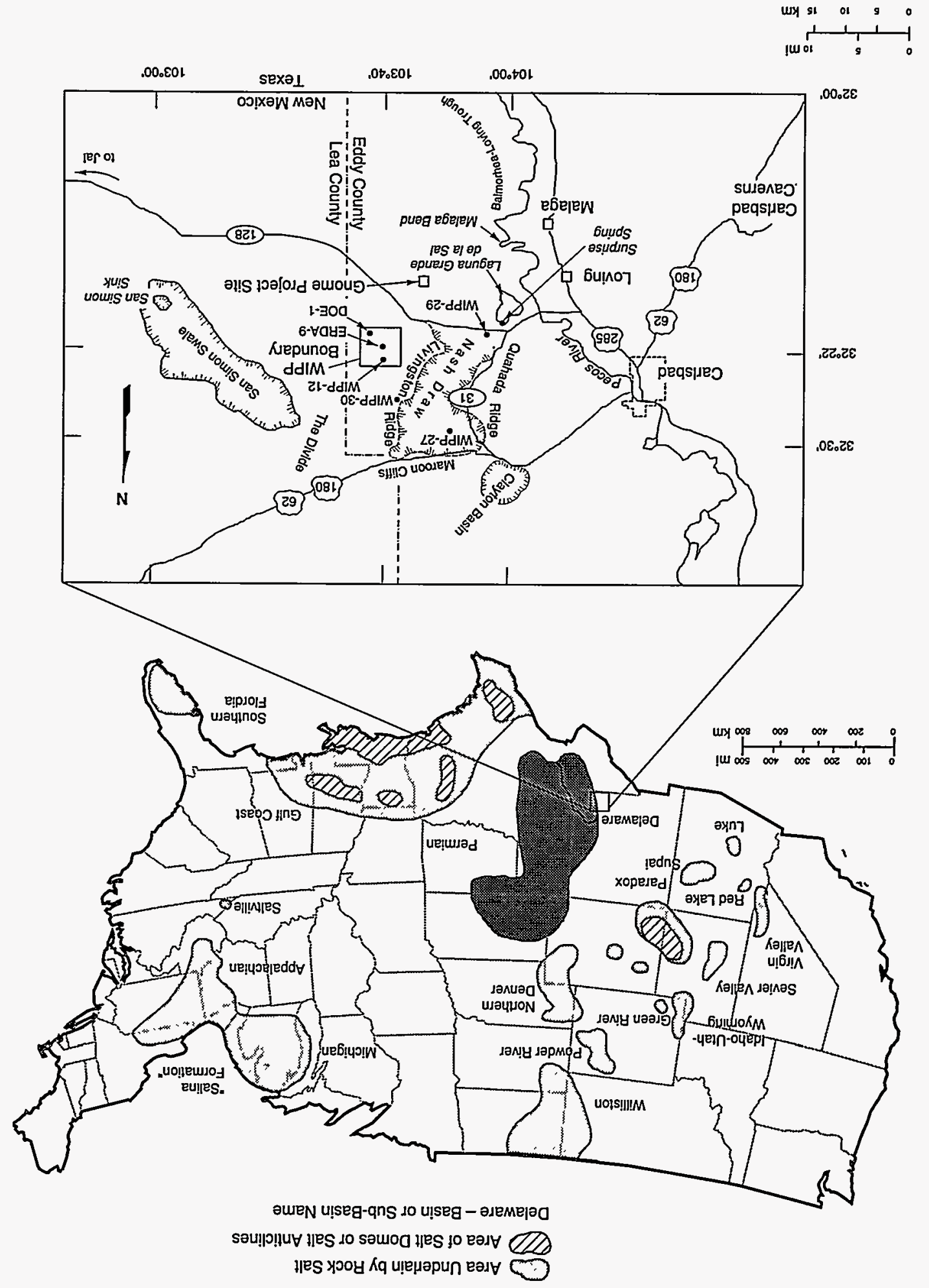




\subsubsection{Stratigraphy}

The repository level of the Waste Isolation Pilot Plant (WIPP) is located within the Salado Formation* (Figure 2.1-2), which consists primarily of nearly horizontal ( $<1$ degree dip), 600-m (1968-ft) thick halite $(\mathrm{NaCl})$ with occasional interbeds of minerals such as clay and anhydrites $\left(\mathrm{CaSO}_{4}\right)$ of the Late Permian Period (approximately 255 million yr old). One such anhydrite interbed, known as Marker Bed 139

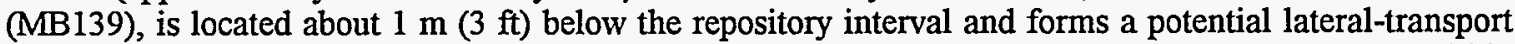
pathway away from the repository. It is about $1-\mathrm{m}$ (3-ft) thick and is one of about 45 interbed units within the Salado Formation. ${ }^{1}$

Most of the strata above the Salado are more variable in elevation. They are also well known to be permeable, being host to numerous wells throughout the basin. The Rustler Formation ${ }^{* *}$ contains the most permeable units above the repository and is therefore the most likely pathway for lateral transport of radionuclides. Below the repository reside the Castile Formation, ${ }^{* * *}$ the Bell Canyon Formation, and deeper units. Their elevations are known at relatively few points, the remainder being inferred. Because the geologic structure in the center of the Delaware Basin is uncomplicated in relation to many other sedimentary basins or metamorphic rocks, the uncertainty of inferred elevations is likely small on a regional geologic scale. The upper layer of the Castile Formation contains irregularly spaced brine reservoirs in some parts of the basin. ${ }^{2}$ Current data suggest they are hydraulically isolated pockets of pressurized fluids.

\section{References}

1 Lappin, A.R. 1988. Summary of Site-Characterization Studies Conducted From 1983 Through 1987 at the Waste Isolation Pilot Plant (WIPP) Site, Southeastern New Mexico. SAND88-0157. Albuquerque, NM: Sandia National Laboratories.

2 Popielak, R.S., R.L. Beauheim, S.R. Black, W.E. Coons, C.T. Ellingson, and R.L. Olsen. 1983. Brine Reservoirs in the Castile Formation, Waste Isolation Pilot Plant (WIPP) Project, Southeastern New Mexico. TME 3153. Albuquerque, NM: U.S. Department of Energy, Waste Isolation Pilot Plant.

3 . WIPP PA (Performance Assessment) Division. 1991. Preliminary Comparison with 40 CFR Part 191, Subpart B for the Waste Isolation Pilot Plant, December 1991. Volume 3: Reference Data. Eds. R.P. Rechard, A.C. Peterson, J.D. Schreiber, H.J. Iuzzolino, M.S. Tierney, and J.S. Sandha. SAND91-0893/3. Albuquerque, NM: Sandia National Laboratories.

* The Salado formation is the fourth principal formation below the surface. It is composed primarily of halite and is the host medium for the WIPP repository. The Salado unit is about $600-\mathrm{m}$ (1968-ft) thick and consists of three informal members. The lower member is about 340-m (1115-f) thick and is mostly halite with lesser amounts of anhydrite $\left(\mathrm{CaSO}_{4}\right)$ and polyhalite, a hard, poorly soluble, evaporite mineral $\left(\mathrm{K}_{2} \mathrm{MgCa}_{2}\left(\mathrm{SO}_{4}\right) \cdot 2 \mathrm{H}_{2} \mathrm{O}\right)$. Anhydrite is anhydrous calcium sulfate that is, gypsum without water or

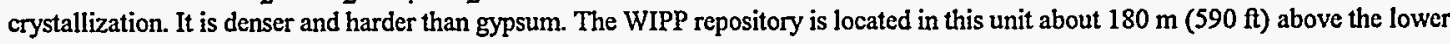
contact with the Castile Formation. The middle member of the Salado is the McNutt Potash Zone. It is about 110-m (360-ft) thick and consists of reddish-orange and brown halite interbedded with sylvite and langbeinite. These minerals yield potassium salts (potash) and are mined in the nearby region. The McNutt Potash Zone is separated from the lower member by a thin silty sandstone and from the upper unit by a thin anhydrite. The upper unit is $150 \mathrm{~m}$ (492 ft) of halite interbedded with polyhalite, anhydrite, and sandstone.

** The Rustler Formation conformally overlies the Salado Formation and is the youngest unit of the evaporite series. The formation is a cyclical series of deposits consisting of $10 \%$ carbonates (dolomite), $30 \%$ sulfates (gypsum and anhydrite), $40 \%$ salts (halite and some polyhalite), and $20 \%$ clastic rocks (mudstone and shale). In the surrounding region, the Rustler Formation rises close to the surface. There, the anhydrite component has been hydrated and converted to gypsum. The formation has an average thickness of $110 \mathrm{~m}$ ( $360 \mathrm{ft}$ ), but actual thicknesses range from 8 to $216 \mathrm{~m}$ (26 to $709 \mathrm{ft}$ ). The Culebra Dolomite Member of the Rustler Formation (lower dolomite), ranging in thickness from 3 to $14 \mathrm{~m}$ (10 to $46 \mathrm{f}$ ), is a unit with brine that could provide a pathway for lateral transport of radionuclides to the accessible environment. It is composed of a microcrystalline dolomite and dolomitic limestone with solution cavities containing gypsum and anhydrite filling. Close to the repository, the dolomite has an average thickness of $7.5 \mathrm{~m}(25 \mathrm{ft}$ ).

*** The 500-m (1640-ft) thick Castile Formation underlies the Salado. It is the lowest and the oldest formation considered in most WIPP conceptual models. The Castile Formation consists of five principal lithologic units under the WIPP site-three anhydrite members interbedded with two halite members. Pressurized brine reservoirs have been intersected occasionally in three wells around the site and, using accepted geophysical methods, cannot be ruled out conclusively beneath the site. Brine at pressures greater than hydrostatic occur west of the site in the Anhydrite III layer (fractured part) of the Castile Formation. The possible existence of a brine pocket beneath the repository is important. If one were present and if an exploratory borehole breached both it and the repository above, the resultant vertical brine flow could influence the release of repository materials to the brine aquifer in the Culebra. For modeling purposes, pressurized brine reservoirs are assumed to exist (without reduction in pressures) beneath the repository for the next 10,000 yr (see Section 3.2.4, Human Intrusion Summary Scenarios). 


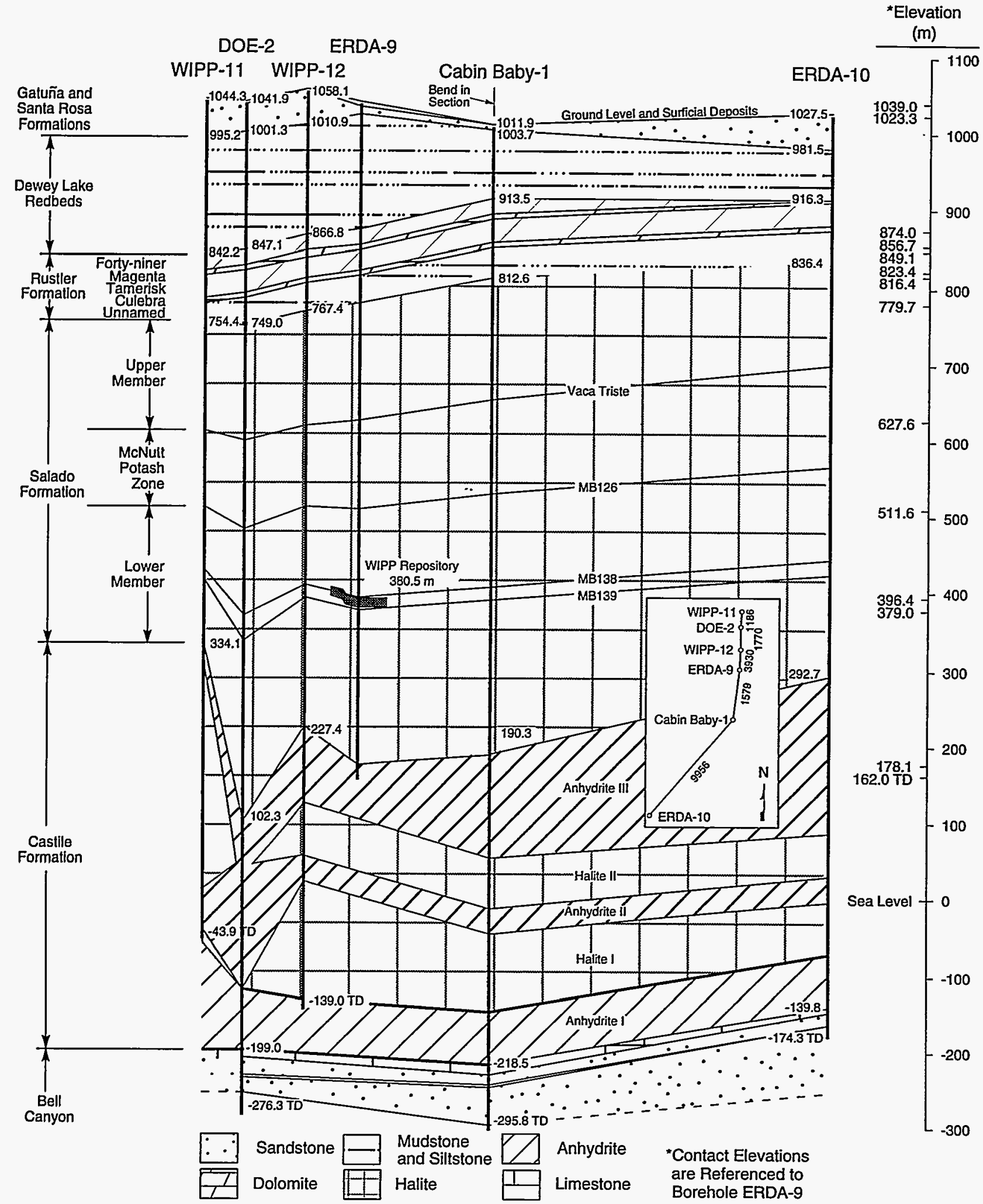

TR1-6342-49-1

Figure 2.1-2. Stratigraphy above and below the WIPP repository (after WIPP PA Division, 1991, Vol. 3, Figure 2.2-1). ${ }^{3}$ 


\subsubsection{Regional Geology}

The Waste Isolation Pilot Plant (WIPP) is located near the northern end of the Delaware Basin, a portion of the Permian Basin that is a structural depression. It was formed during the Late Pennsylvanian and Permian Periods, (approximately 320 to 245 million yr ago; see Figure 2.1-3). Sedimentation within the subsiding basin resulted in the deposition of up to $4,000 \mathrm{~m}(13,000 \mathrm{ft})$ of marine strata. Biological activity at the basin margins produced massive carbonate reefs that separated deep-water sediments from the shallow-water shelf sediments deposited shoreward.

During the Permian Period, subsidence in the Delaware Basin was initially rapid, resulting in deposition of the deep-water shales, sandstones, and limestones of the Delaware Mountain Group. The Bell Canyon Formation is the topmost formation of this group. Intermittent connection with the open ocean and a decrease in clastic sediment supply, possibly in response to regional tectonic adjustments, led to the deposition of the thick evaporite sequence of the Castile and Salado Formations. Anhydrites and halites of the Castile Formation are limited to the deeper portion of the basin, which is enclosed partially by rocks of the Capitan Reef Limestone. Subsidence within the basin slowed in Late Permian time. The halites of the Salado Formation (which include the host strata for the WIPP) extend outward from the basin center over the Capitan Reef and the shallow-water shelf facies. Latest Permian-age evaporites, carbonates, and clastic rocks of the Rustler Formation and the Dewey Lake Red Beds record the end of regional subsidence and include the last marine rocks deposited in southeastern New Mexico during the Paleozoic. The overlying sandstones of the Triassic-age Dockum Group reflect continental deposition and mark the onset of a period of regional tectonic stability that lasted approximately 240 million yr, until late in the Tertiary Period.

\section{Reference}

1 Lappin, A.R. 1988. Summary of Site-Characterization Studies Conducted From 1983 Through 1987 at the Waste Isolation Pilot Plant (WIPP) Site, Southeastern New Mexico. SAND88-0157. Albuquerque, NM: Sandia National Laboratories. 


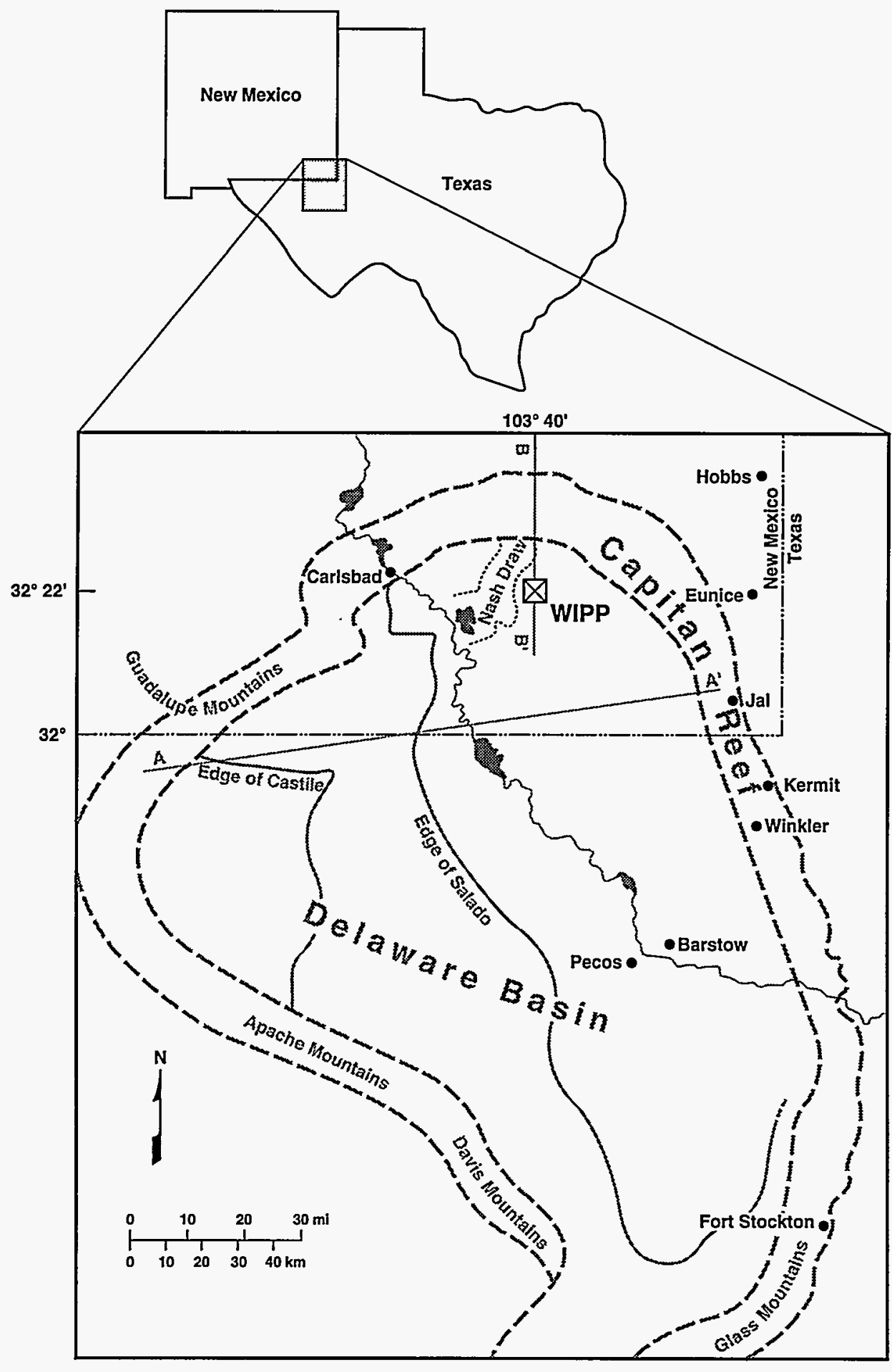

TRI-6342-237-6

Figure 2.1-3. Regional geology. Generalized geology of the Delaware Basin $\left(-33,000 \mathrm{~km}^{2}\right.$ $\left[12,750 \mathrm{mi}^{2}\right]$, showing the location of the Capitan Reef and the erosional limits of the bedded salt formations (after Lappin, 1988, Figure 1-4).1 


\subsubsection{Regional Cross-Sections}

Permian-age strata of the Delaware Basin now dip gently (generally less than 1 degree) to the east, and erosion has exposed progressively older units toward the western edge of the basin (Figure 2.1-4a). This tilting reflects an uplifting of the Capitan Reef that occurred during the Late Pliocene and early Pleistocene (approximately 3.5 million to 1 million yr ago) and resulted in the formation of the Guadalupe Mountains about $60 \mathrm{~km}$ (37 miles) west of the Waste Isolation Pilot Plant (WIPP) site. Field evidence suggests additional uplifting may have occurred during the late Pleistocene and Holocene, and some faults of the Guadalupe Mountains may have been active within the last $1,000 \mathrm{yr}^{1}{ }^{1}$ North and east of the WIPP, the Capitan Reef has not been uplifted and remains covered (Figure 2.1-4b).

The present landscape of the Delaware Basin has been influenced by near-surface dissolution of the evaporites. 2,3 Karst features created by dissolution include sinkholes, subsidence valleys, and breccia pipes. Most of these features formed during the wetter climates of the Pleistocene, although active dissolution is still occurring wherever evaporites are exposed at the surface. Some dissolution may also be occurring in the subsurface where circulating fresh groundwater comes in contact with evaporites.

\section{References}

1 Powers, D.W., S.J. Lambert, S-E. Shaffer, L.R. Hill, and W.D. Weart, eds. 1978. Geological Characterization Report, Waste Isolation Pilot Plant (WIPP) Site, Southeastem New Mexico. SAND78-1596. Albuquerque, NM: Sandia National Laboratories. Vols. I-II.

2 Bachman, G.O. 1984. Regional Geology of Ochoan Evaporites, Northern Part of Delaware Basin. New Mexico Bureau of Mines \& Mineral Resources Circular 184. Socorro, NM: New Mexico Bureau of Mines \& Mineral Resources.

3 Bachman, G.O. 1987. Karst in Evaporites in Southeastern New Mexico. SAND86-7078. Albuquerque, NM: Sandia National Laboratories. 


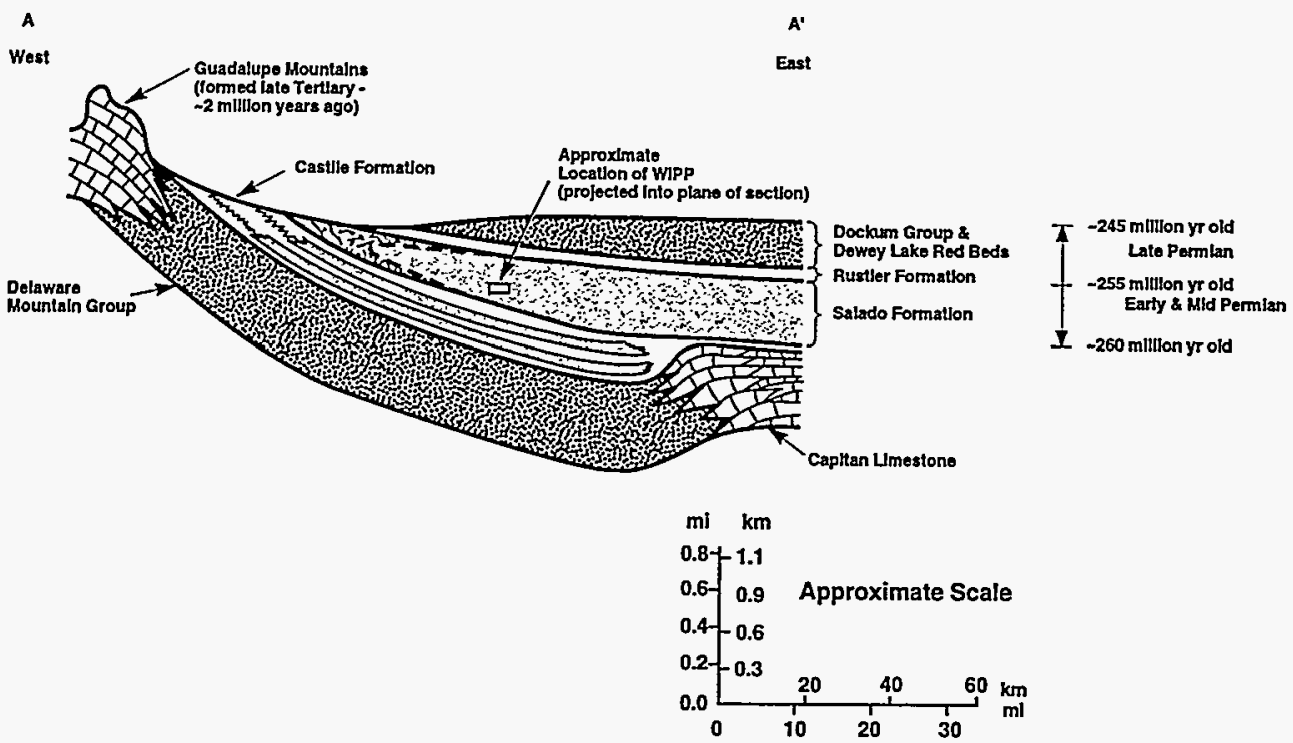

(a)

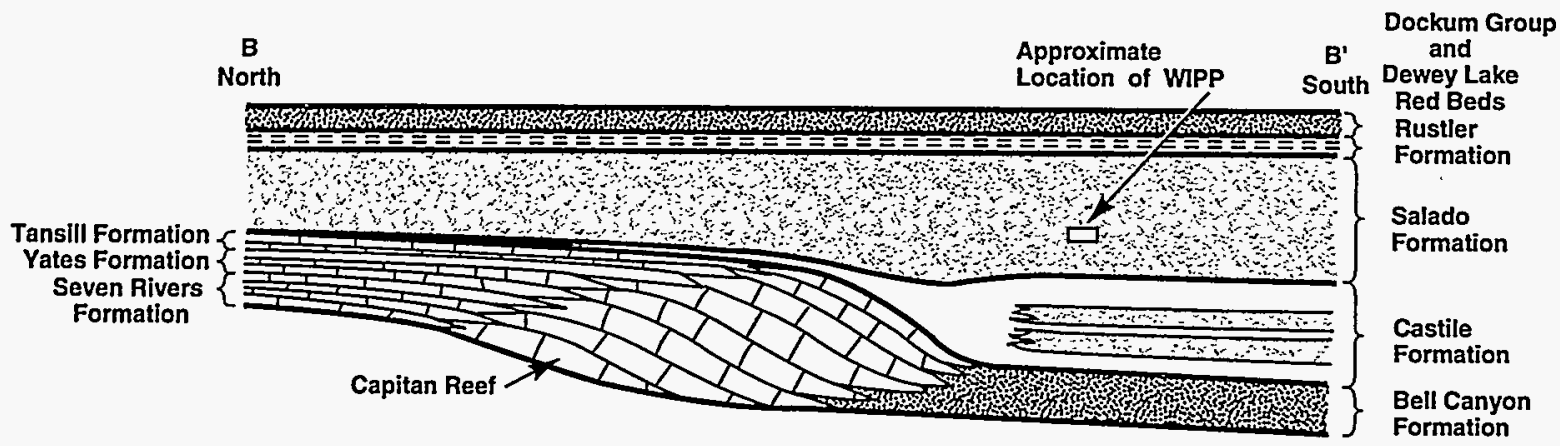

D. Limestone and

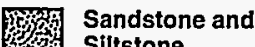

Siltstone

Halite

Anhydrite with

Dolomite Bed (- - -)

R: Insoluble Residue from Halite Dissolution

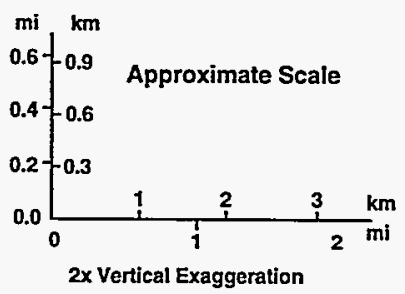

Anhydrite (gypsum near

ground surface)

TFH -632234000

(b)

Figure 2.1-4. Regional cross-sections. Approximate locations of cross sections shown on Figure 2.1-3. 


\subsubsection{Hydrological Characterization of the Culebra}

The Culebra Dolomite Member is a thin dolomite stratum within the Rustler Formation. At several locations, it contains various clays (argillaceous) and sands (arenaceous) with vugular spaces (small solution cavities). Near the Waste Isolation Pilot Plant (WIPP) site, it varies in thickness from about $7 \mathrm{~m}$ (23 ft) (at DOE-1) to about $14 \mathrm{~m}(46 \mathrm{ft})($ at $\mathrm{H}-7)$. During initial WIPP siting investigations, the Culebra was considered the most important potential groundwater-transport pathway for radionuclides to the biosphere and was used in evaluating doses to humans in the 1980 Environmental Impact Statement. ${ }^{1}$ Subsequent agreements between the DOE and the State of New Mexico (see Section 1.5.1, Timeline of Events for the WIPP Project) called for continued characterization of the Culebra. Accordingly, the WIPP Project scientists devoted much attention to determining the hydrogeologic properties of the Culebra. It has been hydrologically sampled at 41 locations in the vicinity of the WIPP (Figure 2.1-5). Results of these tests and interpretations of measurements have been reported in detail by, for example, Beauheim, 2,3 and Avis and Saulnier ${ }^{4}$ (see Sections 5.2.6 and 5.2.7 for use of these data).

In December 1982,5 when the proposed draft of 40 CFR 191 appeared, attention shifted somewhat to the controlled area, which is defined to be a vertical surface and area below the Land Withdrawal boundary. At its closest point it is $.4 \mathrm{~km}(1.5 \mathrm{mi})$ from the waste disposal area (see Section 1.4.1). Because halite and interbeds transmit water poorly, lateral radionuclide transport $2.4 \mathrm{~km}(1.5 \mathrm{mi})$ to the edge of the accessible environment, at repository depth, is unlikely during the 10,000-yr regulatory period (see, for example, Rechard et al. ${ }^{6}$ and the discussion of the $1992 \mathrm{PA}^{7}$ ). Accordingly, models assume radionuclide pathways to the accessible environment through the Culebra. However, hazardous gaseous chemicals, thought to exist in potential WIPP wastes, could conceivably move that distance at depth via fractured anhydrite marker beds. Consequently, their behavior has been modeled in other calculations (Helton et al. ${ }^{8}$ ) (see Section 3.2.1).

\section{References}

1 U.S. DOE (U.S. Department of Energy). 1980b. Final Environmental Impact Statement: Waste Isolation Pilot Plant. DOE/EIS-0026. Washington, DC: U.S. Department of Energy. Vols. 1-2.

2 Beauheim, R.L. 1987. Analysis of Pumping Tests of the Culebra Dolomite Conducted at the H-3 Hydropad at the Waste Isolation Pilot Plant (WIPP) Site. SAND86-2311. Albuquerque, NM: Sandia National Laboratories.

3 Beauheim, R.L. 1989. Interpretation of the H-1 Ib4 Hydraulic Tests and the H-11 Multipad Pumping Test of the Culebra Dolomite at the Waste Isolation Pilot Plant (WIPP) Site. SAND89-0536. Albuquerque, NM: Sandia National Laboratories.

4 Avis, J.D., and G.J. Saulnier, Jr. 1990. Analysis of the Fluid-Pressure Responses of the Rustler Formation at H-16 to the Construction of the Air-Intake Shaft at the Waste Isolation Pilot Plant (WIPP) Site. SAND89-7067. Albuquerque, NM: Sandia National Laboratories.

5 EPA (Environmental Protection Agency). 1982. "40 CFR Part 191: Environmental Standards for the Management and Disposal of Spent Nuclear Fuel, High-Level and Transuranic Radioactive Wastes; Proposed Rule," Federal Register. Vol. 47, no. 250, 58196-58206.

6 Rechard, R.P., W. Beyeler, R.D. McCurley, D.K. Rudeen, J.E. Bean, and J.D. Schreiber. 1990b. Parameter Sensitivity Studies of Selected Components of the Waste Isolation Pilot Plant Repository/Shaft System. SAND892030. Albuquerque, NM: Sandia National Laboratories.

7 WIPP PA (Performance Assessment) Department. 1993. Preliminary Performance Assessment for the Waste Isolation Pilot Plant, December 1992. Volume 4: Uncertainty and Sensitivity Analysis for 40 CFR 191, Subpart B. SAND92-0700/4. Albuquerque, NM: Sandia National Laboratories.

8 Helton, J.C., J.E. Bean, B.M. Butcher, J.W. Garner, J.D. Schreiber, P.N. Swift, and P. Vaughn. 1993b. Uncertainty and Sensitivity Analyses for Gas and Brine Migration at the Waste Isolation Pilot Plant, May 1992. SAND92-2013. Albuquerque, NM: Sandia National Laboratories.

9 WIPP PA (Performance Assessment) Division. 1991. Preliminary Comparison with 40 CFR Part 191, Subpart B for the Waste Isolation Pilot Plant, December 1991. Volume 3: Reference Data. Eds. R.P. Rechard, A.C. Peterson, J.D. Schreiber, H.J. Iuzzolino, M.S. Tierney, and J.S. Sandha. SAND91-0893/3. Albuquerque, NM: Sandia National Laboratories. 

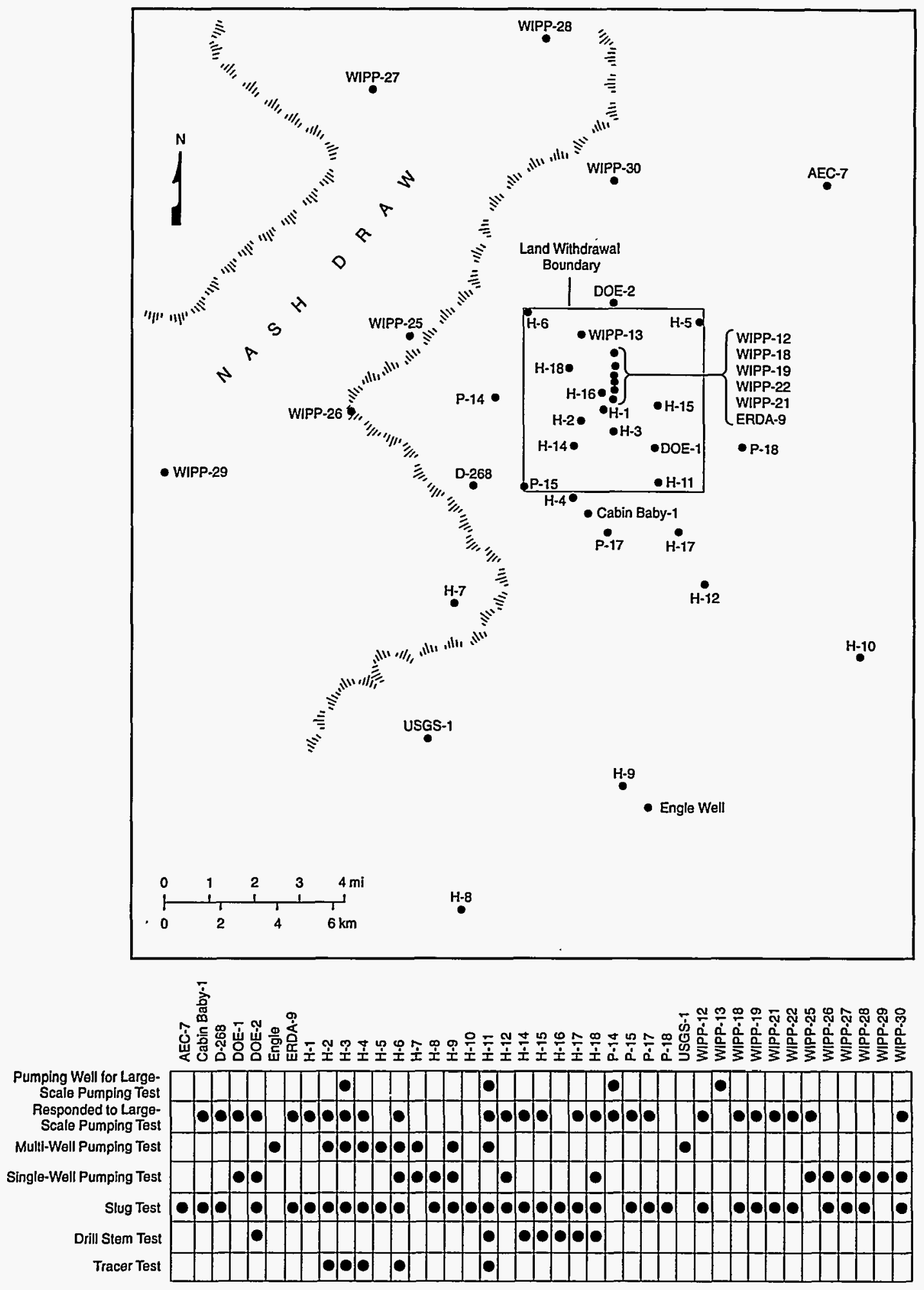

TRI-6344-665-3

Figure 2.1-5. Location of wells used to define hydrologic parameters for Culebra Dolomite Member of Rustler Formation (WIPP PA Division, 1991, Vol. 3, Figure 2.6-3). ${ }^{9}$ 


\subsubsection{Climatic Variability}

Climate variability is well known to be a large-scale process that could potentially affect the disposal system. The primary concern is precipitation and, ultimately, recharge of the strata above the Salado Formation, especially the Culebra Dolomite Member, which is the principal brine-bearing member of the Rustler Formation. The Culebra Dolomite is generally thought to be the most important potential groundwater-transport pathway for radionuclides to the accessible environment, assuming human intrusion provides a pathway from the repository to the Culebra (see Section 2.1.5, Hydrological Characterization of the Culebra).

\section{Present Climate}

The climate of southeastern New Mexico is arid to semiarid. ${ }^{1}$ Annual precipitation occurs mainly during the late summer monsoon. Winters are cool and generally dry. At present, mean annual precipitation at the Waste Isolation Pilot Plant (WIPP) site measures between 28 and $34 \mathrm{~cm} / \mathrm{yr}$ (10.9 and $13.5 \mathrm{in} / \mathrm{yr}){ }^{2}$

\section{Paleoclimates and Climatic Variability}

Based on our knowledge of past climates, it is reasonable to assume climate at the WIPP will change somewhat during the next 10,000 yr. Consequently, performance-assessment hydrologic models have examined climatic variability. At present, long-term climate models are incapable of spatial resolution on the scales required for numerical predictions of future climates at the WIPP. $3,4,5$ Moreover, simulations using these models are of limited value beyond a few hundred years into the future. Direct modeling of climate variability during the next 10,000 yr has not been attempted for WIPP performance assessments. Instead, performance-assessment modeling uses past climates to set limits for future variability ${ }^{1,6}$ (see Figure 2.1-6). The illustrated function is not a predictive function for future precipitation. Rather, it is a simplistic function that illustrates the sorts of variabilities that might occur. The magnitude of climatic variabilities caused by human-induced changes in the $\mathrm{CO}_{2}$ composition of the Earth's atmosphere is uncertain. Presently available models of climatic response to an enhanced greenhouse effect ${ }^{4,5}$ predict changes no greater in magnitude than those of the Pleistocene, although predicted rates of change are greater. Thus, the use of a Pleistocene analog for future climatic extremes remains appropriate.

\section{References}

1 Swift, P.N. 1993. "Long-Term Climate Variability at the Waste Isolation Pilot Plant, Southeastern New Mexico, USA," Environmental Management. Vol. 17, no. 1, 83-97.

2 Hunter, R.L. 1985. A Regional Water Balance for the Waste Isolation Pilot Plant (WIPP) Site and Surrounding Area. SAND84-2233. Albuquerque, NM: Sandia National Laboratories.

3 Hansen, J., I. Fung, A. Lacis, D. Rind, S. Lebedeff, R. Ruedy, and G. Russell. 1988. "Global Climate Changes as Forecast by Goddard Institute for Space Studies Three-Dimensional Model," Journal of Geophysical Research. Vol. 93, no. D8, 9341-9364.

4 Mitchell, J.F.B. 1989. "The 'Greenhouse Effect' and Climate Change," Reviews of Geophysics. Vol. 27, no. 1, 115-139.

5 Houghton, J.T., G.J. Jenkins, and J.J. Ephraums. 1990. Climate Change: The IPCC Scientific Assessment. New York, NY: Cambridge University Press.

6 Swift, P.N. 1991. "Appendix A: Climate and Recharge Variability Parameters for the 1991 WIPP PA Calculations," Preliminary Comparison with 40 CFR Part 191, Subpart B for the Waste Isolation Pilot Plant, December 1991. Volume 3: Reference Data. Eds. R.P. Rechard, A.C. Peterson, J.D. Schreiber, H.J. Iuzzolino, M.S. Tierney, and J.S. Sandha. SAND91-0893/3. Albuquerque, NM: Sandia National Laboratories. A-107 through A-121. 
$\frac{r_{f}}{r_{p}}=\left[\left(\frac{3 A_{m}+1}{4}\right)-\left(\frac{A_{m-1}}{2}\right)\left(\cos \theta t+\frac{1}{2} \cos (\phi t)-\sin -t\right)\right]$

where

$r_{f} \quad$ - future mean annual precipitation

$r_{p} \quad$ - present mean annual precipitation

$A_{m} \quad$ - amplitude scaling factor (i.e., past precipitation maximum was $A_{\mathrm{m}}$ times the present)

$\theta$ - frequency parameter for Pleistocene glaciations $=3.3 \times$ $10^{-12} \mathrm{rad} / \mathrm{s}(60,000 \mathrm{yr}$ period $)$

$\phi \quad$ - frequency parameter for Holocene-type climatic fluctuations $=1.15 \times 10^{-11} \mathrm{rad} / \mathrm{s}$ (2750 yr period)

$t \quad$ - time(s)

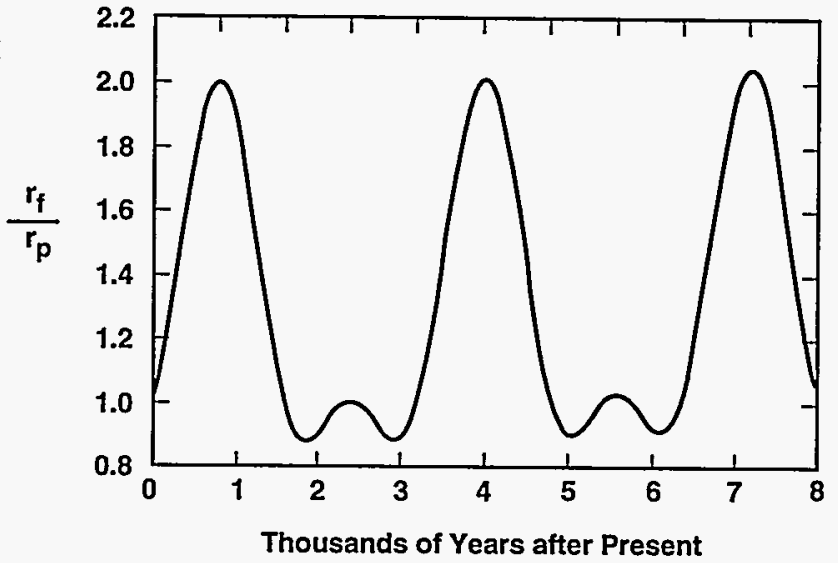
ime(s)
Average Annual
Precipitation (cm/yr) ime(s)
Average Annual
Precipitation (cm/yr)

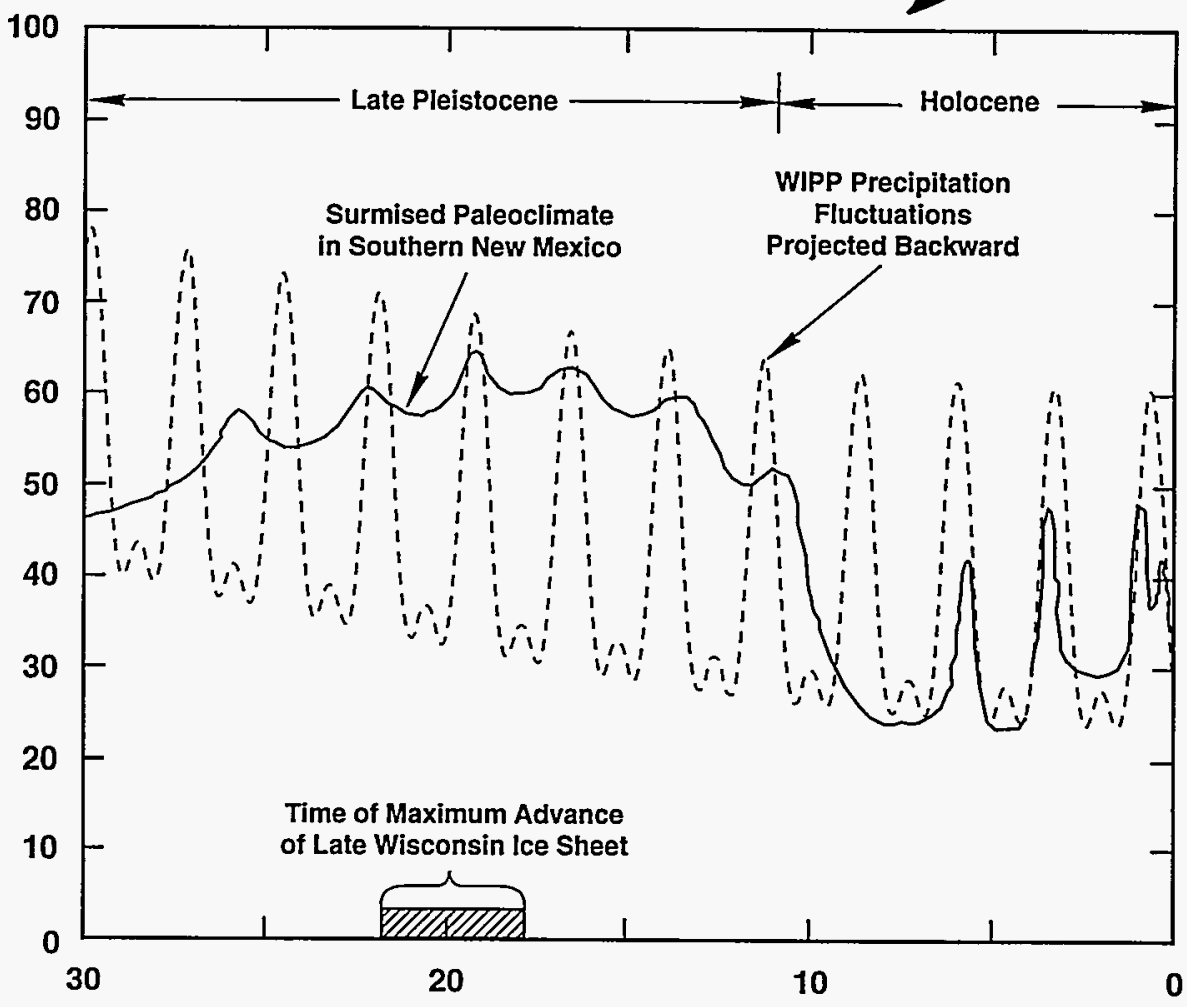

Thousands of Years before Present

TRI-6342-3439-0

Figure 2.1-6. Modeled average annual precipitation fluctuations in next 10,000 $\mathrm{yr}$ and comparison with surmised paleoprecipitation for past 30,000 yr (after Swift, 1993). 1 


\subsection{Properties of the Waste}

Waste Isolation Pilot Plant (WIPP) wastes consist of laboratory and production materials such as glassware, metal pipes, spent solvents that are sorbed or solidified, disposable laboratory clothing, cleaning rags, and solidified sludges (see Figure 2.2). These wastes are contaminated by alpha-emitting transuranic (TRU) elements. Any waste that is contaminated with alpha $(\alpha)$-emitting transuranic radionuclides having half-lives greater than $20 \mathrm{yr}$ and has activities greater than $100 \mathrm{nCi} / \mathrm{g}$, is considered TRU waste in the United States. Normally, the waste is any material (e.g., smocks, used tools, scrap metal, rags, etc.) that has been in contact with TRU radionuclides. TRU waste is also known as AlphaBearing Waste in some countries. Approximately 60 percent of the wastes may be co-contaminated with other hazardous constituents such as those defined under the Resource Conservation and Recovery Act of 1976 (Public Law 94-580 and subsequent amendments). The following subsections of Section 2.2 describe various aspects of the radionuclide inventory.

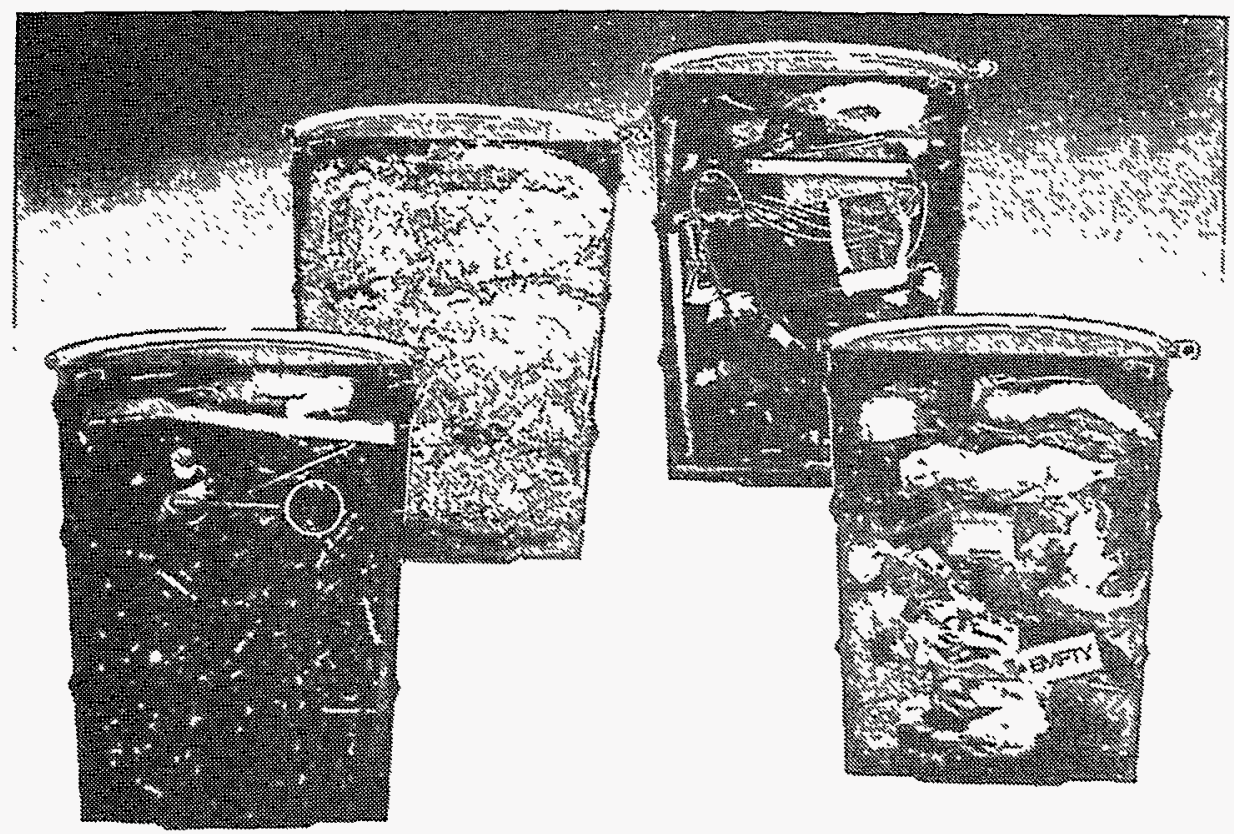

Figure 2.2. Simulated waste drums containing contact-handled TRU waste (see Section 2.2 .1 for definition of contact handled).

*ther types of radioactive waste and material include high-level waste (HLW), spent nuclear fuel (SNF), and low-level waste (LLW): HLW is " ... the highly radioactive material (fission products and some actinides, atomic number 89-103) resulting from the reprocessing of spent nuclear fuel, including liquid waste produced directly in reprocessing any solid material derived from such liquid waste that contains fission products in sufficient concentrations ... " (Nuclear Waste Policy Act of 1982, Public Law 97-425). SNF is "... fuel that has been withdrawn from a nuclear reactor following irradiation, the constituent elements of which have not been separated by reprocessing" (Nuclear Waste Policy Act of 1982, Public Law 97-425). Although spent nuclear fuel contains fissionable ${ }^{235} \mathrm{U}$, it contains too many radionuclides (primarily short-lived) that adsorb neutrons from the fission process for it to be usefully left in the reactor. Occasionally, general articles regarding radioactive waste use the term high-level waste to imply any combination of spent nuclear fuel and HLW (and sometimes transuranic waste) that requires disposal in a deep, geologic repository. The Nuclear Regulatory Commission (NRC) includes spent nuclear fuel in its definition of high-level waste. LLW is all radioactive waste other than spent nuclear fuel, high-level waste, transuranic waste, and mill tailings. In the United States, LLW is divided into three categories: $A, B$, and $C$. Category $A$ has the lowest activity, and Category $C$ has the highest. Some countries create a category called "Intermediate-Level Waste (ILW)" by grouping together transuranic waste and the U.S.'s Category C LLW, which requires shielding during handling. 


\subsubsection{Contact-Handled and Remotely Handled TRU}

The transuranic (TRU) waste for which the Waste Isolation Pilot Plant (WIPP) is designed has been generated at 10 facilities that have supported the nuclear weapons complex. The waste consists of laboratory and production waste such as glassware, metal pipes, solvents that are sorbed or solidified, disposable laboratory clothing, cleaning rags, and solidified sludges. Current plans specify that most of the TRU waste generated since 1970 will be placed in the WIPP repository, with the remaining waste to be disposed of elsewhere.

As of 1992, the 10 TRU waste generator and/or storage sites that are scheduled to ship waste to the WIPP are (1) Argonne National Laboratory-East (Argonne), Illinois; (2) Hanford Reservation (Hanford), Washington; (3) Idaho National Engineering Laboratory (Idaho Lab), Idaho; (4) Los Alamos National Laboratory (Los Alamos), New Mexico; (5) Lawrence Livermore National Laboratory (Livermore), California; (6) Mound Laboratory (Mound), Ohio; (7) Nevada Test Site (Nevada Site), Nevada; (8) Oak Ridge National Laboratory (Oak Ridge), Tennessee; (9) Rocky Flats Plant (Rocky Flats), Colorado; and (10) Savannah River Site (Savannah River), South Carolina. ${ }^{1}$

TRU waste is waste contaminated by alpha-emitting elements having atomic numbers greater than uranium (i.e., >92), half-lives greater than $20 \mathrm{yr}$, and an activity greater than $100 \mathrm{nCi} / \mathrm{g}$. Other contaminants include uranium and several radionuclides with half-lives less than $20 \mathrm{yr}$. Approximately 60 percent of the waste may be co-contaminated with materials considered hazardous under the Resource Conservation and Recovery Act of $1976,{ }^{2}$ e.g., lead. ${ }^{3}$

\section{Contact-Handled Waste}

Radioactive waste that emits alpha radiation, although dangerous if inhaled or ingested, is not hazardous if contact is external and if the external dose rate is $5.6 \times 10^{-7} \mathrm{~Sv} / \mathrm{s}[200 \mathrm{mrem} / \mathrm{h}]$ or less. Most of the WIPP waste falls in that category. It can, therefore, be contact-handled $(\mathrm{CH})$, which means people can handle waste drums and boxes without wearing special shielding. All 10 waste generator and/or storage sites are scheduled to send CH-TRU waste to the WIPP. The estimated $\mathrm{CH}$ waste contributions used in 1991 PA calculations, from each of these 10 producer sites, expressed in curies, is shown in the upper portion of Figure 2.2-1.

\section{Remotely Handled Waste}

Because some surface dose rates exceed $5.6 \times 10^{-7} \mathrm{~Sv} / \mathrm{s}(200 \mathrm{mrem} / \mathrm{h})$, a portion of the TRU waste must be transported and handled in shielded casks. These wastes are known as remotely handled (RH) wastes. No surface dose rates of RH-TRU canisters can exceed $2.8 \times 10^{-3} \mathrm{~Sv} / \mathrm{s}(1000 \mathrm{rem} / \mathrm{h})$. No more than 5 percent of the canisters can exceed $2.8 \times 10^{-4} \mathrm{~Sv} / \mathrm{s}(100 \mathrm{rem} / \mathrm{h}){ }^{1}$ The volume of RH TRU wastes must be less than $250,000 \mathrm{ft}^{3}\left(7080 \mathrm{~m}^{3}\right)$, and the total curie content of TRU radionuclides must be less than $5.1 \times$ $10^{6} \mathrm{Ci}\left(1.89 \times 10^{17} \mathrm{~Bq}\right)$ according to legal agreements between the Department of Energy and the State of New Mexico. ${ }^{4}$ Only 5 of the 10 waste generator and/or storage sites are scheduled to send RH-TRU waste to the WIPP. The projected RH waste contributions from each of these five sites expressed in curies, as used for the 1991 performance assessment calculations, is shown in the lower portion of Figure 2.2-1.

\section{References}

1 U.S. DOE (U.S. Department of Energy). 1994. Integrated Data Base for 1993: U.S. Spent Fuel and Radioactive Waste Inventories, Projections, and Characteristics. DOE/RW-0006, Rev. 9. Oak Ridge, TN: Oak Ridge National Laboratory.

2 Public Law 94-580. 1976. Resource Conservation and Recovery Act of 1976. (90 Stat. 2795) and subsequent amendments.

3 WEC (Westinghouse Electric Corporation). 1990. Waste Isolation Pilot Plant No-Migration Variance Petition. DOE/WIPP 89-003, Rev. 1. Prepared for U.S. Department of Energy. Carlsbad, NM: Westinghouse Electric Corporation.

4 U.S. DOE (U.S. Department of Energy) and State of New Mexico. 1984. "First Modification to the July 1, 1981 'Agreement for Consultation and Cooperation' on WIPP by the State of New Mexico and U.S. Department of Energy." November 30, 1984. (Copy on file at the Sandia WIPP Central Files, Sandia National Laboratories, Albuquerque, NM.)

5 WIPP PA (Performance Assessment) Division. 1991. Preliminary Comparison with 40 CFR Part 191, Subpart B for the Waste Isolation Pilot Plant, December 1991. Volume 3: Reference Data. Eds. R.P. Rechard, A.C. Peterson, J.D. Schreiber, H.J. Iuzzolino, M.S. Tierney, and J.S. Sandha. SAND91-0893/3. Albuquerque, NM: Sandia National Laboratories. 


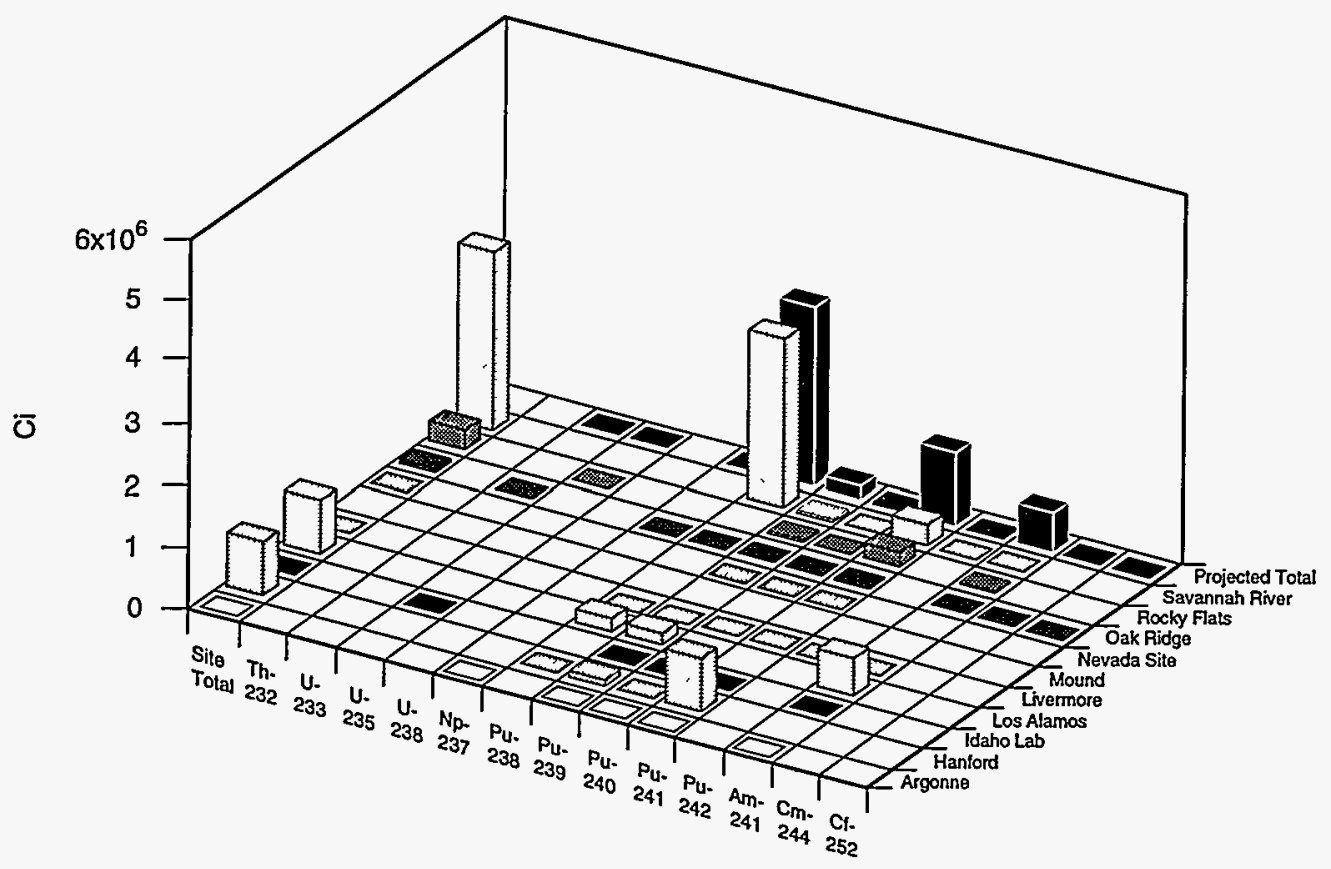

\section{Contact Handled}

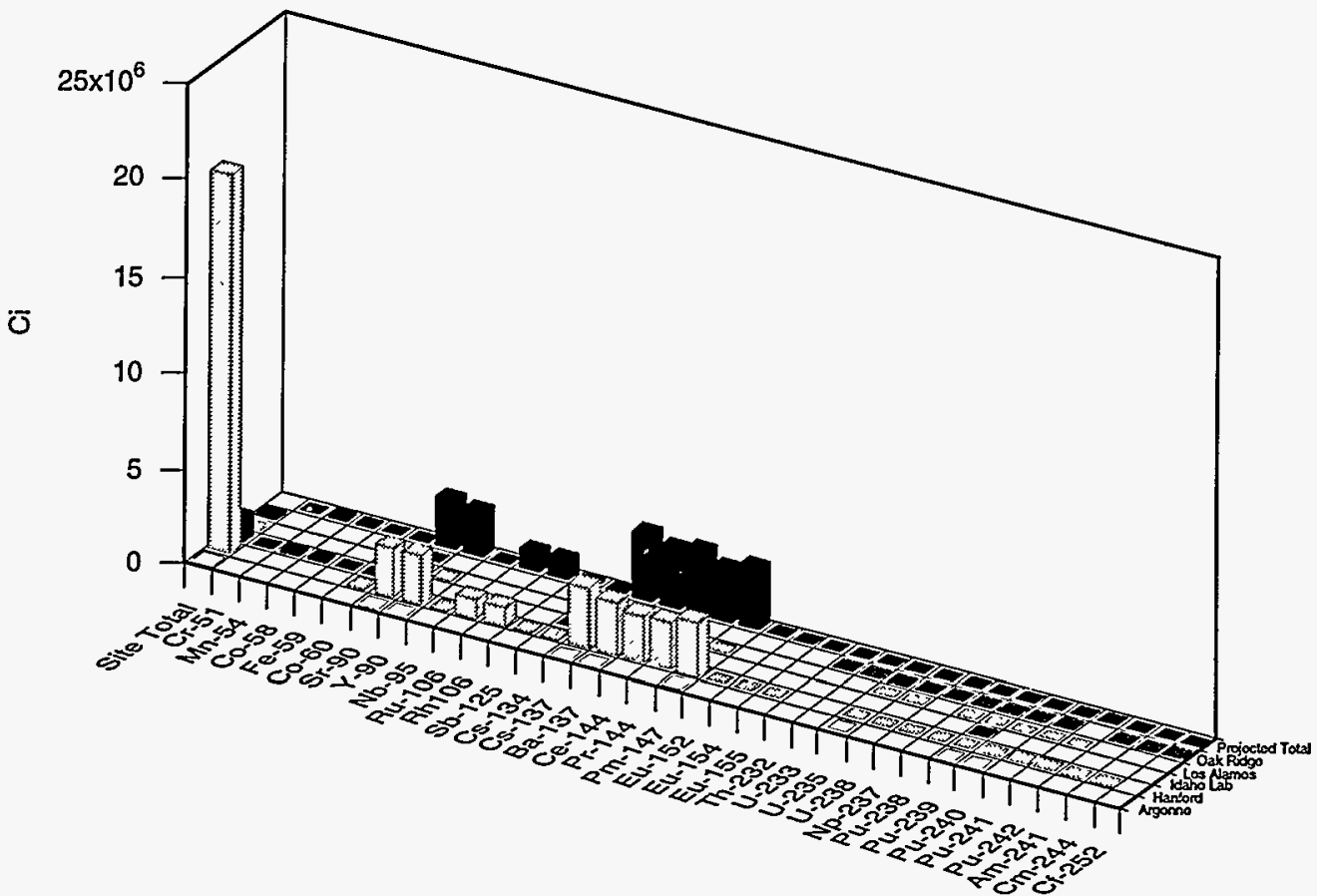

Remotely Handled

TRl-6342-3466-0

Figure 2.2-1. Anticipated contributions to radionuclide inventory for contact-handled and remotely handled waste assumed in 1991 performance assessment (WIPP PA Division, 1991, Vol. 3, Figure 3.3-4)..$^{5}$ Not all radionuclides are transuranic and so totals of activity do not reflect totals of activity of transuranic radionuclides [radionuclides with atomic numbers greater than uranium (92)]. 


\subsubsection{Radioactive Decay}

Subpart B of 40 CFR $191^{1,2}$ sets release limits in curies for isotopes of americium, carbon, cesium, iodine, neptunium, plutonium, radium, strontium, technetium, thorium, tin, and uranium, as well as for certain other radionuclides (see Section 6.1.2, Environmental Protection Agency Release Limits). Although the initial Waste Isolation Pilot Plant inventory contains little or none of some of the listed nuclides, they may be produced as a result of radioactive decay (by either alpha or beta emission*) and must be accounted for in the compliance evaluation. Moreover, radionuclides not listed in Subpart B must be accounted for if they would contribute to human doses used in Environmental Impact Statements required by the National Environmental Policy Act of $1969^{3}$ (e.g., ${ }^{210} \mathrm{~Pb}$ ).

Four decay chains for the initial radionuclides in the contact-handled $(\mathrm{CH})$ transuranic (TRU) inventory are shown in the accompanying Figure 2.2-2. Note that many of the daughter radionuclides have extremely short half-lives. ${ }^{* *}$

The remotely handled $(\mathrm{RH})$ inventory decay chains include the chains in the $\mathrm{CH}$ inventory plus three other chains originating from cesium-137, promethium-147, and strontium-90.

In the 1992 performance assessment (PA) calculations, 23 of the $70 \mathrm{CH}$ radionuclides shown in Figure 2.2-2, were considered to be major contributors to the inventory. They were used to calculate the radionuclide releases from drilling into the repository, bringing cuttings to the surface, and calculating concentration within the repository prior to transport to the Culebra. Nine radionuclides of the 23 were considered in the 1992 PA calculations for the much longer-term transport through the overlying Culebra. These nine radionuclides comprise $99 \%$ of the normalized activity, and omitting radium-226, comprise $98 \%$ of the normalized activity (see Section 2.2 .3 ).

\section{References}

1 EPA (Environmental Protection Agency). 1985a. "40 CFR Part 191: Environmental Standards for the Management and Disposal of Spent Nuclear Fuel, High-Level and Transuranic Radioactive Wastes; Final Rule," Federal Register. Vol. 50, no. 182, 38066-38089.

2 EPA (Environmental Protection Agency). 1992a. "Environmental Radiation Protection Standards for Management and Disposal of Spent Nuclear Fuel, High-Level and Transuranic Radioactive Wastes," Code of Federal Regulations 40, Part 191. Washington, DC: Superintendent of Documents, U.S. Government Printing Office.

3 Public Law 91-190. 1970. National Environmental Policy Act of 1969 (83 Stat. 852; 42 U.S.C. 1801 et seq.).

4 WIPP PA (Performance Assessment) Division. 1991. Preliminary Comparison with 40 CFR Part 191, Subpart B for the Waste Isolation Pilot Plant, December 1991. Volume 3: Reference Data. Eds. R.P. Rechard, A.C. Peterson, J.D. Schreiber, H.J. Iuzzolino, M.S. Tierney, and J.S. Sandha. SAND91-0893/3. Albuquerque, NM: Sandia National Laboratories.

\footnotetext{
* An alpha $(\alpha)$ particle is a helium nucleus (2 protons and 2 Neutrons, where a neutron is a basic atomic particle that is electronically neutral and has nearly the same weight as thepositively-charged proton). A beta ( $\beta$ ) particle is a high-energy electron, or positron. Both constitute types of radiation.

** Half-life is defined as the time required for half the atoms of a radioactive substance to decay.
} 

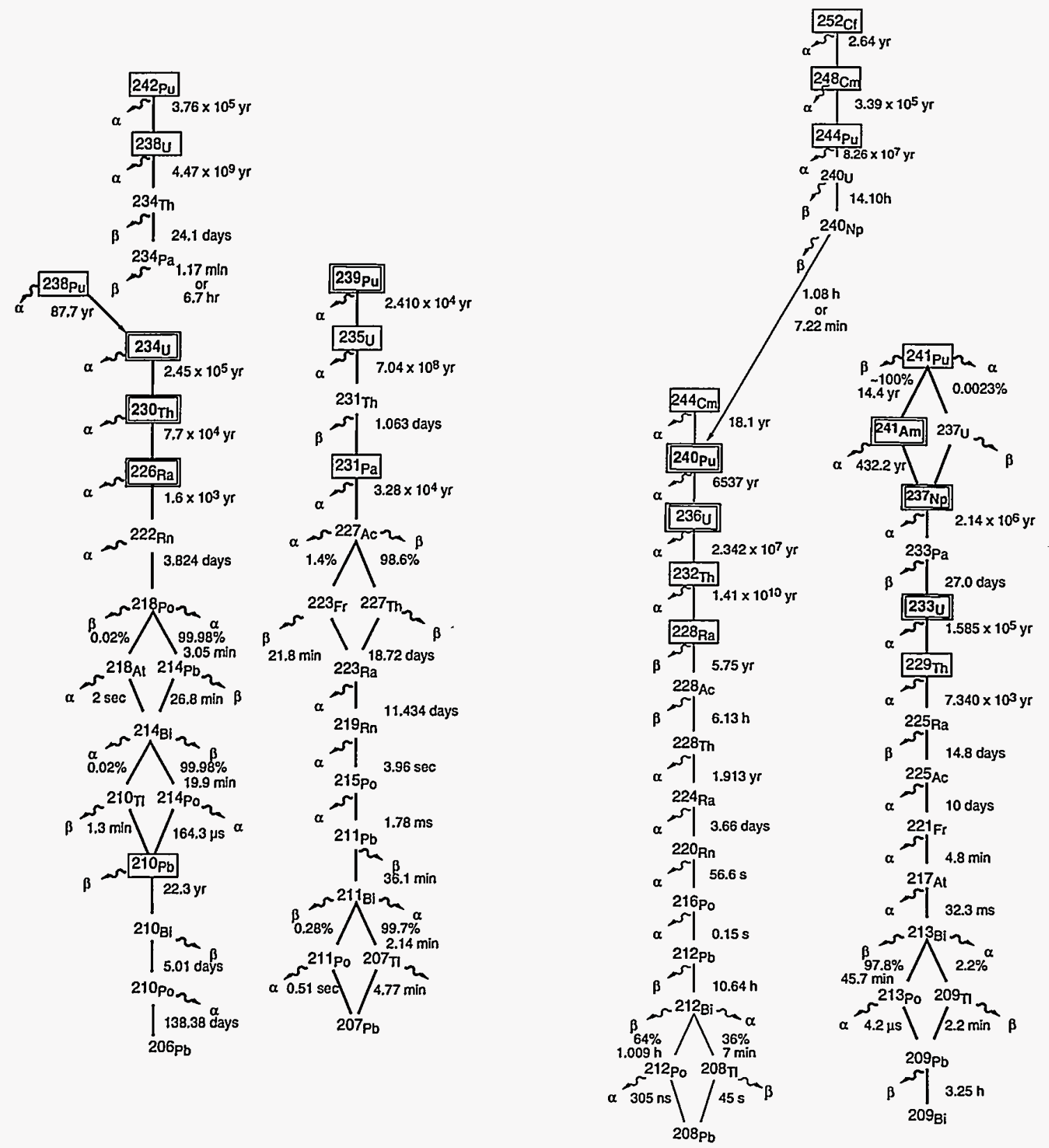

23 Radionuclides Considered in Calculations Evaluating the Release from Drill Cuttings and Evaluating Concentrations within the Repository (See $§ 5.1 .4 \& 5.1 .8$ )

9 Radionuclides Considered in Transport Calculations in Geologic Barrier beyond the Repository (See § 5.3.3)

TRI-6342-3442-0

Figure 2.2-2. Radioactive decay chains of contact-handled transuranic waste (WIPP PA Division, 1991, Vol. 3, Figure 3.3-5). ${ }^{4}$ 


\subsubsection{Changes in Radionuclide Activity}

Figure 2.2-3 shows the temporal changes in radionuclide activity in a panel of the Waste Isolation Pilot Plant (WIPP) repository that occurs as a result of radioactive decay for the eight most important radionuclides. Activities are normalized using limits set in the Environmental Protection Agency's (EPA's) long-term disposal regulations (40 CFR 191). ${ }^{1}$ The activity plotted for each of the eight radionuclides plotted is the total curies in the inventory normalized by the EPA release limits (see Section 6.1.2, Environmental Protection Agency Release Limits). Some radionuclides in the decay chains are not considered in performance assessment calculations. At 10,000 yr, the total normalized activity in a panel for all omitted radionuclides is less than 2 percent of the EPA limit. (Inclusion of radium-226 drops the total normalized activity to one percent.)

\section{References}

1 EPA (Environmental Protection Agency). 1985a. "40 CFR Part 191: Environmental Standards for the Management and Disposal of Spent Nuclear Fuel, High-Level and Transuranic Radioactive Wastes; Final Rule," Federal Register. Vol. 50, no. 182, 38066-38089.

2 WIPP PA (Performance Assessment) Department. 1993. Preliminary Performance Assessment for the Waste Isolation Pilot Plant, December 1992-Volume 4: Uncertainty and Sensitivity Analysis for 40 CFR 191, Subpart B. SAND92-0700/4. Albuquerque, NM: Sandia National Laboratories. 


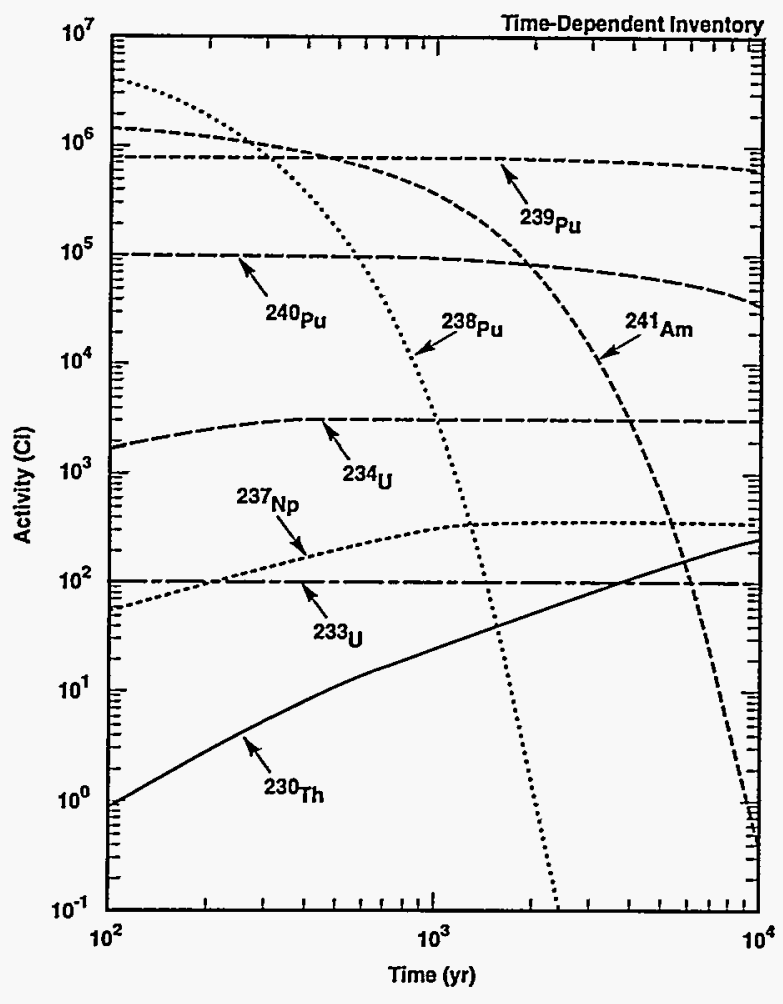

(a)

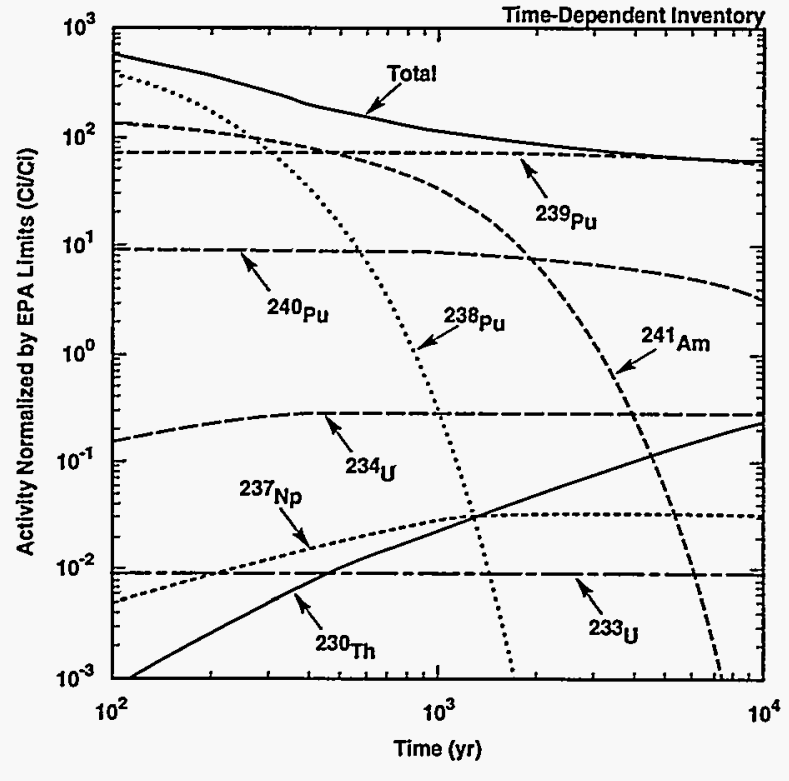

(b)

Figure 2.2-3. Changes in radionuclide activity of waste in (based on the inventory used in 1991 performance assessment calculations) a) activity unnormalized, b) and the one WIPP panel normalized by number of panels in the WIPP (9.49), waste unit factor 4.225 (million curies in 1992), and the EPA release limits (usually 1000) (see Section 6.1.2) (see WIPP PA Department, 1993, App. D, for a similar plot of the time-dependent inventory). ${ }^{2}$ 
2.0 Disposal System and Regional Characterization 


\subsection{Design of the Repository (Engineered Barrier)}

As defined in 40 CFR 191 (Section 191.12), ${ }^{1}$ a barrier "means any material or structure that prevents or substantially delays movement of water or radionuclides toward the accessible environment." An engineered barrier is any human-designed barrier of the waste-disposal system. As used herein, the engineered barrier includes shafts, boreholes, and their seals. Note that the definition in the Nuclear Regulatory Commission 10 CFR $60^{2}$ is narrower and omits shafts, boreholes, and their seals in its definition.

When the Waste Isolation Pilot Plant repository is completed, the disposal area is expected to consist of eight panels of seven rooms each and two equivalent panels in the central drifts. Because the WIPP is a research and development facility, an extensive experimental area has already been excavated and is in use north of the waste-disposal area. As each panel of the disposal area is filled with wastes, the next panel will be mined. As modeled in the 1990-1992 PA calculations, each panel was assumed to have backfilled and sealed, and access ways will be sealed off from the shafts.

The following three subsections describe the repository layout, emplacement of waste, and general sealing strategy.

\section{References}

1 EPA (Environmental Protection Agency). 1985a. "40 CFR 191: Environmental Standards for the Management and Disposal of Spent Nuclear Fuel, High-Level and Transuranic Radioactive Wastes; Final Rule," Federal Register. Vol. 50, no. 182, 38066-38089.

2 NRC (Nuclear Regulatory Commission). 1993. "Part 60-Disposal of High-Level Radioactive Wastes in Geologic Repositories," Code of Federal Regulations 10. Part 60. Washington, DC: Superintendent of Documents, U.S. Government Printing Office. 


\subsubsection{Repository Layout}

The Waste Isolation Pilot Plant (WIPP) repository* (Figure 2.3-1) is a single-level, $15 \times 10^{4} \mathrm{~m}^{2}$ (38-acre), underground disposal facility constructed within a single, nearly level, stratigraphic interval (it dips to the south $<1$ degree). As Figure 2.3-1 shows, the repository level consists of an experimental region at the northern end, an operations region with shafts ${ }^{* *}$ to the surface in the center for wastehandling and repository equipment maintenance, and a disposal region at the southern end. The disposal region will ultimately contain access drifts ${ }^{* * *}$ and eight waste-emplacement panels. ${ }^{\dagger}$ Drifts will eventually be used for waste emplacement, thereby providing the equivalent of an additional two panels for waste emplacement. At present, only the first panel has been excavated.

All underground horizontal openings are rectangular in cross section. The emplacement area drifts are $4.0-\mathrm{m}(13-\mathrm{ft})$ high by $7.6-\mathrm{m}$ (25-ft) wide. Disposal rooms ${ }^{\dagger \dagger}$ are $4.0-\mathrm{m}(13-\mathrm{ft})$ high, 10.1-m (33-ft) wide, and $91.4 \mathrm{~m}$ (300-ft) long. Pillars $\ddagger$ between rooms are $30.5-\mathrm{m}(100-\mathrm{ft})$ wide. The eight wasteemplacement panels will each have an initial volume of $46,000 \mathrm{~m}^{3}\left(1.6 \times 10^{6} \mathrm{ft}^{3}\right)$. The northern and southern drift emplacement areas will have initial volumes of $35,000 \mathrm{~m}^{3}\left(1.2 \times 10^{6} \mathrm{ft}^{3}\right)$ and $32,000 \mathrm{~m}^{3}$ $\left(1.1 \times 10^{6} \mathrm{ft}^{3}\right)$, respectively $\left(-3,000 \mathrm{~m}^{3}\right.$ difference). ${ }^{1}$ Thus, the overall, initial, waste-emplacement volume will be about $435,000 \mathrm{~m}^{3}\left(1.5 \times 10^{7} \mathrm{ft}^{3}\right)$. The design waste-disposal volume is $1.756 \times 10^{5} \mathrm{~m}^{3}(6.2$ $\times 10^{6} \mathrm{ft}^{3}$ ) or about 40 percent of the excavated volume. ${ }^{2}$ The remaining volume was assumed to be partially filled with backfill (e.g., crushed salt) (see Section 2.3.3, Sealing) in the 1989-1992 performance assessment (PA) calculations.

The four vertical access shafts in the operations area include the Air Intake Shaft, the Exhaust Shaft, the Salt Handling Shaft, and the Waste Shaft. They are cylindrical in shape and range from $6.2 \mathrm{~m}(20 \mathrm{ft})$

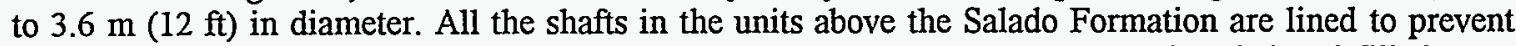
groundwater inflow and thereby enhance stability. All four shafts were assumed sealed and filled upon decommissioning of the WIPP in the 1989 - 1992 PA calculations (see Section 2.3.3, Sealing). ${ }^{3}$

\section{References}

1 Rechard, R.P., H.J. Iuzzolino, and J.S. Sandha. 1990a. Data Used in Preliminary Performance Assessment of the Waste Isolation Pilot Plant (1990). SAND89-2408. Albuquerque, NM: Sandia National Laboratories.

2 Bechtel National, Inc. 1986. Waste Isolation Pilot Plant Design Validation Final Report. DOE/WIPP-86-010. Prepared for U.S. Department of Energy. San Francisco, CA: Bechtel National, Inc.

3 Nowak, E.J., J.R. Tillerson, and T.M. Torres. 1990. Initial Reference Seal System Design: Waste Isolation Pilot Plant. SAND90-0355. Albuquerque, NM: Sandia National Laboratories.

4 WIPP PA (Performance Assessment) Division. 1991. Preliminary Comparison with 40 CFR Part 191, Subpart B for the Waste Isolation Pilot Plant, December 1991. Volume 3: Reference Data. Eds. R.P. Rechard, A.C. Peterson, J.D. Schreiber, H.J. Iuzzolino, M.S. Tierney, and J.S. Sandha. SAND91-0893/3. Albuquerque, NM: Sandia National Laboratories.

\footnotetext{
* Repository is the portion of a waste disposal facility that includes the waste panels, access drifts, and access shafts. The repository does not include the undisturbed host rock.

** Shaft is an approximately vertically or steeply inclined passageway from the ground surface to the underground level of the disposal region.

*** Drift or access drift is an approximately horizontally excavated underground passageway from the shaft(s) to the mined panels and $\operatorname{room}(\mathrm{s})$.

$\dagger$ Panel is a grouping of pillars and rooms; in the WIPP there are seven rooms per panel.

I† Room is an excavated cavity for disposal of waste. It is part of a panel.

$\ddagger \quad$ Pillar is a block of rock left intact to support the overlying strate of the excavations.
} 


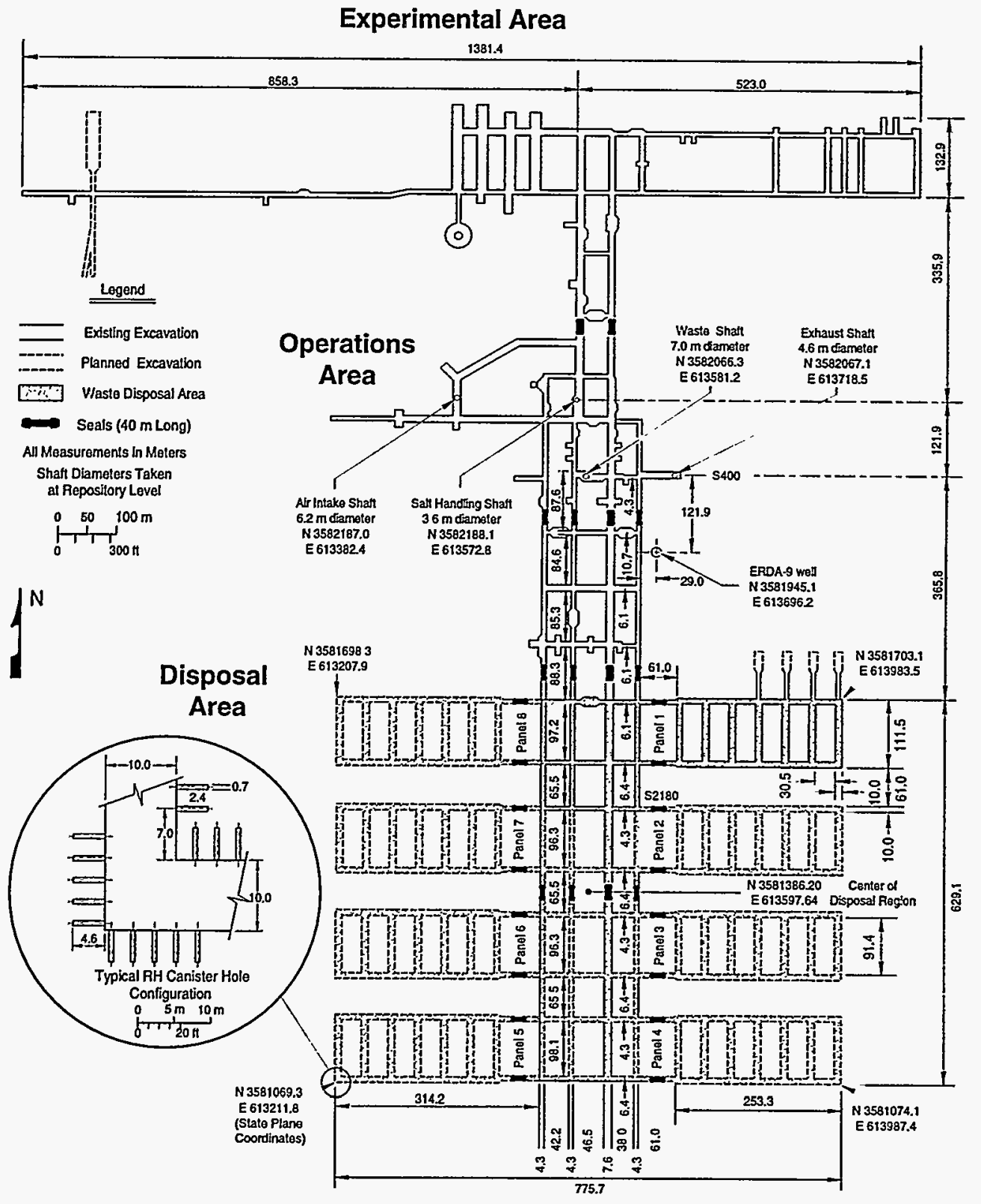

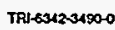

Figure 2.3-1. Planned dimensions, in meters, of the WIPP repository (dimensions originally specified in units of feet) (WIPP PA Division, 1991, Vol. 3, Figure 3.1-2). ${ }^{4}$ 


\subsubsection{Emplacement of Waste}

\section{Contact-Handled Transuranic Waste}

Current plans for transporting contact-handled (CH) transuranic (TRU) waste to the Waste Isolation Pilot Plant (WIPP) call for shipping it in 55-gal steel drums [0.892-m (2.93-ft) high, 0.602-m (1.98-ft) diameter] or in metallic standard waste boxes that are approximately $0.94-\mathrm{m}$ high $\times 1.3-\mathrm{m}$ wide $\times 1.8-\mathrm{m}$ long (3-ft high $\times 4.3-\mathrm{ft}$ wide $\times 6$ - $\mathrm{ft}$ long). Waste currently stored in containers other than 55-gal drums and standard waste boxes will be repackaged in standard waste boxes. TRUPACT (Transuranic Package Transporter) II, the transportation container designed for trucking TRU waste to the WIPP (see Figure 2.3-2a), has space for two seven-pack units of drums or two standard waste boxes.

At the WIPP, the seven-pack units will be removed from the low bay trailer, and then transported to the waste disposal rooms where they were assumed to be and stacked three high and six wide across the room (see Figure 2.3-2b). In the ideal packing configuration, a total of 6,804 drums (972 seven-pack units) can be placed in one room. The ideal packing configuration for the standard waste boxes is three high and six across the room for a total of 900 . Seven-packs and standard waste boxes may be intermixed, as practical.

\section{Remotely Handled Transuranic Waste}

The reference canister design for the remotely handled (RH) TRU waste is a right-circular cylinder of outside diameter $0.65-\mathrm{m}(26-\mathrm{in}$.) and length $3 \mathrm{~m}(10 \mathrm{ft})$. It is made of $6.35 \mathrm{~mm}(0.25$-in.) carbon steel plate. In the reference design, both end caps are welded, as is the handling point. Inside, the waste occupies about $0.89 \mathrm{~m}^{3}\left(30 \mathrm{ft}^{3}\right) .{ }^{1}$ Currently, RH-TRU waste is shipped in commercially available casks. The Department of Energy has plans for developing a new cask (NuPack 72B) specifically for $\mathrm{RH}$ canisters.

The 1989 - 1992 PA calculations emplaced one RH-TRU canister horizontally every $2.4 \mathrm{~m}(8 \mathrm{ft})$ into the drift and room walls of the WIPP Repository (see Section 2.3.1). Based on this technique, the capacity in each panel for RH-TRU canisters along drifts and rooms $10-\mathrm{m}$ wide is 874 canisters or about $6,000 \mathrm{~m}^{3}$ $\left(214,300 \mathrm{ft}^{3}\right)$. The intended capacity of the repository for RH-TRU waste is $7,080 \mathrm{~m}^{3}\left(250,000 \mathrm{ft}^{3}\right)$; hence, additional methods may be explored to find additional space.

\section{References}

1 U.S. DOE (U.S. Department of Energy). 1990b. Final Safety Analysis Report, Waste Isolation Pilot Plant, Carlsbad, New Mexico. WP 02-9, Rev. 0. Carlsbad, NM: Westinghouse Electric Corporation.

2 WIPP PA (Performance Assessment) Division. 1991. Prelininary Comparison with 40 CFR Part 191, Subpart B for the Waste Isolation Pilot Plant, December 1991. Volume 3: Reference Data. Eds. R.P. Rechard, A.C. Peterson, J.D. Schreiber, H.J. Iuzzolino, M.S. Tierney, and J.S. Sandha. SAND91-0893/3. Albuquerque, NM: Sandia National Laboratories.

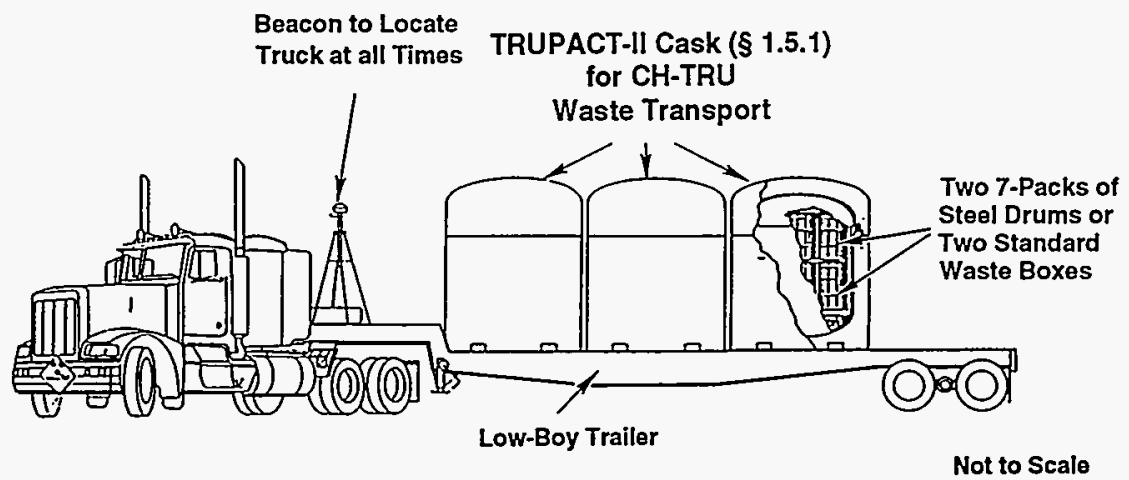

TRSESM1.428-O

Figure 2.3-2a. Transportation of contact-handled transuranic (CH-TRU) waste. 


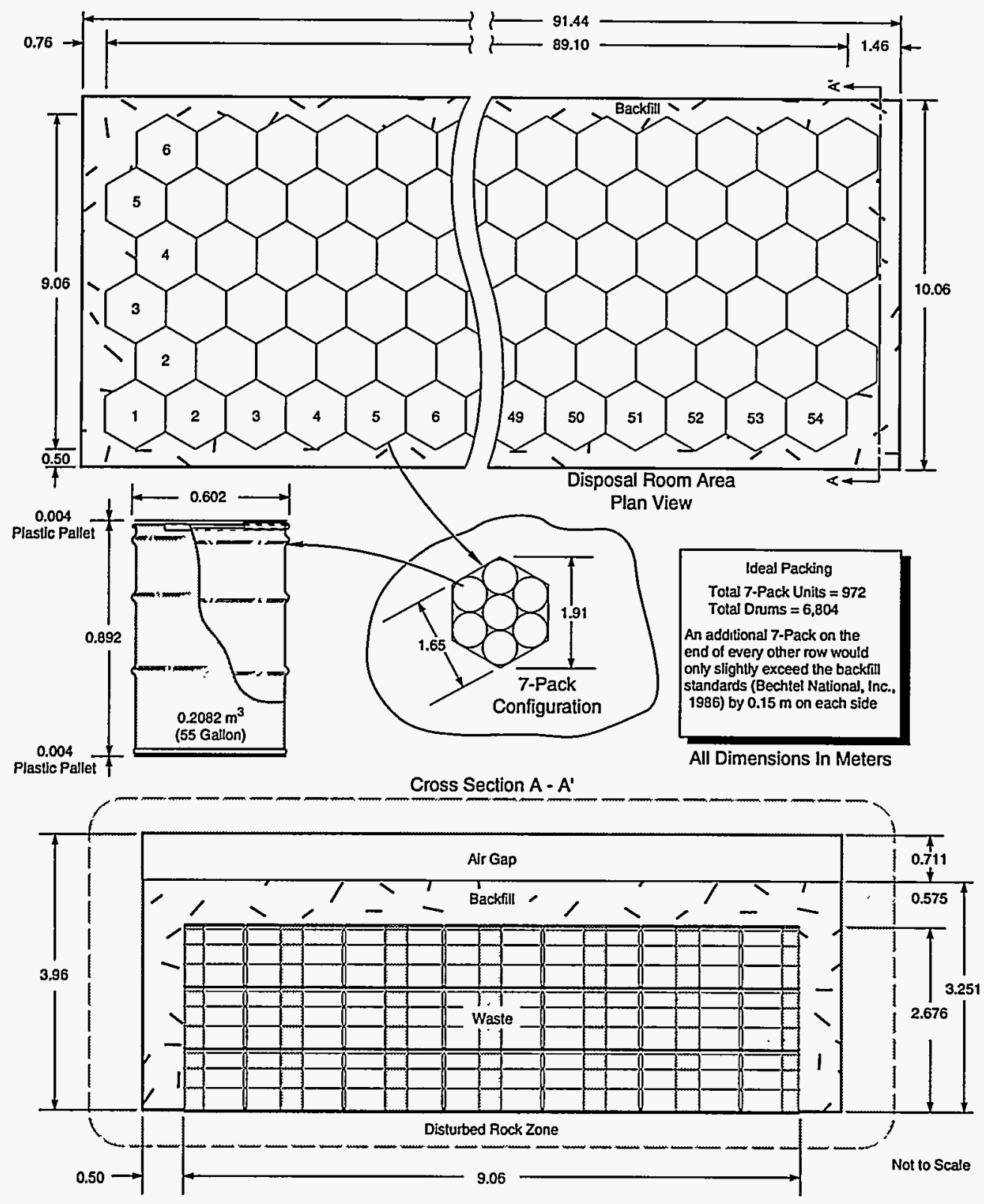

TRI-6342-3468-0

Figure 2.3-2b. Ideal packing of waste drums in rooms and 10-m-wide (33-ft-wide) access drifts envisioned for 1990-1992 performance assessment calculations (WIPP PA Division, 1991, Vol. 3, Figure 3.1-3). ${ }^{2}$ 


\subsubsection{Sealing}

\section{General Sealing Strategy Proposed for 1990-1992 PA Calculations}

As envisioned in the 1990-1992 performance assessment calculations (see Figure 2.3-3), the entire underground facility and shafts (see Sections 1.4.1 and 2.3.1 for definitions) would be backfilled, primarily with crushed salt to limit the creation of a preferred pathway for contaminant migration. Portions of the backfill ${ }^{*}$ emplaced at several locations within the shafts and various drifts would be specially prepared from preconsolidated salt with concrete plugs. It would serve to protect the ordinary backfill from fluids (gases or liquids). Inhibiting fluid flow likely hastens backfill consolidation and thus increases the likelihood that the salt backfill would rapidly $(<100 \mathrm{yr})$ assume properties near to those of the surrounding host rock. Within the Waste Isolation Pilot Plant (WIPP) Project, prepared backfill plugs are termed "seals."**

The strategy for sealing combines both short- and long-term components. Preconsolidated crushed salt is the principal long-term component in the Salado Formation. Bentonite clay, a swelling clay material shown to be stable and to have low permeability to brines, is the principal long-term component in the overlying Rustler Formation. Bentonite is a common term applied to clay containing montmorillonite as the predominate mineral. Concrete is the principal short-term component at both locations.

Short-term seals provide the initial sealing functions necessary until the long-term seal components and remaining backfill become adequately reconsolidated. ${ }^{1}$ Preconsolidated crushed-salt and clay components are assumed to become fully functional for sealing within $100 \mathrm{yr}$ after emplacement. ${ }^{2,3} \mathrm{At}$ that time, the long-term seals and backfill are assumed to take over all sealing functions.

\section{Seal Locations}

In the reference design, ${ }^{* * *}$ multicomponent seals between 30 - and $40-\mathrm{m}(100-$ and $130-\mathrm{ft})$ long were used in each of the entrances to the waste-disposal panels and in selected access drifts. ${ }^{1}$ Furthermore, the entire length of all shafts between the Rustler Formation and the repository level were "seals." Seals near the Rustler Formation (upper shaft and water-bearing zone seals) serve to limit vertical brine flow from water-bearing zones down to the crushed-salt backfill. Seals within the drifts were thought to reduce horizontal fluid flow (gas and brine) within the underground facility during operations.

\section{References}

1 Nowak, E.J., J.R. Tillerson, and T.M. Torres. 1990. Initial Reference Seal System Design: Waste Isolation Pilot Plant. SAND90-0355. Albuquerque, NM: Sandia National Laboratories.

2 Nowak, E.J., and J.C. Stormont. 1987. Scoping Model Calculations of the Reconsolidation of Crushed Salt in WIPP Shafts. SAND87-0879. Albuquerque, NM: Sandia National Laboratories.

3 Argüello, J.G., and T.M. Torres. 1988. WIPP Panel Entryway Seal-Numerical Simulation of Seal Composite Interaction for Preliminary Design Evaluation. SAND87-2804. Albuquerque, NM: Sandia National Laboratories.

4 Van Sambeek, L.L., D.D. Luo, M.S. Lin, W. Ostrowski, and D. Oyenuga. 1993. Seal Design Alternatives Study. SAND92-7340. Albuquerque, NM: Sandia National Laboratories.

5 WIPP PA (Performance Assessment) Division. 1991. Preliminary Comparison with 40 CFR 191, Subpart B for the Waste Isolation Pilot Plant, December 1991. Volume 3: Reference Data. Eds. R.P. Rechard, A.C. Peterson, J.D. Schreiber, H.J. Iuzzolino, M.S. Tierney, and J.S. Sandha. SAND91-0893/3. Albuquerque, NM: Sandia National Laboratories.

* Backfill is the material used to fill the shafts, access drifts, and other excavated openings. Special types of backfill include concrete and bentonite clay plugs (seals) and optionally a mixture of bentonite clay and salt around the waste parcel (backfill-buffer).

** In 10 CFR 60 , Section 60.134 , the term "seals" is used only in reference to material backfilling the shafts. In the WIPP, the term is also applied to specially prepared backfill with concrete components in the drifts as well as the shafts.

*** The purpose of the reference seal design, which Sandia has developed for sealing the WIPP repository, was to provide a common basis for model calculations. The reference design is a starting point for developing experiments and analysis from which a determined design will evolve. More recent options for backfill and seal design differ from those used here and are described by Van Sambeek et al. ${ }^{4}$; a report describing the more current options is in preparation. 


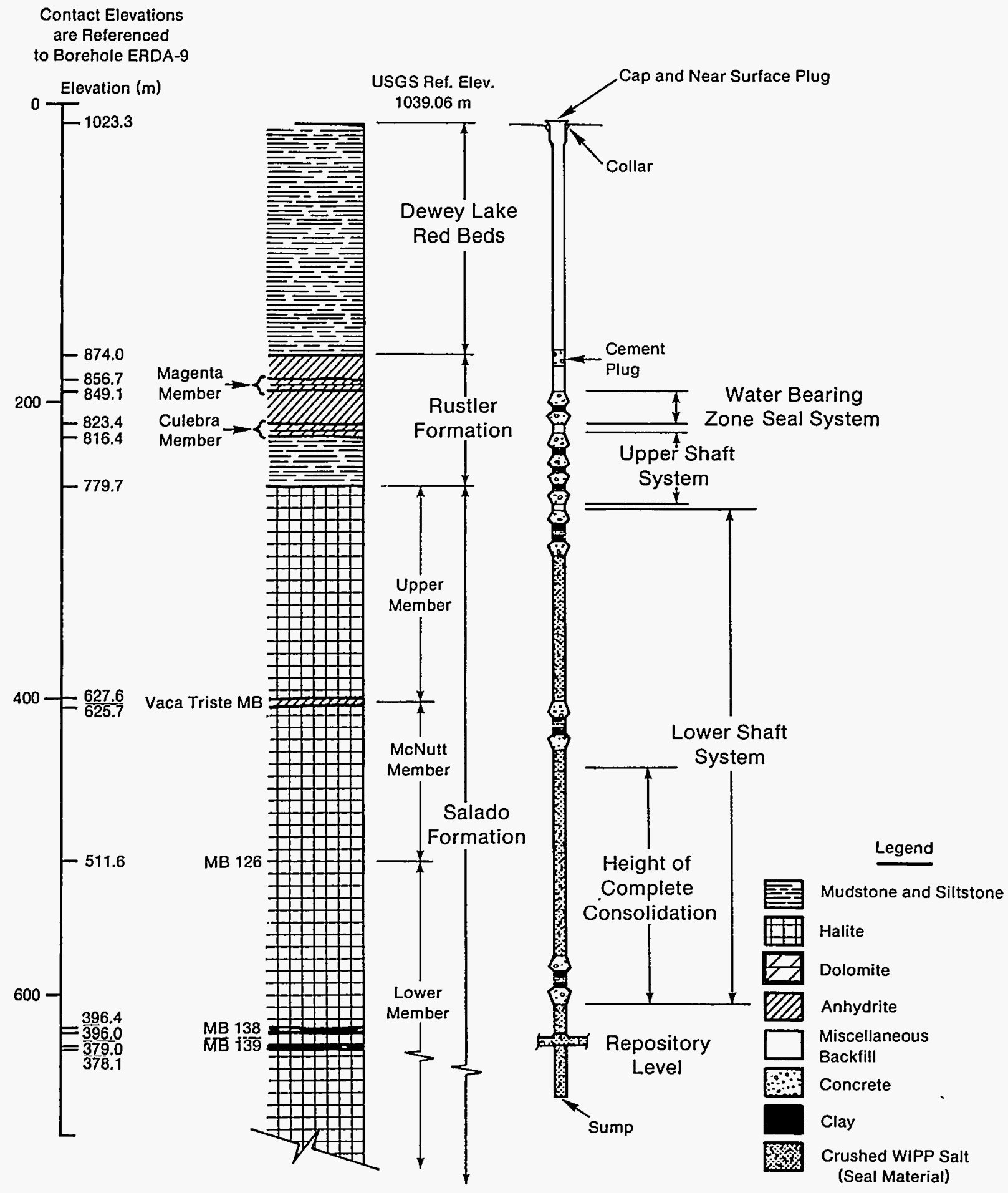

TRI-6342-311-2

Figure 2.3-3. Diagram of typical sealed shaft envisioned for 1990-1992 performance assessment calculations (WIPP PA Division, 1991, Vol. 3, Figure 3.2-1). 5 


\subsection{SCENARIO DEVELOPMENT}

Scenario development encompasses the processes of deciding (a) what may happen to the disposal system in the future and (b) how to model what may happen for effective consequence analysis. It is the second phase of conceptual-model development, the first phase being disposal system and regional characterization (see Section 2.0). System characterization and scenario development together establish how scientific reality will be represented in a conceptual model(s). Mathematically, a "scenario" is the subset of all features, events, and processes ${ }^{* * *}$ characterizing a disposal system incorporated into a conceptual model of that system. ${ }^{1}$ In common terminology, it is "an outline of a hypothetical chain of events." ${ }^{2}$ (See also Section 1.1.2, Multiple Iterations: a Performance Assessment Strategy. There, scenarios are the first elements in a set of ordered triplets. They reply to the question, "What can happen?") Although much scientific modeling is not done with scenario development as a formal step, it is useful and one aspect of a performance assessment (or probabilistic risk assessment) that sets it apart from small-scale, scientific modeling.

The scenario-development process entails selecting features (e.g., a brine reservoir under the repository), events (e.g., humans drilling into the repository), and processes (e.g., generation of gas in the repository after disposal of the wastes) relevant to the functioning of the repository. In part, scenario development is a heuristic process and for the 1990-1992 calculations consisted of the following steps $\mathbf{3}^{3,4}$ :

1. Identify and list the full scope of features, events, and processes relevant to the functioning of the disposal system. This list is known as "the universe" (of discourse).

2. Select for consideration those features, events, and/or processes that might reasonably contribute to contaminant releases to a regulatory endpoint such as the accessible environment.

3. Group these features, events, and processes into summary scenarios ${ }_{,}^{\dagger \dagger}$ omitting elements having (a) exceedingly low probabilities of occurrence, (b) exceedingly low consequences, or (c) no role in accepted definitions of the calculation (normally based on guidance from Appendix C of 40 CFR 191). Upon completion of this step, a set of comprehensive, mutually exclusive summary scenarios for consequence analysis usually exists.

4. Create conceptual models based on (a) established disposal-system characteristics and (b) the selected and grouped features, events, and processes.

5. Design performance-assessment calculations based on these conceptual models. If desirable, subdivide the summary scenarios into computational scenarios.

The first two steps are discussed in Section 3.1, the third step in Section 3.2, and parts of the last two steps in Section 3.3. The majority of the last two steps is more conveniently described in conjunction with the probability and consequence modeling treated in Chapters 4 and 5 , respectively. ${ }^{\ddagger}$

\footnotetext{
* A feature is an aspect or condition of the disposal system that influences the release and/or transport of contaminants.

** An event is a natural or anthropogenic phenomenon that occurs over a small portion of the time frame of interest, in other words, a "short-term" phenomenon.

***

A physical process is a natural or anthropogenic phenomenon that occurs over a significant portion of the time frame of interest, in other words, a "long-term" phenomenon.

$\dagger$ Once a mathematical model of the disposal system has been developed, the term "scenario" can be precisely defined in terms of the parameter space of the model, that is, a scenario is a subset of the model parameter space. Elaborating, a scenario is a "class" of histories with a subset of similar parameters, where a "history" is a point in the parameter space.

†† In the WIPP, scenarios are often described as summary or computational. Summary scenarios are those scenarios retained after the first two steps of scenario development. Computational scenarios include further divisions of coarse summary scenarios into units that are computationally more convenient.

$\mp \quad$ Other authors have used the term scenario development to refer to steps 1 through 3 , exclusively, because the first three steps and the last two steps may be performed by two different groups—a scenario team and modeling team. In this report, "scenario development" will include the identification and selection of features, events, and processes, as well as the incorporation of those components into the conceptual model to acknowledge the close relationship between modeling and scenario uncertainty and the need to have close communication between individuals performing these two tasks.
} 
The heuristic nature of this process suggests that continued re-evaluation is necessary as the general inquiry about the disposal system continues (see Section 1.1.2, Multiple Iterations: a Performance Assessment Strategy). This has indeed occurred at the WIPP. The first list of scenarios to be considered was published in $1979^{5}$ and differs somewhat from those presented in this report.6,7 Also, current suggestions on scenario development and scenarios to consider differ from those presented in this report. ${ }^{8}$

\section{References}

1 Tierney, M.S., R.V. Guzowski, and R.P. Rechard. 1993. "Scenario Development," Initial Performance Assessment of the Disposal of Spent Nuclear Fuel and High-Level Waste Stored at Idaho National Engineering Laboratory. Volume 1: Methodology and Results. Ed. R.P. Rechard. SAND93-2330/1. Albuquerque, NM: Sandia National Laboratories. 7-1 through 7-27.

2 Morris, W., ed. 1975. The American Heritage Dictionary of the English Language. New York, NY: American Heritage Pub. Co.

3 Cranwell, R.M., R.V. Guzowski, J.E. Campbell, and N.R. Ortiz. 1990. Risk Methodology for Geologic Disposal of Radioactive Waste: Scenario Selection Procedure. SAND80-1429, NUREG/CR-1667. Albuquerque, NM: Sandia National Laboratories.

4 NEA (Nuclear Energy Agency). 1992. Safety Assessment of Radioactive Waste Repositories: Systematic Approaches to Scenario Development. Paris: Nuclear Energy Agency, Organisation for Economic Co-Operation and Development.

5 Bingham, F.W., and G.E. Barr. 1979. Scenarios for Long-Term Release of Radionuclides from a NuclearWaste Repository in the Los Medaños Region of New Mexico. SAND78-1730. Albuquerque, NM: Sandia National Laboratories.

6 Hunter, R.L. 1989. Events and Processes for Constructing Scenarios for the Release of Transuranic Waste From the Waste Isolation Pilot Plant, Southeastern New Mexico. SAND89-2546. Albuquerque, NM: Sandia National Laboratories.

7 Guzowski, R.V. 1990. Preliminary Identification of Scenarios That May Affect the Escape and Transport of Radionuclides From the Waste Isolation Pilot Plant, Southeastern New Mexico. SAND89-7149. Albuquerque, NM: Sandia National Laboratories.

8 Galson, D.A., and P.N. Swift. 1995. "Recent Progress in Scenario Development for the WIPP," High Level Radioactive Waste Management, Proceedings of the Sixth Annual International Conference, Las Vegas, NV, April 30 - May 5, 1995. La Grange Park, Il: American Nuclear Society, Inc.; New York, NY: American Society of Civil Engineers. 391-396. 


\subsection{Identifying Features, Events, and Processes}

Assessing the performance of the Waste Isolation Pilot Plant (WIPP) disposal system requires developing models to simulate plausible future behaviors of the disposal system. Each single history $(\chi)$ (here meaning one future disposal-system condition of interest) consists of a defined sequence of features, events, and processes that could lead to radionuclide release to the accessible environment during a prescribed time period. Specifically, for the WIPP and 40 CFR 191 the single-history space is the set, $\zeta$, of chosen $\chi \mathrm{s}$, where $\chi$ is a single 10,000-yr WIPP history beginning at the time of decommissioning.

Innumerable histories $(\chi)$ exist (i.e., there are infinitely many points in single-history space). Histories that have several attributes in common are frequently grouped together to form a scenario, $S_{j}$ (i.e., a bundle of points in the single-history space). The $S_{j}$ are disjoint (exclusive) subsets of $\zeta$; in other words,

$$
\zeta=\cup_{j=1}^{n S} S_{j}
$$

where $n S$ is the total number of scenario subsets.

An important part of any performance assessment is the discretization of $\zeta$ into the sets $S_{j}$, commonly referred to as scenario identification and selection. In defining the disjoint sets, the following three conditions apply: (1) estimation of consequence results $C\left(S_{j}\right)$ must be computationally feasible, (2) each $S_{j}$ must be sufficiently homogeneous that it is reasonable to use the same consequence result (for all elements of the subset $S_{j}$ ), and (3) determination of a probability $P\left(S_{j}\right)$ must be possible for each $S_{j}$.

As part of the scenario-development process, the performance assessment team for the 1990, 1991, and 1992 performance assessment (PA) calculations used a formalized identification and selection procedure 1,2 to identify features, events, and processes to be modeled (see Sections 3.1.1 and 3.1.2). Note that although this list was extensive, it must be viewed as but a starting point for the analysis. Because so much of the disposal system is characterized rather than designed, future additions to the "universe" of possibilities remain a likelihood.

The basic features, events, and processes selected for modeling in the PAs summarized in this report are described below.

Features. The basic features include seals in shafts and between panels; an overlying, fractured brine aquifer; anhydrite beds slightly above or below the repository horizon, full saturation of the salt; and a possible underlying pressurized brine reservoir.

Events. The basic events include human intrusion and its absence.

Processes. The basic processes (i.e., long-term phenomena) include creep of salt around the waste, gas generation within the waste because of container corrosion (drum or box) of microbial degradation of organics, two-phase (brine and gas) Darcy flow in and around the repository, and hydrological transport through fractures. Colloid transport suspended solids was not treated. Because of fractures, increased permeability formed by locally generated gas was not considered.

The two subsections that follow elaborate on the identification and selection procedure and provide an example of the initial "comprehensive list" of features, events, and procedures considered for the WIPP.

\section{References}

1 Guzowski, R.V. 1990. Preliminary Identification of Scenarios That May Affect the Escape and Transport of Radionuclides From the Waste Isolation Pilot Plant, Southeastern New Mexico. SAND89-7149. Albuquerque, NM: Sandia National Laboratories.

2 Cranwell, R.M., R.V. Guzowski, J.E. Campbell, and N.R. Ortiz. 1990. Risk Methodology for Geologic Disposal of Radioactive Waste: Scenario Selection Procedure. SAND80-1429, NUREG/CR-1667. Albuquerque, NM: Sandia National Laboratories.

* Scenario selection is a necessary but sometimes a vague step in the construction of a model of a repository system in which the analyst(s) identify the natural and anthropogenic phenomena that might play a significant role in measuring the performance of the system. As stated in Chapter 3.0, once a mathematical model of the disposal system has been developed, the single history space $\zeta$ can be defined in terms of the parameter space $D$ used in discussions for the remainder of the report. The single history space $\zeta$ is isomorphic (i.e., has a one-to-one correspondence) with the parameter space $D$. 


\subsubsection{Identification and Selection Procedures}

Identification and selection of features, events, and processes for use in performance assessments (PAs) of the Waste Isolation Pilot Plant (WIPP) are based on the following procedure (Figure 3.1-1) ${ }^{1,2}$ :

1. Identifying the "comprehensive list" of features, events, and processes. An initial list of features, events, and processes is developed as either an original list or adopted (or adapted) from one or more existing sources. The question of whether or not a list is comprehensive must be addressed for compliance assessment regardless of which approach is selected. (See Section 3.1.2 for more detail.)

2. Providing rough estimates of probabilities and consequences of features, events, and processes. PA analysts use judgment, existing data, and simple modeling to develop rough estimates of probabilities as more thoroughly described below. The estimates are then used to screen features, events, and processes.

3. Screening features, events, and processes to establish history space. Three criteria listed below are used to eliminate from scenario development those events and processes that are not applicable to a specific disposal system or that do not have the potential of contributing significantly to the performance measure (e.g., integrated radionuclide releases).

Regulatory guidance. Guidance in 40 CFR 191 restricts events and processes that must be included in PAs. This guidance (a) limits assessments to the 10,000-yr time period immediately after disposalfacility closure, (b) limits consideration of inadvertent human intrusion, and (c) limits the severity of human intrusions at the disposal-facility location.

Probability of occurrence. Guidance in Appendix C of 40 CFR 191 states that events and processes estimated to have a probability of occurrence less than $1 / 10,000$ in 10,000 years need not be considered. The philosophy behind this screening criterion is that extremely rare events and/or processes should not be permitted to influence the performance measure for a disposal system no matter how severe the specific consequence associated with such events and processes might be. "Physical reasonableness" is also considered and may be classified as a subset of probability of occurrence. This screening is based on subjective judgment derived from logical arguments as to whether conditions can exist within the period of regulatory concern that will result in the occurrence of a particular event or process of sufficient magnitude to affect disposal-system performance. The logical arguments are based on available data and information, sometimes supplemented by calculations. In the WIPP PA, the distinction between probability of occurrence and physical reasonableness as screening criteria is the difference between (1) the ability to assign a distinct albeit small probability to an event (for example, a significant meteorite impact) versus (2) the inability to assign a meaningful probability at all because no such event has ever occurred (for example, glaciation at the WIPP site). Events in the second category have inordinately low probabilities and seem "physically unreasonable" during the next 10,000 yr.

Consequence. Regardless of likelihood, if an event or process alone or in combination with other events and processes has little to no potential to affect the performance of the disposal system (e.g., through the alteration of transport pathways or the creation of new pathways), it may be omitted, providing there is a reasonable expectation that cumulative releases would remain essentially unchanged by the omission. Simplified conceptual and mathematical models are used to estimate consequences of single events and/or processes. The possibility remains, however, that a single event or process may of itself have no consequence on the disposal system, but that it could have a measurable consequence when combined with one or more other events and processes. Consequently, combinations must also be evaluated.

\section{References}

1 Cranwell, R.M., R.V. Guzowski, J.E. Campbell, and N.R. Ortiz. 1990. Risk Methodology for Geologic Disposal of Radioactive Waste: Scenario Selection Procedure. SAND80-1429, NUREG/CR-1667. Albuquerque, NM: Sandia National Laboratories.

2 Tierney, M.S., R.V. Guzowski, and R.P. Rechard. 1993. "Scenario Development," Initial Performance Assessment of the Disposal of Spent Nuclear Fuel and High-Level Waste Stored at Idaho National Engineering Laboratory. Volume 1: Methodology and Results. Ed. R.P. Rechard. SAND93-2330/1. Albuquerque, NM: Sandia National Laboratories. 7-1 through 7-27. 


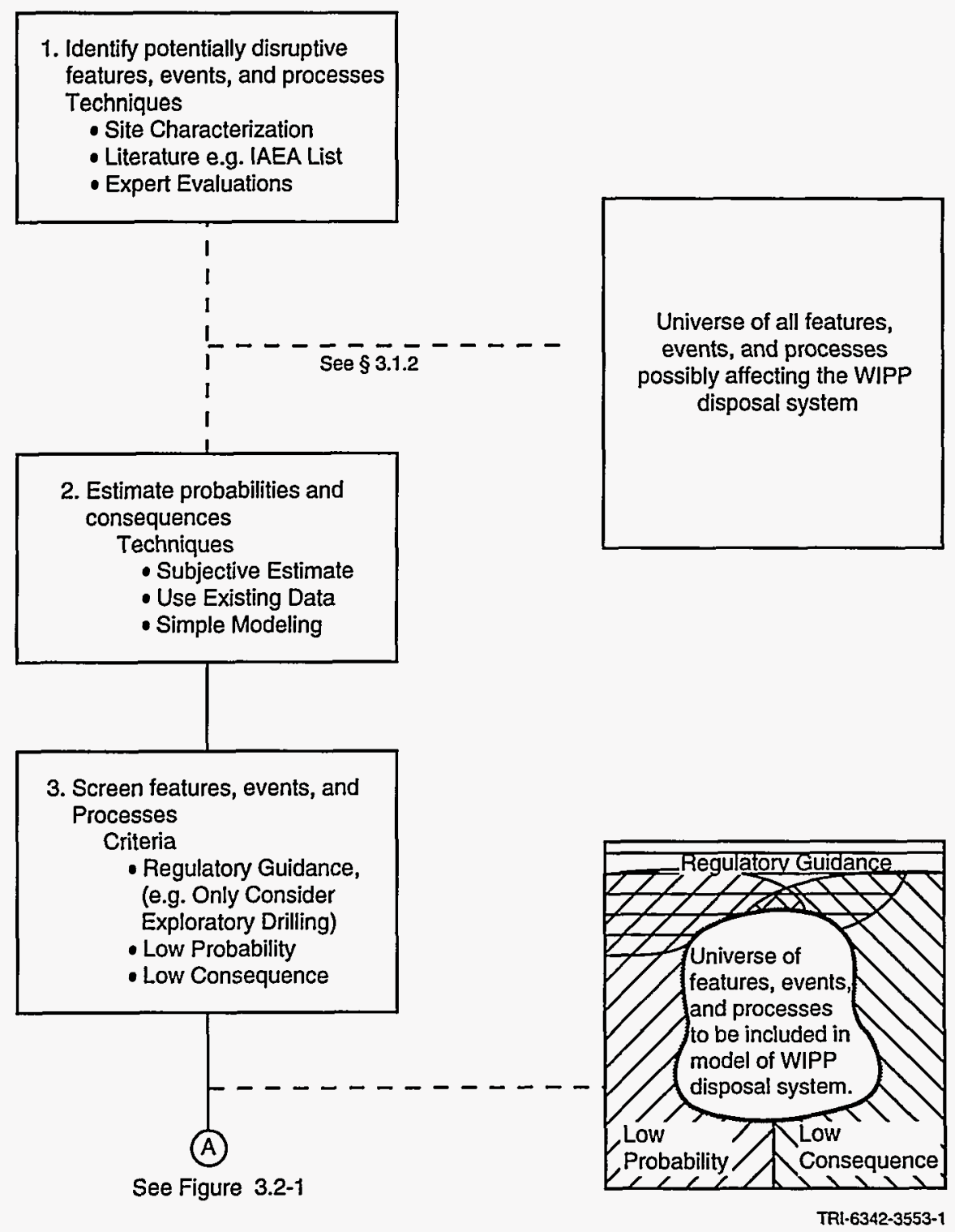

Figure 3.1-1. Identification and selection of features, events, and processes to model (Tierney et al., 1993). ${ }^{2}$ 


\subsubsection{The Universe of Features, Events, and Processes}

The procedure for identifying and selecting features, events, and processes begins with creating the "universe," an initial list of features, events, and processes that is developed either as an original list or adopted (adapted) from one or more existing sources (see Section 3.1.1, Identification and Selection Procedures) that is as comprehensive as necessary for the purposes of the analysis. An example of such a list was provided by the International Atomic Energy Agency in 1981. ${ }^{1}$ Another list derived from events and processes identified by a panel of experts with diverse professional backgrounds has been provided by Cranwell et al. ${ }^{2}$ The panel met in 1976 and 1977 under the auspices of the U.S. Nuclear Regulatory Commission. ${ }^{3}$ It identified events and processes that could influence the escape or affect the transport of radionuclides from a generic, engineered, disposal facility. The list was intended to be modified on sitespecific and/or performance-measure bases. Figure 3.1-2 shows an example of a modification of the list by Guzowski. $^{4}$

Note that although this list is extensive, it should be viewed as but a starting point for the analysis. Because so much of the disposal system is characterized, rather than designed, additions to the initial "universe" remain a possibility and has occurred at the WIPP. The uncertainty that all features, events, and processes have been included is a type of modeling uncertainty that often is called "completeness uncertainty." (See Section 1.3, Types of Uncertainty in Performance Assessments.)

\section{References}

1 IAEA (International Atomic Energy Agency). 1981. Safety Assessment for the Underground Disposal of Radioactive Wastes. Safety Series No. 56. Vienna, Austria: International Atomic Energy Agency.

2 Cranwell, R.M., R.V. Guzowski, J.E. Campbell, and N.R. Ortiz. 1990. Risk Methodology for Geologic Disposal of Radioactive Waste: Scenario Selection Procedure. SAND80-1429, NUREG/CR-1667. Albuquerque, NM: Sandia National Laboratories.

3 Campbell, J.E., R.T. Dillon, M.S. Tierney, H.T. Davis, P.E. McGrath, F.J. Pearson, Jr., H.R. Shaw, J.C. Helton, and F.A. Donath. 1978. Risk Methodology for Geologic Disposal of Radioactive Waste: Interim Report. SAND78-0029, NUREG/CR-0458. Albuquerque, NM: Sandia National Laboratories.

4 Guzowski, R.V. 1990. Preliminary Identification of Scenarios That May Affect the Escape and Transport of Radionuclides From the Waste Isolation Pilot Plant, Southeastern New Mexico. SAND89-7149. Albuquerque, NM: Sandia National Laboratories. 


\section{Natural Phenomena and Processes}

Celestial Events

- Meteorites

\section{Surficial Phenomena and Processes}

Events

- Hurricanes

- Seiches

- Tsunamis

- Landslides and Other Mass Wasting

- Flooding
Processes

- Erosion/Sedimentation

- Glaciation

- Pluvial Periods

- Sea Level Variations

- Regional Subsidence or Uplift

Subsurface Features, Events, and Processes

Features

- Undetected Fluid Reservoirs
Events

- Earthquakes (Seismic Activity)

- Volcanic Activity

- Magmatic Activity

- Faulting
Processes

- Diapirism (Regional Subsidence or Uplift)

- Dissolution Cavities

- Interconnected Fracture Systems

\section{Human-Induced Events and Processes}

Inadvertent Intrusions

- Mining

- Drilling

- Waste Injection Wells

- Explosions
Hydrologic Stresses

- Withdrawal Wells

- Irrigation

- Damming of Streams

\section{Waste- and Repository-Induced Processes}

Subsidence and Caving

Shaft and Borehole Seal Degradation

Thermally Induced Stress/Fracturing in Host Rock Excavation-Induced Stress/Fracturing in Host Rock

TRL-6342-3851-0

Figure 3.1-2. Original comprehensive list of potentially disruptive events, features, and processes affecting a generic disposal system based on work of a Nuclear Regulatory Commission Panel ${ }^{3}$ (after Guzowski, 1990). ${ }^{4}$ 
3.0 Scenario Development

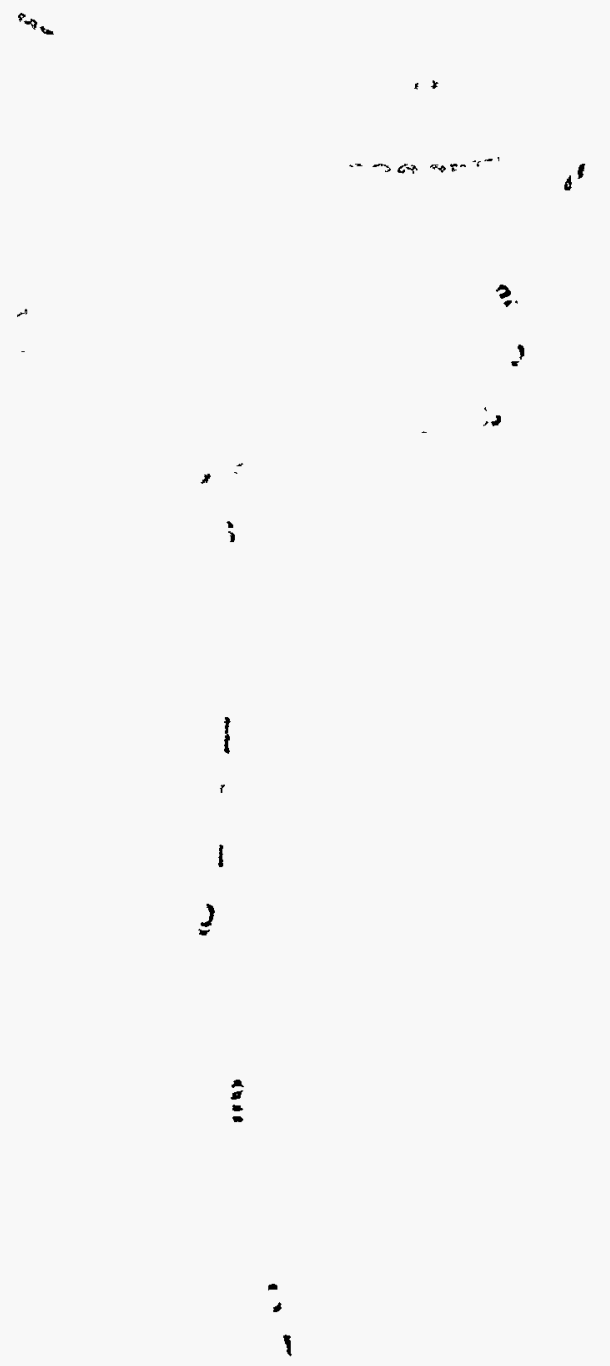




\subsection{Grouping Features, Events, and Processes into Scenarios}

After identifying features, events, and processes to be modeled, the parameter space can be grouped into scenarios. The advantage of scenario groupings, called summary scenarios, is that attention in the analysis can be focused on selected events and processes. Grouping is feasible if the probabilities of residing in certain regions of the sample space are easily calculated. At this stage of scenario development, it is assumed that behavior within the summary scenarios is similar enough that a representative (or a key subset) single history can characterize the whole subset. The scenarios retained for consequence analysis in the 1990, 1991, and 1992 performance-assessment calculations belong to two principal categories: undisturbed (base-case) performance, and disturbed (human-intrusion) performance. They are described in Sections 3.2.3 and 3.2.4.

Sections 3.2.1 and 3.2.2 describe the techniques used to arrive at the summary scenarios introduced in Sections 3.2.3 and 3.2.4. 


\subsubsection{General Development Procedure}

The general process of grouping features, events, and processes into summary scenarios was discussed in Sections 3.2.3 and 3.2.4 and consists of the following three steps (Figure 3.2-1) ${ }^{1}$ :

1. Classifying features, events, and processes. Any of a variety of classification schemes can serve as organizational tools to aid in determining completeness. Two classification schemes are mentioned by Cranwell et al. ${ }^{2}$ One scheme is based on the origin of events and processes (i.e., naturally occurring, human induced, and waste/repository induced). The other is based on their primary effect on the disposal system (i.e., primarily affecting release of radionuclides from the facility or primarily affecting transport of radionuclides toward the accessible environment).

2. Combining features, events, and processes into summary scenarios. A key assumption of this step is that the various combinations of classified events and processes define all the future states of the disposal system that are of regulatory concern. In some cases, regulatory guidance can be used to eliminate selected events and processes. Thus, step two could be considered as dividing the history space into subsets. Venn diagrams assist in developing the set of summary scenarios (i.e., all possible combinations of events and processes). Each pathway through a Venn diagram results in a summary scenario that includes some and rejects other events and processes, although rejected events and processes are generally not listed. The complete diagram develops all possible combinations of events and processes located across the top of the diagram. If $n$ is the number of events and processes, the total number of scenarios will be $2^{n}$. See Section 3.2.2, Applying the Grouping Procedure to the WIPP (Waste Isolation Pilot Plant), for an example of this diagrammatic logic. Because of the assumption that these combinations define all possible future states of the disposal system that are of regulatory concern, the sum of the probabilities of the summary scenarios developed in Figure 3.1-1 must be 1 . Scenario probabilities must include values for occurrence and for nonoccurrence of all events and processes. The inclusion of non-occurring events and processes in each scenario assures that the sum of the scenario probabilities will be 1 .

3. Grouping summary scenarios with similar consequences. In general, separate calculations of performance measures must be made for each summary scenario. To minimize the number of calculations, the number of distinct summary scenarios should be reduced to an absolute minimum. ${ }^{3}$ This reduction may be possible through a careful, logical examination of the nature of the agents (features, events, and processes) in each summary scenario and the way those agents can interact to produce consequences. In many cases, a logical, nonnumerical analysis will show that two or more summary scenarios will have identical consequences. Two summary scenarios having identical consequences may be combined in a single scenario; the probability of this single scenario is the sum of the probabilities attached to each of the two scenarios in the combination.

The application of this grouping procedure to the WIPP is described in Section 3.2.2.

\section{References}

1 Tierney, M.S., R.V. Guzowski, and R.P. Rechard. 1993. "Scenario Development," Initial Performance Assessment of the Disposal of Spent Nuclear Fuel and High-Level Waste Stored at Idaho National Engineering Laboratory. Volume 1: Methodology and Results. Ed. R.P. Rechard. SAND93-2330/1. Albuquerque, NM: Sandia National Laboratories. 7-1 through 7-27.

2 Cranwell, R.M., R.V. Guzowski, J.E. Campbell, and N.R. Ortiz. 1990. Risk Methodology for Geologic Disposal of Radioactive Waste: Scenario Selection Procedure. SAND80-1429, NUREG/CR-1667. Albuquerque, NM: Sandia National Laboratories.

3 Tierney, M.S. 1991. Combining Scenarios in a Calculation of the Overall Probability Distribution of Cumulative Releases of Radioactivity From the Waste Isolation Pilot Plant, Southeastern New Mexico. SAND90-0838. Albuquerque, NM: Sandia National Laboratories. p. 3-30. 
See Figure $3.1-1$

(A)

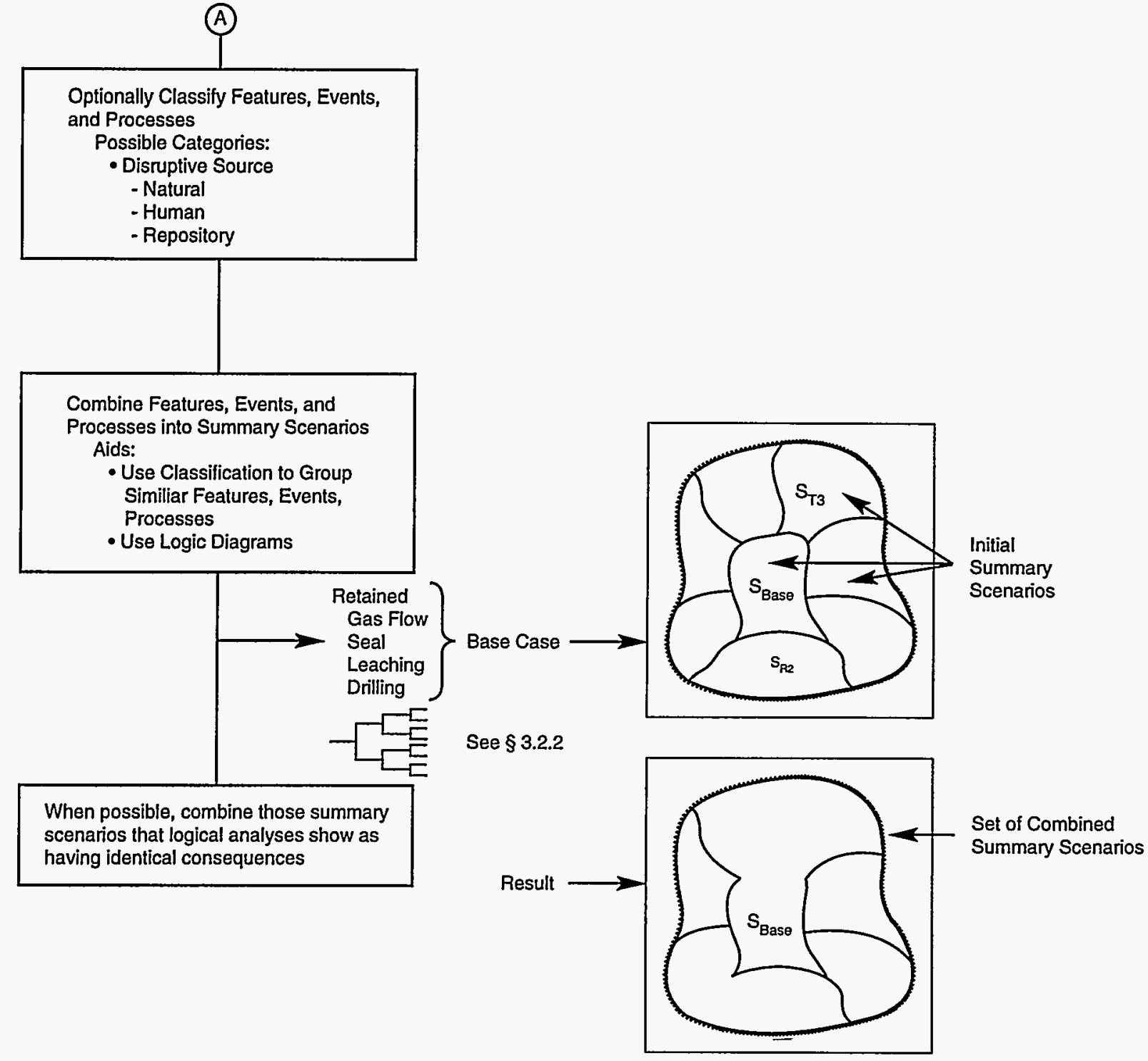

TRI-6342-3552-1

Figure 3.2-1. Grouping of features, events, and processes (which survive initial screening) into summary scenarios (Tierney et al., 1993). ${ }^{3}$ 


\subsubsection{Applying the Grouping Procedure to the WIPP}

In the scenario derelopment process for the Waste Isolation Pilot Plant (WIPP) disposal system. scicral unlikely crents and processes werc screcned out.

Exploraton drilling. potash minng near the waste panels. and water wells-lhese threc crents and processes were used to derelop summan scenarios in the 1990. 1991. and 1992 performance assessment (PA) calculations. Exploratory drilling was subdwided into the following two possibilitics: drilling into a waste-filled room or drift and a brine reservorr in the underlving Castile Formation (Erent El). and drilling into a waste-filled room or drift without penetrating a brine reserioir (Event E2). Mining (Event TS) was limited to potash extraction by cether conventional or solution methods in areas becrond the boundarics of the waste pancls: drilling of withdrawal wells (Event E.3) was limited to watcr wells in areas where water quantity and quality would permut water use. Retained erents and processes were grouped or divided as shown in Figure 3.2-2

The grouped erents and processes are used in a decision tree to construct a preliminary set of scenarios (sec Figure 3 2-2. bottom) (ne result of the decision tree is a basc-case scenario that includes repositor conditions undisturbed b! polash minng or human intrusion. Figure 3.2-2 (bottom) shows all possible combinations of the first three of the four abore erents For the 1990. 1991. and 1992 PA calculations. onls four summan scenarios were craluated: the basc case (expected behavior of the disposal system without distuption by human intrusion) (sce Section 3.2.3). El. E2. and E1E2 (sce Scction 3.2.4). The drilling of whthdrawal wells (E.3 cient) was craluated in a Nattonal-Envronmental-Policy-Act-lype calculation because it provided a potentual pathway through wheh human doses could occur (sec Section 6.2. National Environmental Policy Act Simulations). The minıng crent (TS crent) was omitted. but it could be evaluated in future performance assessments for tts effect on groundwater flow in the WIPP area. Omitting this erent is equivalent to assuming that subsidence has no effect on the base-case consequences calculated.

Once the summary scenarios are formed. the WIPP PA Department discretized the summary scenarios into "computational" scenarios $(1 \mathrm{c}$. . unts of the scenario that are computationally contenicnt). The following assumptions were used to define computational scenarios in the 1991 and $1992 \mathrm{PA}$ calculations:

1. No connections cxist between pancls.

2. No syncrgistıc cffects result from multuple borcholes. except for ElE2-type computational sccnarios.

3. An E1E2-11pe computational scenario only occurs when mtrusions of cach type happen in the same panel withun the same tume interal. where the $10.00(0)$-yr regulatory period is divided into five tume interals.

+ An E1E2-1ype computational scenario has the same release with more than two intrusions in one pancl as with exactly two intrusions

$5 \quad$ In an E2-ivpe computational scenario. a plug cxists directly above the Culebra Unit in the Rustler Formation that dirccts flow into the Culcbra. and this plug is effectwe for $10 .(0)(0)$ ? cars following decommissioning

6) In an El-type computational scenario. a plug exists as in number five and no other plug cxists to retard flow from the Castulc pressurı/cd brine reservour

7 In an EIE2-type computational scenario. number fixe is true for one intrusion. and a similar plug exists between the repository and the Rustler Formation that dircets flow through the penetrated waste pancl toward the other intrusion in the same pancl. Further. both intrusions are conservatiscly assumed to occur at the same tume

8 Closure of the intrusion borcholes is not included

\section{Reference}

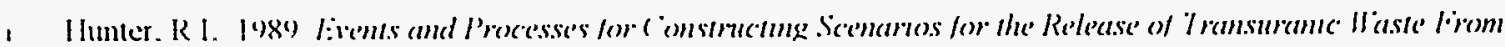

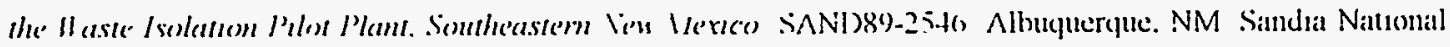
I aboratories

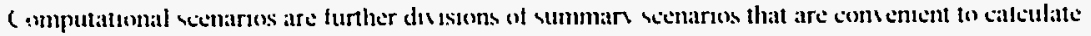



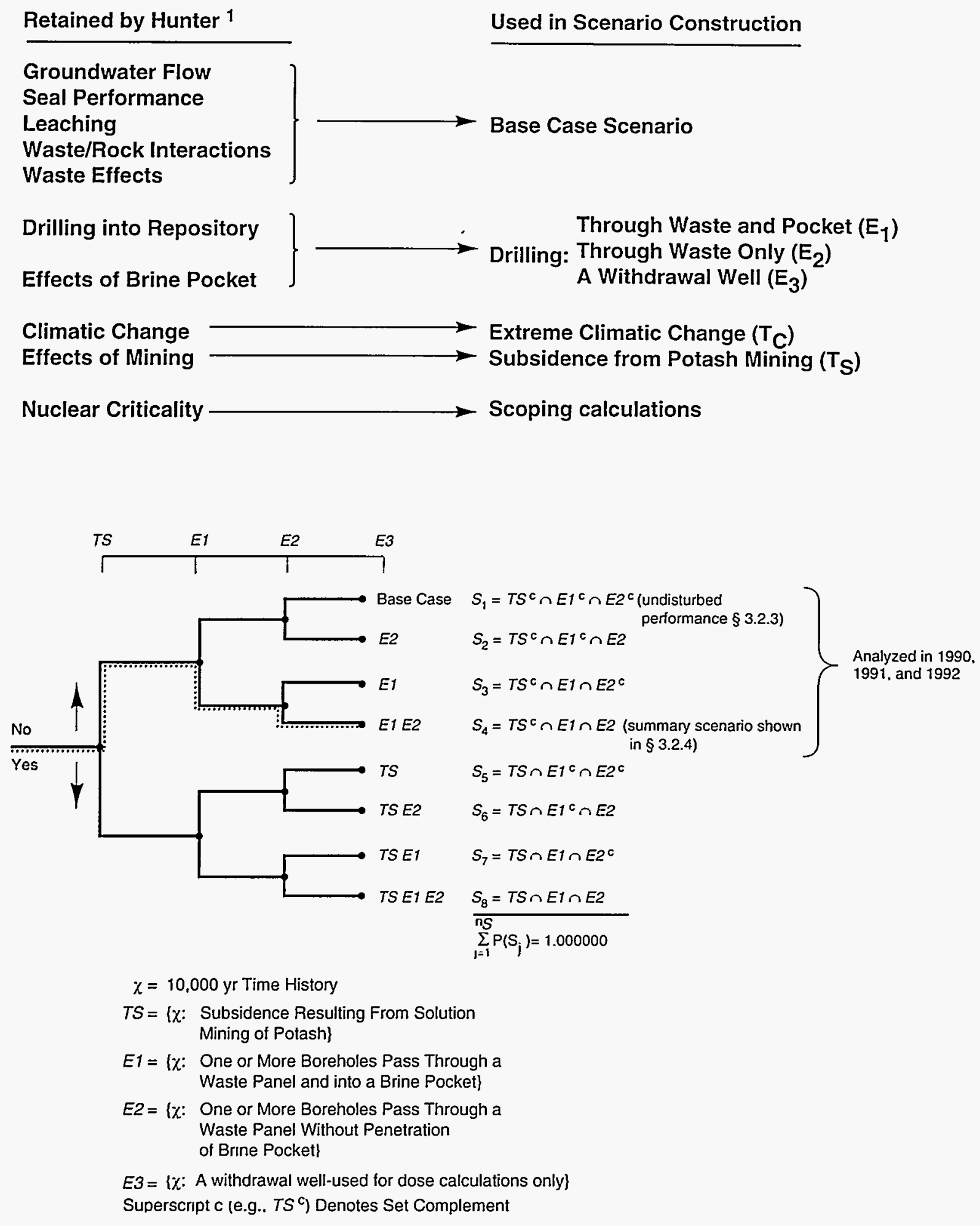

Figure 3.2-2. Development of summary scenarios for 1990-1992 performance assessment calculations. 


\subsubsection{Undisturbed Summary Scenario}

The undisturbed scenario describes the undisturbed performance ${ }^{*}$ disposal system from the time of disposal $^{* *}$ and incorporates all cxpected changes in the system and associated uncertaintics for the 10.0()(0)-yr regulatory period. As described in Section 3.i. the basic features. crents. and processes considered for the 1990 through 1992 performance assessments (PAs) were as follows. The basic features important for the undisturbed scenario include scals in the shafts to limit downward morement of Culcbra brine or upward morement of contamınated gas and brinc from the repository (sec Scction 2.3.3. Scaling). an overlying. fractured brine aquifer in the Culcbra Dolomic Member of the Rustler Formation. and anhydrite beds slightly above or below the repository horizon (sec Section 2.1.2. Stratıgraphỵ) Anhydrite is more brittle than halite. so fracturing within these interbeds has the potentlal to provide a pathway for gas and brinc (and. thereforc. contaminants) to migrate from the repository. Becausc disruptive natural events with probabilities greater than $10^{*}$ were not identified. the only basic erent considered was human intrusion and is discussed in Section 3.2.4. All natural processes retanned for sccnario construction (c.g.. climate variability) were considered to occur and be nondisruptuc. The processes include hydrologic transport in fractures of the Culcbra. generating gas because of container corrosion or microbial degradation of organic matcral (c.g.. ccllulose) in the wastc. dynamic pressuredependent crecp of salt around the waste. and two-phase (brine and gas) Darey flow in and around the repository in the Salado Formation. The Salado Formation is assumed to be saturated with brine throughout, but low permeability (from low porosity and lack of open fractures in the plaste salt) allows for little groundwater movement.

Two potcntual pathways for migration of contaminants were considered in this undisturbed scenario (Figure 3.2-3). In the first path. the pressure gradient between the waste-disposal pancis and the Culcbra causes brine and radionuclides to migrate either through drifts or through the anhydrite interbeds to the base of the shafts and then upward to the Culcbra. which is the most permeable water-saturated unit overlying the repositor: Transport may then occur laterally in the Culcbra toward the subsurlace boundary of the accessible environment. In the sccond path. brinc and radionuclides mugrate laterally from the undisturbed repository through thin anhydrite interbeds toward the subsurface boundary of the accessible environment within the Salado Formation. These undisturbed pathways may also function as routes for releases of hazardous gascous chemicals (sec Section 6.3. Resource Conservation and Recorery. Act Simulations).

The geologic disposal sỵstem as shown in Figure 3.2-3 appcars simple. but it is deceptre becausc all geologic and engincered barricrs and their various components change slowly with time and are not independent of each other. The modeling of the processes that influences these changes with time can become quite complex. Further. eren those aspects and components of the geologic disposal system that can be studicd scparatcly require consistent assumptions of behavior: hence a data base of model parameters used throughout the analysis is tery important to the performance assessment process (sce Section 4.2. Compiling Model Parameters).

Calculated aqueous relcases (consequences)from the undisturbed scenario are used for the Containment Requirements. Individual Protection Requirements. and the Groundwater Protection Requirements (Refer to Section 6.1.1. Orericw of 40 CFR 191) For the 199()-1992 PAs no radionuclide relcases occurred.

Calculated gascous releases from the undisturbed scenario were used 10 eraluate parameicr importance in sensitivity analysis (sec Section 7.1 1. Ranking Important Model Parameters)

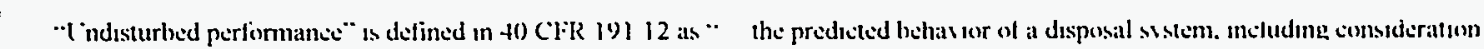

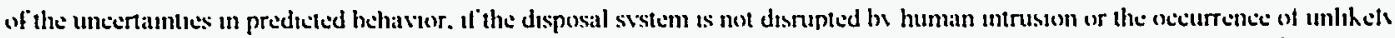

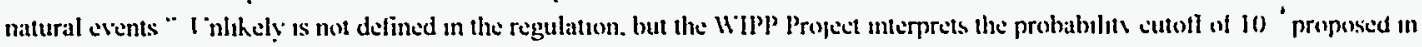

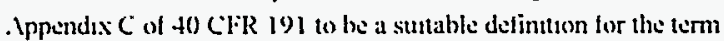

* . I sequence of episodes leading from the pont of waste placement to consolidation of the waste through ereep elosure is postulated on Section 5.11. Repositon l:pisodes l.cading to I indisturbed Conditions 


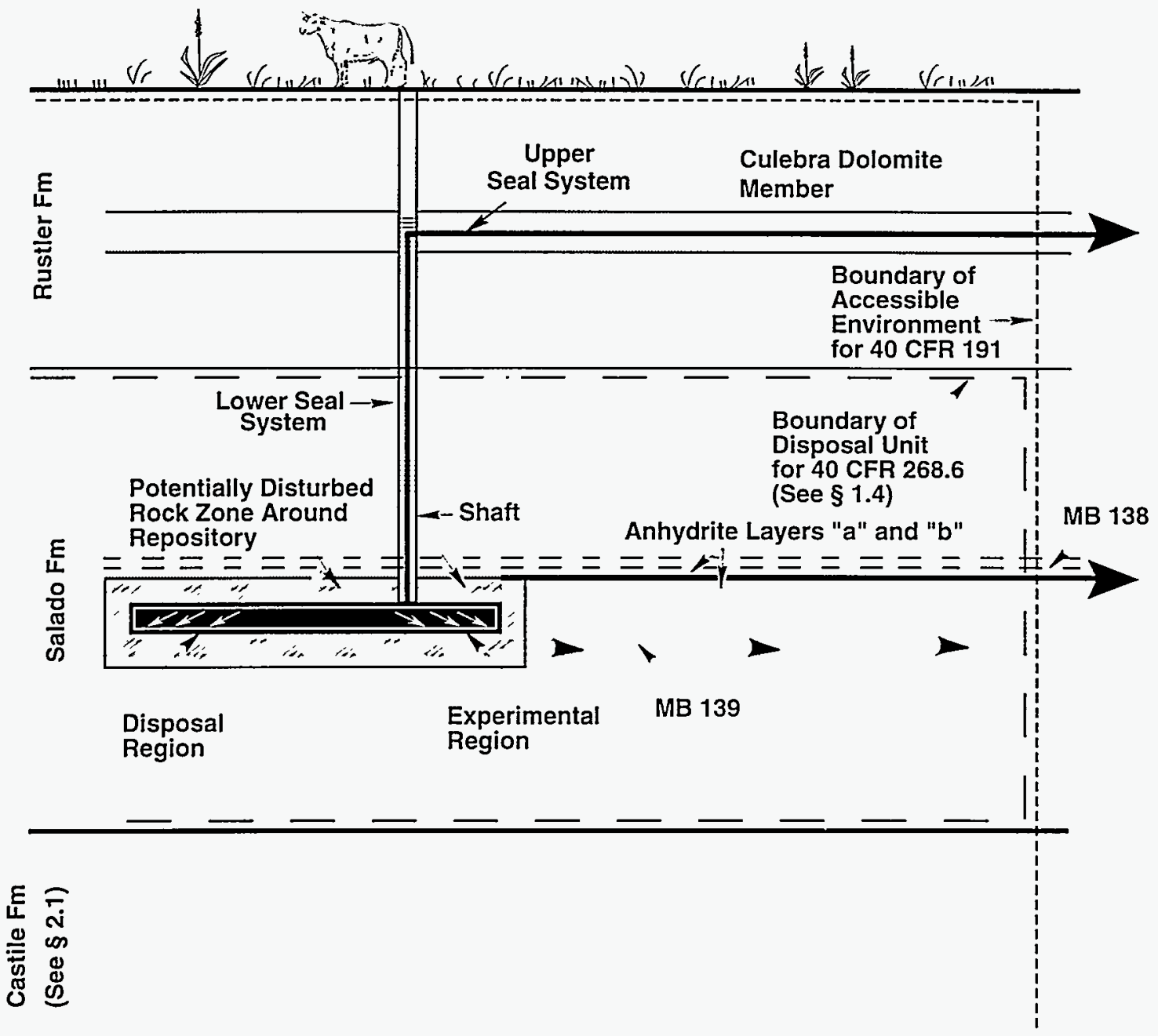

(Not to Scale)

TRI-6342-3485-0

Figure 3.2-3. Undisturbed summary scenario (base case scenario) used in the 1991 and 1992 performance assessment simulations for the Resource Conservation and Recovery Act of 1976 (sce Section 6.3). Heary arrows indicate two possible pathways to the accessible environment defined in 40 CFR 191. 


\subsubsection{Human Intrusion Summary Scenarios}

In the 1990. 1991. and 1992 performance asscssments (PAs). the only disruptive crent used for scenario construction (Sec Section 3.2.2. Applying the Groupıng Procedure to the WIPP) was inadvertent human intrusion. Appendix $\mathrm{C}$ of 40 CFR iglstates ... Inadiertent and intermittent intrusion by exploratory drilling for resources . . can be the most scicre intrusion sccnario assumed." Conscquently. the inadvertent human intrusion was assumed to be a result of cxploratory drilling for oil and gas deposits using technolog currently in use in the region around the WIPP. Furthermorc. when modeling the human intrusion summary scenarios. the 1990. 1991. and 1992 PAs assumed future inadicrtent drilling erents would occur as a random process in ume and space-cach drilling erent being independent of crery other drilling crent. the sulte thus being mathematically describable as an ideal Poisson process (sce Scction 4.3.1. Using Poisson Functions to Estımate the Probability of Human Intrusion). Finally: the brine was assumed be thoroughly mixed with the entire waste contents of one panel and thus mathematically described as a "mi.ing cell" (sec Section 5.1.8. Linkage of PANEL Code).

If the disposal arca of the repository is penctrated by an cxploratory borcholc. radionuclides may be releases in two different ways at two different tumes (sce also Section 5.1. Repository Modeling). First. an immediate relcase occurs durıng the drilling process. because it is assumed the drill bit directly bores vertically through a stack of contact-handled TRU waste contancrs (or through a single remotely handled waste container). Matcrial within the contanners is ground up by the drill bit (cuttings) and transported to the surface by the circulating drilling fluid. Additional matcrial may be croded from the walls of the borchole by the swirling action of the drilling fluid (cavings) or the spalling of solid material into the hole as the panel depressurizes. It is assumed the borcholes would be plugged according to current industry standards upon abandonment Selcctive degradation of these plugs leads to the possibility of much longer-term relcases bv the sccond method. that is. transport up the borcholes to the aquifer in the Culcbra and then tatcrally. toward the subsurface boundary withn the accessible cnironment.

Three representative intrusion scenarios were used in the 1990-1992 PAs (sce also Section 3.2.2. Applying the Grouping Procedure to the WIPP) In the El scenario. a borchole penetrates the repository and a hypothetical pressurised brine reservolr in the underlyng Castile Formation. In the E2 scenario. a borchole pencirates the repository and misses the hypothetical brine reservorr. In the EIE2 scenario two or more borcholes occur: onc borchole that penctrates the repository and the hypothetical brine reservoir (El-type borchole) and a second borchole that penetrates the repositor but misses the pressurizcd brine reserioir (E2-lype borchole). The borcholes are assumed to penctrate a waste-filled room within a single pancl ${ }^{1}$ (Figure 3.2-4). In all scenarios. the borchole plugs were assumed to degrade in such a way as to maximuse contact between the pressurı.cd Castilc brinc and pancl wastes. For cxample. for the E1E2 scenario. the borchole that penetrates the Castile brine rescrioir (El-type borchole) is assumed to remain plugged just above the level of the waste pancl. the other (E2-type borchole) is assumed to remain plugged just above the level of the Culcbra aquifer Thus. the pressure-driven brine flows through the pancl before flowing up the E2 borchole to the Culcbra aquifer. These plug configurations were chosen to facilitate exammation of the specific scenarios and do not reflect the most realistic conditions cxpected.

For improved computational resolution. the threc scenarios were divided further into computational scenarios (see Section 6.1.5) on the basis of time intrusion and radioaclivity of the intersected wastes Relcases of cuttings were calculated for s1. tume intervals. Five different levels of radioactivity in the intersected wastes were consıdered. In addition. El-lype intrusions were not analÿcd cxplicitly but rather assumed to have the same conscquences as E2-type intrusıons.

\section{Reference}

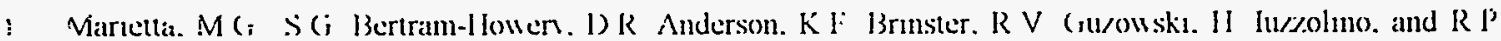

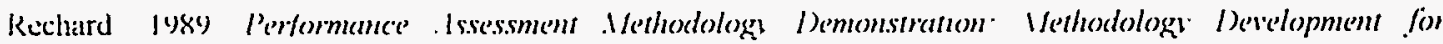

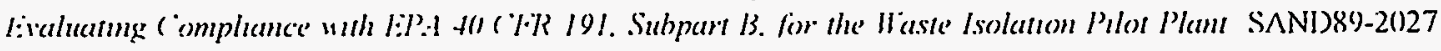
Albucuerque. NM Sanda National l.aboratories 


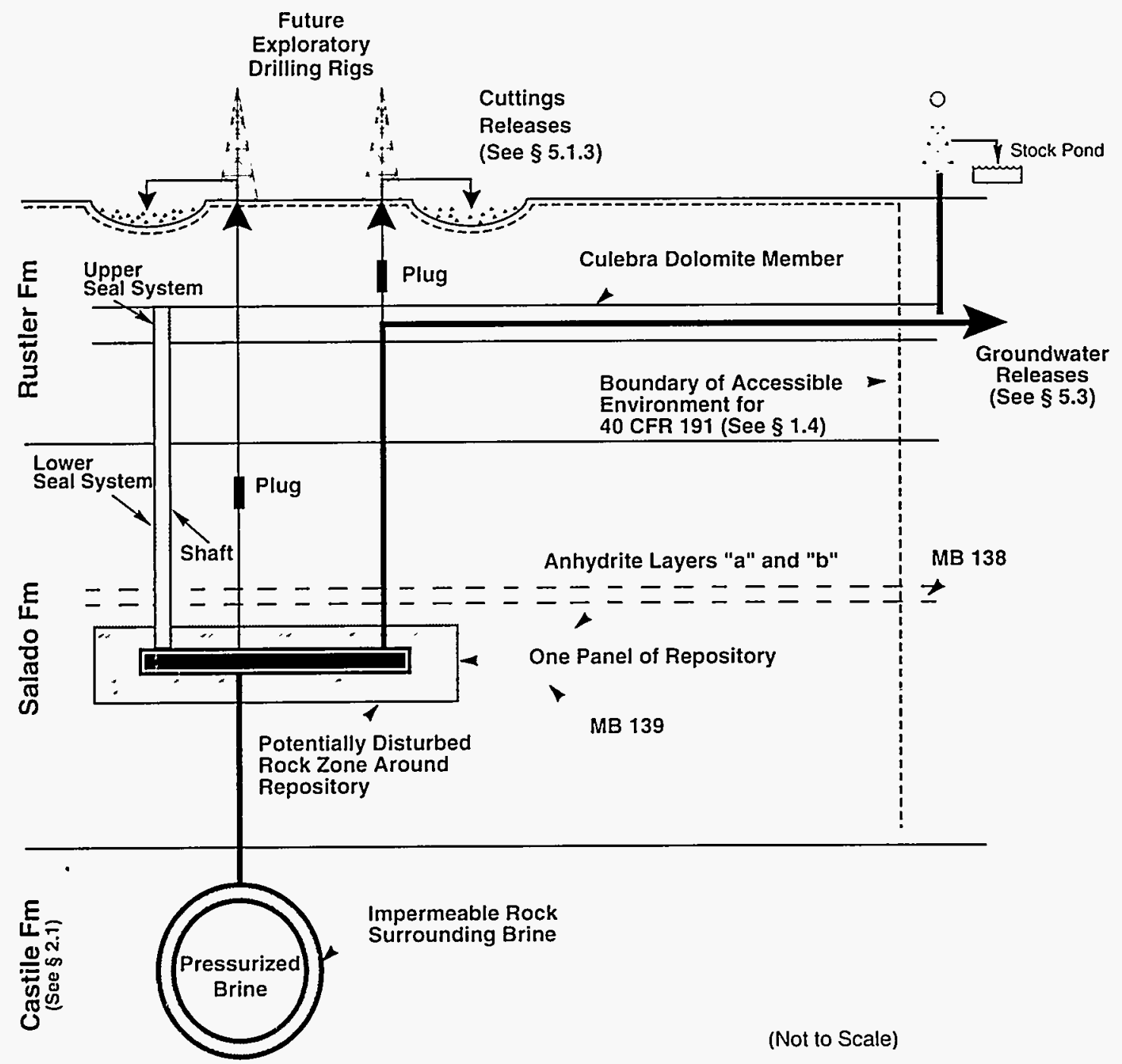

TRI-6342-3449.0

Figure 3.2-4. One human intrusion summary scenario (E1E2 scenario) considered in the 1990, 1991, and 1992 performance assessment simulations for Environmental Protection Agency standard, 40 CFR 191, and the National Environmental Policy Act of 1969 (sec Sections 6.1 and 6.2). Heary arrow indicates pathway of radionuclides to accessible environment or to food chain. 
3.0 Scenario Development 


\subsection{Modeling System Selection}

Once site charactcrization and the choice of features. erents. and processes has been completed. ${ }_{*}^{*}$ design of a performance assessment (PA) calculation can begin. In this section. we discuss the calculational design that was selected for the 1990. 1991. and 1992 simulations. Other design choices are discussed clscwherc. For cxample. simplifying assumptions made for some features. and simplifications of certain processes are discussed in Sections 3.2.3 and 3.2.4.

Consequence models may be catcgorized into groups that mirror the fundamental steps of a performance assessment: model design. consequence modeling. probability modeling. compliance assessment (complementary cumulative distribution function construction), and sensitivity analysis. For the Waste Isolation Pilot Plant PA. the consequence modeling category is divided into repository modeling. groundwater flow modeling. and transport modeling: scenario probability modeling and compliance assessment modeling are grouped together. Each of these catcgorics contains a few principal modeling codes and various utility codes that support them. The linkage of these software components into a well integrated modeling system is through CAMCON. 1

The subsections that follow describe the modeling scales used for consequence modeling (Section 3.3.1), introduce the main modeling codes (Section 3.3.2. these modeling codes being discussed further in Section 5.()), introduce several utility codes that support the main modeling codes (Section 3.3.3). and provide further detail of CAMCON (Sections 3.3.4 and 3.3.5).

\section{Reference}

1 Rechard, R.P. 1991a. "C $\triangle M C O N$ : Computer Sỵtem for Assessing Regulatory Complance of the Waste Isolation Pilot Plant," Proceedings of the Intenational ('onference on Probabilistic Safety Assessment and

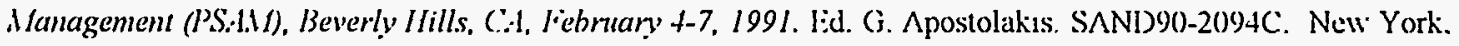
NY: J:lsevier Science Publishers. Vol. 2, 899-904.

\footnotetext{
- Remember, the PA process is iterative Thus. the site characteriation mav be preliminar and incomplete. and the ehoses of leatures, events, and processes mav accordingly be tentative Stall. the l'A can be run. although results will be prelumurs and the foundations incomplete

As noted in Section 3.(5. the incorporation of the results of features. cients. and processes adentulication and selection tnto conceptual models. and the subsequent design of the l'. I calculation. is considered as the later part of scenario development in this report
} 


\subsubsection{External Scales for Consequence Models}

As shown in Figure 3.3-1. there are three Iength scales imposed by the physical configuration of the Waste Isolation Pilot Plant disposal sỵstem:

1. The Repository Scalc. which is determined by the repository/shaft/borchole system and runs a few meters to a kilometer. This domain contains the repository itself. the shaft. the immediatcly surrounding gcology: and any intruding borcholcs. Within this domain. repository phenomena are modeled. including (a) gas generation from corrosion and microbiological degradation of the waste. (b) brine movement around the waste over time. as well as (c) the hypothesized saturation of the waste by the brine reservorr following intrusion and creep closure (sec Section 5.1).

2 and 3. The Local and Regional Scalcs include variabilitics from 1 to $10 \mathrm{~km}(.62106 .2 \mathrm{mt})$, and from 10 to $100 \mathrm{~km}(6.2$ to $62 \mathrm{mi})$. respectively. The groundwater flow is modeled separately on two different domain and resolution scalcs. local and regional. to provide increased resolution in the area of primañ interest immediatels around the borcholes. Depending upon geological and hydrological conditıons along regional boundarics. regional boundary conditions may be prescribed as values of (a) the dependent variable (Dirichlct conditions). (b) the gradient of the dependent variable (Ncuman conditions). or (3) a lincar combination of cases (a) and (b) (mixed conditions). Once the regional flow ficld is calculated. boundary conditions for the local grid. orer which radionuclide transport is modelcd. may be detcrmined. This is done by interpolating the solution of the calculated groundwater flow from the regional grid onto the nodal points or clements of the superimposed local grid. The local grid is then calculated over time in such a way that the two solutions always agree at their common boundarics.

The largest cxtcrnal tume scalcs are determined by the duration of the calculation itself $(10.000$ yr). the scales of climatic variability (a few thousand ycars). the five times of intrusion. the half-lives of the various radionuclides (decades to millions of ycars). and the various flow characteristıcs (for cxample. transmissivities) in combination with the three cxternal length scalcs noted above. The effects of climate change are simulated through the inclusion of a slowly varying time-dependent. regional Dirichlet boundary condition. Because there was. in the undisturbed case. no predicted liquid radionuclide transport beyond the top of the repository shaft. the regional- and local-model Culcbra calculations were used only for the disturbed performance (human intrusion) calculations (sce Sections 5.2 and 5.3).

\section{Reference}

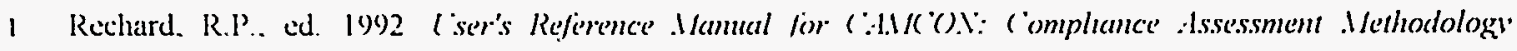

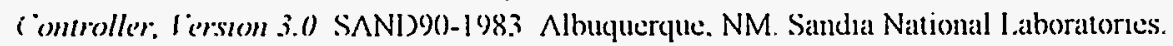




\section{REGIONAL SCALE}

Regional (Los Medaños) Model Domain

Boundaries Set by:

- Known Head or Flux Conditions

- Scenario Requirements (e.g., Climatic

Change with Increased Aquifer Recharge)

- Model Size Feasibility
2. LOCAL SCALE

Local Model Domain

Boundaries Usually Set by

Transport Considerations

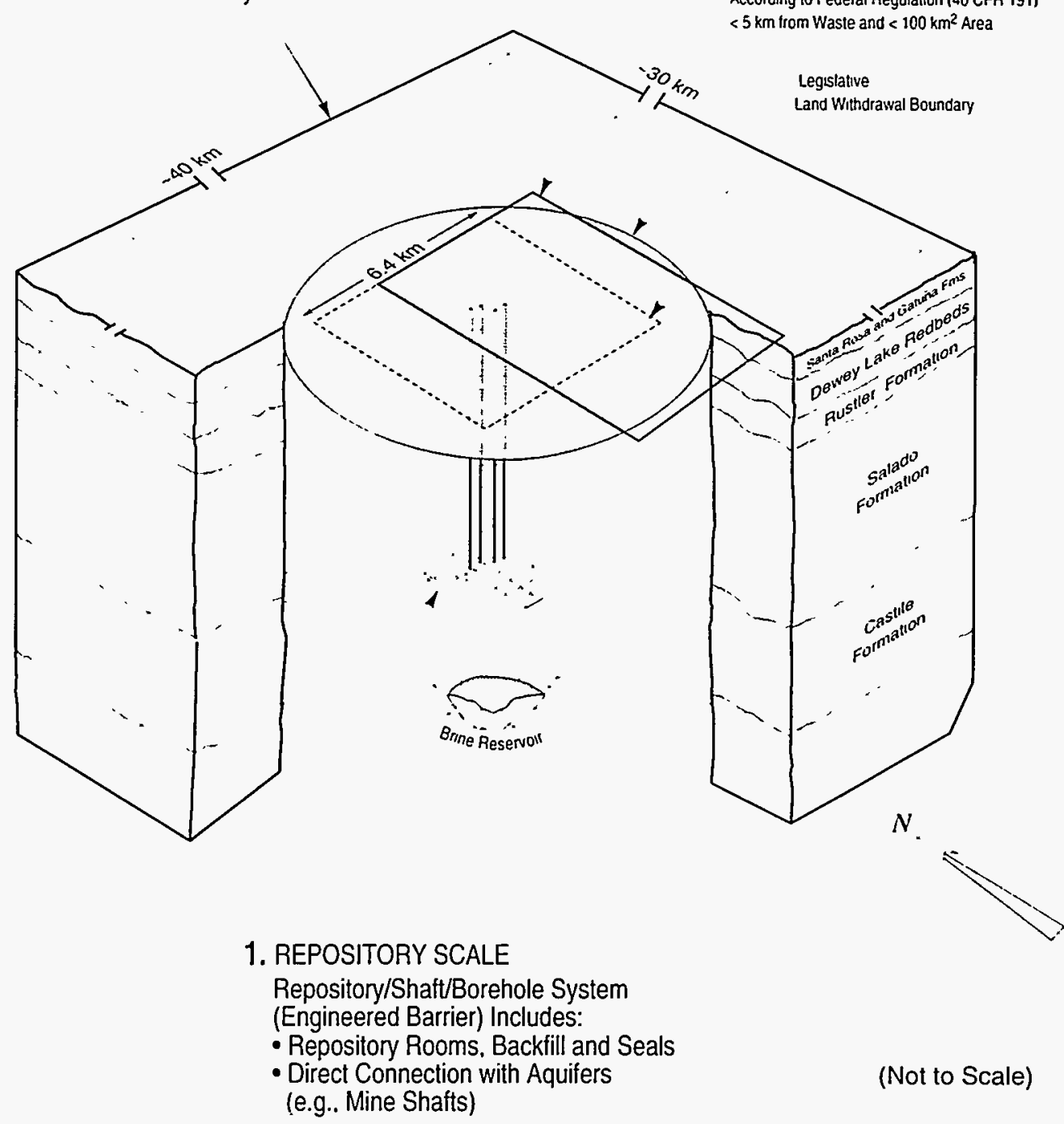

TRI.6342-3446.0

Figure 3.3-1. Three model scales used for consequence modeling for the Waste Isolation Pilot Plant. (Rechard, ed., 1992, Figure A-11). ${ }^{1}$ 


\subsubsection{The Component Computational Models}

A "complete" (or "total system") consequence model, $C$, for the Waste Isolation Pilot Plant (WIPP) disposal system predicts a consequence, $C\left[x, S_{j}(\mathrm{x})\right]$, for each value of the scenario, $S_{j}$, and each value of the model parameter vector $x$. The consequence model, $C$, is actually a sequential hierarchy comprised of many component, computational models, $M_{\ell}$, that transform variables produced by the $M_{\ell-1}$ model to variables used by the next model, $M_{\ell+1}$. The last model in the sequence illustrates potential releases. All models, $M_{\ell}$, are dependent on the scenario, $S_{j}$, and the complete suite of model parameters $\mathrm{x}=\left(x_{1}, x_{2}, \ldots, x_{n P}\right)$.

The individual computational models (or "codes," as they are also known) are the heart of the performance assessment (PA) analysis. They are selected and/or designed by PA analysts to simulate the major physical features of the WIPP disposal system such as the following: inadvertent drilling into the repository, two-phase ground-fluid flow, source-term concentrations, aquifer flow, and radionuclide transport in the groundwater.

In the 1991 performance assessment, ${ }^{1}$ the principal, component, computational models, $M_{\ell}$, were as shown in Figures 3.3-2a and 3.3-2b. A simple example of a partial sequence is sketched below in Figure 3.3-2a. For simplicity, a few of the major computational codes, such as CUTTINGS and GENII-S, are omitted from the cxample below, although they are also necessary to model various intrusion phenomena in the WIPP disposal system. CUTTINGS and GENII-S are shown in Figure 3.3-2b.

\section{Reference}

1 Rechard, R.P. 1991b. "Introduction," Prelininary Comparison with 40 CFR Part 191, Subpart B for the Waste Isolation Pilot Plant, Decentber 1991. Volume 2: Probability and Consequence Modeling. WIPP Performance Assessment Division. SAND91-0893/2. Albuquerque, NM: Sandia National Laboratories. 1-1 through 1-22.

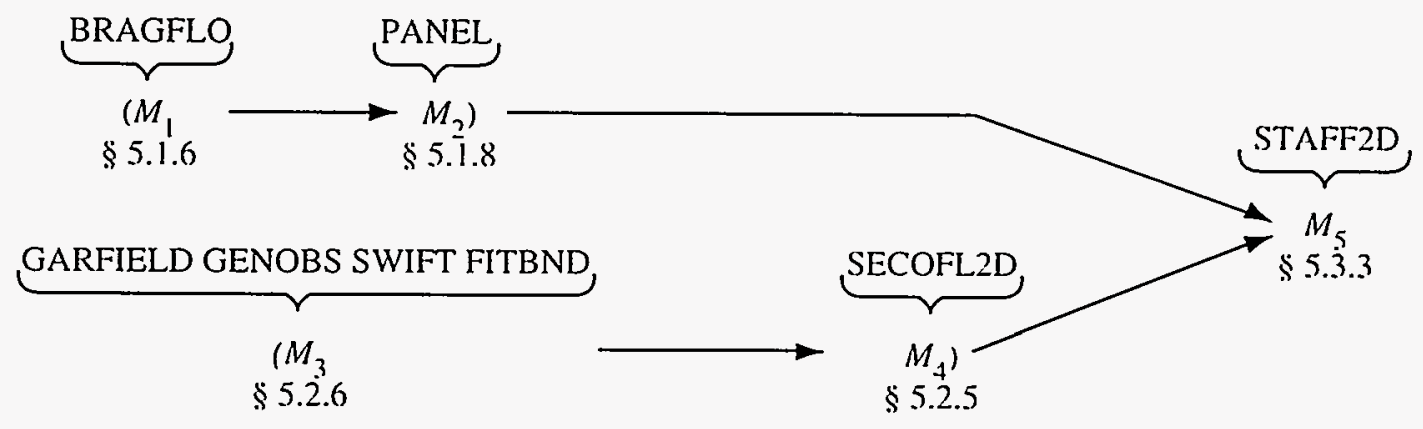

TRI.6342-4352.0

Figure 3.3-2a. Partial linked sequence of the component computational models of the WIPP consequence model. 


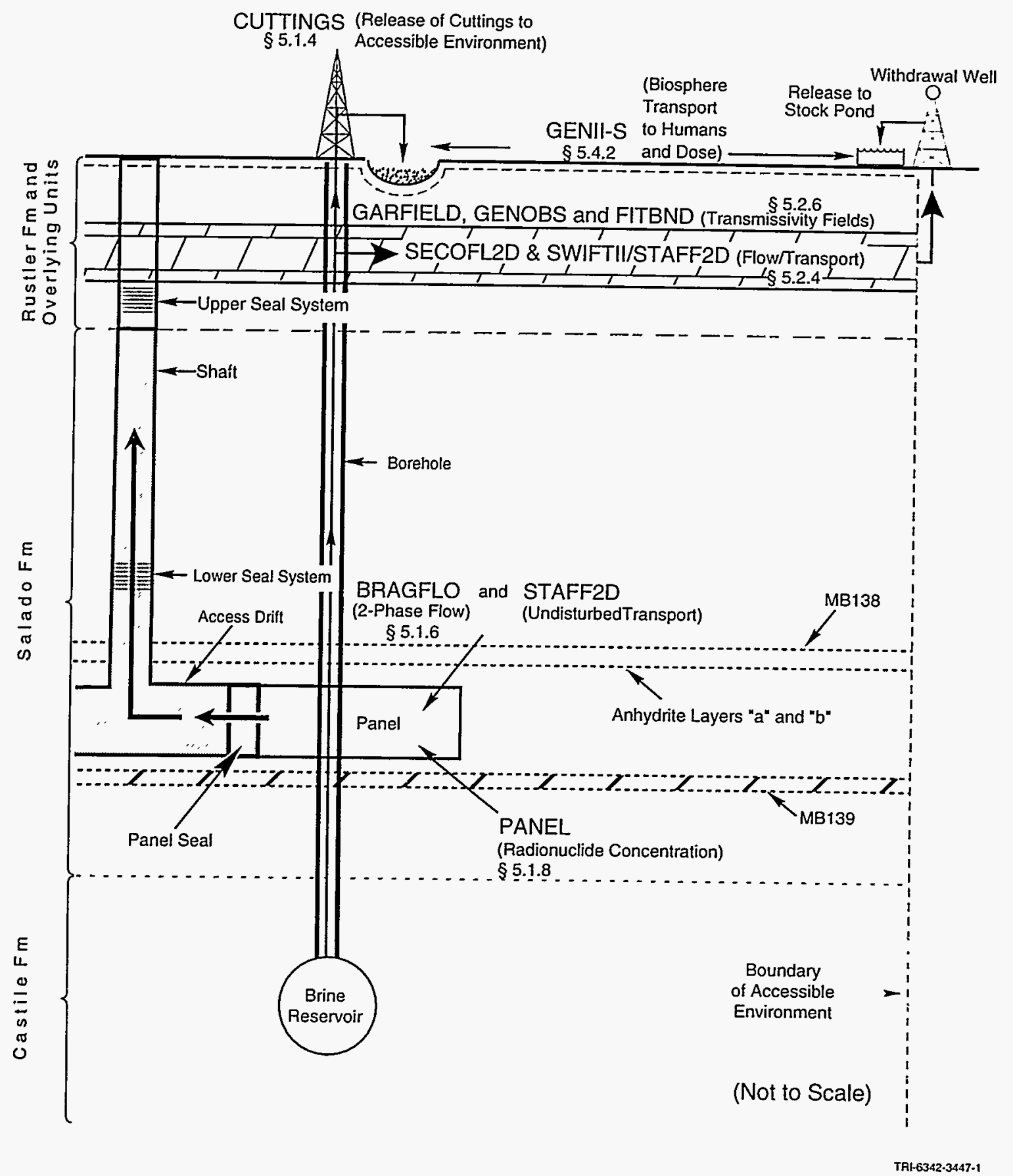

Figure 3.3-2b. Generic computational models selected for 1991 preliminary performance assessment. The use and linkage of these models to evaluate consequences (consequence model) is described in Chapter 5. 


\subsubsection{Support Codes Used in the Modeling System}

The codes available in the Waste Isolation Pilot Plant (WIPP) performance assessment (PA) modeling system may be catcgorized into various groupings according to their functions. For cxample, many of the specialized requirements for pre- and post-processing of input data and results, respectivcly, of a modeling system have been separated into individual codes that reside in the Compliance Assessment Methodology Controller (CAMCON) system. Several (but not all) of these codes, which include the mesh generation, property assignment, boundary and initial condition assignment, and visualization codes, are described here (see Figure 3.3-3) rather than in Chapters 4.5 . and 6. All the codes of the CAMCON modeling system (sec Section 3.3.4) used in the 1990-1992 PA calculations were documented via on-line help commands on WIPP PA computers and by Rechard. 1

\section{Mesh Generation Modules}

GENMESH is the principal mesh-generation code that produces a rectilinear, finite-element or finitcdifference mesh that is right-handed. Cartesian. rectangular, and onc-, two-, or threc-dimensional. User input files define the cxact geometry. In addition to setting the node coordinates and mesh connectivity. GENMESH sets material regions. identifies (flags) nodes or elements for boundary conditions. and sets clevations of elements. GENMESH outputs its computed results as a computational data base file (.CDB filc) in Compliance Asscssment Methodology Data Base (CAMDAT) (sec Section 3.3.4).

GENNET is also a mesh-generation code. It constructs simple one-, two-, and threc-dimensional networks from a geometry specification input file. GENNET's output is also stored in a computational data base filc.

\section{Property Assignment Modules}

MATSET scts matcrial names to specified regions (c.g., defined by GENMESH or GENNET), sets material property values. and sets attribute values into the performance-assessment computational database. CAMDAT. Both property and attribute values are obtained from either the property secondary databasc (usually median or mean values read from PROPERTY.SDB) (sec Section 4.2) or the uscrsupplicd MATSET input text filc. Later. the user normally overwrites a subset of these parameter values with sampled values provided by' running the Montc Carlo modulc. LHS (sce Scction 4.2).

BCSET assigns boundary valucs at nodal boundary flags and element boundary flags. The flags are defined cither by the mesh gencration module or by BCSET in a user input file.

ICSET sets initial conditions. Spccifically. ICSET scts CAMDAT analysis array variables: history. global, nodal, and/or clement variable values, at the first time step. It obtains the values from a user filc. In addition. any nodal or element variables (existing or new) can be lincarly interpolated by specifying interpolation tables in the ICSET input text filc.

\section{Algebraic Manipulation Module}

ALGEBRACDB is capable of performing most algebraic manipulations to preparc alrcady cxisting data for transfer between analytic codes. This normally entails changing units. decomposing vectors to appropriate components. integrating over-time results at specificd boundarics, and delcting redundant data. With ALGEBRACDB, an analyst can generate pertinent data external to a code by combining data already stored in CAMDAT rather than by modifying a code and thereby involving a ncw quality assessment.

\section{Visualization Modules}

CAMDAT data are stored and manipulated in binary format and are not. therefore, readily readable. BLOTCDB is the plottıng support modulc. It plots binary results from all main modules directly on screen by reading the CAMDAT files and plottıng them in scientific units. Threc plotting subroutincs are available: (1) the computational mesh with contourcd analysis results overlaid. (2) grid distance versus any variablc. and/or (3) any variable versus any other variablc. GROPE docs cssentially the same thing. but reports its results numerically in tabular format.

\section{Reference}

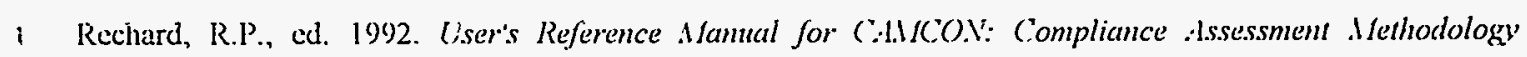
Controller: I'ersion 3.0. S^N1)90-1983. Albuquerque, NM: Sanda National Laboratories. 


\section{Consequence}

Data Preparation

- Mesh

Generation Module

GENMESH

GENNET

- Property

Assignment Module

BCSET

ICSET

MATSET

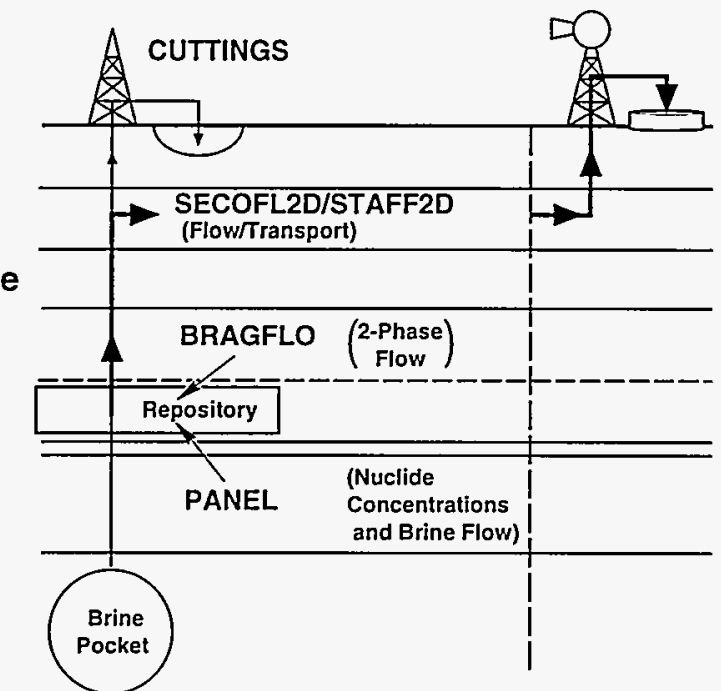

Analysis Results

- Support Module

ALGEBRACDB

BLOTCDB

GROPE

RELATE

SUMMARIZE

- Compliance Module

§ 6.1.6

Statistical Module

$\S 7.1 .2$

TR1-6342-93-12

Figure 3.3-3. Software used to model the WIPP shown according to function. The computational codes for cvaluating consequence under "Consequence Modeling" are discussed in Section 3.3.2 (The Component Computational Models). 


\subsubsection{The CAMCON Modeling System}

Assessing compliance of the Waste Isolation Pilot Plant (WIPP) with the Environmental Protection Agency's nuclear waste standard $40 \mathrm{CFR} 191$, Subparts B and C, is a multidisciplinary task requiring scores of codes and personnel to predict probabilistic releases into the accessible environment as a consequence of various hypothetical performance scenarios. The massiveness of the system and the scrutiny with which it will be examined leads to two general computational-system requirements, namely: flexibility and quality assurance. Because of the variety of release scenarios analyzed, the varying complexity of the models used, and the need to interchange codes readily, a flexible and versatile ovcrall computational tool is vital. Likewise, because of the large number of repetitive computer simulations, the need to identify simulation results properly, and the need to document steps and numbers that might influence the results, quality-assurance scheme is equally vital.

Although several software analysis systems have been built to perform the numerous computcr simulations necessary for a performance assessment (PA), the Sandia WIPP PA Department chose to build the (Compliance Assessment Methodology CONtroller) CAMCON system (see Figure 3.3-4), ${ }^{1}$ the analysis tool that helps coordinate the many diverse aspects of a performance assessment. ${ }^{2,3}$ The CAMCON approach (1) accepts the disciplinary expertise represented in pre-existing codes rather than endeavoring to incorporate all the individual concepts into one, interdisciplinary, comprehensive codc, and (2) allows the same managerial system to be used for individual components as well as the overall computational system as a whole (with the possible exception of substituting fast-running codes or modeling subdomains in the latter analysis when necessary). Both points are especially important for radioactive waste disposal where the calculations are under intense scrutiny and elaborate procedures are sometimes necessary to ensure that all steps taken in the analysis are documented and defensible. A PA system that is capable of handling both detailed and simplificd computational models is invaluable in this regard.

The CAMCON system consists of six components: (1) a directory structure that facilitates configuration control; (2) a serics of procedural files that allows an analyst to link the individual component codes and execute portions or all of a compliance assessment, CAMCONexec; (3) two data bases; (4) a set of libraries to interface with; (5) a series of help files containing instructions on use and history of updates and (6) code groupings, or modules. CAMDAT (Compliance Assessment Methodology DATabase) is a computational data base containing code outputs in ".CDB files." It is used as the link between the computer modules and the secondary data base, which contains all WIPP parameter distributions. The primary data base contains raw measured data.

\section{References}

1 Rechard, R.P. 1991a. "CAMCON: Computer System for Assessing Regulatory Complaance of the Waste Isolation Pilot Plant," Proceedings of the Intermational Conference on Probabilistic Safety Assessment and Management (PSAM), Beverly Hills, CA, Febriary 4-7, 1991. Ed. G. Apostolakis. SAND90-2094C. New York, NY: Elsevier Science Publishers. Vol. 2, 899-904.

2 Rechard, R.P., ed. 1992. User's Reference Manual for CAMCON: Compliance Assessment Methodology Controller, Version 3.0. SAND90-1983. Albuquerque, NM: Sandia National Laboratories.

3 Rechard, R.P., A.P. Gilkey, H.J. Iuzzolnno, D.K. Rudeen, and K.A. Bylc. 1993a. Programmer's Manual for CAMCON: Compliance Assessment Methodology Controller. SAND90-1984. Albuquerque, NM: Sandia National Laboratorics.

4 Rechard, R.P. 1989. Review and Discussion of Code Linkage and Data Flow in Nuclear Waste Compliance Assessments. SAND87-2833. Albuquerque, NM: Sandia National Laboratorics. 


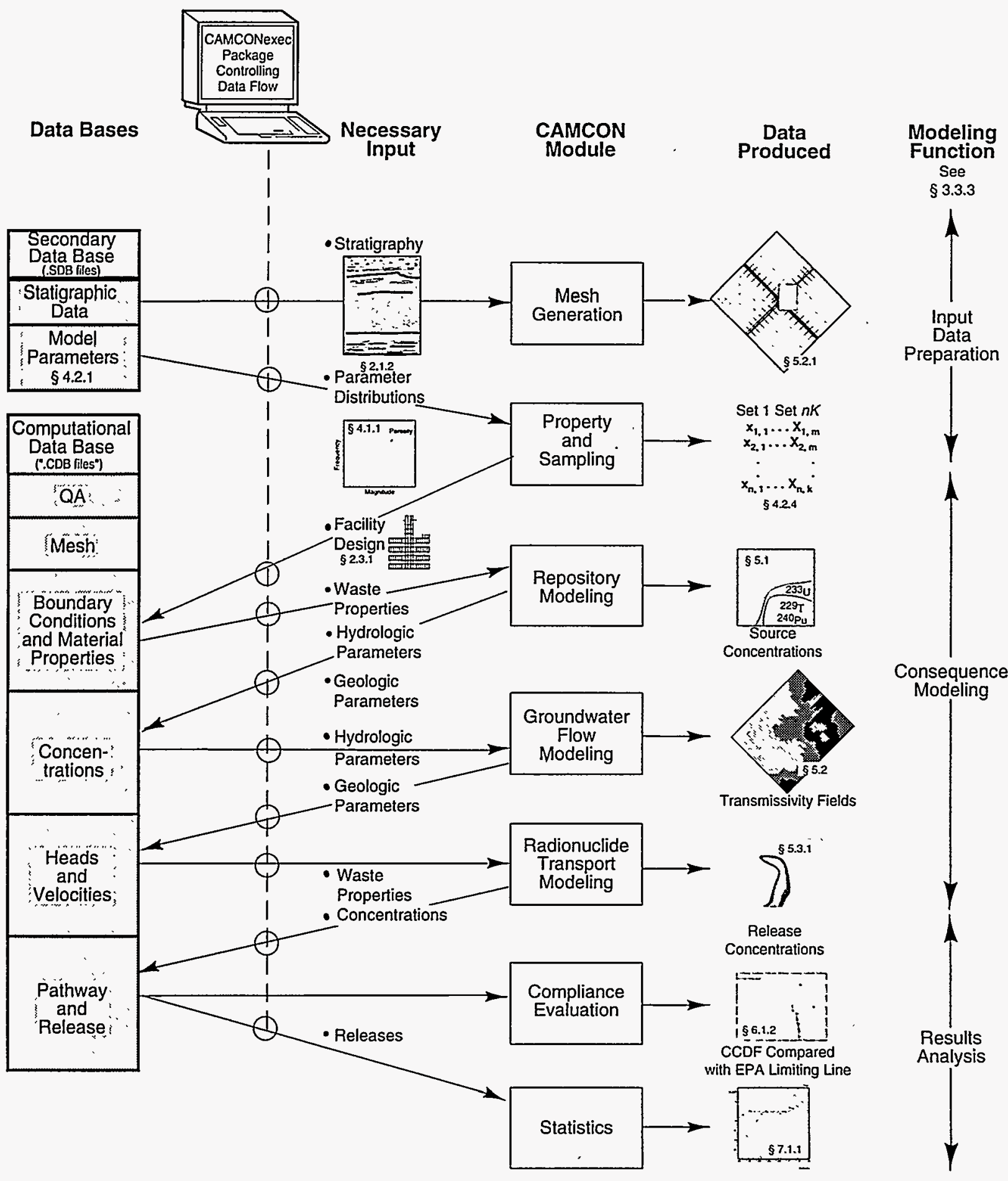

TRI-6342-0094-2

Figure 3.3-4. The modeling system CAMCON. The CAMCON system consists of (1) directory structures and protocols for storing software (not shown); (2) an executive package to access modules; (3) code modules consisting of seven computational modules, one support module, one utility module, and a data base module; (4) the computational data base (CAMDAT contains ".CDB" files) and secondary data base; (5) software libraries (not shown); and (6) help files for on-line documentation (not shown). (After Rechard, 1989, Figure 1.1). ${ }^{4}$ 


\subsubsection{CAMCON Support of Performance Assessment Calculations}

The components of the Compliance Assessment Methodology CONtroller (CAMCON) modeling system provide the structural framework that supports performance-assessment (PA) calculations. The simplified drawing of this framework shown in Fig 3.3-5 provides an overview of the flow of information within PA calculations and of the numerous computational data base files (".CDB" files) produced by each Monte Carlo sample set (see Section 4.2.3, Executing Latin Hypercube Sampling).

All ".CDB" files have the same format, and any number of codes can write to a ".CDB" file. A .CDB file is generated by the very first GENMESH run. The intermediate results of all computer codes thereafter must pass through the same evolving .CDB file for each Monte Carlo simulation. This concept of tracking a run through the complcx code systcm via its developing .CDB file is the single most important concept used by the CAMCON system to process the tasks of the compliance assessment. It controls the linking codes, the property-identifying Monte Carlo simulations, and the overall data flow. There are several advantages of linking codes by a "zig-zag" connection (see figure below) rather than by the more common serial connection. 1

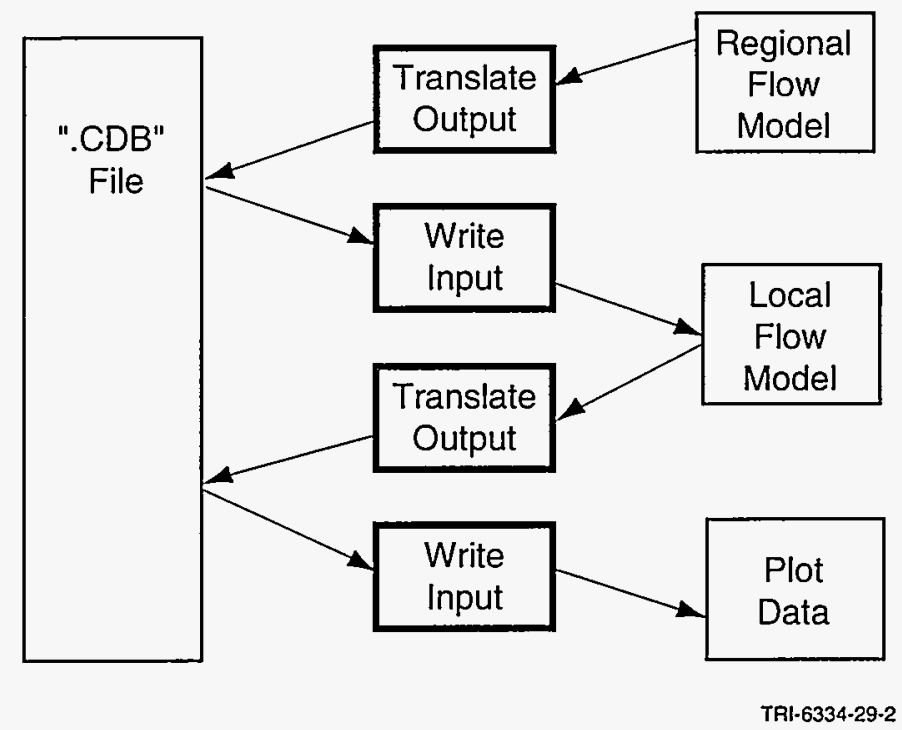

- Linking to a plotting code is more straightforward and though not limited to one plotting code, one general-purpose plotting code can be easily used at all plases of data analysis.

- Algebraic manipulation of the data can be easily accomplished by one standard code that can read a .CDB file and, for example, integrate stored fluxes crossing a boundary.

- Analysts can more easily change to different codes to obtain better precision, faster speed, etc.

- The code-application order is easily changed.

- Crude interactions at each time step between uncoupled codes can be attempted.

- Design of an executive package (CAMCONexec) to aid in running numerous simulations is facilitated.

- Quality assurance is straightforward because all input data, except code-control input parameters, reside within the .CDB file for each sample set.

\section{Reference}

1 Rechard, R.P., A.P. Gilkey, H.J. Iuzzolino, D.K. Rudeen, and K.A. Byle. 1993a. Progranmer's Manual for CAMCON: Conpliance Assessnent Mfethodology Controller. SAND90-1984. Albuquerque, NM: Sandia National Laboratories. 


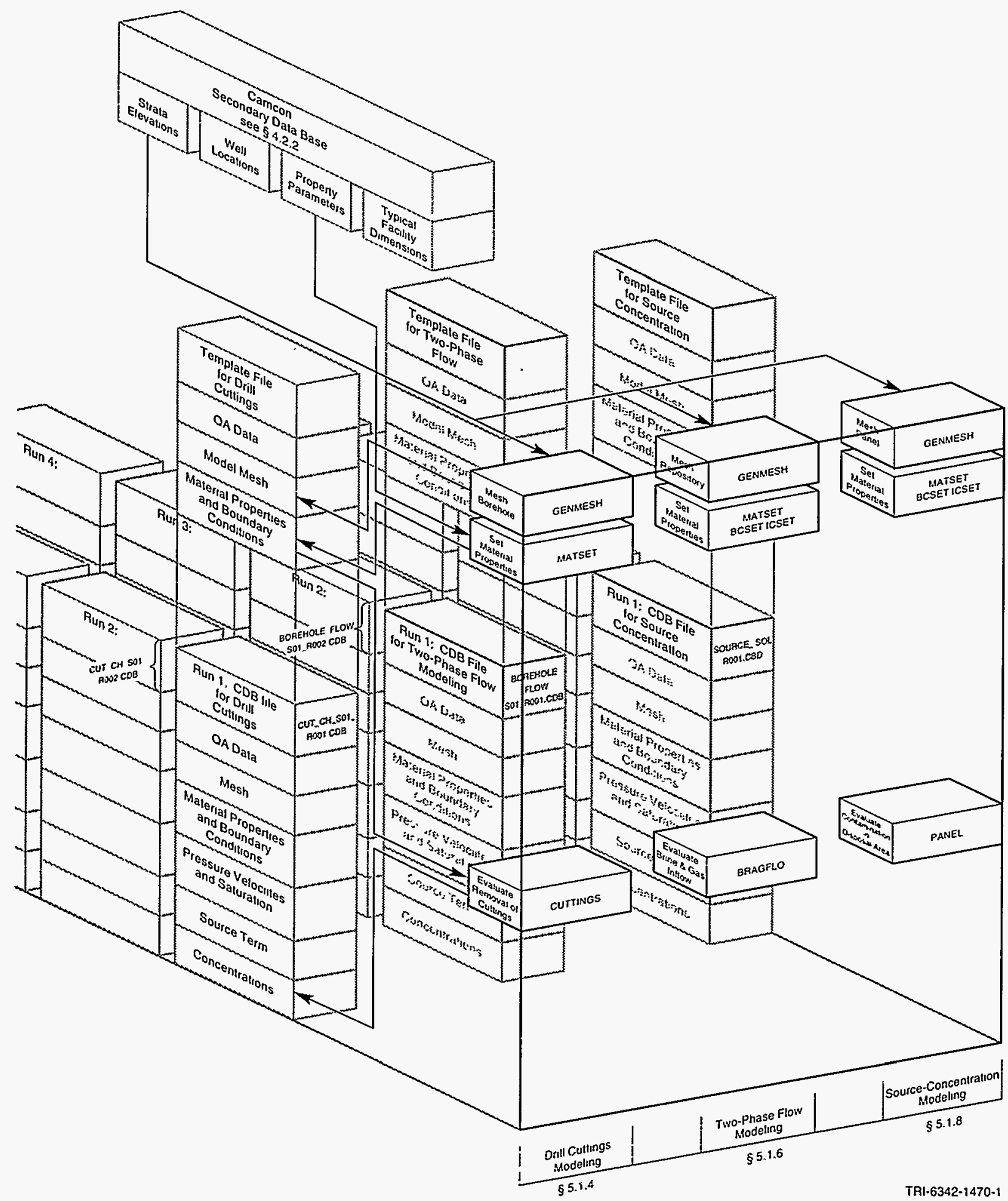

Figure 3.3-5. The computational data base files (".CDB files"), a primary component of the CAMCON system, are the behind-the-scenes structure that supports the performance assessment calculations. The calculations necessary for repository consequence modeling (Section 5.1) are shown as an example. The numerous ".CDB files" are not shown in subsequent figures of this report; rather, the repetitive simulations and numerous files are depicted as multiple sheets of a book (after Rechard et al., 1991, figure $A-5){ }^{1}$ 
3.0 Scenario Development 


\subsection{PROBABILITY ESTIMATION}

Answering the second question in the risk triplet-How likely are things to happen? (see Section 1.2.2)-requires probability estimates. Two types of probability models are used in a performance assessment (PA). The first estimates the likelihood of uncertain (imprecisely known) model parameters by constructing distributions of their values. The construction of a probability distribution is itself an exercise in mathematical modeling and is thus validly called a probability model. The second PA probability model estimates the likelihood of scenarios (see Chapter 3, Scenario Development.) These two types of uncertainty arc closely related and were introduced in Section 1.3, Types of Uncertainty in Performance Assessments.

Various degrees of formality can be used in developing probability models for both types of uncertainty. Probability models for estimating parameter uncertainty can be (1) fully objective, if sufficient high-quality data are available, or (2) more subjective, if only indirect data are available or if no data are available (e.g., the future states of society). In Waste Isolation Pilot Plant/(WIPP) modeling, variations in degree of formality are more common for the first type of probability modeling because there are many parameters to be treated and great differences in the quantity and quality of the data. Examples of two different degrees of formality for the first type of probability model are presented in Section 4.1, Assigning Parameter Uncertainties.

Compilation of the hundreds of parameters required for a WIPP PA calculation is an enormous task. In Section 4.2, Compiling Model Parameters, that process is described. Section 4.2 deals with model parameters themselves, as distinct from the numerical data that characterize them.

Section 4.3, Estimating Probability of Human Intrusion Scenario, describes a probability model of the second type, that is, probability models to estimate scenario probabilities. Preliminary assessments prior to 1990 had considered a fixed number of human intrusions with fixed probabilities estimated by one individual. ${ }^{1}$ In the 1990-1992 PAs, the Poisson analytical function was used to evaluate the probability of inadvertent intrusion into the repository by exploratory drillers. In addition, the 1992 PA used an external expert judgment panel to estimate time-varying rates of future intrusion, taking into consideration the fcatures of the WIPP site, repository design, and proposed institutional controls as suggested in Appendix $\mathrm{C}$ of $40 \mathrm{CFR}$ 191. Specifically, teams of experts from outside the WIPP Project looked at (1) the nature of future socicties and possible modes of intrusion and (2) the type of markers and their potential cffectiveness in deterring intrusion. ${ }^{2}$ The time-dependent procedure that included the deterrence effect of markers and the future states of society resulted in significantly fewer intrusions (a maximum of 3 by 1000 $\mathrm{yr}$, and 4 by $10,000 \mathrm{yr}$ ) compared to the time invariant rate of intrusion used in 1991 and 1992 (a maximum of 8 by $1000 \mathrm{yr}$ and 10 by $10,000 \mathrm{yr}$ ). ${ }^{3}$

\section{Reference}

I Marietta, M.G., S.G. Bertram-Howery, D.R. Anderson, K.F. Brinster, R.V. Guzowski, H. Iuzzolino, and R.P. Rechard. 1989. Performance Assessment Methodology Demonstration: Methodology Development for Evaluating Compliance with EPA 40 CFR 191, Subpart B, for the Waste Isolation Pilot Plant. SAND89-2027. Albuquerque, NM: Sandia National Laboratories

2 Hora, S.C. 1992. "Probabilitics of Human Intrusion into the WIPP, Methodology for the 1992 Preliminary Comparison," Prelimnary Performance Assessment for the Waste Isolation Pilot Plant, December 1992, Volume 3: Model Parameters. Sandia WIPP Project. SAND92-0700/3. Albuquerque, NM: Sandia National Laboratories. A-69 through A-99

3 WIPP PA (Performance Assessment) Department. 1992/1993. Preliminary Performance Assessment for the Waste Isolation Pilot Plant. December 1992. SAND92-0700/1,2,3,4,5. Albuquerque, NM: Sandia National Laboratories. Vols. 1-5. 
4.0 Probability Estimation 


\subsection{Assigning Parameter Uncertainties}

A model parameter is virtually any number required in a mathematical model. It may be a scalar, a vector, or a higher order quantity, and it may have a functional dependency on the dependent or independent variables of the problem. However, most Waste Isolation Pilot Plant (WIPP) performance assessment (PA) parameters are scalar quantities. An uncertain (or imprecisely known) parameter is one that cannot be assigned a single, universally accepted value. The manner in which parameter uncertainty is quantified and the magnitude of its influence on calculated results depend on the type of model parameter involved as described below.

In WIPP PAs, three types of model parameters ${ }^{1 *}$ are recognized. They are (1) fixed parameters consisting of (a) model constants, (b) model-domain and model-control parameters, (c) decision or value parameters, and (d) indices for alternative models; (2) probabilistic epistemic parameters; and (3) event and feature aleatoric parameters. ${ }^{*}$ Only in categories 2 and 3 is it common to express uncertainty as a probability distribution and thus to use the techniques of uncertainty propagation (see in Section 1.3.1.)

To elaborate, model constants (category 1a) are certain, by definition. For the WIPP disposal system, they include precisely known values (for the purposes of the analysis) such as radionuclide half-lives, acceleration of gravity, etc. Model-domain parameters (category lb) reflect the overall size and appropriate temporal and spatial mesh used in discretizing the calculation. Model-control parameters represent, for example, convergence criteria for solution algorithms. Both model-domain and model-control parameter types can be uncertain and, although it is necessary to examine how different values influence results, it is impractical to express the uncertainty as a probability distribution.

Decision and value parameters (category 1c) represent the various alternatives that are of high interest to decision makers. Index parameters (category ld) represent model-form choices. Sometimes, different weights can be assigned to alternative models explicitly identified, and the alternatives combined to form a single "megamodel." In both cases, this type of parameter uncertainty may be described by a distribution. However, that is uncommon when strong disagreements exist about the decisions and/or altemative model forms. The impact of decision and index parameters with strong disagreements (categories $1 \mathrm{c}$ and $1 \mathrm{ld}$ ) is usually evaluated with all other parameters being held constant, ceteris paribus, and results are presented individually. Decisions and model form alternatives not explicitly identified are treated in the analysis along with epistemic parameters described below or not at all.

Some degree of uncertainty always exists for probabilistic epistemic parameters (category 2 ). These include properties such as transmissivity fields whose values are uncertain because geological formations are inhomogeneous and mostly inaccessible, and therefore impossible to characterize precisely without destroying the formation. The same is true for the aleatoric parameters in category 3, which represent, for example, the times of occurrence of exploratory drilling events. The probability of occurrence of the various scenarios must be evaluated with a probability model that, in turn, has uncertain model parameters (of category 2). Apart from placing known, commonsense bounds on their ranges, these parameters are not amenable to estimation by classical techniques. This situation is true whether or not event and feature parameters are used to define scenarios. ${ }^{* *}$

The remainder of this section discusses category 2 and 3 parameters that are characterized by probability distributions. Section 4.1.1 provides examples of various types of probabilistic distributions used to characterize uncertain parameters. Section 4.1.2, describes different degrees of formalism in assigning parameter distributions. Sections 4.1.3 and 4.1.4, give examples of assigning parameter distributions (a) in a classical statistical sense and (b) with a formalized subjective interpretation.

\section{Reference}

1 Morgan, M.G., M. Henrion, and M. Small. 1990. Uncertainty: A Guide to Dealing with Uncertainty in Quantitative Risk and Policy Analysis. New York, NY: Cambridge University Press.

* Morgan et al. ${ }^{1}$ provide a different taxonomy, but the purpose is the same: to demonstrate that not all parameter uncertainty should be expressed and evaluated in the same way.

* * Use of process parameters to describe scenarios is possible in theory, but difficult in practice. They act continuously in time rather than at discrete times, like events.

*** As discussed in Chapter 3, Scenario Development, event and feature aleatoric parameters may be used to define scenarios. The influence of their uncertainty on results is described in Section 1.3.2, Propagating Aleatoric Uncertainty through Performance Assessment. 


\subsubsection{Characterizing Parameter Uncertainty}

Characterizing the uncertainty of any parameters $\mathrm{x}=x_{1}, x_{2}, \ldots, x_{n V}$ of the performance assessment (PA) consequence and/or probability models requires developing a joint cumulative distribution function $(\mathrm{CDF}), F(\mathrm{x})$. ' Usually, the joint distribution is approximated by the product of the distributions of the individual parameters, $F\left(x_{1}\right) \cdot F\left(x_{2}\right) \cdot \ldots F\left(x_{n}\right) \ldots \cdot F\left(x_{n} V\right)$. This substitution is exact if the parameters vary independently, which is usually assumed. (However, in contradiction to this assumption, rank correlations are sometimes specified among a few of the $x_{n}$ during sampling.) Individual distribution functions, $F\left(x_{n}\right)$, are defined by individual CDFs. ${ }^{1-3}$ The CDF of a parameter, $x_{n}$. ideally represents what is known and what is not known about that parameter, and should reflect current knowledge of the range and likelihood of the parameter values most appropriate for consequence and/or probability modeling. ${ }^{1-3}$ It is especially true for nonlinear computational models because it is often impossible to know a priorl how a bias in a parameter distribution will affect results. In other words, preselecting a bias to ensure "conservative" results is sometimes impossible with nonlinear models, especially when several linear models are linked together as in a PA.

To appropriately assign a distribution, $F\left(x_{n}\right)$, that reflects both the numerical discretization of the model domain and the small-scale spatial variability that may appear in measurements, both experimentalists and PA analysts (modelers) are involved. Parameter distribution characterization is not guided by a rigid series of steps because distributions must be tailored to the type of data available and to the parameter's role in PA computational models. It is possible that the $F\left(x_{n}\right)$ may be obtained by classical statistical techniques for some parameters (i.e., objective techniques that are easily reproduced by others. See, for example Figure 4.1-1). However, in most cases, each $F\left(x_{n}\right)$ will include subjective factors representing the "degree of belief" of program investigators. Subjective opinions are developed using available scientific information that a consensus developed through a suitable review process. Results of these techniques are not easily reproduced unless the methods are well documented. Examples of both methods are presented in Sections 4.1.3 and 4.1.4.

In general, a maximum entropy formalism was used to minimize the amount of spurious information and to provide a consistent procedure for constructing the CDFs. ${ }^{1}$ In practice, the maximum entropy formalism involves connecting data points or subjectively estimated points with straight lines.

\section{References}

1 Tierney, M.S. 1994a. "Using Data and Information to Form Distributions of Model Parameters in Stochastic Simulations of Performance of the Waste Isolation Pilot Plant (WIPP)," Proceedings of PSAM - II, An International Conference Devoted to the Advancement of System-based Methods for the Design and Operation of Technological Systems and Processes, San Francisco, CA, March 20-25, 1994. Eds. G.E. Apostolakis and J.S. Wu. SAND93-1302A. 051-9 through 051-16.

2 Feller, W. 1966. An Introduction to Probability Theory and Its Applications. New York, NY: John Wiley and Sons, Inc. Vol. 1.

3 WIPP PA (Performance Assessment) Division. 1991. Preliminary Comparison with 40 CFR Part 191, Subpart B for the Waste Isolation Pilot Plant, December 1991. Volume 3: Reference Data. Eds. R.P. Rechard, A.C. Peterson, J.D. Schreiber, H.J. Iuzzolino, M.S. Tierney, and J.S. Sandha. SAND91-0893/3. Albuquerque, NM: Sandia National Laboratories.

- A cumulative distribution function (CDF), $F(x)$, is the integral of the probability distribution function (PDF) $f(t)$ from $t=0$ to $x$. 


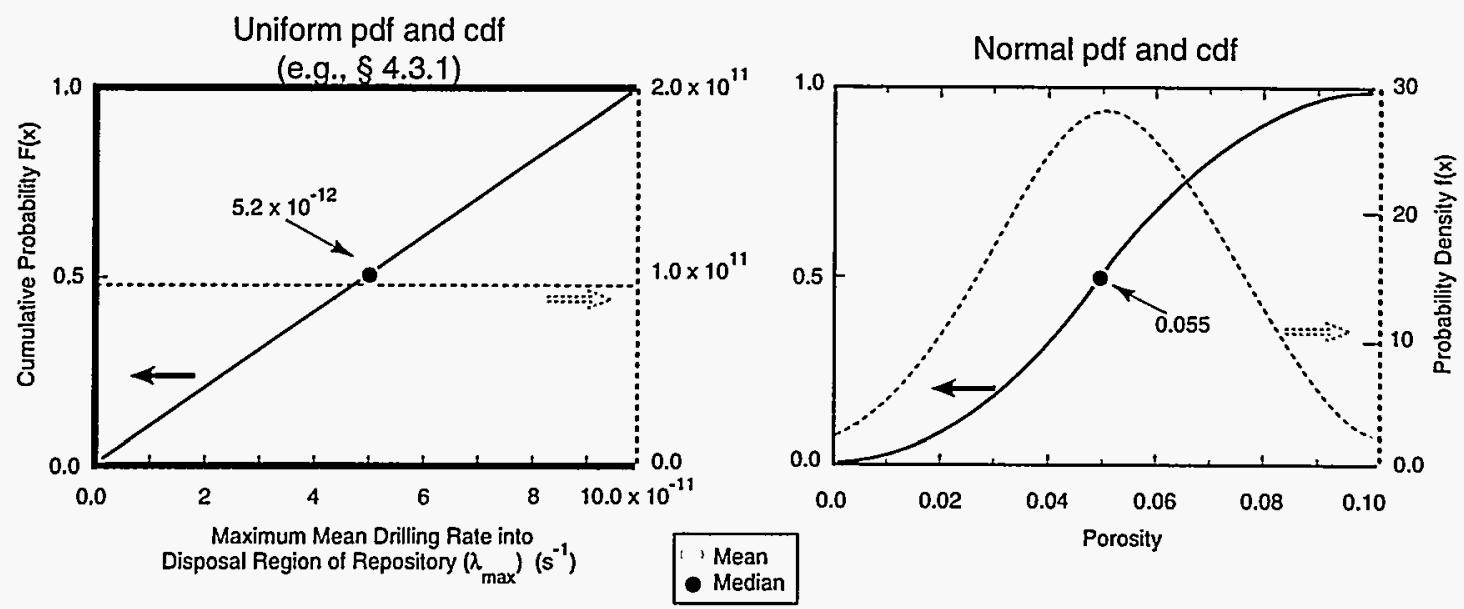

(a) Continuous Distribution Plots
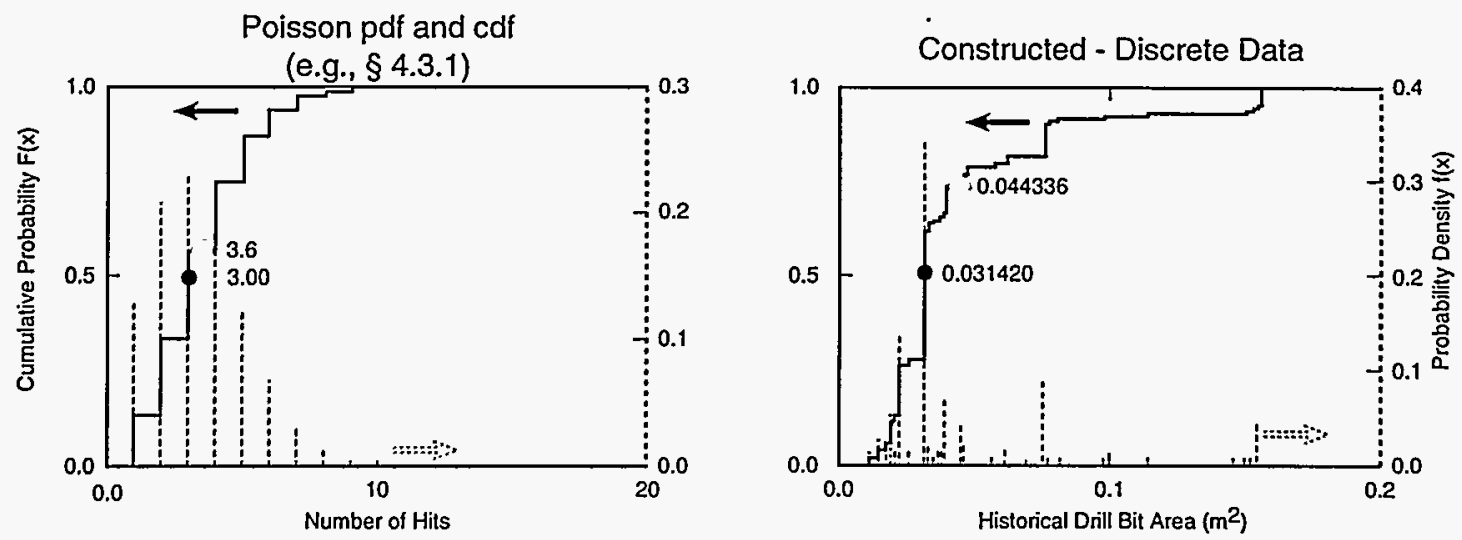

Constructed - Continuous Data (e.g., § 4.1.3)
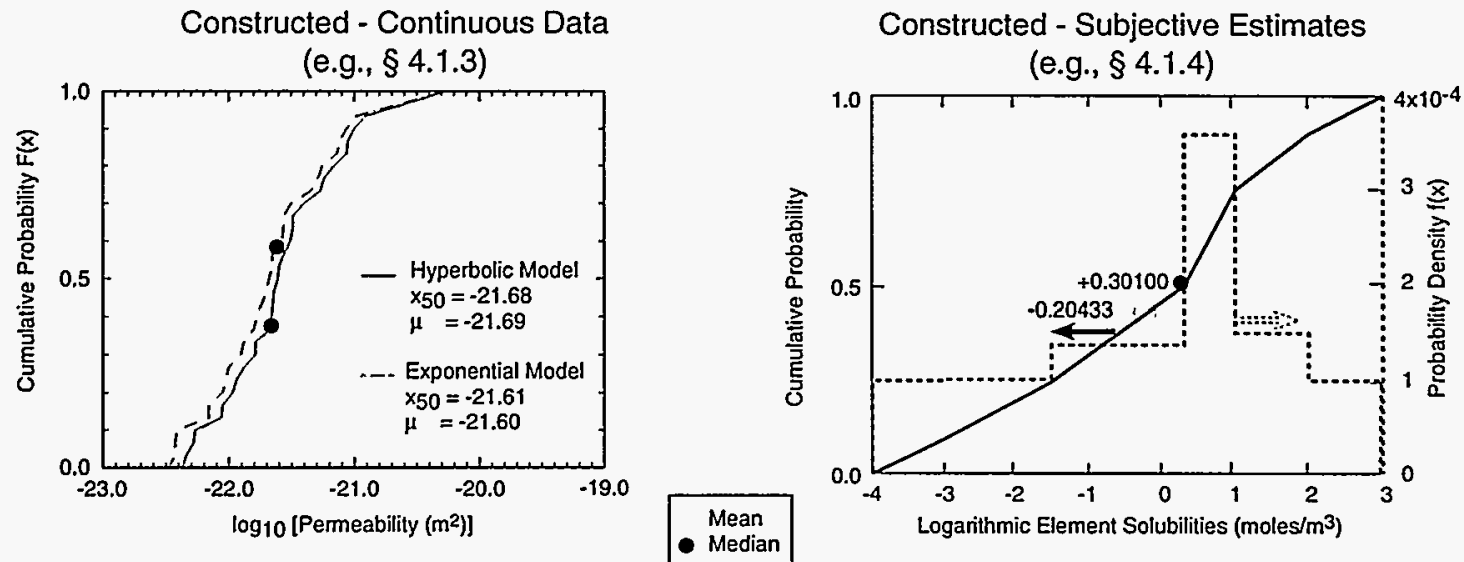

(b) Discrete and Constructed Distribution Plots

TRI-6342-3450-0

Figure 4.1-1. Examples of various probability distribution functions (dotted) and their corresponding cumulative distribution functions (solid) characterizing different kinds of parameter uncertainties (WIPP PA Division, 1991, Vol. 3, Figure 1.2-1). ${ }^{3}$ 


\subsubsection{Degree of Formalism}

The degree of formalism used for the interpretation of primary (raw) data and subsequent . determination of model parameters and uncertainties can vary over a wide spectrum. It ranges from (1) interpretation by an individual with general knowledge of a given subject area, to (2) interpretation and publication by a recognized expert, to (3) general interpretation by a group of consultants, to (4) formal selection of a panel of experts and formal elicitation of interpretations from the panel (sce Figure 4.1-2). At one end of the spectrum, an investigator with general knowledge in a given subject area applies personal professional judgment to interpret observational data, either from personal experiments or experiments of others, and within the context of performance-assessment analysis assumptions and requirements. At the other end of the spectrum, the process of interpreting data and information can involve a group of recognized experts-called an expert judgment panel-who are formally selected from representative disciplines, nominated by various stakeholders and from whom judgments are formally elicited. The reasoning behind panel judgmental interpretations is more likely to be formally documented and thus plainly acknowledge the importance of subjective judgments in the performance assessment. Like individual professional judgments, expert-panel judgments do not create data. Rather, they combine separate pieces of existing data and related information to determine appropriate model parameters, parameter ranges, and uncertainties. ${ }^{1}$

Performance assessments have used varying degrees of formality in the acceptance of professional judgments regarding data. The advantages of formalizing how judgments are elicited are that (1) it promotes clear and thorough documentation of how an interpretation was achieved, for example, characterizing parameter uncertainty through a cumulative probability distribution function, (2) it offers a structured procedure for gathering opinions, (3) it encourages diversity of opinion and thus guards against understating or overstating uncertainties, and (4) it brings together representatives of diverse disciplincs to address interdisciplinary issues, which, in turn, (5) initiates exchanges of ideas that would take many years to occur through the open literature. ${ }^{1}$

\section{Reference}

1 Rechard, R.P., K.M. Trauth, J.S. Rath, R.V. Guzowski, S.C. Hora, and M.S. Tierney. 1993b. "The Usc of Formal and Informal Expert Judgments When Interpreting Data for Performance Assessments," Scientific Basis for Nuclear Waste Management XVI, Materials Research Society Symposium Proceedings, Boston. MA, November 30-December 4, 1992. Eds. C.G. Interrante and R.T. Pabalan. SAND92-1148C. Pittsburgh, PA: Materials Research Society. Vol. 294, 943-950. 


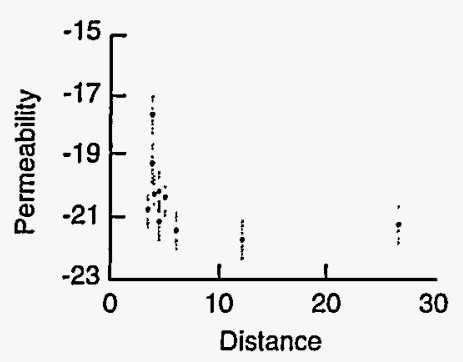

Raw data from the WIPP site and data from analogous work is provided from many investigators and entered into the Primary Data Base

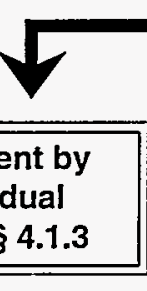

\section{Advantages:}

- More rapid and much less expensive

- Deep understanding of one subject possible

- Personal ownership

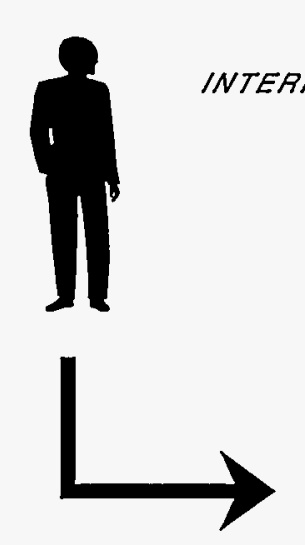

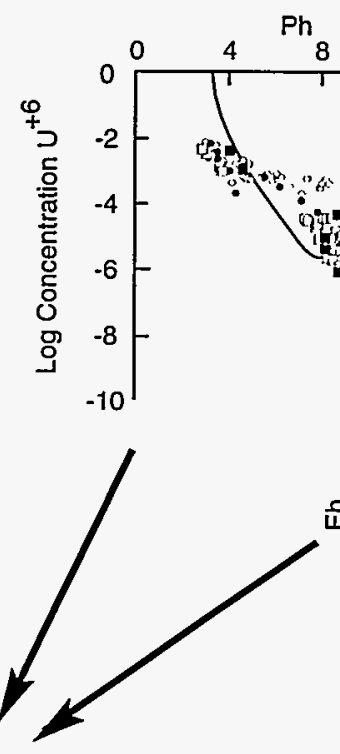

\section{Primary Data Base}

Available data are

interpreted by one or more individuals to develop appropriate parameter distribution for consequence model
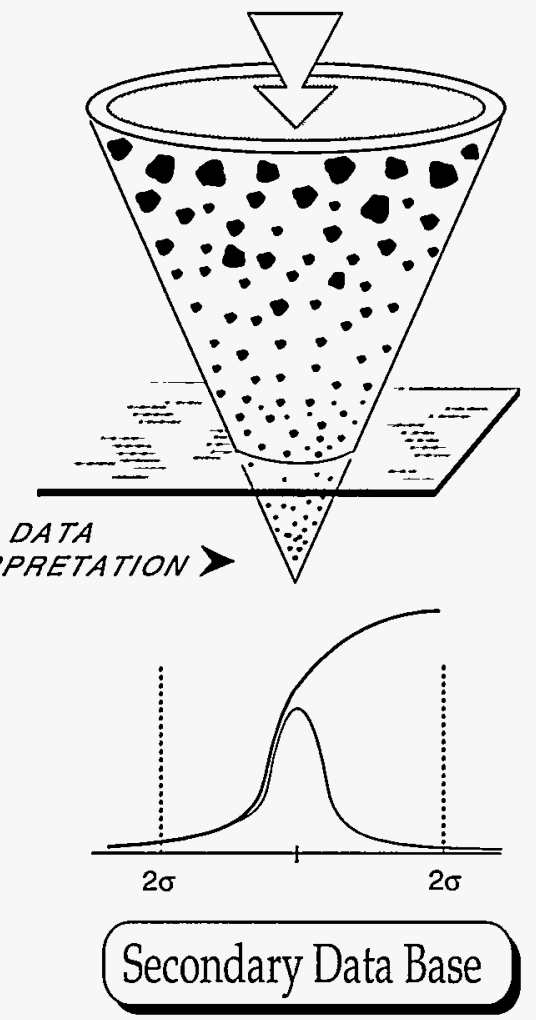
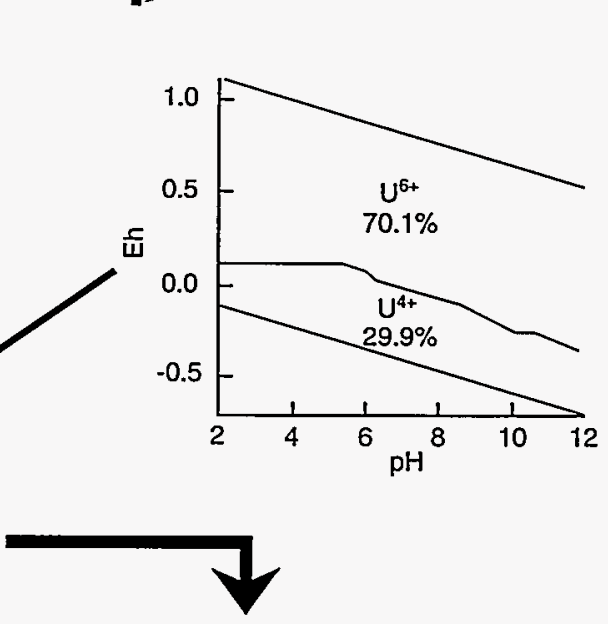
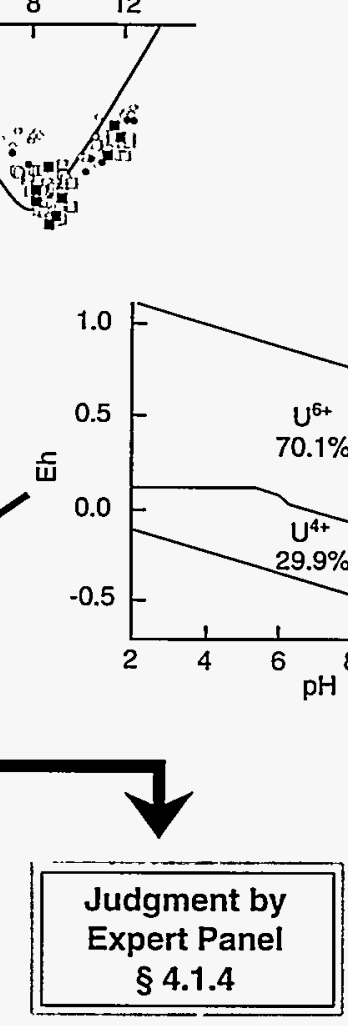

Advantages:

- Thorough documentation of process of developing interpretation produced (not just the judgment and its basis)

- Structural procedure for gathering opinions

- Encouragement of breadth of opinions, which guards against understating the uncertainty

- Motivation to exchange ideas between disciplines

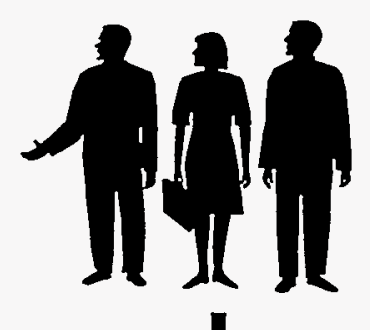

A final parameter range is decided upon and entered into the Secondary Data Base for input to WIPP modeling codes. § 4.2.1

Figure 4.1-2. Various degrees of formalism are possible in interpreting observational data to develop model parameters appropriate for individual computational models of the WIPP consequence model. 


\subsubsection{Example of Data Interpretation to Evaluate Model Parameters}

Excavations at the Waste Isolation Pilot Plant (WIPP) are very dry, which affects the modeling of radionuclide mobility because mobility depends critically on the presence of fluids. One hypothesized sequence of events envisions brine inflows from the surrounding bedded halite and anhydrites that will, over time, supply sufficient fluids to the repository to saturate the waste and backfill, at least partially, thus allowing for radionuclide movement ${ }^{1}$ (see Section 5.1, Repository Modeling). A critical parameter that affects the movement of brine into the repository is the intrinsic permeability of the halite and anhydrite beds.

Measuring intrinsic permeability of rock salt has been a demanding exercise at the WIPP, and several specialized measurement techniques have been developed. 2,3 Plots of the interpreted permeability versus distance from the excavation (see Figure 4.1-3, inset) show a clear correlation between distance from the excavation, $x$, and a decreasing trend in permeability to an asymptotic far-field value denoted as $a$. To represent this variability, an exponential curve with undetermined asymptote (three unspecified coefficients) was used to approximate the data: $y=a+b e^{-c x}$.

For WIPP performance assessment purposes, the distribution of the far-field undisturbed permeability (the unspecified coefficient $a$ ), not the near-field, short-term disturbed permeability, is of primary interest. The distribution of $a$ was simulated by sampling values at each of the normally distributed measurement points and repeatedly fitting the nonlinear curve to the sampled values. ${ }^{4}$ Because the functional form used in the non-linear regression is not unique, a hyperbolic functional form with four rather than three adjustable coefficients was also applied. The distribution of the far-field permeability was similar to that developed with an exponential approximation and, thus, apparently not unduly sensitive to the chosen functional form of the model.

\section{References}

1 Rechard, R.P., W. Beyeler, R.D. McCurley, D.K. Rudeen, J.E. Bean, and J.D. Schreiber. 1990b. Parameter Sensitivity Studies of Selected Components of the Waste Isolation Pilot Plant Repository/Shaft System. SAND892030. Albuquerque, NM: Sandia National Laboratories.

2 Beauheim, R.L., G.J. Saulnier, Jr., and J.D. Avis. 1991. Interpretation of Brine-Permeability Tests of the Salado Formation at the Waste Isolation Pilot Plant Site: First Interim Report. SAND90-0083. Albuquerque, NM: Sandia National Laboratories.

3 Howarth, S.M., E.W. Peterson, P.L. Lagus, K-H. Lie, S.J. Finley, and E.J. Nowak. 1991. "Interpretation of InSitu Pressure and Flow Measurements of the Salado Formation at the Waste Isolation Pilot Plant," Rocky Mountain Regional Meeting and Low-Permeability Reservoirs Symposium, Denver, CO, April 15-17, 1991. SAND90-2334C, SPE 21840. Richardson, TX: Society of Petroleum Engineers. 355-369.

4 Press, W.H., B.P. Flannery, S.A. Teukolsky, and W.T. Vetterling. 1986. Numerical Recipes, The Art of Scientific Computing. New York, NY: Cambridge University Press. p. 529.

5 Rechard, R.P., K.M. Trauth, J.S. Rath, R.V. Guzowski, S.C. Hora, and M.S. Tierney. 1993b. "The Use of Formal and Informal Expert Judgments When Interpreting Data for Performance Assessment," Scientific Basis for Nuclear Waste Management XVI, Materials Research Society Symposium Proceedings, Boston, MA, November 30-December 4, 1992. Eds. C.G. Interrante and R.T. Pabalan. SAND92-1148C. Pittsburgh, PA: Materials Research Society. Vol. 294, 943-950. 


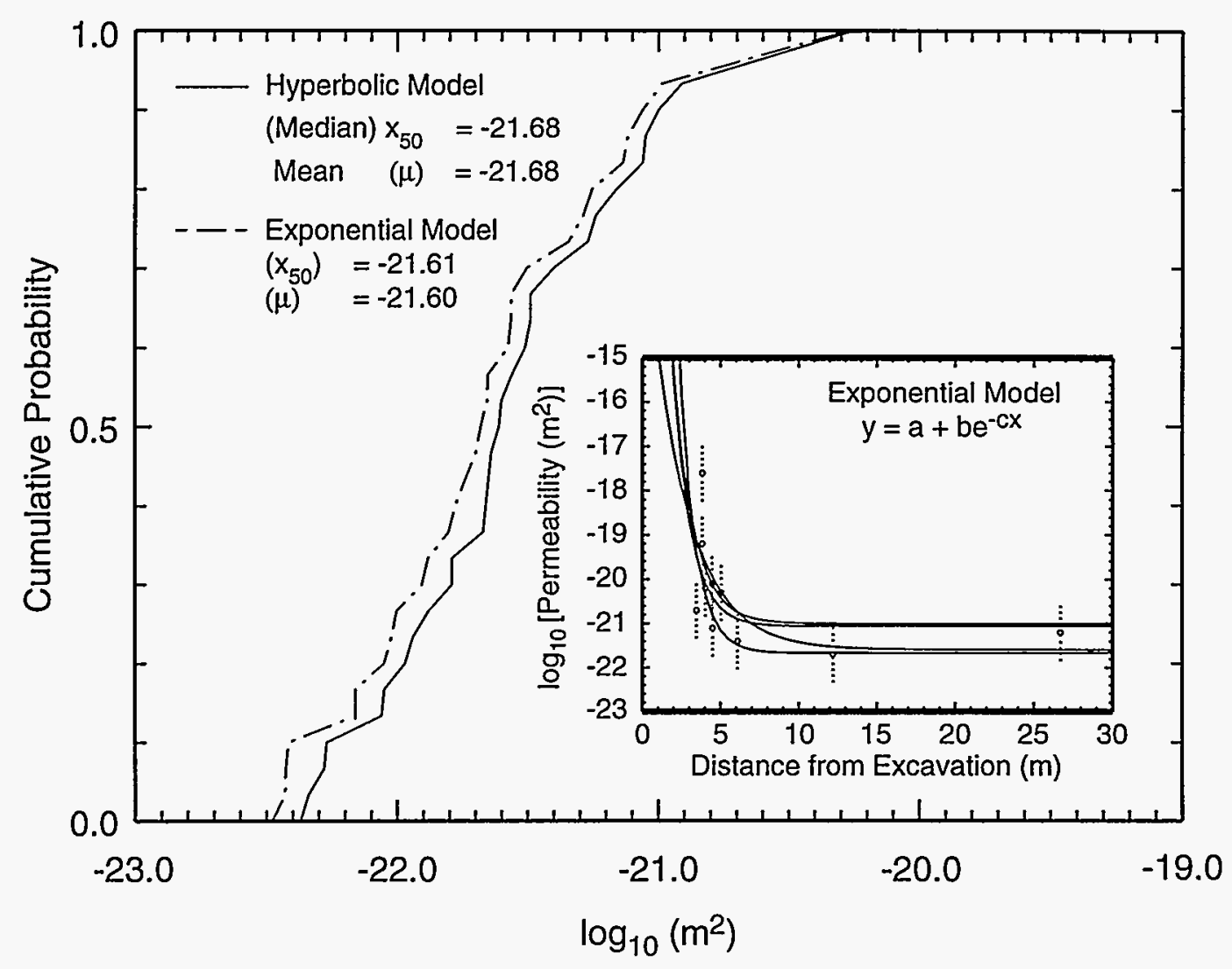

TRI-6342-3469-0

Figure 4.1-3. Example of standard interpretation of data to evaluate the far-field cumulative distribution function (CDF) of the halite permeability ..$^{5}$ 


\subsubsection{Example of Formalized Data Interpretation}

Formal procedures to elicit expert judgment arise for any of the following reasons: (1) an issue is of particular interest or sensitivity to policy makers or the public; (2) requisite data will never be available; or (3) previous performance assessment calculations have shown a particular parameter value to influence results greatly, but site-specific data or information are unavailable, conflicting, or too expensive to obtain. An example of formalized interpretations in which the requisite data will never be available (Case 2) is provided by the two groups of external experts formed to address questions regarding future states of society and how they might relate to future intrusion boreholes into the Waste Isolation Pilot Plant (WIPP). 1,2 One group of experts (called the Futures Panel) studied technology levels that might be attained by future societies and how/why these societies might inadvertently intrude into the wastc panels. ${ }^{1}$ The second group of experts (called the Markers Panel) studied how markers might be used to warn future societies about the presence of buried wastes ${ }^{2}$ and the dangers of on-site drilling. An example of the use of formalized interpretation for Case 3 is the formation of an expert panel to evaluate solubility data of radionuclides. Questions of radionuclide solubility in WIPP-repository-like environments are interdisciplinary, and a synthesis of disparate data in the literature has not yet occurred. Consequently, an expert panel was convened to examine existing data and develop plausible distributions of radionuclide solubilities for conditions thought to pertain to the WIPP repository (see Figure 4.1-4). 3,4

\section{References}

1 Hora, S.C., D. von Winterfeldt, and K.M. Trauth. 1991. Expert Judgment on Inadvertent Human Intrusion into the Waste Isolation Pilot Plant. SAND90-3063. Albuquerque, NM: Sandia National Laboratories.

2 Hora, S.C. 1992. "Probabilities of Human Intrusion into the WIPP, Methodology for the 1992 Preliminary Comparison," Preliminary Performance Assessment for the Waste Isolation Pilot Plant, December 1992. Volume 3: Model Parameters. Sandia WIPP Project. SAND92-0700/3. Albuquerque, NM: Sandia National Laboratories. A-69 through A-99.

3 Trauth, K.M., S.C. Hora, and R.P. Rechard. 1991. "Expert Judgment as Input to Waste Isolation Pilot Plant Performance Assessment Calculations: Probability Distributions of Significant System Parameters," Proceedings of the First Intemational Mixed Waste Symposium, Baltimore, MD, August 26-29, 1991. Eds. A.A. Moghissi and G.A. Benda. SAND91-0625C. Baltimore, MD: University of Maryland. 4.3.1 through 4.3.9.

4 Trauth, K.M., S.C. Hora, R.P. Rechard, and D.R. Anderson. 1992. The Use of Expert Judgment to Quantify Uncertainty in Solubility and Sorption Parameters for Waste Isolation Pilot Plant Performance Assessment. SAND92-0479. Albuquerque, NM: Sandia National Laboratories.

5 WIPP PA (Performance Assessment) Division. 1991. Preliminary Comparison with 40 CFR Part 191, Subpart B for the Waste Isolation Pilot Plant, December 1991. Volume 3: Reference Data. Eds. R.P. Rechard, A.C. Peterson, J.D. Schreiber, H.J. Iuzzolino, M.S. Tierney, and J.S. Sandha. SAND91-0893/3. Albuquerque, NM: Sandia National Laboratories. 

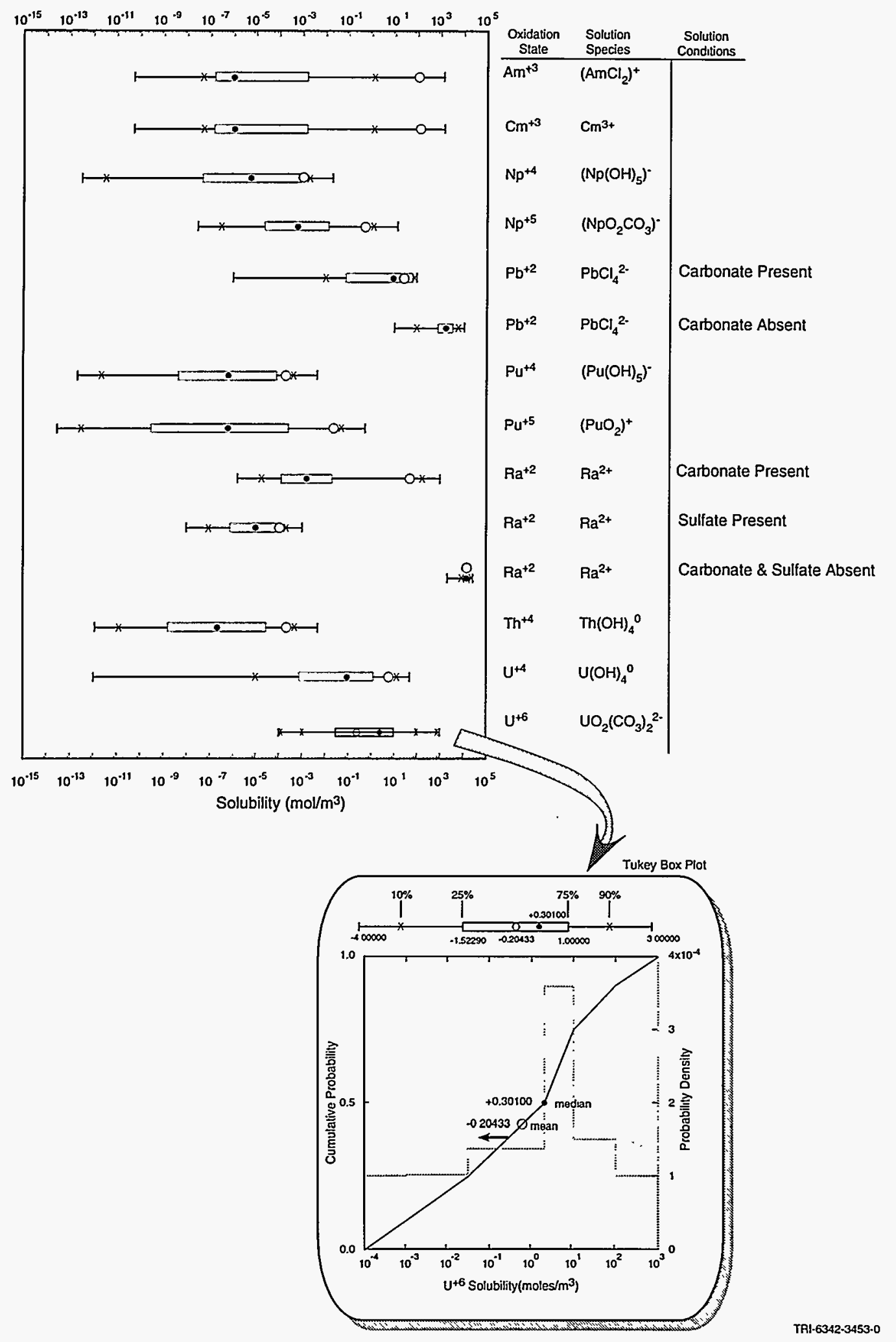

Figure 4.1-4. Results of formalized interpretation of solubility data for radionuclides in the WIPP disposal room [probability density functions (PDFs) shown as Tukey box plots, whose meaning is shown for plus-6-valence uranium $\left(U^{+6}\right)$ ] [after WIPP Performance Assessment Division, 1991, Figure 3.3-8]. 5 


\subsection{Compiling Model Parameters}

The use of a consistent set of parameters for the performance assessments was an important aspect of the 1989-1992 PA calculations and done to help coordinate the many diverse aspects of the performance analysis of the WIPP. In this section, we describe the mechanical steps usually followed to compile model parameters and to apply them in analytical models. The two previous procedural steps, (i) developing the model form (Section 3.3, Modeling System Selection) and (ii) assigning uncertainties in parameter values (Section 4.1, Assigning Parameter Uncertainties), are not disjoint. Rather, one step flows smoothly into the next as part of the overall "modeling" process. Boundaries were introduced primarily as pedagogical artifacts to help the reader understand the many diverse facets of the modeling process. However, the boundary demarking the realm of model parameter compilation is real. From this point onward, the CAMCON modeling system (see Section 3.3, Modeling System Selection) provides assistance in the process of determining parameters with which to assess the performance of the Waste Isolation Pilot Plant disposal system.

Section 4.2.1 describes the gathering of model parameters. Sections 4.2.2 and 4.2.3 describe the sampling of probabilistic random parameters (see Section 4.1) for propagation (see Section 1.3.1) and parameter uncertainty (see Section 4.1) using Latin hypercube sampling. 


\subsubsection{Gathering and Storing Model Parameters}

Three categories of data bases are used in Waste Isolation Pilot Plant (WIPP) performance assessments (PAs) and are known as the primary, secondary, and "computational" data bases. The "computational" data base is generated during each analysis and contains the calculated results generated each time one of the system's codes is exercised (see Section 3.3.4, The CAMCON Modeling System). The primary data bases contain measured field and laboratory data gathered by the experimental groups (e.g., investigators) to characterize the WIPP disposal system (see Chapter 2.0). In general, the information stored in the primary data base is controlled by the investigators. The secondary data base contains distributions of model parameters constructed specifically for the computational models. It is developed from the primary data base by PA personnel. The general procedure used to acquire parameter distributions in the 1990, 1991, and 1992 PA calculations is as follows (see Figure 4.2-1) ${ }^{1,2}$ :

1. Identify Necessary Data. Annually from $1990-1992$, the PA group identified parameter sets $(x=$ $\left.x_{1}, \ldots, x_{n P}\right)$ that were necessary for PA calculations. Occasionally, the PA personnel also informally compiled data to aid preliminary calculations and gathered information to document the status of the data, in order to inform experimental investigators.

2. Set Parameter Values. After essential model parameters had been identified, the PA group formally requested WIPP observational data from appropriate WIPP Project investigators Ideally, investigators who provided observational data also (1) provided a statement regarding the precision of the observed data (measurement error), (2) removed known systematic errors or biases through calibration curves or other means (accuracy), (3) provided a clear statement of what was measured and the scale or representative volume over which the property was measured (representativeness), and (4) provided citable sources. ${ }^{1}$ The investigator or PA personnel may have supplemented these data with additional data and general information from various sources to bridge any remaining data gaps in the conceptual model. From this information, consistent with the manner of use in PA consequence models, the PA group then either constructed parameter distributions or used distributions provided by investigators as described in Section 4.1, Assigning Parameter Uncertainties. As this annual data-acquisition procedure was repeated from 1990-1992, some of the parameters were re-evaluated through the formal elicitation process (e.g., by expert panels. See Section 4.1.2, Degree of Formalism).

3. Update Secondary Data Base. The next step was updating or entering endorsed or elicited information on the model parameters into the secondary data base. From this secondary data base, several ASCII.SDB computer files are created for consequence modeling and a formal report on the model parameters is written (e.g., a model parameter report). ${ }^{2}$

4. Select parameters $\left(\mathrm{x}=x_{1}, \ldots, x_{n}\right)$ to be sampled. Once the secondary data base was complete, several model parameters were chosen for sampling in each annual PA based on one of the following criteria: (1) the parameter had proved to be at least moderately sensitive in previous sensitivity analysis; (2) the parameter was new and thought to be a highly or moderately imprecise, and (3) new observational data suggested a significant revision of the parameter's distribution. All other parameters were kept consistent at their median values, unless specifically noted.

\section{Sample parameters with Latin hypercube sampling (LHS).}

This fifth step is discussed in greater detail in Sections 4.2.2 and 4.2.3.

\section{References}

1 Rechard, R.P., K.M. Trauth, and R.V. Guzowski. 1992b. Quality Assurance Procedures for Parameter Selection and Use of Expert Panels Supporting Performance Assessments of the Waste Isolation Pilot Plant. SAND910429. Albuquerque, NM: Sandia National Laboratories.

2 WIPP PA (Performance Assessment) Division. 1991. Preliminary Comparison with 40 CFR Part 191, Subpart B for the Waste Isolation Pilot Plant, December 1991. Volume 3: Reference Data. Eds. R.P. Rechard, A.C. Peterson, J.D. Schreiber, H.J. Iuzzolino, M.S. Tiemey, and J.S. Sandha. SAND91-0893/3. Albuquerque, NM: Sandia National Laboratories. 


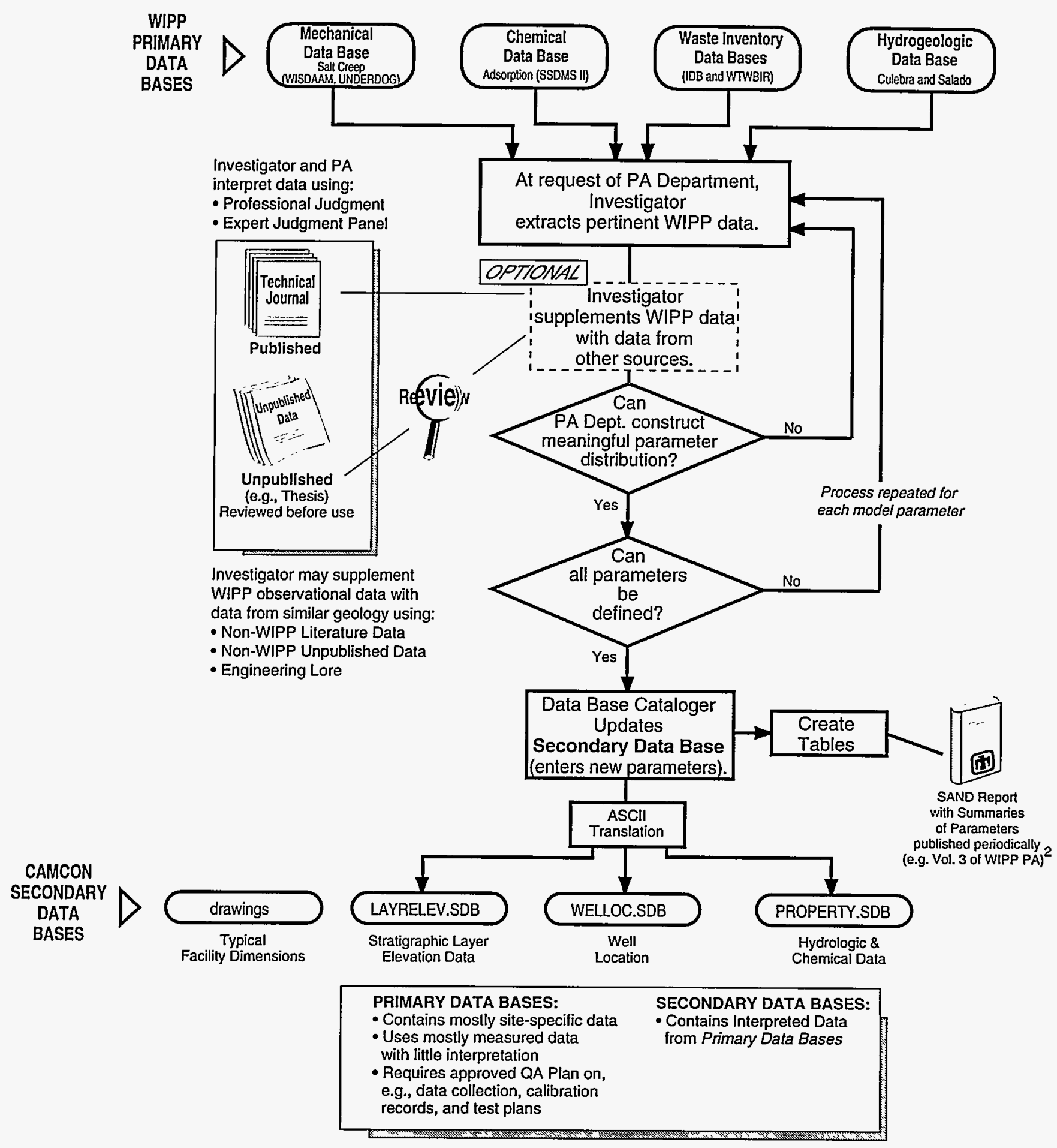

TRI-6342-3471-0

Figure 4.2-1. Overview of compilation and storage of model parameters for their eventual use by various codes in the CAMCON modeling system (after Rechard et al., ${ }^{1}$ Figure 1-3). 


\subsubsection{Latin Hypercube Sampling}

The Waste Isolation Pilot Plant performance assessments use Latin hypercube sampling methods to generate samples from the distributions developed in the first step of a Monte Carlo analysis (see Section 1.3.2). Latin hypercube sampling ensures representative coverage of the full range of each variable. ${ }^{1}$

Once cumulative distribution functions have been developed for each parameter to be sampled, Latin hypercube methods are used to generate a sample. For example, in a five-sample set, the range of each parameter is divided into five intervals of equal probability (see Figure 4.2-2, top), and one value is selected at random from each such interval. The five values thus obtained for $x_{1}$ are paired at random with five similarly obtained values for $x_{2}$. These five ordered pairs are further combined at random with the five similarly obtained values of $x_{3}$ to form five ordered triples, and so on until all sampled variables have been included. The final result is five ordered sets of different parameter values. The results of a Latin hypercube sample can be visualized in scatterplots (see Figure 4.2-2, bottom). A sample over two, normally distributed parameters from the $n=5$ example is used. Five ordered pairs result.

Latin hypercube sampling has a number of desirable properties, ${ }^{1}$ including

- full coverage ("stratification") across the range of each variable (extremes as well as midpoints)

- relatively small sample sizes

- direct estimation of means, variances, and distribution functions

- availability of a variety of techniques for sensitivity analysis

Another desirable property of Latin hypercube sampling is that it is possible to determine the effects of different distributions for the input variables on the estimated distribution for an output variable without rerunning the model. 2,3

\section{References}

1 McKay, M.D., R.J. Beckman, and W.J. Conover. 1979. "A Comparison of Three Methods for Selecting Values of Input Variables in the Analysis of Output from a Computer Code," Technometrics. Vol. 21, no. 2, 239-245.

2 Iman, R.L., and W.J. Conover. 1980a. "Small Sample Sensitivity Analysis Techniques for Computer Models, With an Application to Risk Assessment," Communications in Statistics. Vol. A9, no. 17, 1749-1842.

3 Iman, R.L., and W.J. Conover. 1980b. "Rejoinder to Comments," Communications in Statistics. Vol. A9, no. 17, 1863-1874. 


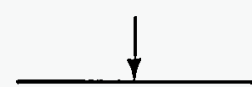

Equal Probability Intervals

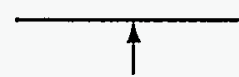

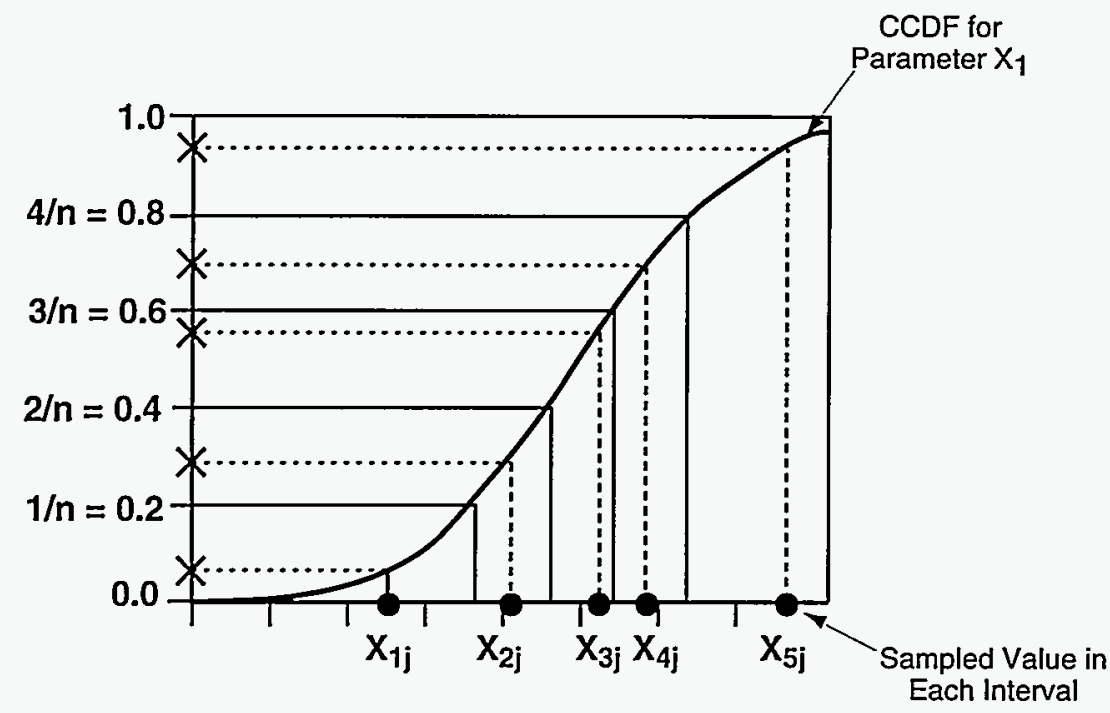

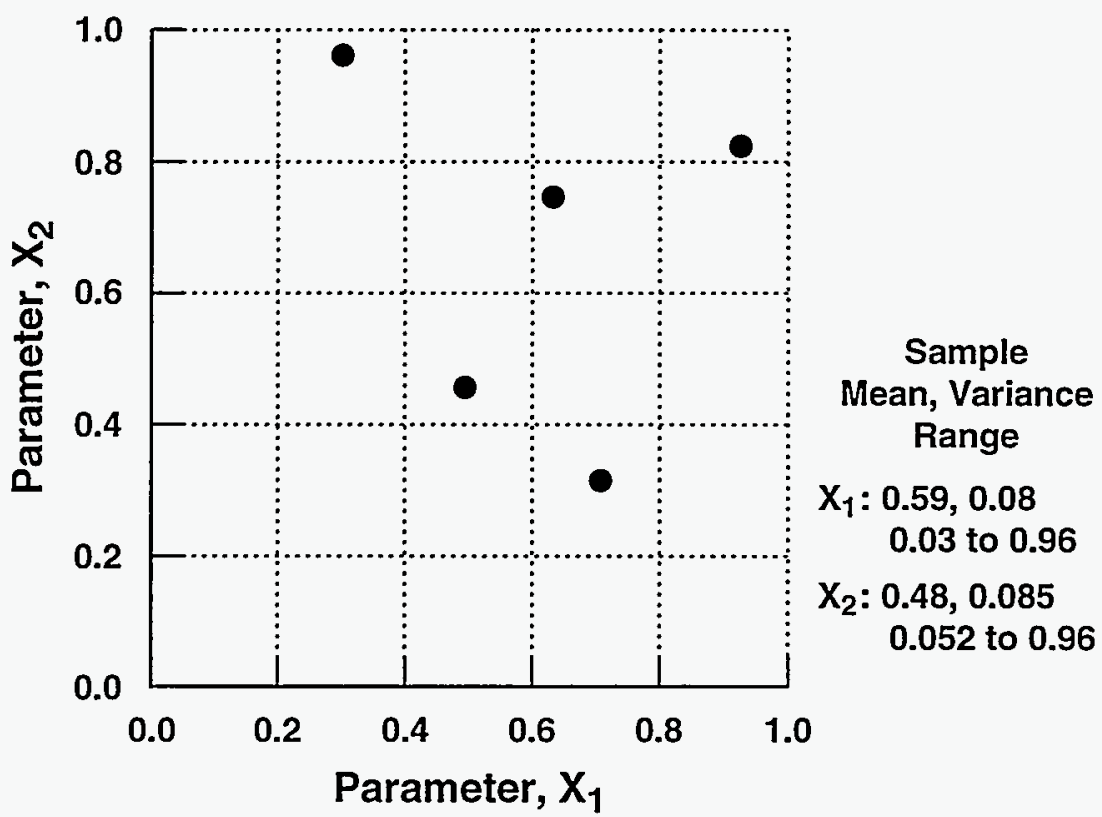

TRI-6342-3460-00

Figure 4.2-2. Latin hypercube samples from cumulative distribution function of one parameter, $x_{1}$, [Latin hypercube samples $(n=5)$ ] and resulting scatterplot of joint probability space for two parameters, $x_{1}$ and $x_{2}$. 


\subsubsection{Executing Latin Hypercube Sampling}

The Waste Isolation Pilot Plant performance assessment codes used to execute Latin hypercube sampling (LHS) are INGRES, PRELHS, and LHS (see Figure 4.2-3).

- INGRES®

Function: INGRES is the relational data-base software. It stores and manipulates distributions of model parameters.

- PRELHS ${ }^{1}$

Function: PRELHS translates from the ASCII.SDB file (see Section 4.2.1) to the LHS code. It extracts parameter-distribution data requested by the user from the PROPERTY.SDB file and sets up the LHS input file.

- LHS $^{1,2}$

Function: LHS samples distributions of input parameters using either normal Monte Carlo sampling or the more efficient Latin hypercube sampling. LHS permits correlations (restricted pairings) between parameters. In the 1990-1992 analysis, the number of sample sets $[n K]$ was set at about $(4 / 3) n V$, where $n V$ is the number of varying parameters from the total number of parameters $n P .^{2}$

References

1 Rechard, R.P., ed., 1992. User's Reference Manual for CAMCON: Compliance Assessment Methodology Controller, Version 3.0. SAND93-1983 Albuquerque, NM: Sandia National Laboratories.

2 Iman, R.L., and M.J. Shortencarier. 1984. A Fortran 77 Program and User's Guide for the Generation of Latin Hypercube and Random Samples for Use with Computer Models. SAND83-2365, NUREG/CR-3624. Albuquerque, NM: Sandia National Laboratories. 


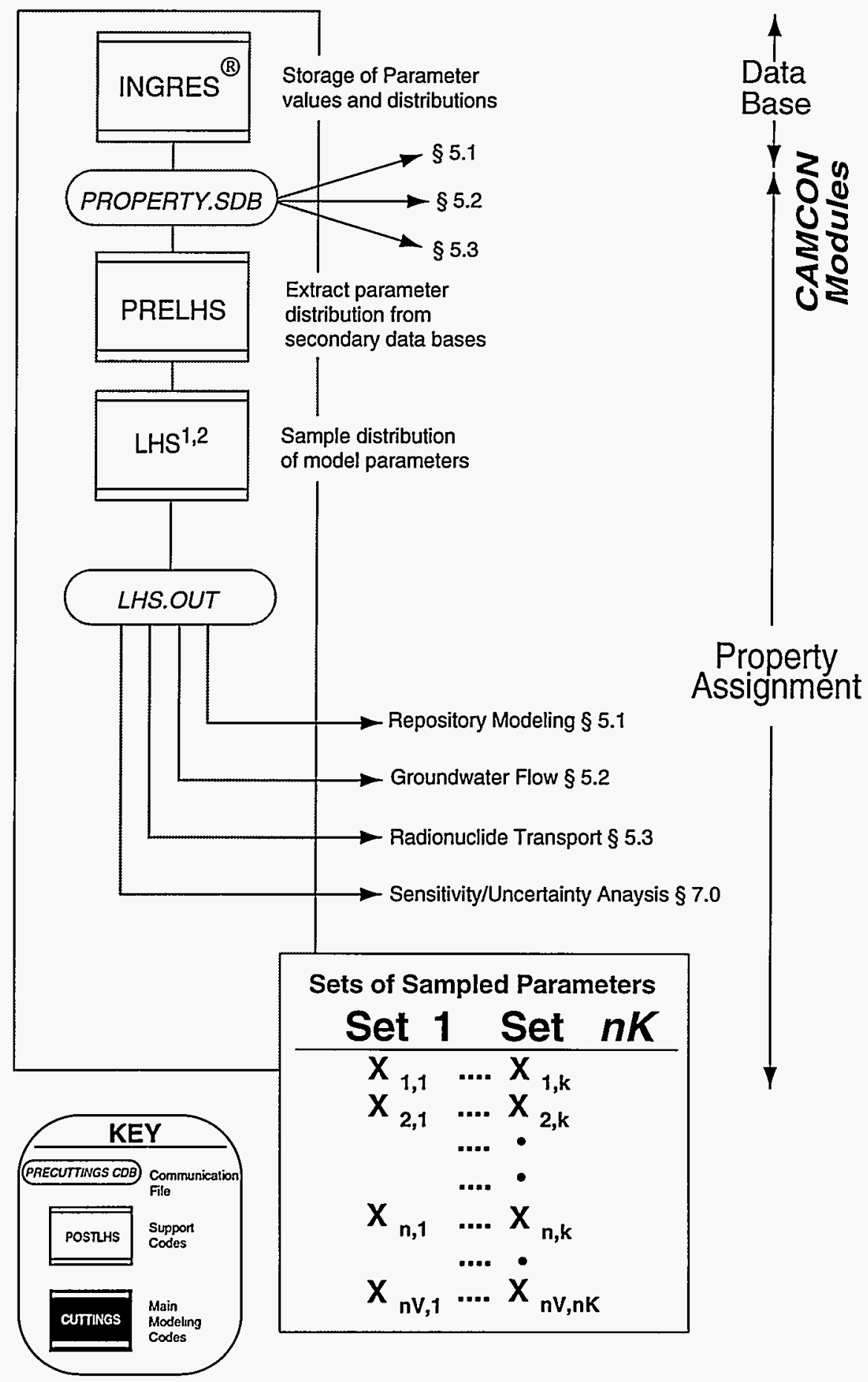

TRI-6342-3455-0

Figure 4.2-3. Linkage of software to perform Latin hypercube sampling in the 1990-1992 performance assessment calculations. 


\subsection{Estimating Probability of Human Intrusion Scenario}

The exploratory drilling and inadvertent intrusion into the Waste Isolation Pilot Plant (WIPP) repository that occurs in the hydrocarbon-exploration scenarios are treated as random processes. That is, intrusions are treated as processes that are controlled, at least in part, by chance mechanisms. The Poisson analytic distribution function adequately describes many random processes that take place over time. Correspondingly, the Poisson distribution was assumed to describe exploratory drilling events in the 1990, 1991, and 1992 PA calculations.

Although it is formally a part of "probability estimation" in WIPP performance assessments (PAs), the coding that implements the Poisson analytic function is actually imbedded in the software that constructs the complementary cumulative distribution functions (CCDFs). The function is straightforward to evaluate and computationally easy to implement at that point in the PA simulation (see Sections 6.1.4 and 6.1.5 about constructing CCDFs).

Section 4.3.1 describes the Poisson analytic function. 


\subsubsection{Using Poisson Functions to Estimate the Probability of Human Intrusion}

\section{The 1990 through 1992 Models}

In 1990 through 1992, the probability model for the event "unintentional intrusion into Waste Isolation Pilot Plant (WIPP) waste panels by exploratory drilling" was based on the assumption that future episodes of exploratory drilling are describable as a Poisson processes with constant intensity, $\lambda$ (see Figure 4.3-1). Under those conditions, the probability that the waste panels are drilled through exactly $n$ times in a period of $T$ years is given by $1,2,3$

$$
\operatorname{Pr}\{N=n\}=\frac{(\lambda T)^{n}}{n !} e^{-\lambda T}, \quad n=0,1,2, \ldots
$$

The intensity of drilling, $\lambda$, was an imprecisely known parameter assumed to be uniformly distributed within a range of 0 to 30 boreholes $/\left(\mathrm{km}^{2} \cdot 10^{4} \mathrm{yr}\right.$ ) for the area of the excavated disposal region (see distribution in Section 4.1.1). This maximum rate is defined in Appendix C of 40 CFR 191: "the likelihood of such inadvertent and intermittent drilling need not be taken to be greater than 30 boreholes per square kilometer per 10,000 yr for a geologic repository in proximity to sedimentary rock formations. . ." For $\lambda=\lambda_{\max }=\left[30\right.$ boreholes $\left./\left(\mathrm{km}^{2} \cdot 10^{4} \mathrm{yr}\right)\right] \cdot\left[1.09 \times 10^{5} \mathrm{~m}^{2}\right]$, the average number of drilling intrusions into the disposal panels over the 10,000 -yr regulatory period is 3.6 .

\section{The 1992 Model}

In 1992 , the probability model also used a Poisson counting process with a time-varying $\lambda(t)$. Under those conditions, the probability, $P_{i}$, that exactly $n$ intrusions occur in a time interval, $T_{i}=t_{i}-t_{i-1}$, is

$$
\begin{aligned}
& P_{i}[n]=\frac{\left[M_{i}\right]^{n}}{n !} e^{-s_{t}} \\
& M_{i}=\int_{t_{i-1}}^{t_{i}} \lambda(t) d t
\end{aligned}
$$

A set of intensity functions, $\lambda(t)$, was generated using the results of the expert panels describing future states of society and efforts to construct adequate markers. ${ }^{4,5}$ The $\lambda(t)$ were ordered by increasing values of intrusions and one intensity function randomly selected for each sample set from Monte Carlo analysis through Latin hypercube sampling (see Section 4.2.2).

\section{References}

1 Tierney, M.S. 1991. Combining Scenarios in a Calculation of the Overall Probability Distribution of Cumulative Releases of Radioactivity from the Waste Isolation Pilot Plant, Southeastern New Mexico. SAND900838. Albuquerque, NM: Sandia National Laboratories.

2 Tierney, M.S. 1994b. "Probability of Intrusion by Exploratory Drilling at the WIPP Site," Transactions of the American Nuclear Society, 1993 Winter Meeting, San Francisco, CA, November 14-18, 1993. SAND93-3986C. Vol. 69, 130-132.

3 Helton, J.C. 1993c. "Drilling Intrusion Probabilities for Use in Performance Assessment for Radioactive Waste Disposal," Reliability Engineering and System Safety. SAND93-7001J. Vol. 40, no. 3, 259-275.

4 Hora, S.C. 1992. "Probabilities of Human Intrusion into the WIPP, Methodology for the 1992 Preliminary Comparison," Preliminary Performance Assessment for the Waste Isolation Pilot Plant, December 1992. Volume 3: Model Parameters. Sandia WIPP Project. SAND92-0700/3. Albuquerque, NM: Sandia National Laboratories. A-69 to A-99.

5 Hora, S.C., D. von Winterfeldt, and K.M. Trauth. 1991. Expert Judgment on Inadvertent Human Intrusion into the Waste Isolation Pilot Plant. SAND90-3063. Albuquerque, NM: Sandia National Laboratories. 

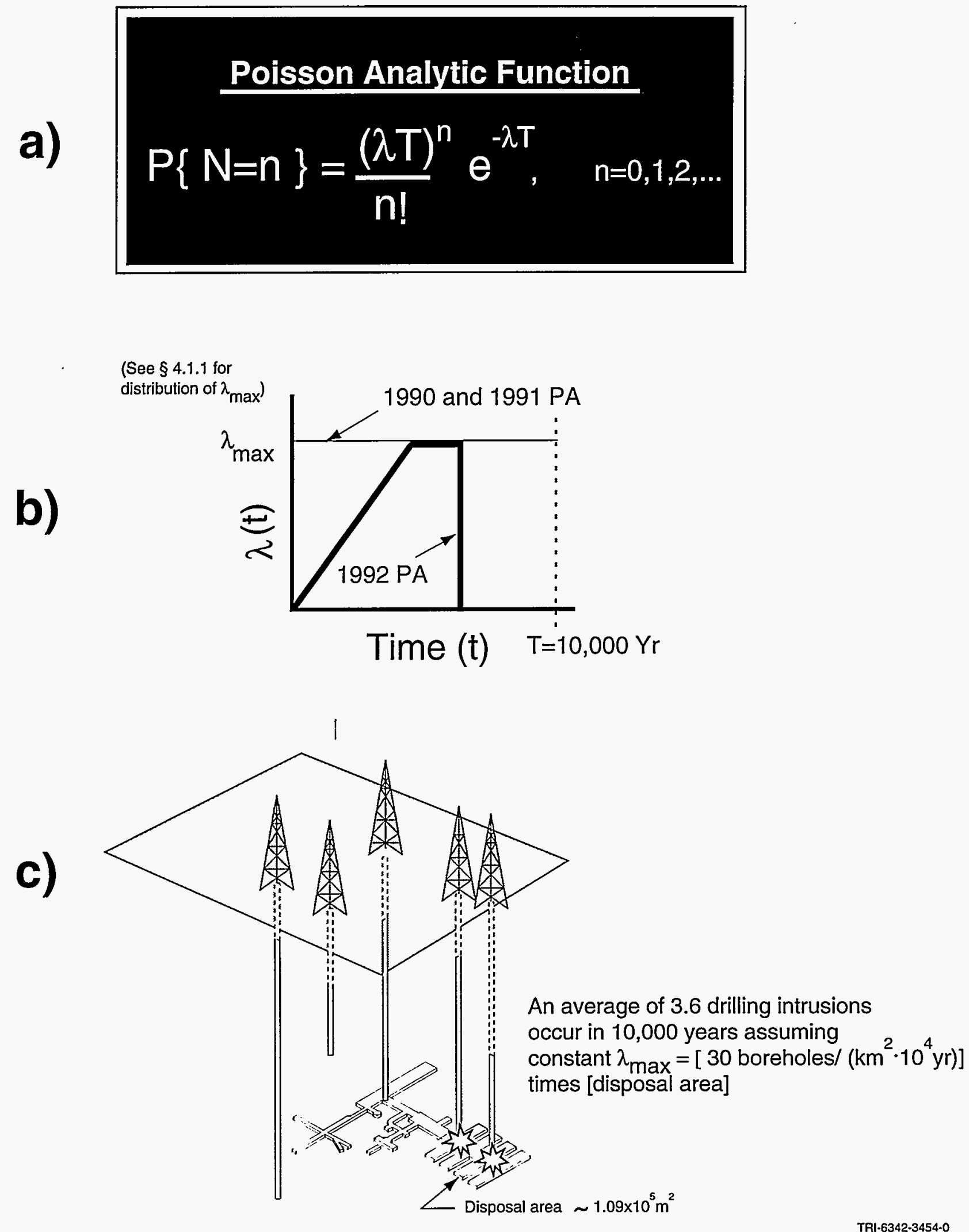

Figure 4.3-1. Poisson analytic function model for estimating the probability of inadvertent human intrusion. 
4.0 Probability Estimation 


\subsection{CONSEQUENCE ANALYSIS}

Here, we address the question: "What are the consequences of the various hypothetical chains of events called scenarios?" (See Section 1.2.2.) The quantitative answers required by the Environmental Protection Agency are specific performance measures that must be estimated using a site-specific modeling system designed to calculate the amount of contaminants released to the accessible environment because of hypothesized features, events, and processes, and include in the answer estimates of the uncertainties associated with the illustrative calculations. This step in the performance-assessment (PA) process is referred to as consequence modeling and analysis. The "model" used for consequence modeling is actually an ordered system or hierarchy of composite models linked together.

Because a single three-dimensional consequence model having the detail necessary to simulate the features, events, and processes of the entire disposal system would require too much time and money to build and modify and too much computer capacity to solve, the consequence model is divided into four principal submodels that correspond to the major physical components of the Waste Isolation Pilot Plant (WIPP) (see Section 3.3, Modeling System Selection). Each of the four submodels is discussed in the principal four sections of this chapter: (1) repository, (2) groundwater flow, (3) radionuclide transport, and (4) biosphere transport. The repository submodel estimates the amount of radionuclides that leave the repository during drilling as drill cuttings and materials suspended and/or dissolved in drilling fluids. Radionuclides than can leave the repository as a result of natural groundwater flow and leakage up plugged boreholes are also estimated. The radionuclides that escape in this manner become the source input for the groundwater-transport modeling subsystem, where groundwater transport is controlled by the groundwater-flow modeling system. Finally, the radionuclide concentrations from the transport modeling system provide source input for the biospheric-transport modeling subsystem.

In WIPP performance assessments, uncertainty in performance estimates results from (1) the existence of alternative conceptual models and (2) uncertainty in the values of certain model parameters. Uncertainty model parameters are propagated through the WIPP PA calculation through a Monte Carlo * technique (see Section 1.3.1). Latin hypercube sampling ${ }^{* * *}$ is used to minimize the number of samples needed to describe parameter uncertainties adequately and thereby to minimize the number of simulations required to assess performance over the entire range of the parameter space (see Sections 4.2.2 and 4.2.3).

The primary purposes of the descriptions to follow are (1) to enlarge the cursory description of the computational models ("codes") given in Section 3.3 (Modeling System Selection), (2) to document the actual linkages between the various codes, (3) to provide a macroscopic overview of the modeling system and its component functions, (4) to strip away as much of the system's inherent complexity as is possible, and thereby (5) to expose the system's inner workings at their most transparent level. Once the calculational procedure is understood, the reader should be able to focus on the natural phenomena being modeled and the working details of the models. It is beyond the intent of this document to describe the natural science or the mathematical formulations that comprise the theoretical basis for the computational models. For information on those subjects, see the work of Helton et al. ${ }^{1}$ for the 1991 simulation and Volume 2 of the series of volumes describing the 1992 PA simulation. ${ }^{2}$

\section{References}

1 Helton, J.C., D.R. Anderson, B.L. Baker, J.E. Bean, J.W. Berglund, W. Beyeler, J.W. Garner, H.J. Iuzzolino, M.G. Marietta, R.P. Rechard, P.J. Roache, D.K. Rudeen, J.D. Schreiber, P.N. Swift, M.S. Tiemey, and P. Vaughn. 1995. "Effect of Alternative Conceptual Models in a Preliminary Performance Assessment for the Waste Isolation Pilot Plant," Nuclear Engineering and Design. SAND94-2312J. Vol. 154, no. 3, 251-344.

2 WIPP PA (Performance Assessment) Department. 1992. Preliminary Performance Assessment for the Waste Isolation Pilot Plant, December 1992, Volume 2: Technical Basis. SAND92-0700/2. Albuquerque, NM: Sandia National Laboratories.

- Uncertainty propagation includes methods to propagate uncertainty in model parameters through the model and, thereby, to estimate the effects of that uncertainty on the results. It is an important aspect of stochastic simulations.

* * Monte Carlo methods use random sampling to integrate mathematical models approximately. The practicality of their use has increased with the advent of computers.

* * " Latin hypercube sampling is a Monte Carlo sampling technique that divides the cumulative distribution function into intervals of equal probability and then samples from each interval (see Section 4.2.2). 
5.0 Consequence Analysis 


\subsection{Repository Modeling}

The first submodel of the overall consequence model is the repository submodel. It describes removal of radionuclides from the repository and introduction into the surrounding regions. Conceptually, the repository submodel is dominated by phenomena on two very different time scales (see Figure 5-1): (1) short-term cuttings release to the surface and (2) long-term brine inflow and radionuclide dissolution. On the short time scale, fluid inflow to the repository is not required. Rather, transport results from direct contact with the bit used to drill an exploratory borehole as it passes through the repository. Wastes are transported to the surface together with halite and other drilled minerals. Specifically, on the shorter time, the repository submodel calculates contaminant releases to the accessible environment at the surface from drilling byproducts. The longer time scale model requires an inflow of fluid from a source near the repository, the source being scenario dependent. Normally, it is provided by a submodel code that is dedicated to that function. Given the inflow, another code of the repository submodel introduces into the inflow a series of radionuclide concentrations for transport out of the repository. The fluid slowly makes its way toward the accessible environment either laterally through an anhydrite layer or Marker Bed, or vertically up a repository shaft or drilled borehole to the overlying Culebra aquifer. The overall process treats mixing and flow phenomena in the waste parcel, disposal room, drifts, shafts, and backfill. Specifically, on the longer time scale, the repository submodel calculates (1) the fluid flux from a source through the disposal area of the repository and (2) the introduction of contaminant concentrations in the fluid (gas or liquid) flowing through the disposal area.

Sections 5.1.1 and 5.1.2 describe a hypothesized sequence of events for the disposal area of the repository and demonstrate the type of results calculated by repository submodels. Strictly speaking, the sequences are not scenarios because the interaction of the features, events, and process are postulated to aid in the discussion.

Sections 5.1.3 through 5.1.6 provide examples of modeling assumptions and computational models that were actually used in past performance assessments. The short-term time scale consists of one software group, drill cuttings (see Sections 5.1.3 and 5.1.4). The long-term, brine-inflow time scale consists of two main software groups: two-phase flow and source-term modeling (see Sections 5.1.6 and 5.1.8). The three software groups produce the three primary results of the repository submodel introduced above.

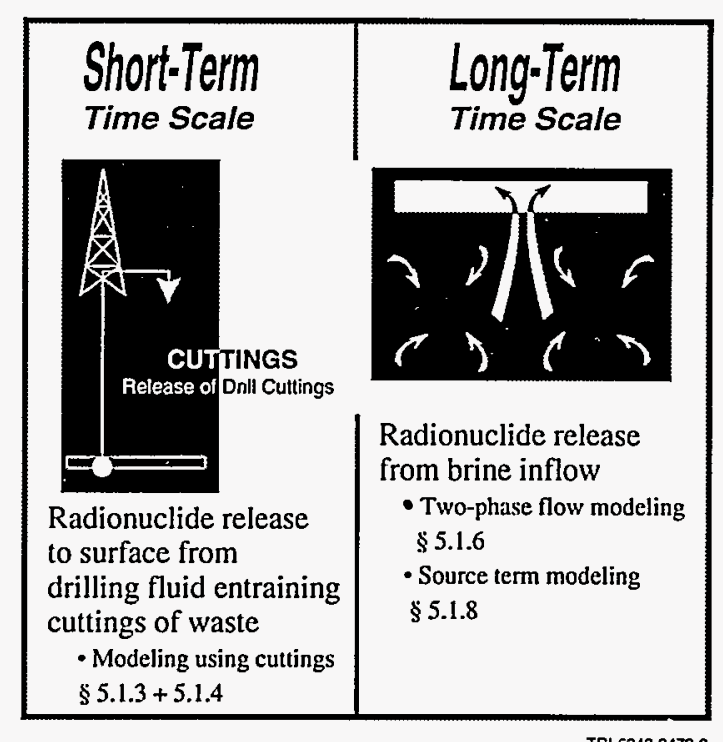

Figure 5-1. Time scales and corresponding software groups for modeling the repository.

\footnotetext{
Recall, WIPP disposal-system phenomena are dominated by four principal spatial scales that form the basis for the subsections of this chapter (see Section 3.3.1, External Scales for Consequence Models). The four scales are (1) repository, (2) local, (3) regional, and (4) external (surface and atmospheric).
} 


\subsubsection{Repository Episodes Leading to Undisturbed Conditions*}

The following hypothesized sequence of episodes leads to so-called "undisturbed conditions" and gives an idea of the types of phenomena modeled as well as the kinds of results to be expected from the repository portion of the consequence model. These are not scenarios. They are hypothetical episodes because the interaction of features, events, and processes is postulated. The "undisturbed conditions" described here are those that may occur because of natural processes in the absence of human intervention or catastrophic natural events (see Section 5.1.2). Initially, panels of the repository would be filled with waste and in the 1990 to 1992 performance assessment (PA) calculation was assumed to be backfilled with salt. All access drifts and the experimental area to the north of the repository were also assumed to be backfilled and the shafts sealed (see Section 2.3.3, Sealing). No free brine would likely be present in the repository at that time, although MB139 might become fractured as a result of excavating repository panels or in response to initial creep into the excavated region. During the operational life of the repository, the fractures in MB139 might fill with brine from the Salado Formation (Figure 5.1-1a). During the first 50 to $200 \mathrm{yr}$ after decommissioning, creep would first collapse the room and then compress the voids around the waste to encapsulate it. Any brine in the salt would likely flow into the disturbed rock zone (DRZ) or remain in small pockets within the waste and panel rooms (Figure 5.1-1b). In the 1990, 1991, and 1992 PAs, the initial disturbance of the salt around the repository and the creep closure of the excavation were modeled prior to the PA calculations and thus used as inputs to the calculations.

The presence of water in the disposal rooms would promote corrosion of the steel containers and of steel wastes within them. Initially this corrosion would consume oxygen. However, once the oxygen was gone, anoxic corrosion could occur and generate hydrogen gas. In the sequence of events described here, room closure is assumed to be nearly complete before anoxic corrosion of the containers begins. Microbial degradation of organic materials in the wastes is also a possibility and would produce carbon dioxide, although its rate of production is thought to be slow. Gases generated in the room would fill interstitial voids, increasing room pressures, and eventually reversing the seepage of brine so as to drive it out of the room. The gas could also migrate into anhydrite layers above the room (Figure 5.1-1c).

The room is assumed to remain in this gas-filled, pressurized state of the "undisturbed" scenario (Figure 5.1-1d) (see Section 3.2.3, Undisturbed Summary Scenario). This episode assumes the lower shaft seal is well consolidated prior to producing gas, such that the gas is trapped in the repository rather than venting through the shaft to the Culebra. In the early 1980 s, pressurization of the room was not considered feasible because of the relatively high permeabilities assigned to the salt formation. However, in the late 1980s, extensive measurements revealed relatively low salt permeabilities (as presented as an example in Section 4.1.3). As a result, room pressurization became an important consideration. ${ }^{1}$

Although this hypothesized sequence of events is regarded as reasonable, a broad range of system responses can occur. Evaluating the interaction of phenomena and predicting the entire range of responses leading up to the "undisturbed state" of the repository is the topic of the two-phase flow modeling described in Section 5.1.6. Although these "undisturbed conditions" are the starting point for evaluating "human-intervention (disturbed) conditions" in the next section, important aspects of the undisturbed conditions must be examined to determine compliance with regulations specified in the Resource Conservation and Recovery Act (RCRA) of 1976 (see Section 6.3). These aspects include the influence of various parameters on the movement of gases that might contain hazardous volatile organic compounds that might be transported into the anhydrite layers above the disposal room or into the seals of the shaft and eventually beyond disposal unit boundaries as defined by RCRA (see Section 1.4.1). An example of an evaluation of the influence of various parameters for undisturbed conditions is given in Section 7.1.1, Ranking Important Model Parameters.

\section{References}

1 Lappin, A.R., R.L. Hunter, D.P. Garber, and P.B. Davies, eds. 1989. Systems Analysis, Long-Term Radionuclide Transport, and Dose Assessments, Waste Isolation Pilot Plant (WIPP), Southeastern New Mexico; March 1989. SAND89-0462. Albuquerque, NM: Sandia National Laboratories.

2 Rechard, R.P., W. Beyeler, R.D. McCurley, D.K. Rudeen, J.E. Bean, and J.D. Schreiber. 1990b. Parameter Sensitivity Studies of Selected Components of the Waste Isolation Pilot Plant Repository/Shaft System. SAND892030. Albuquerque, NM: Sandia National Laboratories.

See also Section 3.2.3, Undisturbed Summary Scenario. 


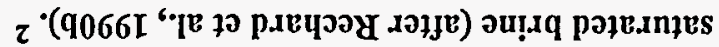

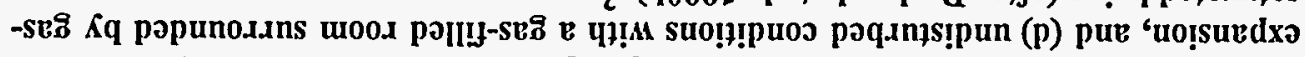

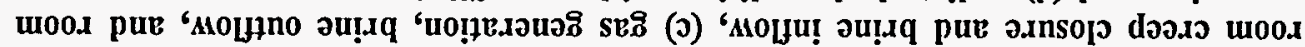

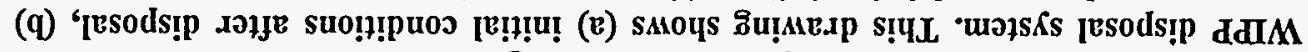

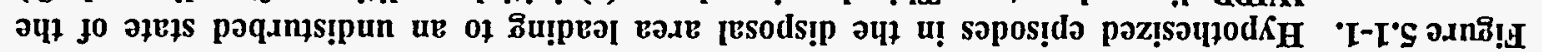

$\not-992-\downarrow \varepsilon \varepsilon 9-14 \perp$

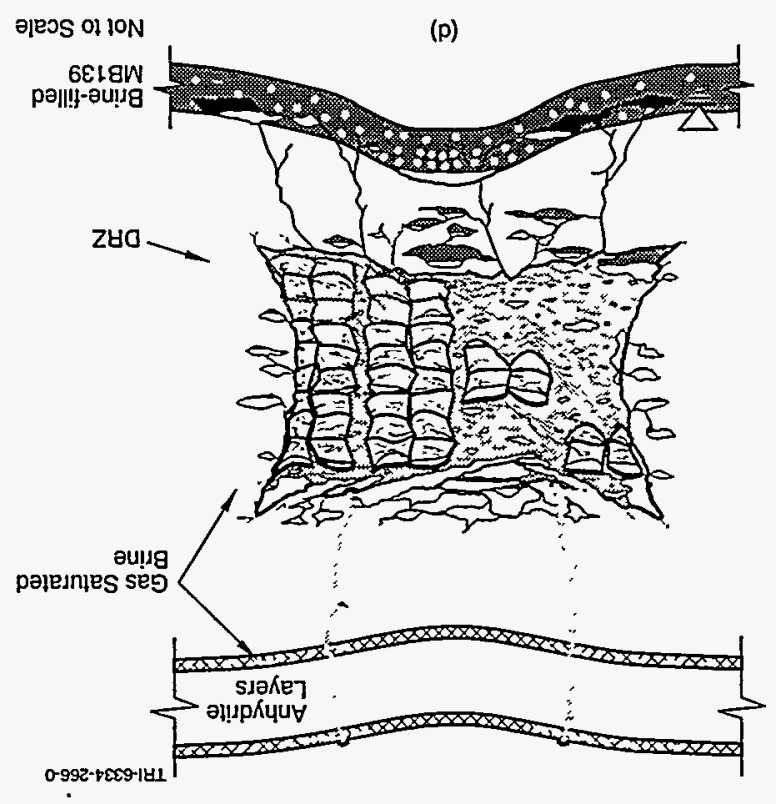

(q)

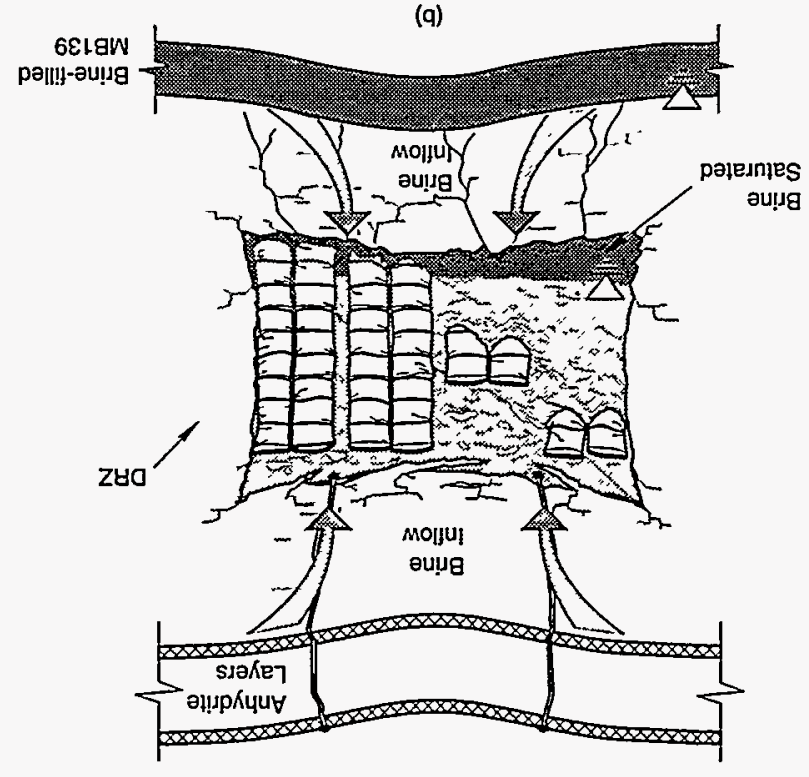

(0)

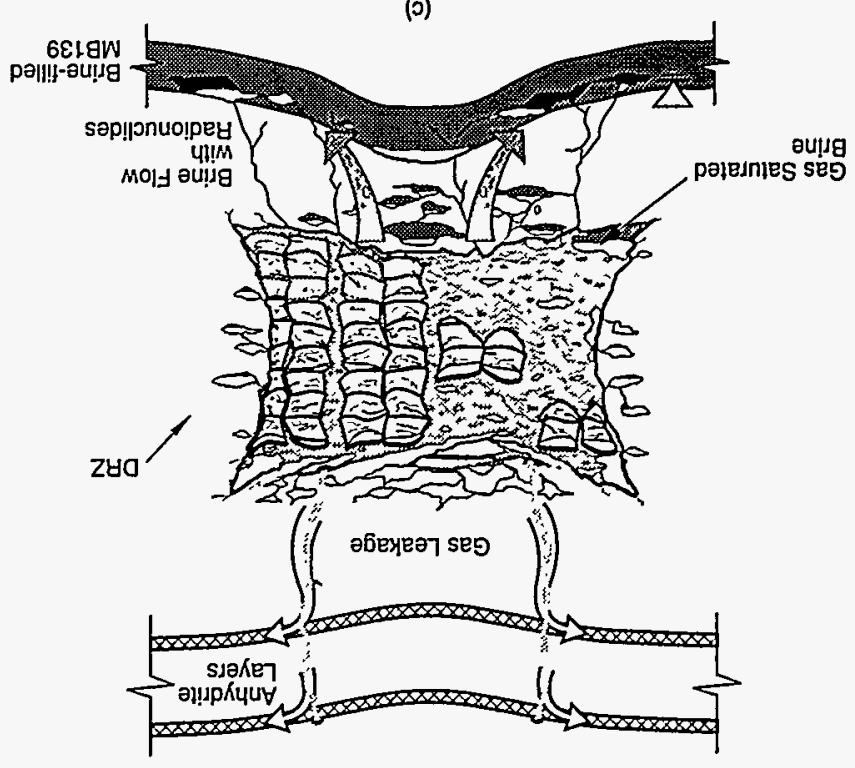

(e)

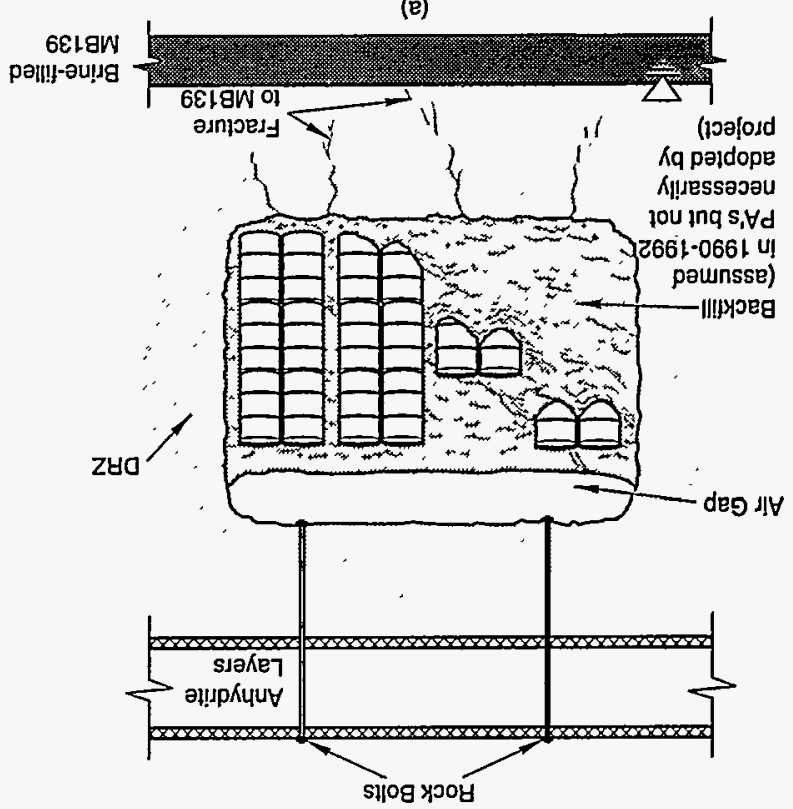




\subsubsection{Repository Episodes after Intrusion}

The scenario-development program for the 1992 performance assessment (PA) retained two events and processes: (1) nearby potash mining resulting in subsidence (TS), and (2) inadvertent human intrusion through three different exploratory drilling events (E1, E2, and E1E2, see Section 3.2.4, Applying the Grouping Procedure to the WIPP). Subsidence was not modeled in 1992. The episode described herein treats the $\mathrm{E} 1$ event in which a borehole is drilled through a disposal room and then into a pressurized brine pocket beneath the repository in the Castile Formation. As is readily seen in Figure $5.1-2$, this drilling event initiates a complicated interaction of phenomena within the disposal room. A two-phase flow code is required to model it (see Section 5.1.5). However, for the 1990, 1991, and 1992 PAs, the most important part of the event was the short-term result, namely the entrainment of wastes into the drilling fluid and their immediate release at the surface during drilling operations (the modeling of which is described in Section 5.1.3, Modeling of Cuttings/Cavings).

In the drilling intrusion scenario $E 1$, the initial breakthrough into a repository panel quickly depressurizes a disposal room (Figure 5.1-2a). According to the 40 CFR 191 Standard, the intruders "soon"* realize the area is "incompatible" with their purposes. The drillers seal the borehole using present-day technology and abandon it. Sealing permits the room to repressurize from on-going gas generation (Figure 5.1-2b).

Within 100 yr following abandonment, degradation of the borehole plug throughout its length allows any remaining gases to migrate out of the room. The degradation also allows the waste and room to reconsolidate at lithostatic pressure with brine refilling any remaining voids. Depending on pressure differences, whether borehole plugs above or below the repository degrade first, and the depth of drilling, brine could flow down from the repository into underpressurized formations below the repository. However, in the cases considered in PA calculations through 1992, brine flow from the Salado Formation and from the brine pocket beneath was assumed to mix within the room, to dissolve the inventory to saturation upon contact, and then to flow up the borehole to the overlying brine aquifer in the Culebra Dolomite Member of the Rustler Formation (Figure 5.1.2c). The dissolution of radionuclides is described in Section 5.1.7. In PA calculations through 1992, movement from the repository to the Culebra was assumed to be instantaneous. The fluid flow regime of the Culebra is described in Section 5.2, Groundwater Flow Modeling. The transport of contaminants through the Culebra to the accessible environment is described in Section 5.3, Radionuclide Transport Modeling.

The above sequence of events resulting from human intrusion is regarded as reasonable. However, it is important to bear in mind that a wide range of system responses can occur. For example, changes in the rate and timing of gas generation, the timing of human intrusion, and the rates of gas leakage through the borehole affect the system. Some mechanisms operate only immediately after plug degradation, such as depressurization within the repository; others, such as fluid from the brine pocket and brine inflow from the Salado Formation, are active over much longer time periods.

\section{References}

1 EPA (Environmental Protection Agency). 1993a. "40 CFR Part 191: Environmental Radiation Protection Standards for the Management and Disposal of Spent Nuclear Fuel, High-Level and Transuranic Radioactive Wastes, Final Rule," Federal Register. Vol. 58, no. 242, 66398-66416.

2 Rechard, R.P., W. Beyeler, R.D. McCurley, D.K. Rudeen, J.E. Bean, and J.D. Schreiber. 1990b. Parameter Sensitivity Studies of Selected Components of the Waste Isolation Pilot Plant Repository/Shaft System. SAND892030. Albuquerque, NM: Sandia National Laboratories.

\footnotetext{
- "Soon" is the term used in the guidance for $40 \mathrm{CFR} 191$. However, it is not defined quantitatively. The author takes it to mean less than a month.
} 

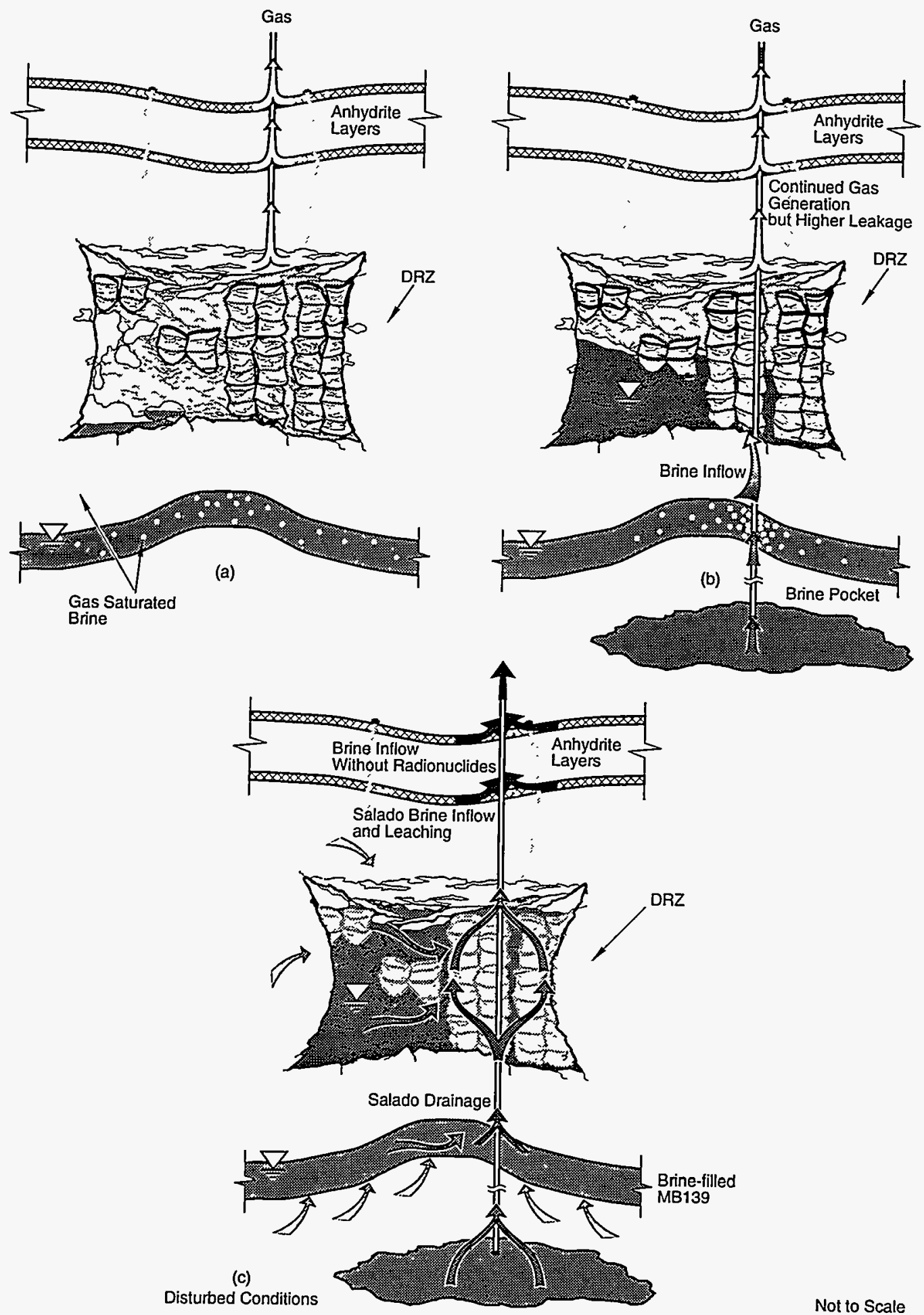

Not to Scale

TRI-6334-268-4

Figure 5.1-2. Hypothesized episodes in the disposal area after human intrusion (E1 scenario, see Section 3.2.2). Drawing (a) shows initial depressurization when the room is penetrated by an exploratory borehole. The hole is plugged, and repressurization occurs. In (b), a second gas and brine depressurization occurs as borehole seals degrade. In (c), brine flows through the borehole to the Culebra Dolomite (after Rechard et al., 1990b). ${ }^{2}$ 


\subsubsection{Modeling of Cuttings/Cavings}

In the 1990 through 1992 PA calculations, the most important pathway for release during the 10,000 -yr regulatory period was direct removal of waste in the event that an exploratory drill bit inadvertently penetrates a waste-storage room. ${ }^{*}$ To quantify the extent of radioactive release resulting from direct removal of wastes, the CUTTINGS model was developed. ${ }^{1}$ The performance assessment (PA) model assumed future drilling techniques would be similar to those in use today. This assumption is necessary to provide a reasonable quantitative basis on which release predictions can be made.

In rotary drilling, a cutting bit attached to a series of hollow drill collars and drill pipes is rotated at a fixed angular velocity and is directed to cut downward through underlying strata. To remove the material loosened by the drilling action, a drilling fluid ("mud") is pumped down the drill pipe, through and around the drill bit, and back up to the surface within the annulus formed by the drill pipe and the borehole wall (see Figure 5.1-3).

If an exploratory drill bit penetrates a waste-filled room, waste resulting from three separate physical processes can mix with the drilling fluid and be transported to the surface. These wastes have three distinct names:

- Cuttings are the wastes that occupied the cylindrical void created by the cutting action of the drill bit through the repository. Cuttings are brought to the surface in the drilling fluid of a rotary drill.

- Cavings are wastes that eroded from the sides of the borehole in response to the upward-flowing drilling fluid within the annulus. They are usually particulates and are brought to the surface in the drilling fluid of a rotary drill.

- Spallings are the wastes surrounding the eroded borehole that are broken away by the action of waste-generated gases escaping to the lower-pressure borehole. Spallings were not incorporated in the 1990,1991 , or 1992 PA calculations.

Section 5.1.4 describes the code linkages surrounding the analytical code used to evaluate cuttings/cavings.

\section{References}

1 Berglund, J.W. 1992. Mechanisms Governing the Direct Removal of Wastes from the Waste Isolation Pilot Plant Repository Caused by Exploratory Drilling. SAND92-7295. Albuquerque, NM: Sandia National Laboratories.

2 EPA (Environmental Protection Agency). 1985b. Background Information Document-Final Rule for HighLevel and Transuranic Radioactive Wastes. EPA 520/1-85-023. Washington, DC: U.S. Environmental Protection Agency, Office of Radiation Programs.

3 O'Brien, P.J., R.B. Lantz, and J. Gormley. 1977. Technical Support of Standards for High-Level Radioactive Waste Management: Volume C: Task C Report, Assessment of Migration Pathways. EPA 520/4-79-007 C. Arthur D. Little, Inc. for Office of Radiation Programs. Washington, DC: U.S. Environmental Protection Agency, Office of Radiation Programs.

4 WIPP PA (Performance Assessment) Division. 1991. Preliminary Comparison with 40 CFR Part 191, Subpart B for the Waste Isolation Pilot Plant, December 1991. Volume 1: Methodology and Results. SAND91-0893/1. Albuquerque, NM: Sandia National Laboratories.

5 Performance Assessment Group. 1990. "Early PA Scoping Calculations-To Help Refocus Research, Development, and Engineering Parts of the WIPP Project, If Necessary," Systems Analysis, Long-Term Radionuclide Transport, and Dose Assessments, Waste Isolation Pilot Plant (WIPP), Southeastern New Mexico; September 1989. A.R. Lappin, R.L. Hunter, P.B. Davies, D.J. Borns, M. Reeves, J. Pickens, and H.J. Iuzzolino. SAND89-1996. Albuquerque, NM: Sandia National Laboratories. A-2 through A-16.

- If a direct repository hit occurs, drilling operation causes the immediate release of radionuclides through the cuttings, cavings, or spallings brought to the surface in the drilling fluid ("mud"). Environmental Protection Agency (EPA) release limits in 40 CFR 191 (see Section 6.1.3, Containment Requirements) Iead to overly conservative limits on this type of release. Specifically, the EPA release limits for all radionuclides except ${ }^{14} \mathrm{C}$ were developed considering only the drinking-water pathway to humans. The release limit for ${ }^{14} \mathrm{C}$ was evaluated considering atmospheric releases (EPA, $1985 \mathrm{~b}^{2}$; O'Brien et al., $1977^{3}$ ). As a result, the EPA release limits are unrealistically scaled for cuttings-type releases. Effects are grossly exaggerated (see Section 5.4.1, Radionuclide Pathways to Humans). Nevertheless, Waste Isolation Pilot Plant (WIPP) performance assessments have traditionally included the cuttings and cavings releases (e.g., WIPP Performance Assessment Division, $1991^{4}$ ). The tradition results from identifying "those 'energy sources' that could move a quantity of waste sufficient to violate the standard from the repository horizon to the land surface" (Performance Assessment Group, $1990^{5}$ ). Drilling fluids in an exploratory drilling operation were regarded as a plausible "energy source." 


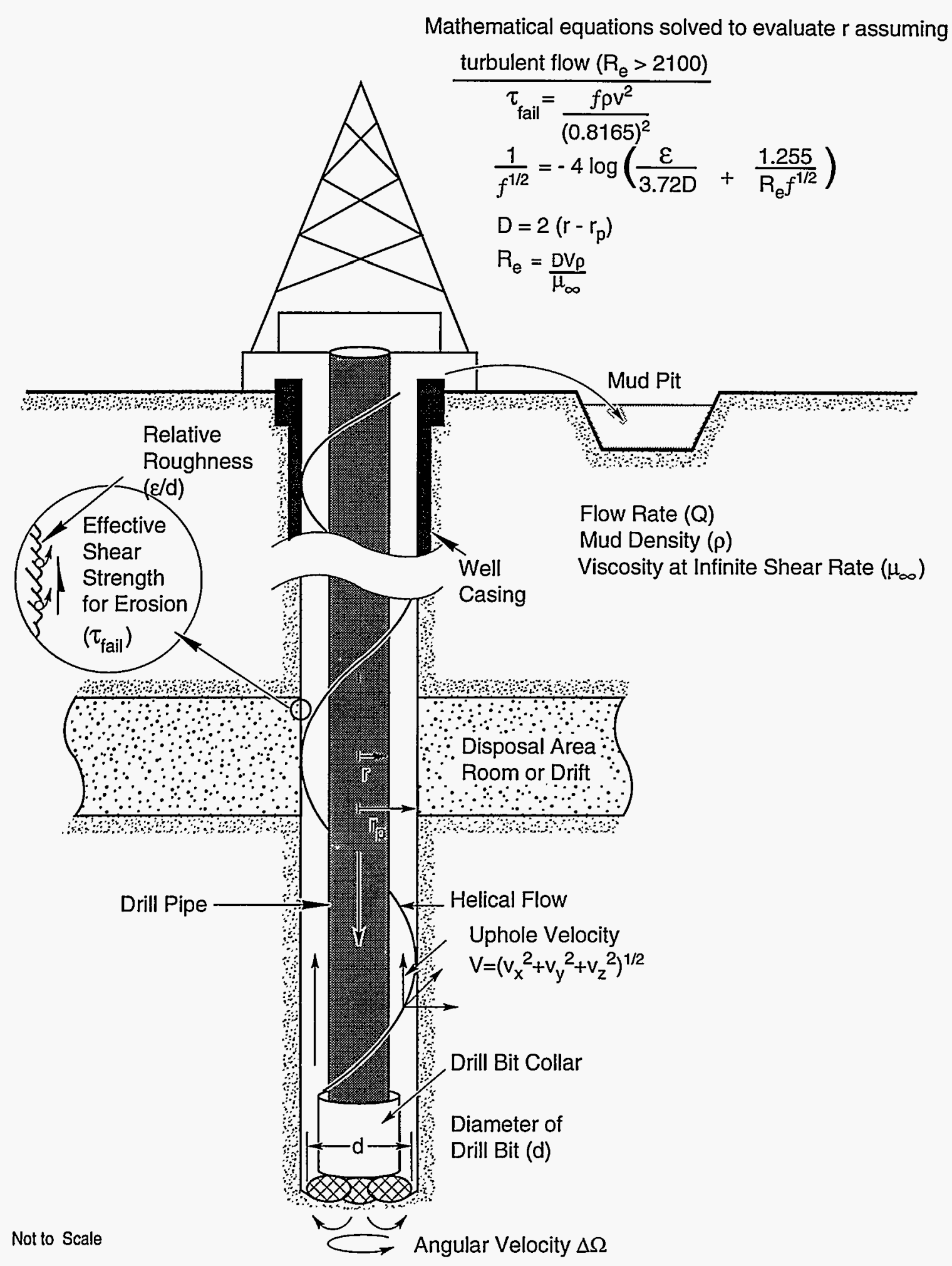

TRI-6330-51-1

Figure 5.1-3. Conceptual model for the removal of cuttings/cavings from the disposal area of an exploratory drilling operation inadvertently intruding into the repository. 


\subsubsection{Linkage of the CUTTINGS Model}

CUTTINGS models the direct removal of wastes from the Waste Isolation Pilot Plant (WIPP) repository as a result of exploratory drilling. ${ }^{1}$ Assuming current industry drilling practices for gas and oil are used, radioactive waste will be released to the ground surface in the drilling fluid (mud) in the form of cuttings and cavings. As currently configured, the CUTTINGS code calculates the drilling mud fluid shear stress acting on the borehole wall and the subsequent erosion of repository materials. The total volume of material removed by drilling is the sum of the eroded material plus the material directly cut by the drill bit. CUTTINGS also decays the radionuclide inventory to the time of intrusion.

The first steps in using CUTTINGS are to use GENNET to establish a grid and then to use MATSET, ${ }^{2}$ which extracts attribute and property data from the secondary data base and generates a computational data base template (PRECUTTINGS.CDB). See Figure 5.1-4 and Section 3.3.3, Support Codes Used in the Modeling System. POSTLHS ${ }^{2}$ is then used to generate $n K$ computational data files (CUT_R\#.CDB) using sampled parameters from LHS.OUT (see Section 4.2.3, Executing Latin Hypercube Sampling).

In the calculations, the drill-bit diameter was a sampled quantity for CUTTINGS; hence, GENNET itself was sampled. This led to double-sampling and $(n K)^{2}$ samples. To reduce the number of samples consistently to $n K$, the $(n K-1)$ samples corresponding to drill-bit diameters other than the bit diameter used in the present GENNET sample are deleted. That process was repeated $n K$ times, resulting in a remainder of $n K$ fully sampled, self-consistent parameter sets that include sampled borehole sizes.

With sampling completed, the CAMDAT.CDB and CUTTINGS.INP files were used as input to the CUTTINGS code. CUTTINGS computed the surface release of radionuclides for the $n K$ sampled cases and placed the results on $n K$ output CDB files. The files were named CUTCH_S\#_R\#.CDB for contacthandled waste and CUTRH_S\#_R\#.CDB for remotely handled waste. These files were then used by CCDFCALC (see Section $\overline{6} .1 . \overline{6}$, Software for Calculating Complementary Cumulative Distribution Functions).

\section{References}

1 Berglund, J.W. 1992. Mechanisms Governing the Direct Removal of Wastes from the Waste Isolation Pilot Plant Reposttory Caused by Exploratory Drilling. SAND92-7295. Albuquerque, NM: Sandia National Laboratories.

2 Rechard, R.P., ed. 1992. User's Reference Manual for CAMCON: Compliance Assessment Methodology Controller, Version 3.0. SAND90-1983. Albuquerque, NM: Sandia National Laboratories. 


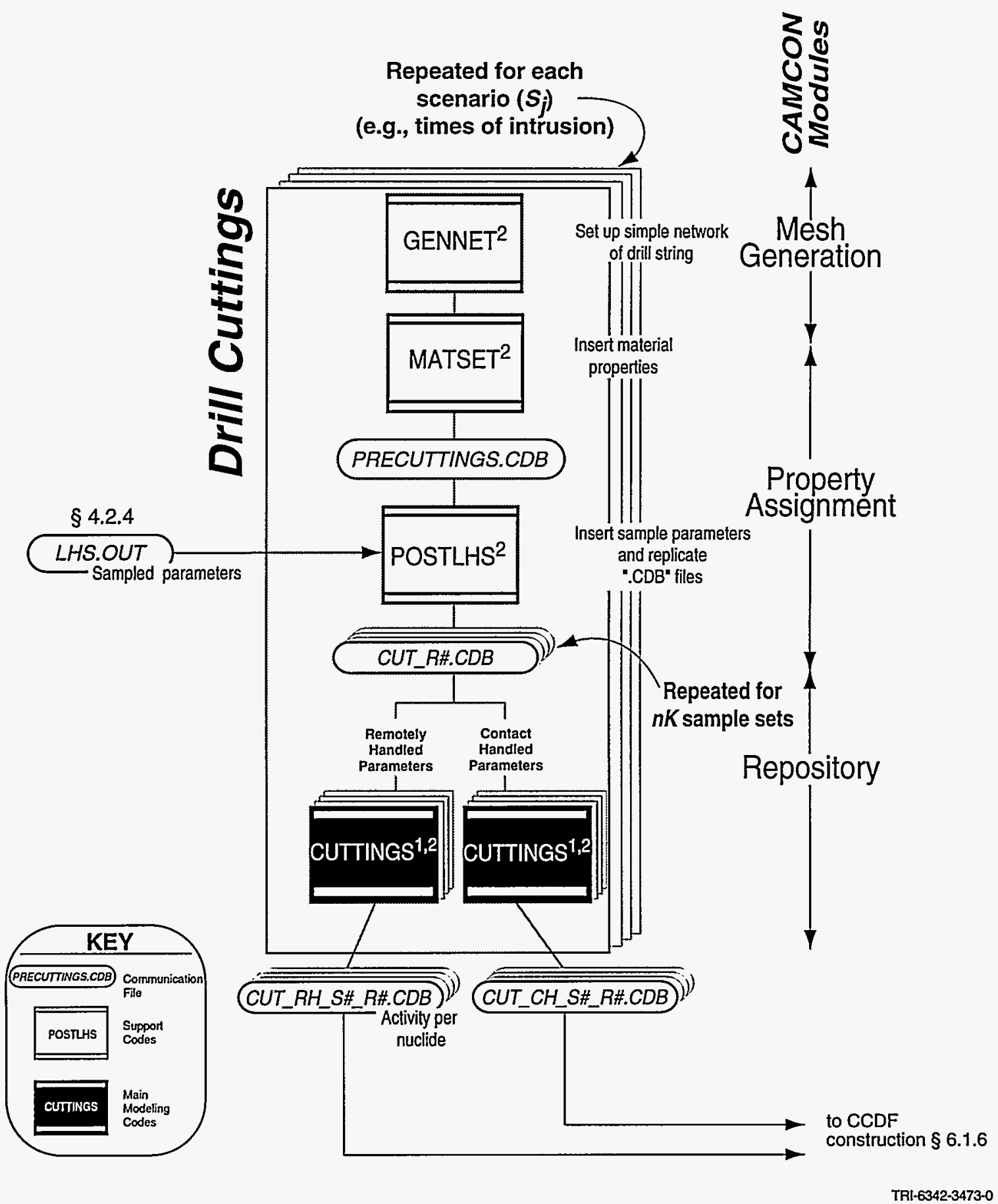

Figure 5.1-4. Linkage of the CUTTINGS computer code to the modeling system to evaluate the release of radionuclides from inadvertent intrusion into the repository. 


\subsubsection{Modeling of Two-Phase Flow}

To study the effects of gas generated by corrosion of metals (primarily steel) and degradation of organic material (primarily cellulose) on the flow of brine into and through the repository and then up an intrusion borehole, Sandia National Laboratories developed a standard mathematical model of two-phase flow through a porous, heterogeneous material. The implementation of this mathematical model was the computational model called BRAGFLO (see Section 5.1.6). The starting equations of the mathematical model are as follows: ${ }^{1}$

Conservation of Gas Components:

$$
\nabla \cdot\left[\frac{\alpha \rho_{n} K k_{r n}}{\mu_{n}}\left(\nabla P_{n}-\rho_{n g} \nabla D\right)+\frac{\alpha C_{N w} \rho_{w} K k_{r w}}{\mu_{w}}\left(\nabla P_{w}-\rho_{n g} \nabla D\right)\right]+\alpha q_{n}+\alpha q_{r n}=\frac{\partial\left(\phi \rho_{n} S_{n}+\phi C_{N w} \rho_{w} S_{w}\right)}{\partial t}
$$

Conservation of Brine Component: $\nabla \bullet\left[\frac{\alpha C_{W_{w}} \rho_{w} K k_{r w}}{\mu_{w}}\left(\nabla P_{w}-\rho_{w} g \nabla D\right)\right]+\alpha q_{w}+\alpha q_{r w}=\alpha \frac{\partial\left(\phi C_{W w} \rho_{w} S_{w}\right)}{\partial t}$,

Constraint on Saturations: $S_{n}+S_{w}=1$,

Constraint on Mass Fraction: $C_{N_{w}}+C_{W w}=1.0$,

Constraint on Capillary Pressure: $P_{n}+P_{w}=P_{c}$,

where the quantities have the following meanings:

$C_{M \ell}=$ mass fraction of component $M$ dissolved or miscible in phase $\ell ; g=$ gravitational acceleration constant $\left[L r^{2}\right],\left[\mathrm{m} \mathrm{s}^{-2}\right] ; K=$ absolute permeability of the reservoir $\left[L^{2}\right],\left[\mathrm{m}^{2}\right] ; k_{\mathrm{r} \ell}=$ relative permeability to phase $\ell$ [dimensionless]; $P_{c}=$ capillary pressure $\left[M L^{-1} t^{-2}\right],[\mathrm{Pa}] ; P_{\ell}=$ pressure of phase $\ell\left[M L^{-1} t^{-2}\right],[\mathrm{Pa}]$; $q_{\ell}=$ mass rate of well injection (or production, if negative) per unit volume of reservoir $\left[M L^{-3} t^{-2}\right]$, $\left[\mathrm{kg} \mathrm{m}^{-3} \mathrm{~s}^{-1}\right] ; q_{\mathrm{r} \ell}=$ mass rate of products produced (or reactant consumed, if negative) per unit volume of reservoir due to chemical reaction $\left[M L^{-3} t^{-1}\right],\left[\mathrm{kg} \mathrm{m}^{-3} \mathrm{~s}^{-1}\right] ; S_{\ell}=$ saturation of phase $\ell$ [dimensionless]; $x, y=$ spatial dimensions ( $x$-horizontal, $y$-vertical); $\alpha=$ geometric factor (in three dimensions, $\alpha=1$; in two dimensions, $\alpha=$ length; in one dimension, $\alpha=$ area); $\nabla=$ gradient, shorthand for vector $\partial / \partial x, \partial / \partial y$ in two dimensions; $\nabla \bullet=$ divergence, shorthand for $\partial / \partial x+\partial / \partial y$ in two dimensions; $\phi=$ reservoir porosity [dimensionless]; $\rho_{\ell}=$ density of phase $\ell\left[M^{1} L^{-3}\right],\left[\mathrm{kg}^{1} \mathrm{~m}^{-3}\right]$; and $\mu_{\ell}=$ viscosity of phase $\ell\left[M L^{-1} t^{-1}\right]$, [cp]. The meaning of the subscripts are as follows: $N=$ nonwetting components (gas component); $n=$ nonwetting phase (gas phase); $W=$ wetting component (brine component); and $w=$ wetting phase (brine phase).

Although the flow-flow fields within and around the repository are three dimensional, the repository was modeled in two rather than three because of the numerous stochastic calculations required. The transformation from three to two dimensions was accomplished using a combination of element radial flaring and volumetrically averaging material properties. The element flaring is discussed further here (Figure 5.1-5). Element flaring is the process of defining one or more subregions in a two-dimensional mesh where radially symmetric flow is assumed to occur, then evaluating the width of the element assuming radial coordinates. This process has been used quite successfully ever since $1989^{2}$ to approximate flow near a point of interest in a system that is not fully axisymmetric. The distinction between element flaring and fully axisymmetric modeling is that not all of the elements are automatically increased in width by the radial distance times the full $2 \pi$ arc. Rather, several origins may be used and portions of the study domain with, for example, an approximately uniform flow can have constant widths.

\section{References}

1 Sandia WIPP Project. 1992. Preliminary Performance Assessment for the Waste Isolation Pilot Plant, December 1992. Volume 3: Model Parameters. SAND92-0700/3. Albuquerque, NM: Sandia National Laboratories.

2 Rechard, R.P., W. Beyeler, R.D. McCurley, D.K. Rudeen, J.E. Bean, and J.D. Schreiber. 1990b. Parameter Sensitivity Studies of Selected Components of the Waste Isolation Pilot Plant Repository/Shaft System. SAND89-2030. Albuquerque, NM: Sandia National Laboratories. 


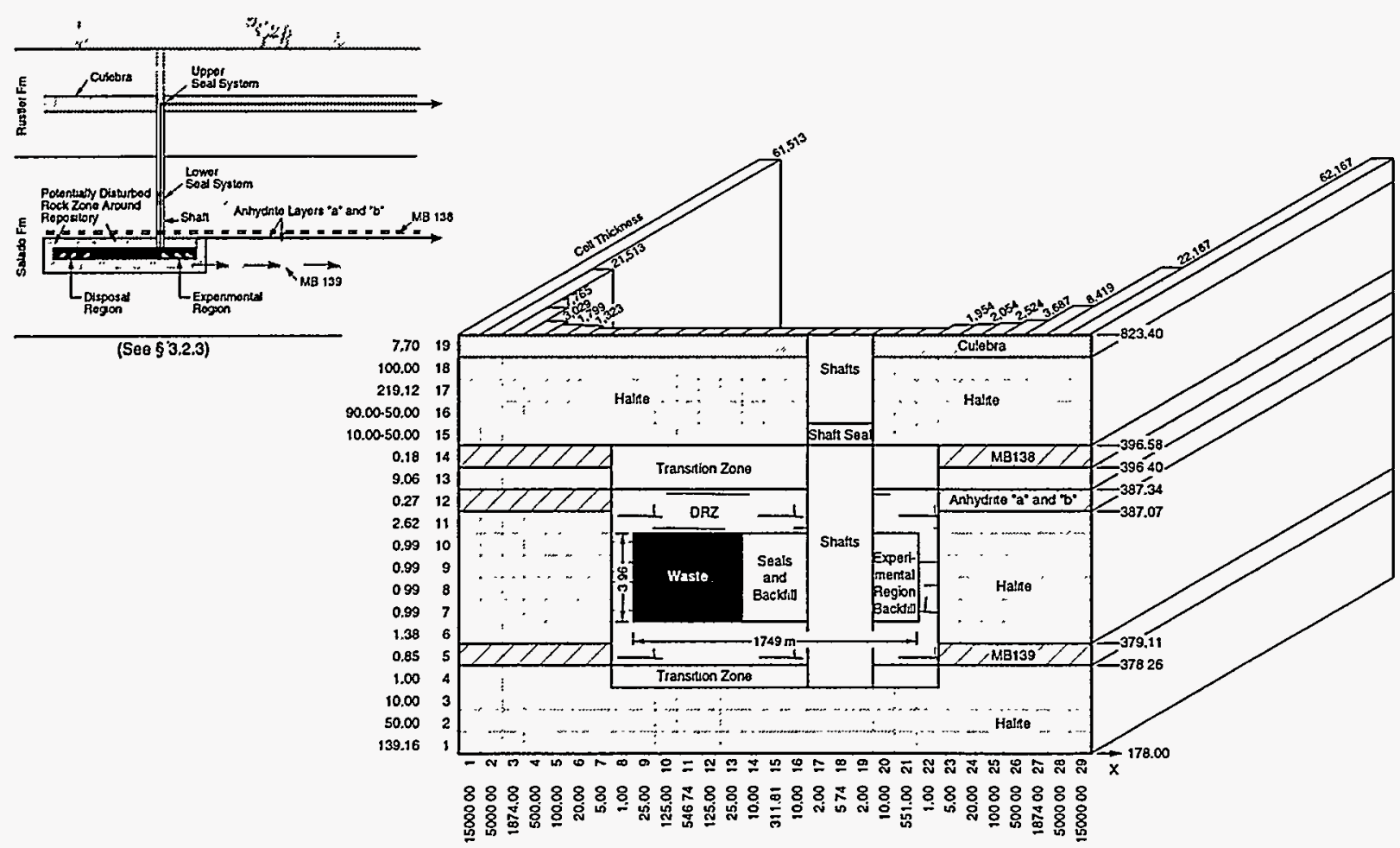

(a)
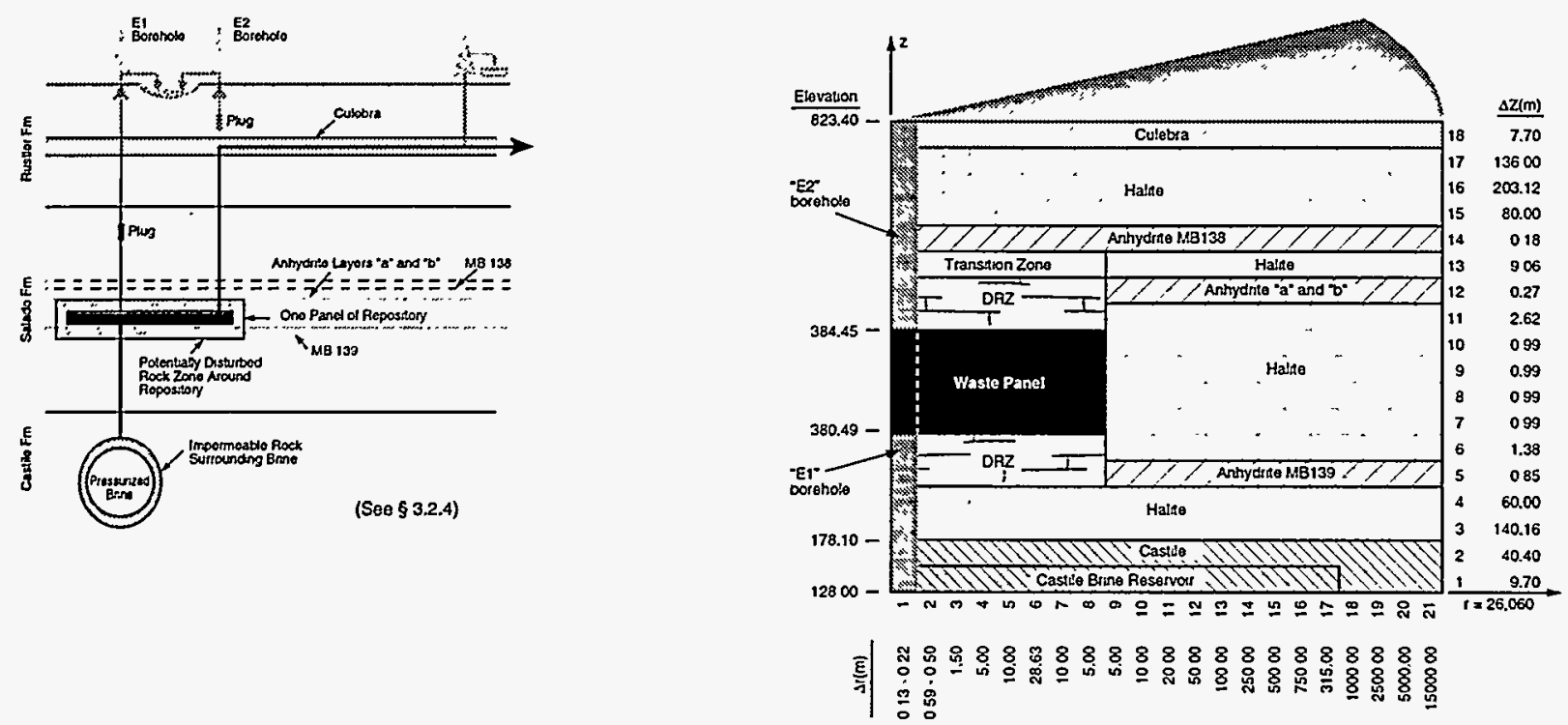

(b)

TRI-6342-4394-0

Figure 5.1-5. Conceptual and numerical logic grids for applied models used for 1992 PA simulations of the repository: (a) mesh of undisturbed scenario using a grid with a portion of the elements "flared" (i.e., elements increased in width to approximate radial flow), and (b) mesh of disturbed scenario using all axisymmetric elements. 


\subsubsection{Linkage of the BRAGFLO Code}

Section 5.1.2. described the interaction of (a) brine flowing into the disposal rooms, (b) gas being generated as steel corrodes and organic materials degrade, and (c) an assumed intrusion into a disposal room by a borehole. These events necessitate the use of a two-phase hydrological flow code. BRAGFLO ${ }^{1}$ was adopted and developed specifically for this purpose.

BRAGFLO $^{1}$ simulates two-phase, three-dimensional, isothermal fluid flow in porous heterogeneous media using a finite-difference numerical solution scheme. The fully implicit formulation makes BRAGFLO well suited for simulating convergent flow into a well. * BRAGFLO includes a corrosion and biodegradation gas-generation submodel that operates on whatever iron and cellulose may be available in the waste. A BRAGFLO user's/theory manual is in preparation.

The linkage of BRAGFLO to other portions of the consequence model (depicted in Section 3.3.2, The Component Computational Models) is typical and is described below (see also Figure 5.1-6):

1. The underlying data for BRAGFLO comes from two files: LHS.OUT and PROPERTY.SDB (described in Section 4.2.3, Executing Latin Hypercube Sampling).

2. The borehole diameter is sampled. Therefore, grid spacing near the borehole must be adjusted accordingly. GEN_INP is a program written specifically for each year's calculational grid. It adjusts the GENMESH input file using mesh parameters from LHS.OUT."

3. GENMESH ${ }^{2}$ defines a finite-difference mesh from the Castile to the Culebra, from the borehole to the accessible environment, and creates a .CDB file for BRAGFLO.

4. MATSET ${ }^{2}$ assigns a constant, usually median value for each parameter required by the model. It uses values from the PROPERTY.SDB file (depicted in Section 4.2.3).

5. POSTLHS ** overwrites the .CBD file using sampled parameters from LHS. This step results in the production of $n K$.CDB files, one for each sampled data set.

6. BRAGFLO requires several parameters that are derived from other parameters stored in the .CDB file. For example, compressibility divided by porosity. This manipulative step is accomplished with ALGEBRACDB. ${ }^{2}$

7. ICSET is used to set initial liquid and gas saturations and pressures.

8. The two-phase flow simulations are run using BRAGFLO, which includes a pre- and a postprocessing code to prepare inputs for BRAGFLO and for the downstream codes. They are named PREBRAG and POSTBRAG.

9. ALGEBRACDB is usually applied at this point to strip the POSTBRAG output .CBD file of data that is not needed for the next step in the process. This step is not absolutely required, but it shortens run times and facilitates troubleshooting.

The dissolution of radionuclides into the brine filling the disposal room is decoupled from BRAGFLO. A specialized code has been written specifically for that purpose. It is described in Section 5.1.8.

\section{References}

1 Vaughn, P. 1986. Numerical Model for Thermal Recovery Processes in Tar Sand: Description and Application. DOE/FE/60177-2219. Report for the U.S. Department of Energy. Laramie, WY: Western Research Institute, University of Wyoming. (Available from National Technical Information Service, Springfield, VA.)

2 Rechard, R.P., ed. 1992. User's Reference Manual for CAMCON: Compliance Assessment Methodology Controller, Version 3.0. SAND90-1983. Albuquerque, NM: Sandia National Laboratories.

3 Fanchi, J.R., J.E. Kennedy, and D.L. Dauben. 1987. BOAST_II: A Three-Dimensional, Three-Phase Black Oil Applied Simulation Tool. DOE/BC-88/2/SP. Tulsa, OK: K and A Technology.

- The 1990 performance assessment (PA) calculations used the two-phase flow code BOAST. ${ }^{3}$ However, its implicit/explicit (IMPES) formulation could not adequately solve convergent flow into an intrusion borehole.

* * If a mesh-dependent parameter is sampled, the following two steps must be run $n K$ times where $n K$ is the number of sample sets.

* * * Pre- and post-processor codes of the Waste Isolation Pilot Plant's (WIPP's) analytical codes are usually omitted in this report. They are ancillary codes used solely to manipulate data in a preparatory fashion. They do not solve equations or embody physical laws. POSTLHS, however, is an exception. It plays a critical role in WIPP PA sampling and is therefore included here and elsewhere. 


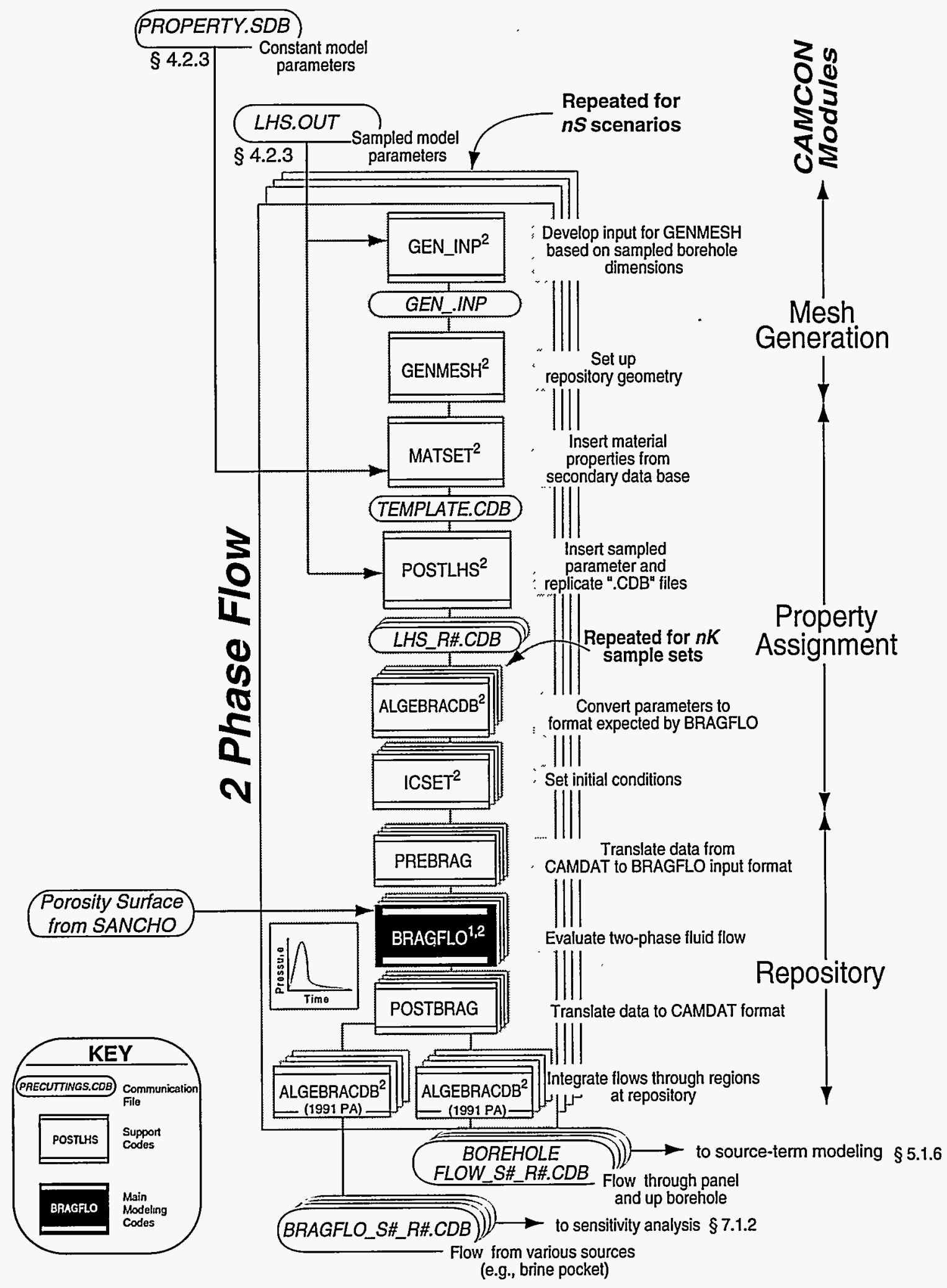

TRI-6342-3467-0-b

Figure 5.1-6. Linkage of software to model two-phase (brine and gas) flow in and around the WIPP repository for both the undisturbed and disturbed scenarios in the 1991 and 1992 performance assessment calculations. 


\subsubsection{Modeling of Source-Term}

The source-term model estimates the radionuclide discharge rates leaving the repository resulting from one or more boreholes penetrating the repository and a possible pressurized brine reservoir in the Castile formation below the Salado Formation (see Sections 3.2.4 and 3.3.2). Specifically, the sourceterm model evaluates the concentration of the $i$ th chemical element (e.g., radionuclide) leaving from a specified portion ("cell") of the repository (usually an entire panel) as a function of time as follows. A cell within the Waste Isolation Pilot Plant (WIPP) repository is idealized as a single connected cavity with contaminants within the waste uniformly distributed throughout the cavity. It assumes dissolution equilibrium at all times (infinitely efficient mixing in the cell, and negligible kinetic effects of dissolution for the time scales used). If sufficient inventory of the element is present at time $t\left(I_{i}(t)\right)$, the model determines concentrations of the $i$ th element $\left(C_{i}(t)\right)$ entirely by solubility limit (suspended radionuclides [colloids] are ignored), that is, $C_{i}(t)=S_{i}$ if $I_{i}(t) N(t) \geq S_{i}$ otherwise $C_{i}(t)=I_{i}(t) / V(t)$ if $I_{i}(t) / V(t)<S_{i}$, where $V(t)$ is the volume of brine present in the cell at time $t$ (concentrations of radionuclides within the gas phase are negligible and concentrations of hazardous volatile compounds are simply set equal to measured concentrations). The volume of fluid flowing through a panel, $\Sigma q_{\text {in }}$, was determined by the repository model BRAGFLO in the 1991 and 1992 performance assessment (PA) calculations (see Section 5.1.5). A simple single-phase, analytic model of the repository, the Salado Formation, and the brine reservoir was used in the $1990 \mathrm{PA}$. The time dependence of the inventory of an element, $I_{i}(t)$, is determined using the Bateman equations ${ }^{4}$ to account for radioactive decay and growth of daughter products. Furthermore, when a chemical element has several isotopes, the relative amount of each isotope in solution is set equal to the relative amount present in the total inventory of the element in the cell.

The calculational procedure at each discrete time step $(\Delta t)$ is as follows:

1. A volume of fluid $\left(\Sigma q_{\text {in }} \Delta t\right)$, constrained to be no more than $10 \%$ of the volume of a cell, displaces an equal volume of fluid leaving the panel, $\left(\Sigma q_{\text {in }} \Delta t=q_{\text {out }} \Delta t\right)$, (hence, $V(t)$ is constant throughout the calculation; furthermore, the cell volume is set equal to the entire panel volume).

2. The concentration of chemical elements, $C_{i}(t)$, within the panel are updated by

a. mixing the remaining panel pore fluid with the introduced fluid

b. evaluating the inventory of an element from radioactive decay at the end of the time step, $I_{i}(t+\nabla t)=I_{i}(t) e^{\lambda \nabla t}$, plus contributions of parents, grandparents, and great-grandparents as defined by Bateman equations plus inventory of other isotopes of the element

c. calculating the concentration of an element $C_{i}(t+\Delta t)$ as the minimum of $S_{i}$ and $I_{i}(t+\Delta t) / V$

d. Calculating the concentration of $j$ th isotopes of an element, $C_{i,}(t+\Delta t)$ by proportioning the isotopes according to the relative abundance in the inventory of each isotope at $t+\Delta t$ [i.e., $C_{i, j}(t+\Delta t)=C_{i}(t+\Delta t)\left(M_{j} / \Sigma M_{i}\right)$ ]

3. The concentration $C_{i, j}(t+\Delta t)$ is assumed to flow up the borehole and discharge directly into the brine aquifer in the Culebra Dolomite Member of the Rustler Formation. This procedure neglects decay or sorption of radionuclides while transported through the upper portion of the borehole because of the short travel time due to the high permeabilities of the borehole fill material.

\section{References}

1 Rechard, R.P., ed. 1992. User's Reference Manual for CAMCON: Compliance Assessment Methodology Controller, Version 3.0. SAND90-1983. Albuquerque, NM: Sandia National Laboratories.

2 WIPP PA (Performance Assessment) Division. 1991. Preliminary Comparison with 40 CFR Part 191, Subpart $B$ for the Waste Isolation Pilot Plant, December 1991. Volume 2: Probability and Consequence Modeling. SAND91-0893/2. Albuquerque, NM: Sandia National Laboratories.

3 WIPP PA (Performance Assessment) Department. 1992. Preliminary Performance Assessment for the Waste Isolation Pilot Plant, December 1992, Volume 2: Technical Basis. Volume 3: Model Parameters. SAND920700/2/3. Albuquerque, NM: Sandia National Laboratories. Vols. 2-3.

4 Wehr, M.R., J.A. Richards, Jr., and T.W. Adair, II. 1984. Physics of the Atom. 4th ed. Reading, MA: Addison Wesley. 


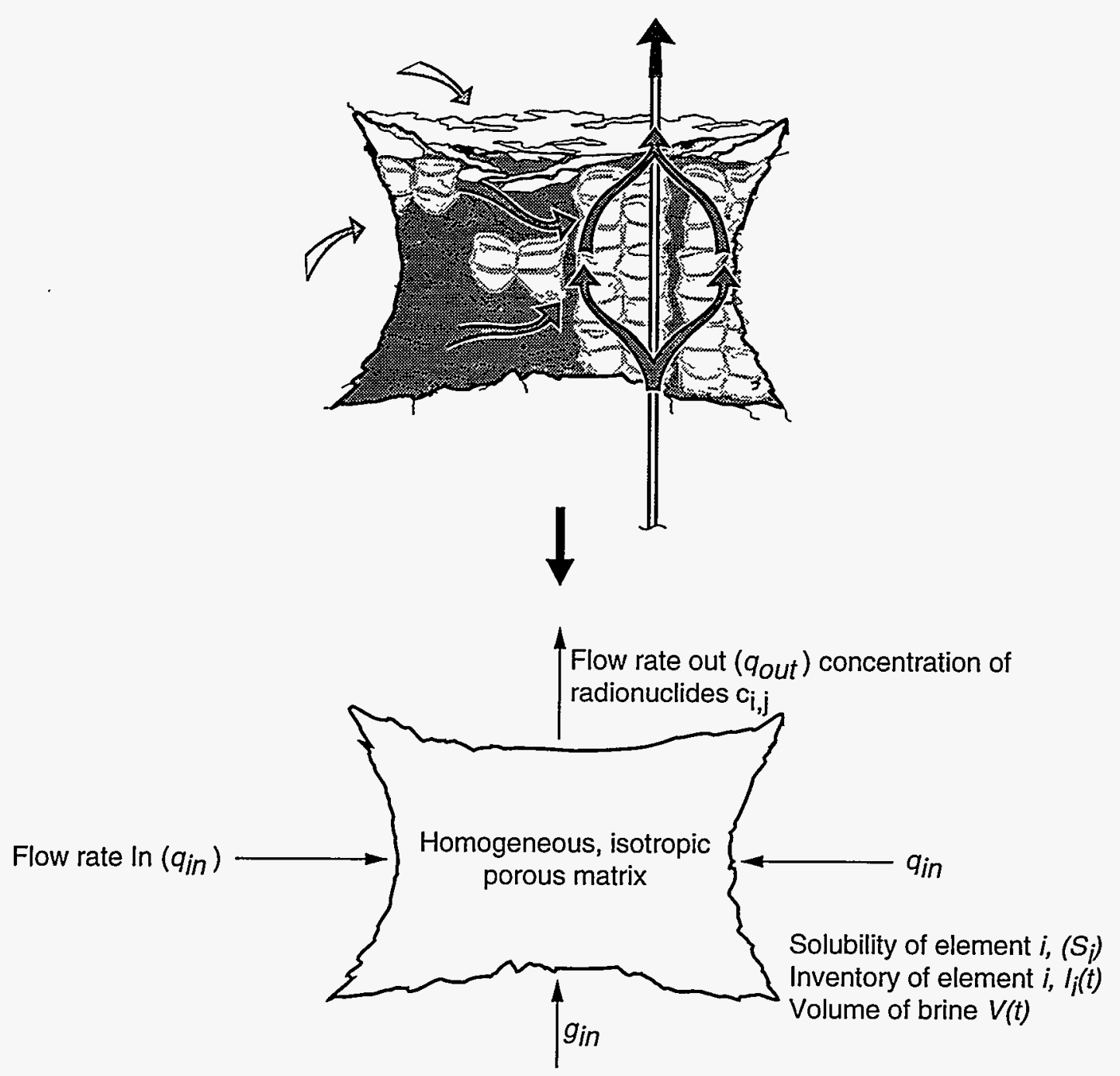

TRI-6342-4396-0

(a)

mass discharge $=\frac{d m_{i}}{d t}=C_{i, j}(t) q_{o u t}\left\{\begin{array}{l}S_{i}\left(\frac{m_{j}}{\sum m_{j}}\right)\left(q_{o u t}\right)-\overbrace{\lambda_{j} m_{j}}^{\text {decay }}+\overbrace{\lambda_{k} m_{k}}^{\text {growth }} \text {, if } I_{i}(t) / v \geq S_{i} \\ \frac{I_{j}(t)}{v(t)}\left(\frac{m_{j}}{\sum m_{j}}\right)\left(q_{o u t}\right)-\lambda_{j} m_{j}+\lambda_{k} m_{k}, \quad \text { if } I_{i}(t) / v<S_{i}\end{array}\right.$

(b)

Figure 5.1-7. Idealization of the WIPP repository for evaluating concentration (or mass discharge) of radionuclides leaving a panel: a) conceptual model and b) mathematical model. 


\subsubsection{Linkage of PANEL Code}

The source-term modeling portion of the repository submodel calculates the amounts of radionuclides that are dissolved from an assumed repository inventory into brines that pass through all or part of the repository. The contaminated brine is then usually transported immediately to the Culebra Dolomite aquifer. The output flow rate to the aquifer is set equal to the rate of brine flow into the repository, as described in Section 5.1.6. These radionuclide concentrations represent the first introduction of radionuclides into the groundwater flow. Thus, they are "source-terms" in the mathematical sense, which explains the name of this subsection, "source-term modeling."

The dissolution of radionuclides from the waste matrix into disposal-room brines is modeled via an infinitely efficient mixing cell. The code that implements this mathematical model is called PANEL ${ }^{1}$ (see Section 5.1.7).

PANEL (1) evaluates radionuclide concentrations discharged from a specified portion of the repository (usually an entire panel) as a function of time. It assumes dissolution equilibrium at all times (infinitely efficient mixing in the cell, and no kinetic effects of dissolution). (2) If sufficient inventories are available, PANEL determines concentrations entirely by solubility. (3) When an element has several isotopes, the relative amount of each isotope in solution is set equal to the relative amount present in the total inventory. (4) PANEL also monitors the natural decay of the radionuclide inventory as a function of time using Bateman's equations. The amount of fluid flowing through PANEL's cell can be input or calculated internally by PANEL assuming simple models of the brine reservoir and Salado Formation. The internally generated flow rates were used only in parts of the 1990 performance assessment. Thereafter, BRAGFLO was used.

PANEL's code-linkage scheme (see Figure 5.1-8) is less complicated than but similar to the process described in Section 5.1.6 for Two-Phase Flow Modeling. Specifically, the simulation begins with GENNET $^{1}$, which is a mesh-generating code similar to but considerably simpler than GENMESH. As PANEL's mesh is a single element, GENNET is adequate. GENNET also creates a template ".CDB" file for PANEL in the CAMDAT data base. MATSET adds constant model parameters such as the inventory (depicted in Section 2.2.1) to the .CDB file. POSTLHS adds sampled model parameters and replicates the .CDB file $n K$ times (depicted in Figure 3.3-5 as Run $1,2, \ldots$ ), once for each sample. PANEL then uses the liquid volume present in a panel, outputted in BRAGFLO's output file, to calculate the maximum radionuclide concentrations that the fluids can carry. An optional step is to use ALGEBRACDB to extract only the flow through the repository panel to speed up the use of the file by PANEL and thereby the calculations. The results are outputted in PANEL's final S\#_R\#.CDB file for use in groundwater-transport calculations for the Culebra aquifer (described in Section $\overline{5} .3$ ). The results can also be used to calculate conditional complementary cumulative distribution functions (CCDFs) using the CCDFCALC and CCDFPLOT codes (described in Section 6.1.6, Software for Calculating Complementary Cumulative Distribution Functions). This step is often performed to allow for comparisons with the final CCDFs calculated at the boundaries of the Waste Isolation Pilot Plant (WIPP) disposal system. An example of the results from PANEL, assuming sufficient water to dissolve all radionuclides at any time, is shown in Section 2.2.3.

\section{Reference}

1 Rechard, R.P., ed. 1992. User's Reference Manual for CAMCON: Compliance Assessment Methodology Controller, Version 3.0. SAND90-1983. Albuquerque, NM: Sandia National Laboratories. 


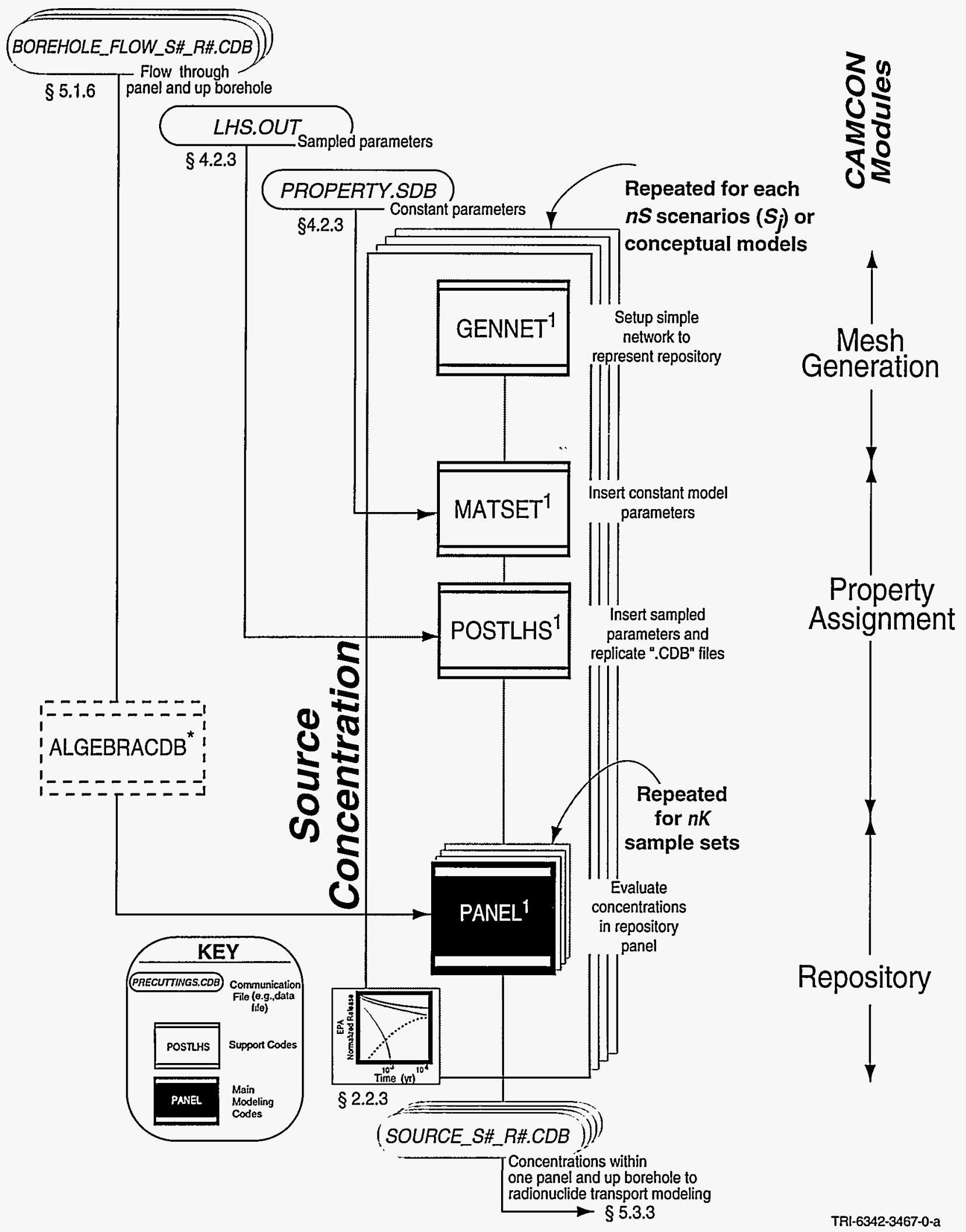

Figure 5.1-8. Linkage of PANEL to the modeling system to evaluate concentrations of radionuclides with one panel of the WIPP repository. The use of ALGEBRACDB to extract only the flow values through the repository panel is optional but greatly speeds up the calculation. 
5.0 Consequence Analysis 


\subsection{Groundwater Flow Modeling}

Groundwater flow modeling within the Culebra Dolomite Member of the Rustler Formation consists of two main models and two corresponding groups of software. The first model generates spatially varying transmissivity ${ }^{*}$ fields over the domain of interest of the Culebra Dolomite. The second model simulates groundwater flow on both regional and local scales of that spatial domain. Transmissivity fields are required parameters for groundwater flow, and their generation is therefore a necessary precursor to groundwater flow modeling. Groundwater-flow simulations modeling software simulates local and regional fluid-flow conditions within (1) a small region immediately overlying the repository and (2) a larger region surrounding the disposal system. Only the liquid phase is treated within the aquifer, so the working fluid is brine. Once a fluid-flow field has been evaluated for each sample set of flow parameters on the regional and local domains, the transport of radionuclides within each of the flow fields is predicted in the third portion of the consequence model (see Section 5.3, Radionuclide Transport Modeling).

Sections 5.2.1 through 5.2.5 discuss groundwater-flow modeling. Sections 5.2.6 and 5.2.7 discuss the generation of the transmissivity fields. As noted above, this is the reverse order in which the simulations are actually run, but a general discussion of groundwater-flow modeling was thought to be of interest to a wider audience and to help the general reader understand the need for the transmissivity fields. Sections 5,2.1 through 5.2.3 present examples of results of groundwater flow modeling. Because the software used for evaluating results differed substantially in the 1990 and 1992 performance assessment calculations, the code linkages for both years are described in Sections 5.2.4 and 5.2.5.

"Transmissivity $(T)$ is the rate at which water, driven by a unit hydraulic gradient, is transmitted through a unit width of aquifer. It is the hydraulic conductivity $(K)$ times the thickness of the aquifer, where hydraulic conductivity measures the ability of a rock or soil to allow fluid to pass through it. In tum, hydraulic conductivity is a function of the intrinsic permeability $(K)$ of the media and the viscosity $(\mu)$ and density $\left(\rho_{f}\right)$ of the fluid. 


\subsubsection{Regional and Local Groundwater Flow Modeling}

Groundwater flow in the Culebra Dolomite located above the Waste Isolation Pilot Plant (WIPP) repository is modeled on both regional and local spatial scales (Figure 5.2-1) (see also Chapter 2.0, Disposal System and Regional Characterization). Climate effects, described in Section 2.1.6, are incorporated into the regional model via time-varying boundary conditions. Boundary conditions for the local scale are interpolated from pressures calculated during the regional simulation.

The conceptual model for evaluating groundwater fluid flow in the Culebra Dolomite consists of the following assumptions: (1) single-porosity Darcian flow (however, dual porosity effects on transport are considered; see Section 5.3.2), (2) two-dimensional flow through uniform thickness aquifer even though localized flow in certain cross-sections is known to occur because most hydrologic test wells (see Section 2.1.5) are completed across entire Culebra thickness, (3) axis of Nash Draw treated as a streamline (noflow) boundary, (4) hydraulic heads (related to fluid pressure) assumed to be in equilibrium with heads around the boundary of the regional modeling domain, (5) future changes in flow induced solely by changes in recharge from climate change on northern boundary of domain, (6) no flow ("leakage") through bottom and top planes of the aquifer as indicated by differences in heads between adjacent layers of the Rustler Formation.

The mathematical model solved in two dimensions $(x, y)$ is ${ }^{2}$

$$
S_{s} \frac{\partial}{\partial t}=\nabla \bullet(\bar{K} \cdot \nabla h)-W,
$$

where $h=h(x, y, t)$, the potentiometric head (m), $S_{S}=S_{S}(x, y, t)$, the specific storage of the Culebra $\left(\mathrm{m}^{-1}\right)$, $\bar{K}=\bar{K}(x, y, t)$, the hydraulic conductivity tensor $(\mathrm{m} / \mathrm{s})$, and $W=W(x, y, t)$, a volumetric flux per unit volume of formation $\left(\mathrm{s}^{-1}\right)$, (used to simulate wells or recharge).

The specific storage and hydraulic conductivity tensor are obtained from more directly measurable quantities,

$$
S_{s} \frac{S(x, y)}{\Delta Z}, \bar{K}=\frac{\bar{T}(x, y)}{\Delta Z},
$$

where $S(x, y)=$ storage coefficient in the Culebra (dimensionless) and $\Delta Z(x, y)$, Culebra thickness $(\mathrm{m})$.

From given initial and boundary conditions, the mathematical model is solved numerically to yield Darcy velocity (or specific discharge) for use in evaluating radionuclide transport (see Section 5.3): ${ }^{2}$

$$
q_{i}(x, y, t)=-\bar{K} \bullet \nabla h(\mathrm{~m} / \mathrm{s}) .
$$

Either of two codes may be used to model groundwater flow. They are as follows: (1) SECOFL2D, 1 developed by the Performance Assessment Department, which automates the calculation of and interaction between the regional and local modeis, and (2) several other flow codes including STAFF2D, ${ }^{2}$ SUTRA, ${ }^{3}$ and SWIFT ${ }^{4}$ in concert with various support modules that can be linked in a serial procedure using the CAMCONexec driver ${ }^{5}$ to calculate regional flow, interpolate properties and pressures onto the local grid and boundary, and calculate local flow. The first procedure uses a code specifically tailored for analysis of the WIPP and is more streamlined. The second procedure allows the analyst to use the capabilities of a greater number of available flow codes. Sections 5.2.2 and 5.2.3 present examples of results from the groundwater-flow modeling. Sections 5.2.4 and 5.2.5 describe the two procedures for linking the above codes.

\section{References}

1 Rechard, R.P., ed. 1992. User's Reference Manual for CAMCON: Compliance Assessment Methodology Controller, Version 3.0. SAND90-1983. Albuquerque, NM: Sandia National Laboratories.

2 Sandia WIPP Project. 1992. Preliminary Performance Assessment for the Waste Isolation Pilot Plant, December 1992. Volume 3: Model Parameters. SAND92-0700/3. Albuquerque, NM: Sandia National Laboratories.

3 WIPP PA (Performance Assessment) Department. 1993. Preliminary Performance Assessment for the Waste Isolation Pilot Plant, December 1992. Volume 4: Uncertainty and Sensitivity Analyses for 40 CFR 191, Subpart B. SAND92-0700/4. Albuquerque, NM: Sandia National Laboratories. 


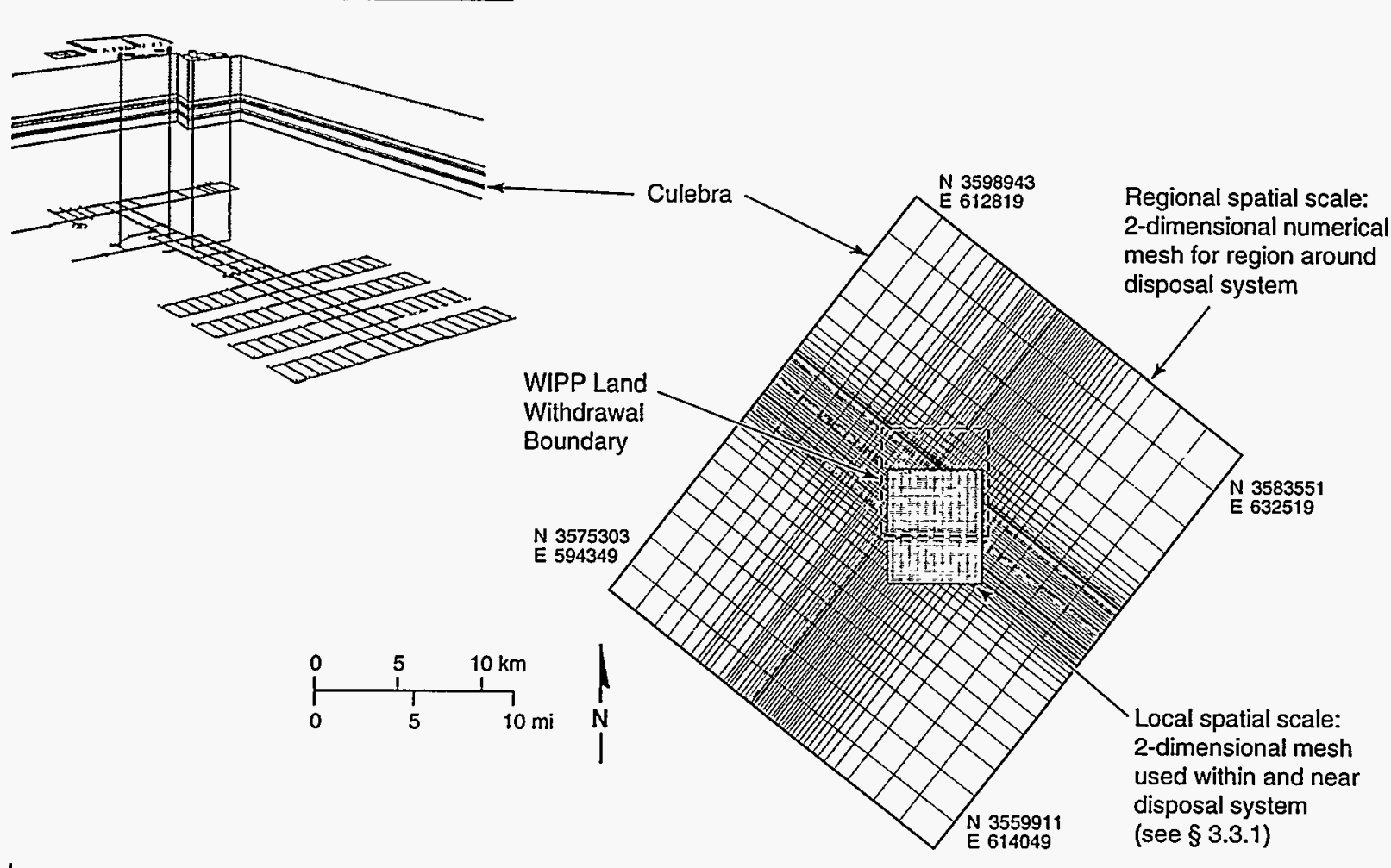

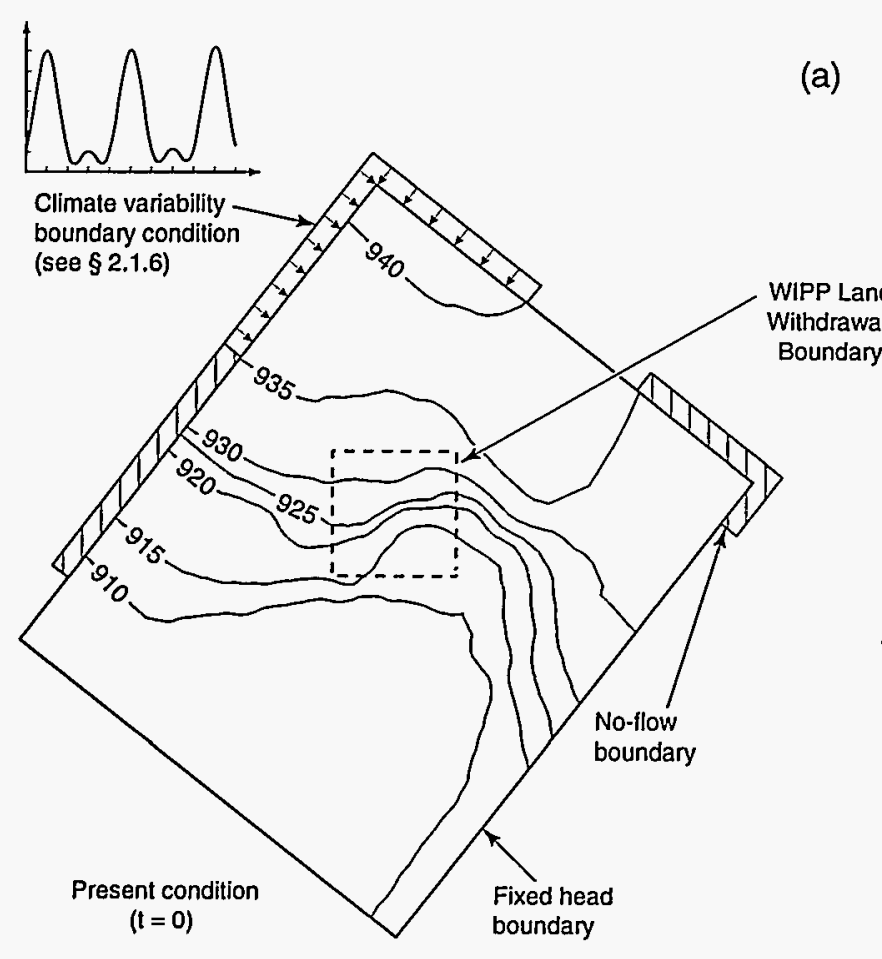

(b)

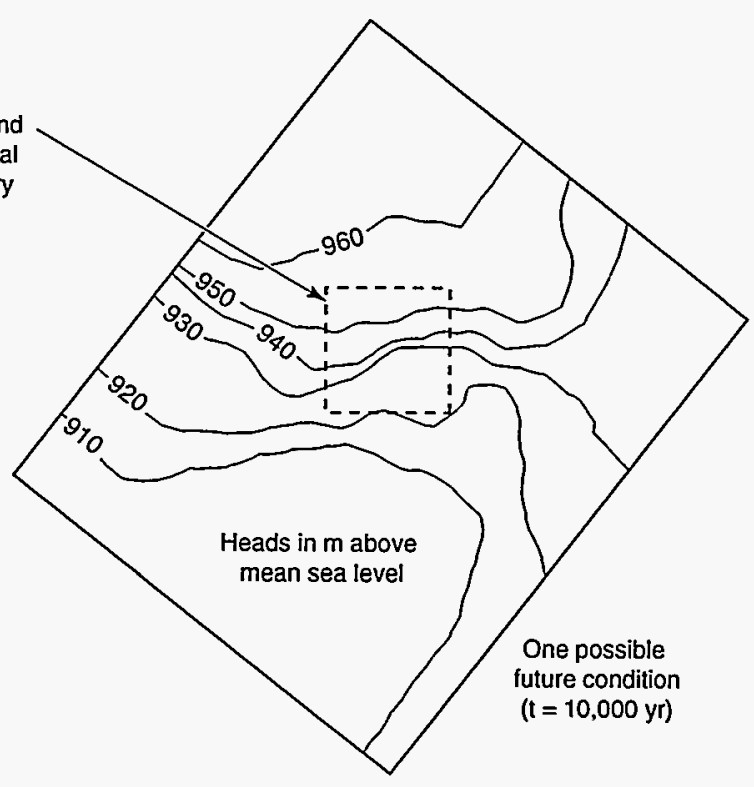

TRI-6342-4501-0

Figure 5.2-1. Regional and local groundwater flow modeling of brine aquifer in the Culebra Dolomite Member of the Rustler Formation $\sim 300 \mathrm{~m}$ above the WIPP repository horizon (see Section 2.2.1): (a) regional and local meshes, (b) contours of equal hydraulic head $\left(h=\frac{p}{\rho g}+z\right)$ for conditions at present and conditions 10,000 $\mathrm{yr}$ in the future from change in climate for one sample in 1992 performance assessment. $^{3}$ 


\subsubsection{Cumulative Travel-Time Distributions}

In the CAMCON modeling system, groundwater-flow fields are used directly by the codes of the groundwater-transport module (see Section 5.3, Radionuclide Transport Modeling) to evaluate radionuclide transports. However, a distribution of travel times of neutrally buoyant particles from the

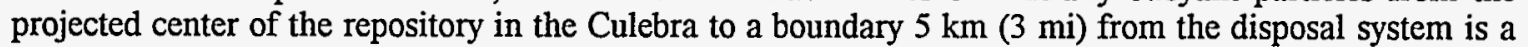
convenient way to summarize the results of the groundwater-modeling step. The resultant distribution of travel times is presented in Figure 5.2-2. The method of calculating particle paths is shown in Section 5.2.3. In general, the travel times of neutrally buoyant particles varied over $27,000 \mathrm{yr}$ for the transmissivity fields generated in the 1992 performance assessment calculations. ${ }^{1}$ (See Section 5.2.3 for examples of particle paths from which the distribution of travel time was evaluated.)

\section{Reference}

1 Sandia WIPP Project. 1992a. "Appendix C: Realizations of Transmissivity Fields in the Culebra Dolomite Member of Rustler Formation," Preliminary Performance Assessment for the Waste Isolation Pilot Plant, December 1992. Volume 3: Model Parameters. SAND92-0700/3. Albuquerque, NM: Sandia National Laboratories. C-1 through C-73. 


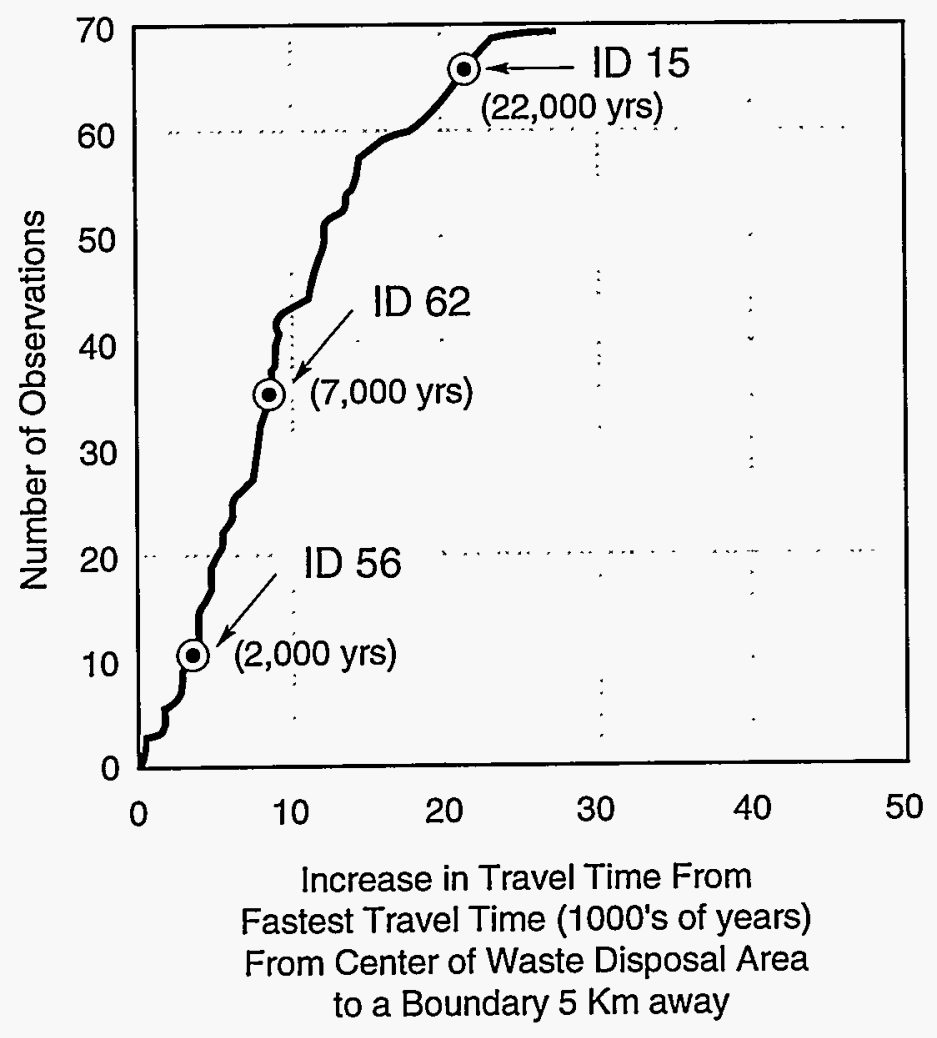

Field ID 56

Field ID 62

Field ID 15

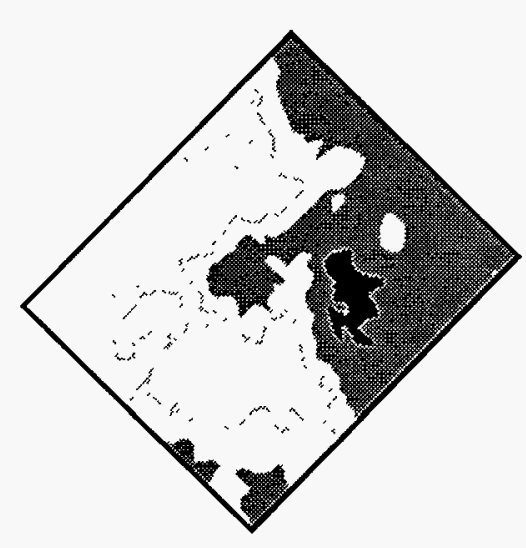

Highest Transmissivity

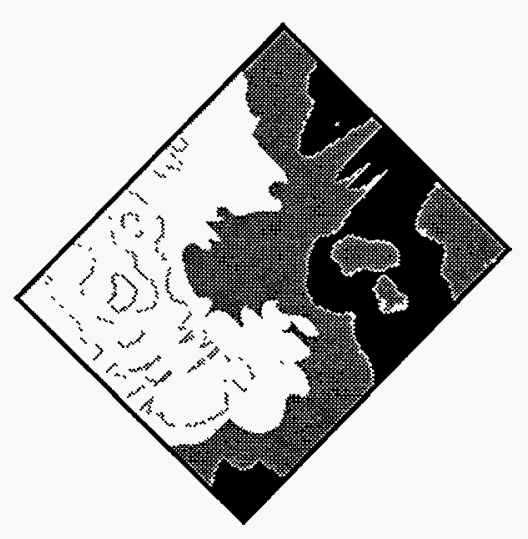

Lowest Transmissivity

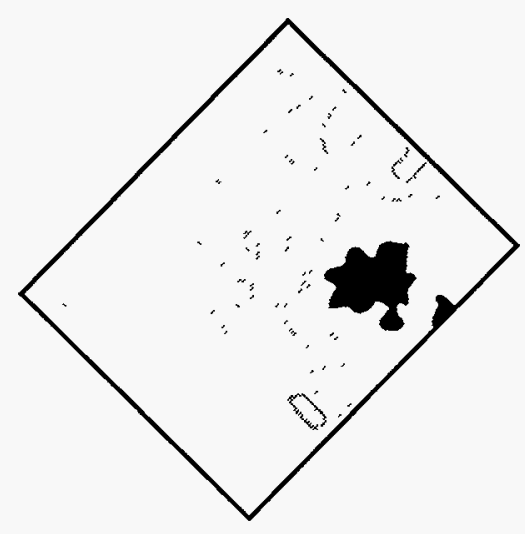

TR!-6342-3489-0

Figure 5.2-2. Cumulative distribution travel time to the maximum 5-km ( $3 \mathrm{mi})$ boundary of the Waste Isolation Pilot Plant disposal system, using transmissivity fields calculated for the 1992 performance assessment simulations (see Section 5.2.7). Travel times change dramatically if matrix or fraction porosity are used. The relative change (rather than absolute value) in travel times across the simulated transmissivity fields assuming contaminated movement through the matrix porosity is presented. 


\subsubsection{Neutrally Buoyant Particle Paths}

A possible summary measure of the groundwater flow is the envelope of shapes of paths taken by neutrally buoyant particles through the various fluid-flow fields (see Figure 5.2-3). Particles are released at an intrusion borehole intersecting the center of the repository. Using the first 20 flow fields generated in the 1992 performance assessment calculations, a considerable variation in travel pathways to the Waste Isolation Pilot Plant (WIPP) disposal-system boundary is observed (the WIPP land-withdrawal boundary is $\sim 2.4 \mathrm{~km}(1.5 \mathrm{mi})$ from the outer edge of the repository). The method of calculating particle paths is shown in Sections 5.3.2 and 5.3.3.

\section{Reference}

1 Rechard, R.P., ed. 1993. Initial Performance Assessment of the Disposal of Spent Nuclear Fuel and High-Level Waste Stored at Idaho National Engineering Laboratory. Volume 1: Methodology and Results. SAND932330/1. Albuquerque, NM: Sandia National Laboratories. 


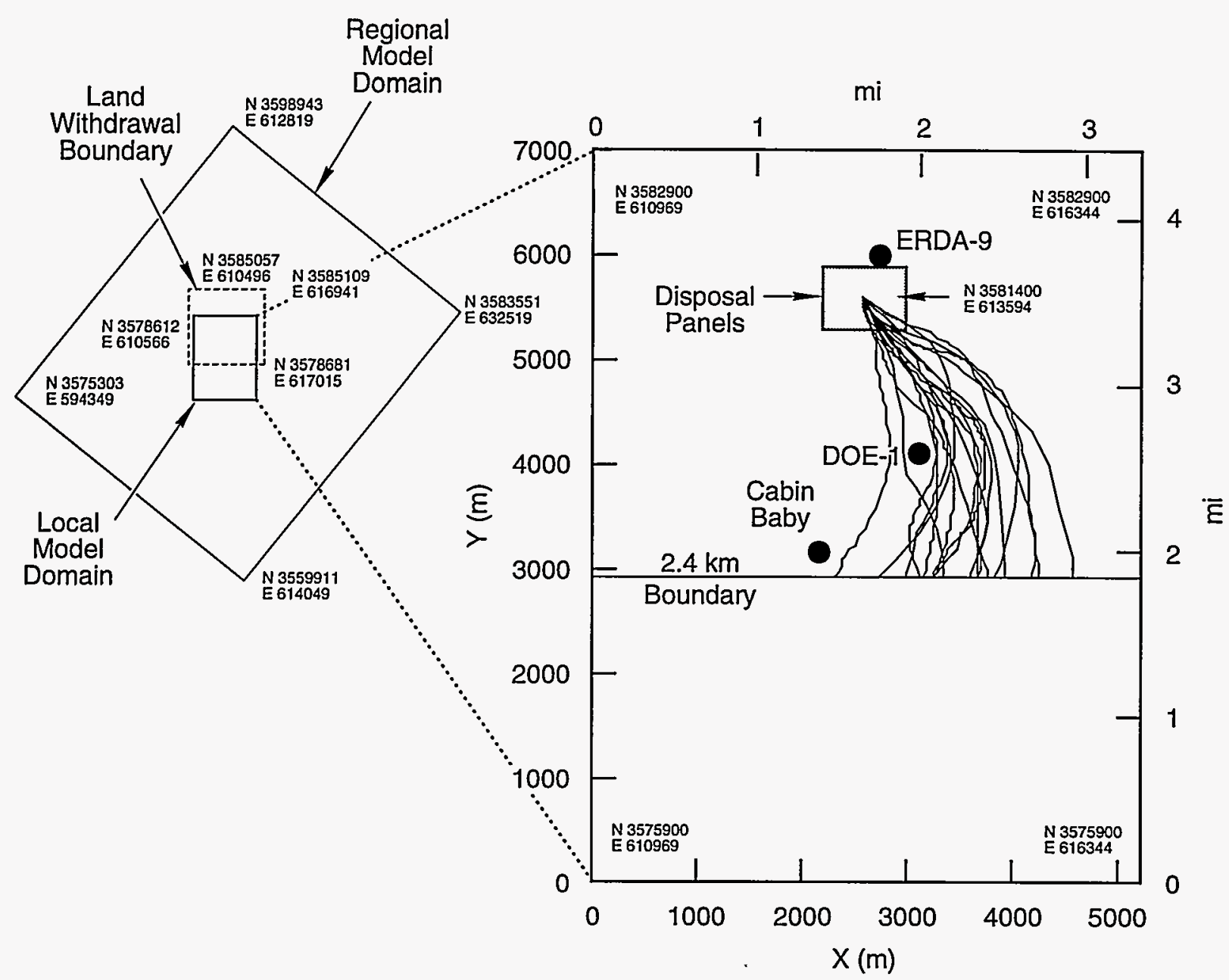

TRI-6342-4315-0

Figure 5.2-3. Paths for neutrally buoyant particles released in the Culebra Dolomite Member of the Rustler Formation at an intrusion borehole intersecting the center of the repository, based on the first 20 flow fields generated from the 1992 performance assessment calculations (after Rechard, ed., 1993, Figure 12-27). 1 


\subsubsection{Linkage for 1990 Groundwater-Flow Simulations}

In the 1990 and some of the 1991 performance assessment calculations, various general-purpose groundwater flow codes, including STAFF2D, ${ }^{1}$ SUTRA, ${ }^{2}$ and SWIFT, ${ }^{3}$ were used to predict the groundwater-flow regime over both regional and local flow domains of the brine aquifer within the Culebra Dolomite Member of the Rustler Formation. The three codes are described as follows:

STAFF2D models single- or dual-porosity fluid flow and radionuclide transport using a finiteelement numerical solution technique. Specifically, STAFF2D is a two-dimensional finite-element code designed to simulate confined and unconfined groundwater flow and single- or multiplecomponent solute transport in fractured or granular aquifers. Fractured porous media are represented using both discrete-fracture and dual-porosity approaches.

SUTRA evaluates saturated or unsaturated density-dependent groundwater flow with either (1) solute transports subject to equilibrium adsorption and zero- and first-order production or decay or (2) thermal-energy transports within the groundwater and solid matrix of the aquifer. SUTRA approximates the governing equations using two-dimensional, finite-element and integrated finitedifference methods.

SWIFT_II is a general-purpose code for solving transient, three-dimensional, and coupled equations for fluid flow, heat transport, brine-miscible displacement, and radionuclide-miscible displacement in porous or fractured media.

In general, several steps were necessary to link these codes to other portions of the consequence model. First, it was necessary to create regional and local CAMDAT ${ }^{4}$ data bases (groupings of .CDB files) for groundwater flow modeling. The regional input .CDB files were created from the files containing transmissivity fields (TFIELDS_R\#.CDB) (created in Section 5.2.6). POSTLHS ${ }^{1}$ was exercised to add sampled parameters. ALGEBR $\bar{A} C \mathrm{CB}^{1}$ was then run to calculate parameters specifically required by the flow codes (see Section 3.3.3, Support Codes Used in the Modeling System, for a description of ALGEBRACDB). The groundwater flow codes followed, including any pre- and/or post-processor codes that were required. Climate changes were modeled as time-dependent boundary conditions (as described in Section 2.1.6). Using RELATE, ${ }^{1}$ results were interpolated (as boundary conditions) and pertinent parameters were transferred from the regional model domain onto a local-scale model domain previously created using GENMESH. ${ }^{1}$ One of the above flow codes, not necessarily the same one used for the regional flow, was then used to calculate the local groundwater flow regime (see Figure 5.2-4). The local fluid-velocity fields (LOCAL_FLOW_R\#.CDB) were saved for subsequent use in groundwater transport modeling (described in Section 5.3).

\section{References}

1 Huyakorn, P.S., H.O. White, Jr., and S.M. Panday. 1991. STAFF2D Solute Transport and Fracture Flow in 2Dimensions. Herndon, VA: HydroGeoLogic, Inc. (Copy on file at the Sandia WIPP Central Files, Sandia National Laboratories, Albuquerque, NM.)

2 Voss, C.I. 1984. SUTRA (Saturated-Unsaturated Transport): A Finite-Element Simulation Model for SaturatedUnsaturated, Fluid-Density-Dependent Ground-Water Flow with Energy Transport or Chemically-Reactive Single-Species Solute Transport. Water-Resources Investigations Report 84-4369. Reston, VA: U.S. Geological Survey. (SUTRANUC is a version of SUTRA modified by Department 6342 at Sandia National Laboratories for transport of multiple nuclide decay chains.)

3 Reeves, M., D.S. Ward, N.D. Johns, and R.M. Cranwell. 1986a. Data Input Guide for SWIFT II, The Sandia Waste-Isolation Flow and Transport Model for Fractured Media, Release 4.84. SAND83-0242, NUREG/CR3162. Albuquerque, NM: Sandia National Laboratories.

4 Rechard, R.P., ed. 1992. User's Reference Manual for CAMCON: Compliance Assessment Methodology Controller, Version 3.0. SAND90-1983. Albuquerque, NM: Sandia National Laboratories. 


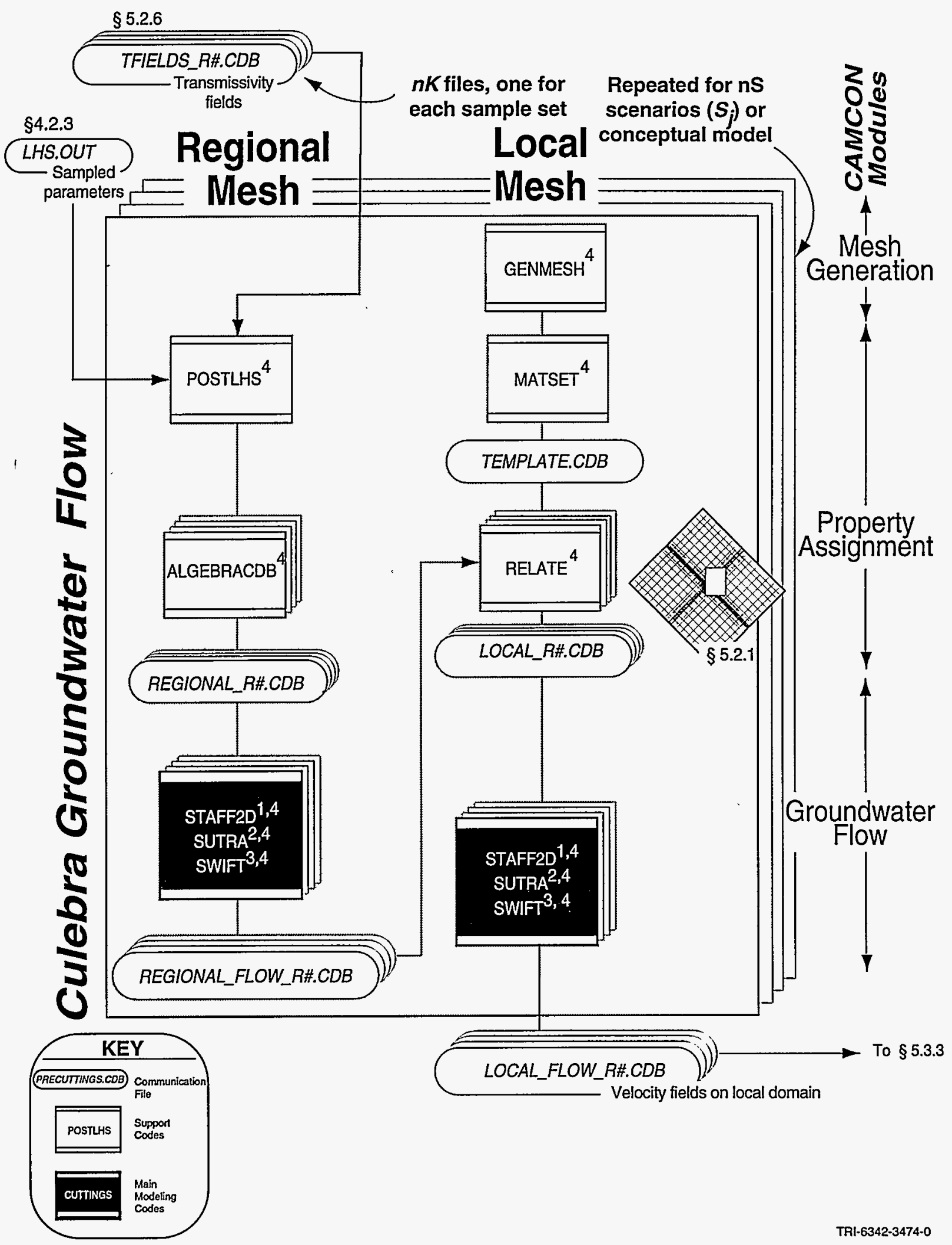

Figure 5.2-4. Linkage of software to calculate the groundwater flow regime (i.e., spatial distribution of brine velocity) within the Culebra Dolomite Member of the Rustler Formation in the 1990 and 1991 performance assessment calculations. 


\subsubsection{Linkage of the SECOFL2D Flow Code}

In the $1991^{*}$ and 1992 performance assessment calculations, SECOFL2D was used to predict the groundwater-flow regime on a regional and local model domain for the brine aquifer in the Culebra Dolomite Member of the Rustler Formation, which overlies the Waste Isolation Pilot Plant. SECOFL2D is described as follows:

SECOFL2D simulates groundwater flow by solving a partial differential equation with head (water elevation) as the solution variable. It uses a fully implicit, finite-difference numerical solution technique. Problems may be run on regional and local model domains in which the local grid is decoupled from the regional mesh in space and time. The code is designed so that the numerical computational meshes are decoupled from the grid-defining material properties. A user's and theory manual is in preparation.

In general, several steps are necessary to link SECOFL2D to other portions of the consequence model (see Figure 5.2-5) using the CAMCON modeling system, but the steps are similar to those required for linking other general-purpose groundwater-flow codes described in Section 5.2.4. First, it is necessary to create regional and local CAMDAT ${ }^{1}$ data base files (".CDB files") for groundwater flow modeling using GENMESH $^{1}$ and MATSET (see Section 3.3.3, Support Codes Used in the Modeling System, for a description of GENMESH, MATSET, and ALGEBRACDB used here). POSTLHS, ${ }^{1}$ a postprocessing code for LHS $^{1}$ is then used to add sampled parameters to the regional .CDB file. The transmissivity fields (TFIELDS R\#.CDB), one for each sample set, are then merged with the regional files (REGIONAL_R\#.CDB). The analyst can use ALGEBRACDB to evaluate specific parameters needed by SECOFL2D, but it is not usually necessary at this point. The regional files (REGIONAL_R\#.CDB) and one file for the local model domain (LOCAL_R\#.CDB) are used by the preprocessor to SECOFL2D to create input files for SECOFL2D, which calculates both the regional and local groundwater flow regime, and most importantly the fluid-flow velocities. The flow velocities on the local-scale domain are used (in double precision) in subsequent groundwater-transport simulations (described in Section 5.3, Radionuclide Transport Modeling).

\section{Reference}

1 Rechard, R.P., ed. 1992. User's Reference Manual for CAMCON: Compliance Assessment Methodology Controller, Version 3.0. SAND90-1983. Albuquerque, NM: Sandia National Laboratories.

- Other groundwater flow codes were also used in 1991. See Section 5.2.4. 


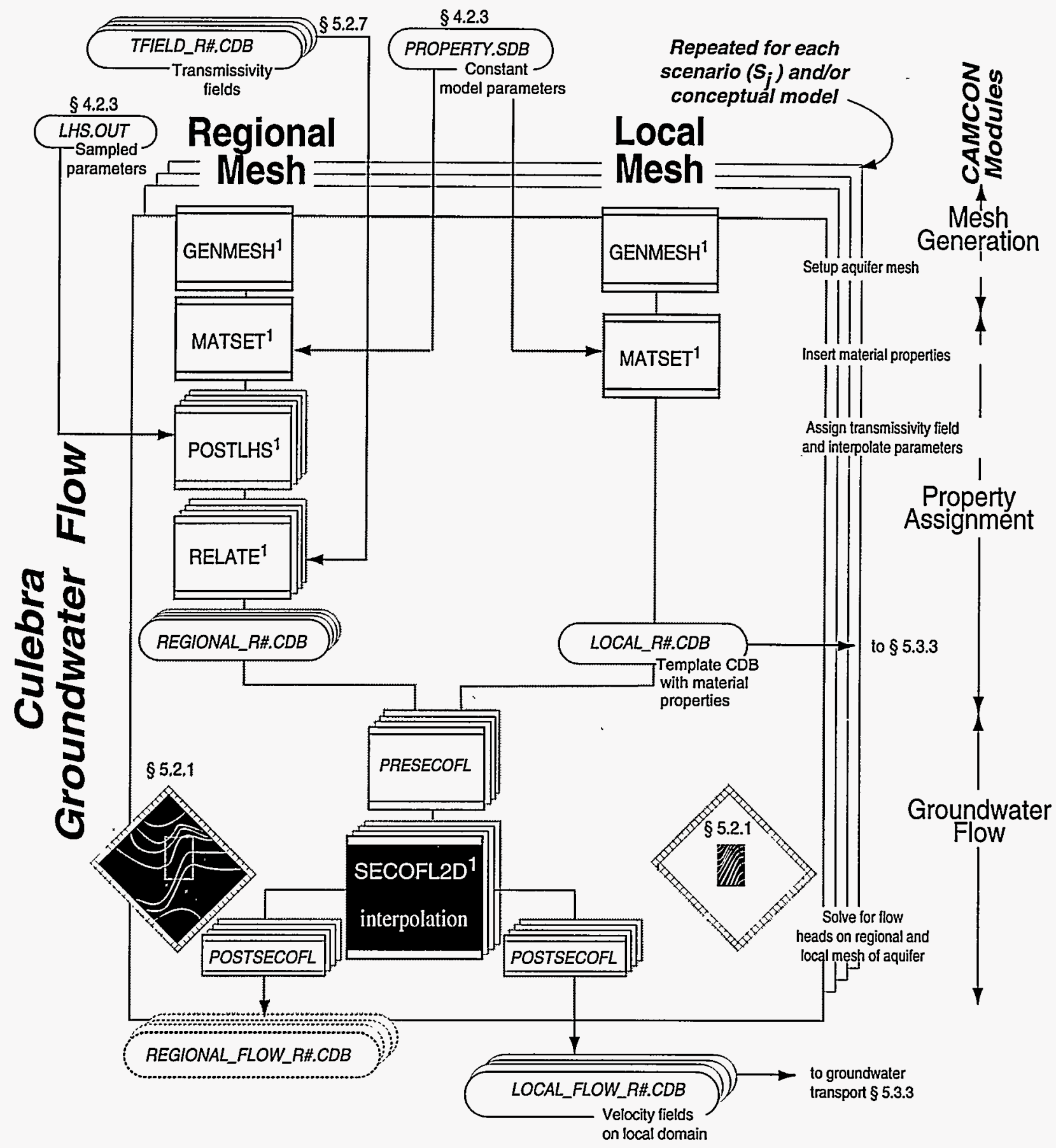

TRI-6342-3475-0

Figure 5.2-5. Linkage of SECOFL2D in the modeling system to calculate velocity of brine moving through the Culebra Dolomite in the 1991 and 1992 performance assessment calculations. 


\subsubsection{Generating Transmissivity Fields}

Efforts to incorporate uncertainty into numerical representations of the Culebra's transmissivity ${ }^{*}$ field have been evolutionary. In the 1990 performance assessment (PA), the Culebra was divided into seven zones or regions. A mean transmissivity value and an associated standard deviation were assigned to each zone. By sampling from the distributions associated with each zone, multiple realizations of zonal transmissivity values were created and subsequently used as input to flow and transport calculations. Although computationally simple, this specification of transmissivity zones significantly reduced the spatial variability within a given realization because each zone was characterized by a constant value. Moreover, in a given realization, large differences in the values assigned to neighboring zones could occur, leading to artificial internal boundaries over which abrupt changes in transmissivity occurred.

In an effort to improve the accuracy and representativeness of the transmissivity fields used in the 1991 PA calculations, simulations of Culebra transmissivity fields were produced that agreed with observed transmissivity values at all tested wells. ${ }^{1}$ This work resulted in 60 transmissivity fields that were also in acceptable agreement with steady-state, freshwater heads calculated from observed water elevations in the region around the Waste Isolation Pilot Plant (see Section 2.1.5 for location of observation wells).

The transmissivity fields of the Culebra Dolomite aquifer were evaluated, in the 1991 PA calculations, using GARFIELD, GENOBS, FITBND, and the groundwater-flow code SWIFT II. ${ }^{2,3}$ The procedure consisted of exercising GARFIELD, which randomly generated hundreds of transmissivity fields from tests at scattered wells (see Section 2.1.5) (see Figure 5.2-6). The estimated mean transmissivity and estimated error were determined for each block of the regional grid previously generated by GENMESH using generalized kriging, which is a type of interpolation that takes account of known or assumed statistical properties of the field that is being interpolated. GARFIELD rapidly created the transmissivity fields using Cholesky decomposition * * of the matrix consisting of covariances of transmissivities measured at the wells. Using GENOBS, a set of linear impulse functions for selected segments of the mesh was generated. The number and shape of the perturbations were controlled independently of the mesh. The steady-state response of modeled pressures (using the hundreds of Culebra transmissivity fields, taken one at a time) to the generated impulse functions was evaluated using the hydrologic code SWIFT II. Finally, FITBND was used to select a weighting of the boundary-condition perturbations, based on minimizing errors with respect to the known, steady-state, freshwater heads at the wells. In the 1991 PA calculations, 45 parameters were assumed uncertain. The number of samples, $n K$, was usually taken approximately equal to $4 / 3$ of the number of uncertain (varied) parameters, $n V$. Hence, 60 samples were taken for propagating uncertainty (see Section 1.3.1). The first $n K(60)$ transmissivity fields that had (1) good agreement (i.e., small error) with the freshwater heads and (2) good subjective agreement with known flow directions and magnitudes in the area were retained. ${ }^{4}$

\section{References}

1 LaVenue, A.M., T.L. Cauffman, and J.F. Pickens. 1990. Ground-Water Flow Modeling of the Culebra Dolomite. Volume I: Model Calibration. SAND89-7068/1. Albuquerque, NM: Sandia National Laboratories.

2 Reeves, M., D.S. Ward, N.D. Johns, and R.M. Cranwell. 1986a. Data Input Guide for SWIFT II, The Sandia Waste-Isolation Flow and Transport Model for Fractured Media, Release 4.84. SAND83-0242, NUREG/CR3162. Albuquerque, NM: Sandia National Laboratories.

3 Rechard, R.P., ed. 1992. User's Reference Manual for CAMCON: Compliance Assessment Methodology Controller, Version 3.0. SAND90-1983. Albuquerque, NM: Sandia National Laboratories.

4 Rechard, R.P. 1991b. "Introduction," Preliminary Comparison with 40 CFR Part 191, Subpart B for the Waste Isolation Pilot Plant, December 1991. Volume 2: Probability and Consequence Modeling. WIPP Performance Assessment Division. SAND91-0893/2. Albuquerque, NM: Sandia National Laboratories. 1-1 through 1-22.

* Transmissivity (T) is the rate at which water, driven by a unit hydraulic gradient, is transmitted through a unit width of aquifer. It is the hydraulic conductivity $(K)$ times the thickness of the aquifer, where hydraulic conductivity measures the ability of a rock or soil to allow fluid to pass through it. In turn, hydraulic conductivity is a function intrinsic permeability $(K)$ of the media and the viscosity and density ( $\rho f)$ of the fluid.

* * Cholesky decomposition is a type of matrix inversion. 


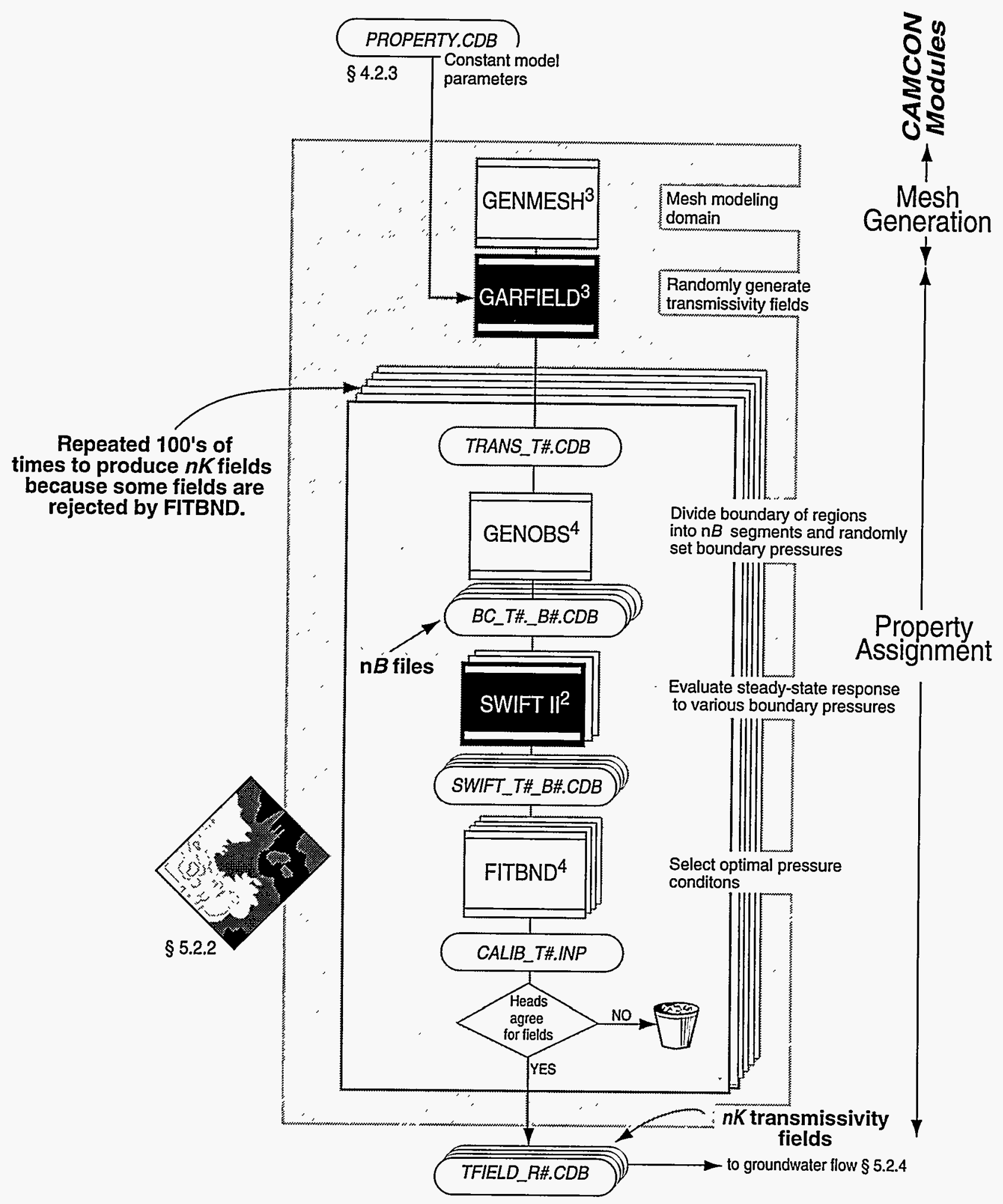

TRI-6342-3462-0

Figure 5.2-6. Linkage of software to generate fields of the Culebra Dolomite transmissivity (hydraulic conductivity times aquifer thickness) in the 1991 performance assessment calculations. 


\subsubsection{Transmissivity Fields by Pilot Points}

In 1992 performance assessment (PA) calculations, pilot-point methods were used to generate transmissivity fields over the calculational grid. ${ }^{1}$ The method involves generation of a large number of random transmissivity fields, each of which is in close agreement with all the measured data at the Waste Isolation Pilot Plant (WIPP) site, namely (1) hydraulic conductivity measurements of samples and (2) steady-state pressure measurements for in-situ well tests, and (3) transient pressure measurements (see Section 2.1.5, Hydrological Characterization of the Culebra). Agreement between generated transmissivity fields and the measured data was achieved by taking the following steps:

1. First, statistically conditioned simulations of the WIPP transmissivity fields were generated. These were random fields that had the same statistical moments (the mean and the variance) and the same spatial correlation structure as the WIPP site's field, based on transmissivity measurements. The generated fields did not generally match the measured transmissivities at every location. However, the two fields were statistically similar.

2. These transmissivity fields were further conditioned so that they agreed with measured transmissivities at every location where hydraulic conductivity measurements were available. The resulting fields are called conditional simulations of the transmissivity field.

3. The conditional simulations of the transmissivity field were still further conditioned, such that the steady and transient pressures computed by the groundwater-flow model agreed closely with measured pressures in a least-squares sense. This step is known as calibration and involves solution of the inverse problem. It accounted for a large part of the time and effort devoted to transmissivity-field generation in the 1992 PA calculations. When the calibration was completed, a random transmissivity field was obtained that conforms with all the data. It is therefore regarded as a plausible representation of the transmissivity field of the Culebra aquifer at the WIPP site.

Calibration is an indirect process. An objective function is defined as the weighted sum of the squared deviations between the model-computed pressures and the observed pressures, the summation being extended in the spatial and temporal domain where pressure measurements were taken. The calibration process endeavors to minimize the objective function by iteratively adjusting the transmissivity field, recalculating pressures using the time-varying groundwater equations, recalculating the objective function, and continuing iteratively until the objective function is reduced to a prescribed minimum value.

Iterative adjustment of the transmissivity fields is accomplished through pilot points, which are artificial transmissivity data points that are intentionally added to the observed transmissivity data set during the course of calibration. A pilot point is characterized by its spatial location and the transmissivity value assigned to it. Addition of a pilot point thus increases or decreases the transmissivity in the neighborhood of the point, which increases or decreases the flow locally and adjusts the local pressure distributions correspondingly. After a pilot point is added to the transmissivity data set, the augmented data set is kriged to generate an adjusted transmissivity field for subsequent solution and calibration. Usually, the kriged transmissivity field is modified most in the neighborhood of the pilot point. Modifications in the different grid blocks are determined by kriging weights, which are not necessarily uniform over the field as a whole.

A coupled kriging-and-adjoint sensitivity analysis was used in 1992 to determine best locations for pilot points. Optimization algorithms were used to assign pilot-point transmissivities. In that way, the pilot-point approach to calibration was more objective, a feature considered desirable for assessing the performance of the WIPP disposal system.

The software for this task was assembled from many codes already developed and frequently used in groundwater-flow simulations (Figure 5.2-7). The codes are listed below. Interested readers will find details of the theory and application of these codes in the references cited below.

TUBA, unconditional simulation of transmissivity field (Zimmerman and Wilson, 1990) ${ }^{2}$

AKRIP, generalized kriging (Kafritsas and Bras, 1981) ${ }^{3}$

SWIFT II, modeling pressures (steady and transient state) (Reeves et al., 1986a,b,c) 4,5,6

GRASP II, adjoint sensitivity analysis (steady and transient state) (Wilson et al., 1986 7; RamaRao and Reeves, $1990^{8}$ ) 

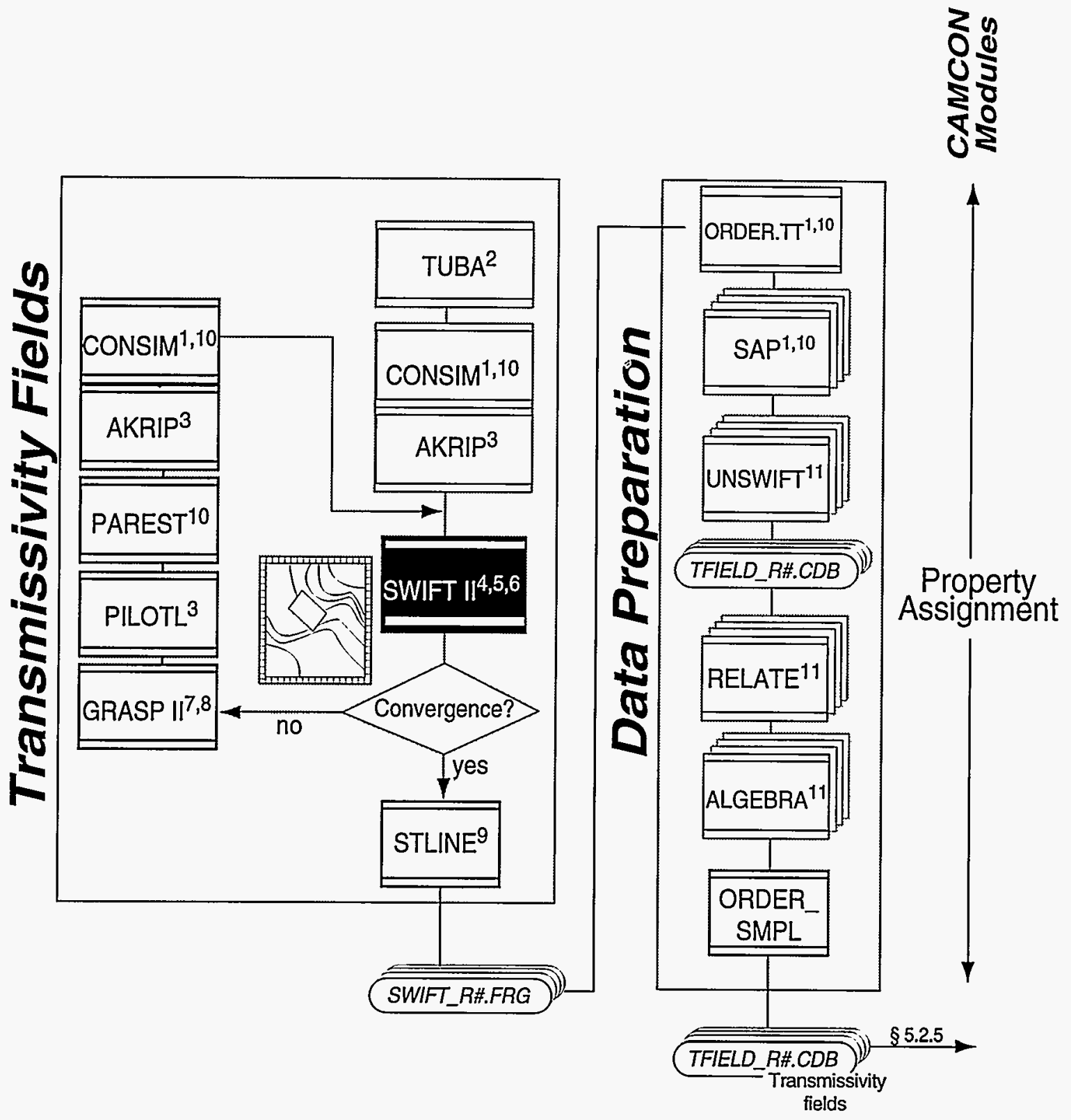

TRI-6342-3476-0

Figure 5.2-7. Linkage of software to generate transmissivity fields by the pilot-point method in the 1992 performance assessment calculations (see Section 5.2.2 for example of results). 
STLINE, groundwater travel time and travel paths (Intera, 1989) ${ }^{9}$

MAIN, drives the different modules (WIPP PA Dept., 1992; LaVenue and RamaRao, 1992) 1,10

CONSIM, generates conditional simulations of transmissivity from the unconditional simulations of transmissivity (WIPP PA Dept., 1992; LaVenue and RamaRao, 1992) 1,10

PILOTL, locates the pilot points based on sensitivity analysis (Kafritsas and Bras, 1981) ${ }^{3}$

PAREST, assigns the pilot point transmissivities by minimization of a least-square objective function (LaVenue and RamaRao, 1992) ${ }^{1}$

\section{References}

1 LaVenue, A.M., and B.S. RamaRao. 1992. A Modeling Approach To Address Spatial Variability within the Culebra Dolomite Transmissivity Field. SAND92-7306. Albuquerque, NM: Sandia National Laboratories.

2 Zimmerman, D.A., and J.L. Wilson. 1990. Description of and User's Manual for TUBA: A Computer Code for Generating Two-Dimensional Random Fields via the Turning Bands Method. Albuquerque, NM: SeaSoft Scientific \& Engineering Analysis Software. (Copy on file at the Nuclear Waste Management Library, Sandia National Laboratories, Albuquerque, NM.)

3 Kafritsas, J., and R.L. Bras. 1981. Practice of Kriging. Report No. 263. Cambridge, MA: Massachusetts Institute of Technology, Ralph M. Parsons Laboratory.

4 Reeves, M., D.S. Ward, N.D. Johns, and R.M. Cranwell. 1986a. Data Input Guide for SWIFT II, The Sandia Waste-Isolation Flow and Transport Model for Fractured Media, Release 4.84. SAND83-0242, NUREG/CR3162. Albuquerque, NM: Sandia National Laboratories.

5 Reeves, M., D.S. Ward, N.D. Johns, and R.M. Cranwell. 1986b. Theory and Implementation for SWIFT II, The Sandia Waste-Isolation Flow and Transport Model for Fractured Media, Release 4.84. SAND83-1159, NUREG/CR-3328. Albuquerque, NM: Sandia National Laboratories.

6 Reeves, M., D.S. Ward, P.A. Davis, and E.J. Bonano. 1986c. SWIFT II Self-Teaching Curriculum: Illustrative Problems for the Sandia Waste-Isolation Flow and Transport Model for Fractured Media. SAND84-1586, NUREG/CR-3295. Albuquerque, NM: Sandia National Laboratories.

7 Wilson, J.L., B.S. RamaRao, and J.A. McNeish. 1986. GRASP: A Computer Code to Perform Post-SWENT Adjoint Sensitivity Analysis of Steady-State Ground-Water Flow. BMI/ONWI-625. Columbus, OH: Office of Nuclear Waste Isolation, Battelle Memorial Institute.

8 RamaRao, B.S., and M. Reeves. 1990. Theory and Verification for the GRASP II Code for Adjoint-Sensitivity Analysis of Steady-State and Transient Ground-Water Flow. SAND89-7143. Albuquerque, NM: Sandia National Laboratories.

9 Intera, Inc. 1989. Users Manual for STLINE. QA CIN097B-12C-001B. [Austin, TX]: Intera, Inc. (Copy on file at the Sandia WIPP Central Files, Sandia National Laboratories, Albuquerque, NM.)

10 WIPP PA (Performance Assessment) Department. 1992. Preliminary Performance Assessment for the Waste Isolation Pilot Plant, December 1992. Volume 2: Technical Basis. SAND92-0700/2. Albuquerque, NM: Sandia National Laboratories. D4 through D-7.

11 Rechard, R.P., ed. 1992. User's Reference Manual for CAMCON: Compliance Methodology Controller, Version 3.0. SAND90-1983. Albuquerque, NM: Sandia National Laboratories. 


\subsection{Radionuclide Transport Modeling}

The third principal part of consequence modeling is devoted to radionuclide transport to the accessible environment. Radionuclides were introduced by PANEL. In the E1 scenario, they are released to the borehole directly above the breached room of the Waste Isolation Pilot Plant (WIPP) repository (evaluated in Section 5.1). From there, they are transported immediately up the borehole to the groundwater-flow regime of the Culebra Dolomite Member of the Rustler Formation (discussed in Section 5.2). In WIPP performance-assessment (PA) calculations to date, radionuclide transport has been modeled only on the local model domain of the Culebra Dolomite (see Section 5.2.1, Regional and Local Groundwater Flow Modeling).

Important potential aspects of the groundwater transport of radionuclides include the following: (1) the fluid velocity fields in the aquifer (discussed in Section 5.2), (2) the ability of the porous dolomite matrix to communicate readily with fluid flowing through secondary porosity postulated to exist within the dolomite, (3) the ability of material within the dolomite to adsorb radionuclides from the contaminated brine, and (4) the ability of clay minerals that may line the secondary porosity surfaces to adsorb radionuclides from the contaminated brine."

The latter three aspects were used to define alternative conceptual models (i.e., alternative sets of assumptions that describe the same process for the same purpose, where each set of assumptions is consistent with existing data and cannot be fully refuted) were considered. The alternative conceptual models were defined on the basis of (1) presence or absence of matrix porosity, (2) presence or absence of chemical retardation in the Culebra matrix, and (3) presence or absence of clay linings in secondary porosity (modeled as fractures) to provide chemical retardation in the secondary porosity. Although one of the conceptual models (the combination of item 1 and 2) was felt to provide the most realistic representation of radionuclide transport, the other alternatives could not be refuted at the time of the 1990-1992 performance assessments (PAs).

Using concentration contours of transmitted radionuclides, analysts calculate (1) the total cumulative release of radionuclides past the disposal-system boundary over $10,000 \mathrm{yr}$ and (2) the maximum concentrations beyond the disposal-system boundary. When salt concentrations in the brine drop low, aquifer waters become suitable for consumption by cattle. Result (1) above becomes an input for the regulatory step of the performance assessment (PA), which is based on complementary cumulative distribution functions (see Section 6.1, Environmental Protection Agency 40 CFR 191 Simulations). Result (2) is necessary for evaluating individual doses (see Section 5.4, Biosphere Transport Modeling).

Section 5.3.1 provides an example of the concentration contours for one transmissivity field used in the 1991 PA calculations. Section 5.3.2 describes the underlying conceptual model for radionuclide transport. Sections 5.3.3 and 5.3.4 provide a discussion of the flow of information through the software used in the 1991 and 1992 PA calculations. 


\subsubsection{Example of Radionuclide Transport}

Contours of radionuclide concentration ("plumes") as a function of time are the direct output of radionuclide-transport models of the Culebra Dolomite Member of the Rustler Formation. Results suggest various long-lived radionuclides-such as americium $\left({ }^{241} \mathrm{Am}\right)$, plutonium $\left({ }^{239} \mathrm{Pu},{ }^{240} \mathrm{Pu},{ }^{238} \mathrm{Pu}\right.$ ), and uranium $\left({ }^{233} \mathrm{U},{ }^{234} \mathrm{U}\right)$ - can, under some circumstances, be released at the disposal-system boundary.

Because they are biologically more harmful, the maximum concentration of short-lived daughter radionuclides at the land-withdrawal boundary within the 10,000-yr regulatory period are critical inputs to the biosphere transport model (see Section 5.4, Biosphere Transport Modeling).

The total amounts of each of the long-lived radionuclides, accumulated over 10,000 yr, are critical inputs to the regulatory-assessment software for constructing the complementary cumulative distribution function for comparison with the Containment Requirements in 40 CFR 191 (see Section 6.1, Environmental Protection Agency 40 CFR 191 Simulations).

As an example of these types of output, Figure 5.3-1 shows both (a) a contour of the concentrations of ${ }^{234} \mathrm{U}$ after 10,000 yr for one transmissivity field from the 1991 performance assessment calculations and (b) the cumulative release of ${ }^{234} \mathrm{U}$. The variations in the cumulative releases are considerable when sampling all $45^{\circ}$ model parameters, except the parameter that selected the transmissivity field ${ }^{1}$ (Figure 5.3-1).

\section{Reference}

1 WIPP PA (Performance Assessment) Division. 1991. "Summary of Parameters Sampled in 1991," Preliminary Comparison with 40 CFR Part 191, Subpart B for the Waste Isolation Pilot Plant, December 1991. Volume 3: Reference Data. Eds. R.P. Rechard, A.C. Peterson, J.D. Schreiber, H.J. Iuzzolino, M.S. Tierney, and J.S. Sandha. SAND91-0893/3. Albuquerque, NM: Sandia National Laboratories. 6-1 through 6-7.

* The Waste Isolation Pilot Plant land-withdrawal boundary is $\sim 2.4 \mathrm{~km}$ (1.5 mi) from the edge of the repository.

* * Not all of the 45 parameters influenced the observed variation at this point of the calculation. Several parameters, such as $\lambda$ in the Poisson analytic function (see Section 4.2, Compiling Model Parameters), were used only in later submodels. 


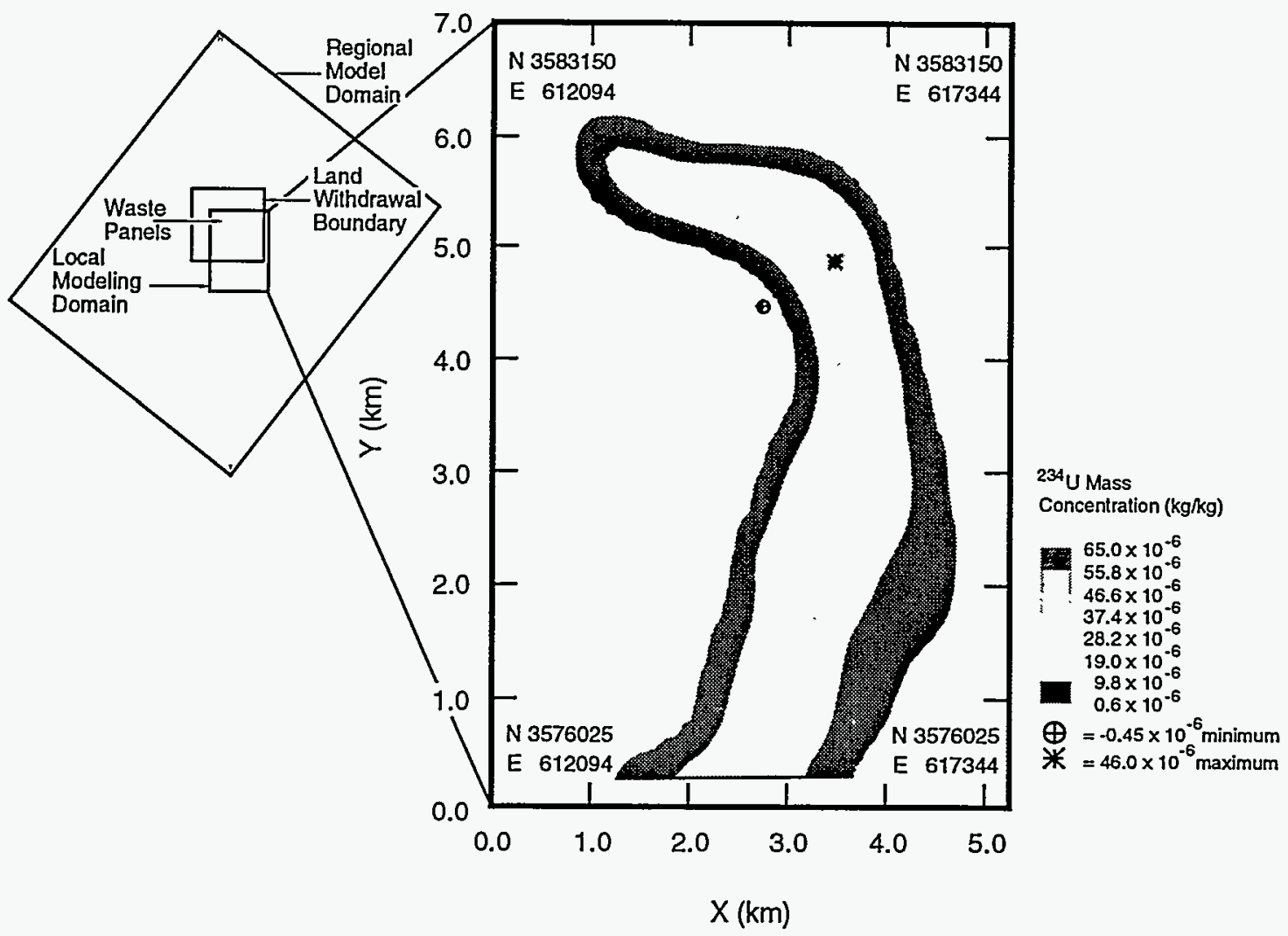

(a)

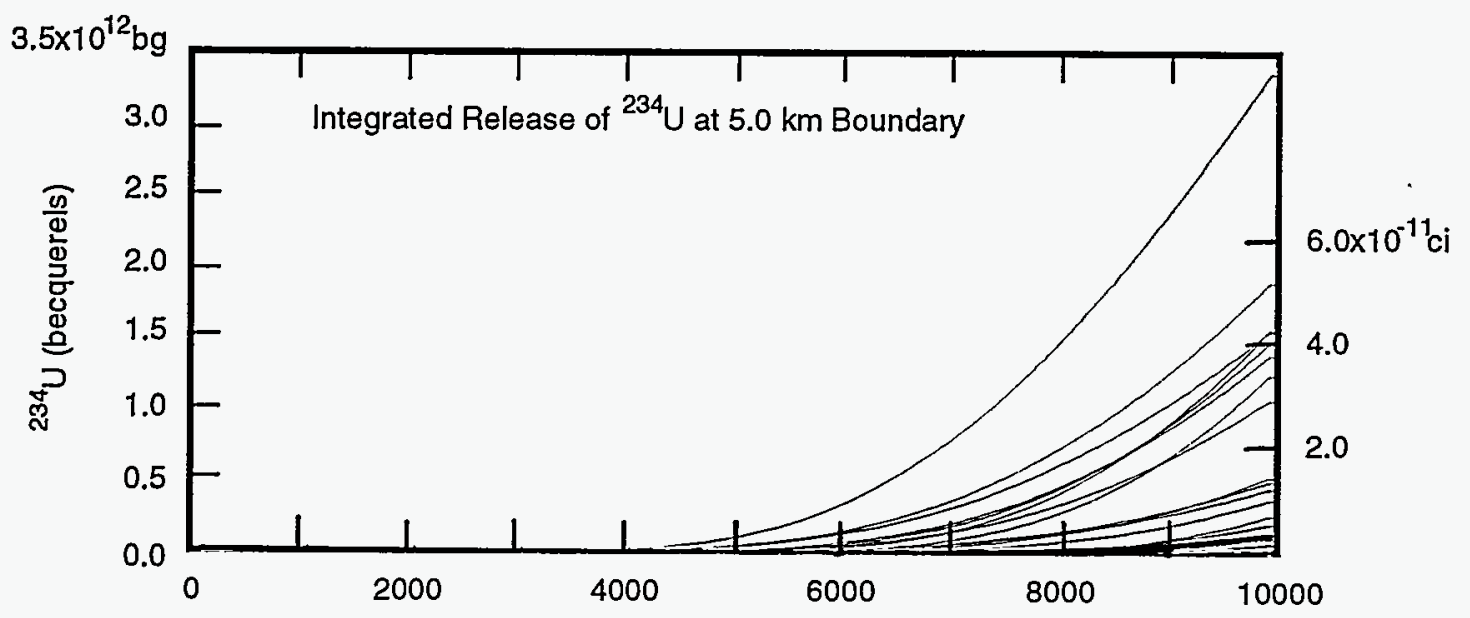

Time (years)

(b)

Figure 5.3-1. Example of radionuclide release (a) concentration contours of ${ }^{234} \mathrm{U}$ after $10,000 \mathrm{yr}$ for one simulation and (b) variation in cumulative release of ${ }^{234} \mathrm{U}$ to the $5-\mathrm{km}$ (3-mi) boundary when varying model parameters, except those associated with the transmissivity field. [This example used data from the 1991 performance assessment (PA) calculations, but uses SECOTP2D, a transport code used in the 1992 PA calculations and mentioned in Section 5.3.4. This work was part of the Probabilistic Safety Assessment Code Intercomparisons (PSACOIN), an exercise sponsored by the Nuclear Energy Agency (NEA) of the Organisation for Economic Co-Operation and Development (OECD).] 


\subsubsection{Modeling of Radionuclide Transport}

Releases of radionuclides from the WIPP repository to the accessible environment might occur along liquid pathways through the brine aquifer in the Culebra Dolomite Member of the Rustler Formation (see Sections 3.3.3 and 3.3.4). The conceptualization of the Culebra consisted of two continuums: one continuum associated with the intact dolomite matrix with an original porosity and one continuum associated with secondary porosity through the dolomite matrix that is modeled as fractures. Based on available field evidence at the time ${ }^{1}$ a dual porosity model of contaminant transport in the Culebra was used, that is, transport of contaminants was advected by fluid flow through the fracture continuum but diffusion of contaminants into the matrix continuum surrounding the fracture could occur. The fracture system was idealized as planar and parallel (Figure 5.3-2); in some alternative conceptual models each fracture was coated with a layer of clay of uniform thickness.

The governing equation for mass transport in a single fracture is ${ }^{2}$

$$
\frac{\partial C_{\ell}}{\partial t}=-\frac{\partial}{\partial x_{i}}\left(V_{i} C_{\ell}-D_{i j} \frac{\partial C_{\ell}}{\partial x_{j}}\right)-\lambda_{\ell} C_{\ell}+\sum_{m=1}^{m} \xi_{\ell m} \lambda_{m} C_{\ell}+Q\left(C_{\ell}^{0}-C_{\ell}\right)+\Gamma_{\ell},
$$

where the summation convention has been used $\left(x_{1}=x, x_{2}=y\right) ; \ell, m=1,2, \ldots, m$, label the radionuclides; and the quantities have the following meanings:

$C_{\ell}=$ concentration of $\ell$ th radionuclide in fracture fluid $\left(\mathrm{kg} / \mathrm{m}^{3}\right)$,

$V_{i}=$ average linear velocity vector in fracture system $(\mathrm{m} / \mathrm{s})$,

$D_{i j}=$ Hydrodynamic dispersion tensor $\left(\mathrm{m}^{2} / \mathrm{s}\right)$,

$\lambda_{\ell}=$ decay constant for $\ell$ th radionuclide (radionuclide, $\mathrm{s}^{-1}$ ),

$\xi_{\ell m}=$ fraction of $m$ th parent radionuclide that decays into $\ell$ th radionuclide (dimensionless),

$Q$ = rate of fluid injection per unit volume of formation $\left(\mathrm{s}^{-1}\right)$ (see Section 5.1.7),

$C_{\ell}^{0}=$ concentration of $\ell$ th radionuclide in injected fluid $\left(\mathrm{kg} / \mathrm{m}^{3}\right.$ ) (see Section 5.1.7),

$\Gamma_{\ell}=$ rate of mass transfer of $\ell$ th radionuclide from matrix system to fracture system $\left(\mathrm{kg} / \mathrm{m}^{3} \cdot \mathrm{s}\right)$.

The average linear velocity vector, $V_{i}$, is related to the specific discharge in the Culebra by $V_{i}=q_{i} / \phi_{f}$ where the specific discharge, $q_{i}$, is provided by the fluid flow model (see Section 5.2) and $\phi_{f}$ is the fracture porosity of the Culebra. For planar parallel fractures (Figure 5.3-2) and $b<<B, \phi_{f}=\frac{b}{b+B}$.

Mass transport into the matrix occurs by diffusion across the fracture facings. The governing equation is ${ }^{2}$

where new quantities have the following meanings.

$$
\phi R_{\ell} \frac{\partial C_{\ell}^{\prime}}{\partial t}=\frac{\partial}{\partial z} D^{\prime} \frac{\partial C_{\ell}^{\prime}}{\partial z}-\phi R_{\ell} \lambda_{\ell} C_{\ell}^{\prime}+\sum_{m=1}^{m} \xi_{\ell m} \phi R_{m} \lambda_{m} C_{m}^{\prime},
$$

$C_{\ell}^{\prime}(z, t)=$ concentration of $\ell$ th radionuclide in pore fluid of matrix $\left(\mathrm{kg} / \mathrm{m}^{3}\right)$,

$\phi \quad=$ porosity of matrix (dimensionless),

$R_{\ell} \quad=$ retardation coefficient of $\ell$ th radionuclide in matrix (dimensionless),

$D^{\prime} \quad=$ effective molecular diffusion coefficient through matrix $\left(\mathrm{m}^{2} / \mathrm{s}\right)$.

The term $\Gamma_{\ell}$ specifies the rate of mass transfer of the $\ell$ th solute species from the fracture to the matrix continuum and takes the form $\Gamma_{\ell}(x, y, t)=-\frac{2}{b_{f}}\left(D^{\prime} \frac{\partial C_{\ell}^{\prime}}{\partial z}\right)_{z=b_{f}}$, where all quantities have been defined.

\section{References}

1 Reeves, M., G.A. Freeze, V.A. Kelley, J.F. Pickens, and D.T. Upton. 1991. Regional Double-Porosity Solute Transport in the Culebra Dolomite under Brine-Reservoir-Breach Release Conditions: An Analysis of Parameter Sensitivity and Importance. SAND89-7069. Albuquerque, NM: Sandia National Laboratories.

2 Sandia WIPP Project. 1992. Preliminary Performance Assessment for the Waste Isolation Pilot Plant, December 1992. Volume 3: Model Parameters. SAND92-0700/3. Albuquerque, NM: Sandia National Laboratories. 


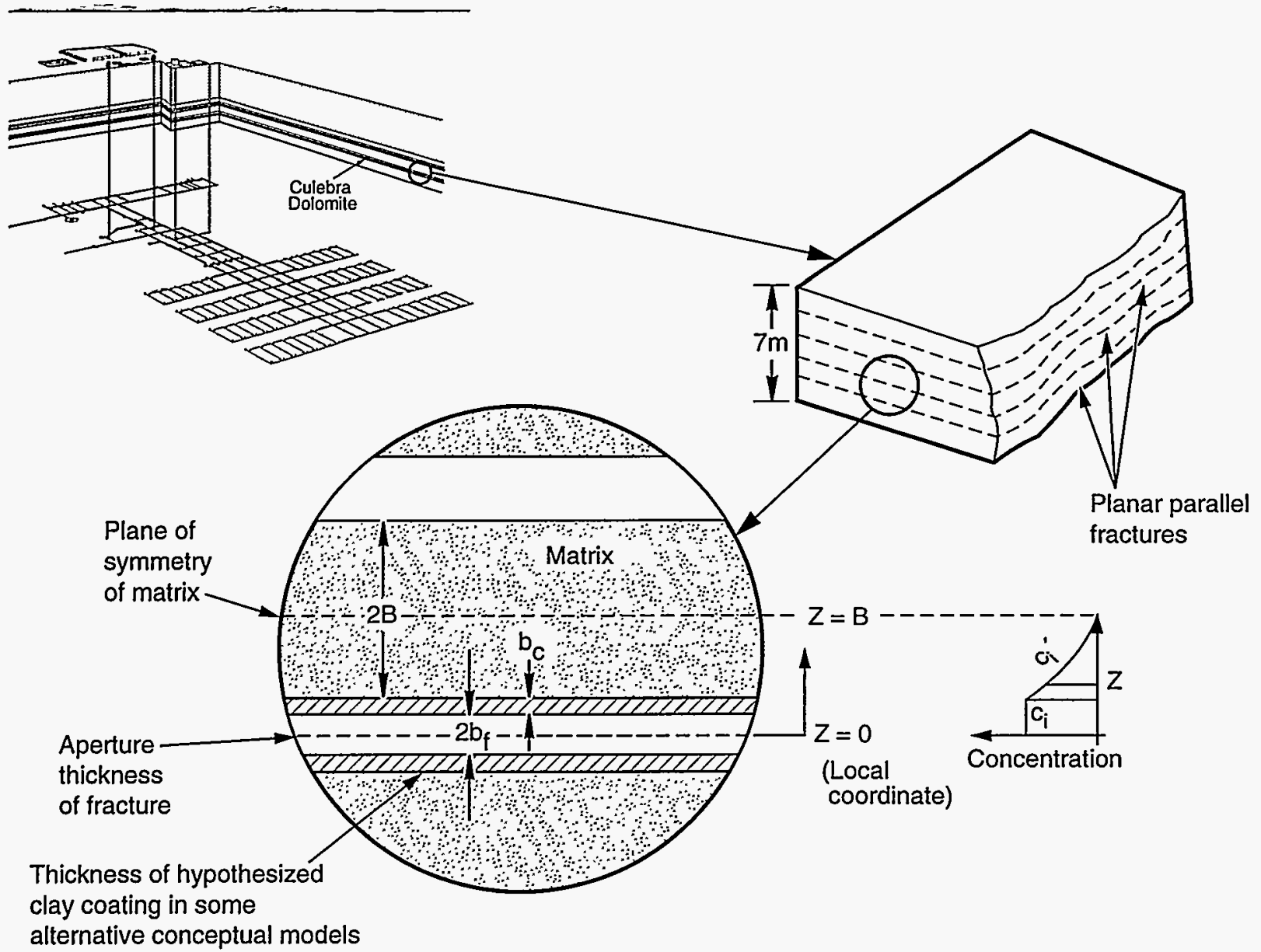

(a)

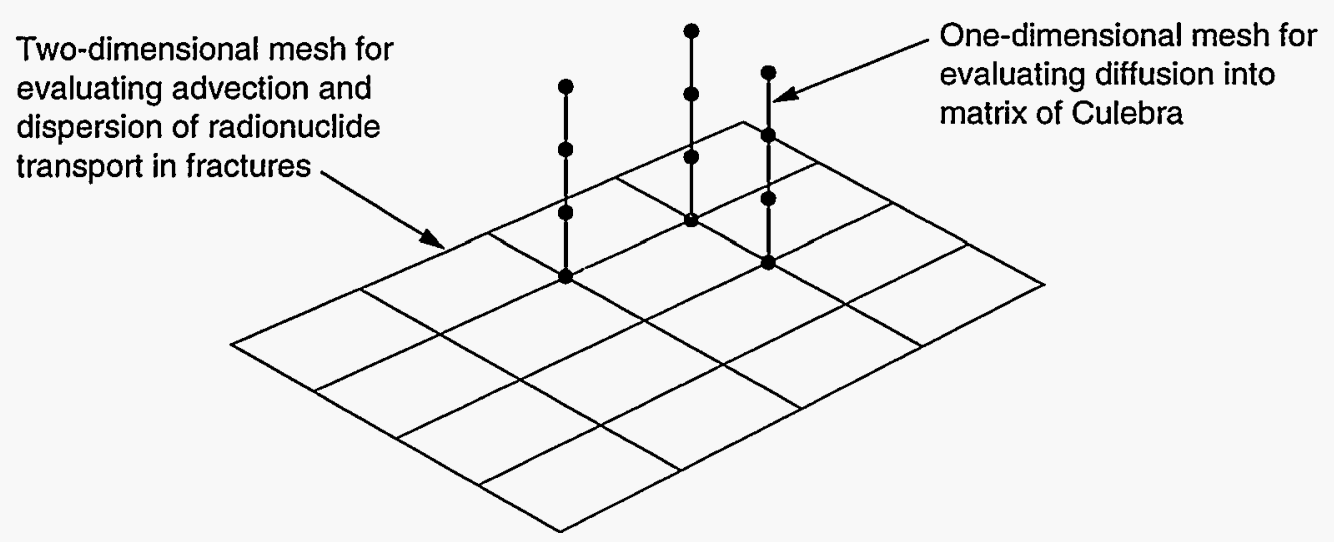

(b)

TRI-6342-4395-0

Figure 5.3-2. Idealized section of the Culebra Dolomite Member of the Rustler Formation for radionuclide transport: (a) conceptual model and (b) corresponding numerical mesh. 


\subsubsection{Code Linkage for 1990-1991 Transport}

In the 1990 and 1991 performance assessment, various general radionuclide transport codes, including STAFF2D, ${ }^{1}$ SUTRA, ${ }^{2}$ and SWIFT $^{3}$, were used to describe quantitatively the transport of radionuclides through the Culebra Dolomite Member of the Rustler Formation. These codes are described as follows:

STAFF2D models single- or dual-porosity fluid flow and radionuclide transport using a finiteelement numerical solution technique. Specifically, STAFF2D is a two-dimensional finite-element code designed to simulate confined and unconfined groundwater flow and single- or multiplecomponent solute transport in fractured or granular aquifers. Fractured porous media are represented using both discrete-fracture and dual-porosity approaches. The dual porosity model's advective transport approach of contaminants through a fracture system (usually parallel plates) in the material and diffusion of contaminants into the rock matrix surrounding the fracture system.

SUTRA evaluates saturated or unsaturated density-dependent groundwater flow with either (1) solute transport subject to equilibrium adsorption and zero- and first-order production or decay or (2) thermal energy transports in the groundwater and solid matrix of the aquifer. SUTRA approximates the governing equations using a two-dimensional, finite-element, and integrated finite-difference method.

SWIFT_ $\boldsymbol{\Pi}$ is general-purpose code for solving transient, three-dimensional, and coupled equations for fluid flow, heat transport, brine-miscible displacement, and radionuclide-miscible displacement in porous or fractured media.

Generally, the method of linking the transport software to the other portions of the consequence model starts with the local-flow, CAMDAT, ${ }^{4}$ data files (".CDB files" created in Section 5.2.5 and named LOCAL_FLOW_R\#.CDB; see Figure 5.3-3). RELATE ${ }^{4}$ is used to interpolate pertinent parameters from the regional mesh, as necessary. POSTLHS 4 adds sampled transport parameters to the local flow .CDB files. ALGEBRACDB ${ }^{4}$ manipulates those parameter values to produce the specific parametric forms required by the selected transport code (see Section 3.3.3, Support Codes Used in the Modeling System, for a description of ALGEBRACDB). One of several available transport codes, which include STAFF2D, 1 SUTRA, ${ }^{2}$ and SWIFT, ${ }^{3}$ uses this modified file to simulate transport of the radionuclides released from the repository and contained in the source-term files (SOURCE_R\#.CDB, created in Section 5.1.8). The analyst can exercise $\mathrm{ALGEBRACDB}{ }^{4}$ to determine radionuclide flux rates across the Waste Isolation Pilot Plant (WIPP) disposal-system boundary. The results are passed on to the biosphere submodel (Section 5.4) or a compliance module (described in Section 6.1.6). This process is repeated for each scenario $\left(S_{j}\right)$ using the appropriate source-term files.

The use of a groundwater-transport code developed specifically for the WIPP 1992 PA calculations is described in Section 5.3.4.

\section{References}

1 Huyakom, P.S., H.O. White, Jr., and S.M. Panday. 1991. STAFF2D Solute Transport and Fracture Flow in 2-Dimensions. Herndon, VA: HydroGeoLogic, Inc. (Copy on file at the Sandia WIPP Central Files, Sandia National Laboratories, Albuquerque, NM.)

2 Voss, C.I. 1984. SUTRA (Saturated-Unsaturated Transport): A Finite-Element Simulation Model for SaturatedUnsaturated, Fluid-Density-Dependent Ground-Water Flow with Energy Transport or Chemically-Reactive Single-Species Solute Transport. Water-Resources Investigations Report 84-4369. Reston, VA: U.S. Geological Survey. (SUTRANUC is a version of SUTRA modified by Department 6342 at Sandia National Laboratories for transport of multiple nuclide decay chains.)

3 Reeves, M., D.S. Ward, N.D. Johns, and R.M. Cranwell. 1986a. Data Input Guide for SWIFT II, The Sandia Waste-Isolation Flow and Transport Model for Fractured Media, Release 4.84. SAND83-0242, NUREG/CR3162. Albuquerque, NM: Sandia National Laboratories.

4 Rechard, R.P., ed. 1992. User's Reference Manual for CAMCON: Compliance Assessment Methodology Controller, Version 3.0. SAND90-1983. Albuquerque, NM: Sandia National Laboratories. 
$\S 5.1 .8$

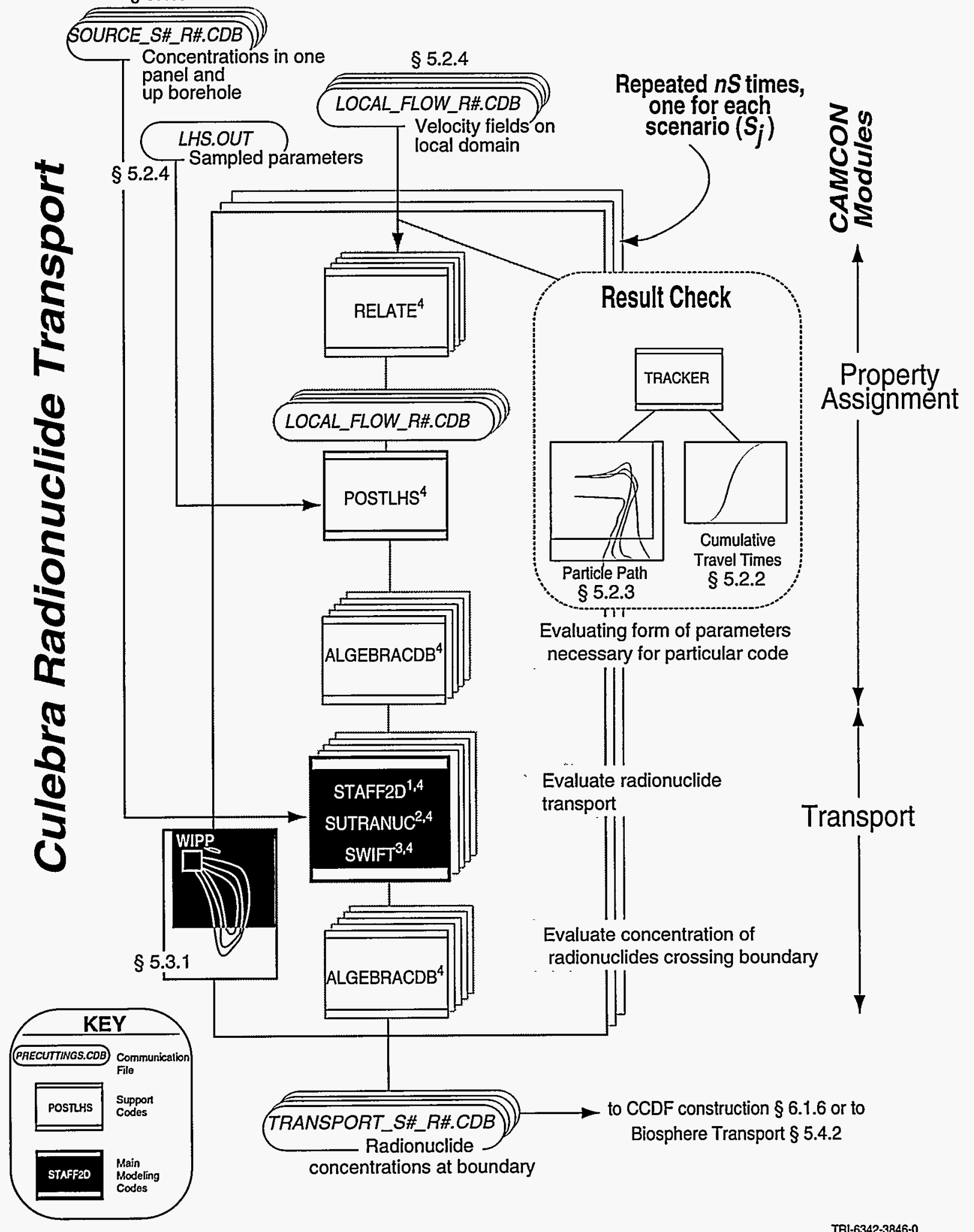

Figure 5.3-3. Linkage of software to simulate radionuclide-transport in the Culebra Dolomite Member of the Rustler Formation for the 1990 and 1992 performance assessment calculations. 


\subsubsection{Linkage of the SECOTP2D Transport Code}

SECOTP2D ${ }^{1}$ was used in the 1992 performance-assessment $(\mathrm{PA})$ calculations to evaluate the transport of radionuclides released directly above the center of the repository in the brine within the Culebra Dolomite of the Rustler Formation. SECOTP2D is defined as follows:

SECOTP2D ${ }^{1}$ is a transport code that simulates single- or multiple-component radionuclide transports in fractured or porous aquifers. Fractured porous media are represented by a dual-porosity model. In 1992, the code was two-dimensional, did not allow mixtures of fractured and non-fractured materials, and required a constant aquifer thickness. The code uses total-variation-diminishing (TVD) schemes to model the advective part of the transport equation. The TVD schemes help eliminate the need to guess the required amount of "upwinding" (numerical smoothing) to control sharp gradients in the solution. Traditional upwind weighting schemes require the user to specify a weight, a priori. A user's and theory manual is in preparation.

Generally, the method of linking SECOTP2D is similar to the 1990 and 1991 PA transport-code linkage method in that the transfer files are the local velocity fields (LOCAL_FLOW_R\#.CDB). However, these files are now created by SECOFL2D, which produces both regional and local .CDB flow files (both files are described in Section 5.2.5). The local .CDB file with double-precision velocities is used in SECOTP2D. As in the linkage of other transport codes (Section 5.3.3), POSTLHS ${ }^{2}$ and RELATE ${ }^{2}$ are used to place sampled transport parameters and to interpolate pertinent parameters from the regional mesh onto the local flow files (".CDB" files). The analyst exercises ALGEBRACDB ${ }^{1}$ to compute specific parametric forms required by SECOTP2D ${ }^{1}$ from parameters already existing on the data base. SECOTP2 $D^{1}$ uses the modified file and time-varying concentrations of radionuclides released from the repository and stored in the source-term files (SOURCE_R\#.CDB-created in Section 5.1.8) to simulate radionuclide transport in the Culebra. SECOTP2D calculates radionuclide flux rates at specified boundaries to estimate releases to the accessible environment and places them on the output ".CDB files," TRANSPORT_R\#.CDB. This file is used by the biosphere transport submodel (described in Section 5.4) or the compliance module to estimate cumulative releases (described in Section 6.1.6). As with other transport codes, the process is repeated for each scenario $\left(S_{j}\right)$ using the appropriate source-term files.

The use of various other transport codes for the 1990 and 1991 PA calculations is described in Section 5.3.3.

\section{References}

1 Salari, K., P. Knupp, P.J. Roache, and S. Steinberg. 1992. "TVD Applied to Radionuclide Transport in Fractured Porous Media," Finite Elements in Water Resources, Proceedings of the 9th International Conference on Computational Methods in Water Resources, Denver, CO, June 1992. Southampton, UK: Computational Mechanics. Vol. 1, 141-148.

2 Rechard, R.P., ed. 1992. User's Reference Manual for CAMCON: Compliance Assessment Methodology Controller, Version 3.0. SAND90-1983. Albuquerque, NM: Sandia National Laboratories. 


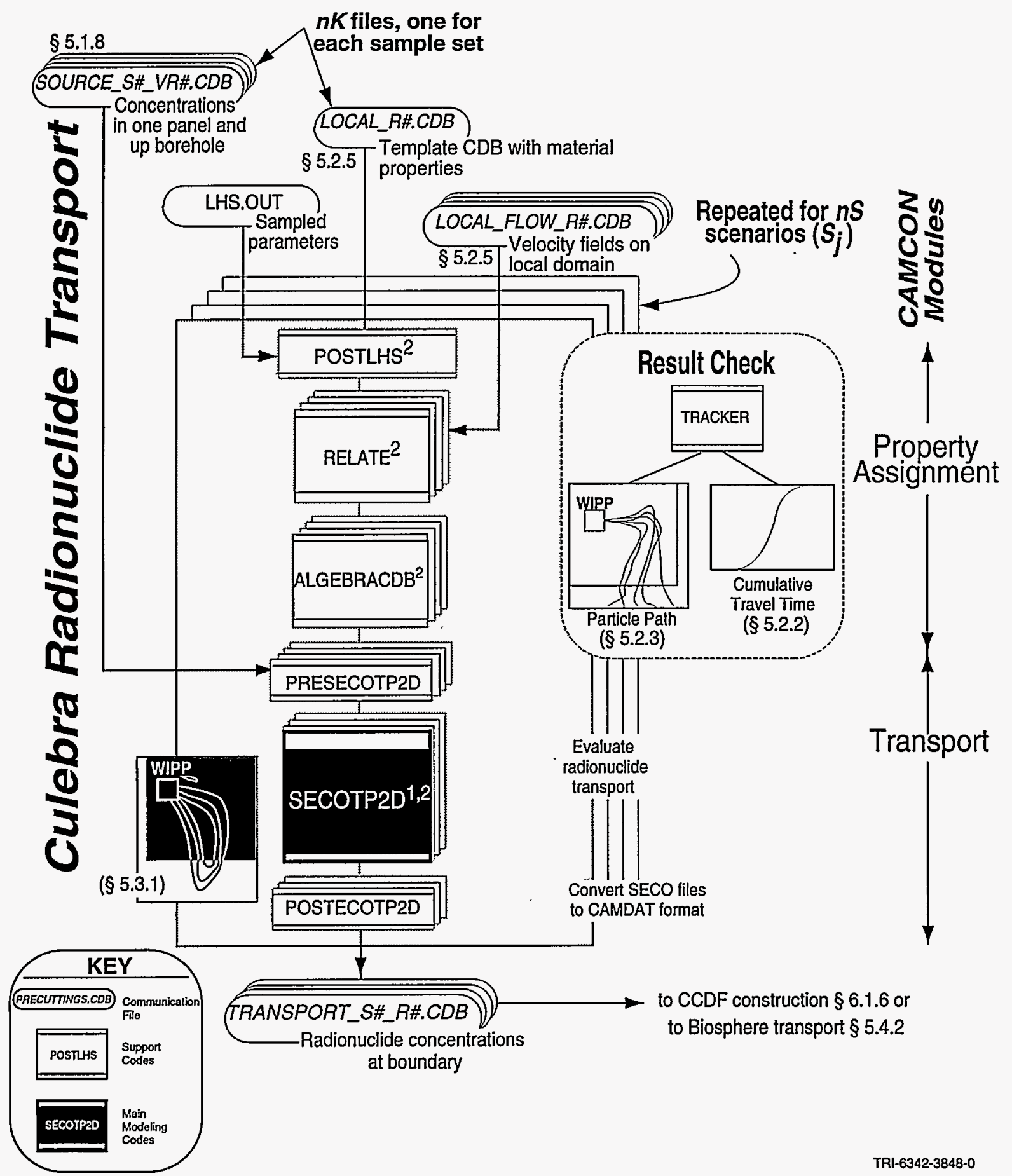

Figure 5.3-4. The linkage of SECOTP2D with the modeling system to predict transport of radionuclides within the Culebra Dolomite Member of the Rustler Formation above the Waste Isolation Pilot Plant repository in the 1992 performance assessment calculations. 
5.0 Consequence Analysis 


\subsection{Biosphere Transport Modeling}

Traditionally, estimates of radiological doses have been used to evaluate the impact of the Waste Isolation Pilot Plant (WIPP) project on the human environment, at least in Environmental Impact Statements, ${ }^{1,2}$ which have been required of major federal projects, according to the National Environmental Policy $\mathrm{Act}^{3}$ (see Section 6.2, National Environmental Policy Act Simulations). To evaluate potential radiological effects on hypothetical individuals living around the WIPP site up to $10,000 \mathrm{yr}$ in the future, it is necessary to model radionuclide transport through the Earth's biosphere. The WIPP Project's approach in the 1990-1992 performance assessment was stochastic. Performance-assessment analysts use the stochastic concentrations of the various radionuclides transported in the groundwater from the previous section (Section 5.3). However, constant, median values were used for all numerous model parameters required by the biosphere transport model described here (i.e., no biosphere model parameters were sampled). The mean doses from biospheric-transport calculations were then reported and compared with other types of radiological doses and accepted risk limits from other national geologicdisposal programs (see Section 6.2, National Environmental Policy Act Simulations).

Sections 5.4.1 and 5.4.2 briefly describe the three predominate pathways for radionuclides that might be released from the WIPP repository to reach humans and the linkage of software in the consequencemodeling system that calculates them.

\section{References}

1 U.S. DOE (U.S. Department of Energy). 1980b. Final Environmental Impact Statement: Waste Isolation Pilot Plant. DOE/EIS-0026. Washington, DC: U.S. Department of Energy. Vols. 1-2.

2 U.S. DOE (U.S. Department of Energy). 1990c. Final Supplement Environmental Impact Statement, Waste Isolation Pilot Plant. DOE/EIS-0026-FS. Washington, DC: U.S. Department of Energy, Office of Environmental Restoration and Waste Management. Vols. 1-13.

3 Public Law 91-190. 1970. National Environmental Policy Act of 1969 (83 Stat. 852; 42 U.S.C. 1801 et seq.). 


\subsubsection{Radionuclide Pathways to Humans}

Biospheric transport models use results from both cuttings-removal calculations and groundwatertransport calculations (Section 5.3) to assess potential radiological effects on individuals. In evaluating the transport of radionuclides through the biosphere (Section 5.1.6), three principal exposure routes or pathways through the biosphere were considered in the 1991 and 1992 performance assessment calculations. Each requires a human-intrusion event. The pathways are briefly sketched as follows: (a) Individuals operating the exploratory drill that penetrates the Waste Isolation Pilot Plant repository are exposed externally and internally (through inhalation) to contaminated soil and rock dust because of their proximity to the drilling operations (see Figure 5.4-1, top). (b) Contaminated brine from an exploratory drillhole leaks into the Culebra Dolomite aquifer and its groundwater is pumped into a stockpond. Livestock drink exclusively from this pond and ranchers consume the livestock (see Figure 5.4-1, middle). (c) Contaminants from either a dried stockpond or dried drilling-mud pit are suspended in an air plume that continually deposits the contaminants onto a nearby farm. The farm family consumes food produced from the contaminated soil (see Figure 5.4-1, bottom). In all these pathways, present-day conditions regarding social behavior, eating habits, and available technology, etc., are assumed to persist for the next 10,000 yr. Furthermore, the hypothetical stock well in Case (b) is assumed to be located downgradient from the waste panels at a point where the high-salinity groundwater is dilute enough that cattle can consume it exclusively. Moreover, the stock well is assumed to be located so it pumps the highest concentration of groundwater radionuclides near their peak arrival time or at 10,000 yr, whichever occurs first. Finally, none of the exposures to (1) the driller, (2) the ranch families who consume contaminated beef, (3) the ranch families who receive contaminated dust from the dried stockpond, or (4) the ranch families who receive contaminated dust from the drilling-mud pit are assumed necessarily to occur at the same time. These assumptions are consistent with recommendations by the International Commission on Radiological Protection (ICRP), ${ }^{1}$ the National Council on Radiation Protection and Measurements (NCRP), ${ }^{2}$ and the Nuclear Energy Agency (NEA) of the Organisation for Economic Co-Operation and Development. ${ }^{3}$ Results for Case (b) are presented in Section 6.2.1, Dose Assessments.

\section{References}

1 ICRP (International Commission on Radiological Protection). 1985. "ICRP Publication 46: Radiation Protection Principles for the Disposal of Solid Radioactive Waste," Annals of the ICRP. Elmsford, NY: Pergamon Press. Vol. 15, no. 4.

2 NCRP (National Council on Radiation Protection and Measurements). 1984. Radiological Assessment: Predicting the Transport, Bioaccumulation, and Uptake by Man of Radionuclides Released to the Environment. NCRP Report No. 76. Bethesda, MD: National Council on Radiation Protection and Measurements.

3 NEA (Nuclear Energy Agency). 1992. Safety Assessment of Radioactive Waste Repositories: Systematic Approaches to Scenario Development. Paris: Nuclear Energy Agency, Organisation for Economic Co-Operation and Development. 


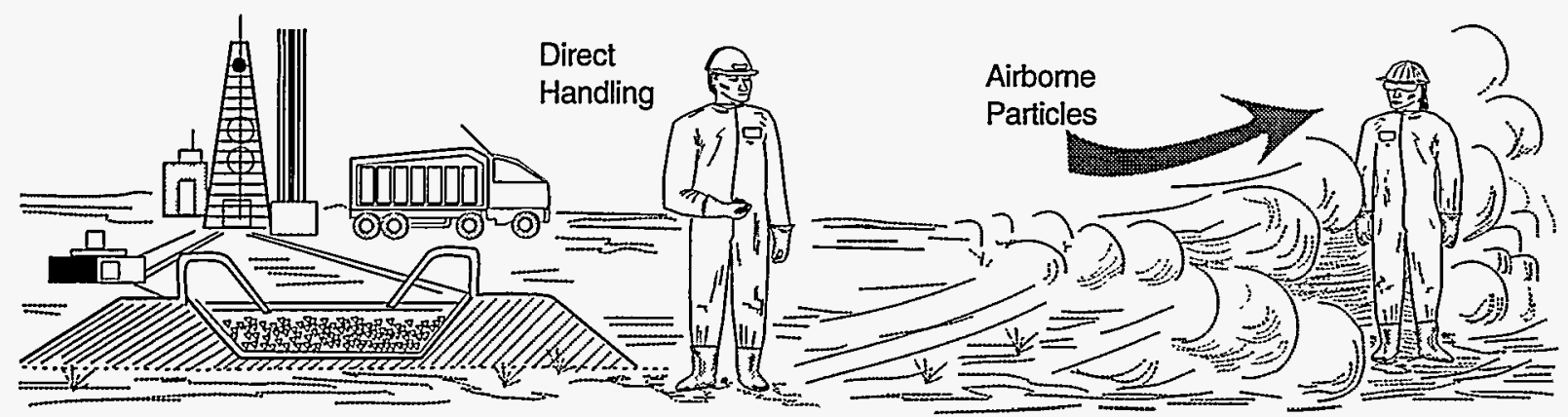

(a) Future drillers contact contaminated cuttings by direct handling or inhalation of particles.

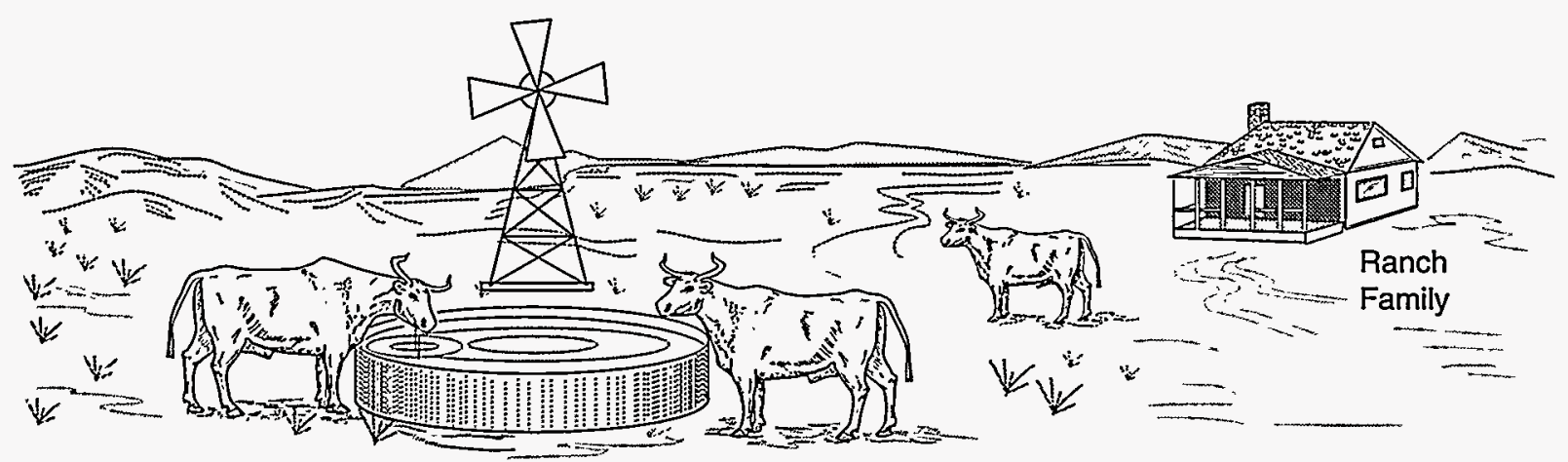

(b) Cattle drink from stock pond filled with contaminated water pumped from local aquifer; beef is later consumed by local ranch family.

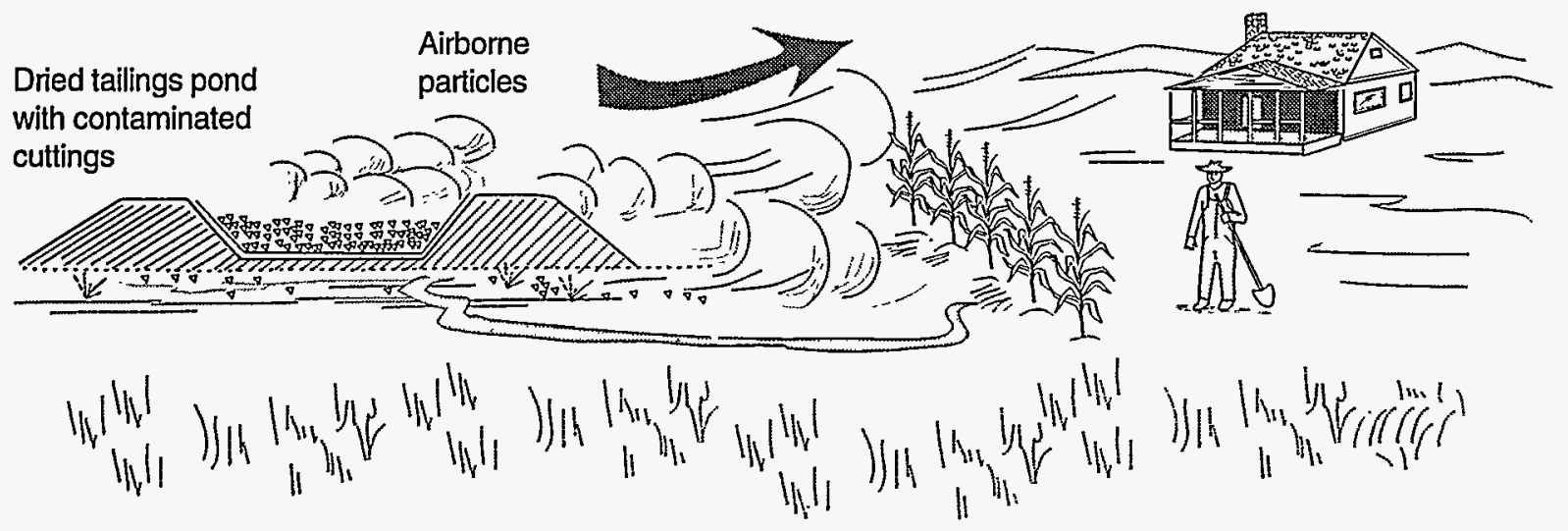

(c) Wind blown dust and water runoff from contaminated tailings is deposited onto local crops; crops are later consumed by humans.

TRI-6342-3845-0

Figure 5.4-1. Three potential pathways for humans to come into contact with radionuclides released from the Waste Isolation Pilot Plant disposal system. 


\subsubsection{Executing Biosphere Transport Codes}

In the 1992 performance-assessment calculations, the computer code GENII-S ${ }^{1,2}$ simulated contaminant transport in the biosphere (Figure 5.4-2). Initial radionuclide concentrations in contaminated groundwater or drill cuttings were retrieved from TRANSPORT_S\#_R\#.CDB or CUT_CH or CUT_RH_SH_RH.CD_S\#_R\#.CDB, respectively, where S\# is the scenario identification number and R\# is the three-digit sample set number. Because GENII-S has a built-in version of Latin hypercube sampling ${ }^{3}$ (LHS), GENII-S allows both deterministic and statistical calculations. For statistical calculations, the radionuclide concentrations must be statistically characterized to allow for LHS sampling within GENII-S. Based on directives in an input file (named PREGENII.INP), PREGENII processes statistically characterized radionuclide concentrations so they are compatible with input required by GENII-S. Depending on whether the cumulative distribution functions (CDFs) for the input parameters are continuous (e.g., uniform or normal) or discrete ("empirical," e.g., step or piecewise linear) (see Section 4.1.1, Characterizing Parameter Uncertainty), two file formats are produced by PREGENII. For continuous distributions, the processed file is NUCSTAT_Source_S\#_R\#_Location_Flag.TRN, where Source is either TR for groundwater transport, $\mathrm{CH}$ for contact-handled cuttings, or $\mathrm{RH}$ for remotely handled cuttings. For discrete distributions, the processed file is Fnuclide Name_S\#_R\#_Location_Flag.TRN, where location_Flag identifies the location of groundwater withdrawal. In both files, the results from all Monte Carlo simulations are contained in one file.

In addition to these processed files, the analyst enters other pertinent input information manually using a menu to run GENIISS on a personal computer. ${ }^{1}$ However, much of the necessary data such as biologic transfer factors or internal dose factors are available from and described in an internal data base (Section 6.2, National Environmental Policy Act Simulations). The output for GENII-S includes doses to the whole body or to individual organs displayed in various graphics (e.g., complementary cumulative distribution functions [CCDFs] of doses) and an ASCII file. ${ }^{1}$

References

1 Leigh, C.D., B.M. Thompson, J.E. Campbell, D.E. Longsine, R.A. Kennedy, and B.A. Napier. 1993. User's Guide for GENII-S: A Code for Statistical and Deterministic Simulations of Radiation Doses to Humans from Radionuclides in the Environment. SAND91-0561. Albuquerque, NM: Sandia National Laboratories.

2 Napier, B.A., R.A. Peloquin, D.L. Strenge, and J.V. Ramsdell. 1988. GENII: The Hanford Environmental Radiation Dosimetry Software System. PNL-6584. Richland, WA: Pacific Northwest Laboratory. Vols. 1-3.

3 Iman, R.L., and M.J. Shortencarier. 1984. A Fortran 77 Program and User's Guide for the Generation of Latin Hypercube and Random Samples for Use with Computer Models. SAND83-2365, NUREG/CR-3624. Albuquerque, NM: Sandia National Laboratories. 


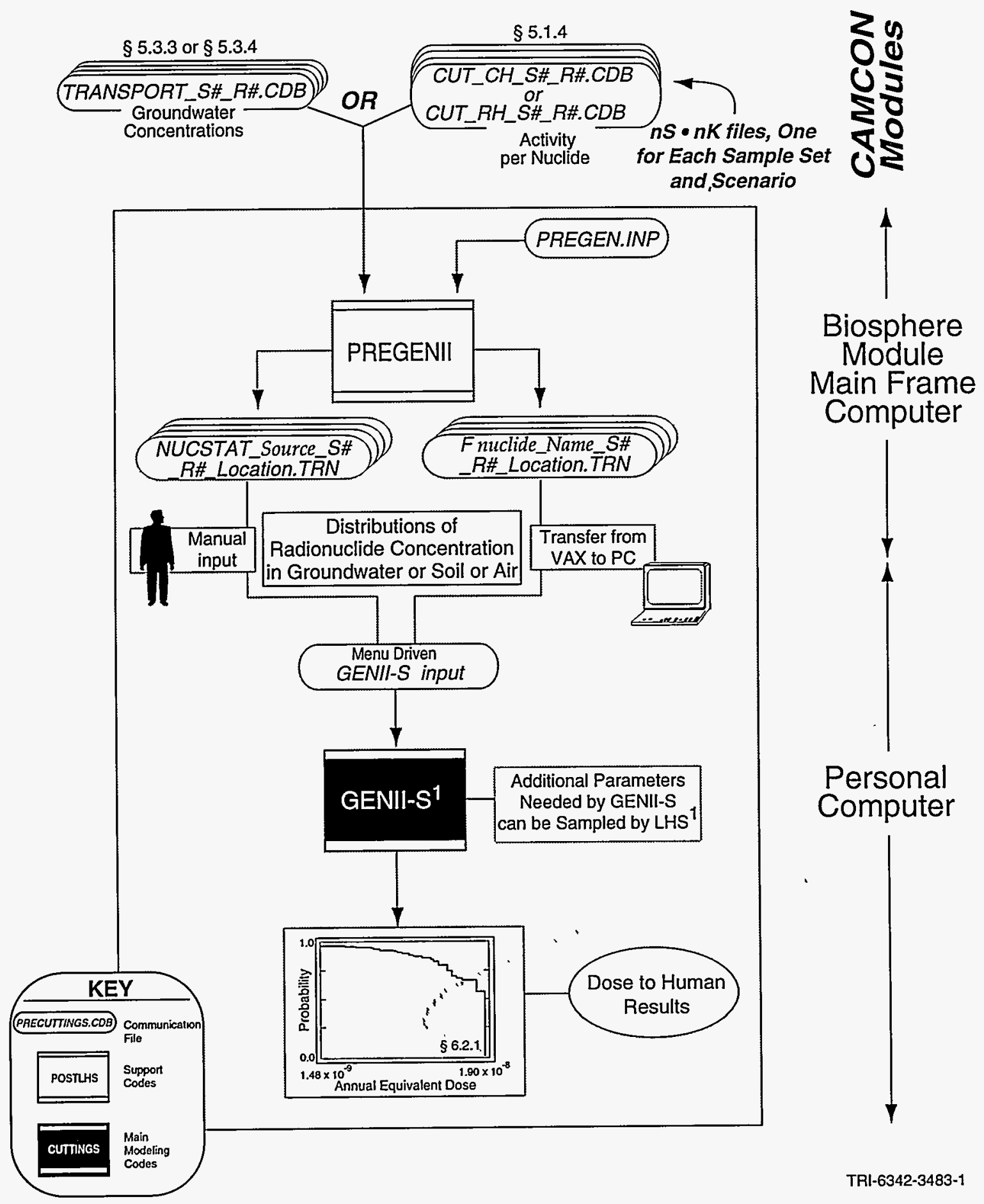

Figure 5.4-2. Flow of information for 1992 performance assessment calculations for biosphere transport code, GENII-S to evaluate potential radionuclide doses to humans. 
5.0 Consequence Analysis 


\subsection{LONG-TERM REGULATORY ASSESSMENT}

The Waste Isolation Pilot Plant (WIPP) must comply with or is indirectly affected by a wide assortment of laws and regulations. Although the Environmental Protection Agency Standard (EPA), 40 CFR 191 Subpart B, Environmental Radiation Protection Standards for the Management and Disposal of Spent Nuclear Fuel, High-Level and Transuranic Radioactive Wastes ${ }^{1,2}$ is the focal point of this document, three other laws and corresponding implementation regulations have prominent effects on the model simulations designed for performance assessments and are therefore summarized in this chapter:

1. EPA Standard, 40 CFR 191 Subpart B

- Requires probabilistic model simulations to evaluate 10,000-yr compliance for scenarios with and without human intrusion (see Section 3.2.4, Human Intrusion Summary Scenarios)

- Requires 10,000-yr individual dose calculations for scenarios without human intrusion (see Section 3.2.3, Undisturbed Summary Scenario)

- Requires 10,000 -yr calculation of radionuclide concentrations in underground sources of drinking water for scenarios without human intrusion

2. National Environmental Policy Act (NEPA) of $1969^{3}$ (83 Stat. 852, 42 U.S.C. 1801 et seq.).

- Requires Environmental Impact Statement and supporting scientific information

3. Laws amending the Solid Waste Disposal Act (SWDA) of $1965^{4}$ (42 U.S.C. 6901 et seq.), popularly known as the Resource Conservation and Recovery Act (RCRA) of $1976^{5}$ (90 Stat. 2795) and subsequent amendments, most notably the Hazardous Solid Waste Amendments (HSWA) of $1984^{6}$ (98 Stat. 3221) and its Implementing Regulations, specifically, 40 CFR 268.67

- Requires model calculations, verified with monitoring, that indicate "no migration" of hazardous materials, such as lead or volatile organic compounds, beyond the "unit" boundary (see Section 1.4.1)

4. Waste Isolation Pilot Plant Land Withdrawal Act (WIPP LWA) of 1992 (106 Stat. 4777) $^{8}$

- Requires EPA to certify that the WIPP meets 40 CFR 191 standards. The certification process will be detailed in $40 \mathrm{CFR} 194^{9}$ (criteria for implementing $40 \mathrm{CFR}$ 191), which will likely contain requirements that influence future model simulations

- Requires Department of Energy (DOE) compliance with numerous other laws

Other laws and regulations have indirect influences on WIPP long-term performance calculations. Although there are too many to list exhaustively here, the following list provides a representative sample:

1. Other environmental laws

- Safe Drinking Water Act ${ }^{10}$ (42 U.S.C. 300 f et seq.) and regulations in 40 CFR 700

- Toxic Substances Control Act 11 (15 U.S.C. \$2601 et seq.) and corresponding implementation regulations ( $40 \mathrm{CFR} 761^{12}$ ) that could affect disposal of materials contaminated with polychlorinated biphenyls (PCBs)

2. Hazardous Materials Transportation Uniform Safety Act of $1990{ }^{13}$ (49 U.S.C. $\$ 1801$ et seq.) and applicable regulations such as 49 CFR 171-177 14 and Nuclear Regulatory Commission (NRC) regulations in 10 CFR $71^{15}$ that specify rules on transportation containers and transportation practices for nuclear materials

3. Laws and regulations applicable to the operating phase of the WIPP

- Federal Mine Safety and Health Amendments Acts (MSHA) of $1977^{16}$ (30 U.S.C. $\S 801$ et seq.)

- Occupational Safety and Health Act of $1970^{17}$ (OSHA) (Pub L. 91-596, 84 Stat. 1590, 29 U.S.C. 651 et seq.) and implementing regulations such as 29 CFR $1910{ }^{18}$ that specify training for hazardous waste and noise exposure to employees

- Clean Air Amendments of $1970{ }^{19}$ (CAA) (Pub L. 91-604), Clean Air Amendments of 1977 (Pub L. 95-95, 42 U.S.C. 7401-7428), 20 and implementing regulations such as 40 CFR 61,21 which establishes standards for radionuclides in air 


\section{- Federal Water Pollution Control Act of $1982^{22}$ (33 U.S.C. $\$ 1311$ et seq.)}

The main sections of this chapter describe the first three principal laws and regulations, which influence model simulations for the WIPP. Section 6.1 describes simulations for 40 CFR 191. Section 6.2 describes simulations for NEPA. Section 6.3 describes simulations for RCRA.

\section{References}

1 EPA (Environmental Protection Agency). 1985a. "40 CFR Part 191: Environmental Standards for the Management and Disposal of Spent Nuclear Fuel, High-Level and Transuranic Radioactive Wastes; Final Rule," Federal Register. Vol. 50, no. 182, 38066-38089.

2 EPA (Environmental Protection Agency). 1993a. "40 CFR Part 191: Environmental Radiation Protection Standards for the Management and Disposal of Spent Nuclear Fuel, High-Level and Transuranic Radioactive Wastes; Final Rule," Federal Register. Vol. 58, no. 242, 66398-66416.

3 Public Law 91-190. 1970. National Environmental Policy Act of 1969 (83 Stat. 852; 42 U.S.C. 1801 et seq.).

4 Public Law 89-272. 1965. Solid Waste Disposal Act (42 U.S.C. 6901 et seq.).

5 Public Law 94-580. 1976. Resource Conservation and Recovery Act of 1976 (90 Stat. 2795 and subsequent amendments).

6 Public Law 98-616. 1984. The Hazardous and Solid Waste Amendments of 1984 (98 Stat. 3221).

7 EPA (Environmental Protection Agency). 1992b. "Land Disposal Restrictions," Code of Federal Regulations 40, Part 268. Washington, DC: Superintendent of Documents, U.S. Government Printing Office.

8 Public Law 102-579. 1992. Waste Isolation Pilot Plant Land Withdrawal Act (106 Stat. 4777).

9 EPA (Environmental Protection Agency). 1993b. "Criteria for the Certification of Compliance with Environmental Radiation Protection Standards for the Management and Disposal of Spent Nuclear Fuel, HighLevel and Transuranic Radioactive Wastes; Advanced Notice and Proposed Rulemaking," Federal Register. Vol. 58 , no. 27, 8029-8030.

10 Public Law 93-523. 1974. Safe Drinking Water Act (42 U.S.C. 300f et seq.).

11 EPA (Environmental Protection Agency). 1993f. "Subchapter R-Toxic Substances Control Act," Code of Federal Regulations 40, Part 700. Washington, DC: Superintendent of Documents, U.S. Government Printing Office.

12 EPA (Environmental Protection Agency). 1993e. "Part 761-Polychlorinated Biphenyls (PCBs) Manufacturing, Processing, Distribution in Commerce, and Use Prohibitions," Code of Federal Regulations 40, Part 761. Washington, DC: Superintendent of Documents, U.S. Government Printing Office.

13 Public Law 101-615. 1990. Hazardous Materials Transportation Uniform Safety Act of 1990 (104 Stat. 3244; 49 U.S.C. 1801 et seq.).

14 Research and Special Programs Administration. Department of Transportation. 1993. "Subchapter CHazardous Materials Regulations," Code of Federal Regulations 49, Parts 171-177. Washington, DC: Superintendent of Documents, U.S. Government Printing Office.

15 NRC (Nuclear Regulatory Commission). 1994a. "Part 71-Packaging and Transportation of Radioactive Material," Code of Federal Regulations 10, Part 71. Washington, DC: Superintendent of Documents, U.S. Government Printing Office.

Public Law 95-164. 1977. Federal Mine Safety and Health Amendments Acts of 1977 (30 U.S.C. 801 et seq.). Code of Federal Regulations 29, Part 1910. Washington, DC: Superintendent of Documents, U.S. Government Printing Office.

19 Public Law 91-604. 1970. Clean Air Amendments of 1970 (81 Stat. 486; 42 U.S.C. 1857 et seq.).

20 Public Law 95-95. 1977. Clean Air Act Amendments of 1977 (42 U.S.C. 7401 et seq.).

21 EPA (Environmental Protection Agency). 1993d. "Part 61-National Emission Standards for Hazardous Air Pollutants," Code of Federal Regulations 40, Part 61. Washington, DC: Superintendent of Documents, U.S. Government Printing Office.

Public Law 97-440. 1982. Federal Water Pollution Control Act, Amendment (33 U.S.C. 1311 et seq.). 


\subsection{Environmental Protection Agency 40 CFR 191 Simulations}

In September 1985, the U.S. Environmental Protection Agency (EPA) promulgated 40 CFR 191, Environmental Standards for the Management and Disposal of Spent Nuclear Fuel, High-Level and Transuranic Radioactive Wastes. ${ }^{1}$ The regulation's preamble states that the intent of 40 CFR 191 is (1) to provide an achievable level of protection, given the existing disposal alternatives, and (2) to reduce the risk from nuclear waste to future generations to "acceptably" low levels. The latter purpose is accomplished by isolating the wastes for a significantly long time such that the risk is no greater than if the source of the waste, uranium ore, had not been mined. ${ }^{1}$

The EPA 40 CFR 191 Subpart B Standard requires simulations to evaluate (1) total releases over 10,000 yr from the Waste Isolation Pilot Plant (WIPP) disposal system, (2) individual doses to the public in the accessible environment beyond the boundary of the disposal system, and (3) radionuclides concentration in any underground drinking water. These later requirements do not greatly influence the required simulation at the WIPP and so they are not emphasized in the remainder of the section. As described in Chapter 1, Sandia's approach to evaluating the WIPP against first environmental criteria resembles a scenario-based, probabilistic risk assessment (PRA) such as those designed for nuclear reactor safety studies-in which the performance metric, total cumulative radioactive release, is specified in probabilistic terms as a complementary cumulative distribution function (CCDF). ${ }^{*}$

The U S. Court of Appeals for the First Circuit vacated (i.e., rescinded) Subpart B of 40 CFR 191 in July $1987^{2}$ and remanded it to the EPA for further consideration. Some major points of contention were the 1000-yr time period for Individual Protection Requirements and the Groundwater Protection Requirements.

The Waste Isolation Pilot Plant Land Withdrawal Act ${ }^{3}$ (WIPP LWA) (Pub. L. 102-579, 1992) transferred land for the site from the Bureau of Land Management in the Department of the Interior to the Department of Energy. More important from the standpoint of the PA process, it set policy guidelines for the certification of the WIPP as a disposal facility for transuranic waste. Specifically, it established the EPA as the regulator for the WIPP. The EPA intends to provide further guidance on how it will interpret aspects of 40 CFR 191 in 40 CFR $194,{ }^{4}$ which will possibly influence the style of calculations to be performed.

The WIPP LWA also required the EPA to repromulgate 40 CFR 191 for the WIPP. Although the repromulgation of 40 CFR 191 in December 1993, 5 increased the regulatory period for individual protection and groundwater-protection requirements to $10,000 \mathrm{yr}$, it did not significantly change the application of 40 CFR 191 to the WIPP.

Section 6.1.1 describes 40 CFR 191 and two aspects of the Containment Requirements. Section 6.1.2 outlines EPA release limits. A brief overview of CCDF construction is given in Section 6.1.3. Sections 6.1.4 through 6.1.6 provide details on the construction of CCDFs for WIPP PAs.

\section{References}

1 EPA (Environmental Protection Agency). 1985a. "40 CFR Part 191: Environmental Standards for the Management and Disposal of Spent Nuclear Fuel, High-Level and Transuranic Radioactive Wastes; Final Rule," Federal Register. Vol. 50, no. 182, 38066-38089.

2 NRDC (Natural Resources Defense Council, Inc.) v. United States Environmental Protection Agency, et al. 1987. 824 Federal Reporter, $2 d$ Series 1258.

3 Public Law 102-579. 1992. Waste Isolation Pilot Plant Land Withdrawal Act (106 Stat. 4777).

4 EPA (Environmental Protection Agency). 1993b. "Criteria for the Certification of Compliance with Environmental Radiation Protection Standards for the Management and Disposal of Spent Nuclear Fuel, HighLevel and Transuranic Radioactive Wastes; Advanced Notice and Proposed Rulemaking," Federal Register. Vol. 58 , no. 27, 8029-8030.

5 EPA (Environmental Protection Agency). 1993a. "40 CFR Part 191: Environmental Radiation Protection Standards for the Management and Disposal of Spent Nuclear Fuel, High-Level and Transuranic Radioactive Wastes; Final Rule," Federal Register. Vol. 58, no. 242, 66398-66416.

\footnotetext{
* A plot of probability of exceedance of a given level versus that level.
} 


\subsubsection{Overview of 40 CFR 191}

The Environmental Protection Agency's (EPA's) radioactive-waste disposal regulation, 40 CFR Part 191, Environmental Standards for the Management and Disposal of Spent Nuclear Fuel, High-Level and Transuranic Radioactive Wastes, was originally promulgated in $1985 .{ }^{1}$ The 1985 regulation was divided into two subparts [see Figure 6.1-1(a)]. Subpart A limited the radiation doses received by members of the public in the "general environment" as a result of management and storage of transuranic waste, highlevel waste, and spent nuclear fuel. Subpart B provided long-term performance measures for the disposal system and contained four major sections: post-closure Containment Requirements (Section 191.13), Assurance Requirements (Section 191.14), post-closure Individual Protection Requirements (Section 191.15), and post-closure Groundwater Requirements.

The Containment Requirements were based on a fundamental criterion that no more than one premature cancer death per decade would occur over the first $10,000 \mathrm{yr}$ from the disposal of wastes produced from 100,000 metric tons of heavy metals (MTHM), or $10^{-6}$ health effects/MTHM-yr on average. ${ }^{1,2}$ This corresponds to one hundredth the risk factor predicted for an equivalent amount of unmined uranium from three actual ore bodies ${ }^{1}$ and appeared achievable without significant effects on the costs of deep geologic disposal. The derived criteria given in the Containment Requirements were probabilistic limits (see Section 6.1.2, Environmental Protection Agency Release Limits) on timeintegrated radionuclide releases from the disposal system (see Section 1.4.1, Terminology Used in 40 CFR 191). The models the EPA used to move from the fundamental criterion to quantitative limits considered releases to a river, an ocean, the land surface, and included a volcanic and meteoritic disruption. The most stringent of the three pathways - river water ingestion-was used in calculating the release limits (see Section 6.1.2). The regulatory time period for assessments, $10,000 \mathrm{yr}$, was selected to be sufficiently short that potential changes in geologic conditions would not add undue uncertainty to the calculations yet long enough that (1) many radionuclides would have undergone decay, (2) several radionuclides would likely be in transit through the disposal system, and (3) the probability of inadvertent disruptive events would be large enough to include. ${ }^{2}$

The Assurance Requirements established a qualitative design and control philosophy to increase confidence that the probabilistic release limits in the Containment Requirements would be met. The Assurance Requirements included a multiple-barrier concept, a feasibility-of-retrievability position, and passive institutional controls such as government ownership and permanent markers. The Individual Protection Requirements established maximum annual radiation doses to the public in the accessible environment. The Groundwater Protection Requirements established limits on radionuclide contamination in certain sources of water near or within the controlled area. The latter two requirements were established to promote the use of well engineered barriers.

The repromulgated 1993 regulation, ${ }^{3}$ is now divided into three subparts [see Figure 6.1-1(b)]. Subpart A remains unchanged from the 1985 version. Changes were made to the Individual Protection Requirements of Subpart B, and Subpart C redefined the Groundwater Protection Requirements that were originally included in Subpart B. The important change to the Individual Protection Requirements in Subpart $B$ was the lengthening of the time interval for consideration of undisturbed performance from 1000 to 10,000 yr. Subpart C includes the Environmental Standards for Groundwater Protection that are also based on evaluations for a period of 10,000 yr. In addition, the groundwater protection standards are now more closely tied to Safe Drinking Water Act ${ }^{4}$ requirements.

\section{References}

1 EPA (Environmental Protection Agency). 1985a. "40 CFR Part 191: Environmental Standards for the Management and Disposal of Spent Nuclear Fuel, High-Level and Transuranic Radioactive Wastes; Final Rule," Federal Register. Vol. 50, no. 182, 38066-38089.

2 EPA (Environmental Protection Agency). 1985b. Background Information Document-Final Rule for HighLevel and Transuranic Radioactive Wastes. EPA 520/1-85-023. Washington, DC: U.S. Environmental Protection Agency, Office of Radiation Programs.

3 EPA (Environmental Protection Agency). 1993a. "40 CFR Part 191: Environmental Radiation Protection Standards for the Management and Disposal of Spent Nuclear Fuel, High-Level and Transuranic Radioactive Wastes, Final Rule," Federal Register. Vol. 58, no. 242, 66398-66416.

4 Public Law 93-523. 1974. Safe Drinking Water Act (42 U.S.C. $300 \mathrm{f}$ et seq.). 


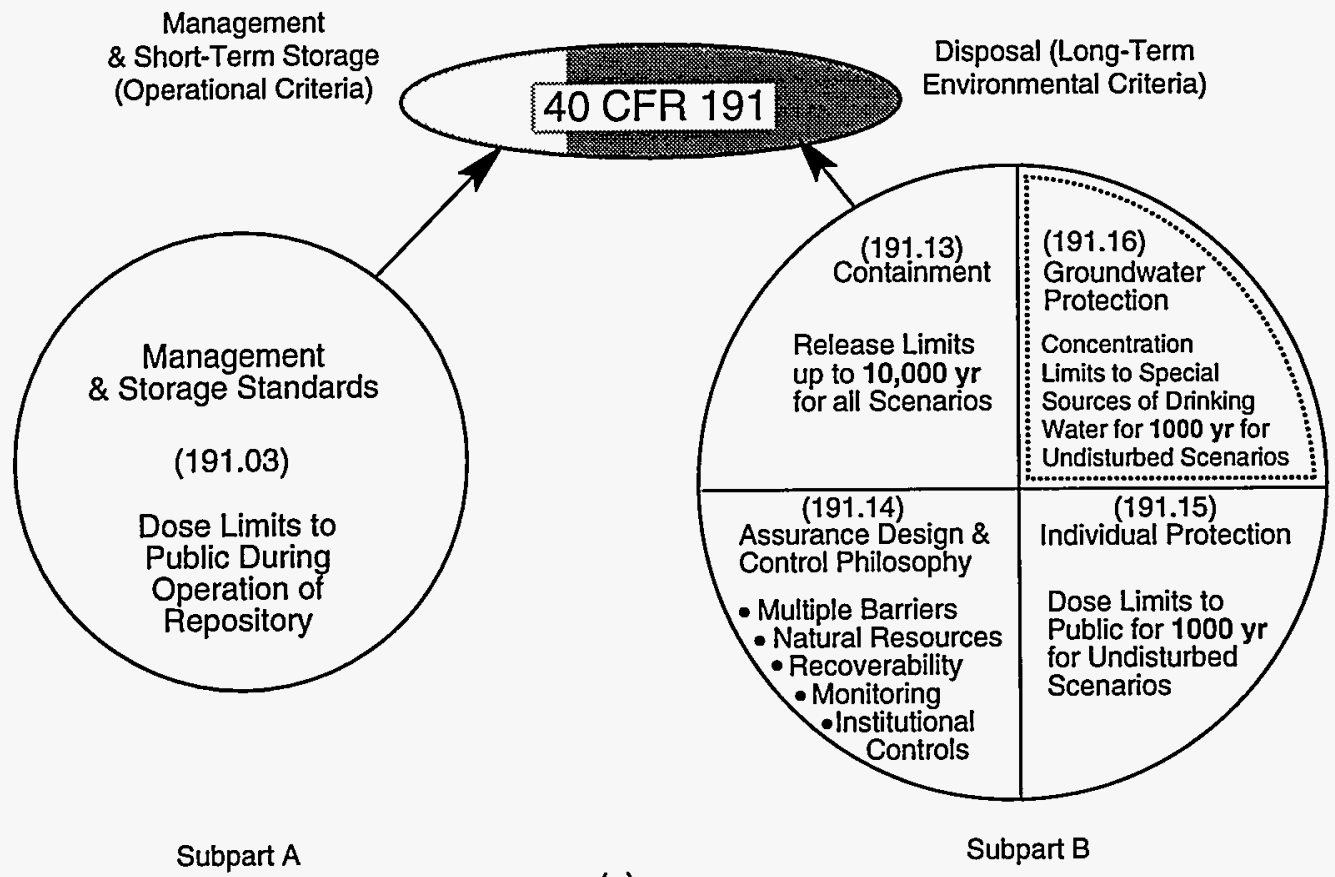

(a)

TRI-6342-3479-3-a

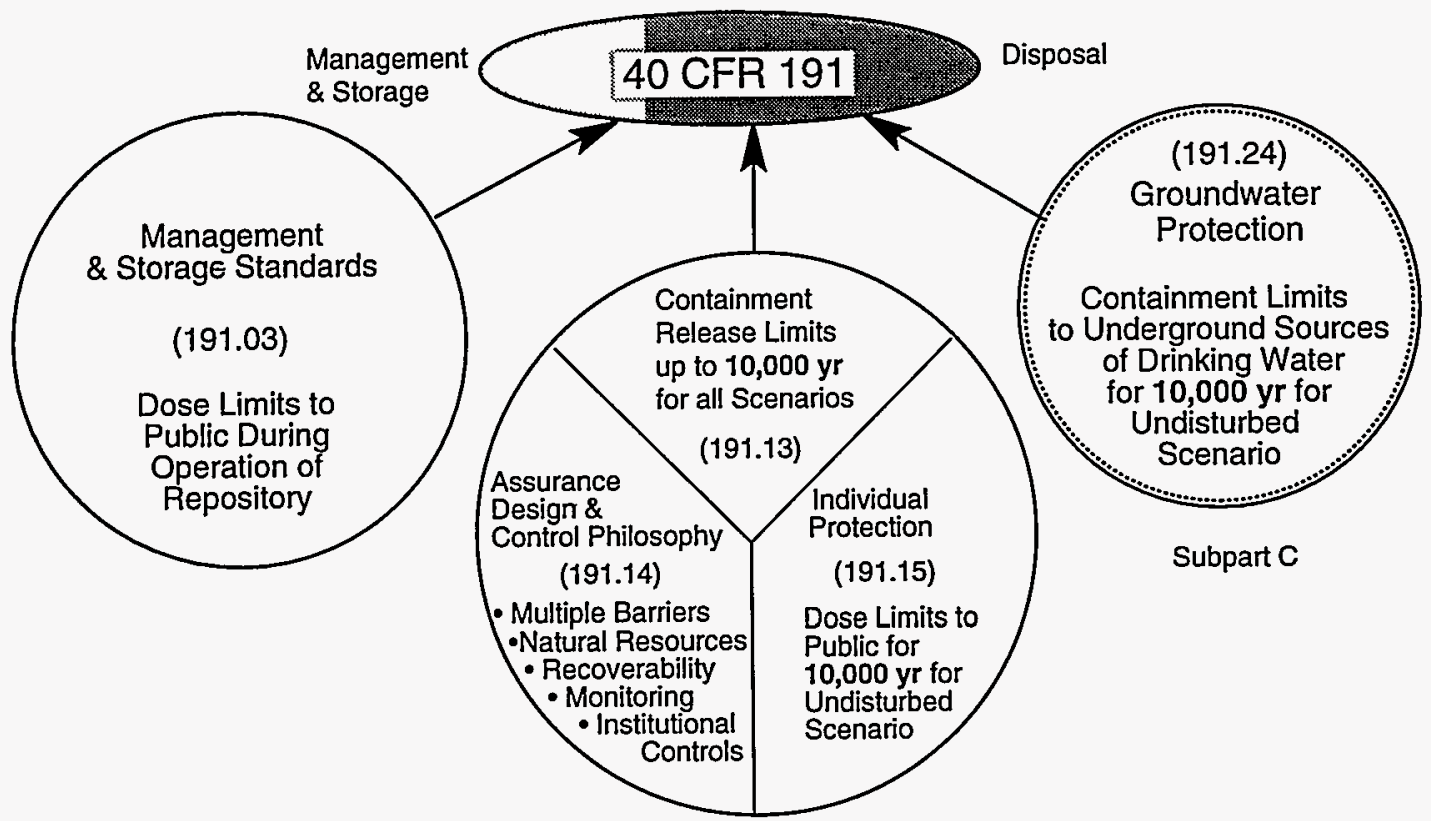

Subpart B

(b)

TRI-6342-3479-3-b

Figure 6.1-1. Organization of 40 CFR 191: (a) original 1985 Rule ${ }^{1}$ and (b) repromulgated 1993 Rule. ${ }^{3}$ 


\subsubsection{Environmental Protection Agency Release Limits}

Containment Requirements (40 CFR 191.13) specify general limits on the release of transuranic (TRU) waste, high-level waste, or spent nuclear fuel (SNF) from a geologic repository. Environmental Protection Agency (EPA) release limits are defined as the normalizing factors for various radionuclides listed in Table I of Appendix A of EPA regulation 40 CFR 191 (see Figure 6.1-2). According to the Containment Requirements, there must be a reasonable expectation, based on a performance assessment that includes all significant processes and events, that the cumulative release of any one radionuclide over $10,000 \mathrm{yr}$ to the accessible environment shall have*

- less than 1 chance in 10 of exceeding the promulgated EPA radionuclide limits $\left(L_{i}\right)$, and

- less than 1 chance in 1000 of exceeding 10 times those quantities.

For a mix of radionuclides, the sum of all releases, where each radionuclide is normalized with respect to its $L_{i}$, shall have ${ }^{*}$

- less than 1 chance in 10 of exceeding 1 , and

- less than 1 chance in 1000 of exceeding 10.

$$
R_{j}=\frac{1}{f_{w}}\left(\frac{Q_{1 j}}{L_{1}}+\frac{Q_{2 j}}{L_{2}}+\ldots+\frac{Q_{n R j}}{L_{n R}}\right)=\sum_{i=1}^{n R} \frac{Q_{i j}}{f_{w} L_{i}} \leq 1 \text { (or 10) }
$$

where

$$
\begin{aligned}
& f_{w}=\text { waste unit factor }=\frac{\sum W_{i}}{10^{6} \mathrm{Ci}}, \text { see Figure } 6.1-2 \text { for units } \\
& W_{i}=\begin{array}{l}
\text { activities in Curies }(C i) \text { for } \alpha \text {-emitting TRU repository wastes having half-lives }\left(\mathrm{t}_{1 / 2}\right) \\
\text { greater than } 20 \mathrm{yr}
\end{array} \\
& L_{i}=\text { the EPA release limit for radionuclide } i \text { (see Figure } 6.1-2 \text { for examples and units) } \\
& n R=\text { number of radionuclides contributing to the release } \\
& R_{J}=\text { total normalized release (EPA sum) for the } j \text { th scenario } \\
& Q_{i j}=\text { cumulative release for radionuclide } i \text { beyond a specified boundary, } \int_{0}^{10,000 y r} q_{i j} d t \\
& q_{i j}=\text { release rate into accessible environment at time } t \text { for radionuclide } i \text { and scenario } j
\end{aligned}
$$

The EPA release limits $\left(L_{i}\right)$ for radionuclides $i=1, \ldots, n R$ are based on generic analyses of hypothetical repositories containing SNF, not TRU waste. The models the contractors for the EPA used to establish the limits considered releases to a river, an ocean, and the land surface. The analysis assumed radionuclides released from the disposal-system boundary were instantaneously deposited into a river, an ocean, or into the land surface. The total cancers per curie were then calculated for each of the three pathways to humans. The-most stringent of the three pathways, river water ingestion, was used in calculating the release limits. That is, the release limits are determined such that releases from the disposal system, the land withdrawal boundary for the WIPP [less than the maximum $5 \mathrm{~km}(-3 \mathrm{mi})$ from the boundary of the disposal region] into a river providing a large population with drinking water, would result in fewer than 1000 cancer deaths over $10,000 \mathrm{yr}$, a health hazard less than the hazard from the amount of unmined uranium ore needed to produce 100,000 metric tons of reactor fuel. ${ }^{1}$ (Refer to Section 5.1.4, Linkage of the CUTTINGS Code, for unforeseen consequences of this conservative definition.)

\section{Reference}

1 EPA (Environmental Protection Agency). 1985b. Background Information Document-Final Rule for HighLevel and Transuranic Radioactive Wastes. EPA 520/1-85-023. Washington, DC: U.S. Environmental Protection Agency, Office of Radiation Programs.

\footnotetext{
- These two points alone determine the EPA limits drawn on all WIPP CCDFs. See Section 6.1.3, Containment Requirements.
} 
Radionuclides with limits on release

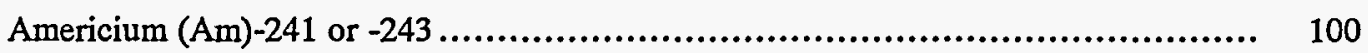

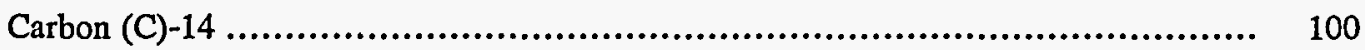

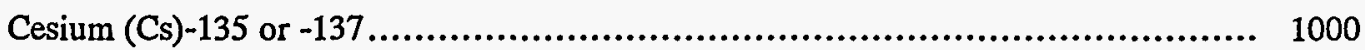

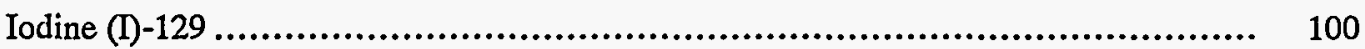

Neptunium (Np)-237........................................................... 100

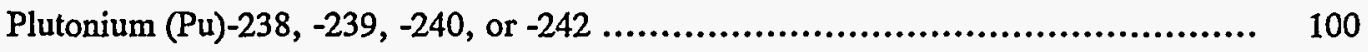

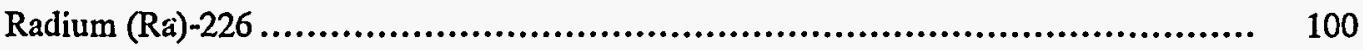

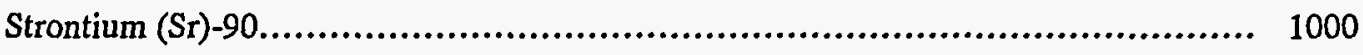

Technetium (Tc)-99 .......................................................... 10000

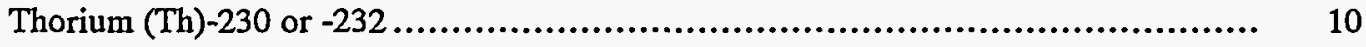

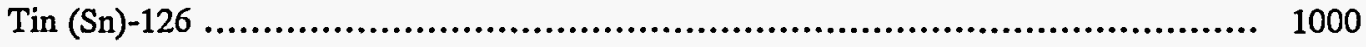

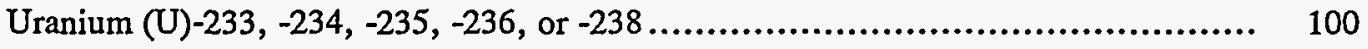

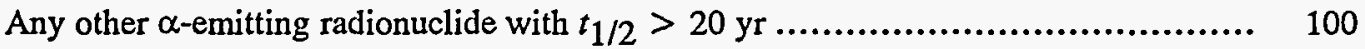

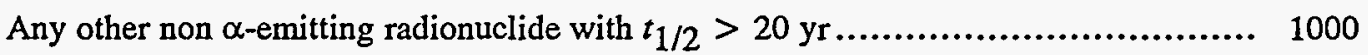

*For transuranic waste, these limits apply to $10^{6} \mathrm{Ci}$ of $\alpha$-emitting TRU nuclides with $\mathrm{t}_{1 / 2}>20 \mathrm{yr}$ (hence, the waste unit factor, $f_{w}$ is the amount of the $\alpha$-emitting TRU nuclides with $\mathrm{t}_{1 / 2}>20 \mathrm{yr}$ in the repository divided by $10^{6} \mathrm{Ci}$ ). Other units of waste are described in $40 \mathrm{CFR} 191$, Appendix A.

Figure 6.1-2. Environmental Protection Agency release limits defined in Table 1 of Appendix A of 40 CFR 191. 


\subsubsection{Containment Requirements}

The Containment Requirements given in Section 13 of 40 CFR $191^{1}$ express Environmental Protection Agency (EPA) probabilistic release limits, normally plotted as a line ${ }^{*}$ (see Section 6.1.2, Environmental Protection Agency Release Limits). In evaluating compliance with these requirements, predicted releases $q_{i j}$ from a consequence model $C$ (see Section 3.3.2, The Component Computational Models) are integrated and normalized by the EPA release limits to produce the performance measure $R_{j}$. See Section 6.1.2 for the equation defining $R\left(S_{j}\right)$. The values of $R\left(S_{j}\right)$ are then ordered from least to greatest,

$$
R\left(S_{j}\right)<R\left(S_{j+1}\right), \text { for } j=1, \ldots, n S-1
$$

and are paired with the estimated cumulative probability for the $j$ th scenario

$$
\sum_{m=j}^{n S} P\left[x, S_{m}(x)\right]
$$

All the consequence-probability pairs, one for each scenario, are plotted and joined stepwise to produce a piecewise continuous curve defining the probability of exceeding any given consequence value $R$, normalized by the EPA release limit. This curve is a complementary cumulative distribution function (CCDF) " from which direct comparisons with EPA regulatory limits may be made. In Appendix $C$ of 40 CFR 191, the EPA specifically suggests this type of display for the best results. For example: "... whenever practicable, the implementing agency will assemble all of the results of the performance assessments to determine compliance with $\$ 191.13$ into a complementary cumulative distribution function that indicates the probability of exceeding various levels of cumulative release." A CCDF is actually a sum of horizontal step functions. Vertical segments are usually added to avoid a broken appearance. The theoretical foundations of CCDF construction are explained in detail by Tierney ${ }^{2}$ and Helton. ${ }^{3}$

If the sampled parameters $\left(\mathrm{x}=x_{1}, x_{2}, \ldots, x_{n K}\right)$ vary on account of uncertainties, the variation is propagated through the consequence model via Monte Carlo sampled sets, and results in a set of $n K$ CCDFs, one for each set of sampled values (see Section 1.3.1, Propagating Uncertain Parameters [Epistemic Uncertainty] through Consequence Models). The resulting distribution of CCDFs and various statistical measures of this family such as the mean, median, and percentiles are plotted. Percentiles display variance. For example, $n \%$ of the family of CCDFs lie beneath the $n$th percentile curve. (Also, the median is the 50th percentile curve.) This suite of curves (see Figure 6.1-3, bottom), together with extensive documentation of the performance assessment process, was typically presented in the 1990-1992 calculations.

\section{References}

1 EPA (Environmental Protection Agency). 1985a. "40 CFR Part 191: Environmental Standards for the Management and Disposal of Spent Nuclear Fuel, High-Level and Transuranic Radioactive Wastes; Final Rule," Federal Register. Vol. 50, no. 182, 38066.

2 Tierney, M.S. 1991. Combining Scenarios in a Calculation of the Overall Probability Distribution of Cumulative Releases of Radioactivity from the Waste Isolation Pilot Plant, Southeastern New Mexico. SAND900838. Albuquerque, NM: Sandia National Laboratories.

3 Helton, J.C. 1993a. "Risk, Uncertainty in Risk, and the EPA Release Limits for Radioactive Waste Disposal," Nuclear Technology. SAND91-1255J. Vol. 101, no. 1, 18-39.

4 Rechard, R.P., ed. 1992. User's Reference Manual for CAMCON: Compliance Assessment Methodology Controller, Version 3.0. SAND90-1983. Albuquerque, NM: Sandia National Laboratories.

* The EPA limits, quoted in Section 6.1.2 are depicted in CCDF space as a set of lines connecting the two EPA limiting points as shown in Figure 6.1-3. According to the guidance of Appendix C of 40 CFR 191, the EPA can consider a disposal system to be in compliance if the CCDF (predicted by the appropriate probability and consequence models) equals or is less than the two limiting points.

**

The CCDF is one minus the values of the CDF $(1-\mathrm{CDF})$, where the cumulative distribution function is the integral (or sum, as appropriate) of the probability density function from zero to a variable upper limit. 


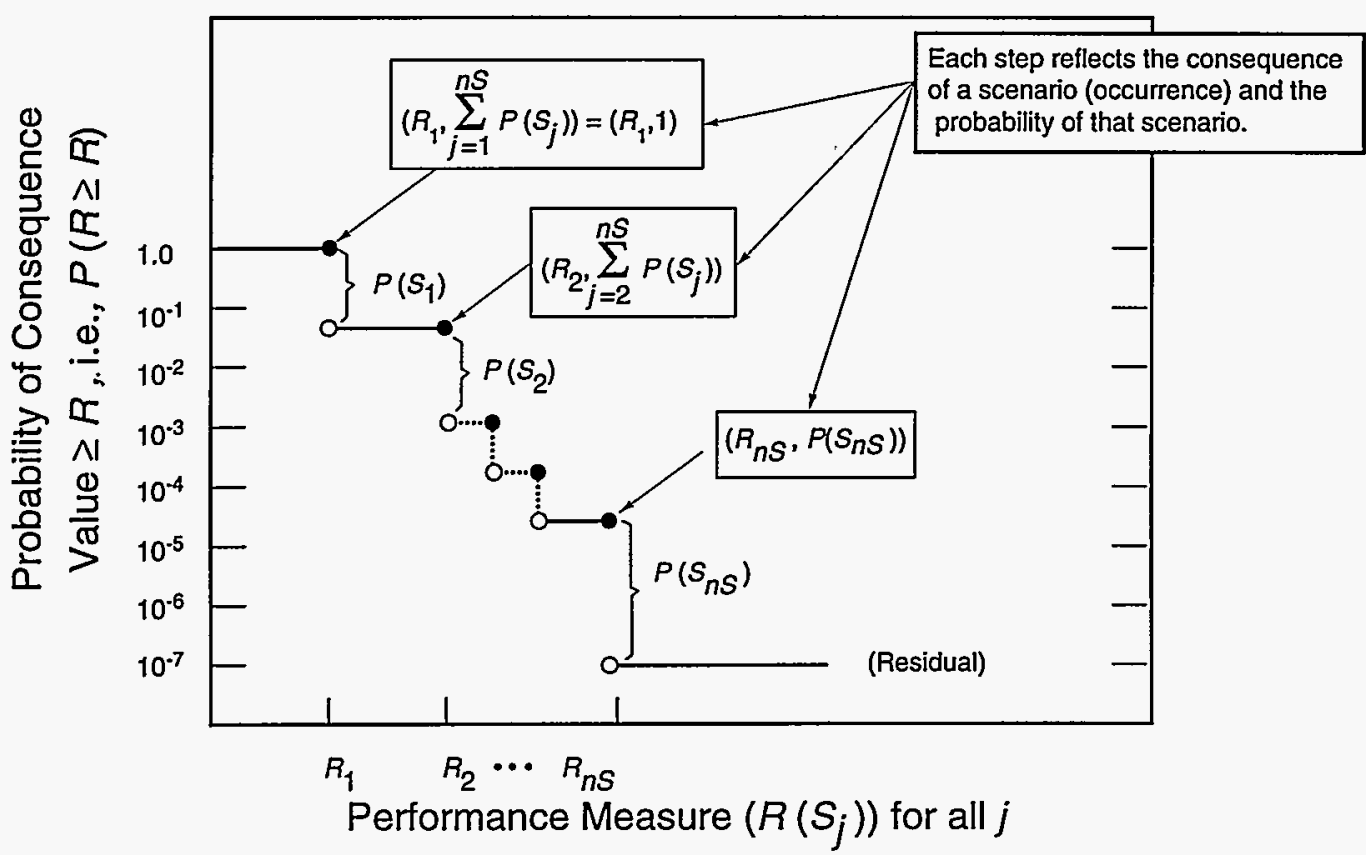

TRI-6342-3806-0

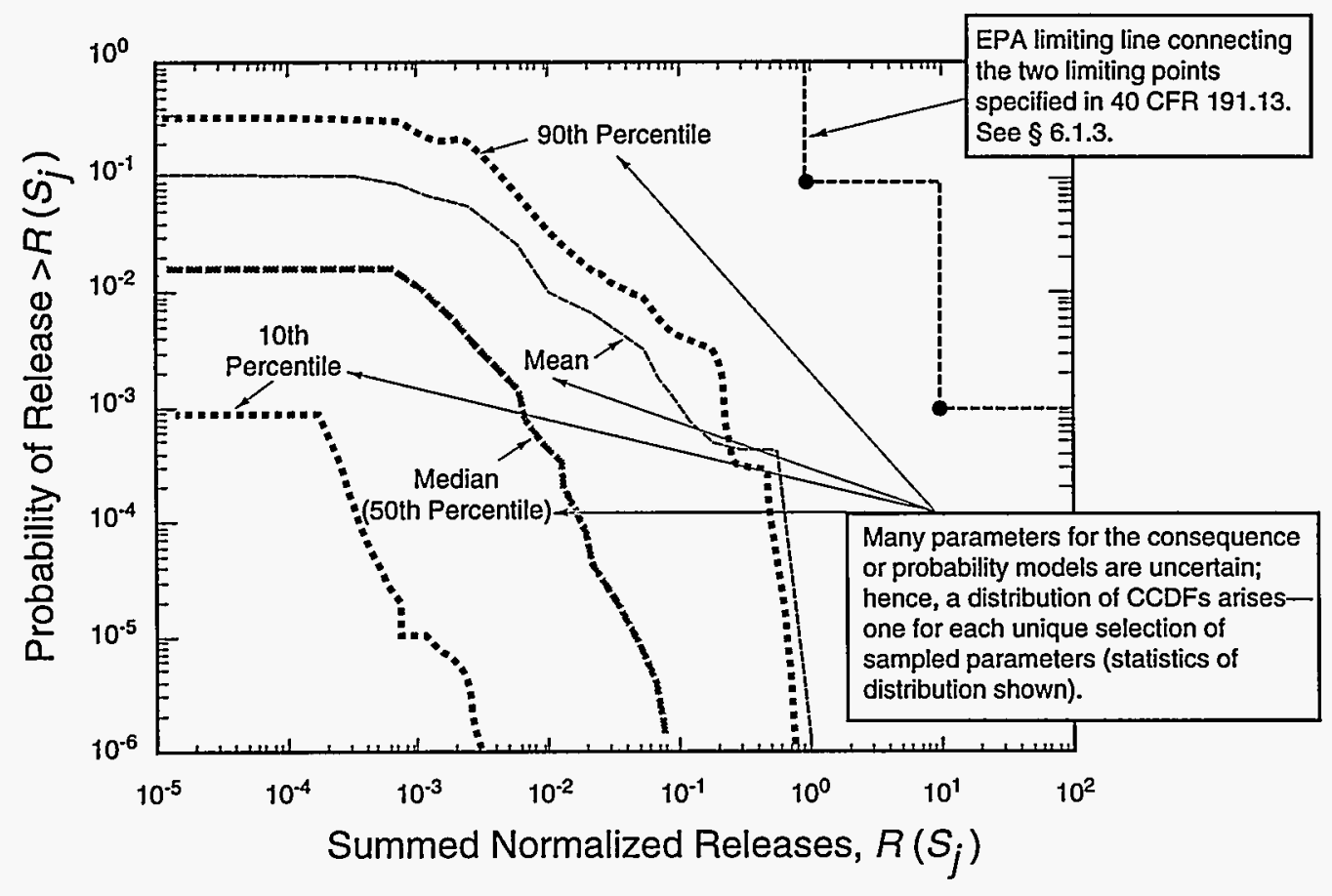

TRl-6342-3480-0

Figure 6.1-3. Construction of complementary cumulative distribution functions (CCDFs) (Rechard, ed., 1992. Figures A-6, A-8). ${ }^{4}$ (a) A single CCDF constructed by pairing exceedance probabilities $\left[\Sigma P\left(S_{j}\right)\right]$ and normalized releases $R_{j}$ calculated for a consequence model C using one set of model parameters $x_{n}$ (b) Summary statistics of a distribution (family) of CCDFs produced from all Monte Carlo samples of model parameters and used for comparison with the EPA limiting line. 


\subsubsection{CCDFs When Parameter Space Is Not Decomposed into Scenarios*}

If the sample space of possible futures of the disposal system is not divided into $n S$ summary scenarios or computational scenarios, the complementary cumulative distribution function (CCDF) is calculated as follows ${ }^{1}$ (Figure 6.1-4):

1. $n K$ Latin hypercube samples are drawn from the $n P$-dimensional parameter space, where $n P$ is the total number of model parameters in the model of the disposal system and $n V$ is the number of parameters that vary $n V \leq n P$ and $n V \leq n K$ ).

2. Radionuclide releases of each $i$ th radionuclide over time, $q_{i k}$, are evaluated using each of the $n K$ sample sets of uncertain parameters; all other parameters are held constant in the modeling system. Results of each of the $n K$ evaluations are recorded.

3. The performance measure, $R_{k}$ (e.g., the EPA summed normalized release), is evaluated for each of the $k=1, \ldots n K$ releases.

$$
R_{k}=\sum_{i=1}^{n R} \frac{Q_{i k}}{f_{w} L_{i}}, k=1,2, \ldots, n K
$$

where

$f_{w} \quad=$ the waste unit factor for scaling EPA release limits

$L_{i} \quad=$ the EPA release limit for $i$ th radionuclide

$n R=$ number of radionuclides monitored for $40 \mathrm{CFR} 191$

$n K=$ number of samples

$Q_{i k}=$ cumulative release for $i$ th radionuclide, $\int_{0}^{10,000 \mathrm{yr}} q_{i k} d t$

$q_{i k}=$ release rate at time $t$ for radionuclide $i$ calculated from consequence models.

4. The performance measures, $R_{k}$, are ranked.

5. The probability of the performance measure exceeding a specified value $P\left(R_{j}>R\right)$ is estimated from the frequency:

$$
P\left(R_{k}>R\right)=n G / n K
$$

where

$$
\begin{aligned}
n G & =\text { number of simulations with } R_{k} \text { exceeding } R \\
n K & =\text { number of samples } \\
R & =\text { specified value (on graph abscissa) }
\end{aligned}
$$

6. The value of the performance measure, $R_{k}$, is then paired with the probability $P\left(R_{k}>R\right)$ to produce a mean CCDF.

\section{Reference}

1 Tiemey, M.S., R.V. Guzowski, and R.P. Rechard. 1993. "Scenario Development," Initial Performance Assessment of the Disposal of Spent Nuclear Fuel and High-Level Waste Stored at Idaho National Engineering Laboratory. Volume I: Methodology and Results. Ed. R.P. Rechard. SAND93-2330/1. Albuquerque, NM: Sandia National Laboratories. 7-1 through 7-27.

\footnotetext{
In WIPP PAs, parameter space is decomposed into scenarios. Section 6.1.4 is included only because it lays the groundwork for the WIPP case in which parameter space is decomposed into scenarios (see Section 6.1.5).
} 


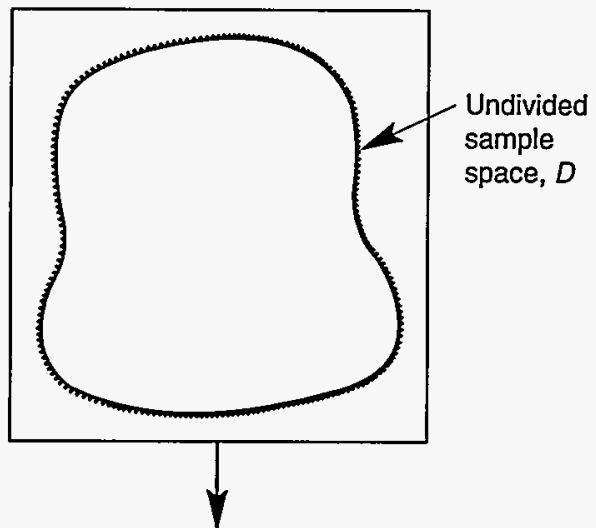

Sample all $n V$ parameters $n K$ times (e.g., time of intrusion, drilling position, and number).

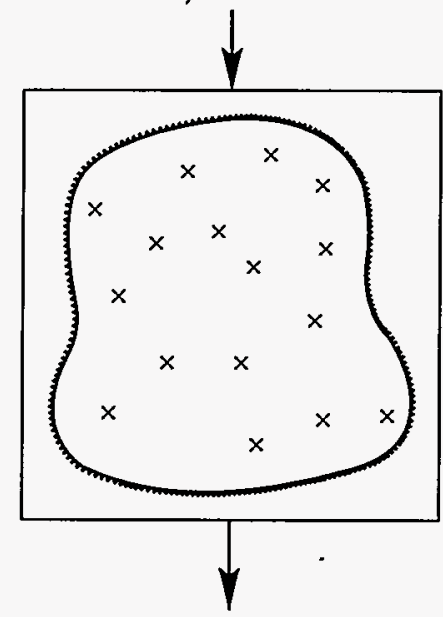

Order all performance metric values,

$R$, evaluated from the

consequences, $C$.

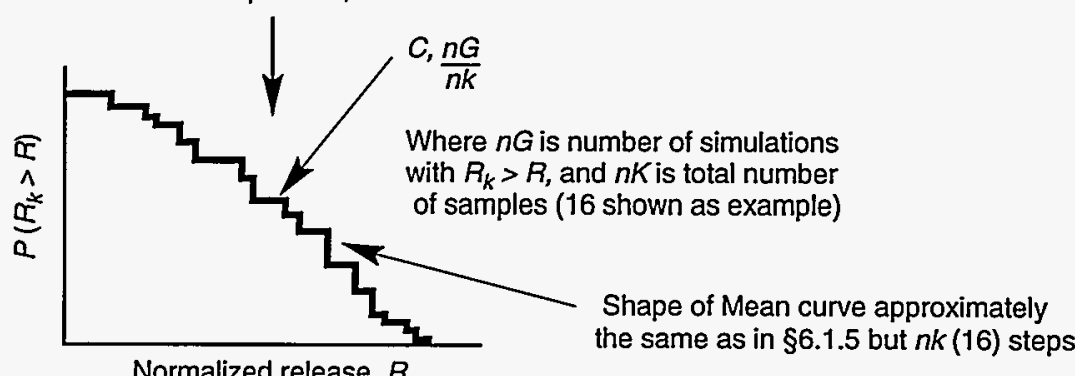

TRI-6342-3554-0-a

Figure 6.1-4. Method of calculating CCDF when parameter space is not decomposed into scenarios (Tierney et al., 1993). ${ }^{1}$ 


\subsubsection{CCDFs When Parameter Space Is Decomposed into Scenarios}

When a sample space is discretized, results may be presented in several ways ${ }^{1,2}$ : (1) a complementary cumulative distribution function (CCDF) can be calculated for each scenario, conditional on the scenario occurring; (2) a CCDF can be calculated for all the scenarios, using the sample space set for each scenario; or (3) the mean CCDF can be calculated from either (1) or (2). This mean CCDF is approximately equal to the mean CCDF calculated without discretizing the sample space into scenarios (provided the scenario discretization is not so coarse that it ignores significant variations and provided the approximations in calculating the individual scenario probabilities $P\left(S_{j}\right)$ are acceptable). The following text describes the steps necessary for presenting the results by the three methods. The second method was used for the 1991 and 1992 PAs; the third method was used for the 1990 and 1991 PAs.

$C C D F$ Conditional on Scenario $S_{j}$ Occurring. The method of calculating a CCDF conditional on the scenario occurring is identical to that described for CCDF construction without scenarios except that only those performance metric values, $R\left(S_{j}\right)$, from the scenario of interest, $S_{j}$, are used.

$C C D F$ of All Scenarios Using One Sample Set (used by the Waste Isolation Pilot Plant [WIPP] Project). To calculate one CCDF for a sample set over all scenarios, only subtle differences exist in a few of the steps from Section 6.1.4:

1. Radionuclide releases over time, $q_{i k}$, are evaluated using one sample set of varied parameters with all other parameters held constant in the modeling system. The sample sets of varied parameters are slightly different from those without scenario discretization because those parameters that define the scenario are now held constant. This step is repeated for each sample set.

2. The performance measures are ranked such that $R_{k}\left(S_{j}\right)<R_{k}\left(S_{j+1}\right)$ for $j=1, \ldots, n S-1$.

3. The probability of a scenario, $P_{k}\left(S_{j}\right)$, is evaluated from the probability model of the scenario.

4. The value of the performance measure, $R_{k}$, for one sample set is then paired with the cumulative probability

$$
\sum_{m=j}^{n S} P(S m)
$$

This is repeated for each scenario $S_{j}, j=1, \ldots, n S$, to produce a CCDF.

5. Step 4 is repeated for each sample set to produce a distribution (or "family") of $n K$ CCDFs.

Mean CCDF. The mean CCDF can be estimated from either the distribution of CCDFs produced above or the CCDFs conditional on the scenario. The mean CCDF from the distribution of CCDFs is the arithmetic average of the probabilities of the family of CCDFs at specified values of $R$. The mean CCDF from the CCDFs conditional on the scenario is calculated as follows:

1. Produce a family of $n S$ CCDFs by evaluating the scaled CCDF, i.e., $P\left(R_{k}>R\right)=P\left(R_{k}>R \mid S_{j}\right) \bullet$ $P\left(S_{j}\right)$.

2. Provided that parameters in the probability model used to evaluate $P\left(S_{j}\right)$ were not varied, the mean CCDF is the arithmetic average of this distribution of CCDFs.

3. If parameters in the probability model were varied, then $P\left(x, S_{j}\right)$ would vary with each sample, $x_{k}$, so that each conditional CCDF results in $n K$ scaled CCDFs, i.e., $P_{k}\left(R_{k}>R\right)=P_{k}\left(R_{k}>R \mid S_{j}\right) \bullet$ $P_{k}\left(x_{k}, S_{j}\right)$. This distribution of $n K \bullet n S$ CCDFs can now be averaged as before to calculate the mean CCDF (used by the Waste Isolation Pilot Plant Project).

\section{References}

1 Tierney, M.S., R.V. Guzowski, and R.P. Rechard. 1993. "Scenario Development," Initial Performance Assessment of the Disposal of Spent Nuclear Fuel and High-Level Waste Stored at Idaho National Engineering Laboratory. Volume I: Methodology and Results. Ed. R.P. Rechard. SAND93-2330/1. Albuquerque, NM: Sandia National Laboratories. 7-1 through 7-27.

2 Helton, J.C., and H.J. Iuzzolino. 1993. "Construction of Complementary Cumulative Distribution Functions for Comparison with the EPA Release Limits for Radioactive Waste Disposal," Reliability Engineering and System Safety. SAND93-7002J. Vol. 40, no. 3, 277-293. 


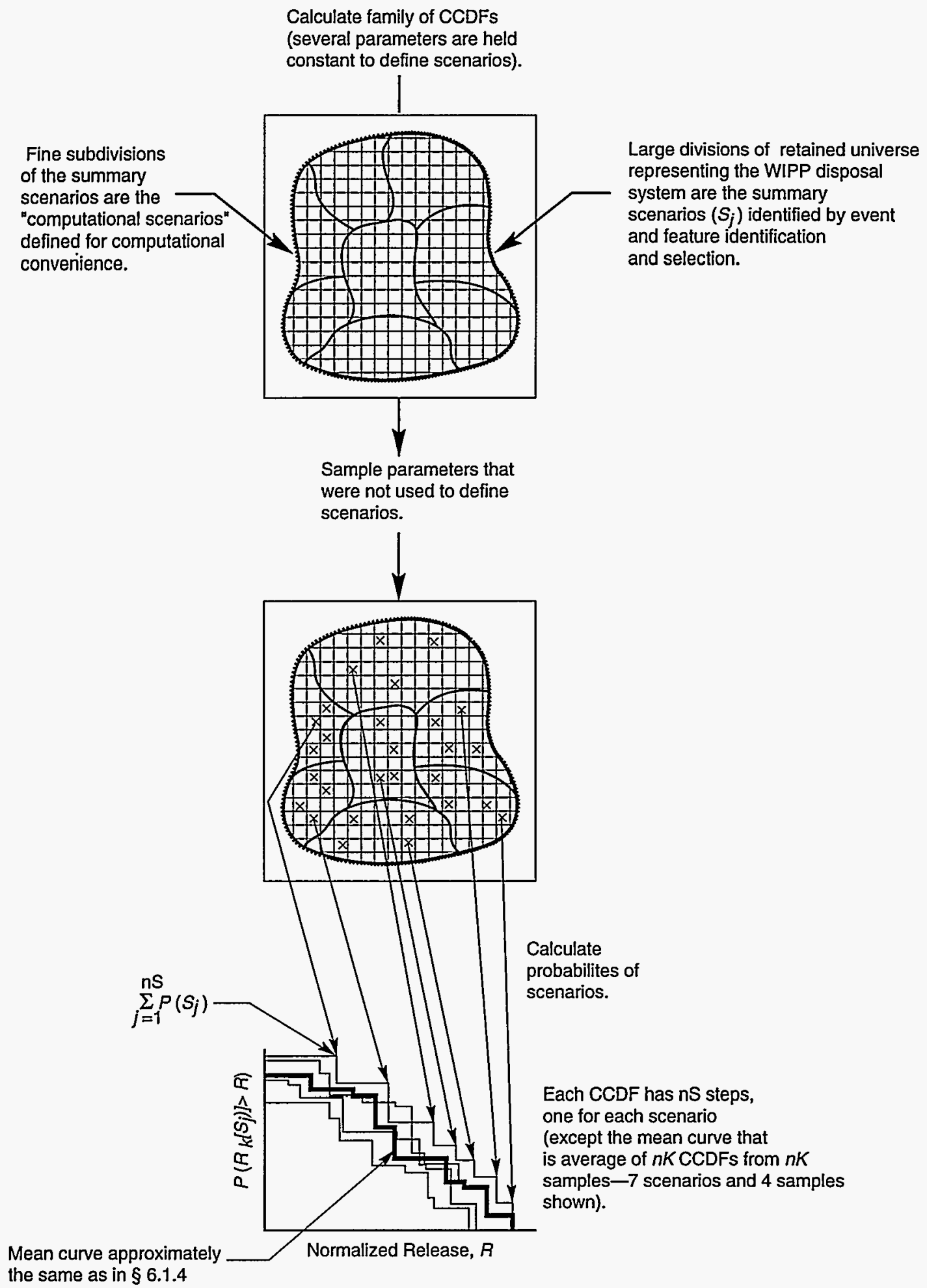

TRI-6342-3554-0-b

Figure 6.1-5. Method of calculating a CCDF when part of the parameter space is decomposed into scenarios (Tierney et al., 1993). 1 


\subsubsection{Software for Calculating Complementary Cumulative Distribution Functions}

Construction of a complementary cumulative distribution function (CCDF) for comparison with the Containment Requirements of 40 CFR 191 consists of (1) normalizing and summing cumulative releases $\left(Q_{i k}\right)$ of $n R$ radionuclides to the accessible environment $\left(R_{k}\right)$ for each $n K$, samples to obtain $n K$ summed, normalized releases for each of the $n S$ scenarios, and (2) plotting the $n R * n K$ summed normalized releases versus the appropriate scenario probabilities $(p)$ (see Sections 6.1.3, 6.1.4, and 6.1.5.). The following software is typically used:

\section{CCDFCALC1}

The CCDFCALC code ${ }^{1}$ generates conditional CCDFs where "conditional" means the CCDF is contingent on certain events or processes occurring. Most frequently, the selected event was a single or double intrusion into the Waste Isolation Pilot Plant (WIPP) repository for performance assessment calculations in 1991 and 1992.

The CCDFCALC code uses contaminant releases across a specified boundary such as the 2.4-km (1.5-mi) land-withdrawal boundary depicted in Section 1.4.1. Releases were generated by a groundwater transport code such as STAFF2D or SECOTP2D (see Section 5.3.3 or 5.3.4) for each set of sampled parameters. One conditional CCDF curve is generated from each sampled set in which the following three types of intrusions usually are considered: a single intrusion into a panel of the repository (Case E2); a single panel intrusion that continues down to a pressurized brine pocket (Case E1); and a double intrusion into one panel with one intrusion continuing down to a pressurized brine pocket (Case E1E2) (see Section 3.2.2, Applying the Grouping Procedure to the WIPP).

Radionuclides brought to the surface by drilling into the repository (see Section 5.1.4) can also be included in the CCDFCALC plot. Those data include contact-handled (CH) and remotely handled (RH) contaminant releases that reside in the binary files CUT_CH_R\#.CDB and CUT_RH_R\#.CDB (see Figure 6.1-6). CCDFCALC writes the normalized discharges (cuttings and groundwater releases) for all the sample sets to the ASCII file, CCDFCALC.TRN, that can be used for sensitivity/uncertainty analysis (see Chapter 7).

\section{CCDFPERM ${ }^{1,2}$}

If groundwater discharge and cuttings data are available for several intrusion times and for different intrusion geometries (Cases E1, E2, and E1E2), linear combinations of the data can be used by the CCDFPERM code (see Figure 6.1-6) to include the effects of intrusion geometry, multiple drilling intrusions, and different concentrations of waste activity to produce the "composite" CCDF, which is the relevant measure to compare with the EPA limiting line.

CCDFPERM takes a sampled drilling intrusion rate, $\lambda$, either constant or time dependent, and determines the probabilities of intrusions over 10,000 yr. Some specific assumptions used in the 1991 and 1992 PA calculations are as follows. When two intrusions fall in the same time interval, the intrusion probability is apportioned between the E1E2 and non-E1E2 cases based on the number of panels. The E1E2 case requires two hits in the same panel during the same time interval. For each intrusion, all possible combinations of waste activities are considered. Each combination of intrusion time intervals and waste activities generates one point for the CCDF plot.

\section{NUCPLOT ${ }^{1}$}

NUCPLOT depicts the contribution [in activity (Ci) or percentage] of each radionuclide to the final $\mathrm{CCDF}$. The contribution of each radionuclide varies slightly for each parameter set. The contribution is therefore a distribution and is depicted as a Tukey bar graph.

\section{References}

1 Rechard, R.P., ed. 1992. User's Reference Manual for CAMCON: Compliance Assessment Methodology Controller, Version 3.0. SAND90-1983. Albuquerque, NM: Sandia National Laboratories.

2 Helton, J.C., and H.J. Iuzzolino. 1993. "Construction of Complementary Cumulative Distribution Functions for Comparison with the EPA Release Limits for Radioactive Waste Disposal," Reliability Engineering and System Safety. SAND93-7002J. Vol. 40, no. 3, 277-293. 


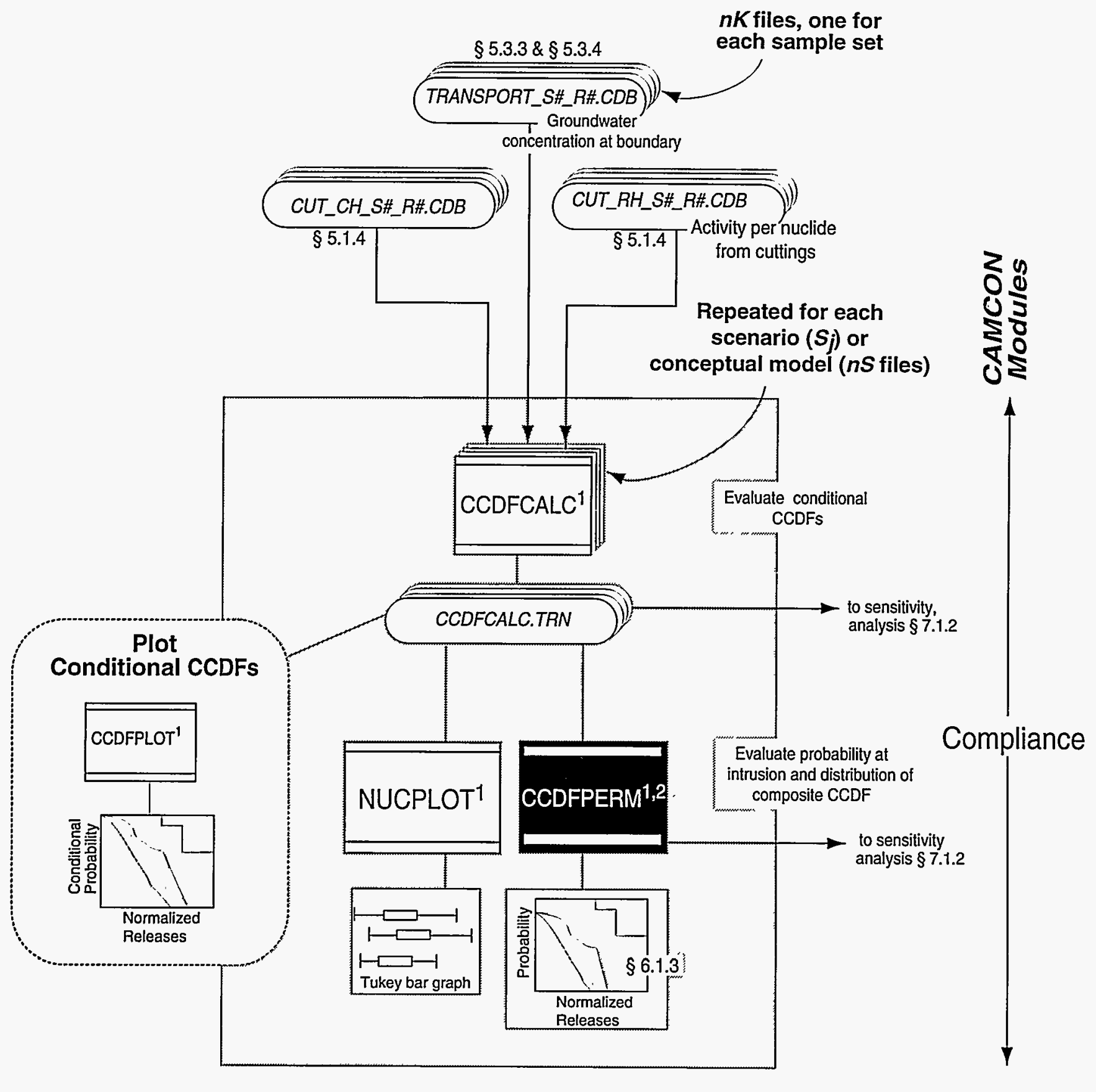

TRI-6342-3849-0

Figure 6.1-6. Linkage of software for constructing complementary cumulative distribution functions (CCDFs) in the 1991 and 1992 performance assessment calculations. 
6.0 Long-Term Regulatory Assessment 


\subsection{National Environmental Policy Act Simulations}

The National Environmental Policy Act (NEPA) of $1969^{1}$ and implementing regulations in 40 CFR 1500-1508 require all federal agencies to prepare detailed statements on the impact of proposed "major federal actions significantly affecting the quality of the human environment," followed by adequate time for public comment. NEPA was the first environmental policy law to apply to the Waste Isolation Pilot Plant (WIPP) (see Section 1.5, Regulatory Influences on the Waste Isolation Pilot Plant Project). NEPA only establishes policy and regulations that implement the NEPA statute do not require specific types of model simulations.

Two environmental impact statements (EISs) have been prepared for the WIPP, one in 1979-80 during deliberations to decide whether to proceed with construction of the facility, ${ }^{2}$ and a supplement in 1989-90 during deliberations to decide whether to proceed with an experimental phase. ${ }^{3}$ In both EISs, the Department of Energy (DOE) included dose ${ }^{*}$ assessments from hypothetical exposure pathways after human disturbance. Furthermore, the WIPP Panel of the Board of Radioactive Waste Management of the National Academy of Sciences, a panel that reviews the scientific basis of the WIPP, has requested dose assessments over $10,000 \mathrm{yr}$ for individuals living in the future.

What follows are the types of results that have been presented to the WIPP Panel based on the 1991 and 1992 performance assessment calculations using the modeling system of Section 5.4, Biosphere Transport Modeling. These kinds of results would likely be included in future supplemental EISs. ${ }^{3 *}$

\section{References}

1 Public Law 91-190. 1970. National Environmental Policy Act of 1969 (83 Stat. 852; 42 U.S.C. 1801 et seq.).

2 U.S. DOE (U.S. Department of Energy). 1980b. Final Environmental Impact Statement: Waste Isolation Pilot Plant. DOE/EIS-0026. Washington, DC: U.S. Department of Energy. Vols. 1-2.

3 U.S. DOE (U.S. Department of Energy). 1990c. Final Supplement Environmental Impact Statement, Waste Isolation Pilot Plant. DOE/EIS-0026-FS. Washington, DC: U.S. Department of Energy, Office of Environmental Restoration and Waste Management. Vols. 1-13.

- Dose is defined as the quantity of radiation absorbed. It accounts for biologic effects and is measured in sieverts (Sv) or rem.

* " The new 40 CFR 191 promulgated in 1993 requires dose calculations (see Section 6.1.1) assuming no human disruption of the area. Although human disnuption is not required for radionuclide releases to occur at many sites in the thick, bedded salt of the WIPP, human intrusion was found to be required before any radionuclides were released in the 1990-1992 PA. Therefore, the dose requirements in 40 CFR 191 would not have been applicable. 


\subsubsection{Dose Assessments}

For the Waste Isolation Pilot Plant (WIPP) scenarios, the concentration of radionuclides inhaled and ingested by humans depends on a number of factors. For the most important pathway to humans at the WIPP, consumption of beef stock cattle that drink water from a contaminated stockpond, the concentrations depend on (1) the concentration of radionuclides in the stockpond, (2) drinking rates of cattle from the pond, and (3) how much meat is ingested by the humans residing at the ranch site (see Section 5.4.1, Radionuclide Pathways to Humans). The damage to various organs of the human body and the chance of cancer depends, in turn, on the type of radiation and the organs of the body exposed.

The first step is the evaluation of the mean absorbed dose rate on the $j$ th organ (or tissue) from radionuclide $k\left(\dot{D}^{k} R j\right)$. This evaluation involves four primary factors: (1) the activity in source region(s) $(\Omega)$ irradiating the organ $\left(A_{\Omega}\right)$, (2) the mean energy emitted by radionuclide $k$ of radiation type $\mathrm{R}\left(\Delta_{R}^{k}\right)$, (3) the ratio of energy absorbed by the $j$ th organ to energy emitted at the source region $\left(\Phi_{R}^{k}\right)$, and adjustment factors for the last two terms, a quality factor $\left(Q_{R}\right)$ accounting for the biological effectiveness of the radiation type and a general factor $(N)$ that is currently set equal to 1; hence, $\dot{D}_{R, j}^{k}=\sum_{\Omega} A^{k} \Omega(\tau)\left(\Delta_{R}^{k} \Phi_{R}^{k}\right) Q_{R} N$ where only $\mathrm{A}_{\Omega}(\tau)$ is assumed to vary with time.

The,next step is the calculation of the equivalent dose rate to the $j$ th organ (or tissue) ( $\dot{H}_{j}$ ) to humans from a pathway considering the various types of radiation from an absorbed dose on the $j$ th organ $\left(\dot{D}_{R, j}^{k}\right)$ and the appropriate weighting factor ${ }^{1}$ for the type of radiation $R\left(w_{r}\right)$, that is, $\dot{H}_{j}=\sum \sum \dot{D}^{k}{ }_{R j}^{\bullet} w_{R}$. The equivalent dose $\left(\dot{H}_{j}\right)$ relates radiation types $(\alpha, \beta, \gamma)$, energy levels of neutrons, ${ }^{k}$ protons, and fission fragments to biological effects in various organs and is measured in units of sieverts (Sv) or rem per time.

From ingested or inhaled radionuclides emitting radiation, this equivalent dose will be spread out over time, being gradually delivered as the $k t h$ radionuclide decays. By convention, a constant rate of intake of each radionuclide is assumed to occur over one year, and then the equivalent dose over $50 \mathrm{yr}$ is evaluated, the "50-yr committed dose" (Figure 6.2-1a). In other words, the committed equivalent dose over the next $50 \mathrm{yr}$ to the $j$ th organ from the $k$ th radionuclide emitting radiation $R$ from one year of ingestion is

$$
\mathrm{H}_{\mathrm{j}}=\int_{0}^{50 \mathrm{yr}} \dot{\mathrm{H}}(\tau) \mathrm{d} \tau=\int_{0}^{50 \mathrm{yr}} \sum_{\mathrm{kR}} \dot{\mathrm{D}}_{\mathrm{R}, \mathrm{j}}^{\mathrm{k}} \bullet \mathrm{w}_{\mathrm{r}} \mathrm{d} \tau \text {. }
$$

The next step is the calculation of the effective dose $(E)$ to the whole body considering the equivalent doses to the major organs. To arrive at a total risk to the whole body, each of the organs (or tissue) has a organ weighting factor ${ }^{1}\left(w_{j}\right)$ that takes into account the risk irradiation or ingestion of radionuclides of that organ contributes to the total whole body risk; thus

$$
\mathrm{E}=\sum_{\mathrm{j}} \mathrm{w}_{\mathrm{j}} \cdot \mathrm{H}_{\mathrm{j}}=\sum_{\mathrm{j}} \mathrm{w}_{\mathrm{j}} \sum_{\Omega \mathrm{k} R} \sum_{0} \int_{0}^{50 \mathrm{yr}} \mathrm{A}^{\mathrm{k}} \Omega(\tau) \mathrm{d} \tau\left(\Delta_{\mathrm{R}}^{\mathrm{k}} \Phi_{\mathrm{R}}^{\mathrm{k}}\right) \mathrm{Q}_{\mathrm{R}} \mathrm{N} \mathrm{w}_{\mathrm{R}}
$$

A detailed description of these calculations can be found in Till and Meyer. ${ }^{2}$ Because most factors are considered independent, the order of summation and integration can be varied; the order shown is as described for codes in Section 5.4.2, Executing Biosphere Transport Codes.

Because the concentrations of radionuclides ingested and the numerous parameters used to calculate the transfer factors to the various organs all vary, the committed effective dose $(E)$ varies. It can be displayed as a complementary cumulative distribution function. A comparison of the mean simulated committed effective dose $(E)$ from the stockpond-to-cow-to-human pathway at the WIPP with other general risks to the public (Figure 6.2-1b) shows the absorbed dose from the WIPP over 10,000 yr to be very small.

\section{References}

1 ICRP (International Commission on Radiological Protection). 1990. "ICRP Publication 60: 1990 Recommendations of the International Commission on Radiological Protection," Annals of The ICRP. Elmsford, NY: Pergamon Press, Inc. Vol. 21, no. 1-3.

2 Till, J.E., and H.R. Meyer, eds. 1983. Radiological Assessment: A Textbook on Environmental Dose Analysis. ORNL-5968; NUREG/CR-3332. Oak Ridge, TN: Oak Ridge National Laboratory. Chapter 7. 


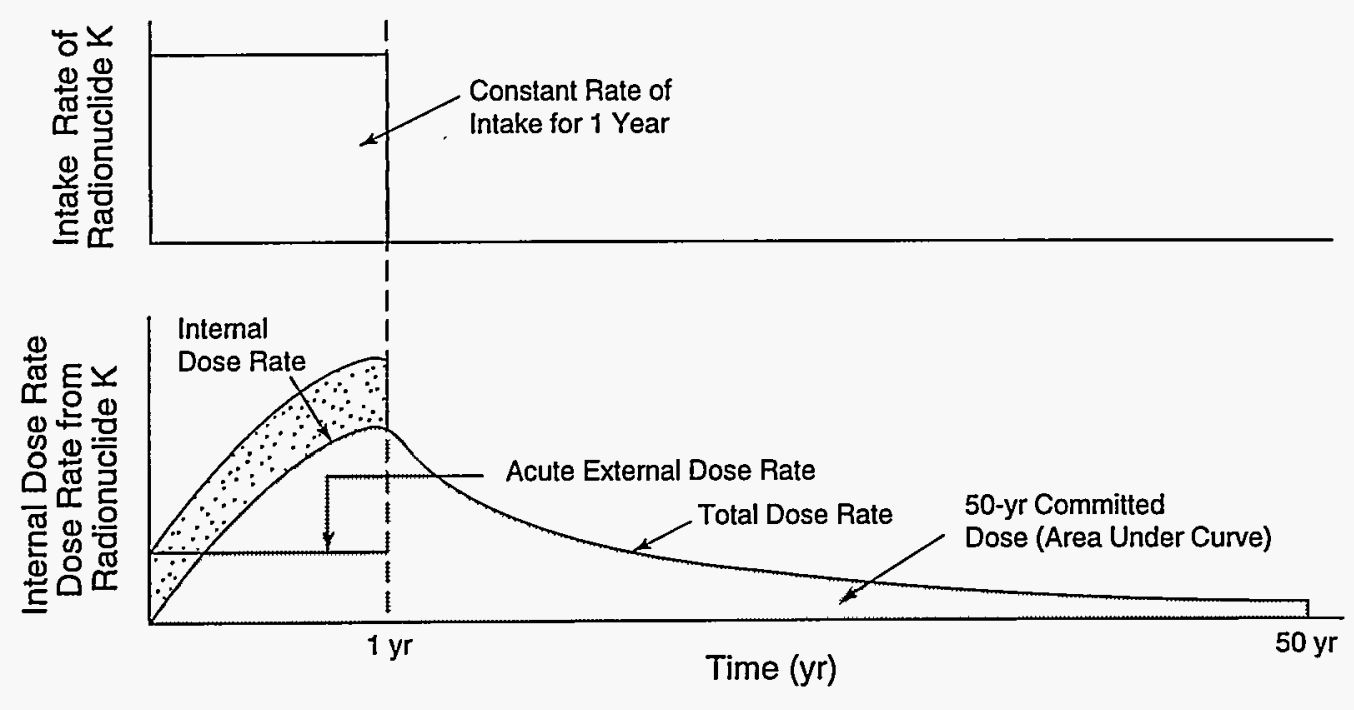

TRI-6342-4141-0

(a)

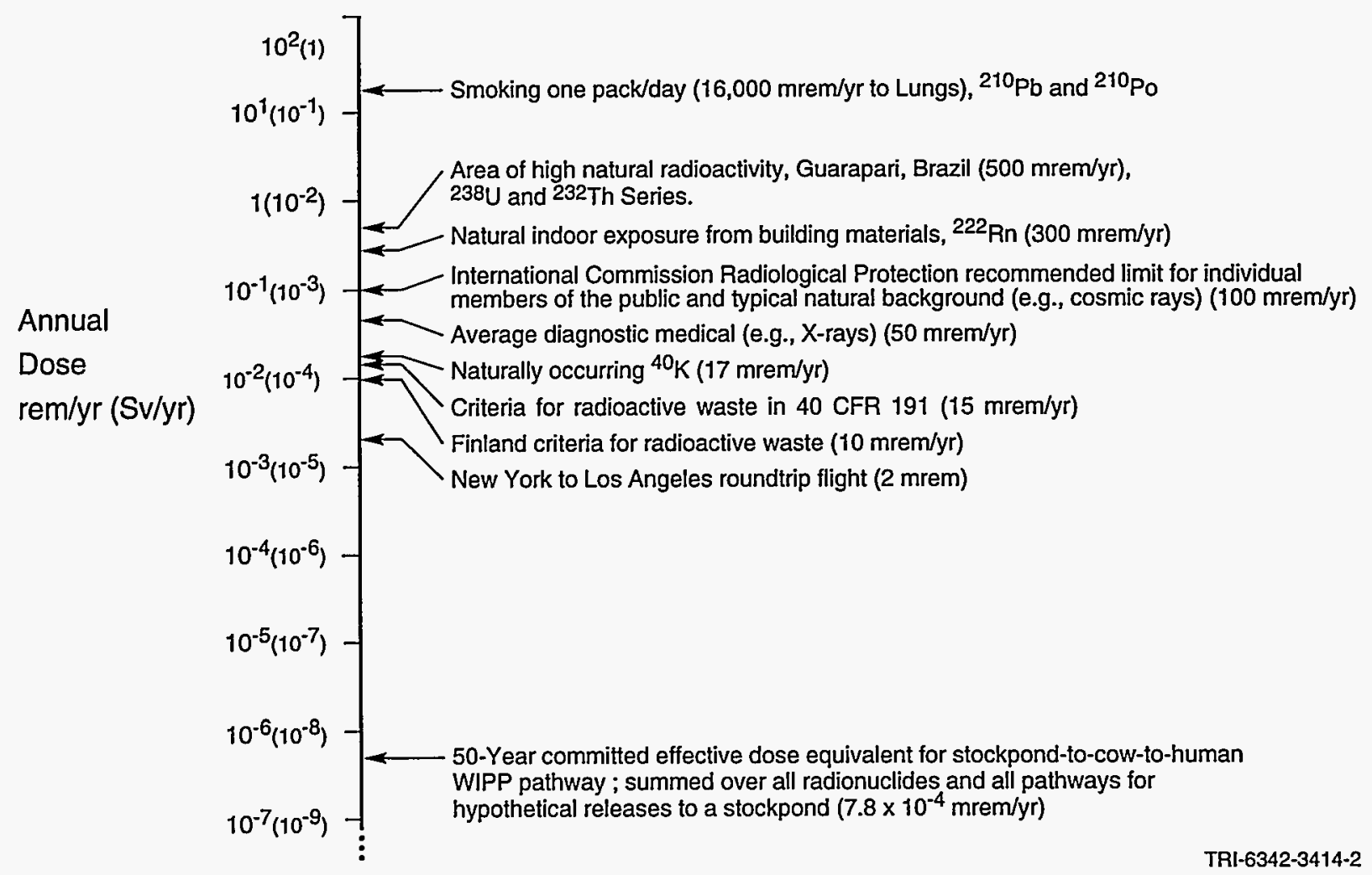

(b)

Figure 6.2-1. Dose assessment from 1991 performance assessment calculations (a) 50-yr committed effective dose (area under curve) from 1-yr internal intake and acute external exposure of radionuclides and the accompanying extended internal dose, and (b) comparison of mean annual effective dose equivalent radionuclide dose for the Waste Isolation Pilot Plant repository with radiation doses received from other sources. 


\subsubsection{Evaluation of Human Health Effects Per Year}

Radiation protection criteria published by international organizations provide the basis for regulations in many countries for radioactive waste disposal. In 1984, the Nuclear Energy Agency (NEA) published an expert group report that introduced the concept of individual risk criteria for radioactive-waste disposal ${ }^{1}$ where risk was defined as the product of the dose exposure. Also, it was determined that the probability that doses received would give rise to deleterious health effects in the future after a latent period could be a few years for leukemia to tens of years for other forms of malignant cancer (external and internal radiation dose is usually assumed to increase the probability of cancer, regardless of the source or the amount of radiation dose). The prestigious International Commission on Radiological Protection (ICRP) recommendations in the 1985 Report $46^{2}$ (reiterated more recently in 1990 Report $60^{3}$ ) complemented the 1984 NEA report. The principal recommendation is as follows: Risk for individuals of the public should correspond to the risk associated with the current ICRP individual dose limit ( $1 \mathrm{mSv} / \mathrm{yr}$ ) (see Section 6.2.1). This annual limit corresponds to a risk of about 1 in 100,000 of experiencing a fatal cancer in any year (Figure 6.2-2). Several national regulations (e.g., the United Kingdom, Canada, and the Nordic countries) follow this recommendation but set the risk limit one order of magnitude lower than at $10^{-6}$ health effects/yr for radioactive waste disposal on the belief that waste disposal is only one of several potential sources for radiation exposure. Other differences in the application of this principal recommendation occur among countries because (1) some exclusively express the limits in terms of dose rather than health effects or vice-versa, (2) some use individual while others use population dose or health effect limits (3) some specify different regulatory periods, and (4) some require different levels of detail or style of the calculations.

For the purpose of making comparisons with recommendations by the ICRP and other internal criteria in the 1991 performance assessment (PA) calculations, the Waste Isolation Pilot Plant (WIPP) made the usual assumption that there was a probability of $10^{-2}$ health effects per sievert of mean annual committed effective dose equivalent in the 1991 PA calculations. Hence, the calculated risk was about $10^{-10}$ health effects per year $\left(10^{-2}\right.$ health effects/Sv $-7.8 \times 10^{-9} \mathrm{~Sv} / \mathrm{yr}$ ) (see Section 6.2 .1$)$ for the hypothetical stockpond-to-cattle-to-human pathway at the WIPP (see Section 5.4.1, Radionuclide Pathways to Humans). The hazard in this preliminary calculation was orders of magnitude less than the ICRP recommended limit and target-hazard criteria for deep geologic nuclear-waste repositories in other nations (Figure 6.2-2).

\section{References}

1 NEA (Nuclear Energy Agency). 1984. Long-Term Radiation Protection Objectives for Radioactive Waste Disposal. Paris, France: Nuclear Energy Agency, Organisation for Economic Co-Operation and Development.

2 ICRP (International Commission on Radiological Protection). 1985. "ICRP Publication 46: Radiation Protection Principles for the Disposal of Solid Radioactive Waste," Annals of the ICRP. Elmsford, NY: Pergamon Press, Inc. Vol. 15, no. 4.

3 ICRP (International Commission on Radiological Protection). 1990. "ICRP Publication 60: 1990 Recommendations of the International Commission on Radiological Protection," Annals of the ICRP. Elmsford, NY: Pergamon Press, Inc. Vol. 21, no. 1-3. 


\section{Probability \\ of Human Health \\ Effects/Yr}

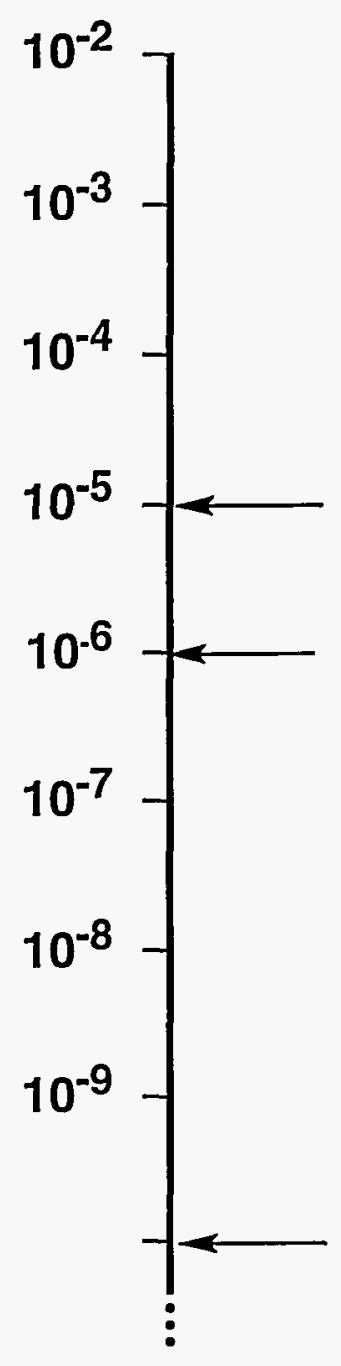

International Commission on Radiologic Protection (ICRP), Nuclear Energy Agency (NEA), and International Atomic Energy Agency (IAEA) recommended limit

Design target, high-level and low-level repository probabilistic safety assessments by United Kingdom and Canada, and deterninistic assessments by Finland, Sweden, and Norway

WIPP; probability of human health effect from whole-body doses summed over all radionuclides for stockpond-to-cattle-to-human exposure pathway (see $\S 5.4 .1$, Radionuclide Pathways to Humans), assuming:

1. $10^{-4}$ health effects/rem;

2. an E1E2-type (See $\S 3.2 .4$, Human Intrusion Summary Scenarios) or E1-type scenario

3. stockpond radionuclide concentrations calculated assuming a dual-porosity transport model with chemical retardation (See § 5.3, Radionuclide Transport Modeling); and

4. varying Culebra brine aquifer recharge (See $\S 2.1 .6$, Climatic Variability).

TRI-6342-3843-0

Figure 6.2-2. Comparison of cancer health effects from the WIPP (from 1991 performance assessment calculations, assuming $5 \times 10^{-4}$ health effects per rem) with acceptable hazards permitted by other countries. 
6.0 Long-Term Regulatory Assessment 


\subsection{Resource Conservation and Recovery Act Simulations}

The Resource Conservation and Recovery Act (RCRA) of $1976^{1}$ and subsequent amendments, most notably the Hazardous and Solid Waste Amendments of $1984,{ }^{2}$ provide for the management of hazardous chemical wastes. The corresponding Environmental Protection Agency (EPA) regulations are 40 CFR Parts 124-181. The primary influence of RCRA to the Waste Isolation Pilot Plant (WIPP) are the following implementing regulations:

- 40 CFR 270-specifying the permitting process and the two parts of the RCRA permit, Parts A and $B$. In particular, Section 270.23 specifies information required in Part $B$ for a "miscellaneous unit" such as the WIPP.

- 40 CFR 268-specifying land-disposal restrictions for hazardous waste; specifically, Section 268.6 describes the petitioning procedure for applying for a "No-migration" variance under these provisions.

The current WIPP approach to these RCRA regulations is to petition for a "no-migration" variance to the land-disposal restrictions for hazardous wastes that are not treated (e.g., neutralized) by approved procedures (40 CFR 268.6). Such a petition allows hazardous chemicals to be disposed of in the repository for the maximum length of time allowed in the permit, with renewals as necessary. However, the petitioner must demonstrate "to a reasonable degree of certainty that there will be no migration of hazardous constituents from the disposal unit . . . " (40 CFR 268.6[a]). In March 1990, the U.S. Department of Energy (DOE) petitioned the EPA for a "no-migration" determination for the test phase of the WIPP, submitting results from deterministic modeling demonstrating to a reasonable degree of certainty, that any test wastes would not migrate from the disposal unit for the WIPP ${ }^{4}$ (the Salado Formation bounded by the WIPP land-withdrawal boundary-see Section 1.4.1). The EPA issued a conditional "no-migration" determination for the WIPP Test Phase only in November 1990. ${ }^{3}$ Also in 1990, the EPA authorized the State of New Mexico to apply RCRA regulations to facilities in the state that manage radioactive wastes (see Section 1.5.1, Timeline of Events for the WIPP Project).

In addition in May 1995, the DOE sent a draft to the EPA for a "no migration" determination for the 35-yr operational/closure phase of the WIPP that again included deterministic modeling demonstrating that concentrations of hazardous constituents remained far below health standards outside the disposal unit during operations. ${ }^{5}$ The analysis were limited to deterministic consequence modeling following current EPA guidance that states "model assumptions and input data should be conservative and tend toward overestimating rather than underestimating migration."

The petition for the variance for permanent disposal (after the operational phase) will require predictive calculations, but the stochastic nature and similarity to calculations performed to evaluate compliance with 40 CFR 191 must be negotiated with the EPA and the state of New Mexico. In contrast to $40 \mathrm{CFR} 191$ calculations, it is likely that only repository performance and no human intrusion, whether purposeful or inadvertent, will be evaluated. However, calculations done to date for the WIPP have used stochastic consequence modeling to present a consistent style of calculation to the EPA and the public (see Section 7.1.1, Ranking Important Model Parameters, for examples of simulations for RCRA) and this is the current intent of the DOE. ${ }^{5}$

\section{References}

1 Public Law 94-580. 1976. Resource Conservation and Recovery Act of 1976 (90 Stat. 2795 and subsequent amendments).

2 Public Law 98-616. 1984. The Hazardous and Solid Waste Amendments of 1984 (98 Stat. 3221).

3 EPA (Environmental Protection Agency). 1990. "Conditional No-Migration Determination for the Department of Energy Waste Isolation Pilot Plant (WIPP)," Federal Register. Vol. 55, no. 220, 47700-47721.

4 WEC (Westinghouse Electric Corporation). 1990. Waste Isolation Pilot Plant No-Migration Variance Petition. DOE/WIPP89-003, Rev. 1. Prepared for U.S. Department of Energy. Carlsbad, NM: Westinghouse Electric Corporation, Waste Isolation Division.

5 U.S. DOE (Department of Energy). 1995a. Draft No-Migration Variance Petition. DOE/CAO-95-2043. Carlsbad, NM: U.S. Department of Energy, Waste Isolation Pilot Plant, Carlsbad Area Office.

6 EPA (Environmental Protection Agency). 1992c. No-Migration Variances to the Hazardous Waste Land Disposal Prohibitions: A Guidance Manual for Petitioners, Draft, July 1992. EPA/530/R-92/03. Washington, DC: U.S. Environmental Protection Agency, Office of Solid Waste. 
6.0 Long-Term Regulatory Assessment 


\subsection{SENSITIVITYIUNCERTAINTY ANALYSIS}

Sensitivity analysis involves determining the effect of varying parameters of a model on the consequences, $C\left[\mathrm{x}, S_{j}(\mathrm{x})\right]$, of the model. Uncertainty analysis involves determining the contribution (importance) of variation of an individual parameter $\left(x_{n}\right)$ to the associated uncertainty of the consequences (distribution of $\left.C\left[\mathbf{x}, S_{j}(\mathbf{x})\right]\right) .{ }^{*}$ The latter, uncertainty analysis, is discussed in more detail elsewhere in this report. Both analyses are strongly influenced by the parameter range used, but uncertainty analysis also includes the likelihood that the parameter will reach the endpoints of its range. The uncertainty analysis method described herein includes the creation of scatterplots, the development of regression models between parameters and results (see for example, Helton et al. ${ }^{2}$ ) and the use of absolute values of standardized regression coefficients (or the mathematically related partial correlation coefficients) from the regression models.

The four principal purposes of the sensitivity/uncertainty analysis are (1) to gain understanding and insight about the disposal system, (2) to help verify the correctness of the calculations, (3) to evaluate the influence of various options for waste forms on the results, and (4) to provide input so decision makers can allocate resources in later performance assessment iterations to collect data about the parameters that most influence the results, based on what is already known about the site or waste. Because uncertainty and sensitivity analyses are inherently conditional on the models, data distributions, and techniques used to generate them, they cannot provide insight about parameters not sampled, conceptual and computational models not used in the analysis in question, or processes that have been oversimplified in the analysis. Hence, qualitative judgment about the modeling system must be used in combination with the results of sensitivity/uncertainty analyses to set priorities for additional data acquisition and model development.

\section{References}

1 Morgan, M.G., M. Henrion, and M. Small. 1990. Uncertainty: A Guide to Dealing with Uncertainty in Quantitative Risk and Policy Analysis. New York, NY: Cambridge University Press. p. 172.

2 Helton, J.C., J.W. Garner, R.P. Rechard, D.K. Rudeen, and P.N. Swift. 1992. Preliminary Comparison with 40 CFR Part 191, Subpart B for the Waste Isolation Pilot Plant, December 1991. Volume 4: Uncertainty and Sensitivity Analysis Results. SAND91-0893/4. Albuquerque, NM: Sandia National Laboratories.

- Uncertainty analysis is a technique to evaluate how the uncertainties in a parameter (i.e., how likely it is to vary) relate to uncertainty in the results. The results of a model may be very sensitive to varying a parameter, but if the parameter's value is precisely known, the parameter will not contribute to producing uncertainty in the prediction. (Uncertainty analysis is sometimes called importance analysis.) 
7.0 Sensitivity/Uncertainty Analysis 


\subsection{Evaluations of Statistical Correlations}

The purpose of uncertainty analysis is to determine the contribution (importance) of uncertainties in model parameters to the associated uncertainty in the result (where the results are usually the consequences, $C\left[\mathrm{x}, S_{j}(\mathbf{x})\right]$, but can also be the probabilities, $\left.P\left[x, S_{j}(x)\right]\right)$. The primary measures of the uncertainty include the mean, variance, and distribution of the results of interest. This section describes briefly the uncertainty analysis techniques used, including scatterplots and stepwise regression analyses. A more detailed discussion of these techniques and their applications is given by Helton et al. $1,2,3$

Scatterplots are the simplest sensitivity-analysis tools. The scatterplot approach consists of generating plots of the results (dependent variables) vs. model parameters (independent variables), ${ }^{*}$ each point in the plot representing one "realization," that is, one deterministic calculation of probability and consequence models using one set of sampled model parameters. When there is no relationship between the independent and dependent variable, the individual points are incoherently scattered over the plot or spread along a horizontal line. In contrast, the existence of a well-defined relationship between the independent and dependent variable is often revealed by patterns in the distribution of the individual points such as a spread of points along a nonhorizontal locus.

In stepwise regression analysis, a sequence of regression models is constructed. The first regression model contains the one independent variable that has the largest impact on the dependent variable. The second regression model contains the two independent variables that have the largest impacts on the dependent variable, i.e., the independent variable from the first step, plus whichever of the remaining variables has the largest impact on the variation not accounted for by the first step. Additional models are constructed in the same manner until a point is reached at which additional independent variables are unable to account meaningfully for any of variation in the dependent variable.

One way to describe meaningful improvement mathematically is through the coefficient of determination $R^{2}$, which is re-evaluated at each step of the regression process. $R^{2}$ is defined as the fraction of the total variability in the dependent variable that can be accounted for by the individual independent variable added at that step. The order in which the variables are selected in the stepwise procedure provides an indication of variable importance, with the most important variable usually being selected first, the next most important variable selected second, and so on. Further, the absolute values of the lead coefficients of the regression model normalized to make dimensionless (standardized regression coefficients [SRCs]) also provide an indication of variable importance and the sign of the SRC indicates whether the independent and dependent variables tend to increase and decrease together (a positive SRC) or tend to move in opposite directions (a negative SRC).

When the relationships between the independent and dependent variables are nonlinear, the results of regression analyses are often poor. Poor linear fits to nonlinear data can often be avoided if, instead of using the data directly, one uses the corresponding rank of the data points in order of progressive magnitude and performs the regression procedures on these ranks. ${ }^{4}$ Examples of that process are included in Figure 7.1-1.

\section{References}

1 Helton, J.C. 1993b. "Uncertainty and Sensitivity Analysis Techniques for Use in Performance Assessment for Radioactive Waste Disposal," Reliability Engineering \& System Safety. Vol. 42, no. 2-3, 327-367.

2 Helton, J.C., J.W. Garner, R:P. Rechard, D.K. Rudeen, and P.N. Swift. 1992. Preliminary Comparison with 40 CFR Part 191, Subpart B for the Waste Isolation Pilot Plant, December 1991. Volume 4: Uncertainty and Sensitivity Analysis Results. SAND91-0893/4. Albuquerque, NM: Sandia National Laboratories.

3 Helton, J.C., J.W. Garner, R.D. McCurley, and D.K. Rudeen. 1991. Sensitivity Analysis Techniques and Results for Performance Assessment at the Waste Isolation Pilot Plant. SAND90-7103. Albuquerque, NM: Sandia National Laboratories.

4 Iman, R.L., and W.J. Conover. 1979. "The Use of the Rank Transform in Regression," Technometrics. Vol. 21, no. 4, 499-509.

* The terms "dependent variable" and "independent variable" are used in the following paragraphs to emphasize that the result or model parameter may be modified to highlight relationships (e.g., the rank of a result may become the dependent variable and the rank of two or more model parameters multiplied together may become the independent variable). 


\subsubsection{Ranking Important Model Parameters}

To demonstrate how parameter ranking is used, this section presents a small portion of the sensitivity and uncertainty analyses performed in the 1992 performance-assessment (PA) calculations to determine the factors that affect gas generation and the movement of gas and brine away from the repository for the specific purposes of assessing compliance with Resource Conservation and Recovery Act regulations (see Section 6.3). ${ }^{1}$ The sensitivity and uncertainty analyses use techniques based on Latin hypercube sampling, including examination of scatterplots, partial correlation analysis, and stepwise regression analysis. Specific performance measures include cumulative gas and brine outflows through the three anhydrite layers to the south of the repository (see Section 3.2.3. Undisturbed Summary Scenario), the total distance gases flow through the three anhydrite layers, and the cumulative gas and brine that flows up through the shaft seal. Also examined were various measures of the behavior of the repository itself, including cumulative gas generation by means of corrosion and biodegradation, pressure in the repository, and repository pore volume. These were analyzed to show how gas generation is affected by variability in the sampled parameters because gas generation is the driving force behind gas and brine migration away from the repository in the undisturbed scenario.

The results show that the most important parameter affecting gas and brine migration from the repository is the initial brine saturation in the waste (see Table 7.1-1 and Figure 7.1-1). This one parameter has the greatest impact on total gas generation, which in turn controls gas and brine flow into and out of the waste. Figure 7.1-1 shows several scatterplots relating brine flow to brine saturation and to anhydrite interbed porosity. It suggests that brine flows tend to increase as initial brine saturation increases. Net brine flows out of the repository range from $-24,000 \mathrm{~m}^{3}\left(-845,000 \mathrm{ft}^{3}\right)$ to $+11,400 \mathrm{~m}^{3}$ $\left(+403,000 \mathrm{ft}^{3}\right)$, which suggests there is a minimum initial brine saturation $\left(S_{\text {init }}\right)$ below which brine does not flow out of the waste. Because the initial brine saturation is at most half of the residual brine saturation ${ }^{*}$ of the waste $\left(S_{\text {resid }}\right)$, the initial saturation $\left(S_{\text {init }}\right)$ itself is not sufficient to cause flow from the waste. When more brine is initially present, less inflow is required to exceed the residual saturation before brine flows out. The partial rank correlation coefficients in Figure 7.1-1 confirmed that $S_{\text {init }}$ is the dominant variable affecting net flow from the waste for the 1992 PA.

Table 7.1-1. Stepwise Regression Analysis with Rank-Transformed Data for Cumulative Net Brine Flow from the Repository (from WIPP PA Dept., 1993, Vol. 5, Table 5-15) ${ }^{1}$

\begin{tabular}{|c|c|c|c|c|}
\hline Step & Variable & Description & SRC & $\mathrm{R}^{2}$ \\
\hline 1 & $S_{\text {init }}$ & Initial liquid saturation in waste & 0.72 & 0.53 \\
\hline 2 & $\varphi_{M B}$ & $\begin{array}{l}\text { Undisturbed anhydrite marker } \\
\text { bed porosity }\end{array}$ & -0.30 & 0.61 \\
\hline 3 & $k_{M B}$ & $\begin{array}{l}\text { Log of anhydrite marker bed } \\
\text { permeability }\end{array}$ & -0.24 & 0.67 \\
\hline 4 & $S_{\text {resid }}$ & $\begin{array}{l}\text { Residual brine saturation in all } \\
\text { regions except waste }\end{array}$ & 0.18 & 0.70 \\
\hline
\end{tabular}

\section{Reference}

1 WIPP PA (Performance Assessment) Department. 1993. Preliminary Performance Assessment for the Waste Isolation Pilot Plant, December 1992. Volume 5: Uncertainty and Sensitivity Analyses of Gas and Brine Migration for Undisturbed Performance. SAND92-0700/5. Albuquerque, NM: Sandia National Laboratories.

- The residual brine saturation is the saturation below which liquids are no longer connected through the pore network of the porous medium and therefore cannot flow regardless of the pressure gradient. 

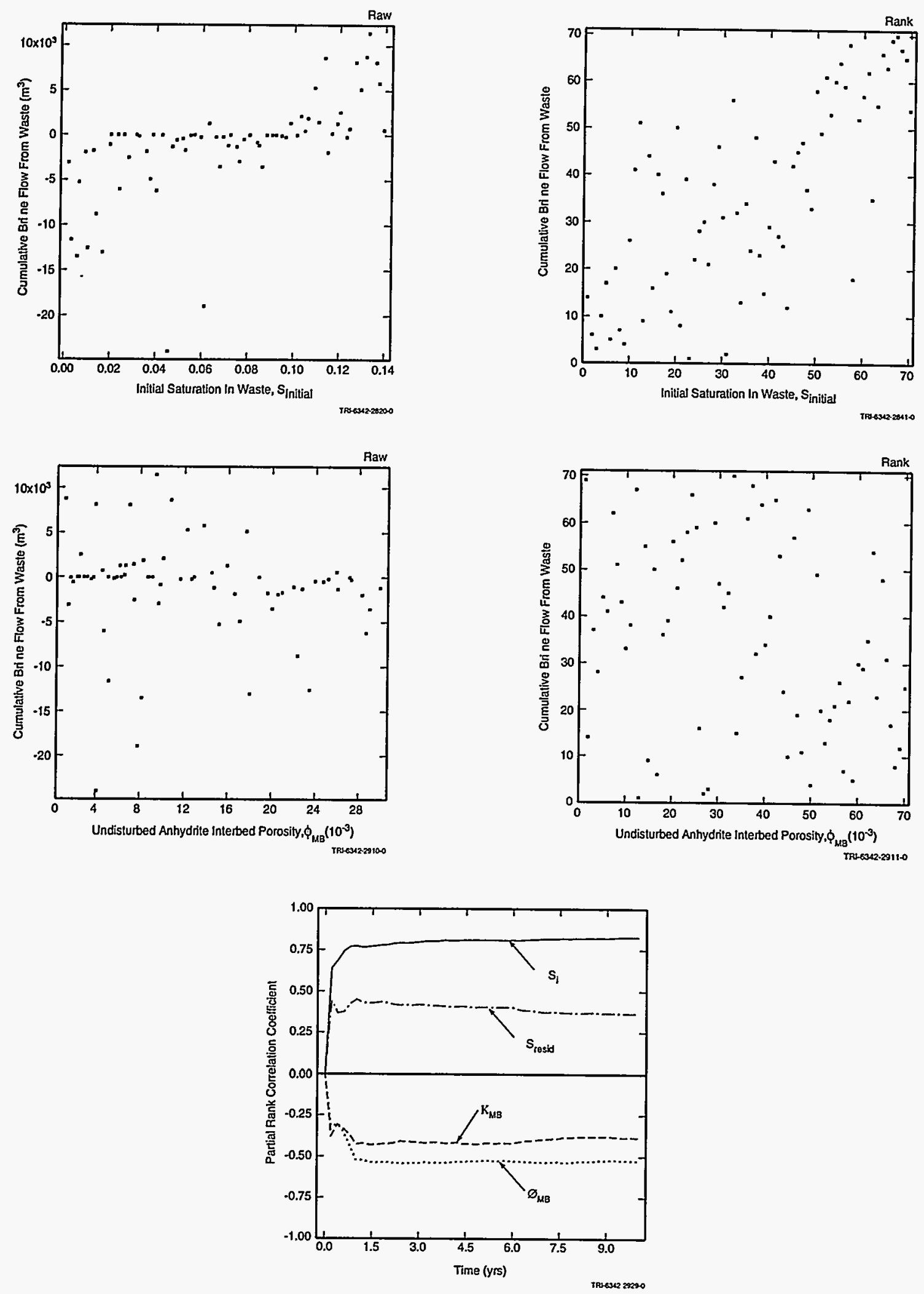

Figure 7.1-1. Scatterplots produced by STEPWISE and partial rank correlation coefficients produced by PCCSRC for cumulative net brine flow from the repository in the 1992 performance assessment calculations (WIPP PA Dept., 1993, Vol. 5, Figure 5-14). 1 (Refer to Section 7.1.2 for a brief description of STEPWISE and PCCSRC.) 


\subsubsection{Computing Statistical Correlations}

Sensitivity and uncertainty analyses were important parts of Waste Isolation Pilot Plant (WIPP) performance assessments (PA) in 1990 through 1992. The primary codes used to perform them were PCCSRC $^{1}$ and STEPWISE ${ }^{2}$ :

PCCSRC $^{1}$ evaluates variable importance at each time step by reporting the partial correlation coefficients (PCCs) and standardized regression coefficients (SRCs) on either the rank or raw data.

STEPWISE $^{2}$ evaluates variable importance by developing regression models between the input variable and the observed response using a forward, backward, or stepwise regression procedure on the rank or raw data. Because STEPWISE must be run separately at each time step, only regression models having results (e.g., cumulative brine flow through waste) accumulated over a few time periods (e.g. $10,000 \mathrm{yr}$ ) are normally used.

If useful regression models can be developed, coefficient of determination, the absolute values of the standardized regression coefficients or their mathematically related partial correlation coefficients, can be used to rank variable importance.

The complete code linkages used to perform sensitivity and uncertainty analyses on any PA results are shown in Figure 7.1-2. Access to model parameters and calculational results is gained through LHS2STEP ${ }^{3}$ and CCD2STEP, ${ }^{3}$ which act as translators, converting Latin hypercube sample output and radionuclide release output files, respectively, into forms suitable for use by the main statistical analysis codes, PCCSRC ${ }^{1}$ and STEPWISE, ${ }^{2}$ which were described above (see Section 7.1.1 for examples of results).

Two other codes, SUMMARIZE and GRAPH, are shown in Figure 7.1-2. They are support codes used often in this analysis. SUMMARIZE gathers user-specified information from the many PA files and uses it to produce tabular outputs for PCCSRC, STEPWISE, and various plotting packages such as GRAPH.

\section{References}

1 Iman, R.L., M.J. Shortencarier, and J.D. Johnson. 1985. A Fortran 77 Program and User's Guide for the Calculation of Partial Correlation and Standardized Regression Coefficients. SAND85-0044, NUREG/CR4122. Albuquerque, NM: Sandia National Laboratories.

2 Iman, R.L., J.M. Davenport, E.L. Frost, and M.J. Shortencarier. 1980. Stepwise Regression with PRESS and Rank Regression (Program and User's Guide). SAND79-1472. Albuquerque, NM: Sandia National Laboratories.

3 Rechard, R.P., ed. 1992. User's Reference Manual for CAMCON: Compliance Assessment Methodology Controller, Version 3.0. SAND90-1983. Albuquerque, NM: Sandia National Laboratories. 


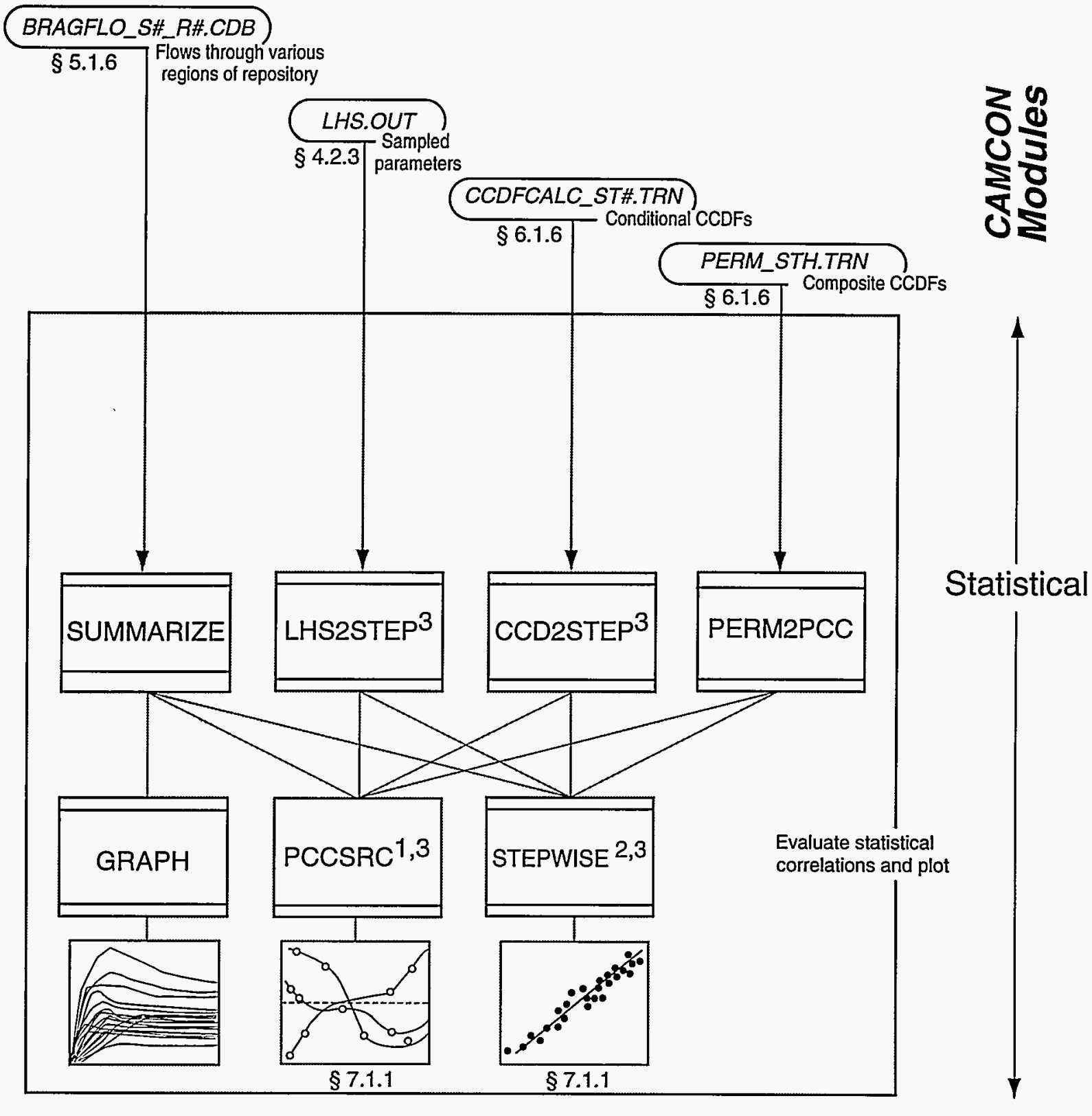

Figure 7.1-2. Linkage of software to compute statistical correlations in the 1990-1992 performance assessment calculations. 
7.0 Sensitivity/Uncertainty Analysis 


\subsection{PERFORMANCE ASSESSMENT ALGORITHM SUMMARY}

In this report, the process of modeling the Waste Isolation Pilot Plant (WIPP) to evaluate its performance between 1989 and 1992 has been organized into six general steps. Actual assessments are, of course, continuous processes so discretization into distinct steps is an artificial and somewhat arbitrary artifact. Nevertheless, discretization is viewed as useful for describing the lengthy assessment process. The report has attempted to give concrete examples of many (but not all) of the various tasks that are associated with the six steps of a performance assessment (PA). The 1989-1992 PAs of the WIPP were a series of complicated and interdisciplinary tasks, requiring diverse skills in the physical sciences, mathematics, statistics, and numerical modeling. No one individual performed all six steps or even all of any one step of a PA. Rather, the PA calculations were performed by a coordinated team of dedicated specialists comprising analysts, modelers, code developers, data base developers, and operators. Sections 8.1 and 8.2 summarize the results of the six steps and the linkage of PA software. 


\subsection{Concise Review of the Six-Step Performance Assessment Process}

In this section, some mathematical ideas and simple sketches are used are used to summarize the six steps of a performance assessment (PA) (see Figure 8.1), to list the processes within, and to state the results of each step as applied primarily to the probabilistic requirements of 40 CFR 191. ${ }^{1}$

1. Characterize the disposal system and surrounding region to develop a conceptual model. This step determines the parameter space of the conceptual model and is succinctly symbolized as $D=\left\{x_{1}, x_{2}, \ldots x_{n P}\right\}$, where $n P$ is the total number of parameters of the model of the disposal system. The parameters are subdivided into three disjoint subsets as follows: (1) uncertain parameters that are classified as aleatoric or chance variables and studied through scenarios (e.g., event and feature parameters), (2) uncertain parameters that are not expressed as chance variables but rather as epistemic variables that reflect uncertainty in knowledge about a parameter (e.g., material property parameters), and (3) parameters that are fixed or varied one at a time (model constants, model domain parameters, decision parameters, and index parameters to select alternative model forms) (see Section 4.1, Assigning Parameter Uncertainties). Categorization into the three subsets is determined primarily by (1) analyst preference in exploring the uncertainty of a particular characteristic and (2) presently accepted methods of calculation, for example, expressing a "choice" or "decision" parameter such as waste-treatment options as a probability distribution is uncommon.

2. Form scenarios from the subset of uncertain parameters selected for study. Although typically handled in a heuristic manner, this step can be described as the process of describing the state of the aleatory parameters that define particular chance conditions of the disposal system such as an event-human intrusion or no human intrusion-or a feature-brine reservoir or no brine reservoir. The feasibility of quantifying the probabilities associated with these aleatory parameter choices is a very important aspect of this step. Without it, the next step becomes impossible.

3. Develop probability models to quantify the probability of occurrence of each scenario and quantify the uncertainty of model parameters. Two types of probability models are developed in this step. The first evaluates the probability of a specific summary scenario occurring. The second produces distributions to express the uncertainty in selected parameters that arise in the consequence and probability models. At this point, the PA model-system parameter space, $D^{\prime}$, can be identified. It usually differs, but only subtly, from the original conceptual-model space.

4. Develop models that simulate consequences for the sets of model parameters that occur and exercise them. This step involves developing consequence models and performing simulations. The simulations are the most mechanical part of the PA process. Because Monte Carlo simulation is used to propagate parameter uncertainties through the model, numerous repetitive simulations are required. Consequently, the model-development process must result in a product that is feasible to run many times. Consequently, several model domains, both spatial and temporal, are used, and several uncoupled but linked computational models are used.

5. Compare the generated consequence of each scenario and its corresponding probability with regulatory criteria. This and the next step correspond to analysis of results. The modeling system is quite complicated if the applied model incorporates many features, events, and processes. Correspondingly, the analysis can be complex and demanding. Results are usually displayed succinctly as complementary cumulative distribution functions (CCDFs). Means and various quantities are commonly shown.

6. Evaluate the sensitivity and uncertainty of results to changes in model parameters. Summary measures such as mean CCDFs distill into simple curves collections of results that require volumes to describe. They can, however, obscure many interesting aspects of the result. Hence, sensitivity and uncertainty analyses must be added to highlight various findings.

\section{References}

1 Rechard, R.P. 1995. "Introduction," Performance Assessment of the Direct Disposal in Unsaturated Tuff of Spent Nuclear Fuel and High-Level Waste Owned by U.S. Department of Energy, Volume 2: Methodology and Results. Ed. R.P. Rechard. SAND94-2563/2. Albuquerque, NM: Sandia National Laboratories. 1-1 through $1-38$. 
1) Characterize disposal system (Develop parameter space) (\$ 2.0)

$D= \begin{cases}\underbrace{x_{1}}_{\text {Subset uncertainty studied separately }} & x_{2}\end{cases}$

Subset uncertainty studied separately Subset uncertainty characterized by (often event and feature parameters) distributions (often natural process

$x_{5}$

$x_{6}$

$\left.x_{7}\right\}$

Subset fixed or varied one at a time (e.g., model form indices, model domain size, and physical constants)

2) Form scenarios (\$ 3.0)

$x_{1}=\left\{\begin{array}{l}\text { intrusion, }(\mathrm{I}) \\ \text { no intrusion, }(\bar{l})\end{array}\right\}$ (\$ 3.2) $x_{2}=\left\{\begin{array}{l}\text { drill into brine pocket, } E_{1} \\ \text { miss brine pocket, } \bar{E}_{1}\end{array}\right\}$

$$
\text { (\$ 3.2) (\$ 3.2) }
$$

Note: no intrusion, İ not combined with $E_{1}$ or $E_{2}$; thus, 3 scenarios

3) Develop probability models ( $\$ 4.0)$

$$
P\{l=n\}=\frac{\lambda t^{n} e^{-\lambda t}}{n !} \quad P\left\{E_{1}\right\}=\frac{A_{\text {rep }}}{A_{\text {pocket }}}
$$
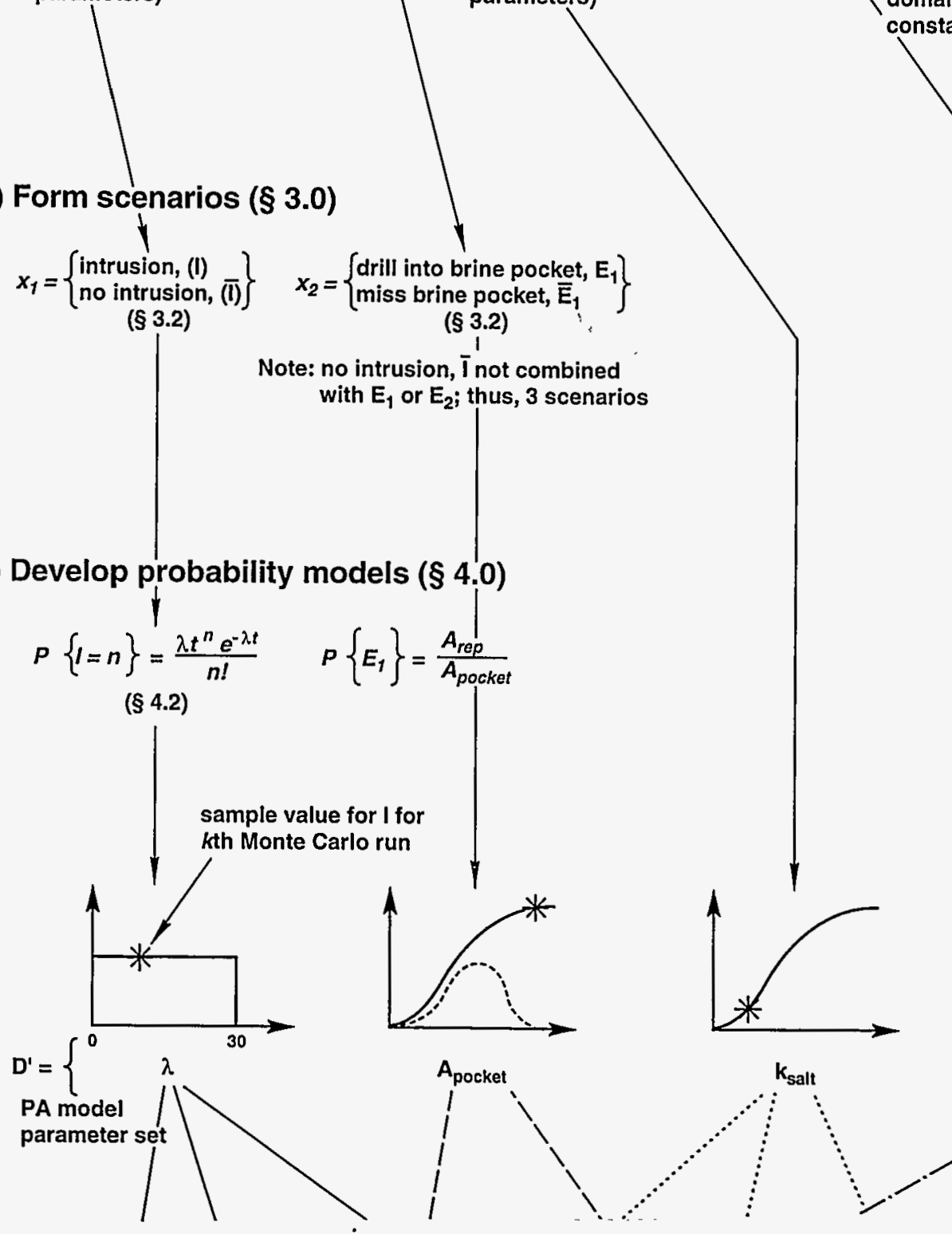
4) Simulate consequences (inclúding propagating uncètainty) for each scenario identified (\$5.0)

5) Compare results with criterion $(\$ 6.0)$

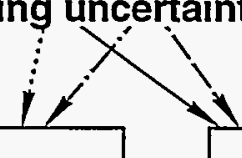

Fixed and $k$ th

sampled model

parameters are

input and run

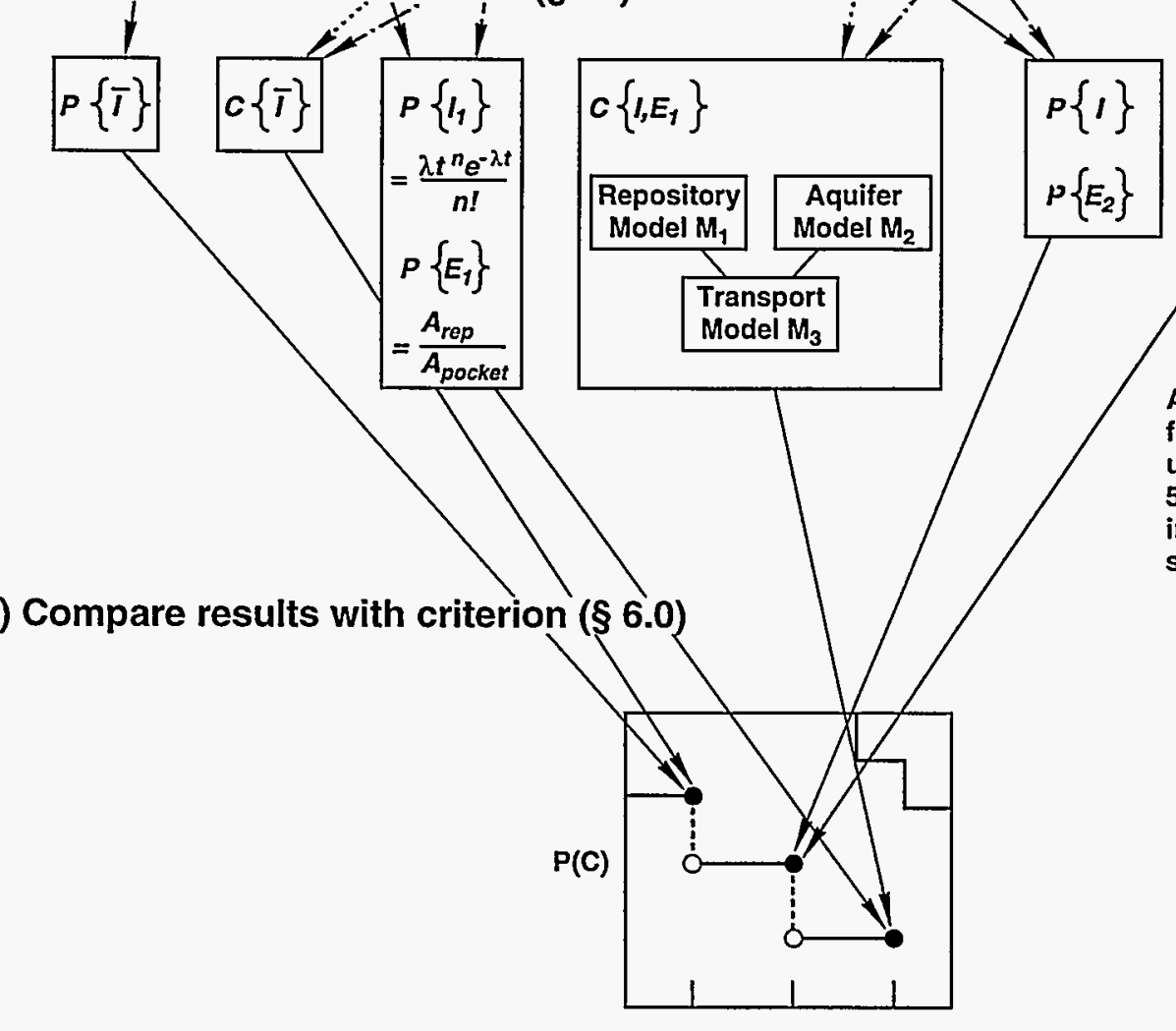

As a surrogate, consequences from other scenarios may be

used if they are bounding (e.g.

$5 x$ consequence of one

intrusion used to bound 5

single intrusions)

6) Evaluate sensitivity/uncertainty (\$ 7.0)

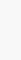
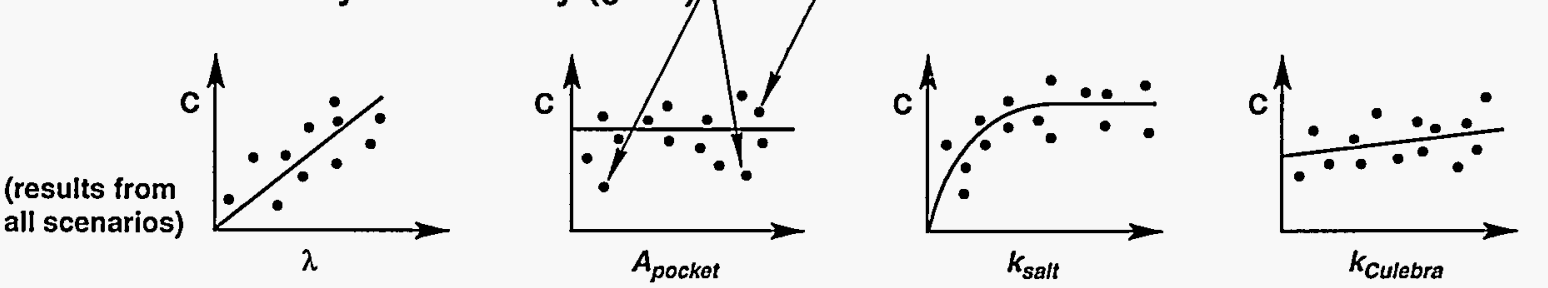

TR1-6342-4314-0

Figure 8.1. A schematic representation of the six principal steps of a WIPP performance assessment. ${ }^{1}$ 
8.0 Performance Assessment Algorithm Summary 


\subsection{Summary of Performance Assessment Software Linkages}

In this report, many of the subsections that describe performance assessment (PA) code applications end with a flow diagram that depicts the software linkages used to perform that particular task of a PA. This section ends with two two-page pictorial descriptions of the entire linkage, that is, summary overviews of all the code linkages shown in all the previous figures. The figures represent the overall flow of information through the PA software and give a rough idea of the "algorithm" used to perform a PA. The first two-page figure depicts the 1991 PA process; the second two-page figure presents the 1992 PA process. As in the previous subsections, important files that pass information between software are identified. However, for the sake of clarity and relative simplicity, complete suites of all the files needed to run the codes (such as input files necessary to control the numerical solution algorithms) are not shown.

Several companion documents can be used to acquire more detailed information on executing the PA modeling system. The Users' Guide to the WIPP PA Codes (version 0.6, May 24, 1995, was available at this writing) currently being written by Simmons and Froehlich describes in step-by-step fashion all the files, procedures, and commands needed to execute the 1992 PA modeling system It does it first for a single, fixed set of model parameters for each of the principal 1992 scenarios. It then reviews that process for sampled variables and reviews sensitivity and uncertainty codes. Also useful are the summary references on the CAMCON system ${ }^{1,2}$ and the user and theory manuals on all individual codes; these latter documents are presently in preparation.

\section{References}

1 Rechard, R.P., A.P. Gilkey, H.J. Iuzzolino, D.K. Rudeen, and K.A. Byle. 1993a. Programmer's Manual for CAMCON: Compliance Assessment Methodology Controller. SAND90-1984. Albuquerque, NM: Sandia National Laboratories.

2 Rechard, R.P., ed. 1992. User's Reference Manual for CAMCON: Compliance Assessment Methodology Controller, Version 3.0. SAND90-1983. Albuquerque, NM: Sandia National Laboratories. 


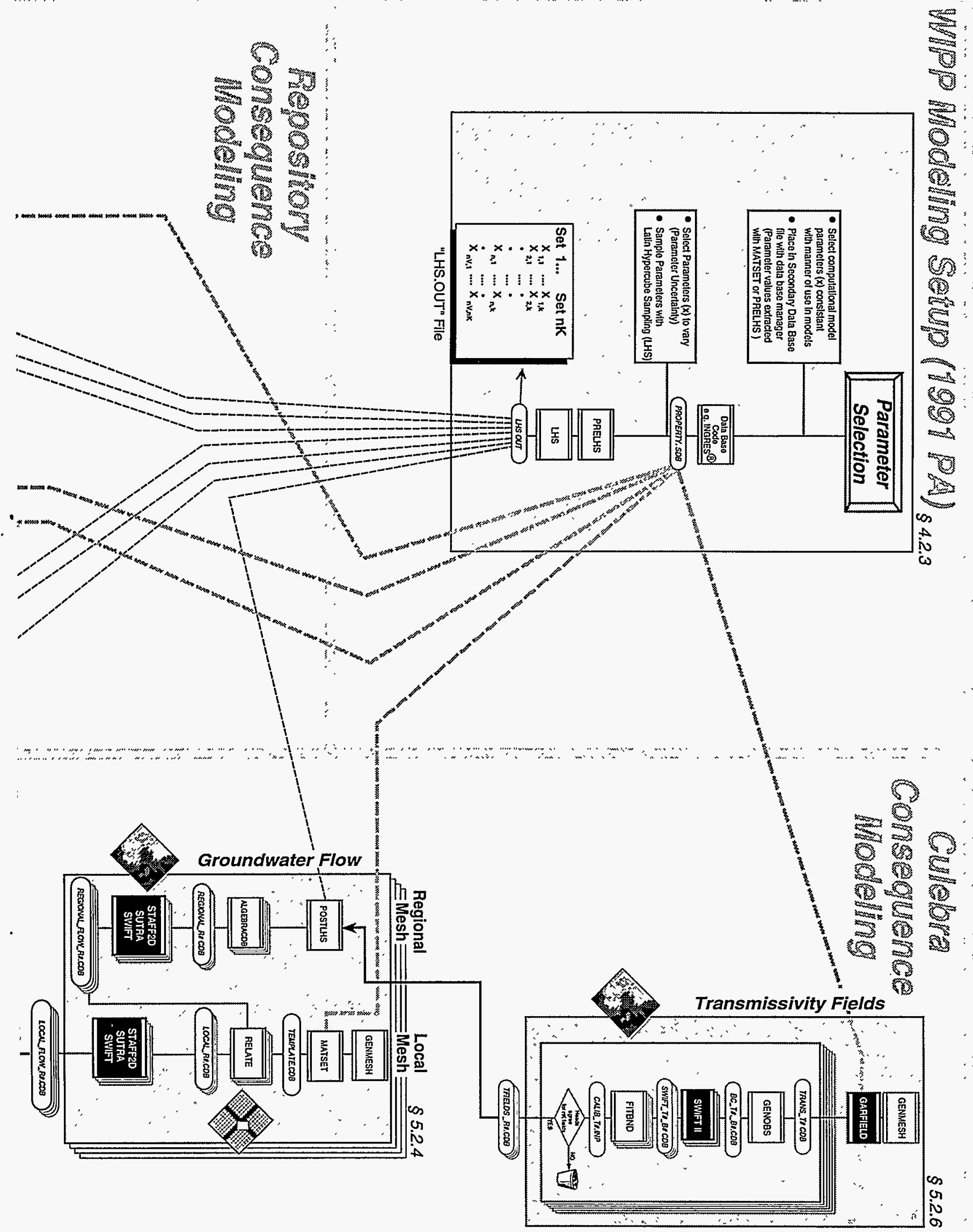




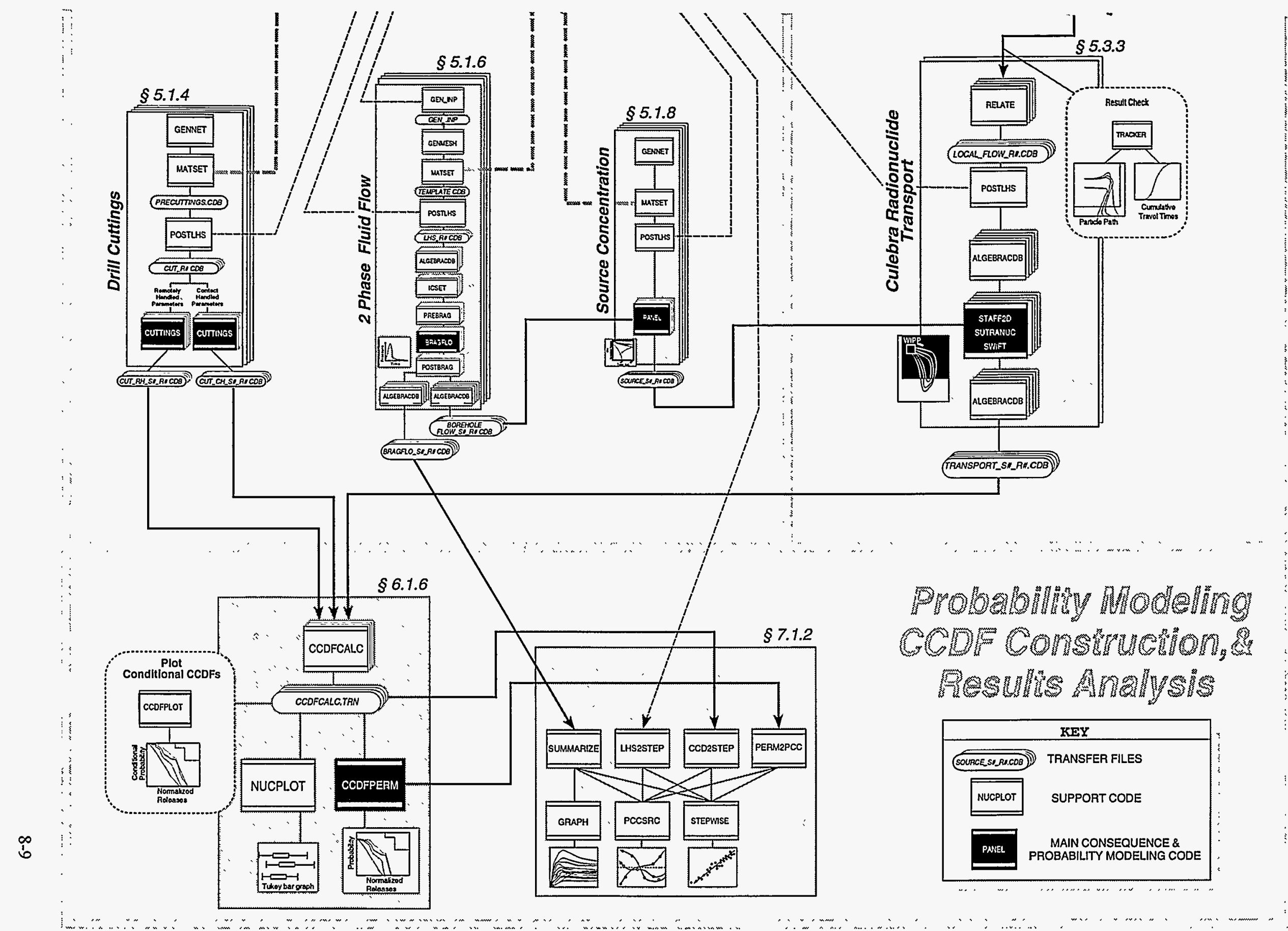




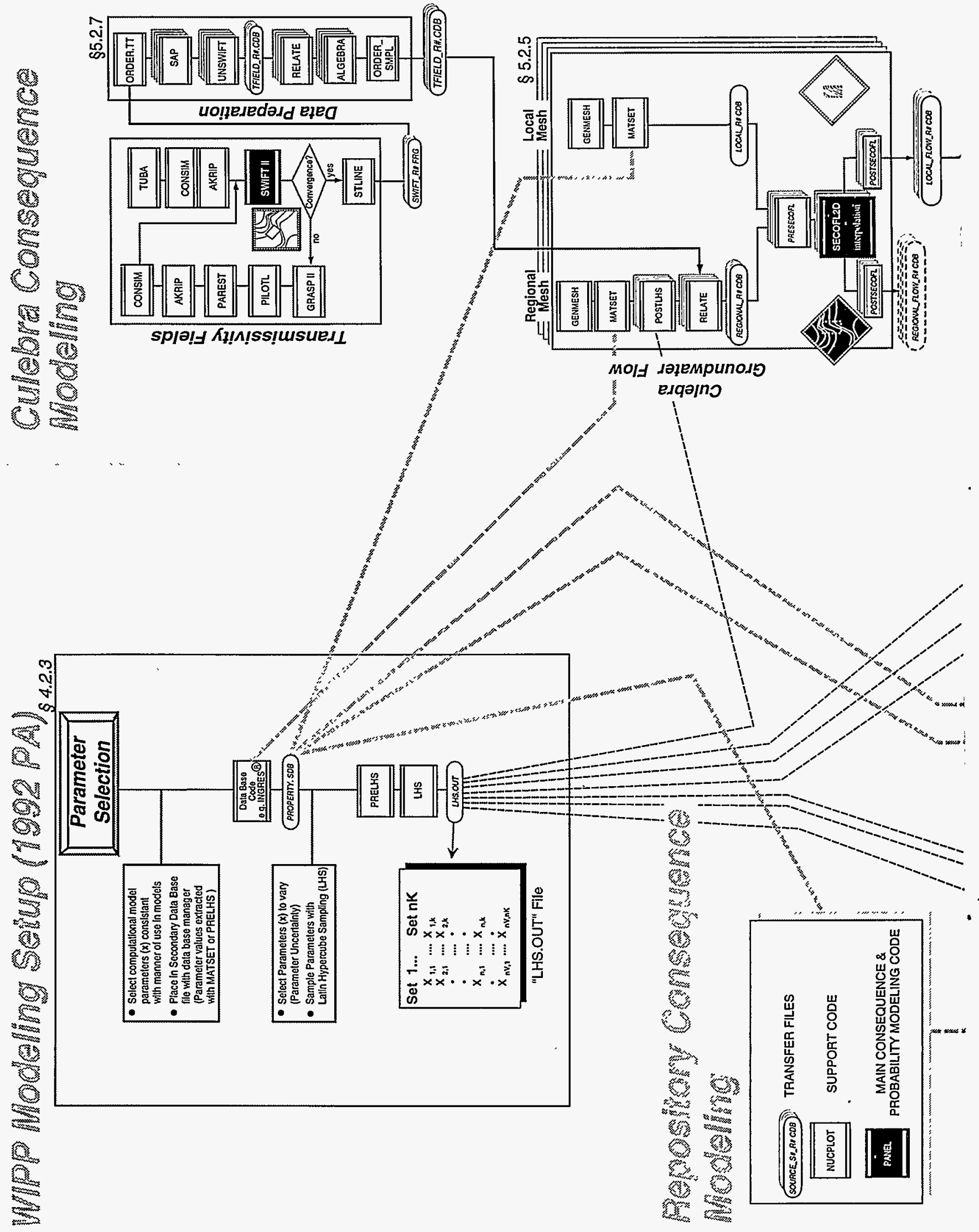




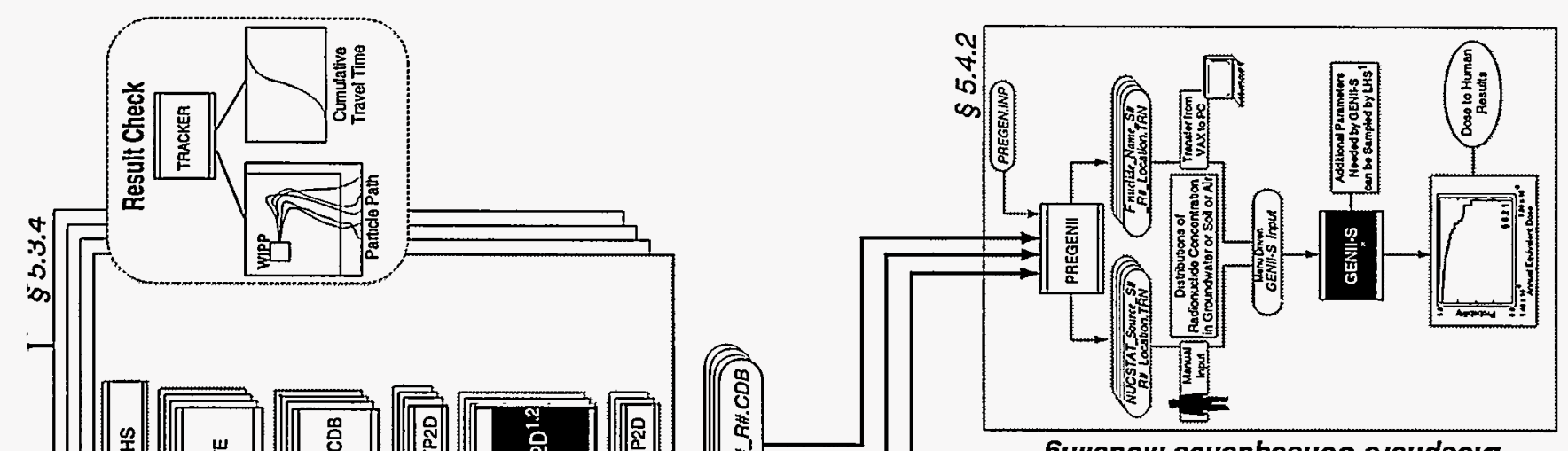

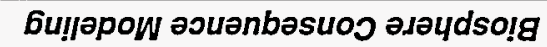
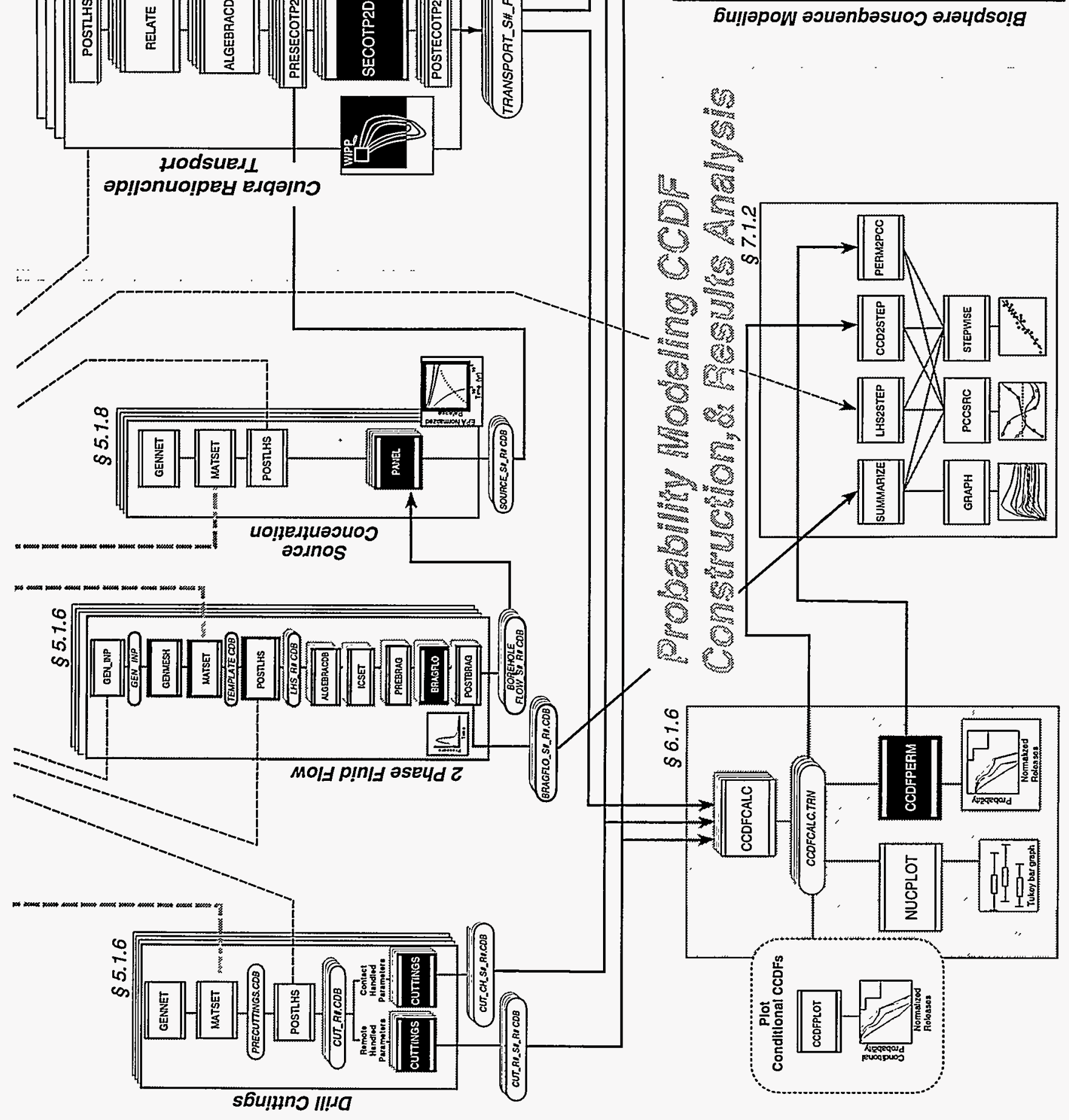
8.0 Performance Assessment Algorithm Summary 


\section{REFERENCES}

AEC (Atomic Energy Commission). 1957. Theoretical Possibilities and Consequences of Major Accidents in Large Nuclear Power Plants: A Study of Possible Consequences if Certain Assumed Accidents, Theoretically Possible but Highly Improbable, Were to Occur in Large Nuclear Power Plants. WASH-740. Washington, DC: Atomic Energy Commission.

AECL (Atomic Energy of Canada, Ltd). 1994. Summary of the Environmental Impact Statement on the Concept for Disposal of Canada's Nuclear Fuel Waste. AECL-10721. Pinawa, Manitoba: Atomic Energy of Canada, Ltd.

Albuquerque Journal. June 28, 1989, p. A1. "Embattled WIPP won't open in '89."

Albuquerque Journal. June 11, 1993, p. 3D. "WIPP staff won't move to Carlsbad."

Apostolakis, G. 1974. Mathematical Methods of Probabilistic Safety Analysis. UCLA-ENG-7464. Los Angeles, CA: University of California, School of Engineering and Applied Science.

APS (American Physical Society). 1975. "Report to the American Physical Society by the Study Group on LightWater Reactor Safety," Reviews of Modern Physics. Vol. 47, Supplement No. 1.

Arguello, J.G., and T.M. Torres. 1988. WIPP Panel Entryway Seal-Numerical Simulation of Seal Composite Interaction for Preliminary Design Evaluation. SAND87-2804. Albuquerque, NM: Sandia National Laboratories.

Avis, J.D., and G.J. Saulnier, Jr. 1990. Analysis of the Fluid-Pressure Responses of the Rustler Formation at $H$-16 to the Construction of the Air-Intake Shaft at the Waste Isolation Pilot Plant (WIPP) Site. SAND89-7067. Albuquerque, NM: Sandia National Laboratories.

Bachman, G.O. 1984. Regional Geology of Ochoan Evaporites, Northern Part of Delaware Basin. New Mexico Bureau of Mines \& Mineral Resources Circular 184. Socorro, NM: New Mexico Bureau of Mines \& Mineral Resources.

Bachman, G.O. 1987. Karst in Evaporites in Southeastern New Mexico. SAND86-7078. Albuquerque, NM: Sandia National Laboratories.

Baer, T.A., L.L. Price, J.N. Emery, and N.E. Olague. 1994. Second Performance Assessment Iteration of the Greater Confinement Disposal Facility at the Nevada Test Site. SAND93-0089. Albuquerque, NM: Sandia National Laboratories.

Barnard, R.W., M.L. Wilson, H.A. Dockery, J.H. Gauthier, P.G. Kaplan, R.R. Eaton, F.W. Bingham, and T.H. Robey. 1992. TSPA 1991: An Initial Total-System Performance Assessment for Yucca Mountain. SAND912795. Albuquerque, NM: Sandia National Laboratories.

Bear, J., and A. Verruijt. 1987. Modeling Groundwater Flow and Pollution: With Computer Programs for Sample Cases. Dordrecht, Holland: D. Reidel Publishing Company.

Beauheim, R.L. 1987. Analysis of Pumping Tests of the Culebra Dolomite Conducted at the H-3 Hydropad at the Waste Isolation Pilot Plant (WIPP) Site. SAND86-2311. Albuquerque, NM: Sandia National Laboratories.

Beauheim, R.L. 1989. Interpretation of the H-11b4 Hydraulic Tests and the H-11 Multipad Pumping Test of the Culebra Dolomite at the Waste Isolation Pilot Plant (WIPP) Site. SAND89-0536. Albuquerque, NM: Sandia National Laboratories.

Beauheim, R.L., and R.M. Holt. 1990. "Hydrogeology of the WIPP Site," Geological and Hydrological Studies of Evaporites in the Northern Delaware Basin for the Waste Isolation Pilot Plant (WIPP). New Mexico, Field Trip \#14 Guidebook, Geological Society of America 1990 Annual Meeting, Dallas, TX, October 29-November 1. 1990. SAND90-2035J. Dallas, TX: Dallas Geological Society. 131-179.

Beauheim, R.L., G.J. Saulnier, Jr., and J.D. Avis. 1991. Interpretation of Brine-Permeability Tests of the Salado Formation at the Waste Isolation Pilot Plant Site: First Interim Report. SAND90-0083. Albuquerque, NM: Sandia National Laboratories.

Bechtel National, Inc. 1986. Waste Isolation Pilot Plant Design Validation Final Report. DOE/WIPP-86-010. Prepared for U.S. Department of Energy. San Francisco, CA: Bechtel National, Inc. 
Berglund, J.W. 1992. Mechanisms Governing the Direct Removal of Wastes from the Waste Isolation Pilot Plant Repository Caused by Exploratory Drilling. SAND92-7295. Albuquerque, NM: Sandia National Laboratories.

Bertram-Howery, S.G., and R.L. Hunter, eds. 1989. Preliminary Plan for Disposal-System Characterization and Long-Term Performance Evaluation of the Waste Isolation Pilot Plant. SAND89-0178. Albuquerque, NM: Sandia National Laboratories.

Bertram-Howery, S.G., M.G. Marietta, D.R. Anderson, K.F. Brinster, L.S. Gomez, R.V. Guzowski, and R.P. Rechard. 1989. Draft Forecast of the Final Report for the Comparison to 40 CFR Part 191, Subpart B, for the Waste Isolation Pilot Plant. SAND88-1452. Albuquerque, NM: Sandia National Laboratories.

Bertram-Howery, S.G., M.G. Marietta, R.P. Rechard, P.N. Swift, D.R. Anderson, B.L. Baker, J.E. Bean, Jr., W. Beyeler, K.F. Brinster, R.V. Guzowski, J.C. Helton, R.D. McCurley, D.K. Rudeen, J.D. Schreiber, and P. Vaughn. 1990a. Preliminary Comparison with 40 CFR Part 191, Subpart B for the Waste Isolation Pilot Plant, December 1990. SAND90-2347. Albuquerque, NM: Sandia National Laboratories.

Bertram-Howery, S.G., M.G. Marietta, R.P. Rechard, P.N. Swift, D.R. Anderson, B.L. Baker, J.E. Bean, Jr., W. Beyeler, K.F. Brinster, R.V. Guzowski, J.C. Helton, R.D. McCurley, D.K. Rudeen, J.D. Schreiber, and P. Vaughn. 1990b. "Appendix D: Response to Review Comments," Preliminary Comparison with 40 CFR Part 191, Subpart B for the Waste Isolation Pilot Plant, December 1990. SAND90-2347. Albuquerque, NM: Sandia National Laboratories. D-1 through D-13.

Bingham, F.W., and G.E. Barr. 1979. Scenarios for Long-Term Release of Radionuclides from a Nuclear-Waste Repository in the Los Medaños Region of New Mexico. SAND78-1730. Albuquerque, NM: Sandia National Laboratories.

Bonano, E.J., P.A. Davis, L.R. Shipers, K.F. Brinster, W.E. Beyeler, C.D. Updegraff, E.R. Shepherd, L.M. Tilton, and K.K. Wahi. 1988. Demonstration of a Performance Assessment Methodology for High-Level Radioactive Waste Disposal in Basalt Formations. SAND86-2325, NUREG/CR-4759. Albuquerque; NM: Sandia National Laboratories.

Bradshaw, R.L., and W.C. McClain. 1971. Project Salt Vault: A Demonstration of the Disposal of High-Activity Solidified Wastes in Underground Salt Mines. ORNL-4555. Oak Ridge, TN: Oak Ridge National Laboratory.

Breeding, R.J., T.J. Leahy, and J. Young. 1985. Probabilistic Risk Assessment Course Documentation. Vol. 1: PRA Fundamentals. SAND85-1495/1, NUREG/CR-4350/1. Albuquerque, NM: Sandia National Laboratories.

Breeding, R.J., J.C. Helton, E.D. Gorham, and F.T. Harper. 1992. "Summary Description of Methods Used in Probabilistic Risk Assessments for NUREG-1150," Nuclear Engineering and Design. Vol. 135, no. 1, 1-27.

Brinster, K.F. 1991. Preliminary Geohydrologic Conceptual Model of the Los Medaños Region Near the Waste Isolation Pilot Plant for the Purpose of Performance Assessment. SAND89-7147. Albuquerque, NM: Sandia National Laboratories.

Calvert Cliffs' Coordinating Committee, Inc., et al., Petitioners v. United States Atomic Energy Commission and United States of America, Respondents. Nos. 24839, 24871. 1971. 449 F.2d 1109.

Campbell, J.E., and R.M. Cranwell. 1988. "Performance Assessment of Radioactive Waste Repositories," Science. Vol. 239 , no. $4846,1389-1392$.

Campbell, J.E., R.T. Dillon, M.S. Tierney, H.T. Davis, P.E. McGrath, F.J. Pearson, Jr., H.R. Shaw, J.C. Helton, and F.A. Donath. 1978. Risk Methodology for Geologic Disposal of Radioactive Waste: Interim Report. SAND78-0029, NUREG/CR-0458. Albuquerque, NM: Sandia National Laboratories.

Campbell, J.E., D.E. Longsine, and R.M. Cranwell. 1981. Risk Methodology for Geologic Disposal of Radioactive Waste: The NWFTIDIM Computer Code Users' Manual. SAND81-0886, NUREG/CR-2081. Albuquerque, NM: Sandia National Laboratories.

Carter, L.J. 1978. "Trouble Even in New Mexico for Nuclear Waste Disposal," Science. Vol. 199, no. 4333, 1050. 1051 .

Carter, L.J. 1987. Nuclear Imperatives and Public Trust: Dealing with Radioactive Waste. Washington, DC: Resources for the Future, Inc. 
Channell, J.K., J.C. Rodgers, and R.H. Neill. 1986. Adequacy of TRUPACT-I Design for Transporting ContactHandled Transuranic Wastes to WIPP (Waste Isolation Pilot Plant). EEG-33. Santa Fe, NM: New Mexico Health and Environment Department, Environmental Evaluation Group.

Cheeseman, R.J. 1978. "Geology and Oil/Potash Resources of Delaware Basin, Eddy and Lea Counties, New Mexico," Geology and Mineral Deposits of Ochoan Rocks in Delaware Basin and Adjacent Areas. Comp. G.S. Austin. New Mexico Bureau of Mines and Mineral Resources Circular No. 159. Socorro, NM: New Mexico Bureau of Mines and Mineral Resources. 7-14.

Chernoff, H., and L.E. Moses. 1959. Elementary Decision Theory. New York, NY: John Wiley \& Sons, Inc.

Chu, M.S., N.R. Ortiz, K.K. Wahi, R.E. Pepping, and J.E. Campbell. 1983. An Assessment of the Proposed Rule (IOCFR60) for Disposal of High-Level Radioactive Wastes in Geologic Repositories. SAND82-2969, NUREG/CR-3111. Albuquerque, NM: Sandia National Laboratories. Vol. 1.

Chu, M.S.Y., J.V. Rodricks, C. St. Hilaire, and R.L. Bras. 1986. Risk Assessment and Ranking Methodologies for Hazardous Chemical Defense Waste: A State-of-the-Art Review and Evaluation, Task 1 Report. SAND860530. Albuquerque, NM: Sandia National Laboratories.

Claiborne, H.C., and F. Gera. 1974. Potential Containment Failure Mechanisms and Their Consequences at a Radioactive Waste Repository in Bedded Salt in New Mexico. ORNL-TM-4639. Oak Ridge, TN: Oak Ridge National Laboratory.

Cooper, J.B., and V.M. Glanzman. 1971. Geohydrology of Project Gnome Site, Eddy County, New Mexico. Geological Survey Professional Paper 712-A. Washington, DC: U.S. Government Printing Office.

Comelissen, A. 1991. "Development on Criteria for Geological Waste Disposal in the Netherlands," Disposal of High-Level Radioactive Wastes, Radiation Protection and Safety Criteria, Proceedings of an NEA Workshop, Paris, France, November 5-7. 1990. Paris, France: Organisation for Economic Co-Operation and Development, Nuclear Energy Agency. 71-80.

Cranwell, R.M., J.E. Campbell, J.C. Helton, R.L. Iman, D.E. Longsine, N.R. Ortiz, G.E. Runkle, and M.J. Shortencarier. 1987. Risk Methodology for Geological Disposal of Radioactive Waste: Final Report. SAND81-2573, NUREG/CR-2452. Albuquerque, NM: Sandia National Laboratories.

Cranwell, R.M., R.V. Guzowski, J.E. Campbell, and N.R. Ortiz. 1990. Risk Methodology for Geologic Disposal of Radioactive Waste: Scenario Selection Procedure. SAND80-1429, NUREG/CR-1667. Albuquerque, NM: Sandia National Laboratories.

de Marsily, G., E. Ledoux, A. Barbreau, and J. Margat. 1977. "Nuclear Waste Disposal: Can the Geologists Guarantee Isolation?" Science. Vol. 197, no. 4303, 519-526.

DOD (U.S. Department of Defense). 1984. System Safety Program Requirements. MIL-STD-882B. Washington, DC: U.S. Department of Defense.

Dormuth, K.W., and G.R. Sherman. 1981. SYVAC-A Computer Program for Assessment of Nuclear-Fuel Waste-Management Systems, Incorporating Parameter Variability. AECL-6814. Pinawa, Manitoba: Atomic Energy of Canada Ltd., Whiteshell Nuclear Research Establishment.

Earth Technology Corporation. 1988. Final Report for Time Domain Electromagnetic (TDEM) Surveys at the WIPP Site. SAND87-7144. Albuquerque, NM: Sandia National Laboratories.

EPA (Environmental Protection Agency). 1982. "40 CFR Part 191: Environmental Standards for the Management and Disposal of Spent Nuclear Fuel, High-Level and Transuranic Radioactive Wastes; Proposed Rule," Federal Register. Vol. 47, no. 250, 58196-58206.

EPA (Environmental Protection Agency). 1985a. "40 CFR Part 191: Environmental Standards for the Management and Disposal of Spent Nuclear Fuel, High-Level and Transuranic Radioactive Wastes; Final Rule," Federal Register. Vol. 50, no. 182, 38066-38089.

EPA (Environmental Protection Agency). 1985b. Background Information Document-Final Rule for High-Level and Transuranic Radioactive Wastes. EPA 520/1-85-023. Washington, DC: U.S. Environmental Protection Agency, Office of Radiation Programs. 
EPA (Environmental Protection Agency). 1985c. "Part 300-National Oil and Hazardous Substances Pollution Contingency Plan," Federal Register. Vol. 50, no. 224, 47950-47979.

EPA (Environmental Protection Agency). 1990. "Conditional No-Migration Determination for the Department of Energy Waste Isolation Pilot Plant (WIPP)," Federal Register. Vol. 55, no. 220, 47700-47721.

EPA (Environmental Protection Agency). 1992a. "Environmental Radiation Protection Standards for Management and Disposal of Spent Nuclear Fuel, High-Level and Transuranic Radioactive Wastes," Code of Federal Regulations 40, Part 191. Washington, DC: Superintendent of Documents, U.S. Government Printing Office.

EPA (Environmental Protection Agency). 1992b. "Land Disposal Restrictions," Code of Federal Regulations 40, Part 268. Washington, DC: Superintendent of Documents, U.S. Government Printing Office.

EPA (Environmental Protection Agency). 1992c. No-Migration Variances to the Hazardous Waste Land Disposal Prohibitions: A Guidance Manual for Petitioners, Draft, July 1992. EPA/530/R-92/03. Washington, DC: U.S. Environmental Protection Agency, Office of Solid Waste.

EPA (Environmental Protection Agency). 1993a. "40 CFR Part 191: Environmental Radiation Protection Standards for the Management and Disposal of Spent Nuclear Fuel, High-Level and Transuranic Radioactive Wastes, Final Rule," Federal Register. Vol. 58, no. 242, 66398-66416.

EPA (Environmental Protection Agency). 1993b. "Criteria for the Certification of Compliance with Environmental Radiation Protection Standards for the Management and Disposal of Spent Nuclear Fuel, High-Level and Transuranic Radioactive Wastes; Advanced Notice and Proposed Rulemaking," Federal Register. Vol. 58, no. 27, 8029-8030.

EPA (Environmental Protection Agency). 1993c. "Part 1-Statement of Organization and General Information," Code of Federal Regulations 40, Part 1. Washington, DC: Superintendent of Documents, U.S. Government Printing Office.

EPA (Environmental Protection Agency). 1993d. "Part 61-National Emission Standards for Hazardous Air Pollutants," Code of Federal Regulations 40, Part 61. Washington, DC: Superintendent of Documents, U.S. Government Printing Office.

EPA (Environmental Protection Agency). 1993e. "Part 761-Polychlorinated Biphenyls (PCBs) Manufacturing, Processing, Distribution in Commerce, and Use Prohibitions," Code of Federal Regulations 40, Part 761. Washington, DC: Superintendent of Documents, U.S. Government Printing Office.

EPA (Environmental Protection Agency). 1993f. "Subchapter R-Toxic Substances Control Act," Code of Federal Regulations 40, Part 700. Washington, DC: Superintendent of Documents, U.S. Government Printing Office.

Ewing, R.I. 1981. WIPP Test of a Radiant Heater in the Avery Island Salt Mine. SAND81-1305. Albuquerque, NM: Sandia National Laboratories.

Fanchi, J.R., J.E. Kennedy, and D.L. Dauben. 1987. BOAST_II: A Three-Dimensional, Three-Phase Black Oil Applied Simulation Tool. DOE/BC-88/2/SP. Tulsa, OK: K and A Technology.

Feagans, T.B., and W.F. Biller. 1981. "Risk Assessment: Describing The Protection Provided by Ambient Air Quality Standards, "The Environmental Professional. Vol. 3, no. 3/4, 235-247.

Feller, W. 1966. An Introduction to Probability Theory and Its Applications. New York, NY: John Wiley and Sons, Inc. Vol. 1.

Galson, D.A., and P.N. Swift. 1995. "Recent Progress in Scenario Development for the WIPP," High Level Radioactive Waste Management, Proceedings of the Sixth Annual International Conference, Las Vegas, NV, April 30 - May 5, 1995. La Grange Park, L: American Nuclear Society, Inc.; New York, NY: American Society of Civil Engineers. 391-396.

Gard, L.M. 1968. Geologic Studies Project Gnome, Eddy County, New Mexico. Professional Paper 589. Washington, DC: U.S. Geological Survey.

Gard, L.M., J.B. Cooper, D.D. Dickey, C.G. Bowles, B.M. Madsen, R.D. Carroll, C.M. Bunker, V.J. Janzer, M.C. Goldberg, C.G. Angelo, W.A. Beetem, and W.A. Mourant. 1962. Hydrologic and Geologic Studies for Project Gnome - Progress Report. PNE-130F. Washington, D.C.: United States Department of the Interior, Geological Survey. (Copy available from the National Technical Information Service, Springfield, VA.) 
Gardner, M.C., and J.J. Sigalove. 1970. Evaluation of the Project Gnome/Coach Site, Carlsbad, New Mexico, for Disposition, Including Identification of Restrictions, Part I. NVO-1229-106. Las Vegas, NV: U.S. Atomic Energy Commission, Nevada Operations Office.

Garrick, B.J. 1987. "Lessons Learned from 21 Nuclear Plant PRAs," Probabilistic Safety Assessment and Risk Management, PSA '87, International Topical Meeting, Zurich, Switzerland, August 31, 1987. Koeln, Germany: Verl. TUEV Rheinland. 369-387.

Garrick, B.J. 1991. "The Approach to Risk Analysis in Three Industries: Nuclear Power, Space Systems and Chemical Process," Risk Management: Expanding Horizons in Nuclear Power and Other Industries. Ed. R.A. Knief. New York, NY: Hemisphere Publishing Corporation. 173-181.

Gulick, C.W., Jr. 1979. Borehole Plugging Program, Plugging of ERDA No. 10 Drill Hole. SAND79-0789. Albuquerque, NM: Sandia National Laboratories.

Guzowski, R.V. 1990. Preliminary Identification of Scenarios That May Affect the Escape and Transport of Radionuclides From the Waste Isolation Pilot Plant, Southeastern New Mexico. SAND89-7149. Albuquerque, NM: Sandia National Laboratories.

Hacking, I. 1975. The Emergence of Probability. New York, NY: Cambridge University Press.

Hammersley, J.M., and D.C. Handscomb. 1964. Monte Carlo Methods. New York, NY: John Wiley \& Sons, Inc.

Hansen, J., I. Fung, A. Lacis, D. Rind, S. Lebedeff, R. Ruedy, and G. Russell. 1988. "Global Climate Changes as Forecast by Goddard Institute for Space Studies Three-Dimensional Model," Journal of Geophysical Research. Vol, 93, no. D8, 9341-9364.

Harms, J.C., and C.R. Williamson. 1988. "Deep-Water Density Current Deposits of Delaware Mountain Group (Permian), Delaware Basin, Texas and New Mexico," American Association of Petroleum Geologists Bulletin. Vol. 72, no. 3, 299-317.

Helton, J.C. 1993a. "Risk, Uncertainty in Risk, and the EPA Release Limits for Radioactive Waste Disposal," Nuclear Technology. SAND91-1255J. Vol. 101, no. 1, 18-39.

Helton, J.C. 1993b. "Uncertainty and Sensitivity Analysis Techniques for Use in Performance Assessment for Radioactive Waste Disposal," Reliability Engineering \& System Safety. Vol. 42, no. 2-3, 327-367.

Helton, J.C. 1993c. "Drilling Intrusion Probabilities for Use in Performance Assessment for Radioactive Waste Disposal," Reliability Engineering and System Safety. SAND93-7001J. Vol. 40, no. 3, 259-275.

Helton, J.C. 1994. "Treatment of Uncertainty in Performance Assessments for Complex Systems," Risk Analysis. SAND93-1713J. Vol. 14, no. 4, 483-511.

Helton, J.C., and H.J. Iuzzolino. 1993. "Construction of Complementary Cumulative Distribution Functions for Comparison with the EPA Release Limits for Radioactive Waste Disposal," Reliability Engineering and System Safety. SAND93-7002J. Vol. 40, no. 3, 277-293.

Helton, J.C., J.W. Garner, R.D. McCurley, and D.K. Rudeen. 1991. Sensitivity Analysis Techniques and Results for Performance Assessment at the Waste Isolation Pilot Plant. SAND90-7103. Albuquerque, NM: Sandia National Laboratories.

Helton, J.C., J.W. Garner, R.P. Rechard, D.K. Rudeen, and P.N. Swift. 1992. Preliminary Comparison with 40 CFR Part 191, Subpart B for the Waste Isolation Pilot Plant, December 1991. Volume 4: Uncertainty and Sensitivity Analysis Results. SAND91-0893/4. Albuquerque, NM: Sandia National Laboratories.

Helton, J.C., M.G. Marietta, and R.P. Rechard. 1993a. "Conceptual Structure of Performance Assessments Conducted for the Waste Isolation Pilot Plant," Scientific Basis for Nuclear Waste Management XVI, Materials Research Society Symposium Proceedings, Boston, MA, November 30-December 4, 1992. Eds. C.G. Interrante and R.T. Pabalan. SAND92-2285C. Pittsburgh, PA: Materials Research Society. Vol. 294, 885-898.

Helton, J.C., J.E. Bean, B.M. Butcher, J.W. Garner, J.D. Schreiber, P.N. Swift, and P. Vaughn. 1993b. Uncertainty and Sensitivity Analyses for Gas and Brine Migration at the Waste Isolation Pilot Plant, May 1992. SAND922013. Albuquerque, NM: Sandia National Laboratories.

Helton, J.C., D.R. Anderson, B.L. Baker, J.E. Bean, J.W. Berglund, W. Beyeler, J.W. Garner, H.J. Iuzzolino, M.G. Marietta, R.P. Rechard, P.J. Roache, D.K. Rudeen, J.D. Schreiber, P.N. Swift, M.S. Tierney, and P. Vaughn. 
1995. "Effect of Alternative Conceptual Models in a Preliminary Performance Assessment for the Waste Isolation Pilot Plant," Nuclear Engineering and Design. SAND94-2312J. Vol. 154, no. 3, 251-344.

Hertz, D.B. 1964. "Risk Analysis in Capital Investment," Harvard Business Review.Vol. 42, no. 1, 95-106.

Hills, J.M. 1984. "Sedimentation, Tectonism, and Hydrocarbon Generation in Delaware Basin, West Texas and Southeastern New Mexico," American Association of Petroleum Geologists Bulletin. Vol. 68, no. 3, $250-267$.

Hirsekorn, R.P., A. Nies, H. Rausch, and R. Storck. 1991. Performance Assessment of Confinements for Medium-Level and $\alpha$-contaminated Waste, Pacoma Project, Rock Salt Option. EUR 13634 EN. Luxembourg: Commission of the European Communities.

Hiss, W.L. 1975. "Stratigraphy and Ground-Water Hydrology of the Capitan Aquifer, Southeastern New Mexico and Western Texas." Ph.D. dissertation. Boulder, CO: University of Colorado.

Hixenbaugh, A.F. 1968. Fault Tree for Safety. D6-53604. Seattle, WA: Boeing Company, Support Systems Engineering.

Holt, R.M., and D.W. Powers. 1988. Facies Variability and Post-Depositional Alteration Within the Rustler Formation in the Vicinity of the Waste Isolation Pilot Plant, Southeastern New Mexico. DOE/WIPP 88-004. Carlsbad, NM: Westinghouse Electric Corporation.

Holt, R.M., and D.W. Powers. 1990. Geologic Mapping of the Air Intake Shaft at the Waste Isolation Pilot Plant. DOE/WIPP 90-051. Carlsbad, NM: Westinghouse Electric Corporation.

Hora, S.C. 1992. "Probabilities of Human Intrusion into the WIPP, Methodology for the 1992 Preliminary Comparison," Preliminary Performance Assessment for the Waste Isolation Pilot Plant, December 1992. Volume 3: Model Parameters. Sandia WIPP Project. SAND92-0700/3. Albuquerque, NM: Sandia National Laboratories. A-69 through A-99.

Hora, S.C., D. von Winterfeldt, and K.M. Trauth. 1991. Expert Judgment on Inadvertent Human Intrusion into the Waste Isolation Pilot Plant. SAND90-3063. Albuquerque, NM: Sandia National Laboratories.

Houghton, J.T., G.J. Jenkins, and J.J. Ephraums. 1990. Climate Change: The IPCC Scientific Assessment. New York, NY: Cambridge University Press.

Howarth, S.M., E.W. Peterson, P.L. Lagus, K-H. Lie, S.J. Finley, and E.J. Nowak. 1991. "Interpretation of In-Situ Pressure and Flow Measurements of the Salado Formation at the Waste Isolation Pilot Plant," Rocky Mountain Regional Meeting and Low-Permeability Reservoirs Symposium, Denver, CO, April 15-17, 1991. SAND902334C, SPE 21840. Richardson, TX: Society of Petroleum Engineers. 355-369.

HRS (Hazard Ranking Scheme) Workshop. 1982. Selection of Hazardous Waste Sites for Superfund Funding: Workshop. Sponsored by Subcommittee on Department of Housing and Urban Development-Independent Agencies for the Committee on Appropriations, U.S. Senate, March 19-20, 1982. Washington: U.S. G.P.O., For Sale by the Superintendent of Documents, U.S. G.P.O.

Hunter, R.L. 1985. A Regional Water Balance for the Waste Isolation Pilot Plant (WIPP) Site and Surrounding Area. SAND84-2233. Albuquerque, NM: Sandia National Laboratories.

Hunter, R.L. 1989. Events and Processes for Constructing Scenarios for the Release of Transuranic Waste From the Waste Isolation Pilot Plant, Southeastem New Mexico. SAND89-2546. Albuquerque, NM: Sandia National Laboratories.

Huyakorn, P.S., H.O. White, Jr., and S.M. Panday. 1991. STAFF2D Solute Transport and Fracture Flow in 2-Dimensions. Herndon, VA: HydroGeoLogic, Inc. (Copy on file at the Sandia WIPP Central Files, Sandia National Laboratories, Albuquerque, NM.)

IAEA (International Atomic Energy Agency). 1977. Site Selection Factors for Repositories of Solid, High-Level and Alpha-Bearing Wastes in Geological Formations. Technical Reports Series No. 177. Vienna, Austria: International Atomic Energy Agency.

IAEA (International Atomic Energy Agency). 1981. Safety Assessment for the Underground Disposal of Radioactive Wastes. Safety Series No. 56. Vienna, Austria: International Atomic Energy Agency. 
ICRP (International Commission on Radiological Protection). 1985. "ICRP Publication 46: Radiation Protection Principles for the Disposal of Solid Radioactive Waste," Annals of the ICRP. Elmsford, NY: Pergamon Press, Inc. Vol. 15, no. 4 .

ICRP (International Commission on Radiological Protection). 1990. "ICRP Publication 60: 1990 Recommendations of the Intemational Commission on Radiological Protection," Annals of the ICRP. Elmsford, NY: Pergamon Press, Inc. Vol. 21, no. 1-3.

Iman, R.L., and W.J. Conover. 1979. "The Use of the Rank Transform in Regression," Technometrics. Vol. 21, no. 4, 499-509.

Iman, R.L., and W.J. Conover. 1980a. "Small Sample Sensitivity Analysis Techniques for Computer Models, With an Application to Risk Assessment," Communications in Statistics. Vol. A9, no. 17, 1749-1842.

Iman, R.L., and W.J. Conover. 1980b. "Rejoinder to Comments," Communications in Statistics. Vol. A9, no. 17, 1863-1874.

Iman, R.L., and M.J. Shortencarier. 1984. A Fortran 77 Program and User's Guide for the Generation of Latin Hypercube and Random Samples for Use with Computer Models. SAND83-2365, NUREG/CR-3624. Albuquerque, NM: Sandia National Laboratories.

Iman, R.L., J.C. Helton, and J.E. Campbell. 1978. Risk Methodology for Geologic Disposal of Radioactive Waste: Sensitivity Analysis Techniques. SAND78-0912, NUREG/CR-0390. Albuquerque, NM: Sandia National Laboratories.

Iman, R.L., J.M. Davenport, E.L. Frost, and M.J. Shortencarier. 1980. Stepwise Regression with PRESS and Rank Regression (Program and User's Guide). SAND79-1472. Albuquerque, NM: Sandia National Laboratories.

Iman, R.L., M.J. Shortencarier, and J.D. Johnson. 1985. A Fortran 77 Program and User's Guide for the Calculation of Partial Correlation and Standardized Regression Coefficients. SAND85-0044, NUREG/CR-4122. Albuquerque, NM: Sandia National Laboratories.

Intera, Inc. 1989. Users Manual for STLINE. QA CIN097B-12C-001B. [Austin, TX]: Intera, Inc. (Copy on file at the Sandia WIPP Central Files, Sandia National Laboratories, Albuquerque, NM.)

Kafritsas, J, and R.L. Bras. 1981. Practice of Kriging. Report No. 263. Cambridge, MA: Massachusetts Institute of Technology, Ralph M. Parsons Laboratory.

Kaplan, S., and B.J. Garrick. 1981. "On the Quantitative Definition of Risk," Risk Analysis. Vol. 1, no. 1, 11-27.

Kaye, S.V. 1983. "Foreword," Radiological Assessment: A Textbook on Environmental Dose Analysis. Eds. J.E. Till and H.R. Meyer. NUREG/CR-3332. Washington, DC: U.S. Nuclear Regulatory Commission, Office of Nuclear Reactor Regulation. xi-xiv.

Lakey, L.T., and J.R. Bower, eds. 1963. ICPP Waste Calcining Facility Safety Analysis Report. IDO-14620. Idaho Falls, ID: Phillips Petroleum Co., Atomic Energy Division.

Lambert, S.J. 1983. Dissolution of Evaporites In and Around the Delaware Basin, Southeastern New Mexico and West Texas. SAND82-0461. Albuquerque, NM: Sandia National Laboratories.

Lambright, J.A., D.A. Brosseau, A.C. Payne, Jr., and S.L. Daniel. 1993. Analysis of the LaSalle Unit 2 Nuclear Power Plant: Risk Methods Integration and Evaluation Program (RMIEP) Internal Fire Analysis. SAND920537 - Vol. 9, NUREG/CR-4832 - Vol. 9. Albuquerque, NM: Sandia National Laboratories.

Lamorcaux, G.H., L.E. Romesberg, S.H. Sutherland, and T.A. Duffey. 1980. "Contact-Handled Transuranic Transportation System Structural Analys1s (TRUPACT)," Patram 80, 6th International Symposium on Packaging and Transporting Radioactive Materials, Berlin, Germany, November 10-14, 1980. SAND80-0792C. Berlin, Germany: Bundesanst für Materialprüf (BAM). 536-539.

LANL (Los Alamos National Laboratory). 1987. "Stanislaw Ulam 1909-1984," Los Alamos Science. No. 15, Special Issue. Los Alamos, NM: Los Alamos National Laboratory.

Lappin, A.R. 1988. Summary of Site-Characterization Studies Conducted From 1983 Through 1987 at the Waste Isolation Pilot Plant (WIPP) Site. Southeastern New Mexico. SAND88-0157. Albuquerque, NM: Sandia National Laboratones. 
Lappin, A.R., R.L. Hunter, D.P. Garber, and P.B. Davies, eds. 1989. Systems Analysis, Lang-Term Radionuclide Transport, and Dose Assessments, Waste Isolation Pilot Plant (WIPP), Southeastern New Mexico; March 1989. SAND89-0462. Albuquerque, NM: Sandia National Laboratories.

Laurens, J.M., B.G.J. Thompson, and T.J. Sumerling. 1989. "The Development and Application of an Integrated Radiological Risk Assessment Procedure Using Time-Dependent Probabilistic Risk Analysis," Proceedings of the Symposium on Safety Assessment of Radiological Waste Repositories, Paris, October 9-13, 1989. Paris: Organisation for Economic Co-Operation and Development. 627-638.

LaVenue, A.M., and B.S. RamaRao. 1992. A Modeling Approach To Address Spatial Variability within the Culebra Dolomite Transmissivity Field. SAND92-7306. Albuquerque, NM: Sandia National Laboratories.

LaVenue, A.M., T.L. Cauffman, and J.F. Pickens. 1990. Ground-Water Flow Modeling of the Culebra Dolomite. Volume I: Model Calibration. SAND89-7068/1. Albuquerque, NM: Sandia National Laboratories.

Legal Environmental Assistance Foundation, Inc. and Natural Resources Defense Council, Inc. State of Tennessee on behalf of Tennessee Department of Health and Environment (Intervening Plaintiff) v. Donald Hodel, Secretary, United States Department of Energy and United States Department of Energy. No. CIV. 3-83-562. 1984.586 Federal Supplement 1163.

Leigh, C.D., B.M. Thompson, J.E. Campbell, D.E. Longsine, R.A. Kennedy, and B.A. Napier. 1993. User's Guide for GENII-S: A Code for Statistical and Deterministic Simulations of Radiation Doses to Humans from Radionuclides in the Environment. SAND91-0561. Albuquerque, NM: Sandia National Laboratories.

Lewis, H.W. 1980. "The Safety of Fission Reactors," Scientific American. Vol. 242, no. 3, 53-65.

Lewis, H.W., R.J. Budnitz, H.J.C. Kouts, W.B. Loewenstein, W.D. Rowe, F.von Hippel, and F. Zachariasen. 1978. Risk Assessment Review Group Report to the U.S. Nuclear Regulatory Commission. NUREG/CR-0400. Washington, DC: U.S. Nuclear Regulatory Commission.

Logan, S.E. 1976. Workshop on Geologic Data Requirements for Radioactive Waste Management Assessment Models, Sante Fe, NM, June 28-July 1, 1976. Y/OW1/SUB-76/8/726. Albuquerque, NM: College of Engineering, University of New Mexico for the Office of Waste Isolation.

Lynch, R.W., R.L. Hunter, D.R. Anderson, F.W. Bingham, J.M. Covan, G.F. Hohnstrieter, T.O. Hunter, R.D. Klett, E.E. Ryder, T.L. Sanders, and W.D. Weart. 1991. Deep Geologic Disposal in the United States: The Waste Isolation Pilot Plant and Yucca Mountain Projects. SAND90-1656. Albuquerque, NM: Sandia National Laboratories.

Lyon, R.B. 1982. "Nuclear Waste Disposal: The Interface Between Performance Assessment and Research," Scientific Basis for Nuclear Waste Management, Proceedings of the Materials Research Society Annual Meeting, Boston, MA, November 1981. Ed. S.V. Topp. New York, NY: North-Holland. Vol. 6, 473-480.

Madsen, M.M., J.M. Taylor, R.M. Ostmeyer, and P.C. Reardon. 1986. RADTRAN III. SAND84-0036. Albuquerque, NM: Sandia National Laboratories.

Marietta, M.G., and W.F. Simmons. 1988. Feasibility of Disposal of High-Level Radioactive Wastes Into the Seabed. Volume 5-Dispersal of Radionuclides in the Oceans: Models, Data Sets, and Regional Descriptions. SAND87-0753. Albuquerque, NM: Sandia National Laboratories.

Marietta, M.G., S.G. Bertram-Howery, D:R. Anderson, K.F. Brinster, R.V. Guzowski, H. Iuzzolino, and R.P. Rechard. 1989. Performance Assessment Methodology Demonstration: Methodology Development for Evaluating Compliance with EPA 40 CFR 191, Subpart B, for the Waste Isolation Pilot Plant. SAND89-2027. Albuquerque, NM: Sandia National Laboratories.

Marietta, M.G., S.G. Bertram-Howery, R.P. Rechard, and D.R. Anderson. 1991. "Status of WIPP Compliance with EPA 40 CFR 191, December 1990," High Level Radioactive Waste Management, Proceedings of the Second Annual International Conference, Las Vegas, NV, April 28-May 3, 1991. SAND90-2424C. La Grange Park, IL: American Nuclear Society, Inc.; New York, NY: American Society of Civil Engineers. Vol. 2, 1181-1188.

Marraro, C.H. 1982. "Revising the Ozone Standard," Quantitative Risk Assessment in Regulation. Ed. L.B. Lave. Washington, D.C: Brookings Institution. 55-97.

Marshall, E. 1986. "Feynman Issues His Own Shuttle Report, Attacking NASA Risk Estimates," Science. Vol. 232, no. $4758,1596$. 
Matalucci, R.V., C.L. Christensen, T.O. Hunter, M.A. Molecke, and D.E. Munson. 1982. Waste Isolation Pilot Plant (WIPP) Research and Development Program: In Situ Testing Plan, March 1982. SAND81-2628. Albuquerque, NM: Sandia National Laboratories.

May, R.A., L.E. Romesberg, H.R. Yoshimura, W.E. Baker, and J.C. Hokanson. 1980. "Analytical and Empirical Evaluation of Low-Level Waste Drum Response to Accident Environments," Patram 80, 6th International Symposium on Packaging and Transporting Radioactive Material, Berlin, Germany, November 10-14, 1980. SAND80-0861C. Berlin, Germany: Bundesanst für Materialprüf (BAM). 584-587.

McKay, M.D., R.J. Beckman, and W.J. Conover. 1979. "A Comparison of Three Methods for Selecting Values of Input Variables in the Analysis of Output from a Computer Code," Technometrics. Vol. 21, no. 2, 239-245.

McVey, D.F. 1981. Analysis of Data from Line Source Thermal Conductivity Measurements Taken In Situ in Dome Salt at the Avery Island Mine. SAND81-1232. Albuquerque, NM: Sandia National Laboratories.

"Memorandum of Understanding between the U.S. Department of Energy and the U.S. Department of Labor," signed by R.L. Bernard, DOL Administrator for Metal and Nonmetal Mine Safety and Health, and R.G. Romatowski, DOE Manager of Albuquerque Operations Office, dated July 9, 1987. (Copy on file in the Sandia WIPP Central Files, Sandia National Laboratories, Albuquerque, NM.)

Mitchell, J.F.B. 1989. "The 'Greenhouse Effect' and Climate Change," Reviews of Geophysics. Vol. 27, no. 1, 115-139.

Molecke, M.A. 1978. Waste Isolation Pilot Plant Transuranic Wastes Experimental Characterization Program: Executive Summary. SAND78-1356. Albuquerque, NM: Sandia [National] Laboratories.

Morgan, M.G., M. Henrion, and M. Small. 1990. Uncertainty: A Guide to Dealing with Uncertainty in Quantitative Risk and Policy Analysis. New York, NY: Cambridge University Press.

Morris, W., ed. 1975. The American Heritage Dictionary of the English Language. New York, NY: American Heritage Pub. Co.

Napier, B.A., R.A. Peloquin, D.L. Strenge, and J.V. Ramsdell. 1988. GENII: The Hanford Environmental Radiation Dosimetry Software System. PNL-6584. Richland, WA: Pacific Northwest Laboratory. Vols. 1-3.

NAS/NRC (National Academy of Sciences/National Research Council). 1957. The Disposal of Radioactive Waste on Land: Report of the Committee on Waste Disposal of the Division of Earth Sciences. Publication 519. Washington, DC: National Academy of Sciences - National Research Council.

NAS/NRC (National Academy of Sciences/National Research Council). 1959. Radioactive Waste Disposal into Atlantic and Gulf Coastal Waters. Publication 655. Washington, DC: Working Group of the Committee on Oceanography, National Academy of Sciences - National Research Council.

NAS/NRC (National Academy of Sciences/National Research Council). 1975. Environmental Impact of Stratospheric Flight: Biological and Climatic Effects of Aircraft Emissions in the Stratosphere. Washington, DC: National Academy of Sciences.

NAS/NRC (National Academy of Sciences/National Research Council). 1976. Halocarbons: Environmental Effects of Chlorofluoromethane Release. Washington, DC: National Research Council, Assembly of Mathematical and Physical Sciences.

NAS/NRC (National Academy of Sciences/National Research Council). 1979. Stratospheric Ozone Depletion by Halocarbons: Chemistry and Transport. Washington, DC: National Academy of Sciences.

NAS/NRC (National Academy of Sciences/National Research Council). 1982. Causes and Effects of Stratospheric Ozone Reduction: An Update. Washington, DC: National Academy Press.

NAS/NRC (National Academy of Sciences/National Research Council). 1983. Risk Assessment in the Federal Government: Managing the Process. Washington, DC: National Academy Press.

NAS/NRC (National Academy of Sciences/National Research Council). 1984. Review of the Scientific and Technical Criteria for the Waste Isolation Pilot Plant (WIPP). DOE/DP/48015-1. Washington, DC: National Academy Press. 
NCRP (National Council on Radiation Protection and Measurements). 1984. Radiological Assessment: Predicting the Transport, Bioaccumulation, and Uptake by Man of Radionuclides Released to the Environment. NCRP Report No. 76. Bethesda, MD: National Council on Radiation Protection and Measurements.

NEA (Nuclear Energy Agency). 1984. Long-Term Radiation Protection Objectives for Radioactive Waste Disposal. Paris, France: Nuclear Energy Agency, Organisation for Economic Co-Operation and Development.

NEA (Nuclear Energy Agency). 1991. Disposal of Radioactive Waste: Review of Safety Assessment Methods. Paris, France: Organisation for Economic Co-Operation and Development, Nuclear Energy Agency.

NEA (Nuclear Energy Agency). 1992. Safety Assessment of Radioactive Waste Repositories: Systematic Approaches to Scenario Development. Paris: Nuclear Energy Agency, Organisation for Economic Co-Operation and Development.

NEA (Nuclear Energy Agency). 1993. "Update on Waste Management Policies and Programmes," Nuclear Waste Bulletin (Bulletin sur les Dechets Nucleaires). Vol. 8, July 1993, 2-84.

Neill, R.H., and J.K. Channell. 1983. Potential Problems from Shipment of High-Curie Content Contact-Handled Transuranic (CH-TRU) Waste to WIPP (Waste Isolation Pilot Plant). EEG-24. Santa Fe, NM: New Mexico Health and Environment Department, Environmental Evaluation Group.

Neill, R.H., J.K. Channell, M.S. Little, K. Rehfeldt, and P. Speigler. 1983. Evaluation of the Suitability of the WIPP Site. EEG-23. Santa Fe, NM: Environmental Evaluation Group.

Neuhauser, K.S. and P.C. Reardon. 1989. "RADTRAN 4.0: Advanced Computer Code for Transportation Risk Assessment," International Symposium on Packaging and Transporting of Radioactive Materials (PATRAM 89), Washington, DC, June 11-16, 1989. SAND89-1137C. Albuquerque, NM: Sandia National Laboratories.

Nowak, E.J., and J.C. Stormont. 1987. Scoping Model Calculations of the Reconsolidation of Crushed Salt in WIPP Shafts. SAND87-0879. Albuquerque, NM: Sandia National Laboratories.

Nowak, E.J., D.F. McTigue, and R. Beraún. 1988. Brine Inflow to WIPP Disposal Rooms: Data, Modeling, and Assessment. SAND88-0112. Albuquerque, NM: Sandia National Laboratories.

Nowak, E.J., J.R. Tillerson, and T.M. Torres. 1990. Initial Reference Seal System Design: Waste Isolation Pilot Plant. SAND90-0355. Albuquerque, NM: Sandia National Laboratories.

NRC (Nuclear Regulatory Commission). 1975. "10 CFR Part 50, Appendix I-Numerical Guides for Design Objectives and Limiting Conditions for Operation to Meet the Criterion 'As Low as Practicable' for Radioactive Material in Light-Water-Cooled Nuclear Power Reactor Effluents," Federal Register. Vol. 40, no. 87, 1944219443.

NRC (Nuclear Regulatory Commission). 1981. "Disposal of High Level Radioactive Wastes in Geologic Repositories: Licensing Procedures," Federal Register. Vol. 46, no. 37, 13971-13987.

NRC (Nuclear Regulatory Commission). 1983. "Disposal of High-Level Radioactive Wastes in Geologic Repositories: Technical Criteria," Federal Register. Vol. 48, no. 120, 28194-28230.

NRC (Nuclear Regulatory Commission). 1986. "Safety Goals for the Operations of Nuclear Power Plants; Policy Statement," Federal Register. Vol. 51, no. 149, 28044-28049.

NRC (Nuclear Regulatory Commission). 1990. Severe Accident Risks: An Assessment for Five U.S. Nuclear Power Plants. NUREG/1150. Washington, DC: Nuclear Regulatory Commission.

NRC (Nuclear Regulatory Commission). 1993. "Part 60-Disposal of High-Level Radioactive Wastes in Geologic Repositories," Code of Federal Regulations 10, Part 60. Washington, DC: Superintendent of Documents, U.S. Government Printing Office.

NRC (Nuclear Regulatory Commission). 1994a. "Part 71-Packaging and Transportation of Radioactive Material," Code of Federal Regulations 10, Part 71. Washington, DC: Superintendent of Documents, U.S. Government Printing Office.

NRC (Nuclear Regulatory Commission). 1994b. "Use of Probabilistic Risk Assessment Methods in Nuclear Regulatory Activities; Proposed Policy Statement," Federal Register. Vol. 59, no. 235, 63389. 
NRDC (Natural Resources Defense Council, Inc.) v. United States Environmental Protection Agency, et al. 1987. 824 Federal Reporter, $2 d$ Series 1258.

Nuclear Packaging, Inc. 1989. Safety Analysis Report for the TRUPACT-II Shipping Package, Rev. 4. SR00045. Washington, DC: Nuclear Packaging, Inc. Vols. 1-5. (Copy on file in the U.S. Nuclear Regulatory Commission Reading Room, Washington, DC.)

O'Brien, P.J., R.B. Lantz, and J. Gormley. 1977. Technical Support of Standards for High-Level Radioactive Waste Management: Volume C: Task C Report, Assessment of Migration Pathways. EPA 520/4-79-007 C. Arthur D. Little, Inc. for Office of Radiation Programs. Washington, DC: U.S. Environmental Protection Agency, Office of Radiation Programs.

OSHA (Occupational Safety and Health Administration). 1993. "Occupational Safety and Health Standards," Code of Federal Regulations 29, Part 1910. Washington, DC: Superintendent of Documents, U.S. Government Printing Office.

Painton, L., and J. Campbell. 1993. "Identification of Components to Optimize Improvement in System Reliability," Probabilistic Safety Assessment and Management (PSAM), 2nd, San Diego, CA, March 20-25, 1993. SAND932420C. Albuquerque, NM: Sandia National Laboratories.

Panton, L, and J.E. Campbell. 1995. "Genetic Algorithms in Optimization of System Reliability," IEEE Transactions on Reliability. Vol. 44, no. 2, 172-178.

Pepping, R.E., M.S. Chu, and M.D. Siegel. 1983. "A Simplified Analysis of a Hypothetical High-Level Waste Repository in a Bedded Salt Formation," Technical Assistance for Regulatory Development: Review and Evaluation of the Draft EPA Standard 40CFR191 for Disposal of High-Level Waste. SAND82-1557. NUREG/CR-3235. Albuquerque, NM: Sandia National Laboratories. Vol. 4.

Performance Assessment Group. 1990. "Early PA Scoping Calculations-To Help Refocus Research, Development, and Engineering Parts of the WIPP Project, If Necessary," Systems Analysis, Long-Term Radionuclide Transport, and Dose Assessments, Waste Isolation Pilot Plant (WIPP). Southeastern New Mexico; September 1989. A.R. Lappin, R.L. Hunter, P.B. Davies, D.J. Borns, M. Reeves, J. Pickens, and H.J. Iuzzolino. SAND891996. Albuquerque, NM: Sandia National Laboratories. A-2 through A-16.

Pierce, W.G., and E.I. Rich. 1962. Summary of Rock Salt Deposits in the United States as Possible Storage Sites for Radioactive Waste Materials. Geological Survey Bulletin 1148. Washington, DC: Geological Survey.

Popielak, R.S., R.L. Beauheim, S.R. Black, W.E. Coons, C.T. Ellingson, and R.L. Olsen. 1983. Brine Reservoirs in the Castile Formation, Waste Isolation Pilot Plant (WIPP) Project, Southeastern New Mexico. TME 3153. Albuquerque, NM: U.S. Department of Energy, Waste Isolation Pilot Plant.

Powers, D.W., and M.L. Martin. 1993. A Select Bibliography with Abstracts of Reports Related to Waste Isolation Pilot Plant Geotechnical Studies (1972-1990). SAND92-7277. Albuquerque, NM: Sandia National Laboratories.

Powers, D.W., S.J. Lambert, S-E. Shaffer, L.R. Hill, and W.D. Weart, eds. 1978. Geological Characterization Report, Waste Isolation Pilot Plant (WIPP) Site, Southeastern New Mexico. SAND78-1596. Albuquerque, NM: Sandia National Laboratories. Vols. I-II.

Press, W.H., B.P. Flannery, S.A. Teukolsky, and W.T. Vetterling. 1986. Numerical Recipes, The Art of Scientific Computing. New York, NY: Cambridge University Press. p. 529.

Price, L.L., S.H. Conrad, D.A. Zimmerman, N.E. Olague, K.C. Gaither, W.B. Cox, J.T. McCord, and C.P. Harlan. 1993. Preliminary Performance Assessment of the Greater Confinement Disposal Facility at the Nevada Test Site, Volume 1: Executive Summary. Volume 2: Technical Discussion. Volume 3: Supporting Details. SAND91-0047. Albuquerque, NM: Sandia National Laboratories.

Public Law 585. 1946. Atomic Energy Act of 1946.

Public Law 703. 1954. Atomic Energy Act of 1954 (60 Stat. 755; 42 U.S.C. 1801 et seq.).

Public Law 89-272. 1965. Solid Waste Disposal Act (42 U.S.C. 6901 et seq.).

Public Law 91-190. 1970. National Environmental Policy Act of 1969 (83 Stat. 852; 42 U.S.C. 1801 et seq.).

Public Law 91-596. 1970. Occupational Safety and Health Act of 1970 (84 Stat. 1590, 29 U.S.C 651 et seq.).

Public Law 91-604. 1970. Clean Air Amendments of 1970 (81 Stat. 486; 42 U.S.C. 1857 et seq.). 
Public Law 93-438. 1974. Energy Reorganization Act of 1974 (42 U.S.C. 5801 et seq.).

Public Law 93-523. 1974. Safe Drinking Water Act (42 U.S.C. 300f et seq.).

Public Law 94-580. 1976. Resource Conservation and Recovery Act of 1976 (90 Stat. 2795 and subsequent amendments).

Public Law 95-91. 1977. Department of Energy Organization Act (42 U.S.C. 7101 et seq.).

Public Law 95-95. 1977. Clean Air Act Amendments of 1977 (42 U.S.C. 7401 et seq.).

Public Law 95-164. 1977. Federal Mine Safety and Health Amendments Acts of 1977 (30 U.S.C. 801 et seq.).

Public Law 96-164. 1979. Department of Energy National Security and Military Applications of Nuclear Energy Authorization Act of 1980.

Public Law 96-510. Comprehensive Environmental Response, Compensation, and Liability Act of 1980 (Superfund). 94 Stat. 2767.

Public Law 97-425. 1983. Nuclear Waste Policy Act of 1982. (42 U.S.C. 10101 et. seq).

Public Law 97-440. 1982. Federal Water Pollution Control Act, Amendment (33 U.S.C. 1311 et seq.).

Public Law 98-616. 1984. The Hazardous and Solid Waste Amendments of 1984 (98 Stat. 3221).

Public Law 99-499. 1986. The Superfund Amendment and Reauthorization Act of 1986 (SARA).

Public Law 100-203. 1987. Nuclear Waste Policy Act Amendments of 1987 (42 U.S.C. 10101 et seq.).

Public Law 100-456. 1988. National Defense Authorization Act, Fiscal Year 1989.

Public Law 101-549. 1990. Clean Air Act Amendments of 1990.

Public Law 101-615. 1990. Hazardous Materials Transportation Uniform Safety Act of 1990 (104 Stat. 3244; 49 U.S.C. 1801 et seq.).

Public Law 102-386. 1992. Federal Facility Compliance Act of 1992.

Public Law 102-486. 1976. Energy Policy Act of 1992 (106 Stat. 2776; 42 U.S.C. 13201).

Public Law 102-579. 1992. Waste Isolation Pilot Plant Land Withdrawal Act (106 Stat. 4777).

Public Law 103-160. 1993. National Defense Authorization Act for Fiscal Year 1994 (107 Stat. 1547).

"Radioactive and Hazardous Materials Act," New Mexico Statutes Annotated 1978 (1993 Repl.). Vol. 13, Chapter 74, Article 4A, Section 74-4A-2. Charlottesville, VA: The Michie Company.

RamaRao, B.S., and M. Reeves. 1990. Theory and Verification for the GRASP II Code for Adjoint-Sensitivity Analysis of Steady-State and Transient Ground-Water Flow. SAND89-7143. Albuquerque, NM: Sandia National Laboratories.

Rasmussen, N.C. 1975. Reactor Safety Study: An Assessment of Accident Risks in U.S. Commercial Nuclear Power Plants. NUREG-75/014, WASH-1400. Washington, DC: U.S. Nuclear Regulatory Commission.

Rechard, R.P. 1989. Review and Discussion of Code Linkage and Data Flow in Nuclear Waste Compliance Assessments. SAND87-2833. Albuquerque, NM: Sandia National Laboratories.

Rechard, R.P. 1991a. "CAMCON: Computer System for Assessing Regulatory Compliance of the Waste Isolation Pilot Plant," Proceedings of the International Conference on Probabilistic Safety Assessment and Management (PSAM), Beverly Hills, CA, February 4-7, 1991. Ed. G. Apostolakis. SAND90-2094C. New York, NY: Elsevier Science Publishers. Vol. 2, 899-904.

Rechard, R.P. 1991b. "Introduction," Preliminary Comparison with 40 CFR Part 191, Subpart B for the Waste Isolation Pilot Plant, December 1991. Volume 2: Probability and Consequence Modeling. WIPP Performance Assessment Division. SAND91-0893/2. Albuquerque, NM: Sandia National Laboratories. 1-1 through 1-22.

Rechard, R.P., ed. 1992. User's Reference Manual for CAMCON: Compliance Assessment Methodology Controller, Version 3.0. SAND90-1983. Albuquerque, NM: Sandia National Laboratories. 
Rechard, R.P., ed. 1993. Initial Performance Assessment of the Disposal of Spent Nuclear Fuel and High-Level Waste Stored at Idaho National Engineering Laboratory. Volume 1: Methodology and Results. Volume 2: Appendices. SAND93-2330/1/2. Albuquerque, NM: Sandia National Laboratories. Vols. 1-2.

Rechard, R.P., ed. 1995. Performance Assessment of the Direct Disposal in Unsaturated Tuff of Spent Nuclear Fuel and High-Level Waste Owned by U.S. Department of Energy. Volume 1: Executive Summary. Volume 2: Methodology and Results. Volume 3: Appendices. SAND94-2563/1/2/3. Albuquerque, NM: Sandia National Laboratories. Vols. 1-3.

Rechard, R.P., M.S.Y. Chu, and S.J. Brown. 1988. SRS: Site Ranking System for Hazardous Chemical and Radioactive Waste. SAND86-2994, DOE/HWP-26. Albuquerque, NM: Sandia National Laboratories.

Rechard, R.P., H.J. Iuzzolino, J.S. Rath, A.P. Gilkey, R.D. McCurley, and D.K. Rudeen. 1989. User's Manual for CAMCON: Compliance Assessment Methodology Controller. SAND88-1496. Albuquerque, NM: Sandia National Laboratories.

Rechard, R.P., H.J. Iuzzolino, and J.S. Sandha. 1990a. Data Used in Preliminary Performance Assessment of the Waste Isolation Pilot Plant (1990). SAND89-2408. Albuquerque, NM: Sandia National Laboratories.

Rechard, R.P., W. Beyeler, R.D. McCurley, D.K. Rudeen, J.E. Bean, and J.D. Schreiber. 1990b. Parameter Sensitivity Studies of Selected Components of the Waste Isolation Pilot Plant Repository/Shaft System. SAND892030. Albuquerque, NM: Sandia National Laboratories.

Rechard, R.P., G.F. Wilkinson, and J.D. Schreiber. 1991a. User's Manual for SRS88: Site Ranking System for Chemical and Radioactive Waste. SAND87-2815, DOE/HWP-26. Albuquerque, NM: Sandia National Laboratories.

Rechard, R.P., P.J. Roache, R.L. Blaine, A.P. Gilkey, and D.K. Rudeen. 1991b. Quality Assurance Procedures for Computer Software Supporting Performance Assessments of the Waste Isolation Pilot Plant. SAND90-1240. Albuquerque, NM: Sandia National Laboratories.

Rechard, R.P., D.K. Rudeen, and P.J. Roache. 1992a. Quality Assurance Procedures for Analyses and Report Reviews Supporting Performance Assessments of the Waste Isolation Pilot Plant. SAND91-0428. Albuquerque, NM: Sandia National Laboratories.

Rechard, R.P., K.M. Trauth, and R.V. Guzowski. 1992b. Quality Assurance Procedures for Parameter Selection and Use of Expert Judgment Panels Supporting Performance Assessments of the Waste Isolation Pilot Plant. SAND91-0429. Albuquerque, NM: Sandia National Laboratories.

Rechard, R.P., A.P. Gilkey, H.J. Iuzzolino, D.K. Rudeen, and K.A. Byle. 1993a. Programmer's Manual for CAMCON: Compliance Assessment Methodology Controller. SAND90-1984. Albuquerque, NM: Sandia National Laboratories.

Rechard, R.P., K.M. Trauth, J.S. Rath, R.V. Guzowski, S.C. Hora, and M.S. Tierney. 1993b. "The Use of Formal and Informal Expert Judgments When Interpreting Data for Performance Assessments," Scientific Basis for Nuclear Waste Management XVI, Materials Research Society Symposium Proceedings, Boston, MA, November 30December 4, 1992. Eds. C.G. Interrante and R.T. Pabalan. SAND92-1148C. Pittsburgh, PA: Materials Research Society. Vol. 294, 943-950.

Reeves, M., D.S. Ward, N.D. Johns, and R.M. Cranwell. 1986a. Data Input Guide for SWIFT II, The Sandia WasteIsolation Flow and Transport Model for Fractured Media, Release 4.84. SAND83-0242, NUREG/CR-3162. Albuquerque, NM: Sandia National Laboratories.

Reeves, M., D.S. Ward, N.D. Johns, and R.M. Cranwell. 1986b. Theory and Implementation for SWIFT II, The Sandia Waste-Isolation Flow and Transport Model for Fractured Media, Release 4.84. SAND83-1159, NUREG/CR-3328. Albuquerque, NM: Sandia National Laboratories.

Reeves, M., D.S. Ward, P.A. Davis, and E.J. Bonano. 1986c. SWIFT II Self-Teaching Curriculum: Illustrative Problems for the Sandia Waste-Isolation Flow and Transport Model for Fractured Media. SAND84-1586, NUREG/CR-3295. Albuquerque, NM: Sandia National Laboratories.

Reeves, M., G.A. Freeze, V.A. Kelley, J.F. Pickens, D.T. Upton, and P.B. Davies. 1991. Regional Double-Porosity Solute Transport in the Culebra Dolomite Under Brine-Reservoir-Breach Release Conditions: An Analysis of Parameter Sensitivity and Importance. SAND89-7069. Albuquerque, NM: Sandia National Laboratories. 
Research and Special Programs Administration. Department of Transportation. 1993. "Subchapter C-Hazardous Materials Regulations," Code of Federal Regulations 49, Parts 171-177. Washington, DC: Superintendent of Documents, U.S. Government Printing Office.

"Reversal on Nuclear Waste Tests," Science News, Vol. 144, no. 19, 303.

Richmond, H.M. 1987. "Development of Probabilistic Health Risk Assessment for National Ambient Air Quality Standards," Regulatory Approaches for Control of Air Pollutants, Proceedings of an APCA Specialty Conference, Atlanta, GA, February 1987. Pittsburgh, PA: Air Pollution Control Association. 178-192.

Ripley, B.D. 1987. Stochastic Simulation. New York, NY: John Wiley \& Sons, Inc.

Romesberg, L.E., and M.L. Hudson. 1986. "Impact, Puncture and Thermal Testing of TRUPACT-I," Proceedings of an International Symposium on the Packaging and Transportation of Radioactive Materials (PATRAM '86), Davos, Switzerland, June 16-20, 1986. SAND84-2067C, IAEA-SM-286/107. Vienna, Austria: International Atomic Energy Agency. Vol. 2, 511-519.

Romesberg, L.E., S.H. Sutherland, G.H. Lamoreaux, and R.G. Eakes. 1981. "Design of Packaging for Transporting Transuranic Contaminated Wastes," Conference on Designing for Damage Prevention in the Transportation Environment, Gaithersburg, MD, October 21, 1981. SAND81-1308C. Albuquerque, NM: Sandia National Laboratories.

Romesberg, L.E., R.S. Longenbaugh, and B.J. Joseph. 1989. Fire Testing and Analysis of TRUPACT-I Thermal Test Article. SAND86-2710, TTC-0704. Albuquerque, NM: Sandia National Laboratories.

Salari, K., P. Knupp, P.J. Roache, and S. Steinberg. 1992. "TVD Applied to Radionuclide Transport in Fractured Porous Media," Finite Elements in Water Resources, Proceedings of the 9th International Conference on Computational Methods in Water Resources, Denver, CO, June 1992. Southampton, UK: Computational Mechanics. Vol. 1, 141-148.

Saltelli, A., T. Homma, P. Prado, and C. Torres. 1990. "Development of the LISA Code," Proceedings of the Symposium on Safety Assessment of Radioactive Waste Repositories, Paris, October 9-13, 1989. Paris: Organisation for Economic Co-Operation and Development. 639-648.

Sandia [National] Laboratories. 1977. Waste Isolation Pilot Plant (WIPP) Conceptual Design Report. SAND77-0274. Albuquerque, NM: Sandia Laboratories.

Sandia [National] Laboratories. 1979. Summary of Research and Development Activities in Support of Waste Acceptance Criteria for WIPP. Comp. T.O. Hunter. SAND79-1305. Albuquerque, NM: Sandia Laboratories.

Sandia WIPP Project. 1992a. "Appendix C: Realizations of Transmissivity Fields in the Culebra Dolomite Member of Rustler Formation," Preliminary Performance Assessment for the Waste Isolation Pilot Plant, December 1992. Volume 3: Model Parameters. SAND92-0700/3. Albuquerque, NM: Sandia National Laboratories. C-1 through C-73.

Sandia WIPP Project. 1992b. Preliminary Performance Assessment for the Waste Isolation Pilot Plant, December 1992. Volume 3: Model Parameters. SAND92-0700/3. Albuquerque, NM: Sandia National Laboratories.

Sandoval, R.P., and L.C. Sanchez. 1986. "TRUPACT Containment Issues," Proceedings of an International Symposium on the Packaging and Transportation of Radioactive Materials (PATRAM '86), Davos, Switzerland, June 16-20, 1986. SAND85-2203C. Vienna, Austria: International Atomic Energy Agency. Vol. 2, 719-727.

Sattler, A.R., and C.L. Christensen. 1980. Measurements of Very Large Deformations in "Potash Salt" in Conjunction With an Ongoing Mining Operation. SAND79-2254. Albuquerque, NM: Sandia National Laboratories.

Sherman, G.R., D.C. Donahue, S.G. King, and A. So. 1986. The Systems Variability Analysis Code SYVAC2 and Submodels for the Second Interim Assessment of the Canadian Concept for Nuclear Fuel Waste Disposal. TR317. Pinawa, Manitoba: Atomic Energy of Canada Limited, Whiteshell Nuclear Research Establishment.

Stannard, J.N. 1988. Radioactivity and Health, A History. Ed. R.W. Baalman, Jr. DOE/RL/01830-T59. Richland, WA: Pacific Northwest Laboratory; Springfield, VA: Available from National Technical Information Service.

State of New Mexico, ex rel., Jeff Bingaman, Attorney General of the State of New Mexico, Plaintiff, v. The United States Department of Energy, et al., Defendants. 1981. "Stipulated Agreement." Civil Action No. 81-0363 JB. 
(United States District Court for the District of New Mexico). July 1, 1981. (Copy on file at the Sandia WIPP Central Files, Sandia National Laboratories, Albuquerque, NM.)

State of New Mexico, ex rel., Tom Udall, Attorney General, Plaintiffs, Natural Resources Defense Council, et al., and State of Texas, ex rel., Dan Morales, Attorney General, Plaintiffs-Intervenors, v. James D. Watkins, Secretary of the Department of Energy, et al., Defendants. Environmental Defense Fund, et al., Plaintiffs, v. James D. Watkins, Secretary of the Department of Energy, et al., Defendants. Civ. A. Nos. 91-2527, 91-2929. United States District Court, District of Columbia. Dec. 13, 1991. 783 Federal Supplement 628.

State of New Mexico, ex rel., Tom Udall, Attorney General, Plaintiffs, Natural Resources Defense Council, et al., and State of Texas, ex rel., Dan Morales, Attorney General, Plaintiffs-Intervenors, v. James D. Watkins, Secretary of Energy, et al., Defendants. Civ. A. No. 91-2527, 91-2929. United States District Court, District of Columbia. February 3, 1992. 783 Federal Supplement 633.

Storck, R., J. Aschenbach, R.P. Hirsekorn, A. Nies, and N. Stelte. 1988. Performance Assessment of Geological Isolation Systems for Radioactive Waste, Disposal in Salt Formations. EUR 11778 EN. Luxembourg: Commission of the European Communities.

Swift, P.N. 1991. "Appendix A: Climate and Recharge Variability Parameters for the 1991 WIPP PA Calculations," Preliminary Comparison with 40 CFR Part 191, Subpart B for the Waste Isolation Pilot Plant, December 1991. Volume 3: Reference Data. Eds. R.P. Rechard, A.C. Peterson, J.D. Schreiber, H.J. Iuzzolino, M.S. Tierney, and J.S. Sandha. SAND91-0893/3. Albuquerque, NM: Sandia National Laboratories. A-107 through A-121.

Swift, P.N. 1993. "Long-Term Climate Variability at the Waste Isolation Pilot Plant, Southeastern New Mexico, USA," Environmental Management. Vol. 17, no. 1, 83-97.

Taylor, J.M., and S.L. Daniel. 1977. RADTRAN: A Computer Code to Analyze Transportation of Radioactive Material. SAND76-0243. Albuquerque, NM: Sandia [National] Laboratories.

Taylor, J.M., S.L. Daniel, and B.E. Biringer. 1980. "RADTRAN II: A Computerized Model for Risk Analysis for Transportation of Radioactive Material," Proceedings of 6th Intemational Sympositum, Packaging and Transportation of Radioactive Materials, PATRAM '80, West Berlin, West Germany, November 10-14, 1980. Ed. H.W. Hübner. Hamburg: K.O. Storck \& Co. Vol. 1, 161-167.

Teller, E. 1959. "The Plowshare Program," Proceedings of the Second Plowshare Symposium, San Francisco, CA, May 13-15, 1959. UCRL-5675. Livermore, CA: Lawrence Radiation Laboratory. 8-13.

Thompson, B.G.J. 1987. "The Development of Procedures for the Risk Assessment of Underground Disposal of Radioactive Wastes: Research Funded by the Department of the Environment 1982-1987," Radioactive Waste Management (Switzerland). Vol. 91, no. 1-3, 215-256.

Thompson, B.G.J., and B. Sagar. 1993. "The Development and Application of Integrated Procedures for PostClosure Assessment, Based Upon Monte Carlo Simulation: The Probabilistic Systems Assessment (PSA) Approach," Reliability Engineering and System Safety. Vol. 42, no. 2-3, 125-160.

Ticrney, M.S. 1991. Combining Scenarios in a Calculation of the Overall Probability Distribution of Cumulative Releases of Radioactivity from the Waste Isolation Pilot Plant, Southeastern New Mexico. SAND90-0838. Albuquerque, NM: Sandia National Laboratories.

Tierney, M.S. 1993. "PA Methodology Overview," Initial Performance Assessment of the Disposal of Spent Nuclear Fuel and High-Level Waste Stored at Idaho National Engineering Laboratory. Volume I: Methodology and Results. Ed. R.P. Rechard. SAND93-2330/1. Albuquerque, NM: Sandia National Laboratories. 3-1 through 3-28.

Tierncy, M.S. 1994a. "Using Data and Information to Form Distributions of Model Parameters in Stochastic Simulations of Performance of the Waste Isolation Pilot Plant (WIPP)," Proceedings of PSAM - II, An International Conference Devoted to the Advancement of System-based Methods for the Design and Operation of Technological Systems and Processes, San Francisco, CA, March 20-25, 1994. Eds. G.E. Apostolakis and J.S. Wu. SAND93-1302A. 051-9 through 051-16.

Tiemey, M.S. 1994b. "Probability of Intrusion by Exploratory Drilling at the WIPP Site," Transactions of the American Nuclear Society, 1993 Winter Meeting, San Francisco, CA, November 14-18, 1993. SAND93-3986C. Vol. 69, 130-132.

Tiemey, M.S., R.V. Guzowski, and R.P. Rechard. 1993. "Scenario Development," Initial Performance Assessment of the Disposal of Spent Nuclear Fuel and High-Level Waste Stored at Idaho National Engineering Laboratory. 
Volume 1: Methodology and Results. Ed. R.P. Rechard. SAND93-2330/1. Albuquerque, NM: Sandia National Laboratories. 7-1 through 7-27.

Till, J.E., and H.R. Meyer, eds. 1983. Radiological Assessment: A Textbook on Environmental Dose Analysis. ORNL-5968; NUREG/CR-3332. Oak Ridge, TN: Oak Ridge National Laboratory. Chapter 7.

Trauth, K.M., S.C. Hora, and R.P. Rechard. 1991. "Expert Judgment as Input to Waste Isolation Pilot Plant Performance Assessment Calculations: Probability Distributions of Significant System Parameters," Proceedings of the First International Mixed Waste Symposium, Baltimore, MD, August 26-29, 1991. Eds. A.A. Moghissi and G.A. Benda. SAND91-0625C. Baltimore, MD: University of Maryland. 4.3.1 through 4.3.9.

Trauth, K.M., S.C. Hora, R.P. Rechard, and D.R. Anderson. 1992. The Use of Expert Judgment to Quantify Uncertainty in Solubility and Sorption Parameters for Waste Isolation Pilot Plant Performance Assessment. SAND92-0479. Albuquerque, NM: Sandia National Laboratories.

Trauth, K.M., S.C. Hora, and R.V. Guzowski. 1993. Expert Judgment on Markers to Deter Inadvertent Human Intrusion into the Waste Isolation Pilot Plant. SAND92-1382. Albuquerque, NM: Sandia National Laboratories.

Tyler, L.D., R.V. Matalucci, M.A. Molecke, D.E. Munson, E.J. Nowak, and J.C. Stormont. 1988. Summary Report for the WIPP Technology Development Program for Isolation of Radioactive Waste. SAND88-0844. Albuquerque, NM: Sandia National Laboratories.

U.S. Congress. 1986. "Investigation of the Challenger Accident," House Report 99-1016 U.S. House of Representatives, Committee on Science and Technology, Ninety-Ninth Congress, Second Session. Washington, DC: U.S. Government Printing Office.

U.S. Congress. Office of Technology Assessment. 1985. Managing the Nation's Commercial High-Level Radioactive Waste. OTA-O-171. Washington, DC: Superintendent of Documents, U.S. Government Printing Office.

U.S. Department of the Interior. Bureau of Land Management. 1982. "43 CFR Public Land Order 6232. New Mexico; Withdrawal of Lands," Federal Register. Vol. 47, no. 61, 13340.

U.S. Department of the Interior. Bureau of Land Management. 1983. "43 CFR Public Land Order 6403. New Mexico; Withdrawal of Lands," Federal Register. Vol. 48, no. 130, 31038-31039.

U.S. Department of the Interior. Bureau of Land Management. 1991a. "43 CFR Public Land Order 6826. Modification of Public Land Order No. 6503; New Mexico," Federal Register. Vol. 56, no. 18, 3038-3039.

U.S. Department of the Interior. Bureau of Land Management. 1991b. "Record of Decision (ROD), Waste Isolation Pilot Plant (WIPP) Project; New Mexico," Federal Register. Vol. 56, no. 18, 3114-3115.

U.S. Department of the Interior. Bureau of Land Management. 1991c. "43 CFR Public Land Order 6826. Modification of Public Land Order No. 6403; New Mexico," Federal Register. Vol. 56, no. 29, 5731.

U.S. Department of the Interior. Bureau of Land Management. 1991d. "Notice to Proceed, Waste Isolation Pilot Plant (WIPP) Project, New Mexico," Federal Register. Vol. 56, no. 196, 50923-50924.

U.S. DOE (U.S. Department of Energy). 1980a. "New Mexico; Proposed Withdrawal and Reservations of Lands," Federal Register. Vol. 45, no. 223, 75768-75769.

U.S. DOE (U.S. Department of Energy). 1980b. Final Environmental Impact Statement: Waste Isolation Pilot Plant. DOE/EIS-0026. Washington, DC: U.S. Department of Energy. p. 1-1.

U.S. DOE (U.S. Department of Energy). 1983a. "Announcement of Decision to Proceed with Construction of the Waste Isolation Pilot Plant (WTPP)," Federal Register. Vol. 48, no. 128, 30427-30428.

U.S. DOE (U.S. Department of Energy). 1983b. Summary of the Results of the Evaluation of the WIPP Site and Preliminary Design Validation Program. WIPP-DOE-161. Albuquerque, NM: U.S. Department of Energy.

U.S. DOE (U.S. Department of Energy). 1987. "10 CFR Part 962-Byproduct Material," Federal Register. Vol. 52, no. $84,15940$.

U.S. DOE (U.S. Department of Energy). 1988. Site Characterization Plan, Yucca Mountain Site, Nevada Research and Development Area, Nevada. DOE/RW-0199. Washington, DC: U.S. Department of Energy. Section 8.3.5.13.

U.S. DOE (U.S. Department of Energy). 1989a. "Waste Isolation Pilot Plant; Availability of Draft Supplement to the Final Environmental Impact Statement," Federal Register. Vol. 54, no. 76, 16350-16352. 
U.S. DOE (U.S. Department of Energy). 1989b. Waste Isolation Pilot Plant No-Migration Variance Petition. DOE/WIPP 89-003, Rev. 0. Carlsbad, NM: Westinghouse Electric Corporation, Waste Isolation Division.

U.S. DOE (U.S. Department of Energy). 1990a. "Record of Decision; Waste Isolation Pilot Plant," Federal Register. Vol. 55, no. 121, 25689-25692.

U.S. DOE (U.S. Department of Energy). 1990b. Final Safety Analysis Report, Waste Isolation Pilot Plant, Carlsbad, New Mexico. WP 02-9, Rev. 0. Carlsbad, NM: Westinghouse Electric Corporation.

U.S. DOE (U.S. Department of Energy). 1990c. Final Supplement Environmental Impact Statement, Waste Isolation Pilot Plant. DOE/EIS-0026-FS. Washington, DC: U.S. Department of Energy, Office of Environmental Restoration and Waste Management. Vols. 1-13.

U.S. DOE (U.S. Department of Energy). 1992. "Definitive Design (Title II)," Project Management System. DOE Order 4700.1. Washington, DC: U.S. Department of Energy. V-40 through V-41.

U.S. DOE (U.S. Department of Energy). 1993a. Test Phase Plan for the Waste Isolation Pilot Plant. DOE/WIPP 89011, Revision 1. Albuquerque, NM: U.S. Department of Energy, WIPP Project Integration Office.

U.S. DOE (U.S. Department of Energy). 1993b. Waste Retrieval Plan for the Waste Isolation Pilot Plant. DOE/WIPP-89-022, Rev. 1. Washington, DC: U.S. Department of Energy.

U.S. DOE (U.S. Department of Energy). 1994. Integrated Data Base for 1993: U.S. Spent Fuel and Radioactive Waste Inventories, Projections, and Characteristics. DOE/RW-0006, Rev. 9. Oak Ridge, TN: Oak Ridge National Laboratory.

U.S. DOE (U.S. Department of Energy). 1995a. Draft No-Migration Variance Petition. DOE/CAO-95-2043. Carlsbad, NM: U.S. Department of Energy, Waste Isolation Pilot Plant, Carlsbad Area Office.

U.S. DOE (U.S. Department of Energy). 1995b. Draft 40 CFR 191 Compliance Certification Application for the Waste Isolation Pilot Plant. Phase II Review. DOE/CAO - Predecisional Draft-2056. Carlsbad, NM: U.S. Department of Energy, Waste Isolation Pilot Plant, Carlsbad Area Office.

U.S. DOE (U.S. Department of Energy) and State of New Mexico. 1984. "First Modification to the July 1, 1981 'Agreement for Consultation and Cooperation' on WIPP by the State of New Mexico and U.S. Department of Energy." November 30, 1984. (Copy on file at the Sandia WIPP Central Files, Sandia National Laboratories, Albuquerque, NM.)

Van Sambeek, L.L., D.D. Luo, M.S. Lin, W. Ostrowski, and D. Oyenuga. 1993. Seal Design Alternatives Study. SAND92-7340. Albuquerque, NM: Sandia National Laboratories.

Vaughn, P. 1986. Numerical Model for Thermal Recovery Processes in Tar Sand: Description and Application. DOE/FE/60177-2219. Report for the U.S. Department of Energy. Laramie, WY: Western Research Institute, University of Wyoming. (Available from National Technical Information Service, Springfield, VA.)

Voss, C.I. 1984. SUTRA (Saturated-Unsaturated Transport): A Finite-Element Simulation Model for SaturatedUnsaturated, Fluid-Density-Dependent Ground-Water Flow with Energy Transport or Chemically-Reactive Single-Species Solute Transport. Water-Resources Investigations Report 84-4369. Reston, VA: U.S. Geological Survey. (SUTRANUC is a version of SUTRA modified by Department 6342 at Sandia National Laboratories for transport of multiple nuclide decay chains.)

Ward, R.F., C.G. St. C. Kendall, and P.M. Harris. 1986. "Upper Permian (Guadalupian) Facies and Their Association with Hydrocarbons-Permian Basin, West Texas and New Mexico," American Association of Petroleum Geologists Bulletin. Vol. 70, no. 3, 239-262.

Warrant, M.M., J.M. Nelsen, and S.W. Woolfolk. 1986. "Containment Analysis of TRUPACT-I," Proceedings of an International Symposium on the Packaging and Transportation of Radioactive Materials (PATRAM '86), Davos, Switzerland, June 16-20, 1986. SAND85-2188C, IAEA-SM-286-111P. Vienna, Austria: International Atomic Energy Agency. Vol. 2, 529-536.

Weart, W.D. 1979. "WIPP: A Bedded Salt Repository for Defense Radioactive Waste in Southeastern New Mexico," Radioactive Waste in Geologic Storage, 176th Annual Meeting of the American Chemical Society, Miami Beach, FL, September 11-15, 1978. Ed. S. Fried. SAND78-0934C. ACS Symposium Series No. 100. Washington, DC: American Chemical Society. 13-36. 
WEC (Westinghouse Electric Corporation). 1990. Waste Isolation Pilot Plant No-Migration Variance Petition. DOE/WIPP 89-003, Rev. 1. Prepared for U.S. Department of Energy. Carlsbad, NM: Westinghouse Electric Corporation, Waste Isolation Division.

Wehr, M.R., J.A. Richards, Jr., and T.W. Adair, II. 1984. Physics of the Atom. 4th ed. Reading, MA: Addison Wesley.

Welch, B. August 24, 1993. "Local group to meet Energy secretary over WIPP standstill," Current Argus.

Wheeler, B.R., B.R. Dickey, G.E. Lohse, D.E. Black, D.W. Rhodes, and J.A. Buckham. 1967. "Storage of Radioactive Solids in Underground Facilities: Current ICPP Practices and Future Concepts," Disposal of Radioactive Wastes into the Ground, Proceedings of a Symposium Jointly Organized by the International Atomic Energy Agency and the European Nuclear Energy Agency of the OECD, Vienna, Austria, May 29-June 2, 1967. Vienna, Austria: International Atomic Energy Agency. 421-440.

Whitfield, R.G., and T.S. Wallsten. 1989. "A Risk Assessment for Selected Lead-Induced Health Effects: An Example of a General Methodology," Risk Analysis. Vol. 9, no. 2, 197-207.

Williamson, C.R. 1978. "Depositional Processes, Diagenesis and Reservoir Properties of Permian Deep-Sea Sandstones, Bell Canyon Formation, Texas-New Mexico." Ph.D. dissertation. Austin, TX: University of Texas at Austin.

Wilson, J.L., B.S. RamaRao, and J.A. McNeish. 1986. GRASP: A Computer Code to Perform Post-SWENT Adjoint Sensitivity Analysis of Steady-State Ground-Water Flow. BMI/ONWI-625. Columbus, OH: Office of Nuclear Waste Isolation, Battelle Memorial Institute.

Wilson, M.L., et al. 1994. Total-System Performance Assessment for Yucca Mountain-SNL Second Iteration (TSPA-1993). SAND93-2675. Albuquerque, NM: Sandia National Laboratories.

WIPP PA (Performance Assessment) Department. 1992/1993. Preliminary Performance Assessment for the Waste Isolation Pilot Plant, December 1992. SAND92-0700/1,2,3,4,5. Albuquerque, NM: Sandia National Laboratories. Vols. 1-5.

WIPP PA (Performance Assessment) Division. 1991. Preliminary Comparison with 40 CFR Part 191, Subpart B for the Waste Isolation Pilot Plant, December 1991. SAND91-0893/1,2,3,4. Albuquerque, NM: Sandia National Laboratories. Vols. 1-4.

Wuschke, D.M., P.A. Gillespie, K.K. Mehta, W.F. Heinrich, D.M. Leneveu, G.R. Sherman, V.M. Guvanasen, D.C. Donahue, B.W. Goodwin, T.H. Andres, and R.B. Lyon. 1985. Second Interim Assessment of the Canadian Concept for Nuclear Waste Disposal, Volume 4: Post Closure Assessments. AECL-3873-4. Pinawa, Manitoba: Atomic Energy of Canada Limited, Whiteshell Nuclear Research Establishment.

Zimmerman, D.A., and J.L. Wilson. 1990. Description of and User's Manual for TUBA: A Computer Code for Generating Two-Dimensional Random Fields via the Turning Bands Method. Albuquerque, NM: SeaSoft Scientific \& Engineering Analysis Software. (Copy on file at the Nuclear Waste Management Library, Sandia National Laboratories, Albuquerque, NM.)

Zimmerman, R.E., G. Cramer, and E. Joseph. 1956 (Declassified 1959). Monte Carlo Computer War Gaming. A Feasibility Study. RAC-T-325; AD-94 459. McLean, VA: Research Analysis Corp.; St. Paul, MN: Engineering Research Associates, Inc. (Available from National Technical Information Service, Springfield, VA.) 


\section{GLOSSARY}

\section{Acronyms and Initialisms}

$\mathrm{A} / \mathrm{E}$ - architect/engineering firm.

AEA - Atomic Energy Act, either 1946 (Pub. L. 585) or 1954 (Pub. L. 703).

AEC - Atomic Energy Commission, the forerunner of the DOE that was formed in 1946 (August 1, 1946, 60 Stat. 755).

AG - attorney general.

AL - Albuquerque operations office, DOE.

ALARA - As low as reasonably achievable with costs and benefits taken into account; a basic principle of radiation protection.

ALGEBRACDB - An algebraic manipulation code in the support module that is capable of performing most algebraic manipulations in CAMDAT files to prepare already existing data for transfer between software in the CAMCON system.

ANL - Argonne National Laboratory; see definition.

BCSET - A code in the Property Assignment Module that assigns boundary values at nodal boundary flags and element boundary flags to rectilinear one-, two-, or three-dimensional finite different grid or finite-elements meshes, or network-type grids. The flags are defined either by the mesh generation module or by BCSET in a user input file.

BLOTCDB - A plotting code in the Support Module that plots results from all main modules directly on screen or the printer by reading the CAMDAT files.

BOAST_II - A Black Oil Applied Simulation Tool for predicting, isothermal flow of three phase in porous media using an implicit/explicit solution solver (IMPESS). BOAST_II was used in the 1990 PA calculations.

BRAGFLO - BRine And Gas FLOw; two- and three-dimensional code in the Repository Module for evaluating the simultaneous flow of two phases (brine + gas) through a porous heterogeneous media. BRAGFLO uses a fully implicit finite difference solution of the partial differential equation of the mathematical model.

BRWM - Board of Radioactive Waste Management, a permanent Board formed in 1968 in the National Research Council, the principal operating agency of the U.S. National Academy of Sciences (NAS).

C\&C - Consultation and Cooperation agreement between State of New Mexico and the DOE.

CAMCON - Compliance Assessment Methodology CONtroller. Computational system for assessing the performance of a disposal system (usually for nuclear wastes). This complex information management system provides for (1) the interfacing of individual computer codes of the WIPP PA modeling system, and (2) quality assurance.

CAMCONexec - A set of procedure files in the CAMCON system that assists the analyst in interactivity running or alternately building macros for batch submission.

CAMDAT - Compliance Assessment Methodology DATa base. Data base consisting of the collection of binary computer files created during the stochastic simulation for the WIPP.

CAO - Carlsbad Area Office, DOE office for managing WIPP Project, formed in 1993.

CARD - Citizens Against Radioactive Dumping.

CCD2STEP - Software within the Statistical Module that transfers CCDFCALC releases to STEPWISE or PCCSRC.

CCDF - complementary cumulative distribution function; see definition. 
CCDFCALC - A code in the Compliance Module at the CAMCON system that generates conditional CCDFs where "conditional" means the CCDF is contingent on certain events or processes occurring.

CCDFPERM - A code in the Compliance Module of the CAMCON system that builds a CCDF by permutating and summing single and double intrusion data (E1 and E1E2 scenarios) to produce the "composite" CCDF, which is the relevant measure to compare with the EPA limiting line.

CCDFPLOT - A code in the Compliance Module to plot the conditional CCDFs calculated by CCDFCALC.

CDB - computational data base; see CAMDAT.

CDF - cumulative distribution function; see definition.

CEC - Commission of the European Communities.

CFR - Code of Federal Regulations. A codification of all the federal regulations in force as published in the Federal Register by the departments and agencies of the federal government.

CH-TRU waste - contact-handled TransUranic waste; see definition.

CUTTINGS - A computational model (code) that calculates the quantity of radioactive material (in curies) brought to the surface as cuttings/cavings by a drilling operation that penetrates the repository. The code determines the amount of cuttings removed from a borehole by drilling and decays radionuclides within the cuttings/cavings to the specified intrusion time.

DOE - U.S. Department of Energy; formed by DOE Organization Act (Public Law 95-91, 912 Stat 565), which replaced the Energy Research and Development Agency (ERDA). ERDA was formed by the 1974 Energy Reorganization Act (Public Law 93-438) and replaced the Atomic Energy Commission (AEC), which was formed in 1946 (August 1, 1946, 60 Stat. 755).

DOI - U.S. Department of Interior.

DOT - U.S. Department of Transportation.

EEG - Environmental Evaluation Group, formed in 1978 by New Mexico from funds provided by the DOE to conduct independent technical evaluation of the WIPP. The National Defense Authorization Act, Fiscal Year 1989, Public Law 100-456, Section 1433 assigned administrative oversight of EEG to the New Mexico Institute of Mining and Technology.

EIS - Environmental Impact Statement, environmental documentation required by federal law (NEPA) for large, federally-funded programs.

EPA - U.S. Environmental Protection Agency formed by Congress on December 2, 1970, in Reorganization Plan 3 of 1970 (5 U.S.C. 552, App.; 40 CFR 1). In this act, Congress transfers to EPA the tasks of monitoring research, setting standards, and performing enforcement activities related to pollution abatement and control that allow the environment to be considered as a single, interrelated system.

EPA of 1992 - Energy Policy Act of 1992; an act that requires the U.S. Environmental Protection Agency (EPA) to contract with the National Academy of Sciences (NAS) to recommend site-specific healthbased (dose) standards to individuals for the Yucca Mountain Project and subsequent promulgation of new regulations by the EPA and revision of regulations by the Nuclear Regulatory Commission (NRC) consistent with NAS findings.

ERDA - Energy Research and Development Agency, a forerunner of the DOE that was formed in 1974 (Pub. L. 93-438).

FFCA - Federal Facility Compliance Act of 1992; an act that removed sovereign immunity for federal facilities concerning hazardous waste regulations; the act requires a listing of mixed-waste inventory at U.S. DOE facilities, and the DOE chose to include spent fuel.

FITBND - A code used in the Property Assignment Module to evaluate transmissivity fields in the 1991 PA calculations; FITBND determines relationship between heads at wells and the boundary pressures and then optimizes fit of boundary pressures. Specifically, FITBND minimizes errors 
with respect to the known, steady-state freshwater heads at the wells by selecting a weighting of the boundary-condition perturbations.

Fm - geologic formation.

FR - Federal Register.

GA - General Atomic, Inc.

GAC - Governor's Advisory Committee of New Mexico.

GARFIELD - A code in the Property Assignment Module used to evaluate transmissivity fields in the 1991 PA calculations; used generalized kriging, which is a type of interpolation that takes account of known or assumed statistical properties of the field that is being interpolated.

GENII-S - A computer code used to simulate radionuclide transport in the biosphere and resultant radiation doses from internal and external exposure of the radionuclides in the air, water, or soil.

GENMESH - The principal software in the Mesh Generation Module that produces a right-handed, Cartesian, rectangular, one-, two-, or three-dimensional finite-element or finite-difference mesh.

GENNET - Software in the Mesh Generation Module that constructs simple one-, two-, and threedimensional networks using two-node elements from a geometry specification input file.

GENOBS - A code within the Property Assignment Module used to evaluate transmissivity fields in the 1991 PA calculations; generated a set of linear impulse functions for selected segments along the boundary of the mesh.

GRAPH - Software for making simple $x$-y plots.

HLW - high level waste; see definition.

HSWA - Hazardous and Solid Waste Amendments of 1984 (Pub. L. 98-616) (see also RCRA).

IAEA - International Atomic Energy Agency located in Vienna, Austria. Formed in 1956 "to accelerate and enlarge the contribution of atomic energy to peace, health and prosperity throughout the world."

ICRP - International Commission on Radiological Protection, established in 1928 by Second International Congress of Radiology. Maintains special relationship with International Society of Radiology, but also has official relationships with World Health Organization and IAEA.

ICSET - Software in the Property Assignment Module that sets initial conditions, i.e., sets analysis array variables (history, global, nodal, and/or element variable values) in a CAMDAT file at the first time step.

IDB- Integrated Data Base compiled by Oak Ridge.

INEL - Idaho National Engineering Laboratory; see definition.

INGRES $\circledast$ - The relational data base management software that stores and retrieves model parameters necessary for the PA analysis.

LANL - Los Alamos National Laboratory; see definition.

LHS - Latin hypercube sampling. A code in the Property Assignment Module used to execute Latin hypercube sampling. LHS samples distributions of input parameters using either normal Monte Carlo sampling or the more efficient Latin hypercube sampling; permits correlations (restricted pairings) between parameters.

LHS2STEP - Translator software for converting output from LHS to STEPWISE or PCCSRC.

LLNL - Lawrence-Livermore National Laboratory; see definition.

LLW - low level waste; see definition.

MATSET - Software in the Property Assignment Module that sets material names to specified regions (e.g., defined by GENMESH or GENNET), sets material property values, and sets attribute values into a performance-assessment computational database, CAMDAT, file by extracting data from the SDB. 
MB - marker bed; see definition.

MRS - monitored retrievable storage facility for spent fuel from commercial power reactors, proposed in 1982 in NWPA and 1987 in NWPAA (see also RSSF).

NAS - National Academy of Sciences, is a private, nonprofit, self-perpetuating society of distinguished scholars engaged in scientific and engineering research. The Academy was chartered by Congress in 1863 with the mandate to advise the federal government on scientific and technical matters.

NEA - Nuclear Energy Agency, was established in 1958 to promote cooperation among participating countries in furthering the development of nuclear power as a safe, environmentally acceptable, and economic energy source. It is currently a division of the Organisation for Economic Co-operation and Development (OECD).

NEPA - National Environmental Policy Act of 1969, Public Law No. 91-190, 83 Stat. 852; federal law that sets environmental policy by requiring an environmental impact statement on all major federal projects.

NRC - Nuclear Regulatory Commission; formed by the 1974 Energy Reorganization Act (Public Law 93-438) from the Atomic Energy Commission.

NRDC - National Resources Defense Council, U.S. environmental special interest group.

NTS- Nevada Test Site; see definition.

NUCPLOT - Software in the Compliance Module that depicts the contribution [in activity or percentage] of each radionuclide to the EPA summed normalized release, $R$, as a tukey box plot.

NWPA - Nuclear Waste Policy Act of 1982; provides a national policy for the interim storage, monitored retrievable storage, and eventual disposal of radioactive waste.

NWPAA - Nuclear Waste Policy Amendments Act of 1987; amendments to the Nuclear Waste Policy Act of 1982 specifying that only one repository site at Yucca Mountain was to be characterized by the DOE and placing renewed emphasis on the monitored retrievable storage option.

OECD - Organisation for Economic Co-Operation and Development, an international organization formed in 1961 and based in Paris, whose members comprise the principal industrial powers of the world. The CEC takes part in the work of OECD.

ORNL - Oak Ridge National Laboratory; see definition.

OTA - Office of Technology Assessment, U.S. Congress.

PA - performance assessment; see definition.

PANEL - The code in the Repository Module that implements the mixing cell mathematical model to evaluate the dissolution of radionuclides from the TRU waste into brine within the disposal-room.

PCCSRC - A code in the Statistical Module that evaluates variable importance at each time step by reporting the partial correlation coefficients (PCCs) and standardized regression coefficients (SRCs) on either the data or the ranks of the data.

PDF - probability density function; see definition.

PERM2PCC - Software to translate output from CCDFPERM for use by PCCSRC or STEPWISE.

POSTBRAG - Translator software for placing data from BRAGFLO into a CAMDAT file format.

POSTLHS - Software to translate output from LHS to a CAMDAT file format.

POSTSECOTP - Translator software for placing data from SECOTP2D into a CAMDAT file form.

PRA - probabilistic risk assessment; see definition.

PREBRAG - Translator software for extracting data from a CAMDAT file to generate input for BRAGFLO.

PREGENII - PA translator software that statistically characterizes radionuclide concentrations so that they are compatible with input required by GENII-S. 
PRELHS - PA translator software used to extract data from the secondary data base to prepare input for LHS.

PRESECOTP2D - Translator software for extracting data from a CAMDAT file to generate input for SECOTP2D.

QA - quality assurance; see definition.

RCRA - Resource Conservation and Recovery Act of 1976 (Public Law 94-580) and, as used herein, subsequent amendments (e.g., HSWA, Hazardous and Solid Waste Amendments of 1984, Public Law 98-616). RCRA establishes a procedure to track and control hazardous wastes from time of generation to disposal. Regulations in 40 CFR Parts 260-281 implement RCRA with respect to hazardous waste and hazardous waste treatment.

RELATE - Software in the Support Module that is used to interpolate pertinent parameters from one mesh to another mesh (e.g., from the regional mesh to the local mesh).

RFP - Rocky Flats Plant; see definition.

RH-TRU waste - remotely handled TRansUranic waste; see definition.

RSSF - retrievable surface storage facility proposed in 1972 by the AEC (see also MRS).

SA - Stipulated Agreement between State of New Mexico and the DOE.

Sandia - See SNL.

SAR - Safety Analysis Report.

SDB - secondary data base; see definition.

SECOFL2D - A code within the Groundwater Flow Module that is a fully implicit, finite different solution of the partial differential equation based on heads. The groundwater-flow code also automates the calculation of and interaction between models of the regional and local domains.

SECOTP2D - A transport code within the Contaminant Transport Module that simulates single- or multiple-component radionuclide transport in fractured or porous aquifers. The code uses totalvariation-diminishing (TVD) schemes to model the advective part of the transport equation.

SI - "Systeme Internationale d' Unites," an international standard of measurement that is used by the scientific and engineering community.

SNF - spent nuclear fuel; see definition.

SNL - Sandia National Laboratories; see definition.

SPDV - site and preliminary design validation phase performed by Bechtel National.

SRC - standardized regression coefficient in the statistical regression model.

SRP - Savannah River Plant; see definition.

SSDMS II - Sandia Sorption Data Management System Version 2 developed to store and retrieve sorption data on chemicals.

STAFF2D - A code within the Contaminant Transport Module that calculates radionuclide transport in fractured or porous aquifers. One of several PA model-groundwater-flow codes; used in concert with various support modules that can be linked in a serial procedure using the CAMCONexec driver to analyze the WIPP disposal system.

STEPWISE - A code in the Statistical Module that evaluates variable importance by developing regression models between the input variable and the observed response using a forward, backward, or stepwise regression procedure on the rank or raw data.

SUMMARIZE - Software that accesses multiple CAMDAT files and places specified values in one file in tabular form.

SUTRA - Saturated-Unsaturated TRAnsport code. A code in the Groundwater Flow Module that models saturated and unsaturated porous media liquid flow and contaminant transport using a finite- 
element solution technique. SUTRANUC is a modified version of SUTRA that includes transport and decay of radionuclides.

SWIFT - Sandia Waste-Isolation Flow and Transport Code. A code in the Groundwater Flow Module that models dual porosity fluid flow and radionuclide transport using a finite-difference solution technique.

SWRIC - Southwest Research and Information Center.

TRACKER - A code within the Support Module that tracks a neutrally buoyant particle in a fluid velocity field.

TRU - TRansUranic, all elements of the periodic table having atomic numbers greater than 92 .

T,R,U,P,A,C,T - cask TRansUranic PACkage Transporter; the transportation container for trucking TRU waste to the WIPP; TRUPACT_II (current design) has space for two seven-pack units of 55 gallon waste drums or two standard waste boxes.

UNDERDOG - Underground Nuclear Depository Evaluation, Reduction, and Detailed Output Generator developed for data reduction (i.e., reducing raw data [e.g., voltage readings] to meaningful engineering units [e.g., temperature]).

UNSWIFT - Converts material property data from an input file for SWIFT_II into a CAMDAT file format.

USGS - U.S. Geological Survey, Department of Interior (DOI).

VOC - Volatile Organic Compounds, such as solvents used for cleaning.

WIPP - Waste Isolation Pilot Plant; a full-scale research and development repository for transuranic wastes near Carlsbad, NM; authorized in 1979 (Pub. L. 96-164) for the management, storage, and eventual disposal of waste generated by DOE defense programs that is contaminated with transuranic radionuclides and some RCRA hazardous chemicals.

WIPPLWA - Waste Isolation Pilot Plant Land Withdrawal Act (Pub. L. 102-579).

WISDAAM - WIPP In Situ Data Acquisition, Analysis, and Management system developed to group tasks associated with processing experimental data.

WP - waste parcel; see definition.

WPIO - WIPP Project Integration Office, formed in 1989, forerunner of CAO.

WPO - WIPP Project office, forerunner of CAO.

WTWBIR - WIPP Transuranic Waste Baseline Inventory Report compiled by National TRU Program Office of the DOE, Carlsbad, NM.

10 CFR 60 - Code of Federal Regulations, Title 10, Part 60, Licensing Requirements for Land Disposal of Radioactive Waste. This NRC regulation does not apply to the WIPP, but contains terms and concepts frequently used by the scientific community when discussing nuclear waste management.

40 CFR 191 - Code of Federal Regulations, Title 40, Part 191, Environmental Radiation Protection Standards for Management and Disposal of Spent Nuclear Fuel, High-Level and Transuranic Radioactive Wastes. This EPA regulation is the primary standard that applies to the WIPP after closure.

40 CFR 194 - Code of Federal Regulations, Title 40, Part 194, Criteria for the Certification and Compliance with Environmental Radiation Protection Standards for the Management and Disposal of Spent Nuclear Fuel, High-Level Waste and Transuranic Radioactive Waste. (only proposed).

40 CFR 268 - Code of Federal Regulations, Title 40, Part 268, Land Disposal Restrictions. A portion of the regulations implementing RCRA. This part restricts the land disposal of all hazardous wastes before strict treatment standards are met or a no-migration variance petition is approved. 


\section{Definitions}

accessible environment - "... (1) the atmosphere, (2) land surfaces, (3) surface water, (4) oceans, and (5) all of the lithosphere that is beyond the controlled area." (40 CFR 191.12[k]); the overall performance of the disposal system is calculated at the contact of disposal with accessible environment.

actinide - The series of elements beginning with actinium, atomic number 89 , and continuing through lawrencium, atomic number 103; all are radioactive.

activation - The process of making a material radioactive by bombardment with neutrons, protons, or other nuclear radiation (also called induced radioactivity).

activity - See radioactivity.

aleatoric parameters - Parameters in the parameter space of the conceptual model for which sufficient knowledge is unobtainable such that they are treated as chance occurrences of features, events, and processes. These parameters may be conveniently used to form scenarios related to chance.

alpha particle $(\alpha)$ - A type of radiation; positively charged particle (identical to a helium nucleus-two protons and two neutrons) ejected spontaneously from the nuclei of some radionuclides.

alpha-bearing waste - See transuranic waste.

alternative conceptual models - Multiple working sets of hypotheses and assumptions of a system that are all scientifically acceptable (i.e., consistent with the purpose of the model, logically complementary to one another, in agreement with existing facts and observed data, and able to be tested).

alternative models - Alternatives in model form that may exist at each stage of model development. Alternatives at the first stage of model development (alternative conceptual models) are often of the most concern.

americium (Am) - A TRU radionuclide having an atomic number of 95 , containing 95 electrons and 95 protons. ${ }^{241} \mathrm{Am}$ (half-life of $432.7 \mathrm{yr}$ ) results from the decay of ${ }^{241} \mathrm{Pu}$ (half-life of $14.4 \mathrm{yr}$ ). Waste initially containing ${ }^{241} \mathrm{Pu}$ will therefore eventually contain ${ }^{241} \mathrm{Am}$ for several decades as the $\mathrm{Pu}$ decays.

analysis - Analysis is the rational investigation of a natural or artificial phenomenon to discover principles that underlie the phenomenon. More formally, analysis is the five-step process of (1) defining (developing hypothesis and planning), (2) investigating, (3) validating, (4) reviewing, and (5) documenting the study of a system. This rational study often involves "teasing" the system "apart," i.e., dividing the whole system into simpler components to gain understanding. However, it may also involve synthesis, i.e., the bringing together of diverse facts to comprehend the whole system. Consequently, analysis is at the heart of the method of scientific discovery and explanation. (See engineering analysis.)

anhydrite - A mineral consisting of anhydrous calcium sulfate $\left(\mathrm{CaSO}_{4}\right)$. It is gypsum without water, and is denser, harder, and less soluble.

anoxic - Without oxygen.

applied model - The analyst's application of the generic computational model to a particular system, using appropriate values for dimensions of the system components, parameters, and boundary and initial conditions. In a waste management, the system is a waste disposal site, and so this model is also referred to as a site-specific model.

Argonne National Laboratory (ANL) - A national laboratory in Argonne, IL; some TRU waste destined for the WIPP is stored on site.

Assurance Requirements - Qualitative requirements in Subpart B of 40 CFR 191 ( $\$ 191.14)$ that specify actions and procedures to increase confidence that the probabilistic release limits in the Containment Requirements (\$191.13) will be met.

backfill - Material used to fill the shafts, access drifts, and other excavated openings. Special types of backfill include concrete and bentonite clay plugs for sealing (seals) and possibly any backfill around the waste parcel (backfill-buffer). 
backfill-buffer - The earthen backfill between the waste parcel and host rock; because some emplacement designs envision using the backfill material to moderate (or buffer) the release of contaminants to the host rock (e.g., bentonite clay in a granite repository), this backfill is also referred to as "backfill-buffer." The term "backfill-buffer" is used in this report even when the crushed-salt backfill around the waste parcel is discussed, although it does not technically provide a moderating function. The term "buffer" is also frequently found in the literature but is not used here to avoid confusion with the many other uses of the term (e.g., in chemistry, a solution containing a weak acid and conjugate base that resists changes in $\mathrm{pH}$ ).

barrier - As defined in 40 CFR 191, a barrier "means any material or structure that prevents or substantially delays movement of water or radionuclides toward the accessible environment. For example, a barrier may be a geologic structure, a canister, a waste form with physical and chemical characteristics that significantly decrease the mobility of radionuclides, or a material placed over and around water, provided that the material or structure substantially delays movement of water or radionuclides" (Section 191.12).

becquerel - SI unit of radioactivity equal to one transformation per second (see also curie).

Bell Canyon Formation - A sequence of rock strata that form the topmost formation of the Delaware Mountain Group. The Bell Canyon Formation lies below the Castile Formation.

bentonite - A common term applied to clay containing montmorillonite (smectite) as the predominate mineral.

beta particle ( $\beta$ ) - A type of radiation; a charged (positive or negative) particle emitted from the nuclei of some radionuclides during radioactive decay. A negatively charged beta particle is identical to an electron; a positively charged beta particle is a positron.

biosphere - Portion of the earth and atmosphere occupied by living organisms.

borehole - A hole drilled from the surface for purposes of geologic or hydrologic testing, or to explore for resources; sometimes referred to as a drillhole.

brine reservoir - Pressurized brine of unknown origin but of limited extent contained in fractured anhydrite within the Castile Formation (also frequently referred to as a brine pocket). Although a portion of the WIPP waste panels are assumed to have brine pockets beneath them, the pockets are only of concern for human intrusion scenarios where exploratory boreholes penetrate a waste panel and then continue down to the Castile Formation.

buffer - See backfill-buffer.

californium (Cf) - A TRU element having an atomic number 98 (the number of protons in the nucleus). An alpha emitter (half-life of $2.64 \mathrm{yr}$ ), ${ }^{252} \mathrm{Cf}$ also spontaneously fissions, thus making it desirable as a neutron source. ${ }^{252} \mathrm{Cf}$ is created by neutron bombardment of ${ }^{244} \mathrm{Cm}$ targets. Oak Ridge is the only production agency for $\mathrm{Cf}$. As a result, Oak Ridge is the only major generator of TRU waste showing finite quantities of this element.

Castile Formation - A formation of evaporite rocks (interbedded halite and anhydrite) of Permian age that immediately underlies the Salado Formation.

cavings - Particulates brought to the ground surface in the drilling fluid of a rotary drill from erosion of the borehole wall by the circulating drilling fluid.

".CDB" files - computational data base files. All .CDB files have the same format, and any number of codes can write to a .CDB file. The intermediate results of all computer codes pass through the same evolving .CDB file for each Monte Carlo simulation.

code - Software, but usually implying scientific/engineering software that groups together several different computational models.

complementary cumulative distribution function (CCDF) - One minus the cumulative distribution function (CDF). It is the graphical representation of the probability $(P)$ of any consequence value $R$ exceeding a specified consequence value $P(R>\hat{R})$. For the Containment Requirements in $40 \mathrm{CFR}$ 191 , the consequence value $R$ is the sum of the radionuclide releases (normalized by the EPA release limits) accumulated over 10,000 years. 
computational model - The solution and implementation of the mathematical model. The solution may be either analytical, numerical, or empirical (where an empirical solution uses observed data directly by means of lookup tables and/or interpolation on statistical relationships). Conceivably, the implementation may be evaluated either by hand or on a computer. However, because the latter is more frequent, computational model is often synonymous with computer model. The computational model is generic until system-specific data are used. The computational models are the heart of the PA analysis and selected and/or designed by PA analysts to simulate the features, events, and processes of the WIPP disposal system.

computational scenario - A member of a class or subset of the parameter space that is obtained by further subdividing the summary scenario subspace $S_{j}$.

conceptual model - The set of hypotheses and assumptions that postulates the description and behavior of a system. To be scientifically acceptable, the set of hypotheses must be (1) consistent with the purpose of the model, (2) logically consistent with one another, (3) in agreement with existing information and observed data, and (4) able to be tested (i.e., capable of being falsified by the collection of more observed data). At a minimum, these hypotheses and assumptions describe the following about the system, including whether time dependent: (1) the simplified physical arrangement of system components, (2) the initial and boundary condition types, and (3) the nature of the relevant chemical, physical, cultural, or biological phenomena.

consequence - Result or effect on the disposal system from the consequence model. Conceptual and mathematical models are used to estimate consequences of feature events and/or processes.

consequence model - A "complete" (or "total system") consequence model, $C$, for the WIPP disposal system predicts a "consequence," $C[\mathbf{x}, S j(\mathbf{x})]$, for each value of the scenario, $S_{j}$, and each value of the model parameter space $x$.

contact-handled transuranic (CH-TRU) waste - Packaged TRU waste whose external surface dose rate does not exceed 200 mrem per hour (see also dose).

Containment Requirements - Requirements in Subpart B of 40 CFR 191 (\$191.13) that set probabilistic limits on cumulative releases of radionuclides beyond the "controlled area" (defined in the regulation as a surface location that encompasses no more than $100 \mathrm{~km}^{2}$ and extends horizontally no more than a $5-\mathrm{km}$ radius from the outer boundary of a radioactive-waste disposal system, plus the underlying subsurface $[\$ 191.12(\mathrm{~g})]$ ) for 10,000 years.

controlled area - As defined in 40 CFR 191, Subpart B, "(1) a surface location, to be identified by passive institutional controls, that encompasses no more than $100 \mathrm{~km}^{2}$ and extends horizontally no more than $5-\mathrm{km}$ in any direction from the outer boundary of the original location of the radioactive wastes in a disposal system; and (2) the subsurface underlying such a surface location" (Section 191.12).

criticality (nuclear) - A self-sustaining nuclear chain reaction from sufficient mass of a fissionable material.

Culebra Dolomite - The lower of two dolomite strata of the Rustler Formation that ranges in thickness from 3 to $14 \mathrm{~m}$ (10 to $46 \mathrm{ft}$ ) in the regional modeling domain; the strata contains a brine aquifer that could provide a pathway for lateral transport of radionuclides to the accessible environment.

cumulative distribution function (CDF) - The integral of a probability density function (PDF) over those values of a random variable that are less than or equal to a specified value, $R$. It represents the probability that an outcome of $R$ or less will occur.

curic - A curic is the unit describing the intensity of radioactivity of a material sample. A curie equals $3.7 \times 10^{10}$ nuclear transformations per second or $3.7 \times 10^{10}$ becquerel.

curium (Cm) - A TRU element having an atomic number of 96 (the number of protons in the nucleus). . An alpha emitter (half-life of $18.1 \mathrm{yr}$ ), ${ }^{244} \mathrm{Cm}$ is used for neutron bombardment of targets for the production of ${ }^{252} \mathrm{Cf}$ at Oak Ridge. In spite of its half-life being less than 20 years, Oak Ridge considers and handles ${ }^{244} \mathrm{Cm}$ as a TRU element. Some TRU waste at both Oak Ridge and Savannah River contains ${ }^{244} \mathrm{Cm}$.

cuttings - See drill cuttings. 
data - Information that is purposely collected, organized, and used in preparing values for parameters of computational models in an analysis or used as the basis of a decision. As used here, data is a subset of general information.

decision parameters - Also known as value parameters; represent various alternatives that are of high interest to decision makers.

defense waste - Nuclear waste derived mostly from the manufacture of nuclear weapons, weapons-related research programs, the operation of naval propulsion reactors, and the decontamination of production facilities.

Delaware Basin - The part of the Permian Basin in southeastern New Mexico and adjacent parts of Texas where a sea deposited large thicknesses of evaporites some 200 million years ago. It is partially surrounded by the Capitan Reef.

deterministic simulations - Modeling simulations that use an exact mathematical relationship with one to one corresponding between a set of fixed dependent parameters for features, events, and processes and the independent results.

Dewey Lake Red Beds - A formation of the Permian Period that overlies the Rustler Formation and is composed of reddish brown marine mudstones and siltstones interbedded with fine grained sandstone.

disposal - Emplacement of waste in a manner that assures isolation from the biosphere for the foreseeable future with no intent of retrieval and that requires deliberate action to regain access to the waste. For example, disposal of wastes in a mined geologic repository occurs when all of the shafts to the repository area are backfilled and sealed.

disposal system - Any combination of engineered and natural barriers that isolate spent nuclear fuel or radioactive waste after disposal (40 CFR 191.12(a)). The natural barriers extend to the accessible environment.

disturbed (human-intrusion) performance - Performance of the disposal system when human intrusion-e.g., through inadvertent drilling for oil or gas-penetrates the system, creating pathways for radionuclide release.

dose - The quantity of radiation absorbed accounting for biologic effect; measured in sieverts (Sv) or rem.

drift or access drift - Approximately horizontal underground excavated passageway from the shaft(s) to the mined panels and room(s).

drill cuttings - Particulates brought to the surface in the drilling fluid of a rotary drill either from directly cutting through a material with the drill bit or from erosion of the borehole wall by the circulating drilling fluid.

dual permeability mathematical model - A discrete hierarchical model consisting of two continuum, a fracture system and matrix system, that are fully coupled in properties such as pressures of modeled phases, temperatures, and velocities.

dual porosity mathematical model - A special case of the dual permeability mathematical model where the permeability of the matrix is assumed to be zero, such that fluid flow can occur only within the fractures of the two continuums. Only diffusion, not flow advection, can occur in the matrix and is orthogonal to the fractures. This mathematical model is implemented in STAFF2D and SECOTD2D.

E1 - An event used to develop scenarios: intrusion of a borehole through a disposal panel into a pressurized brine reservoir in the Castile Formation, or a simplified notation for a scenario in which event $\mathrm{E} 1$ occurs and other events do not $\left(\mathrm{TS}^{\mathrm{c}}, \mathrm{E} 1, \mathrm{E} 2^{\mathrm{c}}\right)$.

E1E2 - A scenario: intrusion of a borehole through a disposal panel into a pressurized brine reservoir in the Castile Formation (E1) and another intrusion of a borehole into the same panel (E2), without the occurrence of other events. Simplified notation for scenario TS ${ }^{c}, E 1, E 2, E 3^{c}$.

E2 - An event: intrusion of a borehole into a disposal panel, or a simplified notation for a scenario in which event E2 occurs and other events do not $\left(\mathrm{TS}^{\mathrm{c}}, \mathrm{E} \mathbf{1}^{\mathrm{c}}, \mathrm{E} 2\right)$. 
Eh - The redox potential; a measure of the oxidizing or reducing tendency of a solution and defined by the Nernst equation for a half-reaction written as reduction reaction in comparison to the standard hydrogen reaction, $\mathrm{Eh}$ (volts) $=\mathrm{Eh}^{0}+\mathrm{RT} / \mathrm{nF}$ in ([oxidized species]/[reduced species]).

engineered barrier - Human-designed (engineered) barriers of the waste disposal system. This definition, which is used herein and in 40 CFR 191, includes shafts, boreholes, and their seals. Note that the 10 CFR 60 definition is narrower and omits shafts, boreholes and their seals in its definition.

enginecring analysis - An engineering analysis is similar to a general scientific analysis except that engineering analysis (1) has formal constraints on purposes (specifications) rather than the limits of human curiosity, (2) has formal constraints on resources (time and money) rather than the limits of human energy, (3) uses fairly accepted methods rather than novel approaches, and (4) seeks to clarify rather than to discover new knowledge (i.e., the study is likely to further understanding of a system through the application of already discovered knowledge). The term "engineering analysis" applies to the WIPP disposal system provided one understands the formal constraint on the analysis purpose, which is an analysis that is intended to investigate the entire system for the primary purpose of determining compliance with environmental regulations. (See analysis.)

EPA limiting line - The set of lines in space of complementary cumulation distribution function (CCDF) that connect the two limiting points specified in the Containment Requirements (Section 13) of 40 CFR 191. According to the guidance of Appendix C of 40 CFR 191, the EPA can consider a disposal system to be in compliance if the CCDF (predicted by the appropriate probability and consequence models) meets or is less than the two limiting points.

EPA release limits - The normalizing factors for various radionuclides listed in Table 1 of Appendix A of the EPA regulation, 40 CFR 191.

epistemic parameters - Parameters related to precision of knowledge in the parameter space of the conceptual model for which some information has been obtained.

evaporate - A sedimentary rock composed primarily of minerals produced by precipitation from a solution that has become concentrated by the evaporation of a solvent, especially salts deposited from a restricted or enclosed body of sea water or from the water of a salt lake. In addition to halite $(\mathrm{NaCl})$, these salts include potassium, calcium, and magnesium chlorides and sulfates.

event - A natural or anthropogenic phenomenon that occurs either instantaneously or over a small portion of the time frame of interest.

event tree - The result of an inductive probabilistic technique that starts with hypothesizing the occurrence of basic initiating events and proceeds through their logical propagation to a change in (and possible disruption of) the system (e.g., a nuclear disposal system).

feature - An object or condition of the disposal system that influences release of contaminants.

gamma ray $(\gamma)$ - A type of electromagnetic radiation of high energy and short wavelength that originates from within the nucleus of the atom. Gamma radiation can accompany some alpha and beta emissions in radioactive decay and always accompanies fission of nuclei.

gas production - Three gas generation processes are expected to be factors in the degradation of TRU wastes in the WIPP repository. The generation of gaseous species is expected to occur through chemical (i.e., corrosion), microbial, and radiolytic processes.

general environment - Used in 40 CFR 191, Subpart A, as the "total terrestrial, atmospheric, and aquatic environments outside sites within which any activity, operation, or process associated with the management and storage of . . radioactive waste is conducted" (Section 191.02).

geologic barrier - A barrier within the geologic portion of the disposal system (see also barrier).

geologic repository - A system intended to be used for disposal of radioactive waste in excavated geologic media. A geologic repository includes (1) the operations area, including both surface and subsurface area, where waste handling occurs, and (2) the geologic setting, i.e., the geologic, hydrologic, and geochemical systems that isolate radioactive waste (10 CFR 60). 
Groundwater Protection Requirements - Requirements in Subpart C of 40 CFR 191 that set limits on radioactive contamination of certain sources of groundwater within or near the controlled area for 10,000 years after disposal.

half-life, radioactive - The time required for half the atoms of a radioactive substance to decay (see also radioactivity).

halite - Crystalline sodium chloride, also known as common rock salt.

handling container - The container placed around the waste form for handling prior to disposal preparation or disposal itself. At the WIPP, a handling container is the sole container for storage and disposal.

Hanford - Hanford Reservation, Hanford Engineering Development Laboratory, and Pacific Northwest Laboratory, Richland, WA. Site N-reactor for plutonium production and numerous storage tanks for radioactive waste. A large volume of TRU waste is destined for the WIPP.

hazardous waste - Those wastes that are designated hazardous by the EPA (or state) regulations through the RCRA.

head - The hydraulic head of the fluid potential $(\Phi)$ of the system divided by the acceleration of gravity $(g)$; the hydraulic head $(h)$ is the sum of the elevation of the point $(z)$ in the fluid system (elevation head) and the pressure head $\left(\frac{p}{\rho g}\right)$ (pressure divided by the fluid density and $g$ ); $h=\frac{p}{\rho g}+z$.

heavy metal - All uranium, plutonium, and thorium placed into a human-engineered nuclear reactor.

high level (radioactive) waste (HLW) - ". . the highly radioactive material [fission products and some actinides,] resulting from the reprocessing of spent nuclear fuel, including liquid waste produced directly in reprocessing and any solid material derived from such liquid waste that contains fission products in sufficient concentrations..." (NWPA, 1982, §2[12]). Although not used in this manner in this report, general articles regarding radioactive waste use the term high level waste to imply any combination of spent nuclear fuel and HLW (and sometimes transuranic [TRU] waste) that requires disposal in a deep, geologic repository. $10 \mathrm{CFR} 60$, which was promulgated by the NRC prior to NWPA, also includes spent nuclear fuel in its definition of high level waste.

Holocene Age - The more recent of the two epochs of the Quaternary geologic period, extending from the end of the Pleistocene to the present.

hydraulic conductivity $(K)$ - The constant of proportionality in Darcy's law of flow through porous media.

Idaho National Engineering Laboratory (INEL) - A multiprogram laboratory in Idaho Falls, Idaho, furnishing engineering services and products on primarily nuclear energy and related technologies. The Idaho Chemical Processing Plant (ICPP) at the Idaho site processes highly enriched uranium fuel from spent nuclear fuel stored at the site. In addition to receiving spent nuclear fuel from throughout the DOE defense complex, it stores a large volume TRU waste from Rocky Flats destined for WIPP. Prior to 1970, it buried this TRU waste, but now stores it on the surface.

implementing agency - The NRC for facilities licensed by the NRC, the EPA for those implementation responsibilities given to the EPA by the Waste Isolation Pilot Plant Land Withdrawal Act, and the Department of Energy for any other disposal facility and for implementation responsibilities for the WIPP not given to the EPA.

index parameters - Parameters that represent choices for various model forms.

Individual Protection Requirements - Requirements in Subpart B of 40 CFR 191 (\$191.15) that set limits on radiation doses to members of the public in the accessible environment (the environment beyond the controlled area $[\S 191.12(\mathrm{k})])$ for 10,000 years of undisturbed performance.

information - A collection of cognitive or intellective material. Information includes both observational data and communicated knowledge derived by inference and interpretation. 
isomorphism - A one-to-one correspondence through algebraic manipulation between the elements of two mathematical spaces such that the result of a mathematical operation in one space corresponds to analogous operation on the corresponding elements of the other space.

isotope - A species of atom characterized by the number of protons and the number of neutrons in its nucleus. In most instances, an element can exist as any of several isotopes, differing in the number of neutrons, but not the number of protons, in their nuclei. Isotopes can be either stable isotopes or radioactive isotopes (also called radioisotopes or radionuclides).

Latin hypercube sampling (LHS) - A Monte Carlo sampling technique that divides the cumulative distribution function into intervals of equal probability and then samples from each interval to ensure coverage of the full range of each variable with fewer samples.

Lawrence Livermore National Laboratory (LLNL) - A multiprogram laboratory in Livermore, CA, conducting research and development on all facets of nuclear weapon design and basic research in a variety of areas. Some TRU waste stored on site is destined for the WIPP.

Los Alamos National Laboratory (LANL) - A multiprogram laboratory in Los Alamos, NM, conducting research and development on all facets of nuclear weapon design and basic research in a variety of areas. A large volume TRU waste stored on site is destined for the WIPP.

low level waste (LLW) - All radioactive waste other than spent nuclear fuel, high level waste, transuranic waste, and mill tailings. (Mill tailings are the residue from the physical and chemical processing of uranium ore to obtain uranium.) In the United States, LLW is divided into three categories: A, B, and C. Category A has the lowest activity, and Category C has the highest. Some countries create a category called "Intermediate Level Waste (ILW)" by grouping together the United States Category C LLW, which requires shielding during handling, and transuranic waste.

marker bed - A unit of strata within a formation or a member of a formation that can be mapped in a particular area of interest.

mathematical model - The mathematical representation of a conceptual model. That is, the algebraic, differential, or integral equations that predict quantities of interest of a system and any constitutive equations of the physical material that appropriately approximate system phenomena in a specified domain of the conceptual model. Mathematical models can be categorized as either deterministic or stochastic models.

MB139 - An anhydrite marker bed and one of about 45 interbed units within the Salado Formation. It is about 1-m thick and about 1-m below the floor of the repository.

mesh - A subdivision of the domain of some mathematical model into cells, blocks, or elements for purposes of numerical solution.

metric tons of heavy metal (MTHM) - metric tons $(1000 \mathrm{~kg}$ ) of heavy metal (all isotopes of uranium, plutonium, and thorium) before placed into a reactor; the measurement is for initial mass.

mixed waste - waste that contains both radioactive and hazardous components as defined by the Atomic Energy Act and the RCRA in 40 CFR Parts 263, 265, 268, and 270.

model constants - Precisely known values for the intended purposes of the analysis.

model form uncertainty - Uncertainty in the most appropriate model form for a system. The uncertainty results from sparse observed data and lack of information able to corroborate or refute alternative models. Developing alternative models is a way to explicitly acknowledge model form uncertainty; however, in some cases it may be appropriate to combine the alternative models into a megamodel and represent the model form uncertainty as uncertainty in an index parameter.

model-control parameters - Parameters used to control the numerical solution of the mathematical model.

model-domain parameters - Parameters that reflect the overall size and appropriate temporal and spatial mesh used in discretizing a problem for numerical solution of the mathematical model.

module - A grouping or category of codes in the CAMCON system; the module name describes the primary function provided in the performance assessment. 
Monte Carlo method - A technique that obtains a probabilistic approximation to the solution of a problem by using statistical sampling techniques and usually computer simulation. For the WIPP PA, the method is used to evaluate the distribution of the consequence results and thereby approximate the uncertainty in the results. Specifically, the Monte Carlo method of random sampling is used to integrate the multidimensional differential equations expressing the expectation of the results (i.e., to evaluate the distribution of the consequence results and thereby approximate the uncertainty in the results).

montmorillonite - A soft clayey mineral that is a hydrous aluminum silicate with considerable capacity for exchanging part of the aluminum for magnesium and bases.

Mound Laboratory - A laboratory located in Miamisburg, OH; some TRU waste destined for the WIPP is stored on site.

natural barrier - see geologic barrier.

neutron - An elementary particle that has approximately the same mass as the proton but lacks electric charge, and is a constituent of all nuclei having mass number greater than 1.

Nevada Test Site (NTS) - Located in Nevada to field test nuclear components and weapons. Some TRU waste that is destined for the WIPP is stored at this site.

No-Migration Variance Petition (NMVP) - Section 3004 of RCRA allows the EPA to grant a variance from the land disposal restrictions when a determination can be made that, to a reasonable degree of certainty, there will be no migration of hazardous constituents from the disposal unit for as long as the waste remains hazardous. Specific requirements for making this demonstration are found in 40 CFR 268.6, and the EPA has published a draft guidance document to assist petitioners in preparing a variance request.

nuclear fuel - Fuel containing sufficient fissionable material (material able to split after the sorption or capture of a neutron) to maintain critical conditions in a nuclear reactor.

Oak Ridge National Laboratory (ORNL) - Y-12 Plant, Oak Ridge Reservation, Oak Ridge, TN. A large volume of TRU waste in storage is destined for the WIPP.

panel - A grouping of pillars and rooms.

parameter uncertainty - Uncertainty in the most appropriate parameter value for a computational model. The uncertainty results from sparse observed data and lack of information able to corroborate or refute alternative parameter values. Developing distributions of the parameter values is a way to explicitly acknowledge parameter uncertainty and is a part of probability modeling.

parameters - The underlying elements $\left(x=x_{1}, \ldots, x_{n}, \ldots, x_{n V}\right)$ of a computational model. As $x$ changes, so does the model result. The individual parameters, $x_{n}$, may be vectors, tensors, higher order quantities, or even functions, but are usually scalar quantities. Furthermore, the individual parameters are usually coefficients of the mathematical model, but they may also relate to scenario uncertainty or model form uncertainty.

percolation - The movement of liquid (usually water) through unsaturated or saturated solid and rock. This flux is directly controlled by the permeability of the medium.

performance assessment (PA) - The process of assessing whether a system meets a set of performance criteria. For the WIPP PA, the process is a stochastic simulation. The system is a deep geologic repository disposal system (in salt) for DOE TRU waste. The performance criteria are various longterm environmental metrics in U.S. government regulations (not short-term operational safety issues).

permeability $(k)$ - A measurement of the ability of a rock or soil to transmit fluid under hydraulic gradient. It is the hydraulic conductivity divided by the fluid unit weight $(\gamma)$, density times acceleration due to gravity $(\rho g)$ times the fluid dynamic viscosity $(\mu) ; k=\mu K / \rho g$.

Permian Basin - A region in the south-central United States, where during the Permian period (248 to 286 million years ago), there were many shallow sub-basins in which vast beds of marine evaporities were deposited.

Permian Period - The last of the seven periods ( 248 to 286 million years ago) of the Paleozoic Era. 
pH - A measure of the proton activity of a solution and equal to the negative logarithm of concentration of hydrogen ions in a solution, $\mathrm{pH}=-\log \left(\mathrm{c}_{\mathrm{H}}{ }^{+}\right)$.

pillar - A block of rock left intact to support the strata overlying the underground excavations.

Pleistocene Age - The earlier of two epochs of the Quaternary geologic period, characterized by the alternative appearance and recession of northern glaciation and the appearance of the progenitors of humans; climatic changes during this period are used as an analog in estimating future climatic extremes for the WIPP.

plutonium (Pu) - A radionuclide having an atomic number of 94. Pu isotopes exist in some TRU waste at all 10 of the major DOE storage facilities. The significant isotopes that may exist in measurable quantities at these facilities are ${ }^{238} \mathrm{Pu}$ through ${ }^{242} \mathrm{Pu}$. Each isotope is an alpha emitter; the respective half-lives are: ${ }^{238} \mathrm{t}_{1 / 2}=87.7 \mathrm{yr} ;{ }^{289} \mathrm{t}_{1 / 2}=24,000 \mathrm{yr} ;{ }^{240} \mathrm{t}_{1 / 2}=6563 \mathrm{yr} ;+\mathrm{t}_{1 / 2}=14.4 \mathrm{yr}$; ${ }^{242} \mathrm{t}_{1 / 2}=376,000 \mathrm{yr}$. Because of its high activity, ${ }^{238} \mathrm{Pu}$ can contribute significantly to the thermal loading on some TRU waste. ${ }^{241} \mathrm{Pu}$ decays, primarily by beta emission, to ${ }^{241} \mathrm{Am}$.

Poisson distribution - A discrete analytic probability distribution function (PDF) that adequately describes many random processes that involve events taking place over time.

polyhalite - An evaporite mineral: $\mathrm{K}_{2} \mathrm{MgCa}_{2}\left(\mathrm{SO}_{4}\right)_{4} \cdot 2 \mathrm{H}_{2} \mathrm{O}$; a hard, poorly soluble mineral.

potash - Specifically $\mathrm{K}_{2} \mathrm{CO}_{3}$. Also loosely used for many potassium compounds, especially as used in agriculture or industry.

primary data base - The data base storing the raw measured or interpreted data that is under the control of the experimentalist.

probabilistic risk assessment (PRA) - The process of assessing, through a stochastic simulation, the risks from a system. In theory, a PRA is identical to a performance assessment (PA) in the United States. In practice, the two differ because a PRA usually connotes (a) a system composed solely of human-engineered components, and (b) performance criteria that include risk to health over a short time (e.g., human lifetime) relative to geologic time. A PA usually connotes a system composed of both natural and human-engineered components over geologic time. Because the time frame is different, many phenomena for a PRA can be termed events (short-term phenomena); because the components are all human engineered, measured failure rates of components are often available. The modeling tools in a PRA can include elaborate event and fault trees and can substitute empirical data for mechanistic models. For a PA, the event trees are simpler, fault trees are not used, and mechanistic models are used directly.

probability density function (PDF) - If an event depends on a random variable, $x$, and $P(x)$ is its PDF, then $P(x) d x$ represents the probability that the event will occur for values of the random variable between $x$ and $x+d x$. The integral of the PDF from 0 to $R$ represents the probability of occurrence for values of $x$ less than or equal to $R$. The integral of the PDF from 0 to 1 is unity.

process - A physical natural or anthropogenic phenomenon that occurs continuously or over a significant portion of the time frame of interest, in other words, a "long-term" phenomenon.

quality assurance (QA) - All those planned and systemic actions necessary to provide adequate confidence that a structure, system, or component will perform satisfactorily in service. Quality assurance for a product is ensuring that the product does what it is supposed to do to meet the specifications of the customer. The customer expectation, as related to a performance assessment, is that the analysis results present an adequate view of the WIPP performance based on currently available data and information.

radioactive decay - A process whereby the nucleus of an atom spontaneously emits excess energy by emitting particles (alpha, beta, or neutrons).

radioactivity - The spontaneous emission of alpha or beta particles and/or gamma rays, or emission of $\mathrm{x}$-rays following capture of an orbiting electron from the nucleus of an unstable isotope. Measured as disintegration (decay) of radionuclei per unit time (e.g., 1 disintegration per second is 1 becquerel $(\mathrm{Bq}) ; 3.7 \times 10^{10}$ disintegrations per second is one curie [Ci]).

radionuclide - An isotope having an unstable nucleus and thus subject to radioactive decay. 
recharge - Movement of water (usually precipitation) at the surface into soil and rock through infiltration and then percolation flow of liquid through soil and rock to an aquifer to replenish it.

rem - Acronym for roentgen equivalent man; a unit of dosage to measure amount of damage to tissue from ionizing radiation (see sievert and dose).

remotely handled transuranic (RH-TRU) waste - Packaged TRU waste whose external surface dose rate exceeds 200 mrem per hour, but not greater than 1000 rem per hour (see also dose).

repository - The portion of a waste disposal facility that includes the waste panels, access drifts, and access shafts. The term "repository" does not include either the aboveground facilities or the undisturbed host rock. (Note that this term differs from the definition in 10 CFR 60 for "geologic repository," which is described as the disposal system and the current surface facilities.)

risk - Risk is the measure of some unwanted outcome from an activity or use of technology. Risk is commonly quantified as the product of the probability of occurrence of an event and a measure of the consequence of that event. Because analysts prefer to see the elements of this product as well as the product itself, PDFs, CDFs, and CCDFs are commonly used to represent risk.

Rocky Flats Plant (RFP) - plant in Golden, $\mathrm{CO}$, that originally fabricated and assembled fission triggers in nuclear weapons. A large volume of TRU waste was sent to the Idaho Lab, but a large volume is still stored on site.

room - An excavated cavity underground for disposal of waste; in the WIPP, a room is 10-m wide and 4-m high.

Rustler Formation - A sequence of upper Permian age clastic and evaporite sedimentary rocks that contains two dolomite beds, and overlies the Salado Formation. The dolomite bed of primary interest is called the Culebra Member of the Rustler Formation.

safe (disposal system) - The acceptable risk to a society posed by an activity or use of technology.

Salado Formation - A bedded salt deposit composed primarily of halite that is the host medium for the WIPP repository.

salt - In this report, salt refers to evaporite deposits that are predominantly sodium chloride ( $\mathrm{NaCl})$. Mineralogic names such as halite $(\mathrm{NaCl})$, sylvite $(\mathrm{KCL})$, gypsum $(\mathrm{CaSo} \cdot \mathrm{H} 2 \mathrm{O})$, and anhydrite (CaSO4) are used when referring to specific evaporite minerals. The term evaporite includes all of the above minerals; evaporites are formed by the evaporation of a saline solution such as sea water.

Sandia National Laboratories (SNL) - A multiprogram laboratory located in Albuquerque, NM, and Livermore, CA. SNL is operated and managed for the DOE by the Sandia Corporation. From 1949 until October 1993, Sandia Corporation was a wholly owned subsidiary of AT\&T. Sandia Corporation is currently a wholly owned subsidiary of Lockheed-Martin Corp.

Savannah River Plant (SRP) - Laboratory Production Reactors Defense Waste Processing Facility, located southeast of Augusta, Georgia. A large volume of TRU waste produced and stored on site is destined for the WIPP.

scenario - The subset of all features, events, and processes considered for incorporating in the conceptual model of the disposal system. Once a mathematical model of the disposal system has been developed, the term scenario can be more precisely defined in relationship to the parameter space of the mathematical model, i.e., a scenario is a subset of the parameter space defined as a compound statement, $A(x)$, that is built by linking with the conjunction "and" any series of simple statements about values taken by elements of the parameter space, $x$, and/or the set of consequences, $R$.

scenario development - The identification and selection of features, events, and processes, as well as the incorporation of those components into the conceptual model. The inclusion of conceptual model development acknowledges the close relationship between modeling and scenario generation and the need to have close communication between individuals performing these two tasks.

scenario identification - A necessary step in the construction of any model of a natural or engineered system in which the physical, chemical, and anthropogenic phenomena that might play a significant role in determining the performance of the system are identified. 
scenario screening - A necessary step in the construction of any model of a natural or engineered system in which a subset of the phenomena identified through scenario identification is selected for incorporation into a mathematical model of the system.

scenario uncertainty - Uncertainty in the most appropriate scenarios for a system. The uncertainty results from omission of discrete, short-term, natural, or anthropogenic phenomena (events), continuous natural or anthropogenic phenomena (processes), and objects and conditions (features) of a system (completeness errors) and the imperfect aggregation of histories of a system (aggregation errors).

scientific/engineering software - Software that models a physical process, often by the numerical solution of mathematical equations. Software that is used to establish the spatial variation of modeling parameters is also scientific/engineering software. A significant distinction of scientific/engineering software from other software used in performance assessment is that validating the software is often subjective, difficult, and sometimes impossible.

seals - Portions of the backfill emplaced at several locations within the shafts and drifts that would be specially prepared from preconsolidated salt with concrete plugs; would serve to protect the ordinary backfill from fluids (gases or liquids). These plugs would likely hasten backfill consolidation and increase the likelihood that salt backfill would rapidly $(<100 \mathrm{yr})$ assume properties near to those of the surrounding host rock.

secondary data base (SDB) - Data base of interpreted data from the Primary Data Base for use as parameters for the PA simulation models. The information is stored in tabular format within a relational data base system, under the control of the PA Department.

seiche - An oscillation of the surface of a lake or landlocked sea that varies in period from a few minutes to several hours.

sensitivity analysis - An analytic or numerical technique for examining the effects of parameters being varied in a model; specifically, an analysis of the effects that parameter changes have on model predictions.

shaft - An approximately vertical or steeply inclined passageway from the ground surface to the underground level of the disposal region.

sievert (Sv) - SI unit of dosage from ionizing radiation (see dose). $1 \mathrm{~Sv}=100 \mathrm{rem}$.

single history $(\chi)-\chi$ is a single 10,000 -yr WIPP history beginning at the time of decommissioning, i.e., one future disposal-system condition of interest. A single history consists of a defined sequence of features, events, and processes that could lead to radionuclide release to the accessible environment during a prescribed time period. The single-history space is isomorphic to the parameter space, $D$.

site - As used in this report, the "site" is the general location of the controlled area (the disposal system, including the land surface directly above it). The term "site" also includes any important features surrounding the controlled area (e.g., "site characterization"). Except for the latter addition, this report's definition of site is most similar to the regulatory definition in 10 CFR 60.2: "the location of the controlled area." It is roughly equivalent to the regulatory definition of "site" in 40 CFR 191.02, provided "effective control" is loosely defined (e.g., as simply land use or ownership records): "an area contained within the boundary of a location under the effective control of persons possessing or using radioactive waste that are involved in any activity, operation, or process covered by this Subpart."

site-specific model - See applied model.

software - A set of computer operations specified in any language that can be translated unambiguously into machine language. Types of software include computer codes and operating system procedural files.

source term - The kinds and amounts of radionuclides that make up the source of a potential release of radioactivity. For the performance assessment, the source term model calculates the sum of the quantities of the important radionuclides in the WIPP inventory that will be mobilized for possible transport to the accessible environment, and the rates at which these radionuclides will be mobilized. 
spallings - Material that surround the eroded boreholes that may be broken away by the action of wastegenerated gases escaping to the lower-pressure borehole; not included in the 1990, 1991, or 1992 PA calculations.

spent nuclear fuel (SNF) or spent fuel - ". . . fuel that has been withdrawn from a nuclear reactor following irradiation, the constituent elements of which have not been separated by reprocessing" (NWPA, 1982). Spent fuel can include intact and failed fuel assemblies, consolidated fuel rods, nonfuel components that are a part of a fuel assembly (such as neutron sources, instrumentation, and fuel channels). Although spent nuclear fuel has fissionable ${ }^{235} \mathrm{U}$, it contains too many radionuclides (primarily short-lived) that adsorb neutrons from the fission process for it to be usefully left in the reactor. Because of spent nuclear fuel's high value, some countries choose to recycle it (recycling becomes more attractive after the short-lived fission products have decayed away). It is also designated separately from other high-level and transuranic wastes in the U.S. Environmental Protection Agency's standard on disposal of radioactive wastes, 40 CFR 191.

stakeholder - A person, group, or agency who is not a customer, but who nevertheless has a keen interest in a product or service, such as the WIPP, and the recognized right to impact the process.

stochastic simulations - Modeling simulations that involve uncertain parameters for the features, events, and process of the system and thus produce a distribution and/or measures of the distribution of results (see also deterministic simulations).

summary scenario - A retained scenario from the set of plausible histories of the disposal system. The summary scenario is the result of the scenario screening procedure and is a subdivision of the scenario space, which is isomorphic with the parameter space.

thorium (Th) - A radionuclide having an atomic number of 90 . Although not TRU, ${ }^{232} \mathrm{Th}$ is an alpha emitter (half-life is 14 billion years) and exists in finite amounts in some TRU waste at Hanford, Idaho Lab, and Oak Ridge. Thorium is naturally occurring and contributes to background radiation at some sites (e.g., Idaho Lab).

transmissivity - The rate at which water, driven by a unit hydraulic gradient, is transmitted through a unit depth of aquifer. It is the hydraulic conductivity of the aquifer times its depth.

transuranic (TRU) waste - Transuranic waste is contaminated with transuranic radionuclides (atomic number greater than 92) emitting a radiation and having a half-life greater than 20 years and an activity greater than $100 \mathrm{nCi}$ per gram of waste. Transuranic waste is also termed Alpha-Bearing Waste in some countries.

tsunami - A long wavelength surface gravity sea wave produced by submarine earth movement or volcanic eruption.

uncertain parameter - An imprecisely known parameter; one that cannot be assigned a single, universally accepted value.

uncertainty analysis - An analytic or numerical technique to evaluate how important the uncertainties of a parameter are (i.e., how likely it is to vary) in explaining uncertainty in the predictions. For example, the results of a model may be very sensitive to varying a parameter, but if the parameter's value is precisely known, the parameter is not important to producing any uncertainty in the prediction.

uncertainty propagation - Methods for propagating the uncertainty in parameters of a model, through the model, to calculate the uncertainty in the predictions. Uncertainty propagation is an important aspect of stochastic simulation.

underground facility - The underground structure including openings and backfill materials, but excluding shafts, boreholes, and their seals (10 CFR 60.2).

undisturbed (base-case) performance - Performance of the disposal system, including consideration of uncertainties in predicted behavior, if the disposal system is ". . . not disrupted by human intrusion or the occurrence of unlikely natural events." (40 CFR 191.12)

uranium (U) - A naturally slightly radioactive element with the atomic number of 92 (number of protons in the nucleus) and an atomic weight of approximately 238 . The two principal naturally occurring isotopes are the fissionable ${ }^{235} \mathrm{U}\left(0.7\right.$ percent of natural uranium and half life of $\left.\sim 7 \times 10^{8} \mathrm{yr}\right)$ and 
${ }^{238} \mathrm{U}\left(99.3\right.$ percent of natural uranium and half life of $\left.\sim 5 \times 10^{9} \mathrm{yr}\right) ;{ }^{238} \mathrm{U}$ is fertile, meaning that by neutron capture (transmutation), it can be converted to a fissionable material, in this case, ${ }^{239} \mathrm{Pu}$. (An alpha emitter with a half-life of $\sim 1.6 \times 10^{5} \mathrm{yr},{ }^{233} \mathrm{U}$ also spontaneously fissions and is present in some TRU waste inventories at Idaho Lab and Oak Ridge.)

validation - The process of making valid by confirming, corroborating, substantiating, or supporting, where valid means of good authority, well founded, sound and to the point, and applicable to the subject or circumstances against which few objections can be fairly brought.

validation of an (applied) model - The process of validating through sufficient testing (subjective) using system-specific observed data that a conceptual model and the corresponding mathematical and computational models explain a system with sufficient accuracy (subjective), consistent with the purpose of the model. In other words, model validation is the process of confirming that the applied model is solving the appropriate idealization of the system (correct applied model produced). Model validation is an ongoing process.

verification of a (computational) model - The process of verifying that a computational model appropriately solves and implements the mathematical model. In other words, model verification is the process of illustrating that the mathematical model is being solved appropriately (computational model correctly produced). Often the computational model is implemented as a code; thus, verification of the computational model is closely connected to verification of software. Once a computational model is verified, the assumptions of the conceptual model underlying the mathematical and computational model (the applied model) should be validated using system-specific data.

verification of software - The process of illustrating through sufficient (subjective) testing that the software satisfactorily performs its stated capabilities (subjective) and providing a point of reference for future modifications. The extent to which the software can be tested is determined by its complexity.

waste form - The physical and chemical form of the waste after any specific treatment (none for the WIPP) just prior to being placed in the handling container.

waste package or waste emplacement package (WEP) - According to $10 \mathrm{CFR} 60.2$, the waste package is "the waste form and any containers, shielding, packing, and other absorbent materials immediately surrounding an individual waste container." Thus, the waste package contains all components that enclose the waste form out to the host rock. The waste package is defined as a unit as a convenience for subsystem modelers; also 10 CFR 60.113(b) places release limits on this unit.

waste parcel (WP) - The waste form, any internal backfill (none for the WIPP), handling container, and any overpack disposal containers (none for the WIPP). This definition describes a unit that can be handled; it does not include backfill immediately surrounding the waste panel. 
Glos-20 


\section{DISTRIBUTION}

\section{Federal Agencies}

US Department of Energy (5)

Office of Environmental Restoration and Waste Management

Attn: T. Grumbly, EM-1

G.L. Sjoblom, EM-1

C.W. Frank, EM-50

J.E. Lytle, Deputy Assistant

Secretary, EM-30 (2)

Forrestal Building

1000 Independence Avenue SW

Washington, DC 20585

US Department of Energy (6)

Carlsbad Area Office

Attn: G. Dials, Director

V. Daub

M. McFadden

R. Lark

R. Bills, Performance Assessment

Manager

J.A. Mewhinney, Compliance Program Manager

PO Box 3090

Carlsbad, NM 88221-3090

US Department of Energy (2)

Attn: George Basabilvazo

Jim Maes

Carisbad Area Office

Mail Stop 564

PO Box 3090

Carlsbad, NM 88221

US Department of Energy (2)

Office of Civilian Radioactive Waste Management

Attn: S. Hanover, Science Advisor

MS 7F091

K.L. Svinicki, RW-44

Forrestal Building

1000 Independence Avenue SW

Washington, DC 20585
US Department of Energy (6)

Office of Civilian Radioactive Waste Management

Attn: Deputy Director, RW-2

Associate Director, R.W-10/50

Office of Program and Resources

Management

Office of Contract Business

Management

Director, RW-22

Analysis and Verification Division

Associate Director, RW-30

Office of Systems and Compliance

Associate Director, RW-40

Office of Storage and Transportation

Director, RW-4/5

Office of Strategic Planning and International Programs Office of External Relations

Forrestal Building

1000 Independence Avenue SW

Washington, DC 20585

US Department of Energy

Attn: E. Young

Room E-178

GAO/RCED/GTN

Washingtor, DC 20545

US Department of Energy (3)

Office of Environmental Restoration and Waste Management

Attn: M. Frei, EM-34,

Trevion II (2)

S. Schneider, EM-342,

Trevion II (1)

Washington, DC 20585-0002

US Department of Energy (2)

Office of Environment, Safety and Health

Attn: C. Borgstrom, EH-25

R. Pelletier, EH-231

Washington, DC 20585

US Department of Energy (2)

Idaho Operations Office

Fuel Processing and Waste

Management Division

785 DOE Place

Idaho Falls, ID 83402 
US Department of Energy

Research \& Waste Management Division

Attn: Director

PO Box E

Oak Ridge, TN 37831

US Environmental Protection Agency (3)

Radiation Protection Programs

Attn: M. Oge

S. Page

L. Weinstock

ANR-460

Washington, DC 20460

US Environmental Protection Agency (2)

Office of Radiation and Indoor Programs

Attn: J. Benetti

S.J. Chern

PO Box 98517

Las Vegas, NV 89193-8517

US Environmental Protection Agency

Office of Radiation and Indoor Air

Region 6

Attn: C. Byrum, 6T-ET

1445 Ross Ave.

Dallas, TX 75202

US Environmental Protection Agency (3)

Attn: Tim Margulis

Tom Peake

Rosemary Workman

Mail Code 6602J

$401 \mathrm{M}$ St. SW

Washington, DC 20460

US Nuclear Regulatory Commission

Division of Waste Management

Performance Assessment and Hydrology Branch

Attn: M. Federline

Rockville, MD

US Nuclear Regulatory Commission (3)

Division of Waste Management

Attn: H. Marson

R. Codell

N. Eisenberg

Mail Stop 4-H-3

Washington, DC 20555
Boards

Defense Nuclear Facilities Safety Board

Attn: A.J. Eggenberger

625 Indiana Ave. NW, Suite 700

Washington, DC 20004

Nuclear Waste Technical Review

Board (4)

Attn: J.E. Cantlon, Chairman

S.J.S. Parry

W. North

L. Reiter

1100 Wilson Blvd., Suite 910

Arlington, VA 22209-2297

US Nuclear Regulatory Commission (4)

Advisory Committee on Nuclear Waste

Attn: M.J. Steindler

P.W. Pomeroy

W.J. Hinze

R. Major

1155 Rockville Pike

Rockville, MD 20852-2738

J.F. Ahearne

Executive Director, Sigma Xi

99 Alexander Drive

Research Triangel Park, NC 27709

\section{National Academy of Sciences, WIPP Panel}

National Research Council

Board on Radioactive Waste Management

Attn: Carl A. Anderson, Director, HA-456

2101 Constitution Ave.

Washington, DC 20418

Howard Adler

Oxyrase, Incorporated

7327 Oak Ridge Highway

Knoxville, TN 37931

John O. Blomeke

720 Clubhouse Way

Knoxville, TN 37909

Sue B. Clark

University of Georgia

Savannah River Ecology Lab

PO Drawer E

Aiken, SC 29802 
Rodney C. Ewing

Department of Geology

University of New Mexico

Albuquerque, NM 87131

Charles Fairhurst

Department of Civil and Mineral Engineering

University of Minnesota

500 Pillsbury Dr. SE

Minneapolis, MN 55455-0220

B. John Garrick

PLG Incorporated

4590 MacArthur Blvd., Suite 400

Newport Beach, CA 92660-2027

Leonard F. Konikow

US Geological Survey

431 National Center

Reston, VA 22092

Konrad B. Krauskopf

Department of Energy

Stanford University

Stanford, CA 94305-2115

Della Roy

Pennsylvania State University

217 Materials Research Lab

Hastings Road

University Park, PA 16802

David A. Waite

$\mathrm{CH}_{2} \mathrm{M}$ Hill

PO Box 91500

Bellevue, WA 98009-2050

Christopher G. Whipple

ICF Kaiser Engineers

1800 Harrison St., 7th Floor

Oakland, CA 94612-3430

Thomas A. Zordan

Zordan Associates, Inc.

3807 Edinburg Drive

Murrysville, PA 15668

\section{Performance Assessment}

Peer Review Panel

University of Washington

College of Ocean \& Fishery Sciences

Attn: G.R. Heath

583 Henderson Hall HN-15

Seattle, WA 98195

T.H. Pigford

166 Alpine Terrace

Oakland, CA 94618

Future Resources Associates, Inc.

Attn: R.J. Budnitz, President

2000 Center Street, Suite 418

Berkeley, CA 94704

J.K. Research Associates, Inc.

Attn: T.A. Cotton

4429 Butterworth Place, NW

Washington, DC 20016

University of Illinois

Department of Geology

Attn: C.J. Mann

245 Natural History Bldg.

1301 West Green Street

Urbana, IL 61801

Ohio State University

Department of Geology and Mineralogy

Attn: Frank W. Schwartz

Scott Hall

1090 Carmark Rd

Columbus, $\mathrm{OH} 43210$

\section{State Agencies}

Attorney General of New Mexico

PO Drawer 1508

Santa Fe, NM 87504-1508

Environmental Evaluation Group (3)

Attn: Bill Lee

Library (2)

7007 Wyoming NE, Suite F-2

Albuquerque, NM 87109 
NM Energy, Minerals, and Natural Resources Department (4)

New Mexico Radioactive Task Force

Attn: A. Lockwood, Chairman C. Wentz, Policy Analyst Jim Firkins Library

2040 S. Pacheco

Santa Fe, NM 87505

NM Environment Department (3)

Secretary of the Environment

Attn: Mark Weidler

1190 St. Francis Drive

Santa Fe, NM 87503-0968

NM Environment Department (2)

Attn: Steve Zappe John Parker

525 Camino de los Marquez

PO Box 26110

Santa Fe, NM 87502

NM Bureau of Mines and Mineral Resources Socorro, NM 87801

NM Environment Department

WIPP Project Site

Attn: P. McCasland

PO Box 3090

Carlsbad, NM 88221

\section{National Laboratories}

Battelle Pacific Northwest Laboratories Attn: R.E. Westerman, MSIN P8-44 Battelle Blvd.

Richland, WA 99352

Los Alamos National Laboratory

Attn: J.M. Boak, CST10, MS J534

Los Alamos, NM 87545

Los Alamos National Laboratory

Attn: B. Erdal, INC-12

PO Box 1663

Los Alamos, NM 87544
Lockheed Idaho Technologies Company (3)

Attn: H.H. Loo

R.D. Klinger

L.L Taylor

1955 Freemont Avenue

MS 3422

Idaho Falls, ID 83415

\section{Corporations/Members of the Public}

Western Water Consultants

Attn: P.A. Rechard

PO Box 4128

Laramie, WY 82071

Western Water Consultants

Attn: D. Fritz

1949 Sugarland Drive \#134

Sheridan, WY 82801-5720

A.T. Kearney, Inc. (2)

Attn: Connie Walker

Paige Walter

12007 th St., Suite 950

Denver, CO 80202

EPRI

Attn: J. Kessler

3412 Hillview Ave

Palo Alto, CA 94304-1395

INTERA Environmental Inc.

Attn: M. Apted

3609 South Wadsworth Blvd, 5th Fl

Denver, CO 80235

INTERA, Inc.

Attn: G.A. Freeze

1650 University NE, Suite 300

Albuquerque, NM 87102

INTERA, Inc.

Attn: J.F. Pickens

6850 Austin Center Blvd., Suite 300

Austin, TX 78731

INTERA, Inc.

Attn: W. Stensrud

PO Box 2123

Carlsbad, NM 88221 
Ogden Environmental and Energy Services

Attn: R.A. Knief

7301-A Indian School Rd, NE

Albuquerque, NM 87110

RE/SPEC, Inc.

Attn: W. Coons

4775 Indian School NE, Suite 300

Albuquerque, NM 87110-3927

RE/SPEC, Inc.

Attn: J.L. Ratigan

PO Box 725

Rapid City, SD 57709

Sanford Cohen and Associates (2)

Attn: Bill Thurber

Dave Back

1355 Beverly Road

McLean, VA 22101

Southwest Research Institute (2)

Center for Nuclear Waste Regulatory Analysis

Attn: B. Sagar

R.D. Manteufel

6220 Culebra Road

San Antonio, TX 78238-5166

Tech Reps Inc. (10)

Attn: J. Chapman

L. Robledo

T. Peterson (2)

W. Simmons

M. Minahan (3)

H. Olmstead

D. Pulliam

5000 Marble NE, Suite 222

Albuquerque, NM 87110

Westinghouse Electric Corporation (5)

Attn: Library

C. Cox

L. Fitch

B.A. Howard

R. Kehrman

PO Box 2078

Carlsbad, NM 88221

\section{Universities}

University of California

Dept. of Nuclear Engineering

Attn: W. Kastenberg

4153 Etcheverry Hall

Berkeley, CA 94720-1730

University of New Mexico

Department of Civil Engineering

Attn: B. Thompson

Albuquerque, NM 87131

University of Wyoming

Department of Civil Engineering

Attn: V.R. Hasfurther

Laramie, WY 82071

\section{Libraries}

US Department of Energy Albuquerque Operations Office Attn: National Atomic Museum Library PO Box 5400

Albuquerque, NM 87185-5400

WIPP Public Reading Room Carlsbad Public Library

$101 \mathrm{~S}$. Halagueno St.

Carlsbad, NM 88220

Thomas Brannigan Library

Attn: D. Dresp

106 W. Hadley St.

Las Cruces, NM 88001

Government Publications Department

Zimmerman Library

University of New Mexico

Albuquerque, NM 87131

New Mexico Junior College

Pannell Library

Attn: R. Hill

Lovington Highway

Hobbs, NM 88240

New Mexico State Library

Attn: N. McCallan

325 Don Gaspar

Santa Fe, NM 87503 
New Mexico Tech

Martin Speere Memorial Library

Campus Street

Socorro, NM 87810

University of New Mexico

Geology Department

Attn: Library

141 Northrop Hall

Albuquerque, NM 87131

\section{Foreign Addresses}

G. de Marsily (GXG Chairman)

University Pierre et Marie Curie

Laboratorie de Geologie Applique

4, Place Jussieu,

T.26 $-5^{\mathrm{e}}$ etage

75252 Paris Cedex 05, FRANCE

Galson Sciences, Ltd.

Attn: D.A. Galson

5 Grosvenar House

Melton Road

Oakham

Rutland LE15 6AX

UNITED KINGDOM

Studiecentrum Voor Kernenergie

Centre d'Énergie Nucléaire

Attn: A. Bonne

SCK/CEN Boeretang 200

B-2400 Mol, BELGIUM

Atomic Energy of Canada, Ltd.

Whiteshell Laboratories

Attn: B. Goodwin

Pinawa, Manitoba, CANADA ROE 1LO

Francois Chenevier (2)

ANDRA

Route du Panorama Robert Schumann

B.P. 38

92266 Fontenay-aux-Roses, Cedex

FRANCE

Jean-Pierre Olivier

OECD Nuclear Energy Agency

Division of Radiation Protection and Waste

Management

38, Boulevard Suchet

75016 Paris, FRANCE
Claude Sombret

Centre d'Études Nucléaires de la Vallee Rhone

CEN/VALRHO

S.D.H.A. B.P. 171

30205 Bagnols-Sur-Ceze, FRANCE

Commissariat à L'Energie Atomique

Attn: D. Alexandre

Centre d'Études de Cadarache

13108 Saint Paul Les Durance, Cedex

FRANCE

Bundesanstalt für Geowissenschaften und Rohstoffe

Attn: M. Langer

Postfach 510153

D-30631 Hannover, GERMANY

Bundesministerium für Forschung und Technologie Postfach 200706

5300 Bonn 2, GERMANY

Institut für Tieflagerung

Attn: K. Kuhn

Theodor-Heuss-Strasse 4

D-3300 Braunschweig, GERMANY

Gesellschaft für Anlagen und Reaktorsicherheit (GRS)

Attn: B. Baltes

Schwertnergasse 1

D-50667 Cologne, GERMANY

OECD Nuclear Energy Agency

Radiation Protection and Radioactive Waste Management Division

Attn: J.P. Olivier

Le Seine St. German Bldg.

12 , boulevard de Iles

F-92130 Issy-les-moulineaux

\section{FRANCE}

Physikalisch-Technische Bundesanstalt

Attn: P. Brenneke

Postfach 3345

D-3300 Braunschweig, GERMANY

Shingo Tashiro

Japan Atomic Energy Research Inst.

Tokai-Mura, Ibaraki-Ken, 319-11

JAPAN 
Netherlands Energy Research Foundation ECN

Attn: L.H. Vons

3 Westerduinweg

PO Box 1

1755 ZG Petten

THE NETHERLANDS

Svensk Kärnbränsleforsorjning $\mathrm{AB}$

Attn: F. Karlsson

Project KBS (Kärnbränslesakerhet)

Box 5864

S-102 48 Stockholm SWEDEN

Nationale Genossenschaft für die Lagerung

radioaktiver Abfalle (2)

Attn: S. Vomvoris

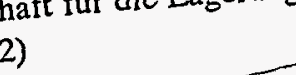

P. Zuidem

$\begin{array}{lll}1335 & 6300 & \text { F. Bingham, actg. } \\ 1326 & 6312 & \text { H.A. Dockery } \\ 1399 & 6314 & \text { M.C. Brady } \\ 1343 & 6351 & \text { R.E. Thompson } \\ 1330 & 6352 & \text { C.B. Michaels (2) } \\ 1330 & 6352 & \text { NWM. Library (150) } \\ 0728 & 6602 & \text { R.L. Hunter } \\ 0727 & 6622 & \text { M.M. Gruebel } \\ 1395 & 6700 & \text { P.E. Brewer } \\ 1395 & 6701 & \text { L.E. Shephard } \\ 1335 & 6705 & \text { M.S.Y. Chu } \\ 1341 & 6706 & \text { A.L. Stevens } \\ 1395 & 6707 & \text { M.G. Marietta } \\ 1341 & 6707 & \text { P.N. Swift } \\ 1329 & 6719 & \text { E.J. Nowak } \\ 1528 & 6741 & \text { L.N. Sow } \\ 1328 & 6741 & \text { M.S. Siernez } \\ 1395 & 6742 & \text { S.Y. Pickering } \\ 1395 & 6743 & \text { V.H. Slaboszewicz } \\ 1341 & 6747 & \text { S.G. Bertram } \\ 1341 & 6747 & \text { D.R. Schafer } \\ 1341 & 6748 & \text { J.T. Holmes } \\ 1328 & 6749 & \text { D.R. Anderson } \\ 1328 & 6749 & \text { G.K. Froehlich } \\ 1328 & 6749 & \text { R.P. Rechard (5) } \\ 1328 & 6749 & \text { C.T. Stockman } \\ 1328 & 6749 & \text { P. Vaughn } \\ 0100 & 7613-2 & \text { Document Processing for } \\ & & \text { DOE/OSTI (2) } \\ 9018 & 8523-2 & \text { Central Technical Files } \\ 0619 & 12615 & \text { Print Media } \\ 0899 & 13414 & \text { Technical Library (5) }\end{array}$

AEA Technology

Attn: J.H. Rees

D5W/29 Culham Laboratory

Abington, Oxfordshire OX14 3DB

UNITED KINGDOM

AEA Technology

Attn: W.R. Rodwell

O44/A31 Winfrith Technical Centre

Dorchester, Dorset DT2 8DH

UNITED KINGDOM

AEA Technology

Attn: J.E. Tinson

B4244 Harwell Laboratory

Didcot, Oxfordshire OXII ORA

UNITED KINGDOM

D.R. Knowles

British Nuclear Fuels, plc

Risley, Warrington, Cheshire WA3 6AS

1002607 UNITED KINGDOM

\section{Internal}

$\begin{array}{lll}\frac{\text { MS }}{0827} & \text { Org. } & \\ 9015 & 5321 & \text { P.J. Hommert } \\ 0724 & 6000 & \text { D.A. Pura } \\ 1335 & 6000 \text { A } & \text { W.D. Hartley } \\ 1324 & 6115 & \text { P.B. Wavies } \\ 1332 & 6121 & \text { J.R. Tillerson }\end{array}$

